AL. $2.2001-136$

C. 2

Preliminary Classification of Native Wheat Grass (Agropyron spp.)

Community Types in Alberta 


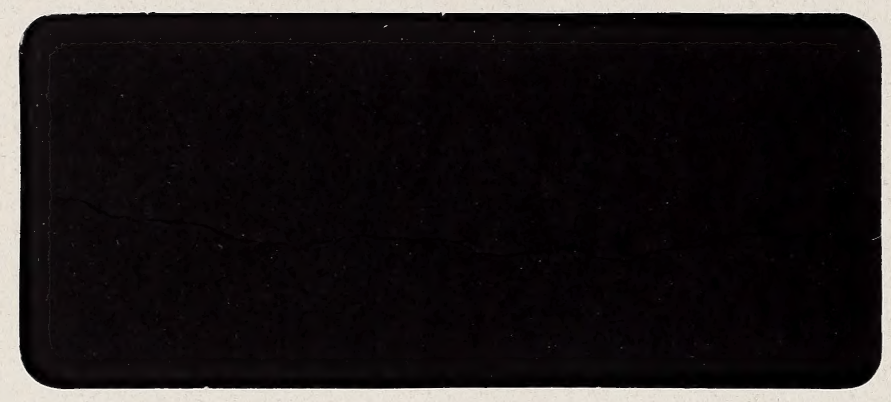




\section{Preliminary Classification of Native Wheat Grass (Agropyron spp.) \\ Community Types in Alberta}

Prepared for:
Alberta Natural Heritage Information Centre
Alberta Environment
Edmonton, Alberta
Prepared by:
K. Vujnovic
J. Bentz
Geowest Environmental Consultants Ltd.
Suite 203, 4209 - 99 Street
Edmonton, Alberta
T6E 5V7

April, 2001 
Digitized by the Internet Archive in 2016 


\section{EXECUTIVE SUMMARY}

Biological diversity is under threat and declining, both within Alberta and Canada, as well as around the world. Alberta's natural regions and the biodiversity they contain are affected by human activities and natural influences, including urban growth, agriculture, large-scale industrial activities such as forest harvesting and petroleum extraction, and climate change. The Canadian Biodiversity Strategy was developed to sustain and promote biological diversity in Canada and to help combat this decline.

Alberta Natural Heritage Information Centre (ANHIC) collects, evaluates and makes available information on elements of natural biodiversity in Alberta, including flora, fauna and natural plant communities. A preliminary tracking list of natural plant community elements is currently under development. However, ANHIC requires more information on plant community types in Alberta to better define their characteristics and species composition and to determine their distribution and provincial ranking. In support of ANHIC, Alberta Environment contracted Geowest Environmental Consultants Ltd. to produce a synopsis of historical data on native Agropyron (wheat grass) plant community types and to create a preliminary provincial classification of these community types.

The following specific project objectives were identified:

- review and compilation of existing information from various sources (including existing field plot data, published literature, unpublished reports, consultations with knowledgeable individuals, etc.) on native Agropyron community types in Alberta;

- development of a comprehensive preliminary classification of Agropyron plant communities for each alliance or major vegetation type;

- cross-referencing of the proposed Agropyron community types to the community types described in other Alberta studies, and in adjacent provinces and states;

- evaluation and assignment of a preliminary provincial ranking to each community type;

- identification of knowledge gaps;

- completion of a community characterization abstract for each community type, for inclusion in the ANHIC database; and

- production of a summary report.

The classification was based on an exhaustive literature review of relevant Agropyron community types identified previously within Alberta and in other geographic jurisdictions including Saskatchewan, British Columbia, Montana, Washington, Colorado, Idaho and Utah. As well, cluster and ordination analyses were completed of 416 selected plots from the Ecological Site Inventory System (ESIS) electronic database provided by Alberta Environment, Resource Data Division. The classification was based on the attributes of the vegetation as well as environmental site factors. Procedures outlined in the publication International Classification of Ecological Communities: Terrestrial Vegetation of the United States: Volume 1 - The National 
Classification System: Development, Status, and Applications (Grossman et al. 1998) were followed.

The preliminary classification of Agropyron community types based on the literature review and the cluster analysis of the ESIS database identified 39 potential Agropyron dominated/codominated community types within Alberta. These were grouped into four Herbaceous Alliances.

Within the Agropyron spicatum Alliance, five communities were identified: Agropyron spicatum; Agropyron spicatum - Festuca campestris; Agropyron spicatum - Elymus innovatus Aster conspicuous; Agropyron spicatum - Carex obtusata; and, Agropyron spicatum - Festuca idahoensis;

Within the Agropyron trachycaulum Alliance, 11 communities were identified: Agropyron trachycaulum; Agropyron trachycaulum - Stipa spp.; Agropyron trachycaulum - Carex atherodes; Agropyron trachycaulum - Carex praegracilis - Fragaria virginiana; Agropyron trachycaulum - Distichlis stricta; Agropyron trachycaulum - Koeleria macrantha; Agropyron trachycaulum - Festuca ovina - Poa palustris - Equisetum arvense; Agropyron trachycaulum Hierochloe odorata; Agropyron trachycaulum - Elymus innovatus - Thalictrum venulosum; Poa interior - Agropyron trachycaulum; and, Hordeum jubatum - Agropyron trachycaulum Distichlis stricta.

Within the Agropyron dasystachyum Alliance, 11 communities were identified: Agropyron dasystachyum; Agropyron dasystachyum - Calamovilfa longifolia; Agropyron dasystachyum Agropyron smithii; Agropyron dasystachyum - Koeleria macrantha - Artemisia frigida; Agropyron dasystachyum - Poa pratensis; Agropyron dasystachyum - Muhlenbergia cuspidata; Agropyron dasystachyum - Artemisia dracunculus - Artemisia frigida; Agropyron dasystachyum - Antennaria nitida; Agropyron dasystachyum - Stipa comata; Agropyron dasystachyum Agropyron subsecundum; and, Juniperus horizontalis - Arctostaphylos uva-ursi / Agropyron dasystachyum - Elymus innovatus.

Within the Agropyron smithii Alliance, 12 communities were identified: Agropyron smithii; Agropyron smithii - Artemisia ludoviciana; Agropyron smithii - Artemisia frigida; Agropyron smithii - Artemisia tilesii - Artemisia frigida; Agropyron smithii - Bouteloua gracilis; Agropyron smithii - Hordeum jubatum; Agropyron smithii - Pyrrocoma uniflora; Agropyron smithii Atriplex nuttallii; Agropyron smithii - Stipa comata - Bouteloua gracilis; Carex stenophylla Agropyron smithii; Distichlis stricta - Agropyron smithii; and, Koeleria macrantha - Agropyron smithii.

All proposed Agropyron community types were described and assigned a preliminary provincial ranking. Knowledge gaps were identified and strategies to address these gaps were provided. Community characterization abstracts were also compiled for each of the proposed community types. The information in this report can be used to update the preliminary community tracking list by including new community types, as well as by changing ranking for those communities that are currently on the list. It can also be used to decide which community types need further studies and to prioritize these studies. Finally, this preliminary classification of Agropyron communities in Alberta is a part of a larger project to classify and describe the vegetation of Alberta within a North American context. 


\section{ACKNOWLEDGEMENTS}

We wish to thank Lorna Allen (Alberta Natural Heritage Information Centre, Alberta Environment), Keith Ainsley (Resource Data Division, Alberta Environment), Arthur Schwarz (University of Alberta), Mike Willoughby (Land and Forest Service, Alberta Environment), and Russell Wells (Resource Data Division, Alberta Environment) for assistance throughout the project. We are also grateful to Dragomir Vujnovic for his assistance in report preparation. Dennis O'Leary, Jim Squarok and Terry Lang (Geowest Environmental Consultants Ltd.) also contributed to the succesful completion of this project. 
EXECUTIVE SUMMARY. ..$i$ ACKNOWLEDGEMENTS iii

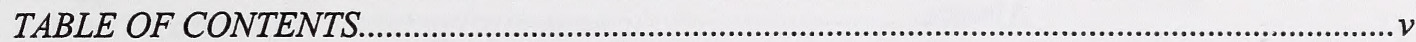

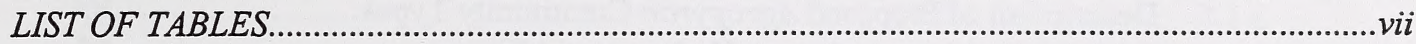

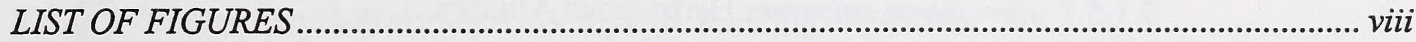

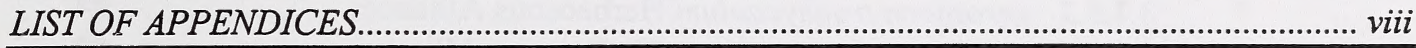

1. INTRODUCTION.

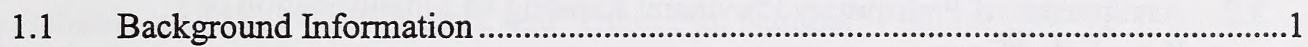

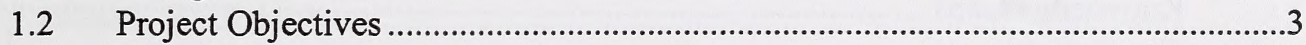

2. METHODS

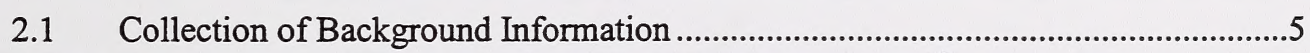

2.2 Development of Comprehensive Classification.........................................................5

2.2.1 Vegetation Data Analyses and Classification ..............................................

2.2.2 Ordination of Agropyron Community Types Identified by Cluster Analysis ......

2.3 Cross referencing of proposed Agropyron community types with the literature and analysis of plot data

2.4 Evaluation and Assignment of Preliminary Provincial Ranking ............................10

2.5 Identification of Knowledge Gaps .................................................................12

2.6 Creation of Community Characterization Abstracts ..................................................13

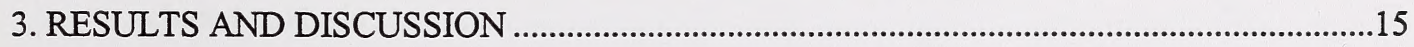

3.1 Preliminary Classification of Native Agropyron Communities ..............................15

3.1.1. Previously Reported Native Agropyron Community Types .....................15

3.1.1.1. Agropyron spicatum Alliance in Alberta ........................................15

3.1.1.2 Agropyron spicatum Alliance Outside Alberta..............................17

3.1.1.3 Agropyron trachycaulum Alliance in Alberta................................21

3.1.1.4 Agropyron trachycaulum Alliance Outside Alberta ......................24

3.1.1.5 Agropyron dasystachyum Alliance in Alberta ...............................25

3.1.1.6 Agropyron dasystachyum Alliance Outside Alberta......................29

3.1.1.7 Agropyron smithii Alliance in Alberta...........................................31

3.1.1.8 Agropyron smithii Alliance Outside Alberta .................................34

3.1.1.9 Agropyron albicans group .........................................................38

3.1.1.10 Other Related Communities Found Within Alberta .....................38

3.1.2 Vegetation Data Analysis and Classification.............................................43 
3.1.3 Relationship Between Classified Agropyron Communities and Environmental Variables

3.1.4 Cross Referencing of Proposed Agropyron Community Types With the Literature and Analysis of Plot Data From Alberta 68

3.1.4.1. Cross Reference Tables With the Literature From Alberta And Analysis of the ESIS Plot Data

3.1.4.2 Cross Reference Tables With the Literature From Outside Alberta. 77

3.1.5 Description of Proposed Agropyron Community Types..............................83

3.1.5.1 Agropyron spicatum Herbaceous Alliance 83

3.1.5.2 Agropyron trachycaulum Herbaceous Alliance..............................84

3.1.5.3. Agropyron dasystachyum Herbaceous Alliance ...............................88

3.1.5.4 Agropyron smithii Herbaceous Alliance.........................................93

3.1.5.5. Agropyron albicans Group ..........................................................96

3.2. Assignment of Preliminary Provincial Ranking and Identification of

Knowledge Gaps 97

3.3 Conclusions. 104

4. LITERATURE CITED 105 
Table 1. Latin names, common names, synonyms, native status, typical habitat description, and hybrids for ten Agropyron species occurring within the province of Alberta, Canada

Table 2. Community Ranking Guidelines.

Table 3. Preliminary Sub-national Community Ranking Guidelines

Table 4. Confidence levels assigned to each community

Table 5: Code equivalents between cluster groups (communities) identified by cluster analysis, PC-ORD plots, and "Other Plot Number" - unique plot codes in ESIS database

Table 6. Descriptive statistics for environmental variables extracted from the ESIS database for 18 Agropyron community types identified by cluster analysis

Table 7. Agropyron spicatum Alliance: crosswalk with literature from Alberta and cluster analysis

Table 8. Agropyron trachycaulum Alliance: crosswalk with literature from Alberta and cluster analysis

Table 9. Agropyron dasystachyum Alliance: crosswalk with literature from Alberta and cluster analysis

Table 10. Agropyron smithii Alliance: crosswalk with literature from Alberta and cluster analysis

Table 11. Other than Agropyron Alliances: crosswalk with literature from Alberta and cluster analysis

Table 12. Agropyron spicatum Alliances: crosswalk with literature from outside Alberta

Table 13. Agropyron trachycaulum Alliances: crosswalk with literature from outside Alberta.

Table 14. Agropyron dasystachyum Alliances: crosswalk with literature from outside Alberta

Table 15. Agropyron smithii Alliances: crosswalk with literature from outside Alberta 
Figure 1. Cluster analysis of 416 selected plots from ESIS database

Figure 2. Ordination diagram based on Detrended Canonical Correspondence Analysis (DCCA) of 120 plots from the Ecological Site Inventory System (ESIS) database

Figure 3. Ordination diagram based on Detrended Canonical Correspondence Analysis (DCCA) of 120 plots from the Ecological Site Inventory System (ESIS) database

\section{LIST OF APPENDICES}

Appendix 1. List of species assigned to the dwarf shrub layer

Appendix 2. Detailed description of fields in the community characterization abstract

Appendix 3. Descriptive statistics for species cover within each cluster (community) derived from the Furthest Neighbor cluster analysis

Appendix 4. Summary of Detrended Canonical Correspondence Analysis (DCCA) of 120 plots from ESIS database.

Appendix 5. Statistics for environmental variables used in Detrended Canonical Correspondence Analysis (DCCA) of 120 plots from ESIS database

Appendix 6. Community characterization absracts 


\section{INTRODUCTION}

\subsection{Background Information}

Biological diversity is under threat and declining, both within Alberta, Canada and the world. Alberta's natural regions and the biodiversity they contain are affected by human activities and natural influences, including urban growth, agriculture, large-scale industrial activities such as forest harvesting and petroleum extraction, and climate change. The Canadian Biodiversity Strategy was developed to sustain and promote biological diversity in Canada and to help combat this decline. Alberta signed a statement of commitment in 1995, along with the federal government and all other provinces and territories, to use the strategy as a guide for actions to conserve biological diversity.

The Resource Data Division of Alberta Environment has contracted Geowest Environmental Consultants Ltd. to undertake a study to compile information on selected Agropyron communities in Alberta. This initiative is in support of the Alberta Natural Heritage Information Centre (ANHIC); ANHIC collects, evaluates and makes available information on elements of natural biodiversity of Alberta, including flora, fauna and natural plant communities. ANHIC develops tracking lists of elements that are considered of high priority because they are rare or special in some way. A preliminary tracking list of natural plant community elements is currently under development. However, ANHIC requires more information on plant community types in Alberta to better define their characteristics and species composition and to determine their distribution and provincial ranking. A number of high priority alliances or major vegetation types have been identified for which information needs to be collected. The long-term goal is to develop a complete list of plant community types within each alliance or major vegetation type, to help identify community types that warrant protection. A consolidation of materials on Agropyron community types in Alberta was necessary to allow for biodiversity measures and more comprehensive plant community rankings.

Agropyron spp., a perennial commonly known as wheat grass, occurs extensively across North America, ranging from Alaska, Yukon, Ellesmere Island, and Greenland in the north to Newfoundland in the east and Texas, California and Arizona in the south. Agropyron species hybridize so that recognition of taxonomic units is somewhat arbitrary. Hybrids between Agropyron species and those of other genera also occur. Ten species of Agropyron have been identified by Moss (1983) in the Flora of Alberta (see table 1). 


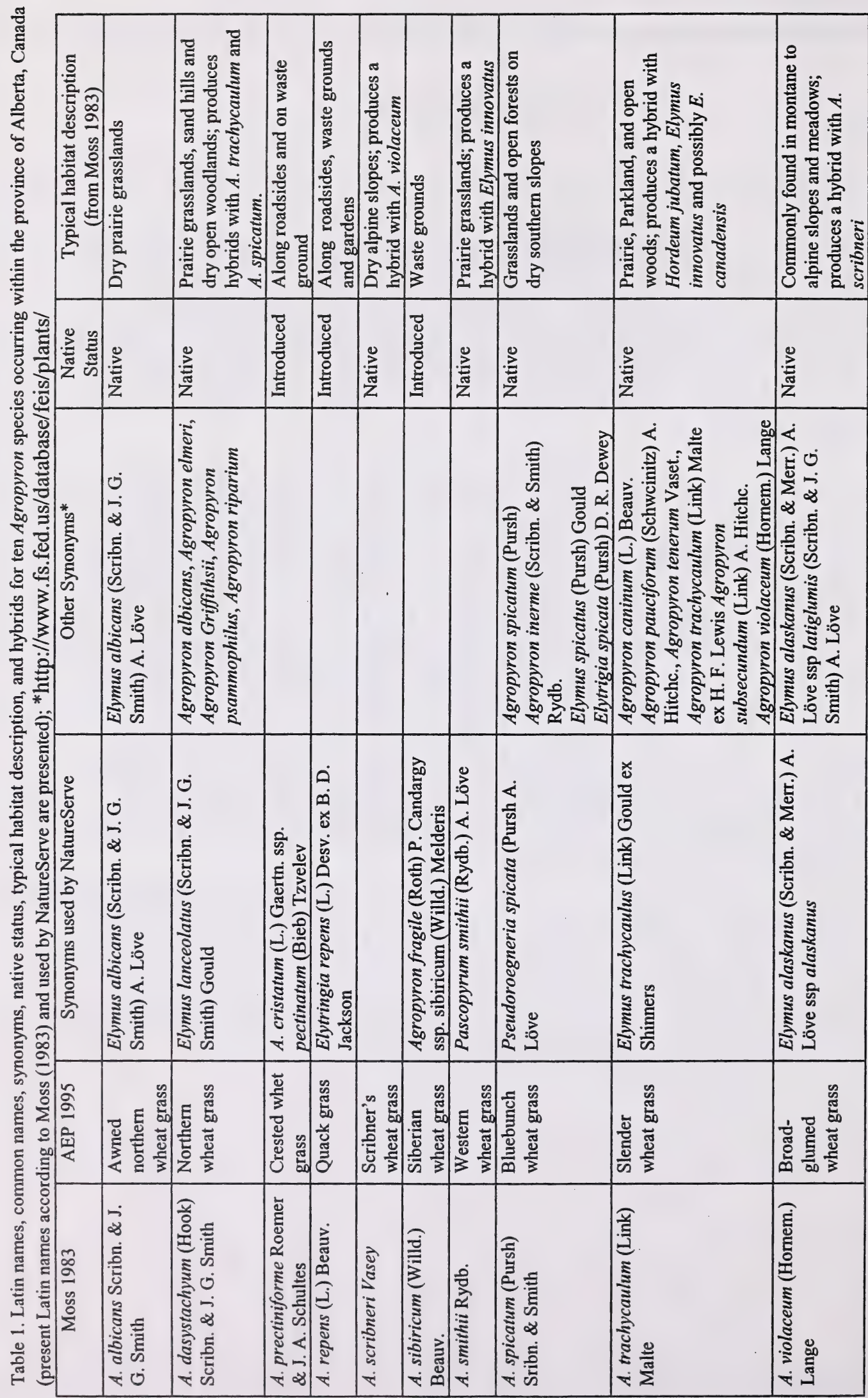

证 
At present, ANHIC's preliminary plant community tracking list contains the following Agropyron dominated communities, as well as communities where Agropyron does not dominate but is an important species (values in brackets signify provincial ranking):

Agropyron albicans - Artemisia frigida (SU);

Elymus lanceolatus (Agropyron dasystachyum) - Artemisia frigida (SU);

Elymus trachycaulus (Agropyron trachycaulum) - Carex atherodes (S1);

Pseudoroegneria spicata (Agropyron spicatum) (SU);

Pseudoroegneria spicata - Leymus innovatus (Elymus innovatus) - Aster conspicuous (SU)

Pseudoroegneria spicata - Festuca campestris (SU)

Spartina gracilis - (Pascopyrum smithii) (S2S3)

Danthonia unispicata - Elymus lanceolatus - Pascopyrum smithii (S3)

Carex spp. - Danthonia intermedia - Stipa curtiseta (S1)

\subsection{Project Objectives}

The overall goal of this project was to produce a synopsis of historical data on selected (native) Agropyron plant community types and to create a preliminary provincial classification of these community types. This information will be used to provide a better understanding of the plant community aspects of Alberta's biodiversity.

In order to meet the overall project goal, the following specific project objectives were developed:

- review and compilation of existing information from various sources (including existing field plot data, published literature, unpublished reports, consultations with knowledgeable individuals, etc.) on native Agropyron community types in Alberta;

- development of a comprehensive preliminary classification of Agropyron plant communities for each alliance or major vegetation type;

- cross-referencing of the proposed Agropyron community types to the community types described in other Alberta studies, and in adjacent provinces and states; 
- evaluation and assignment of a preliminary provincial ranking to each community type;

- identification of knowledge gaps;

- completion of a community characterization abstract for each community type, for inclusion in the ANHIC database; and

- production of a summary report. 


\section{METHODS}

\subsection{Collection of Background Information}

Following the Project Initiation Meeting in early September, Geowest staff obtained and reviewed all available existing information on potential native Agropyron communities in Alberta. Agropyron communities dominated by non-native species (Agropyron repens, A. pectiniforme and $A$. sibiricum) were not considered. In addition, project staff also undertook an exhaustive literature search of relevant Agropyron community types identified in other geographic jurisdictions including Saskatchewan, British Columbia, Montana, Washington, Colorado, Idaho and Utah. Summaries of the previously described Agropyron communities that are presented in the results section of this report contain only the original species names (both Latin and English) as they appear in the literature. No attempt was made to update taxonomy.

This review also involved discussions with knowledgeable experts in the field of grassland ecology (see References).

Geowest also reviewed the Ecological Site Inventory System (ESIS) electronic database provided by Alberta Environment, Resource Data Division, for information on Agropyron community types. The plot data was reviewed for floristic composition and habitat conditions. All pertinent data was utilized for community analysis.

\subsection{Development of Comprehensive Classification}

In order to provide a consistent and useable classification system, Geowest researchers developed a preliminary classification of Alberta's Agropyron communities for each alliance in a manner that is compatible with the classification system utilized by ANHIC. The classification was based on the attributes of the vegetation as well as environmental site factors. All procedures outlined in the publication International Classification of Ecological Communities: Terrestrial Vegetation of the United States: Volume 1 - The National Classification System: Development, Status, and Applications (Grossman et al. 1998) were followed. The hierarchical vegetation classification system outlined in this publication organizes terrestrial vegetation into seven different levels: 


\begin{tabular}{|c|c|c|}
\hline \multicolumn{2}{|c|}{ Hierarchical Levels } & Foundation of the classification within each level \\
\hline \multicolumn{2}{|c|}{ FORMATION CLASS } & $\begin{array}{l}\text { structure of the vegetation (e.g. forest, woodland, } \\
\text { herbaceous) }\end{array}$ \\
\hline \multicolumn{2}{|c|}{ FORMATION SUBCLASS } & $\begin{array}{l}\text { growth-form characteristics such as leaf phenology, } \\
\text { persistence and growth form (e.g. evergreen, } \\
\text { deciduous) }\end{array}$ \\
\hline \multicolumn{2}{|c|}{ FORMATION GROUP } & $\begin{array}{l}\text { Leaf characters such as broad-leaf or xeromorphic, in } \\
\text { combination with broadly defined microclimatic types }\end{array}$ \\
\hline \multicolumn{2}{|c|}{ FORMATION SUBGROUP } & $\begin{array}{l}\text { Further division into Natural, Semi-natural or a } \\
\text { Cultural Subgroup }\end{array}$ \\
\hline $\begin{array}{l}\text { physiognomic } \\
\text { levels }\end{array}$ & FORMATION & $\begin{array}{l}\text { Broadly defined environmental factors such as } \\
\text { relative landscape position or hydrologic regime }\end{array}$ \\
\hline \multirow[t]{2}{*}{ floristic levels } & ALLIANCE & $\begin{array}{l}\text { Group of plant associations sharing one or more } \\
\text { dominant or diagnostic species which must be found } \\
\text { in the uppermost stratum of the vegetation }\end{array}$ \\
\hline & ASSOCIATION & $\begin{array}{l}\text { The names of dominant and diagnostic species; } \\
\text { species within same stratum are separated by hyphen ( } \\
\text {-), while a slash ( / ) separates those occurring in } \\
\text { different strata. }\end{array}$ \\
\hline
\end{tabular}

The ASSOCIATION is the finest level of the hierarchy and is defined as a plant community with a definite floristic composition and uniform physiognomy, occurring on uniform habitat conditions (Grossman et al. 1998). "Habitat" is defined as the combination of environmental (site) conditions and ecological processes (such as disturbances) influencing the community (Grossman et al. 1998). The following example, which is pertinent to this project, is taken from the International Classification of Ecological Communities: Terrestrial Vegetation of the United States: Volume II - The National Classification System: List of Types (Anderson et al. 1998):

V. HERBACEOUS. Herbs (graminoids, forbs, and ferns) dominants (generally forming at lest $25 \%$ cover; trees, shrubs, and dwarf-shrubs generally with

less than $25 \%$ cover). Herb cover may be less than $25 \%$ where it exceeds tree, shrub, dwarf-shrub, and nonvascular cover, respectively.

V.A. Perennial graminoid vegetation (grasslands). Perennial graminoids generally contribute to greater than $50 \%$ of total herbaceous canopy cover when the cover of each of the other life forms present (i.e. tree, shrub, dwarf-shrub, nonvascular) is less than $25 \%$ and herbaceous cover exceeds the cover of the other life forms.

V.A.5. Temperate or subpolar grasslands

V.A.5.N.c. Medium-tall sod temperate or subpolar grasslands (includes sod or mixed sod-bunch graminoids) 


\section{ELYMUS LANCEOLATUS HERBACEOUS ALLIANCE}

Elymus lanceolatus - Phacelia hastata Herbaceous Vegetation Elymus lanceolatus - Stipa comata Herbaceous Vegetation

The data found in ESIS allowed for quantitative analysis using such techniques as clustering and ordination. Where sufficient data was lacking, Geowest researchers used qualitative procedures based on the comparisons of such factors as species composition and environmental conditions. These techniques were reviewed by the Project Monitor to ensure the thoroughness of statistical techniques and to obtain approval of the qualitative techniques. PC ORD4 and CANOCO software were used. Clustering allowed for a more objective classification of Agropyron communities based on species composition only, while ordination strengthened the classification by including environmental variables when available. It also provided the possible explanations for the distribution of Agropyron communities within Alberta.

Naming of plant community types follow standard procedures as outlined Grossman et al. (1998) and Anderson et al. (1998). Plant taxonomy follows Moss (1983) and Kartesz (1999) for scientific nomenclature and Alberta Environmental Protection (1993) for common names.

\subsubsection{Vegetation Data Analysis and Classification}

The majority of plot/species cover data for the quantitative data analysis was extracted from the Alberta Ecological Site Inventory System (ESIS) ASCI data file provided by Alberta Environment. Peter Achuff provided additional plots for Waterton Lakes National Park. Coarse filtration of the original ESIS database, which contained more than 10,000 plots resulted in 757 plots containing at least one of the Agropyron species with at least $4 \%$ ground cover. Additional plots were eliminated if contained introduced species of Agropyron only.

Consultation with Alberta Environment personnel resulted in the decision to concentrate on grassland communities only. Taking into consideration the Anderson et al. (1998) definition of grasslands "Perennial graminoid vegetation (grasslands). Perennial graminoids generally contribute to greater than 50\% of total herbaceous canopy cover when the cover of each of the other life forms present (i.e. tree, shrub, dwarf-shrub, nonvascular) is less than $25 \%$ and herbaceous cover exceeds the cover of the other forms" all plots that contained more than $25 \%$ of either tree, shrub or dwarf shrub cover, were removed. Because the shrub layer in ESIS database is separated on tall (S1) and low (S2) shrub layers according to the Ecological Land Survey Site Description Manual (CFS-LFS 1994), some adjustments had to be made prior to further filtration of the database. All shrub species in layer S2 were screened to decide whether or not they should be placed in the dwarf shrub layer. Anderson et al. (1998) provide the following definition for dwarf shrubs "low-growing shrub life form usually under $0.5 \mathrm{~m}$ (never exceeding 1 $m$ at maturity)". Various publications including Anderson et al. (1998), Field Manual for Describing Terrestrial Ecosystems (MOE and MOF 1998), database provided by Peter Achuff that separated shrub species into tall shrub, low shrub and dwarf shrub layer, and numerous books describing flora of Alberta and surrounding area were consulted to create the list of species that were assigned to the dwarf shrub layer for this project (Appendix 1). Low and tall shrub layers were than combined to be treated as one shrub layer. Removal of all tree, shrub and dwarf shrub dominated plots resulted in the creation of a database containing 432 plots and 714 species. 
An additional 16 plots were removed because they were clearly dominated by introduced species such as Bromus inermis, Poa pratensis, Taraxacum officinale, Phleum pratense and Trifolium spp., whose dominance most probably resulted from heavy disturbances or even deliberate introduction. This resulted in a further reduction of species to 708 .

Since the presence of a large number of species with low frequency in a database tends to distort multivariate community analysis and also makes data manipulation and analysis difficult, further reduction in the number of species was required. Therefore, species that appeared in less than 10 plots (ca $2 \%$ ) were queried and removed from the analysis.

The final version of the database contained 416 plots and 210 species. Further filtration of the database to exclude all plots that may not exactly follow the Anderson et al. (1998) definition of grasslands (i.e. graminoids contributing less than $50 \%$ of total herbaceous canopy cover, having more than $25 \%$ non-vascular cover) was not done prior to the cluster analyses to allow more objective clustering of potential communities. One additional adjustment of the species database had to be done prior to the cluster and ordination analyses. After the consultation with the Alberta Environment personnel, species code CAREPRE (stands for Carex preslii, a rare species in Alberta) was changed into CAREPRG (stands for a widespread species, Carex praegracilis). This change was necessary because a large number of occurrences and their distribution within Alberta of the CAREPRE from the ESIS database and the unusually small number of occurrences for Carex praegracilis indicated an error within the database.

The vegetation classification was not limited to potential or predicted climax communities but was rather applied to existing vegetation at any seral stage (see Braun-Blanquet 1965). Three different clustering methods (TWINSPAN, UPGMA and Furthest Neighbor Analysis) were employed to ensure that all species were considered in the classification, and to facilitate vegetation classification based on related plot data.

TWINSPAN is a polythetic divisive method of classification (Hill 1979, Kent and Coker 1992). It clusters both plots and species and constructs a two-way table from a plot-by-species matrix that are easier to interpret than the outputs of other clustering methods. It assumes that each group of plots can be characterized by a group of species that prevail on one side of the dichotomy (differential species). TWINSPAN ordinates samples by correspondence analysis (Hill 1973) and divides them into negative and positive sides of a dichotomy. Detailed procedures of clustering of species and plots and the construction of a species-by-plots table are given in Jongman et al. (1987).

The two additional clustering methods use a hierarchical agglomerative clustering that proceeds from individual samples or plots and progressively combines them based on their similarity until all samples are in one group (similarity analysis). Dissimilarity (D) is related to similarity (S) in the following way:

$$
\mathrm{D}=1-\mathrm{S}
$$

From eight similarity/dissimilarity measurements available in PC-ORD (version 4.0), the BrayCurtis dissimilarity coefficient was chosen to obtain a dissimilarity matrix (Legendre and 
Legendre 1983). The Bray-Curtis coefficient is a semimetric measure that uses data on species abundance to calculate the distance between plots. The formula for the Bray-Curtis coefficient is:

$$
\mathrm{D}_{(\mathrm{i}, \mathrm{h})}=\Sigma \mid \mathrm{X}_{\mathrm{ij}}-\mathrm{X}_{\mathrm{hj}} / / \Sigma\left(\mathrm{X}_{\mathrm{ij}}+\mathrm{X}_{\mathrm{hj}}\right)
$$

where $D_{(i, h)}$ represents the percentage difference between quadrats $i$ and $h, X_{i j}$ is the value of species $\mathrm{j}$ for quadrat $\mathrm{i}$, and $|\mathrm{X}|$ means the absolute value of quantity $\mathrm{X}$. The property of that distance measure is that a set difference contributes the same amount to the distance, whether it occurs between rare or abundant species. Bloom (1981) emphasized the ability of the Bray Curtis distance measure to identify accurately the true resemblance of plots along the entire range of species abundance. Numerous clustering methods available in PC-ORD4 were explored and the two with the lowest percent chaining (maximum information) were selected for the analyses (Unweighted Arithmetical Average Clustering - UPGMA and Farthest Neighbor). All three cluster analyses were carried out using the PC-ORD (Version 4.0) analysis program.

\subsubsection{Ordination of Agropyron Community Types Identified by Cluster Analysis}

To relate plant species composition of clusters determined by the classification analysis to the underlying environmental factors, a direct gradient analysis was performed (Whittaker 1967, Whittaker 1978). The preference for direct over indirect gradient analysis has been discussed in a number of publications (Legendre and Legendre 1983, Keddy 1991, Kent and Coker 1992). Environmental data found in the ESIS database provided a spatially discontinuous gradient (Keddy 1991), which can be used for a direct gradient analysis. The complexity of topographic and other environmental factors in space make the plant community pattern complicated and the relationships between plant species composition and underlying environmental factors obscure. Direct gradient analysis "disentangles" that spatially complex relationship and shows how patterns of species composition relate to environmental variables (Whittaker 1978). Detrended Canonical Correspondence Analysis (DCCA) was used to relate environmental variables to the plant species composition (Hill and Gauch 1980). This multivariate technique is an extension of Detrended Correspondence Analysis (DCA), with the restriction that canonical axes that are linear combinations of environmental variables replace axes from DCA. Detrended canonical correspondence analysis includes a multiple regression of the original plot scores on the environmental variables during the algorithm. Therefore, DCCA performs environmentally constrained ordinations of plots and species. Detrended canonical correspondence analysis was performed by CANOCO 3.1 .

All data points are necessary in order to run the direct ordination analysis, therefore, the ESIS database was examined for completeness of the data. The majority of variables had too many data points missing to be used in the analysis and only data for the following 7 variables was extracted to be linked through the ordination to the vegetation plot data: moisture, drainage, slope, aspect, elevation, latitude and longitude. Latitude, slope, and aspect data were used to calculate mean annual solar radiations for each plot by the Bonan method (Bonan 1989). Mean annual solar radiation combines the three variables into a more useful indicator of the microclimatic conditions at each particular site and was used in the analyses instead of slope, and aspect data. Latitude was retained in the analysis as a large scale, spatial variable. Only those plots representing Agropyron communities in the cluster analysis were used in the direct ordination analysis. Not all of these plots had all the required environmental data in the ESIS 
database. When data on latitude and longitude was missing, it was calculated from the legal description, if available. Missing altitude data for a number of plots was estimated from the NTS maps based on the positional data (latitude and longitude). After the removal of the plots with missing data, 127 plots were retained for the DCCA analysis. The first run of the analysis indicated 7 plots to be the outliers and they were removed from the final analysis. Species scores, sample (plot) scores, and biplot scores of the environmental variables that are produced as the DCCA output were then used to create a graphic representation of the results from the DCCA analysis. This was performed using SigmaPlot 2.1.

In addition to ordination, descriptive statistics (median, minimum, maximum) were calculated for environmental variables for each proposed Agropyron community type. These calculations were done in SPSS for Windows and included both variables used in the ordination and variables with a lot of missing data (soil drainage, site position - macro, site position - meso, nutrient regimes, $\%$ bedrock, $\%$ mineral soil, and $\%$ organic material. The information on natural subregion was taken directly from the GIS based on the geographical position of each plot. A list of values was presented instead of statistics for the natural subregion.

\subsection{Cross Referencing of Proposed Agropyron Community Types With the Literature and Analysis of Plot Data}

Based upon the review of existing information and the development of a preliminary comprehensive classification for Agropyron community types in Alberta, Geowest researchers developed two types of cross-reference tables. One type cross-references all of the proposed Agropyron community types with those previously identified for Alberta. These tables also include pertinent information from the classification based on the ESIS plot data. A second type cross-references proposed Agropyron community types with those identified in other jurisdictions, including Saskatchewan, British Columbia, Montana, Idaho, Washington and elsewhere. These tables allowed Geowest personnel to identify similarities and differences between community types and assisted in the identification of information gaps.

\subsection{Evaluation and Assignment of Preliminary Provincial Ranking}

Each community type identified was evaluated and given a provincial ranking. The ranking system is intended to help determine conservation priorities through the protection of the best example of all community types. ANHIC criteria guidelines were followed.

The methods for applying conservation rankings to communities is subjective. The relative importance of, and amount of information available for each of the ranking factors vary for each community. Ranks are assigned based on the best available information and are refined over time. The ranking system provides a reasonable estimate of the community rarity and threat, although some degree of error is inherent.

The communities were ranked according to their relative abundance similar to a system originally developed by The Nature Conservancy for ranking species (Grossman et al. 1994). They are ranked on a global, national and sub-national scale of 1 to 5. A rank of G1 (Global 1) indicates that a community is critically imperilled globally due to extreme rarity (five or fewer occurrences or very few remaining acres) or because some factor(s) make it vulnerable to extinction, and a 
rank of G5 (Global 5) indicates that the community is demonstrably widespread and abundant. Similarly, a rank of N1 (National 1) or S1 (Sub-National 1) suggests that the community is of high conservation concern at the national or provincial level, respectively.

The two major criteria for determining a communities ranking are the total number of occurrences and the total area (acreage) of the community range-wide. Measures of geographic range, trends in status (expanding or shrinking range), trends in condition (declining condition of remaining acreage), threats and fragility are secondary ranking factors that are considered when assigning a rank. The criteria used to assign a rank to a particular community are documented in Table 2, using a standardized format as follows:

Table 2. Community Ranking Guidelines (adapted from ANHIC 2001)

\begin{tabular}{|c|l|}
\hline Rank & \multicolumn{1}{|c|}{ General Criteria } \\
\hline S1 & $\begin{array}{l}\text { Five or fewer occurrences or very few remaining hectares, or some factor(s) exist } \\
\text { that make the community especially vulnerable to extirpation. }\end{array}$ \\
S2 & $\begin{array}{l}\text { Six to } 20 \text { occurrences or few remaining hectares or some factor(s) exist that make it } \\
\text { very vulnerable to extirpation throughout its range. }\end{array}$ \\
S3 & $\begin{array}{l}21 \text { to } 100 \text { occurrences; may be rare and local throughout its range or found locally, } \\
\text { even abundantly, in a restricted range, or vulnerable to extirpation throughout it } \\
\text { range because of some specific factor. }\end{array}$ \\
S4 & $\begin{array}{l}\text { Uncommon, but not rare, although it may be quite rare in parts of its range, } \\
\text { especially at the periphery; apparently not vulnerable in most of its range. }\end{array}$ \\
S5 & $\begin{array}{l}\text { Common, widespread and abundant provincially; although it may be quite rare in } \\
\text { parts of its range, especially at the periphery; not vulnerable in most of its range. }\end{array}$ \\
SU & $\begin{array}{l}\text { Unrankable; status is uncertain. } \\
\text { Historic; presumed eliminated in the province with little or no likelihood it will be } \\
\text { rediscovered; there may be potential for restoration. }\end{array}$ \\
SH & $\begin{array}{l}\text { Believed to be eliminated throughout the province with virtually no likelihood that } \\
\text { it will be rediscovered; no restoration potential due to extinction of dominant or } \\
\text { characteristic species. }\end{array}$ \\
SP & $\begin{array}{l}\text { Potentially exists; further documentation required. } \\
\text { Element is not yet ranked. }\end{array}$ \\
S?
\end{tabular}

Where information is incomplete rankings are estimated. Table 3 provides some typical ranks and normal variation in ranks, drawing upon the two major factors in element ranking, the estimated number of occurrences and the estimated overall area or acreage. 
Table 3. Preliminary Sub-national Community Ranking Guidelines (from Grossman et al. 1994)

\begin{tabular}{|c|cccc|}
\hline $\begin{array}{c}\text { Estimated } \\
\text { Provincial } \\
\text { Occurrences }\end{array}$ & \multicolumn{4}{|c|}{ Estimated Provincial Acreage } \\
\hline & $<2,000 \mathrm{ac}$ & $2,000-10,000 \mathrm{ac}$ & $10,000-50,000 \mathrm{ac}$ & $>50,000 \mathrm{ac}$ \\
\hline $\mathrm{A}(1-5)$ & $\mathrm{S} 1$ & $\mathrm{~S} 1$ & $\mathrm{~S} 1$ & $\mathrm{~S} 1$ \\
$\mathrm{~B}(6-20)$ & $\mathrm{S} 1(\mathrm{~S} 2)$ & $\mathrm{S} 2(\mathrm{~S} 1)$ & $\mathrm{S} 2(\mathrm{~S} 1)$ & $\mathrm{S} 2(\mathrm{~S} 1, \mathrm{~S} 3)$ \\
$\mathrm{C}(21-100)$ & $\mathrm{S} 2(\mathrm{~S} 1)$ & $\mathrm{S} 2(\mathrm{~S} 1, \mathrm{~S} 3)$ & $\mathrm{S} 3(\mathrm{~S} 2)$ & $\mathrm{S} 3(\mathrm{~S} 2, \mathrm{~S} 4)$ \\
$\mathrm{D}(>100)$ & $\mathrm{S} 2(\mathrm{~S} 1)$ & $\mathrm{S} 2(\mathrm{~S} 1, \mathrm{~S} 3)$ & $\mathrm{S} 3(\mathrm{~S} 2, \mathrm{~S} 4)$ & $\mathrm{S} 4(\mathrm{~S} 3, \mathrm{~S} 5)$ \\
\hline \multicolumn{5}{|c|}{$\begin{array}{l}\text { The preliminary ranks for communities are determined by considering the estimated acreage } \\
\text { and total number of occurrences province wide. Ranks in parenthesis indicate the acceptance } \\
\text { range of adjustments that can be made on secondary ranking criteria. }\end{array}$} \\
\hline
\end{tabular}

Secondary ranking factors such as trends in status, threats, range size, ecological fragility and similar considerations often shift the rank up or down one level (as indicated in Table 3). When data was insufficient to rank a community type, Geowest researchers outlined the steps necessary to acquire the needed data.

Each community was also assigned a confidence level based on the type and amount of information used to classify it (Table 4)

Table 4. Confidence Levels assigned to each community (adopted from Grossman et al. 1994)

\begin{tabular}{|l|l|}
\hline \multicolumn{1}{|c|}{ Confidence Level } & \multicolumn{1}{c|}{ Basis for the Classification } \\
\hline 1 - STRONG & $\begin{array}{l}\text { Recent, verified field data (includes both species and associated } \\
\text { environmental data); classification is a result of statistical analysis } \\
\text { of more than 10 samples; information is based on occurrences that } \\
\text { can be relocated. }\end{array}$ \\
\hline 2 - MODERATE & $\begin{array}{l}\text { Field data are of questionable quality; include limited number of } \\
\text { samples or have not been statistically analyzed. }\end{array}$ \\
\hline 3 - WEAK & Anecdotal information or community descriptions lacking data. \\
\hline
\end{tabular}

\subsection{Identification of Knowledge Gaps}

The amount and the quality of available information varied from community to community. As a result, some community types were difficult to rank at present due to incomplete or insufficient data. Based on the classification and cross-referencing with previously described communities within and outside the province, our project team identified information gaps and provided strategies to address these gaps. 


\subsection{Creation of Community Characterization Abstract}

For each community type identified within the study, a Community Characterization Abstract was completed according to ANHIC standards. Required fields with detailed description of all fields in the characterization abstract are presented in Appendix 2. 



\section{RESULTS AND DISCUSSION}

\subsection{Preliminary Classification of Agropyron Communities}

The preliminary classification of native Agropyron communities in Alberta involved a review of previously reported native Agropyron community types for Alberta and adjacent states and provinces, qualitative classification of selected ESIS and Waterton Lakes plots, and ordination of Agropyron community types identified by cluster analysis.

\subsubsection{Previously Reported Native Agropyron Community Types}

This section is organized into four Agropyron alliances - Agropyron spicatum, A. trachycaulum, $A$. dasystachyum and $A$. smithii. Within each alliance, references are further organized based on whether the communities occur in Alberta or adjacent States and provinces.

\subsubsection{Agropyron spicatum Alliance in Alberta}

The Agropyron spicatum community type was described for the Waterton Lakes National Park by Achuff et al. (1997) (Type H42) and is considered provincially rare (ranked SU) in the "Alberta Natural Heritage Information Centre Preliminary Plant Community Tracking List" (Allen 2000). This community is associated with subxeric to mesic, moderately sloping, easterly and southerly oriented sites, in the Lower Subalpine Subregion (elevation range: $1700-1900 \mathrm{~m}$ ) within the park (Achuff et al. 1997). Soils are well drained Brunisols and Regosols developed on fluvial, colluvial and morainal landforms. Agropyron spicatum dominates this successionally mature community (30 - 40\% cover) in association with other common grasses such as Bromus marginatus, Phleum pratense and Poa palustris. Main forbs include Achillea millefolium, Fragaria virginiana, Galium boreale and Penstemon confertus, in addition to some other common species such as Aster conspicuous, Campanula rotundifolia, Epilobium angustifolium, Hedysarum sulphurescens, Lathyrus ochroleucus and Thalictrum occidentale. Similar community types noted by Achuff et al. (1997) include Agropyron (Pseudoroegneria) spicatum from Colorado (cited from Baker 1982, Baker and Kennedy 1985) and Agropyron spicatum Festuca idahoensis from portions of the palouse prairie in Montana, Idaho, Washington and Oregon (cited from Anderson 1953, Doubenmire 1970, Hall 1973, Johnson and Clausnitzer 1992, Johnson and Simion 1987, Poulton 1955, Tisdale 1986).

Achuff et al. (1997) also described the Agropyron spicatum - Festuca scabrella community type (Type H27) for the Waterton Lakes National Park. This successionally mature community occurs on subxeric to mesic Foothills Parkland and Lower Subalpine sites in the park (elevation range: $1300-1700 \mathrm{~m}$ ), on gentle to steep slopes with mostly southerly aspects. Soils are developed on fluvial, colluvial and morainal landforms, and include Regosols and Black Chernozems. Agropyron spicatum and Festuca scabrella dominate with $15-40 \%$ and $25-40 \%$ cover, respectively. Other common species include Festuca idahoensis (5 - 15\%), Galium boreale (2 $10 \%$ ) and Anemone multifida (1\%). Erigeron caespitosus, Lupinus sericeus, Geranium viscosissimum, Potentilla fruticosa, and Potentilla gracilis are some of the frequent species. Tortula ruralis is the most common species of the bryoid layer, which generally covers more 
than 5\%. This community type differs from the aforementioned Agropyron spicatum community type by the combined dominance of Agropyron spicatum and Festuca scabrella and by occurring mainly in Foothills Parkland and Lower Subalpine Subregions (Achuff et al. 1997). It is also similar to the Danthonia spp. - Festuca scabrella - Koeleria macrantha (H25) community, from which it differs by the codominance of Agropyron spicatum and Festuca scabrella and a lack of Danthonia spp. (Achuff et al. 1997). The authors also suggested the similarity of the H27 community type to the Agropyron spicatum - Carex obtusata type from the Montane Subregion of southwestern Alberta (Willoughby et al. 1998), and to the Festuca scabrella - Agropyron spicatum community type from Montana (cited from Mueggler and Stewart 1980). The Agropyron spicatum - Festuca campestris ${ }^{1}$ community type is considered provincially rare (Allen 2000).

The Agropyron spicatum - Elymus innovatus - Aster conspicuous community type occupies small areas on dry, moderately steep southwest facing slopes, within the Montane and Lower Subalpine Subregions (elevation $1400 \mathrm{~m}-1700 \mathrm{~m}$ ) of Banff National Park (Type H19 in Corns and Achuff 1982). Soils are predominantly rapidly drained Orthic Regosols with xeric moisture regimes, developed on colluvial and glacial landforms. Shrub cover is low with Juniperus communis and Rosa acicularis occurring sporadically. Agropyron spicatum, Elymus innovatus and Koeleria cristata dominate the community $(15-30 \%, 10-30 \%$, and $3-10 \%$ cover, respectively) accompanied by common forbs such as Aster conspicuous, Oxytropis splendens, Antennaria nitida/rosea and Cerastium arvense ( $3-5 \%,<8 \%,<2 \%$, and $<2 \%$ cover, respectively).. Corns and Achuff (1982) reported that this successionally mature community is limited in extent to slopes above Hillsdale meadow in Banff and has been maintained by the dry conditions on southerly aspects. They also suggested that it resembles the Festuca scabrella - Agropyron spicatum grassland described for Montana by Mueggler and Stewart (1980), with Elymus innovatus in Banff substituting for Festuca scabrella in Montana. The Agropyron spicatum Elymus innovatus - Aster conspicuous community type is considered provincially rare (ranked SU) (Allen 2000).

Willoughby et al. (1998) recognized the Agropyron spicatum - Carex obtusata community type found on well-drained, south to westerly facing slopes (slope range: $0-65 \%$ ) within the Montane Subregion (elevation range: $1394-1848 \mathrm{~m}$ ) throughout southern Alberta. Soils are characterized by subxeric to submesic moisture regimes and submesotrophic to mesotrophic nutrient regimes. Amelanchier alnifolia and Symphoricarpos occidentalis are characteristic shrub species The dominant grass and sedge species, Agropyron spicatum, A. dasystachyum, Carex obtusata, Festuca scabrella, and Koeleria macrantha make up 17.0\%, 1.0\%, 3.0\%, 5.0\% and $9.0 \%$ of the canopy cover, respectively. Some of the dominant forb and dwarf shrub species include Lupinus sericeus, Arctostaphylos uva-ursi and Artemisia frigida. An increase in grazing pressure on the drier sites results in a decline of Agropyron spicatum and an increase of low growing forbs and sedges in this vegetation community (Willoughby et al. 1998). The author also notes similar communities from British Columbia described in Tisdale (1947), with the codominance of Agropyron spicatum with Artemisia tridentata at lower elevations, and fescue at higher elevations.

1 Pavlick, L. E., and J. Looman. (1984) revised the taxonomy and nomenclature of rough fescue, thereby dividing Festuca scabrella into three separate species, namely Festuca altaica, $F$. campestris ( $F$. scabrella var. major), and F. hallii 


\subsubsection{Agropyron spicatum Alliance Outside Alberta}

NatureServe (2000) provides the following summary on the Pseudoroegneria spicata

Herbaceous Vegetation: "This association typically occurs at elevations between 7200 - 9300 feet. It can occur on any aspect but is most likely found on southerly facing, nearly flat to gently sloping rock outcrops, mesas, plateaus and ridgetops. Although this association can occur on steeper surfaces, slopes generally do not exceed $15 \%$. Soils are rocky with an average $\mathrm{pH}$ of 7.9 . The predominant parent materials are sandstone and marlstone of the Uinta and Green River formations. The vegetation cover in this association is very thinly distributed with bare ground often exceeding $40 \%$. This association consists of a very sparse collection of graminoids and low-growing forbs. Artemisia frigida can occur in small amounts but for the most part a shrub layer is non-existent. Pseudoroegneria spicata occurs with $5-7 \%$ cover and Koeleria macrantha is repeatedly present in low abundance. The low-growing forbs that are consistently present with 1 - 5\% cover are Arenaria hookeri, Astragalus spatulatus, Draba oligosperma, Tetraneuris acaulis var. acaulis (= Hymenoxys acaulis), Lesquerella alpina, Paronychia sessiliflora, Phlox hoodii, Townsendia incana and Eriogonum lonchophyllum. There are no clear dominants in this list and the percent of each species present will vary from site to site. A diverse and abundant forb layer probably indicates a degraded occurrence (Rondeau pers. comm. 1998)". This community is also listed in Grossman et al. (1994), Bourgeron and Engelking (1994), as well as in Anderson et al. (1998) under Pseudoroegneria spicata Herbaceous Alliance.

Tisdale (1947) described Agropyron spicatum - Festuca scabrella community type for upper grassland zone in British Columbia. This community occupies relatively small area on the upper slopes of the main valleys, on altitudes ranging from $823 \mathrm{~m}-1005 \mathrm{~m}$. It is more common in Nicola and Okanagan Valleys. Soils occupied by this community type belong mainly to "Black Earth zonal group". Agropyron spicatum dominates throughout this community type, while Festuca scabrella varies in importance from site to site. Where the two species codominate, Festuca scabrella mainly occupies wetter, northern and eastern slopes. Other relatively abundant grasses include Koeleria cristata and Poa secunda. Important forbs include Achillea millefolium, Antennaria parvifolia, and Erigeron campestris. Agropyron spicatum - Festuca scabrella community type represents the climax vegetation, which become replaced by Stipa columbiana Poa pratensis or Poa secunda - Bromus tectorum community types as a result of grazing. Festuca scabrella - Pseudoroegneria spicata Herbaceous Vegetation described by NatureServe (2000) seems be the same vegetation type as Agropyron spicatum - Festuca scabrella type from British Columbia. It is found in the northwestern Great Plains on both level topography and steep slopes of all aspects, on loamy and moderately deep soils. It is heavily dominated by Festuca scabrella. Pseudoroegneria spicata is abundant while Festuca idahoensis is common. Other graminoids that may be found are Bouteloua gracilis, Muhlenbergia cuspidata, and Stipa comata. Forbs may include Heterotheca villosa, Liatris punctata, and Lupinus sericeus, and short shrubs Artemisia frigida and Gutierrezia sarothrae are also common (NatureServe 2000).

Pseudoroegneria spicata - Festuca idahoensis (Palouse) Herbaceous Vegetation was described for the Columbia Basin, central Washington, northwest Idaho and north-central Oregon (Grossman et al. 1994). The authors suggested that this association may occur in the southern British Columbia, as well. The General climate where this community occurs is characterized by moderately cold winters and warm to hot summers. The community occupies flat areas to steep slopes with northerly aspects. Soils are deep loams and silt loams of loess origin, over basalt bedrock. Pseudoroegneria spicata, Festuca idahoensis and Poa secunda var. secunda are the most abundant and diagnostic species. Pseudoroegneria spicata, and Festuca idahoensis contribute from $30 \%$ to $100 \%$ to the vegetation cover, while cover of Poa secunda var. secunda 
varies from $10 \%$ to over $45 \%$. Forbs cover less than $25 \%$ but their richness is high ( 46 species). More common and constant forbs include Achillea millefolium, Lithophragma glabrum, Lomatium triternatum and Calochortus macrocarpus. Shrubs are infrequent. Bromus tectorum increases its cover with increased grazing pressure. Pseudoroegneria spicata - Festuca idahoensis (Palouse) Herbaceous Vegetation is also listed in Tisdale (1982), in "The Preliminary Hierarchical Classification of the Vegetation of the Western United States" under the Pseudoroegneria spicata Alliance (Bourgeron and Engelking 1994), and under Pseudoroegneria spicata Herbaceous Alliance in "The International Classification of Ecological Communities: Terrestrial Vegetation of the United States" (Anderson et al. 1998) and in NatureServe (2000).

Pseudoroegneria spicata - Bouteloua gracilis Herbaceous Vegetation is the only vegetation type listed under the Pseudoroegneria spicata - Bouteloua gracilis Herbaceous Alliance in "The Status of Biodiversity in Great Plains: Great Plains Vegetation Classification" (Schneider et al. 1997), Anderson et al. (1998) and in NatureServe (2000). It is also listed in Tisdale (1982) and in Bourgeron and Engelking (1994) under the Pseudoroegneria spicata Alliance. Comer et al. (1999) described Pseudoroegneria spicata - Bouteloua gracilis Herbaceous Vegetation for Montana stands but notes the presence of the same community in Colorado. In Montana, this community occupies toeslopes of the foothills and steep slopes of valley bottoms. Soils are described as moderately deep $(40-100 \mathrm{~cm})$ and neutral in $\mathrm{pH}$. The vegetation is open $(40-60 \%$ cover) and dominated by Pseudoroegneria spicata, Stipa comata and Bouteloua gracilis. Cover of Bouteloua gracilis increases with increased grazing pressure. Associated species include Carex stenophylla, Koeleria macrantha, Poa sandbergii, Artemisia frigida, Phlox hoodii and Sphaeralcea coccinea. More productive sites contain Calamagrostis montanensis, Carex filifolia, Chrysopsis villosa and Liatris punctata. Additional species include Gutierrezia sarothrae, Opuntia polyacantha and Chrysothamnus nauseosus.

Comer et al. (1999) described Pseudoroegneria spicata - Pascopyrum smithii Herbaceous Vegetation for Montana and Wyoming. This association occurs on gently sloping areas to slopes as steep as $40 \%$, on all aspects. Soils are usually shallow and include sands, sandy loams, loams, and clays. Sites are often exposed to strong, persistent winds. Pseudoroegneria spicata dominates with Pascopyrum smithii and/or Elymus lanceolatus being secondary species (sometimes codominating with Pseudoroegneria spicata). Stipa comata, Koeleria macrantha and Poa secunda are present in small amounts, but Stipa comata may become a codominant (westcentral Montana). Some stands may have a substantial cover of Nassella viridula (Stipa viridula) (Great Plains). Others may contain Poa cusicki, Festuca kingii, Calamagrostis montanensis (foothills) and Bouteloua curtipendula (southeastern Montana and Wyoming). Forbs are of minor importance in this association and include Draba oligosperma, Erigeron compositus, Haplopappus acaulis, Heterotheca villosa, Sphaeralcea coccinea, Phlox hoodii, Tragopogon dubius and Vicia americana. Artemisia frigida and Gutierrezia sarothrae are also frequently present. The Pseudoroegneria spicata - Pascopyrum smithii Herbaceous Vegetation also appears in Tisdale (1982), in Bourgeron and Engelking (1994) under Pseudoroegneria spicata Alliance, as well as in Schneider et al. (1997), Anderson et al. (1998) and NatureServe (2000) under the Pseudoroegneria spicata Herbaceous Alliance.

Comer et al. (1999) described Pseudoroegneria spicata - Carex filifolia Herbaceous Vegetation for Montana and Wyoming. Stands occur on nearly level sites with loam and silt loam soils. Pseudoroegneria spicata dominates the community, Carex filifolia contributes substantially, and 
Bouteloua gracilis may also be present. Frequently present species (in Great Plains stands) include Stipa comata, Koeleria macrantha and Carex heliophila. Artemisia frigida and Gutierrezia sarothrae may also be present. NatureServe (2000) provides the following comments on the association classification: "This association seems to resemble very closely, in environment and vegetation, the more widespread Pseudoroegneria spicata - Bouteloua gracilis association, except that this association contains little or no Bouteloua gracilis. The geographic ranges of the two associations overlap, and it is unclear whether good reasons exist to differentiate the two". The Pseudoroegneria spicata - Carex filifolia Herbaceous Vegetation is also listed under the Pseudoroegneria spicata Alliance in Bourgeron and Engelking (1994), and under the Pseudoroegneria spicata Herbaceous Alliance in Schneider et al. (1997) and Anderson et al. (1998).

Comer et al. (1999) also described Pseudoroegneria spicata - Poa secunda Herbaceous Vegetation. The authors suggested that this association occurs in British Columbia, Washington, Oregon, Idaho, Utah, Colorado, Wyoming and Montana. Stands of this association occur on ridges and slopes of all aspects. Soils are well drained, often shallow, and frequently gravely or rocky, and include loams, silt loams and sandy loams. Wide geographical distribution indicates a wide range of climates and grazing regimes under which this association grows, therefore the composition of the vegetation varies. However, Comer et al. (1999) suggested a number of constant traits. Pseudoroegneria spicata dominates or codominates while Poa secunda and Koeleria macrantha are usually present in substantial amounts. Festuca idahoensis is usually absent. Stipa comata increases in importance with increased grazing pressure along with Bromus tectorum. Other common species include Artemisia tridentata, Chrysothamnus nauseosus and $C$. viscidiflorus. In southern British Columbia, eastern Washington and northeastern Oregon the undisturbed vegetation of this type consists mainly of Pseudoroegneria spicata and Poa secunda with minor importance of other species such as Lomatium macrocarpum, Draba verna, Artemisia frigida, and Gutierrezia sarothrae. In these communities, Stipa comata increases with increased grazing pressure. Many other variations in species diversity are described in Comer et al. (1999).

Tisdale (1982) summarized the classification of bunchgrass communities of western North America, and in addition to some of the Agropyron spicatum dominated communities described above, described the Agropyron spicatum - Poa secunda (Poa sandbergii) community type found in British Columbia, Oregon, Idaho, and Montana. The author compared stands described as the Agropyron spicatum - Poa sandbergii community type in different studies, and noted that aside from the two dominant species, Agropyron spicatum and Poa sandbergii, only Bromus tectorum, Achillea millefolium var. lanulosa, Balsamorhiza sagittata and Tragopogon (dubius/pratensis) were present throughout. Daubenmire (1970) described the Agropyron spicatum - Poa secunda community type and its lithosolic phase for Washington. The two dominant grasses characterize both community types. Chrysothamnus nauseosus and Plantago patagonica are listed as characteristic species for the Agropyron spicatum - Poa secunda community type, while Allium, Erigeron and certain species of Lomatium characterize the lithosolic phase. The lithosolic phase occurs on very shallow soil $(>35 \mathrm{~cm})$ over bedrock. Anderson et al. (1998) and Bourgeron and Engelking (1994) listed Pseudoroegneria spicata - Poa secunda Herbaceous Vegetation and its lithosolic phase under the Pseudoroegneria spicata Herbaceous Alliance and Pseudoroegneria spicata Alliance, respectively. The Pseudoroegneria spicata - Poa secunda Herbaceous Vegetation type is also listed under the Pseudoroegneria spicata Herbaceous Alliance in Schneider et al. (1997) and Anderson et al. (1998), and under the Pseudoroegneria spicata 
Alliance in Bourgeron and Engelking (1994). NatureServe (2000) provides the following comments on association classification: "Relationships between this association and several others are unclear. The Pseudoroegneria spicata - Balsamorhiza sagittata - Poa secunda Herbaceous Vegetation (CEGL001662) from Idaho and Oregon, apparently taken from Tisdale's (1986) Agropyron spicatum / Poa secunda / Balsamorhiza sagittata habitat type of western Idaho, is included here. The Pseudoroegneria spicata - Poa secunda (Lithosol) Herbaceous Vegetation (CEGL001678) of Idaho, Oregon, and Washington may be based on the lithosolic phase of Daubenmire's (1988) habitat type; this association presently includes that vegetation. If these types are to be considered separate associations, clear distinctions must be made between them".

Pseudoroegneria spicata - Koeleria macrantha Herbaceous Vegetation was described by Comer et al. (1999) based on one study in Montana. This type mainly occurs on gentle slopes of fans and outwash areas in the foothills of southcentral, southwestern and maybe central Manitoba. Pseudoroegneria spicata dominates with Koeleria macrantha being a weak-subdominant. Poa sandbergii, Pascopyrum smithii, Stipa comata, Bouteloua gracilis, and Artemisia frigida have high constancy but low cover. The authors questioned the validity of the classification for the Pseudoroegneria spicata - Koeleria macrantha Herbaceous Vegetation type based on the fact that this community resembles other described communities such as Pseudoroegneria spicata Poa secunda, Pseudoroegneria spicata - Bouteloua gracilis, or Pseudoroegneria spicata - Carex filifolia, and that distinction should not be based on the codominance of Koeleria macrantha, a widespread species with broad tolerance of soil types and a frequent associate of numerous other grass species. Pseudoroegneria spicata - Koeleria macrantha Herbaceous Vegetation also appears under the Pseudoroegneria spicata Herbaceous Alliance in Schneider et al. (1997) and Anderson et al. (1998), and under Pseudoroegneria spicata Alliance in Bourgeron and Engelking (1994).

Comer et al. (1999) described Pseudoroegneria spicata-Muhlenbergia cuspidata Herbaceous Vegetation for Montana. This community occurs in small patches on ridgetops and ridge shoulders on cool aspects. Soils are described as stony and poorly developed. Pseudoroegneria spicata and Muhlenbergia cuspidate codominate with combined cover of more than $50 \%$ on average. Other grass species with high constancy but low coverage include Bouteloua gracilis, $B$. curtipendula, Schizachyrium scoparium and Carex filifolia. Artemisia frigida, Gutierrezia sarothrae and Yucca glauca have high constancy. Phlox hoodii, Gaura coccinea, Liatris punctata and Echinacea angustifolia are frequently present. Pseudoroegneria spicata Muhlenbergia cuspidata Herbaceous Vegetation is also listed under the Pseudoroegneria spicata Herbaceous Alliance in Schneider et al. (1997) and Anderson et al. (1998), and under the Pseudoroegneria spicata Alliance in Bourgeron and Engelking (1994).

NatureServe (2000) provides the following summary and classification comments on Pseudoroegneria spicata - Cushion Plant Herbaceous Vegetation: "This association is found in the Tendoy Mountains in southwestern Montana and the Pryor Mountains and adjacent Bighorn Canyon area in south-central Montana. In the Pyror Mountains this type occurs at foothill elevations between 1250 $1680 \mathrm{~m}$ ( 4100 - 5500 feet). In the Tendoy Mountains it has been documented from $2580 \mathrm{~m}$ ( 8450 feet) elevation, but is noted in reconnaissance from $2075-2685 \mathrm{~m}$ ( $6800-8800$ feet) elevation. This vegetation occurs on moderately deep gravelly soils from limestone or calcareous sandstone of mesas, ridgetops and saddles and the upper slopes of outwash plains. The primary influencing environmental factor is wind; in most examples of this type wind deflation has produced a gravel paved surface. This herbaceous type is characterized by the presence of short stature, compact cushion plants of the genera Arenaria, Hymenoxys, Phlox, Cryptantha, Eriogonum and in the Bighorn region, Sphaeromeria capitata. Pseudoroegneria spicata is present at relatively low canopy cover...... This type was described by 
DeVelice and Lesica (1993) as the Agropyron spicatum / cushion plant community type but no clear vegetational parameters were described for the type; in their key this was a default type dropping out at the bottom of the key. To incorporate this type into a comprehensive classification a means of treating the "cushion plant" component would have to be found. It would be a first step to name the various cushion plants that could serve as alternative diagnostic species and also specify what species would not be expected due to severity of these sites. "Pseudoroegneria spicata - Cushion Plant Herbaceous Vegetation was also noted by Bourgeron and Engelking (1994) and Anderson et al. (1998).

Tisdale (1982) listed the Agropyron spicatum - Opuntia polyacantha community type identified for Idaho by the author and his students.

NatureServe (2000) provides the following summary and classification comments on Pseudoroegneria spicata - Opuntia polyacantha - (Poa secunda) Herbaceous Vegetation: "This plant association is described from sites within the Hells Canyon region of the Blue Mountains ecoregional section. The association occurs on the harshest sites occupied by Pseudoroegneria spicata-dominated plant communities. These are moderately steep to steep, south-southeast- to south-southwest-facing slopes in mid- to upper-slope positions. Stands occur at (800) 1800 to 3700 feet elevation. Stands are typically open, with well spaced Pseudoroegneria spicata bunches. Opuntia polyacantha, Erigeron pumilus, and Scutellaria angustifolia are principal forb species. Bromus tectorum and Bromus japonicus are often present. The vegetation is described as Agropyron spicatum - Poa secunda / Opuntia polyacantha by Johnson and Simon (1987). Tisdale (1986) identified the vegetation as Agropyron spicatum / Opuntia polyacantha. The two classification units are identical in composition and function". Pseudoroegneria spicata -Opuntia polyacantha - (Poa secunda) Herbaceous Vegetation was also listed in Anderson et al. (1998) and Bourgeron and Engelking (1994).

The following additional communities are listed under the Pseudoroegneria spicata Herbaceous Alliance in Anderson et al. (1998) and Schneider et al. (1997), and under Pseudoroegneria spicata Alliance in Bourgeron and Engelking (1994): Pseudoroegneria spicata - Oryzopsis hymenoides Herbaceous Vegetation; Pseudoroegneria spicata - Stipa comata Herbaceous Vegetation. In addition to these, the following communities are listed only in Anderson et al. (1998) and Bourgeron and Engelking (1994): Pseudoroegneria spicata ssp. inermis Herbaceous Vegetation; Pseudoroegneria spicata - Balsamorhiza sagittata - Poa secunda Herbaceous Vegetation; Pseudoroegneria spicata - Festuca idahoensis Canyon Herbaceous Vegetation.

Bourgeron and Engelking (1994) also listed Pseudoroegneria spicata - Aristida longiseta Sporobolus cryptandrus association under Aristida longiseta Alliance. The same authors also suggested the possible existence of the Pseudoroegneria spicata-Eriogonum ovalifolium community type, but noted that there was no quantitative documentation for these communities.

\subsubsection{Agropyron trachycaulum Alliance in Alberta}

The Agropyron trachycaulum community type was described for very xeric to xeric, steep southfacing slopes $\left(40-48^{\circ}\right)$ of the Silver Valley study area situated within the Peace River Parkland Subregion (Rintoul 1985). Soils are rapidly to well drained Orthic Regosols and Orthic Eutric Brunisols (clay loam to sandy loam texture). Unvegetated surface varies from $30-75 \%$. Agropyron trachycaulum dominates this community, while other common species include Artemisia frigida, Koeleria macrantha, Vicia americana and Allium cernuum. A similar community occurs in the same area on well-drained moderately steep, south facing slopes, where it becomes dominated by low shrubs such as Symphoricarpos occidentalis, Rosa spp. and Prunus virginiana (Rintoul 1985). The author considered the later community a subtype of the 
Agropyron trachycaulum community type for this study area. Adams et al. (1997) also noted the Agropyron trachycaulum community type for the Suffield National Wildlife Area situated within the Dry Mixedgrass Subregion. This community occurs on well to imperfectly well drained, sandy loam to silty loam soils of lower terraces. No details on the vegetation composition have been provided. Raup (1935) described an A. trachycaulum var. unilaterale dominated grassland community for the Peace Point area in Wood Buffalo National Park. This community occurs on clay loam soils about $60 \mathrm{~cm}$ deep, with some glacial boulders. An assemblage of perennial forbs characterizing these grasslands includes Geum triflorum, Stachys scopulorum, Geum macrophyllum var. perincisum, and Galium boreale. Equisetum pratense, Bromus pumpellianus, Schizachne purpurascens and Calamagrostis spp. are some of the secondary species.

Fairbarns (1990) described a dry meadow community type dominated by Agropyron trachycaulum and/or Hierochloe odorata in the Boreal Region of northwestern Alberta (Child Lake, High Level and Hay River). These community types occupy the wettest and least saline end of the moisture and salinity gradients characterizing saline meadows of northwestern Alberta. Carex spp., Rosa acicularis and Symphoricarpos albus are some of the more abundant species, while Achillea millefolium, Agrostis scabra, Antennaria parviflora, Astragalus dasyglottis, Galium boreale, Geum triflorum, Hieracium umbellatum, Lactuca pulchella, Viola adunca and some halophytic species represent some of the less abundant species characterizing this community type.

Moss (1952) described the Agropyron - Stipa faciation, a prevalent subtype (climax type) of the Agropyron - Stipa - Carex community, for the moderately dry slopes and certain flat mesic grasslands in the Peace River Region ${ }^{2}$. Sites are quite variable and include rocky grounds of an old moraine, well drained alluvial soils, level areas with heavy textured black soils developed on silty flood plains of streams, and black loam of silty to clay mixture with a "solodized solonetz type of profile", developed on lacustrine or alluvial-lacustrine material. This faciation is characterized by the dominance of grass and sedge species such as Agropyron trachycaulum, Stipa curtiseta, Koeleria cristata and Carex obtusata, accompanied by numerous forb species such as Galium boreale, Achillea millefolium and Thalictrum venulosum. Stipa richardsonis, Danthonia intermedia, Agropyron dasystachyum, Carex praticola, C. siccata, and some shrubby species (e.g. Amelanchier alnifolia) may become locally abundant. Although recognizing it's relatively high local variability in species composition related to the differences in local microclimatic and edaphic conditions, as well as disturbance regimes, the author emphasized remarkable constancy of the main floristic features of the Agropyron - Stipa faciation throughout the region. Wilkinson (1981) called this community type Carex spp. - Danthonia intermedia Stipa curtiseta; it is currently on the community tracking list (ranked S1). Western Rangeland Consultants (1999) confirmed the presence of the aforementioned community northeast of Grande Prairie, but indicated that the majority of these grasslands have been lost within the last 50 years due to farming practices. Wallis (1982) suggested that the upland grasslands of the Peace River, which are the edaphic climax on Solonetzic soils, should be classified as Agropyron trachycaulum var. unilaterale - Stipa spartea-Danthonia intermedia - Carex type. 
Redmann and Schwarz (1986) described the similar grassland community for the Peace Point area in Wood Buffalo National Park. This community occupies relatively flat areas with Orthic Cumulic Regosols of sandy-loam texture, developed on glaciolacustrine sediments. Agropyron trachycaulum $(20.8 \%$ cover) and Stipa columbiana $(9.7 \%$ cover) dominate the herb layer. $S$ comata, S. curtiseta, Artemisia frigida and Galium boreale are some of the additional grass and forb species characterizing these grasslands. Heavy grazing in Agropyron - Stipa community type results in a decrease of cover of leading grass species and an increase of other species, particularly Carex obtusata (Moss 1952; Redmann and Schwarz 1986). Redmann and Schwarz 1986 compared grasslands from the Peace Point area in Wood Buffalo National Park with those described for the Peace River region by Moss (1952). They concluded that the Peace River sites are closer in species composition to the Stipa faciation than to the Agropyron - Stipa faciation, and explained it by the drier and non-solonetzic soil nature characterizing the Peace Point grasslands. Moss (1955) suggested that the Agropyron - Stipa grasslands in the Peace River region differed considerably from the Mixed Prairie (Stipa - Bouteloua) association by lacking Bouteloua gracilis and Stipa comata, and from the Festuca scabrella association by the absence of Festuca scabrella, thereby proposing the Agropyron - Stipa association as an eighth association in the Grassland Formation of North America.

Schwarz and Wein (1997) described the Agropyron trachycaulum - Poa glauca - Galium boreale community type for level terrain along the Peace River at Peace Point, Wood Buffalo National Park. Soils inhabited by these grasslands are Cumulic Regosols. In addition to the three dominant species, grasses such as Stipa curtiseta, S. viridula, S. comata and Koeleria macrantha represent important elements of this community type (Schwarz 1994, Schwarz and Wein 1997). Timoney (1999) commented on the classification of dry grasslands within Wood Buffalo National Park by Schwartz and Wein (1997), and suggested that dry grasslands in Wood Buffalo National Park belong predominantly to the Agropyron - Stipa association (Peace River Prairie) as classified by Moss $(1952,1955)$.

The Agropyron - Carex faciation was another community subtype of the Agropyron - Stipa Carex community type described by Moss (1952) for the Peace River region of Alberta. This community is more sporadic than the Agropyron - Stipa faciation, occupying only a shallow basin fed by slope seepage (north of Fort Vermilion and east of the Caribou River, near the base of the Caribou Mountains). It occupies flood plain sites with fertile black loam soils $(5-10 \mathrm{~cm})$ over silty subsoil, as well as deposits of fine sand and clay. Somewhat modified versions of this community occur along the Boyer River on the deposits of fine sand and clay, in Buffalo Prairie on silty flood plain sites, and near the Keg River (Moss 1952). Agropyron trachycaulum and Carex atherodes dominate, accompanied by other grass and forb species such as Carex praticola, Calamagrostis spp., Bromus spp., Solidago lepida and Vicia americana. Symphoricarpos occidentalis, Symphoricarpos albus and Rosa woodsii are frequent species in the shrub layer. Symphoricarpos occidentalis, Rosa woodsii and Carex atherodes become more abundant under modified (grazed) conditions. The Elymus trachycaulus (Agropyron trachycaulum) - Carex atherodes community type is considered provincially rare (Allen 2000).

The Agropyron trachycaulum - Carex spp. / Fragaria virginiana community type was noted on mesic to subhygric, moderately well drained soils with mesotrophic nutrient regimes within the Upper Foothills Subregion (1400 - 2438 masl) (Willoughby and Smith 1999). It represented a degradation of a Festuca scabrella - Deschampsia caespitosa community type and is very 
common in valley bottoms in areas with heavy grazing. The dominant grass and sedge species are Agropyron trachycaulum, Carex praegracilis, Bromus ciliatus and Elymus innovatus. On average, they contributed $26.0 \%, 21.0 \%, 9.0 \%$ and $5.0 \%$ to the canopy cover, respectively. Some of the dominant forbs, Fragaria virginiana, Potentilla gracilis, Achillea millefolium and Aster ciliolatus, made up $12.0 \%, 9.0 \%, 8.0 \%$ and $5.0 \%$ of the canopy cover, respectively.

The Agropyron trachycaulum - Distichlis stricta community type was described for eroded Solods and saline seeps on glacialacustrine materials at the Salt River escarpment in Wood Buffalo National Park (Schwarz 1994, Schwarz and Wein 1997). Sites occur on southerly aspects at approximately 210 masl. Soils are moderately fine textured and rapidly drained, Dark Brown Solods and saline Regosols. A relatively small number of species, including Symphoricarpos occidentalis, Agropyron trachycaulum, Distichlis stricta, Koeleria macrantha, Spartina gracilis, Poa juncifolia and Carex siccata, characterizes this community.

Roup (1935) described the Agropyron trachycaulum - Koeleria cristata community type for the salt plains of Wood Buffalo National Park. This community was reported from an area about two miles south of Heart Lake, on nearly level terrain. Subdominant species include Juniperus horizontalis, Hierochloe odorata, Deschampsia caespitosa, Danthonia intermedia, Schizachne purpurascens and Agrostis scabra. The author emphasized the striking similarity of this prairie community to the Peace Point prairie and a prairie found at the base of the Caribou Mountains (in a few places, the Calamagrostis canadensis - Carex trichocarpa community type from the base of Caribou Mountains was characterized by the nearly pure stands of Agropyron trachycaulum). The Agropyron trachycaulum - Koeleria cristata community type as described by Raup (1935) may no longer exist in Wood Buffalo National Park (Art Schwarz - personal communications).

The Agropyron trachycaulum - Festuca ovina - Poa palustris - Equisetum arvense community type occupies sand beaches at Shelter Point, Athabasca Lake (Raup 1928). Dominant species include Agropyron tenerum, Festuca ovina, Poa palustris, Equisetum arvense. Secondary species include Sisyrinchium angustifolium, Rumex altisimus, Corydalis aurea, Potentilla monspeliensis, Rubus idaeus var. canadensis, and Epilobium angustifolium.

Langevin (1973) listed the Agropyron - Festuca community type for the Kleskun Hills area, situated within the Peace River Parkland Subregion. The author did not provide details on the species composition or the type of habitat where this community occurs.

\subsubsection{Agropyron trachycaulum Alliance Outside Alberta}

Elymus trachycaulus Herbaceous Vegetation was described for a wet meadow area within Sheridan County, Montana (Heidel et al. 2000). Elymus trachycaulus dominates with approximately $70 \%$ ground cover. Some other grasses that contributed more than $1 \%$ to the cover include Muhlenbergia richardsonis and Panicum virgatum, and the most abundant herb is Helianthus nuttallii.

The Elymus trachycaulus - Muhlenbergia richardsonis community type was described by Thieret (1959) who studied grassland vegetation near Fort Providence, Northwest Territories. Only one site is occupied by this community. Dominant species were Agropyron trachycaulum var. glaucum, A. trachycaulum var. novae-angliae, and Muhlenbergia richardsonis. Some of the 
frequent species included Hordeum jubatum, Carex praticola, Stellaria longipes, Potentilla pensylvanica, Vicia americana, Gentiana amarella, Castilleja raupii, Achillea lanulosa, Antennaria subviscosa and Senecio pauperculus. The Agropyron - Muhlenbergia community was also described by Dodd and Coupland (1966) for saline, Calcareous Chernozemic soils of Saskatchewan. Unidentified species of Agropyron and Muhlenbergia richardsonis dominated this community type, accompanied by other species such as Distichlis stricta, Carex spp., Calamagrostis montanensis, Spartina pectinata, Juncus ater, Eleocharis palustris, and Festuca scabrella. Frequent forbs include Grindelia squarrosa, Solidago nemoralis, Achillea lanuginose, Crepis glauca, Suaeda erecta, Helianthus petiolaris, Aster ericoides and Glycyrrhiza lepidota.

Heidel et al. (2000) described another prairie association dominated by Elymus trachycaulus within Sheridan County, Montana, the Elymus trachycaulus - Distichlis spicata Herbaceous Vegetation. This is a wet meadow found on soils with high clay content, which are associated with alkali lakes.

Elymus trachycaulus - Spartina gracilis Herbaceous Vegetation is yet another plant community described by Heidel et al. (2000) for Sheridan County, Montana. This community occupies temporarily inundated wet meadows associated with a series of wetlands and an alkaline lake. The authors suggested that further documentation is needed for the Elymus trachycaulus dominated communities.

\subsubsection{Agropyron dasystachyum Alliance in Alberta}

Jaques and vanEck (1979) described the Agropyron dasystachyum community type on very dry and steep southeast to southwest facing slopes in the Kakwa Falls Region (study site located ca. $160 \mathrm{~km}$ south of Grand Prairie, $50 \mathrm{~km}$ northwest of Grande Cache). Agropyron dasystachyum dominates in undisturbed conditions accompanied by other abundant grass and forb species such as Agropyron caninum var. andinum, Carex obtusata, Calamagrostis purpurascens, Koeleria cristata, Poa interior, Stipa spartea, Stipa occidentalis var. minor, Allium cernuum, Artemisia frigida, Cerastium arvense, and Vicia americana. Selaginella densa, Potentilla arguta and Potentilla hippiana were some of the less abundant, but characteristic species of this community type. Symphoricarpos occidentalis dominates the shrub layer, rarely exceeding $10 \%$ in cover. Willoughby (1999) found a similar community type associated with steep south facing slopes (30 $-60 \%$ ), with shallow soils, at lower elevations within the Subalpine Subregion of Alberta (elevation range 1220 - $1859 \mathrm{~m}$ ). Soils are rapidly drained, with subxeric to xeric moisture regimes and submesotrophic nutrient regimes. Agropyron dasystachyum contributes on average $30 \%$ to the ground cover. Koeleria cristata, Phleum commutatum, Carex obtusata, Elymus innovatus, Thalictrum occidentale, Epilobium angustifolium and Arctostaphylos uva-ursi are present at low cover values. The Agropyron dasystachyum community type described by Wallis and Wershler (1981) for the Kootenay Plains area occurs in only one, moderately well drained, level, mesic site, at the toe position of an alluvial fan. In this community, Agropyron dasystachyum contributes $26-50 \%$ to the ground cover. Other major species included Geum triflorum, Linum lewisii and Stellaria longipes. Koeleria macrantha, Agoseris glauca, and Campanula rotundifolia are present with low cover values. Agropyron dasystachyum dominated community has also been described for very steep slopes $(60-90 \%)$ with northerly aspects in the Suffield National Wildlife Area situated within the Dry Mixedgrass Subregion (Adams et al. 1997). Soils are sandy loam textured and developed on the fluvial materials. Agropyron 
dasystachyum contributes on average $35 \%$ to the ground cover, while Amelanchier alnifolia, Artemisia cana, A. frigida, Koeleria macrantha, Anemone patens, Gutierrezia sarothrae and Comandra umbellata are present with much lower cover values.

The Agropyron dasystachyum - Festuca saximontana community type was described for the Montane Subregion of Alberta (elevation range 1220 - $1859 \mathrm{~m}$ ) for dry, steep (slope range 5 $65 \%$ ), south facing slopes in the river valleys near Banff and Jasper (Willoughby et al. 1998). Soils are rapidly drained with subxeric moisture regimes and submesotrophic nutrient regimes. Agropyron dasystachyum and Festuca saximontana contribute on average $34 \%$ and $2 \%$ to the canopy cover, respectively. Other important species are Koeleria macrantha, Elymus innovatus, Achillea millefolium, Antennaria parviflora and Lupinus sericeus. Amelanchier alnifolia dominates the shrub layer ( $4 \%$ cover).

The Northern Wheat Grass - Sand Grass community type was reported by Adams et al. (1997) from the Suffield National Wildlife Area. This community represented a minor vegetation component on well drained, sandy Orthic Brown Chernozems developed on fluvial materials within broad ravines with relatively low-angle side slopes.

Adams and Moisey (1999) described the Northern wheat grass - Western wheat grass community type for moderately well to well drained Solonetzic soils in the Milk River Natural Area and the Kennedy Coulee Ecological Reserve, situated within the Dry Mixedgrass Subregion. Soils include Brown Solodized Solonetz and Brown Solonetz, with minor importance of Brown Solods, Brow Chernozems and Orthic Regosols. Besides the two dominant grasses, additional species included pasture sagewort, blue grama, needle-and thread, Kentucky bluegrass and June grass.

Adams (1981) identified a rangeland type dominated by northern wheat grass, western wheat grass, upland sedge, June grass and fringed sage for steep, unstable mid-slopes with southerly aspects in the Peace River and Clear River canyons in the Dry Mixedwood Subregion. Soils are Orthic Regosols with silt loam textures, developed on morainal and colluvial materials. Snowberry, Saskatoon and rose intersperse the grassland. The author noted that this type represents rangeland in good condition, whereas the same vegetation community became dominated by western porcupine grass, green needle grass, fringed sage and upland sedge, when in excellent condition (lower grazing pressure).

The Agropyron dasystachyum - Artemisia frigida community type was described for Jasper and Banff National Parks by Corns and Achuff (1982). These grasslands occur within the Montane Subregion (elevation range $1040-1640 \mathrm{~m}$ ) on xeric, generally steeply sloping sites with southerly aspects. Soils are rapidly to well drained and include Orthic Eutric Brunisols and Orthic Regosols developed on colluvial, glacial, and fluvial materials. Agropyron dasystachyum dominates the community (5 - 50\% cover) with lesser amounts of Artemisia frigida (1-10\%), Koeleria cristata $(2-10 \%)$ and Achillea millefolium ( $<5 \%)$. The unvegetated ground reaches up to $50 \%$. Rintoul (1985) described a similar community type for the Silver Valley study site situated within the Dry Mixedwood Subregion. It occurs on very xeric to xeric, moderate to steep south and southwest facing slopes. Soils are rapidly to well drained Orthic Regosols and Orthic Eutric Brunisols with clay loam or sandy loam textures. In addition to Agropyron dasystachyum, Artemisia frigida and Koeleria macrantha, other grass and forb species that occur include Stipa 
spartea, Allium cernuum, Astragalus agrestis, Crepis tectorum and Linum lewisii. Noteworthy species of this community are Lomatium foeniculaceum and Opuntia fragilis, species more commonly found in southeastern Alberta. Beckginham et al. (1996) described a grassland community from the Montane Subregion dominated by Artemisia frigida, Koeleria macrantha, Agropyron dasystachyum, Calamagrostis purpurascens, Poa pratensis, Carex spp. and Linum lewisii. This community occurs on upper slopes with southerly, westerly and easterly aspects, as well as on near level terrain. Soils are xeric to mesic and include Orthic Regosols and Orthic Eutric Brunisols and numerous others.

The Agropyron dasystachyum - Koeleria macrantha / Artemisia frigida community type has been described for south and west facing slopes (slope range $10-90 \%$ ) along the banks of the Peace, Smoky and Wapiti rivers throughout the Dry Mixedwood Subregion (elevation range 345 - 606 $\mathrm{m})$ (Willoughby et al. 2000). Soils are very rapidly drained with xeric-subxeric moisture regimes and submesotrophic nutrient regimes. Wallis and Wershler (1981) described this community type for well drained, submesic alluvial fans in the north and central portions of the Kootenay Plains area situated within the Montane Subregion. This community occupies a variety of slopes and aspects, but generally occurs on near level terrain on alluvial fans. In addition to the three dominant species, Agropyron dasystachyum (10\%), Koeleria macrantha (5\%), and Artemisia frigida (6\%), this community type from the Dry Mixedwood Subregion is characterized by species such as Carex spp. Agropyron trachycaulum, Stipa richardsonis (Willoughby et al. 2000). Amelanchier alnifolia (6\%) and Rosa acicularis (3\%) are the dominant shrubs in the shrub layer. In the Kootenay Plains area, the community is generally forb poor. Bare ground occupies up to $50 \%$ of the area (mineral soil $0-40 \%$, angular detritus $5-50 \%$ ). The moss layer reaches up to $30 \%$ ground cover. Agropyron dasystachyum, Koeleria macrantha and Artemisia frigida contribute $6-75 \%, 6-25 \%$ and $6-25 \%$, to the ground cover, respectively. Antennaria nitida occurs sporadically, mainly in wetter depressions, an all stands. Additional frequent species include Astragalus striatus, Linum lewisii, Orthocarpus luteus, and Erigeron caespitosus. This community is frequently grazed by wapiti and horses (Wallis and Wershler 1981).

Wallis and Wershler (1981) also described the Agropyron dasystachyum - Koeleria macranthaArtemisia frigida - Antennaria nitida community for the Kootenay Plains. It occurs on moderately well to well drained, mesic to submesic sites on alluvial fans in the south-central portion of the area. It occupies depressions, and nearly level sites $(1-35 \%)$ at the toe or upper slopes of alluvial fans. Unvegetated ground surface reaches up to $40 \%$ (mineral soil 5 - $30 \%$, angular detritus $<5-20 \%$ ). Moss cover varies between $2 \%$ and $20 \%$. It is a forb poor community. Some grazing was observed. Agropyron dasystachyum, Koeleria macrantha, Artemisia frigida and Antennaria nitida contributed 6-50\%, 1-15\%, $6-25 \%$, and $6-25 \%$ to the ground cover, respectively. Astragalus striatus, Linum lewisii, Oxytropis splendens, Orthocarpus luteus, Campanula rotundifolia, and Erigeron caespitosus are frequently occurring species. Astragalus striatus and Aster alpinus are locally abundant. Haplopappus uniflora was a significant species of this community.

The Agropyron dasystachyum - Poa pratensis community type was described by Willoughby et al. (1998) for only one site above the Oldman River in the Outer Gap Range Allotment in the Montane Subregion of Alberta (elevation $1545 \mathrm{~m}$ ). The Outer Gap range is subjected to extremely strong desiccating winds. This community occupies dry, moderately to heavily grazed, 
south facing slopes (slope 15\%). Soils are shallow, rapidly drained, with submesic moisture regimes and submesotrophic nutrient regimes. The dominant grass and sedge species are Agropyron dasystachyum (35\%), Carex obtusata (11\%), Poa pratensis (10\%), and Poa canbyi (5\%). Taraxacum officinale, Vicia americana, Antennaria parvifolia, Oxytropis splendens and Solidago missouriensis, which make up $15.0 \%, 13.0 \%, 10.0 \%, 8.0 \%$ and $6.0 \%$ of the canopy cover, respectively, are the dominant forbs. Symphoricarpos occidentalis (12\%) and Rosa arkansana $(7 \%)$ are the dominant species in the shrub and dwarf shrub layers. The authors suggested that this community has been driven by disturbance (grazing pressure) which has favored exotic species such as Poa pratensis and Taraxacum officinale, however, relatively dry soil conditions have prevented Poa pratensis from dominating this community type. In the absence of disturbance, the community would probably resemble moister sites within the Agropyron spicatum - Carex obtusata community type. (Willoughby et al. 1998).

Coupland (1950) described the Agropyron - Muhlenbergia Facies associated with water eroded areas scattered throughout rolling topography of the Canadian mixed prairie. Characterized by frequent bare spots, this community is dominated by Agropyron dasystachyum and Muhlenbergia cuspidata. Agropyron smithii represents only a minor component of the wheat grass cover in this community, and together, the two wheat grass species make up $35.2 \%$ of the total basal area. The codominant species, Muhlenbergia cuspidata, contributes $18.2 \%$ of the total species cover. The principal associated grasses and sedges, Koeleria cristata, Bouteloua gracilis, Stipa comata, S. spartea var. curtiseta, S. viridula, Carex eleocharis and C. filifolia, contribute $8.1 \%, 13.0 \%$, $1.4 \%, 1.4 \%, 1.2 \%, 14.9 \%$ and $1.4 \%$ of the total basal area, respectively. Artemisia frigida and Phlox hoodii were the most abundant forbs, making up $8.8 \%$ and $4.9 \%$ of the total basal area. The author suggested that the vegetation of these sites, in the absence of disturbance, would be that of the Stipa - Bouteloua type, however, water erosion has modified the relative abundance of the grasses. With the exception of Grassland Research Area at Cadillac, Saskatchewan, Coupland (1950) did not provide the precise location of sites supporting this community type. However, the author indicated that this community type occurs throughout the area of rolling topography, with which the Bouteloua - Stipa faciation is associated, indicating that the Agropyron - Muhlenbergia community type may exist in Alberta.

The Agropyron dasystachyum - Artemisia dracunculus - Artemisia frigida community type occurs on near level, well-drained, submesic sites, at the toe edge of alluvial fans in the Kootenay Plains (Wallis and Wershler 1981). Agropyron dasystachyum, Artemisia dracunculus, and Artemisia frigida contribute about $26-50 \%, 16-25 \%$, and $16-25 \%$ to the ground cover, respectively. Agropyron subsecundum and Koeleria cristata are locally abundant. Additional species include Linum lewisii, Oxytropis campestris, Astragalus striatus, Potentilla pensylvanica, Antennaria nitida, Erigeron caespitosus, Orthocarpus luteus and Poa glauca.

The Agropyron dasystachyum - Antennaria nitida community type occupies woodland edges and former wooded sites in the Kootenay Plains area, where it is a significant vegetation component (Wallis and Wershler 1981). It occupies mid slopes (3 - 5\%) with northerly and southerly aspects on alluvial fans. Soils are well drained with submesic moisture regimes. Ground cover of each of the codominant species, Agropyron dasystachyum and Antennaria nitida, generally reaches from 25 to $50 \%$. Numerous other species characterize this community type, including Koeleria cristata, Artemisia frigida, Comandra pallida, Linum lewisii, Astragalus striatus, Anemone multifida, Androsace septentionalis, Gentianella amarella, Galium boreale, Campanula 
rotundifolia, Agoseris glauca, Aster alpinus, Erigeron caespitosus, Gaillardia aristata, Senecio canus, Solidago decumbens, Allium cernuum, Sisyrinchium montanum, and Bromus pumpellianus. In some areas, shrub species such as Rosa woodsii and Potentilla fruticosa invade these grasslands. Some areas are more open with bare soil and rock comprising up to $45 \%$ and $25 \%$, respectively of the ground surface. Antennaria nitida, Artemisia frigida, Agropyron dasystachyum, Koeleria cristata and various lichens are locally common. In certain areas cover of Antennaria reaches $75 \%$.

Wallis and Wershler (1981) described the Agropyron dasystachyum - Stipa comata community type as locally prevalent in one area in the central portion of the Kootenay Plains study site. It occupies alluvial fan sites, with well-drained soils characterized by submesic moisture regimes. It was described as closely related to the Agropyron dasystachyum - Koeleria macrantha I Artemisia frigida community type. Agropyron dasystachyum and Stipa comata dominate, each contributing from $26 \%$ to $50 \%$ to the total ground cover. Artemisia frigida (16-25\%), Koeleria cristata (6-15\%), and Agropyron subsecundum (6 - 15\%) are other significant species in this community. Astragalus agrestis, Linum lewisii, Antennaria nitida, Solidago decumbens, Orthocarpus luteus, Agropyron smithii and Festuca saximontana are present with very low cover. Lichens may cover up to $25 \%$ of the ground surface.

Besides the abovementioned community types, Wallis and Wershler (1981) described another minor type, the Agropyron dasystachyum - Agropyron subsecundum community. It occurs in only one depressional area with considerable bare ground (mineral soil $15 \%$ ) on a river terrace. Soils are well drained with submesic moisture regimes. Agropyron dasystachyum and Agropyron subsecundum codominate contributing about $5 \%$ to the ground cover. Linum lewisii, Astragalus striatus, A. tenellus, Oxytropis sericea, Gentianella amarella, Achillea millefolium, Artemisia dracunculus, A. frigida, and Solidago decumbens (all present at very low covers) are the additional species characterizing this community type.

\subsubsection{Agropyron dasystachyum Alliance Outside Alberta}

The Elymus lanceolatus - Stipa comata Herbaceous Vegetation community was described for Sheridan County, Montana (Heidel et al. 2000). It was described as a productive plant association of northern Great Plain provinces and adjacent states. It inhabits glaciated landscapes on welldrained slopes with fine-textured soils, and gently rolling uplands with silt or silt loam soils. Two dominant grasses usually provide at least $30 \%$ of the total graminoid cover. Carex filifolia, $C$. stenophylla and Bouteloua gracilis represent only minor components of the graminoid cover. Polygala alba is the only important forb, while other associates include Phlox hoodii, Achillea millefolium, Anemone patens and Vicia americana. The authors suggested that this community may be restricted to the northwestern corner of Montana and adjoining areas in Saskatchewan and North Dakota. It is believed that this community represents a "missing link" between the prevailing Pascopyrum smithii - Stipa comata - Bouteloua gracilis association of U.S. Great Plains and the prevailing Elymus lanceolatus - Stipa curtiseta association of the Canadian Great Plains. Heidel et al. (2000) also suggested that this association falls within the "Stipa-Agropyron faciation" of Coupland (1950). The Elymus lanceolatus ssp. lanceolatus - Stipa comata Herbaceous Vegetation community was also described by Comer et al. (1999) for low elevations in the western Columbia Basin in Oregon, primarily along the Columbia River. The environment where the association occurs was described as semi-arid, with typically hot and dry summers and 
moderately-cold winters. Terrain was described as flat to gently sloping with dry, deep loess or sandy soils. Elymus lanceolatus dominates with Stipa comata being a common associate. Very scattered shrubs include Artemisia tridentata, Chrysothamnus nauseosus, and Purshia tridentata. Bromus tectorum increases its cover with increased grazing pressure. NatureServe (2000) provides the following association summary for the Elymus lanceolatus - Stipa comata community: "This is an open, sandy grassland on flat, Columbia River plains. The topography is composed of very low ( 0.5 meter) dunes and open sand comprises almost $50 \%$ of the cover. Elymus lanceolatus is a rhizomatous grass which binds the sand and occurs throughout the site, providing 10 $15 \%$ cover. The bunchgrass Stipa comata occurs in areas that are marginally stabilized, but overall represents only about $1 \%$ cover. Oryzopsis hymenoides and Poa secunda occur at very low cover throughout the stand, as do some forbs: Astragalus sclerocarpus, Oenothera pallida, Achillea millefolium, and Phlox longifolia. Non-native species include Bromus tectorum, Centaurea diffusa, Sisymbrium altissimum, and Salsola kali". The Elymus lanceolatus - Stipa comata association is also listed in Anderson et al. (1998) as one of the two associations within the Elymus lanceolatus Herbaceous Alliance, as well as in Bourgeron and Engelking (1994) under the Agropyron dasystachyum Alliance.

Heidel et al. (2000) described another productive prairie association within Sheridan County, Montana, the Elymus lanceolatus - (Koeleria macrantha) Herbaceous Vegetation association. It is a community of northern Great Plain provinces and the northernmost areas of adjoining states, occurring on glacial landscapes with fine-textured soils. This community prevails on clay deposits of former glacial lakes. In Sheridan County, this community is restricted to near level upland hilltop positions. In this species-poor, but productive upland plant association, graminoid cover ranges from $70 \%$ to $100 \%$. Elymus lanceolatus dominates, contributing at least half of the total cover, sometimes being the sole dominant. Koeleria macrantha is generally present, but its cover may range from $1 \%$ to almost half the total cover. Additional grasses include Carex filifolia, C. stenophylla and Bouteloua gracilis. Total forb cover is less than $5 \%$ and associated forbs include Linum lewisii, Machaeranthera pinnatifida and Sphaeralcea coccinea. This community falls within the "Agropyron - Bouteloua faciation" of Coupland (1950) (Heidel et al. 2000). The Agropyron - Koeleria faciation of the Mixed Prairie (Stipa - Bouteloua) association was described for brown soils developed on uniform clay deposits found in beds of former glacial lakes within mixed grass prairies in southwestern Saskatchewan (Coupland 1950, 1961, 1973). Coupland (1950) emphasized the uniformity of this community type characterized by a few grass and sedge species that dominate at the expense of numerous other species which appear infrequently in sampling plots. Agropyron dasystachyum and Koeleria cristata are the two dominant grasses, contributing $41.2 \%$ and $24.6 \%$ to the total species composition, respectively, whereas three other important grass and sedge species, Stipa viridula, Agropyron smithii and Carex eleocharis, make up $6.1 \%, 8.7 \%$ and $13.8 \%$ of the total species composition, respectively. Principal forbs, Artemisia frigida and Phlox hoodii, make up $2.3 \%$ and $1.3 \%$ of the total species composition, respectively. The Elymus lanceolatus - Koeleria macrantha Herbaceous Vegetation community is also listed as the only community within the Elymus lanceolatus - Koeleria macrantha Herbaceous Alliance in Schneider et al. (1997). NatureServe (2000) states that this community is "a Canadian mixedgrass prairie type that does not occur south into the United States".

The Elymus lanceolatus - Bouteloua gracilis Herbaceous Vegetation community is yet another plant community described by Heidel et al. (2000) for Sheridan County, Montana. This community occupies rocky, silt loam upland sites, above alkaline lake beds. Elymus lanceolatus 
and Bouteloua gracilis dominate in association with stress-tolerant species such as Atriplex gardneri and Astragalus pectinatus.

\subsubsection{Agropyron smithii Alliance in Alberta}

The Agropyron smithii consocies occurs on slightly alkaline clay flats and on some alluviated clay flats within the Mixed Grass prairie in Canada where it is held in a subclimax stage related to the Agropyron - Koeleria faciation by the accumulation of soluble salts or by the deposition of sediments (Coupland 1950). It is solely dominated by Agropyron smithii. Koeleria cristata and Poa secunda are less common grasses, while Gutierrezia diversifolia and Phlox hoodii represent the principal forbs. Wallis (1976) reported a similar community on Solonetzic soils in the Milk River canyon. In this community, Agropyron smithii dominates, accompanied by secondary grasses such as Bouteloua gracilis, Muhlenbergia richardsonis, Carex eleocharis and $C$. filifolia. Numerous forbs characterized this community, including Gutierrezia sarothrae, Phlox hoodii, Lomatium foeniculaceum, L. macrocarpum, and Liatris punctata. The author indicated that nearly pure stands of Agropyron smithii occur in certain old sloughs with finer-textured and slightly alkaline soils. Brierley et al. (1989) and Adams and Moisey (1999) also described communities solely dominated by Agropyron smithii in the Milk River Natural Area. Brierley et al. (1989) found this community type on moderately well drained Brown Solods (possibly some Gleysolic soils) with clay and loamy textures, occupying local depressions. They reported dominance of Agropyron smithii (60 - 99\%), accompanied by species such as Deschampsia caespitosa, Beckmannia syzigachne, and Hordeum jubatum in moister depressions in lakebeds, or Poa juncifolia, Puccinellia spp. and Distichlis stricta in association with saline depressions. Adams and Moisey (1999), who analyzed vegetation for the Milk River Natural Area and the Kennedy Coulee Ecological Reserve, found that northern wheat grass, Kentucky bluegrass, low sedge, prairie sagewort and creeping spike-rush represent important components of the Agropyron smithii community in these two study sites. They occupy lower, swale and depressional sites with moderately well to imperfectly drained Brown Solonetz and Brown Solodized Solonetz soils. Exposed soil may reach up to 50\%. Direct gradient analysis showed that salinity was a major factor affecting plant composition in this vegetation community type (Adams and Moisey 1999).

Adams et al. (1997) noted the presence of the Agropyron smithii - Artemisia ludoviciana community type on sand plains in the Suffield National Wildlife Area (Dry Mixedgrass Subregion). This community occurs in depressions and on gentle slopes (2-9\%) with variable aspects. Soils are Orthic Regosols developed on morainal materials and include imperfectly to well drained sandy soils, well to rapidly drained loamy sends, or well drained sandy loams. Agropyron smithii and Artemisia ludoviciana dominate with $42 \%$ and $9 \%$ ground cover, respectively. Other notable species include Carex stenophylla (6\%), Poa pratensis (4\%), Grindelia squarrosa and Chenopodium pratericola (last two with low covers).

Adams et al. (1997) also reported the Agropyron smithii - Artemisia frigida community type from the Suffield National Wildlife Area in Dry Mixedgrass Subregion. This community occurs on various landform/surficial materials with various soil types. These include sand plains and sand dunes with well drained sandy Orthic Regosols; broad ravines with well drained sandy Orthic Brown Chernozems; glacio-fluvial terraces with well drained sandy Orthic Regosols and Rego Brown Chernozems; glacio-fluvial terraces with well drained loamy sand Orthic Brown 
Chernozems; outwash plains with well drained Orthic and Rego Brown Chernozems and Orthic Regosols of loamy sand texture; undulating outwash and hummocky moraine with well drained Orthic and Rego Brown Chernozems of sandy loam texture; rolling moraine with well drained Orthic and Calcareous Brown Chernozem of sandy loam to loamy texture; and, morainal deposits with thin eolian veneers with well to rapidly drained Orthic Brown Chernozems of loamy sand texture. No details were provided on the vegetation composition for this community type.

Smith (1993) described the Agropyron smithii - Atriplex nuttallii community type for the moderate slopes of the Manyberries badlands (Mixedgrass Subregion, elevation ranges 968 $1066 \mathrm{~m}$ ). Soils of the general area are Brown Solonetzs with loamy textures derived from moderately calcareous till, overlaying shales and sandstones. This community was found on the northeast side of an un-named coulee with gravel-clay pavement and some sandier patches, and was characterized by $75 \%$ to $80 \%$ bare ground. Agropyron smithii and Atriplex nuttallii codominated in this community. Koeleria macrantha and Artemisia frigida are also abundant on one site. Other characteristic species included Phlox hoodii, Gutierrezia sarothrae, Gaura coccinea, Grindelia squarrosa, Haplopappus nuttallii, Chrysothamnus nauseosus, Oenathera caespitosa, Erigeron caespitosus, and Carex filifolia (locally abundant in sandier patches). One of the two sampling sites is one of the most important habitats for the Short-horned Lizard (Phrynosoma douglassii var. brevirostre), both in the study area and in Alberta. The creeping juniper - June grass community type borders the Agropyron smithii - Atriplex nuttallii community in this area.

Adams (1981) found slump sites in colluvial and morainal material on steep slopes (mid-slope position) in the Peace River area re-colonized by western wheat grass, Herriots sage (Artemisia herriotii) and fringed sage. These sites occur just above the areas occupied by the northern wheat grass - western wheat grass - upland sedge - June grass community type. On the upper (less steep) slope it is bordered by the western porcupine grass - green needle grass - upland sedge milk vetch community type. In contrast to the adjacent community types, which are primary range for livestock and primary winter range for mule deer, steep slopes re-colonized by western wheat grass, Herriots sage and fringed sage were rarely used for grazing by either cattle or wildlife. Herriots sage (Artemisia herriotii in Adams (1981), A. tilesii in Moss (1983)) is considered rare in Alberta (ranked S2) (ANHIC 2001).

Comer et al. (1999) described the Pascopyrum smithii (Agropyron smithii) - Bouteloua gracilis Carex filifolia Herbaceous Vegetation community type for the western United States, the southeast corner of Alberta and the southwestern corner of Saskatchewan. It occurs on flat to gently rolling terrain, on loamy, deep fertile soils. Agropyron smithii or Elymus lanceolatus ( $A$. dasystachyum $)^{3}$ dominate this community, accompanied by other grass species such as Koeleria macrantha (sometimes with a substantial cover), Stipa comata, Nassella viridula (Stipa viridula) and Bouteloua gracilis. Stipa comata is more prominent under drier soil conditions, whereas Stipa viridula occurs on the lower slopes and floodplains with finer-textured soils. Carex filifolia is often present but its cover varies or it is absent altogether. Some of the forbs characterizing this community include Tragopogon dubius, Gaura coccinea, Sphaeralcea coccinea, Hedeoma

3 Agropyron smithii and A. dasystachyum have overlapping ecological niches and are difficult to distinguish from one another (Comer et al. 1999). 
hispidum and Phlox hoodii. Comer et al. (1999) suggested that the stands of this community type found in Alberta and Saskatchewan represented the same community type described by Coupland (1961) as Bouteloua - Agropyron faciation of the Mixed Prairie. The authors also noted that in Alberta and Saskatchewan, Stipa spartea var. curtiseta may be as common as S. comata. Comer et al. (1999) also suggested that almost any combination of Agropyron smithii/Elymus lanceolatus, Bouteloua gracilis, Carex filifolia and Stipa comata is found in the northern and northwestern Great plains, depending partially on climatic conditions (wet or dry weather), soil texture and grazing history. Consequently this makes differentiating plant associations based only on the relative species abundance very difficult. As well, any of these species may be absent from certain areas, so an area of at least several acres should be examined to determine which association the vegetation may belong to (Comer et al. 1999). Comer et al. (1999) also suggested that the typical Agropyron smithii - Bouteloua gracilis - Carex filifolia community type grows on the soils finer than loam, while the Stipa comata - Bouteloua gracilis - Carex filifolia community type occupies coarser soils.

The Agropyron - Stipa - Carex associes was described in Moss (1944) for southwestern Alberta. In contrast to the Agropyron - Stipa - Carex community type found in the Peace River Region, which characterized by Agropyron trachycaulum, the Agropyron - Stipa - Carex associes is characterized by Agropyron smithii, A. dasystachyum and A. Grifithsii (20-50\%), with minor importance of $A$. trachycaulum and $A$. spicatum. The author suggested that this associes was favored in the shallow black soil zone in this region, but also occurs on black soils when grazing pressure allowed Agropyron species to replace more palatable fescues. Stipa spartea v. curtiseta, $S$. comata and $S$. viridula are present with $5-10 \%, 1-5 \%$, and $1-5 \%$ cover, respectively. Additional graminoid species include Carex eleocharis and Carex spp. (together cover $5-10 \%$ ), Bouteloua gracilis (1 - 10\%), Koeleria gracilis (5 - 10\%), Poa spp. (5 - 10\%), and Festuca idahoensis (5 - 20\%). Agropyron species dominates over Stipa species on heavier lowland soils, while the opposite situation occurs under lighter and better drained soils (Moss 1944).

Brierley et al. (1989) described the Stipa - Agropyron community type from the Milk River Natural Area, Dry Mixedgrass Subregion. It occupies moderate slopes (10 - 22\%) with westerly and some easterly aspects. Soils are well drained Orthic Brown Chernozems, fine to coarse textured, with mesic moisture regimes, developed on colluvial materials. Agropyron smithii (22\%), Stipa comata/S. curtiseta (23\%) and Selaginella densa (34\%) dominate this community, accompanied by less abundant species such as Carex filifolia, Koeleria macrantha, Poa sandbergii, Bouteloua gracilis, Phlox hoodii and Calamovilfa longifolia.

The Agropyron smithii - Agropyron trachycaulum - Artemisia sp. community type is believed to occur in the Grassland Region, on floodplain terraces (Lorna Allen, personal communications).

In a reconnaissance survey of saline wetlands within the Grassland-Parkland Regions of Eastern Alberta, Wallis (1990) identified the Agropyron smithii - Hordeum jubatum community type. It represented the driest vegetation sequence along a moisture gradient in the northernmost portion of a large saline wetland located within the Neutral Hills central study site (Northern Fescue Subregion).

Wallis and Wershler (1981) described the Agropyron smithii - Haplopappus uniflorus community type as rare within the Kootenay Plains study area. This community type was found 
at only one site in the vicinity of Puccinellia nuttalliana depressions at Whirlpool Point. It occurs in areas with high water tables. The vegetation has low cover values with considerable bare ground. Scattered forbs include Cerastium arvense, Anemone multifida, Astragalus agrestis, Achillea millefolium, Senecio canus, Taraxacum officinale and Aster sibiricus.

\subsubsection{Agropyron smithii Alliance Outside Alberta}

Pascopyrum smithii Herbaceous Vegetation occupies both temporary and permanently flooded areas with fine-textured soils, and is the most widespread seasonally flooded plant association in parts of northern Montana (Heidel et al. 2000). Species diversity is low and Pascopyrum smithii achieves more than $70 \%$ ground cover. Forbs include Grindelia squarrosa, Lactuca canadensis, Conyza canadensis and Hackelia deflexa. The authors noted that this community appears as a minor component of Saskatchewan's mixed grass prairie (cited from Riparian and Wetland Research Program 2000). Pascopyrum smithii Herbaceous Vegetation is also listed in Anderson et al. (1998) and in Schneider et al. (1997) under the Pascopyrum smithii Herbaceous Alliance, as well as in Bourgeron and Engelking (1994) under Pascopyrum smithii Alliance. Dodd and Coupland (1966) noted that Pascopyrum smithii dominated communities occupying depressions and alluvial flood plains in the driest parts of Saskatchewan. NatureServe (2000) provides the following association summary and association classification comments: " This midgrass prairie type is found in the northern and western Great Plains, Rocky Mountains, and western basins of the United States and possibly Canada. Stands occur on level to gently sloping terrain. They are sometimes found on alluvial fans. The soils are clay, clay loam, and silt loam. The dominant mixedgrass species grow to approximately $1 \mathrm{~m}$. Pascopyrum smithii may have as much as $50 \%$ coverage. Other grasses that cooccur and may achieve local dominance are Koeleria macrantha and Poa spp. Many other species common in midgrass prairies are also found in this community. These include Artemisia ludoviciana, Bouteloua gracilis, Nassella viridula, and Stipa comata. This community is similar to several others that have significant amounts of Pascopyrum smithii. Further work needs to be done to better define the diagnostic characteristics of this community...... This community is similar to several others that are dominated or codominated by Pascopyrum smithii. As currently defined, it represents a western Great Plains and foothills version of the western wheatgrass types in the central Great Plains. Further work needs to be done to refine the differences in composition and environmental characteristics. See recent descriptions by Thilenius et al. (1995), "Pascopyrum smithii sodgrass steppe," a more playa-like wheatgrass type) and by Steinauer and Rolfsmeier (1997). In Nebraska, Steinauer and Rolfsmeier (1997) suggest that their stands may resemble Pascopyrum smithii - Nassella viridula Herbaceous Vegetation (CEGL001583)."

The Pascopyrum smithii - Stipa comata - Bouteloua gracilis Herbaceous Vegetation community has been described for Sheridan County, Montana (Heidel et al. 2000). This is a widespread community of the Great Plains centered in North Dakota, South Dakota, Montana and Wyoming, and entering adjoining states and provinces. It prevails on unglaciated plains within the "mixed grass prairie", widespread within the unglaciated "shortgrass prairie" and common to prevalent in the glaciated great plains. It occupies flat to gently sloping terrain with clay loam, loam, silty loam, silty clay and clay soils. Within Sheridan County, this community occupies well-drained creek benches and terraces and some uplands. This community of intermediate productivity and generally high vegetation cover $(60-100 \%)$ is codominated by Pascopyrum smithii, Stipa comata and Bouteloua gracilis. Koeleria macrantha usually contributes with up to $10 \%$ of total cover. Carex filifolia and C. heliophila sometimes replace Bouteloua gracilis. Typical forbs include Phlox hoodii, Sphaeralcea coccinea, Gaura coccinea, Penstemon albidus, Antennaria microphylla, Dalea purpurea and Hedeoma hispidum. Heidel et al. 2000 suggested that this association falls within the "Stipa - Bouteloua - Agropyron faciation" of Coupland (1950). Heidel 
et al. (2000) also suggested that the Pascopyrum smithii - Stipa comata - Bouteloua gracilis association represented an equivalent to the Pascopyrum smithii - Stipa comata in the Central Mixed Grass Prairie, which is listed in Anderson et al. (1998) and in Schneider et al. (1997) under the Pascopyrum smithii Herbaceous Alliance.

The Pascopyrum smithii - Bouteloua gracilis Herbaceous Vegetation community is another community described by Heidel et al. (2000) for Sheridan County. This community occupies hot alluvial and thinsoil settings overlying shale which are saturated in spring but dry during most of the growing season. Pascopyrum smithii contributes at least $20 \%$ of the cover, while Bouteloua covers about twice as much as Pascopyrum smithii. Species diversity is generally low and Opuntia polyacantha, Linum lewisii and Hedeoma hispida are some of the characteristic forbs. This association corresponds well with the "Bouteloua - Agropyron faciation" of Coupland (1950) (Heidel et al. 2000). With an increase in soil salinity, Pascopyrum smithii - Bouteloua gracilis association grades into Pascopyrum smithii - Distichlis spicata. NatureServe (2000) provides the following summary for this association: "This western wheatgrass - blue grama prairie was once an extensive grassland of the Southern Great Plains and Chihuahuan Desert of the United States. Stands occur within montane swales or along upland valley bottoms. It generally occurs on northerly aspects at elevations between 1900 and $2500 \mathrm{~m}$ (6000 and 8000 feet). Slopes are typically gentle with fine-textured and well-developed soils that are predominantly from eroded Paleozoic sandstone and limestone. Luxuriant cover that can be dominated by either Bouteloua gracilis or Pascopyrum smithii typifies this grassland. Juniperus monosperma or Pinus edulis communities usually surround this swale association. Graminoid diversity is usually low, with scattered grasses such as Muhlenbergia repens, Koeleria macrantha and Elymus elymoides, often present. In Kansas, Bouteloua curtipendula and Buchloe dactyloides may also be present. The shrub layer is very open and moderate in diversity and generally includes Atriplex canescens and Krascheninnikovia lanata (which both occur as phases and can become dominant in disturbed areas), Opuntia phaeacantha and Opuntia imbricata. Forb diversity and cover is generally low". Pascopyrum smithii - Bouteloua gracilis Herbaceous Vegetation is also listed in Anderson et al. (1998) and in Schneider et al. (1997) under the Pascopyrum smithii Herbaceous Alliance, as well as in Bourgeron and Engelking (1994) under the Pascopyrum smithii Alliance.

The Pascopyrum smithii - Distichlis spicata Herbaceous Vegetation community occurs on unglaciated landscapes of Wyoming, Nebraska and North Dakota (Comer et al. 1999, Heidel et al. 2000). It is found in depressions and on stream terraces with deep, moderately saline soils, and in alkaline lake systems of the prairie pothole region. Most sites are wet for part of the year and may be flooded periodically, but the community occurs on some upland settings, as well (Heidel et al. 2000). Heidel et al. 2000 suggested that Pascopyrum smithii and Distichlis spicata dominate this community, accompanied by forbs such as Iva annua, Helianthus petiolaris, Plantago patagonica, Gutierrezia sarothrae and Aster falcatus. Bouteloua gracilis may also be present. When present, woody plants are represented by Artemisia tridentata subsp. wyomingensis, Artemisia cana subsp. cana, Salix exigua and Populus deltoides. Comer et al. (1999) provided a slightly different description of this association. Pascopyrum smithii generally dominates, but Distichlis spicata may be codominant. Other frequently present species include Bouteloua gracilis, Poa pratensis, Hordeum jubatum, Spartina gracilis, Stipa comata, Nassella viridula, Artemisia frigida, A. ludoviciana, Aster falcatus and Taraxacum officinale. Scattered woody plants include Artemisia tridentate, A. cana ssp. cana, Salix exigua and Populus deltoids. Poa juncifolia and $P$. glaucifolia are the important species in Nebraska's "alkaline intermittent stream bottoms" included in this community type. NatureServe (2000) provides the following association classification comments: "This type is somewhat complex, with Pascopyrum smithii more 
important in less saline/alkaline areas, and Distichlis spicata and other alkaline indicators present in more alkaline areas. As such this type tends to share similarities to Distichlis spicata - (Hordeum jubatum, Poa arida, Sporobolus airoides) Herbaceous Vegetation (CEGL002042), which, in Nebraska is called "western alkaline meadows" (Steinauer and Rolfsmeier 1997)". Pascopyrum smithii - Distichlis spicata Herbaceous Vegetation appears in Anderson et al. (1998) and Schneider et al. (1997) under the Pascopyrum smithii Temporarily Flooded Herbaceous Alliance, as well as in Bourgeron and Engelking (1994) under the Pascopyrum smithii Alliance.

The Pascopyrum smithii - Nassella viridula Herbaceous Vegetation community was described by Comer et al. (1999) for Montana, North Dakota, South Dakota, Wyoming, and eastern Colorado. It occurs on relatively mesic sites such as narrow valleys, stream terraces and gentle upland slopes, with fine-textured soils. Pascopyrum smithii usually dominates with Nassella viridula contributing at least $5 \%$ cover. Elymus lanceolatus is frequently present and may replace Pascopyrum smithii in some stands. Poa juncifolia, Poa nevadensis, Poa pratensis and Achillea millefolium are present with significant covers in more mesic sites while Calamovilfa longifolia characterizes sandier soils. Bouteloua gracilis, Carex eleocharis, C. filifolia, C. inops ssp. heliophila and $C$. pensylvanica are present but contribute little cover. Bromus commutatus, $B$. japonicus, and $B$. tectorum are frequently present and sometimes achieve significant cover. Associated forbs include Aster falcatus, Lepidium densiflorum, Achillea millefolium, Sphaeralcea coccinea, Artemisia ludoviciana and Vicia americana. The shrub layer is sparse and includes species such as Artemisia cana and Artemisia tridentate ssp. wyomingensis. Comer et al. (1999) suggested that this community may occur in southwestern Saskatchewan where it occurs with an unusually large amount of Koeleria macrantha (described in Coupland 1961). Heidel et al. (2000) described the Pascopyrum smithii - Nassella viridula association as widespread across much of the northern Great Plains. The authors indicated that the community occupies level to nearly level grounds (sometimes slopes of any aspects) in narrow valleys, stream terraces, and on some upland sites. Soils are fine-textured and moderately-drained, and include clays, silty clays, and clay loams (rarely loams). NatureServe (2000) provides the following association classification comments: "This association includes stands growing on mesic sites, and containing substantial cover of plants characteristic of such sites, including Nassella viridula, Poa secunda (= Poa juncifolia, = Poa nevadensis), Poa pratensis, and Achillea millefolium. The amount of these species that is diagnostic of this association is unknown (pending further analysis of stand data), but they contribute at least $5 \%$ of the herbaceous canopy cover. Some of these species (especially Nassella viridula) may be present in upland vegetation such as Pascopyrum smithii - Bouteloua gracilis - Carex filifolia Herbaceous Vegetation (CEGL001579), but they contribute only trace amounts to the vegetation. In Nebraska this type is recognizable, but forms a close association with other mixedgrass types, and thus is lumped with them. Nassella viridula does often strongly dominate with Pascopyrum smithii in mesic bottoms, but if grazing pressures were removed from upland slopes dominated by Pascopyrum smithii and Bouteloua gracilis, it is thought that Nassella viridula would recover its dominance on those slopes (G. Steinauer pers. comm. 2000). Pascopyrum smithii - Nassella viridula Herbaceous Vegetation is also listed in Andreson et al. (1998) and in Schneider et al. (1997) under the Pascopyrum smithii Herbaceous Alliance, as well as in Bourgeron and Engelking (1994) under the Pascopyrum smithii Alliance.

Pascopyrum smithii - Stipa comata Northern Herbaceous Vegetation is yet another vegetation association described for Sheridan County, where it occupies stable northern sandplains and uplands with gentle and nearly-level slopes with medium-textured soils (Heidel et al. 2000). The authors suggest that this type may represent a cold, dry phase of the Pascopyrum smithii - Stipa comata - Bouteloua gracilis community. 
Comer et al. (1999) described Pascopyrum smithii - Stipa comata Central Mixedgrass Herbaceous Vegetation found throughout the north-central Great Plains on many different topographic types, including upland slopes, ridgetops, plateaus, stream terraces, and rolling sandhills. The soils, which are derived from a variety of parent materials, are also variable, from fine- to medium-textured (clay to sandy loam), to moderately deep to deep. Pascopyrum smithii and Stipa comata dominate this moderately open to dense community type, accompanied by other species of various cover such as Aristida purpurea, A. basiramea, Bouteloua gracilis, Calamovilfa longifolia (on sandy soils), Carex eleocharis, C. filifolia, Koeleria macrantha, Schizachyrium scoparium and Stipa spartea. Amorpha canadensis, Artemisia campestris, Helianthus petiolaris, and Tragopogon dubius are some common forbs. Rosa arkansana and Symphoricarpos occidentalis may be present. NatureServe (2000) provides the following association classification comments: "This type may not occur in Nebraska (Steinauer and Rolfsmeier 1997). This type is somewhat conceptually vague. It potentially includes stands that have more moderately coarse-textured and somewhat drier soils than other Pascopyrum smithii types, but not dry enough to shift the dominance toward Stipa comata types. A major review of published material is needed in central North and South Dakota to clarify this type. In particular it would be worth examining whether or not more western Great Plains species are absent from the Central Mixed Grass Region, and where this type is most common".

Anderson et al. (1998) and Schneider et al. (1997) listed Pascopyrum smithii - (Elymus trachycaulus) Clay Pan Herbaceous Vegetation under the Pascopyrum smithii Herbaceous Alliance. Pascopyrum smithii - (Elymus trachycaulus) Wet Meadow Herbaceous Vegetation is listed but not described in Grossman et al. (1994). NatureServe (2000) provides the following summary and the association classification comments for this association: "This western wheatgrass clay flats prairie type is found in the northern Great Plains of the United States and possibly adjacent Canada. Stands occur on a heavy clay pan such as can occur along streams and rivers. These clay pans are particularly extensive in western South Dakota. The vegetation is strongly dominated by Pascopyrum smithii. The associated flora may be very simple. Further review of this type is needed....... type concept is of a heavy clay pan such as can occur along streams and rivers, that tends to promote strong dominance by Pascopyrum smithii. Species associates need to be described. Concept may overlap with temporarily flooded upland depression ponds also dominated by Pascopyrum smithir".

Anderson et al. (1998) and Schneider et al. (1997) listed Pascopyrum smithii - Eleocharis spp. Herbaceous Vegetation under the Temporarily Flooded Herbaceous Alliance. The same community is listed in Bourgeron and Engelking (1994) under the Pascopyrum smithii Alliance. Comer et al. (1999) provided details on species composition and habitat characteristics for this association found in Wyoming and most likely occurring in south-eastern Montana. It occupies periodically-inundated closed basins (playas) underlined by fine-textured soils that impedes drainage. Water tables are higher and the sodium content is lower compared to sites occupied by Pascopyrum smithii - Hordeum jubatum Herbaceous Vegetation. The lowest and the most inundated parts of the stands are dominated by Eleocharis acicularis (sometimes Eleocharis palustris or Eleocharis machrostachya), and may contain Hordeum brachyantherum, Juncus balticus, and Alopecurus aequalis or A. carolinianus. Bare ground may account for up to $75 \%$ of the ground surface. Pascopyrum smithii generally dominates the higher parts of the stand, accompanied by Carex douglasii and Festuca octoflora. Hordeum jubatum occupies stand margins. Some stands may be entirely dominated by Pascopyrum smithii, Eleocharis acicularis and Hordeum jubatum. This community is listed as rare for the Northern Great Plains in FaberLangendoen et al. (1997). NatureServe (2000) provides the following comments on association classification: "Species composition varies among stands of this type depending on the degree of inundation, but the degree of variation is unknown. More stand data might indicate that this association 
and Pascopyrum smithii - Hordeum jubatum Herbaceous Vegetation (CEGL001582) should be combined as it also occupies small playas".

Comer et al. (1999) provided details on species composition and habitat characteristics for Pascopyrum smithii - Hordeum jubatum Herbaceous Vegetation found in Wyoming, Montana, Nebraska, and most likely in North Dakota, South Dakota, Kansas, Alberta, and Saskatchewan. It occurs as small patches in temporarily flooded sites (playas and stock ponds), surrounded by grasslands or shrublands. Soils are deep, poorly drained, clayey and alkaline-saline. Pascopyrum smithii or Elymus lanceolatus are the dominant species, but Hordeum jubatum contributes substantial cover. When present, other species contribute little cover (i.e. Atriplex gardneri). The authors noted that more work needs to be done on the inventory and description of this association to define its characteristics and differentiating features. Pascopyrum smithii Hordeum jubatum Herbaceous Vegetation also appears in Anderson et al. (1998), Schneider et al. (1997) and NatureServe (2000) under the Pascopyrum smithii Temporarily Flooded Herbaceous Alliance and in Bourgeron and Engelking (1994) under the Pascopyrum smithii Alliance.

The Pascopyrum smithii - Carex filifolia association is listed in Bourgeron and Engelking (1994) under Pascopyrum smithii Alliance. The same authors also suggested the possible existence of the Agropyron smithii - Poa secunda association, but noted that there was no quantitative documentation for this community.

The Pascopyrum smithii - Bouteloua gracilis - Carex filifolia Herbaceous Vegetation is listed in Anderson et al. (1998), Schneider et al. (1997) and NatureServe (2000) under the Pascopyrum smithii Herbaceous Alliance.

\subsubsection{Agropyron albicans Group}

Agropyron albicans - Artemisia frigida community type is listed in the "Alberta Natural Heritage Information Centre Preliminary Plant Community Tracking List”" and ranked SU (Allen 2000). It occurs on subxeric, west to southeast facing, active slopes within the Montane or Subalpine Subregions. Some of the characteristic species include Prunus virginiana, Koeleria macrantha and Galium boreale (Allen 2000).

\subsubsection{Other Related Communities Found Within Alberta}

Stacey (1927) reported the Poa - Agropyron association for the Grande Prairie - Beaverlodge district. It was found, among other places, in areas of sand ridges where the growth of pine, spruce and poplar helped the development of an inch or two of black soil. Poa interior, Agropyron tenerum, and $A$. caninum were the dominant grasses in this association. Other characteristic species included Calamagrostis inexpansa, Agrostis hiemalis, Poa palustris, Elymus innovatus, Koeleria cristata, Carex praticola, and C. xerantica. In the numerous local depressions, Calamagrostis canadensis replaced the more xerophytic $C$. inexpansa. The author described this association as very widespread on drier habitats within the study area.

Deschampsia caespitosa - Agropyron trachycaulum - Thalictrum venulosum inhabited higher elevations and moist, level flood plains and fluvial terraces within the Lower Foothills Subregion (Lane et al. 2000). Deschampsia caespitosa, Agropyron trachycaulum and Thalictrum venulosum 
contributed $25 \%, 10 \%$ and $22 \%$ to the ground cover, respectively. The dominant species were accompanied by a number of other species such as Achillea millefolium, Mertensia paniculata and different sedges.

The Deschampsia caespitosa - Carex spp. - Agropyron trachycaulum community type was believed to represent an earlier successional stage (as a result of grazing) of a willow-dominated community in the Upper Foothills Subregion (Willoughby and Smith 1999). Characteristic forbs included Thalictrum venulosum, Mertensia paniculata, Aster ciliolatus and Fragaria virginiana.

The Carex praticola - Agropyron trachycaulum - Thalictrum venulosum inhabited Cutoff Creek rangelands in the Upper Foothills Subregion (Willoughby and Smith 1999). Carex praticola, C. praegracilis, $C$. prairea, Agropyron trachycaulum, and Thalictrum venulosum dominated this community, contributing $24 \%, 15 \%, 14 \%, 12 \%$ and $32 \%$ to the ground cover, respectively. Additional forbs included Geum triflorum, Achillea millefolium, and Potentilla arguta.

Willoughby (1999) described Carex obtusata - Elymus innovatus - Agropyron trachycaulum for the Subalpine Subregion. Potentilla diversifolia, Achillea millefolium and Fragaria virginiana were some of the forbs characterizing this community. The author believed that this community type represented a degradation of the Festuca scabrella-Carex spp. community type resulting from moderate to heavy grazing.

The Carex praegracilis - Agropyron trachycaulum - Bromus ciliatus / forbs community type occurs adjacent to outfitter campsites in the Job Lake, Blackstone-Wapiabi forest land use zones of the Subalpine Subregion (Willoughby 1999). In addition to the dominant grasses, a number of forbs such as Potentilla diversifolia, Fragaria virginiana, and Solidago multiradiata, characterize the community.

Moss (1953) described the Hordeum jubatum - Agropyron trachycaulum - Distichlis stricta saline meadow community for areas about $8 \mathrm{~km}$ west of Fort Vermilion, in northwestern Alberta. Sites included pools, sinkholes, barren patches, and extensive grassy flats. In addition to the three dominant species, the author listed Elymus macounii, Muhlenbergia richardsonis, Puccinellia nuttalliana, Suaeda depressa as leading species. Aster ericoides, Grindelia squarrosa, Vicia americana, Plantago eriopoda, Aster caerulescens, Gallium boreale, Solidago lepida, Carex praticola and Carex praegracilis are just some of the additional species listed for these meadows.

The Sand Grass - Needle Grass - Northern Wheat Grass community type was noted by Adams et al. (1997) for the well drained, sandy soils on valley walls within the Suffield National Wildlife Area.

Coupland $(1950,1961,1973)$ described the Stipa - Agropyron faciation of the Mixed Prairie (Stipa - Bouteloua) association. This faciation occurs on undulating to gently rolling areas with medium textured soils in the dark-brown soil zone of the mixed prairie of Canada. Agropyron dasystachyum is a dominant wheat grass species of this faciation, with a minor importance of Agropyron smithii. The three dominant species Agropyron dasystachyum, Stipa comata, and S. spartea var. curtiseta, contribute $43 \%$ of the cover, while sedges make up $25.5 \%$ of the total basal area. Selaginella densa may cover up to $30 \%$ of the ground area as a result of disturbance. 
The principal subdominant grasses and sedges are Bouteloua gracilis, Koeleria cristata, Carex filifolia, C. eleocharis and C. heliophila (Coupland 1950). Carex eleocharis may reach the same prominence as Agropyron dasystachyum. Coupland (1961) indicated that within this community type in the mixed grass prairie, the abundance of Agropyron smithii and Stipa comata increase at the expense of $A$. dasystachyum and $S$. spartea var. curtiseta under drier, local conditions and/or as a result of disturbances.

Wheeler (1976) noted the existence of the Stipa-Agropyron community dominated by S. spartea var. curtiseta and Agropyron smithii in the Central Parkland Subregion (Kinsella Ranch). Because this community occurs in only two small stands surrounded by fescue grasslands, the author concluded that they resulted from past grazing patterns in interaction with some edaphic and other microclimatic factors.

Brierley et al. (1989) and Adams and Moisey (1999) provided details on the Stipa-Agropyron community type within the Milk River area. It occurs on east- and west-facing colluvial slopes (slope $10-20 \%$ ) in the western third of the Milk River Natural Area (elevation about 1000m) (Brierley et al.1989). Soils are well drained, fine to coarse textured, Orthic Brown Chernozems with submesic moisture regimes. The community is dominated by Stipa comata/S. spartea, Agropyron smithii and Selaginella densa (average percent compositional cover of $23 \%, 22 \%$, and $34 \%$, respectively), accompanied by Carex spp., Koeleria macrantha, Poa sandbergii, Bouteloua gracilis, Calamovilfa longifolia, Phlox hoodii and numerous other species. In agreement with Coupland (1961), Brierley et al. (1989) suggested that on east facing slopes, which were less dry compared to west facing slopes, species characteristic of moister habitats (e.g. Agropyron dasystachyum, Stipa spartea, Festuca scabrella and Fritillaria pudica) occur. Adams and Moisey (1999) described their community as dominated by needle and thread, northern wheat grass, blue grama and plains reed grass. This community occupies landscapes with well-drained soils (slope $1-4 \%$ ), upslope of the western wheat grass and the northern wheat grass - western wheat grass community types within the study area. Soils are mainly Orthic Brown Chernozems with minor importance of Calcareous Brown and Solonetzic Brown Chernozems.

Adams et al. (1997) described the Stipa comata - Agropyron smithii community type from the Suffield National Wildlife Area situated in the Dry Mixedgrass Subregion. Sites occupied with this community type included: middle terraces with well drained, sandy Orthic Brown Chernozems; lower terraces with imperfectly drained, sandy loam Orthic Regosols and Orthic Gleysols; valley walls with well drained sandy Orthic Brown Chernozems; hilly outwash with well drained, loamy sand Orthic Brown Chernozems; hummocky morainal loam with well drained, sandy Orthic Brown Chernozems; and inclined morainal slopes with sandy loam Orthic and Rego Brown Chernozems. The community generally occurs on gentle slopes $(<15 \%)$ with variable aspects. Agropyron smithii, Stipa comata and Carex stenophylla dominate, contributing on average $21 \%, 31 \%$ and $19 \%$ to the ground cover, respectively. Additional species include Bouteloua gracilis (3\%), Chenopodium pratericola (4\%), Descurainia pinnata (1\%), Lactuca pulchella, Lygodesmia juncea and Opuntia polyacantha (low covers).

The Danthonia unispicata - Agropyron dasystachyum - Agropyron smithii community type occupied mesic depressions in the Dry Mixed Subregion of Alberta (Eastern Slopes Rangeland Seeds Ltd. 1995). Danthonia unispicata dominates with ground covers from $25.7 \%$ to $52.4 \%$. Agropyron smithii and Agropyron dasystachyum were the subdominant species, together 
contributing from $14.7 \%$ to $21.2 \%$ of the ground cover. This community is considered provincially rare (ranked S2) (Allen 2000).

NatureServe (2000) describes the Festuca idahoensis - Pascopyrum smithii Herbaceous Vegetation: "..occurs primarily east of the Continental Divide on gentle slopes. It is found on moderately deep soils of sedimentary origin, generally from 1200 to $1800 \mathrm{~m}$ elevation, but may be found up to 2400 $\mathrm{m}$. Festuca idahoensis is the dominant graminoid, but wheatgrasses including Pascopyrum smithii and/or Elymus lanceolatus may be abundant. Pascopyrum smithii appears to become restricted in distribution to the north. In Alberta, it is restricted to swales or to specific soil types and Elymus lanceolatus becomes the prominent wheatgrass. Koeleria macrantha is also an important component of this type. Poa cusickii is often conspicuous; growing with or replacing Poa secunda (= Poa sandbergii). Graminoids are far more abundant than shrubs and forbs. The most prominent forbs are Phlox hoodii, Gaillardia aristata, Antennaria rosea, and Achillea millefolium. The short shrub Artemisia frigida may be present. Other shrubs are absent or scattered..... This type can be recognized by the dominance of Festuca idahoensis and the presence and often abundance of Pascopyrum smithii (= Agropyron smithii) and/or Elymus lanceolatus (= Agropyron dasystachyum). Pascopyrum smithii seems to be more prominent to the south, Elymus lanceolatus to the north. Festuca campestris (= Festuca scabrella) and Pseudoroegneria spicata are only minor components, if present at all. Which species of the Festuca campestris complex occurs in this type has yet to be determined, but based on the distributions of the species, it seems most likely to be Festuca campestris. Tisdale (1982) considers Festuca idahoensis - Pascopyrum smithii Herbaceous Vegetation to be an example of an association that is a result of the interface between the Pacific Northwest bunchgrass and the Great Plains grasslands. He suggests that this is one of a number of types essentially unique to Montana, resulting from the extensive, complex intermingling between the two grassland types. Mueggler and Stewart (1980) suggest that this type is found in the plains/mountains transition area from Wyoming to the Canadian border. In Alberta, a similar type has been documented but with Elymus lanceolatus as the predominant wheatgrass (B. Adams pers. comm.). Additional work is required to determine if these should be split out as different types".

The Bouteloua - Agropyron faciation of the Mixed Prairie (Stipa - Bouteloua) association in Coupland $(1950,1961,1973)$ was described as a "burn-out" occupying $16 \%$ of the ground in studied sites with clay loam Solonetzic soils in the southwestern part of Saskatchewan, south of the Cypress Hills. Bouteloua gracilis, Agropyron smithii and A. dasystachyum contributed $54.7 \%, 13.5 \%$ and $1.7 \%$ to the vegetation cover, respectively. Other important grass species, Stipa comata, Koeleria cristata, Poa secunda and Calamagrostis montanensis made up $13.5 \%$ of the total vegetation cover (Coupland 1950). Carex eleocharis was the dominant sedge with minor importance of $C$. filifolia. Artemisia frigida, Opuntia polyacantha and Phlox hoodii were some of the frequent forbs. Selaginella densa occupied more than $27 \%$ of the ground surface. Coupland (1973) discussed the possibility of renaming this plant community into the Agropyron Bouteloua community because of the tendency of Agropyron to dominate over Bouteloua under moister conditions. However, the author concluded that these "burn-outs" should be considered a natural disturbance feature dictating the species composition, and that the original community name should remain. Brierley et al. (1989) described the Bouteloua gracilis - Agropyron smithii community type from the Milk River area where it occupied gently inclined and undulating morainal deposits. Soils were well drained Brown Solonetz, Brown Solodized Solonetz, and occasionally Orthic Brown Chernozems with loam and clay loam textures. Agropyron smithii ( $28.1 \%$ composition), Poa sandbergii (13.1\% composition), Koeleria macrantha $(6.6 \%$ composition), Stipa comata ( $4.4 \%$ composition), Bouteloua gracilis ( $3.9 \%$ composition), and Selaginella densa (29.3\% composition) dominated, accompanied with secondary species such as Phlox hoodii, Tragopogon dubius, Artemisia frigida, Carex sp., Atriplex nuttallii, Artemisia cana, Eurotia lanata, Achillea millefolium, Opuntia polyacantha and Grindelia squarrosa. 
The Stipa viridula - Agropyron smithii community type was reported by Adams et al. (1997) for the Suffield National Wildlife Area. This community occupied imperfectly to well drained, sandy loam soils of channel banks, moderately drained loams on alluvial materials, well drained loamy sands on glacio-fluvial terraces, and well drained sandy moraines.

Adams et al. (1997) noted the presence of the Stipa comata-Agropyron smithii community type in the Suffield National Wildlife Area. The soils supporting this plant community included: well drained sands on middle terraces, valley walls, moraines, and undulating outwash in shallow glacial drainage channels; well to imperfectly drained sandy loams on inclined morainal slopes and lower terraces; and well drained loamy sands on hilly outwashes.

The Carex stenophylla-Agropyron smithii community type occupied depressional sites on well drained sandy Orthic Regosols and Rego Brown Chernozems on glacio-fluvial terraces, well to rapidly drained loamy sand textured Orthic Brown Chernozems developed on morainal deposits and well drained sandy loam to loam Orthic and Calcareous Brown Chernozems on morainal deposits, within the Suffield National Wildlife Area within the Dry Mixedgrass Subregion (Adams et al. 1997). Agropyron smithii (43\%) and Carex stenophylla (57\%) dominated, accompanied by only three more species, Chenopodium pratericola $(4 \%)$, Vicia americana $(1 \%)$ and Taraxacum officinale $(<1 \%)$.

The Needle \& Thread - Blue Grama - Western Wheat Grass community type was noted by Adams et al. (1997) on well drained sandy loam soils of undulating outwash in the Suffield National Wildlife Area. Johnston et al. (1967) described a similar community type dominated by needle \& thread, blue grama, western wheat grass, northern wheat grass, and western porcupine grass for the mixed grass prairie. Coupland $(1961,1973)$ described the Stipa-Bouteloua Agropyron faciation of the Mixed Prairie (Stipa - Bouteloua) association for the Northern Great Plains. Agropyron smithii, Agropyron dasystachyum, Stipa comata, S. spartea var. curtiseta and Bouteloua gracilis were the principal grasses of this community. The author noted that the dominance of certain principal grass species depended on the moisture conditions, so that drier conditions favored Agropyron smithii, Stipa comata and Bouteloua gracilis, while under moisture conditions, Agropyron dasystachyum increased in cover at the expense of Bouteloua gracilis and, in certain areas, of Agropyron smithii. Other important grasses of this community included Calamagrostis montanensis, Poa secunda, Muhlenbergia cuspidata, Calamovilfa longifolia and Stipa viridula.

In his reconnaissance survey of saline wetlands in the Grassland-Parkland Region of eastern Alberta, Wallis (1990) described the Distichlis stricta-Agropyron smithii saline dry meadow community as transitional between the driest portion of the halophytic communities and the semi-halophytic communities. Numerous upland species accompanied the two dominant grasses, including Aster ericoides and Grindelia squarrosa. The various locations where this community was found included Altario, Birch Lake, Capt. Eyre Lake, Sand Plain North, Irma-Jarrow Lakes, Kenilworth Lake, Neutral Hills South, Old Channel Lake Springs, and Ribstone South. Wallis (1990) described the Spartina gracilis - Agropyron smithii community type as an open sandy site variant of the Distichlis stricta - Agropyron smithii community. The Distichlis stricta Agropyron spp. community type was described as widespread for Saskatchewan's saline areas within the dark brown soil zone by Dodd and Coupland (1966). Soils range in texture from fine sandy loam to clay. Distichlis stricta and Agropyron sp. dominate, contributing from 57 to $100 \%$ 
to the total graminoid cover. Basal cover of these species ranges from $10-10 \%$, with denser stands occupying finer-textured soils. There may be more than one species of Agropyron involved but their identification and relative importance were not investigated. Additional species include Puccinellia airoides, Muhlenbergia richardsonis, Calamagrostis montanensis, Plantago eriopoda, Grindelia squarrosa, Solidago nemoralis, Lactuca pulchella, and Achillea lanuginosa.

The Stipa sp. - Agropyron trachycaulum community type was described for Wood Buffalo National Park by Schwarz and Wein (1997). This community occurs on Black Solod soils and is characterized by grass and sedge species such as Agropyron trachycaulum, Carex siccata, C. xerantica, Stipa richardsonis, $S$. curtiseta and Muhlenbergia richardsonis. Geum triflorum and Potentilla hippiana were two of the important forb species in this community.

Schwarz and Wein (1997) described the Calamagrostis inexpansa - Agropyron trachycaulum Carex sp. community type on Brunisolic soils within Wood Buffalo National Park. Calamagrostis inexpansa, Agropyron trachycaulum, Carex siccata, Muhlenbergia richardsonis and Poa juncifolia were the important species of this community type.

The Koeleria - Agropyron association was described by Stacey (1927) for the Grand Prairie Beaverlodge area. This association inhabited drier upland and exposed sites. Koeleria cristata, Agropyron albicans and A. smithii were the dominant grasses, accompanied by other grass and forb species such as Agrostis hiemalis, Poa interior, Stipa columbiana, S. spartea, Elymus innovatus, Agropyron tenerum, A. inerme, A. caninum, and A. albicans. Agropyron inerme, and A. albicans were more prominent species within the limited range of Niobe. The Koeleria cristata-Agropyron smithii community type was also described for the proposed Rumsey Ecological Reserve, situated within the Central Parkland Subregion (Wroe 1971; Fehr 1982). It occupies xeric sites with Brown and Black Solonetzic soils on level areas and lower slopes. Koeleria cristata (59\%), Agropyron smithii (46\%) Selaginella densa (59\%), Carex eleocharis (35\%), Poa secunda (15\%), Grindelia squarrosa (13\%) and Distichlis stricta (8\%) are the most abundant species of this community. Some additional species include Achillea millefolium, Antennaria nitida, Artemisia frigida, Bouteloua gracilis and Hordeum jubatum.

Langevin (1973) listed the Koeleria - Agropyron - Artemisia community type from the Kleskun Hills area in the Peace River Parkland Subregion. Soils occupied by this community are described as having a shallow layer of peat on grey wooded loam. The author did not provide any details on the species composition.

\subsubsection{Vegetation Data Analysis and Classification}

The TWINSPAN clustering program failed to designate plots dominated or codominated by different Agropyron species into separate groups (with the exception of plots dominated by Agropyron smithii) and was therefore abandoned. Results from the two agglomerative clustering methods were carefully examined for the ecological meaning of the clusters, and those from the Farthest Neighbor analysis were retained for the interpretation. Classification of 416 plots reflected the complexity of environmental factors driving the plant community composition of sampled grassland communities. Careful examination of the dendrogram resulting from the cluster analysis and the matrix of plots by species used in the cluster analysis revealed 55 plot 
groups ("clusters", "community types"), ranging in size from 1 to 50 plots (Figure 1). Descriptive statistics for the species cover within each cluster (range, minimum, maximum, sum, mean, standard deviation and variance) (Appendix 3) showed that 18 out of 55 clusters represented community types that belong to four Agropyron alliances: Agropyron spicatum (communities \# 3, \# 29, \# 31, \# 54), A. trachycaulum (communities \# 4, \# 5, \# 9, \# 12, \# 15, \# 17, \# 48), A. dasystachyum (communities \# 44, \# 45, \# 46, \# 53), and A. smithii (communities \# 36, \# 47, \# 51) (Figure 1). Although 13 out of the remaining 37 communities have a significant cover of one of the four Agropyron species, they are clearly dominated by one or more species other than Agropyron, which indicates that they do not belong to any of Agropyron alliances (Appendix 3).

\subsubsection{Relationship between Classified Agropyron Communities and Environmental Variables}

The first four axes of the Detrended Canonical Correspondence Analysis (DCCA) explain 16\% of the variation in the species data set (Appendix 4). The relative magnitude of the eigenvalues $(\lambda)$ for the first four canonical axes and the species/environmental correlation, indicate that the first two axes are the most important for the interpretation of the ordination of 120 plots and 204 species along 6 environmental variables. The highest eigenvalue of the first axis shows that the highest percentage variance in the species data is accounted for by that axis. The relatively small decrease in the magnitude of the second eigenvalue $(\lambda 1 / \lambda 2=2.8)$ indicates that the vegetation clusters are influenced by environmental gradients, which form at least two (complex) gradients represented by the first two axes.

Based on the canonical coefficients and inter-set correlations (ter Braak 1988), longitude and moisture are the most important variables defining Axis 1, followed by latitude and elevation (Appendix 5). Drainage and annual radiation have no statistical significance in explaining species/environmental correlation along this axis. All four significant factors increase in the same direction. Species (Figure 2) and plots (Figure 3) on the right side of the ordination are generally found in the southeastern portion of the province and/or on drier soils. They are also found on lower elevations. On the other hand, species and plots toward the left end of the first axis are generally found within the northwestern portion of the province, and relate to moister soils, and higher elevations.

Elevation has the highest correlation with Axis 2, followed by latitude, longitude, and drainage (Appendix 5). Elevation increases in the opposite directions of latitude, longitude, and drainage. Species (Figure 2) and plots (Figure 3 ) on the upper end of Axis 2 are generally more northerly situated and associated with lower elevations and moister soils compared to plots found along the lower end of the axes.

In addition to ordination analysis, descriptive statistics that were calculated for environmental variables, including those with a lot of missing data (soil drainage, site position - macro, site position - meso, nutrient regimes, $\%$ bedrock, $\%$ mineral soil, and $\%$ organic material), for each Agropyron community type from cluster analysis are presented in Table 6.

The foregoing results suggest that most of the communities dominated and codominated by Agropyron trachycaulum are found within the northwestern and western portions of the province and on moister soils compared to the communities dominated by other Agropyron species. 
Figure 1. Cluster analysis of 416 selected plots from Ecological Site Inventory System (ESIS) database: Linkage method: FARTHEST NEIGHBOR; Distance measure: Sorensen (Bray-Curtis); Percent chaining $=2.28$; code equivalents between cluster groups (communities) identified by cluster analysis, PC-ORD plots, and "Other Plot Number" - unique plot codes in ESIS database are presented in Table 5.

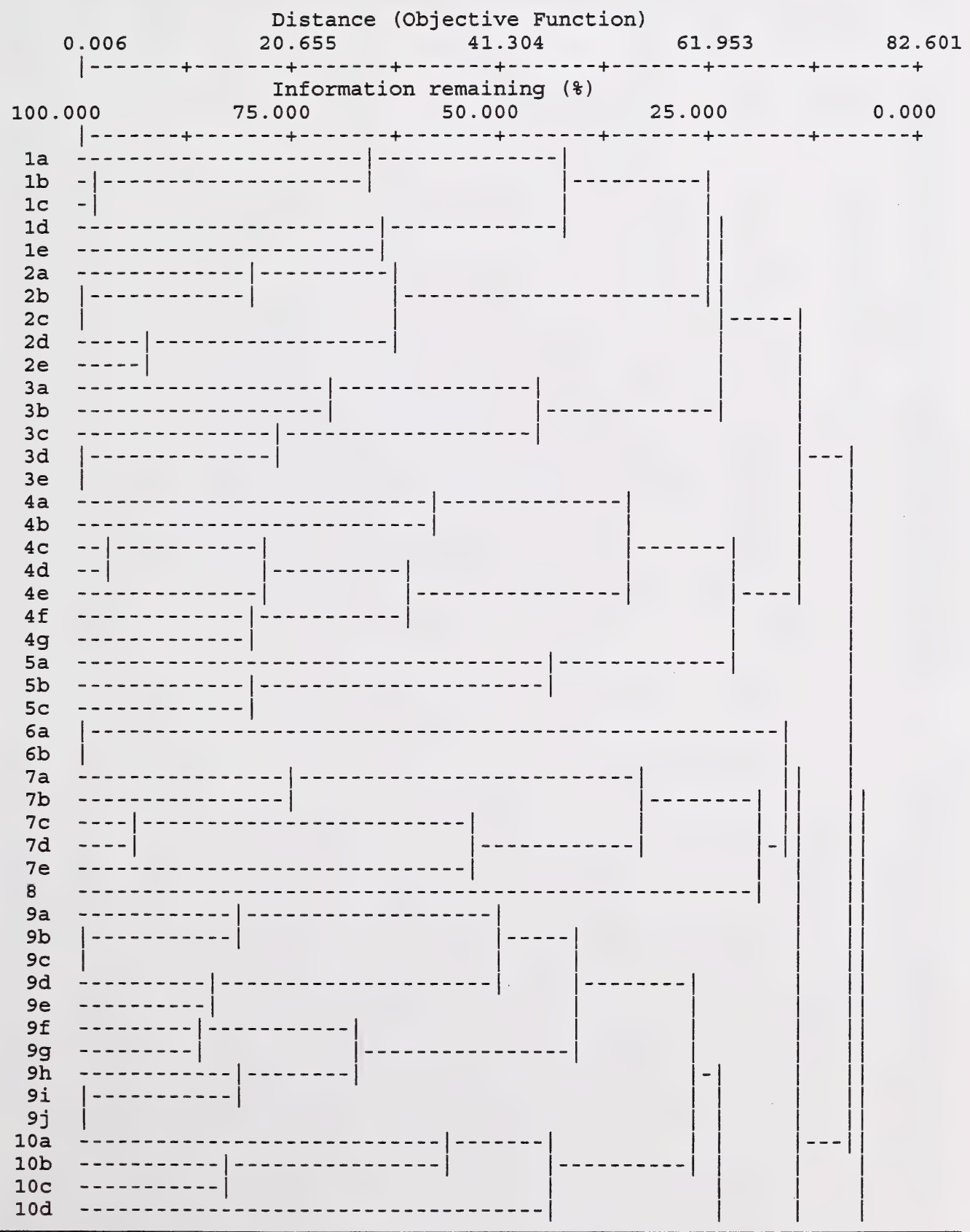




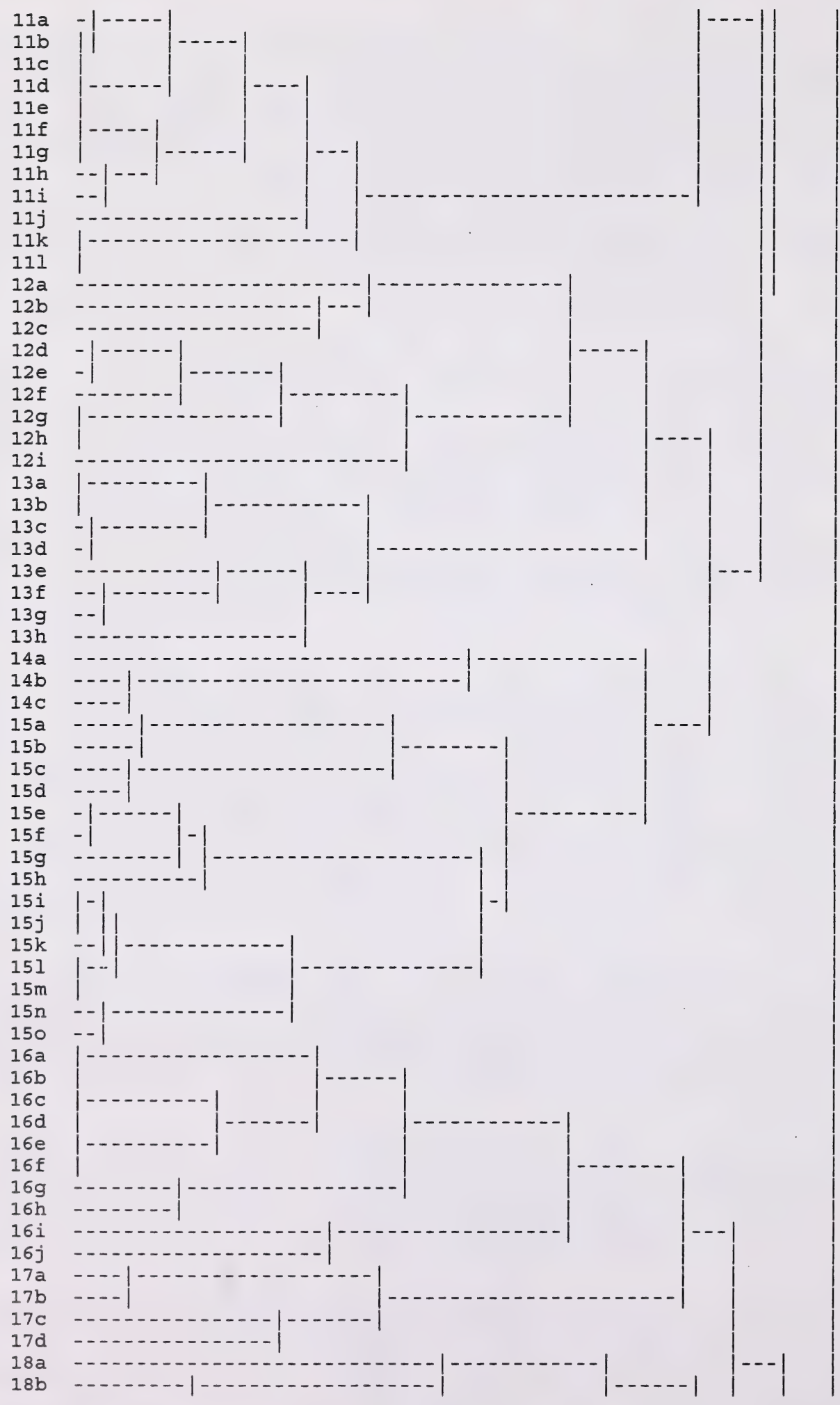




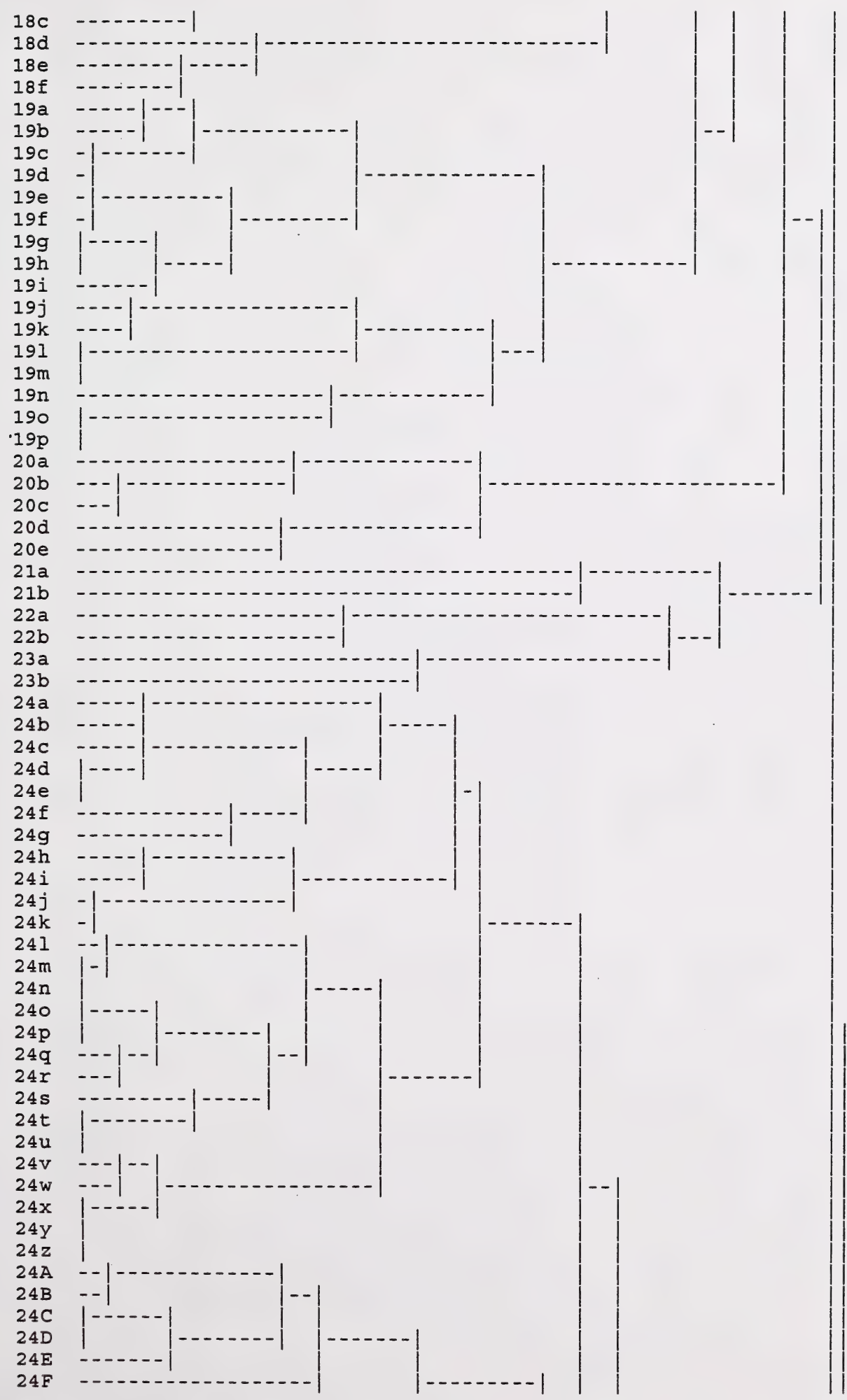




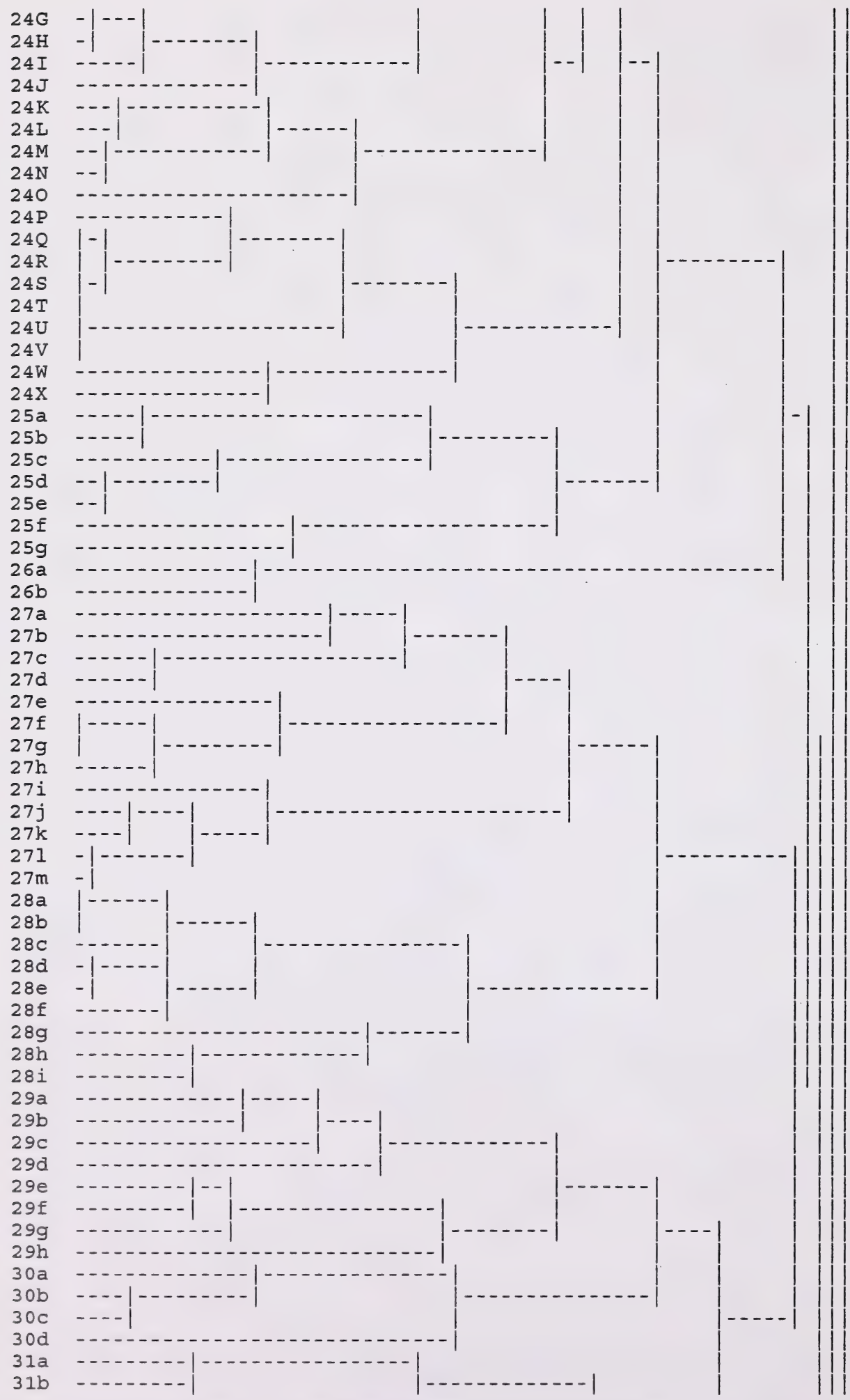




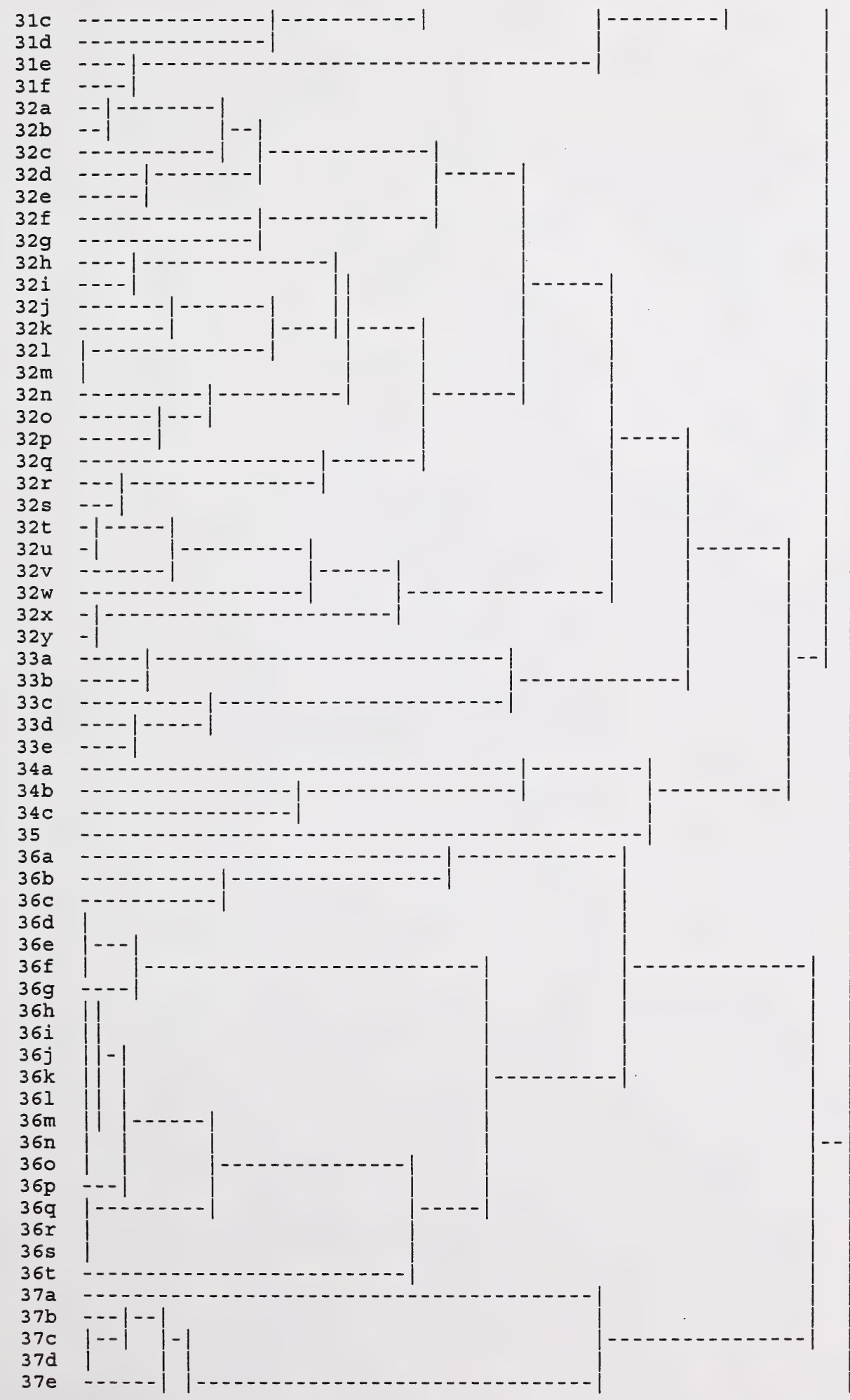




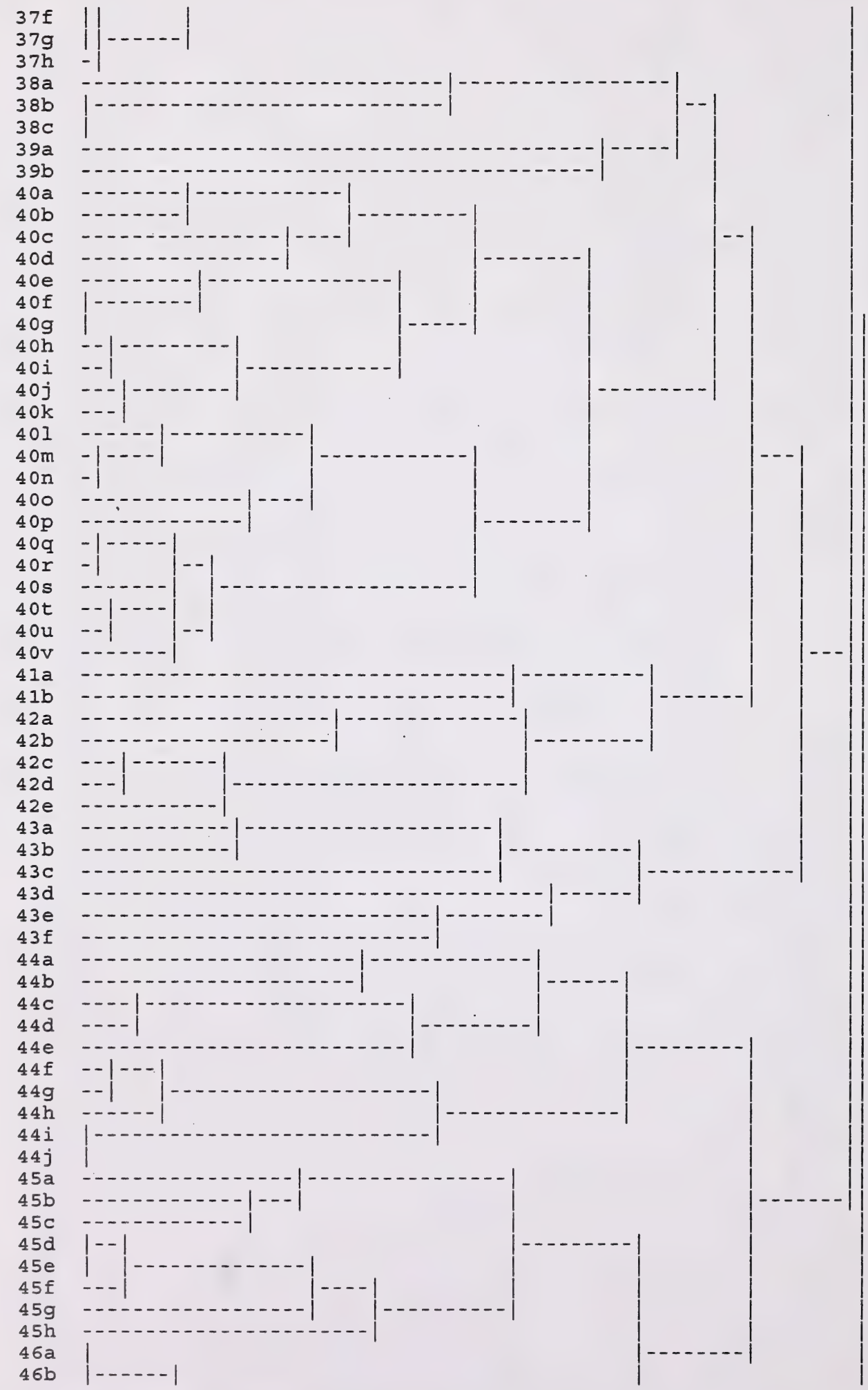




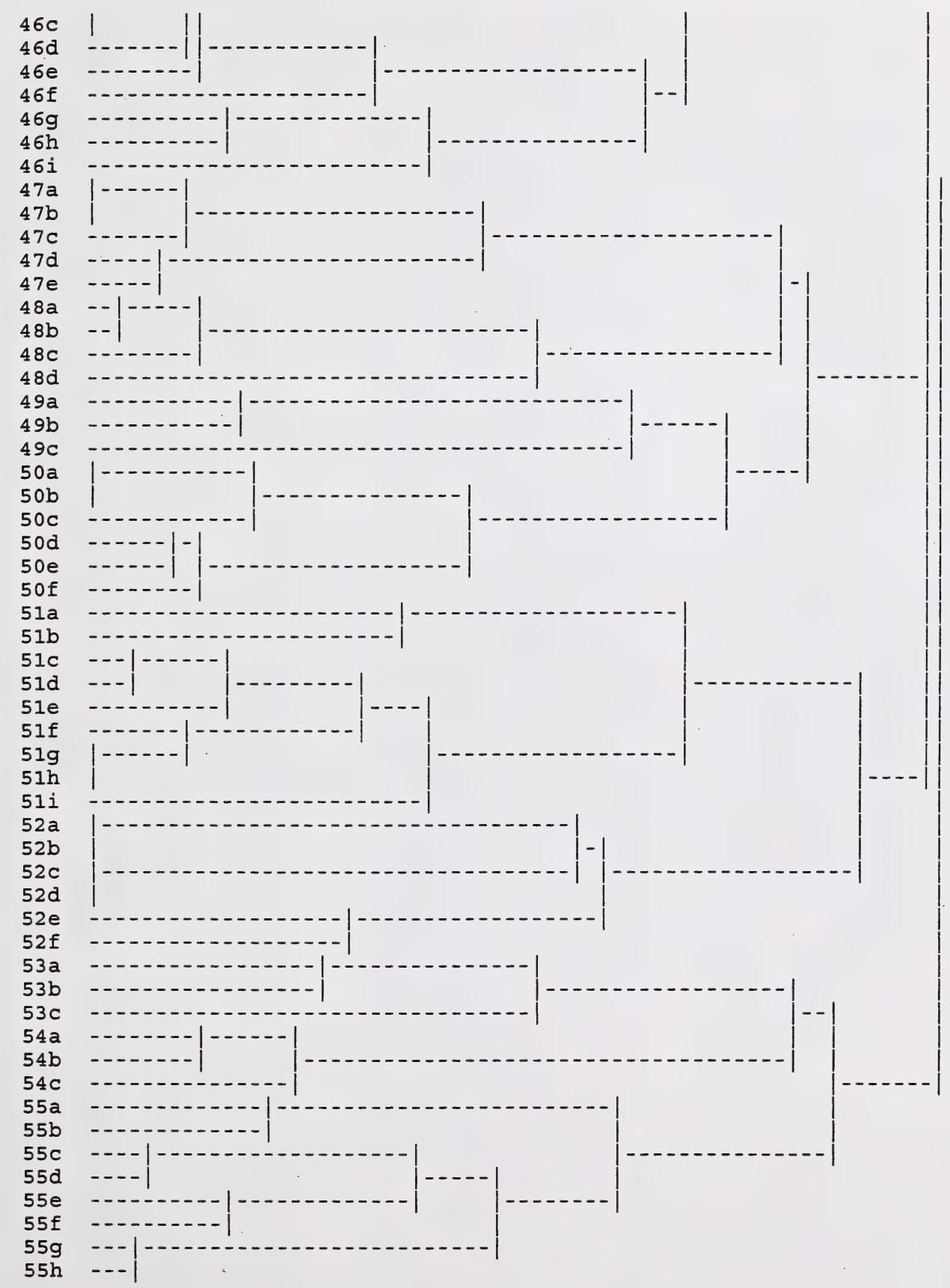

$\star * * * * * * * * * * * * * * * * * * * * * * * *$ Cluster analysis completed 
Table 5: Code equivalents between cluster groups (communities) identified by cluster analysis, PC-ORD plots, and "Other Plot Number" - unique plot codes in ESIS database.

\begin{tabular}{|c|c|c|c|c|c|c|c|c|}
\hline $\begin{array}{c}\text { Cluster } \\
\text { No. }\end{array}$ & PC-ORD & ESIS Code & $\begin{array}{c}\text { Cluster } \\
\text { No. }\end{array}$ & PC-ORD & ESIS Code & $\begin{array}{c}\text { Cluster } \\
\text { No. }\end{array}$ & PC-ORD & ESIS Code \\
\hline 1 & $1 \mathrm{a}$ & 17 SW 1069 & 11 & $11 a$ & 72RCK003 & 16 & $16 a$ & 32BKR005 \\
\hline 1 & 16 & WATE5029 & 11 & $11 \mathrm{~b}$ & RF04 & 16 & $16 \mathrm{~b}$ & 72JEE005 \\
\hline 1 & $1 c$ & WATE5054 & 11 & $11 \mathrm{c}$ & RF05 & 16 & $16 c$ & 32BKR025 \\
\hline 1 & $1 d$ & 94JE8146 & 11 & $11 d$ & RF01 & 16 & $16 \mathrm{~d}$ & 72JEE019 \\
\hline 1 & $1 \mathrm{e}$ & 94JM7010 & 11 & $11 \mathrm{e}$ & SM920 & 16 & $16 \mathrm{e}$ & 32BKR029 \\
\hline 2 & $2 a$ & 72JOG003 & 11 & $11 \mathrm{f}$ & 72RIE015 & 16 & $16 \mathrm{f}$ & 72JEE029 \\
\hline 2 & $2 b$ & 72JOG011 & 11 & $11 \mathrm{~g}$ & 72RIE023 & 16 & $16 \mathrm{~g}$ & 32BKR012 \\
\hline 2 & $2 c$ & 72JOG013 & 11 & $11 \mathrm{~h}$ & 72RIE022 & 16 & $16 \mathrm{~h}$ & 32BKR024 \\
\hline 2 & $2 d$ & 72JOG014 & 11 & $11 \mathrm{i}$ & RR1A & 16 & $16 \mathrm{i}$ & $34 \mathrm{PC} 1012$ \\
\hline 2 & $2 e$ & STODDO & 11 & $11 \mathrm{j}$ & 72RIE028 & 16 & $16 \mathrm{j}$ & 94JM8022 \\
\hline 3 & $3 a$ & 72JOW009 & 11 & $11 \mathrm{k}$ & 72WMP012 & 17 & $17 a$ & 72BSD002 \\
\hline 3 & $3 b$ & 72PFM003 & 11 & 111 & 72WMP013 & 17 & $17 \mathrm{~b}$ & 72BSP002 \\
\hline 3 & $3 c$ & NTODDO & 12 & $12 \mathrm{a}$ & 72BDH002 & 17 & $17 c$ & 72BSS002 \\
\hline 3 & $3 d$ & STATIN & 12 & $12 \mathrm{~b}$ & $72 \mathrm{WMP} 023$ & 17 & $17 \mathrm{~d}$ & 72JWG008 \\
\hline 3 & $3 e$ & STATO & 12 & $12 c$ & 72WMP025 & 18 & $18 \mathrm{a}$ & 72BDH001 \\
\hline 4 & $4 a$ & 32EB0132 & 12 & $12 \mathrm{~d}$ & 72WMP017 & 18 & $18 \mathrm{~b}$ & 72BJP004 \\
\hline 4 & $4 b$ & $37 \mathrm{KR} 1075$ & 12 & $12 \mathrm{e}$ & 72WMP019 & 18 & $18 \mathrm{c}$ & 72BTD002 \\
\hline 4 & $4 c$ & $34 \mathrm{KP} 0019$ & 12 & $12 \mathrm{f}$ & 72WMP018 & 18 & $18 \mathrm{~d}$ & SMB970 \\
\hline 4 & $4 d$ & 37 SP1004 & 12 & $12 \mathrm{~g}$ & SULPI98 & 18 & $18 \mathrm{e}$ & YE03 \\
\hline 4 & $4 \mathrm{e}$ & 94PA8151 & 12 & $12 \mathrm{~h}$ & SULPO98 & 18 & $18 \mathrm{f}$ & YE05 \\
\hline 4 & $4 f$ & 34KP0048 & 12 & $12 \mathrm{i}$ & RF06 & 19 & $19 a$ & 72BHF001 \\
\hline 4 & $4 g$ & 94PA8160 & 13 & $13 a$ & $72 \mathrm{VVH} 004$ & 19 & $19 \mathrm{~b}$ & 72BHF002 \\
\hline 5 & $5 a$ & $34 \mathrm{KCK} 003$ & 13 & $13 \mathrm{~b}$ & $72 \mathrm{JVH} 010$ & 19 & $19 c$ & 72BHF010 \\
\hline 5 & $5 b$ & 72BHF008 & 13 & $13 c$ & $72 \mathrm{JVS} 011$ & 19 & $19 d$ & $72 \mathrm{BSC} 002$ \\
\hline 5 & $5 c$ & 72BPM001 & 13 & $13 d$ & 72JVT002 & 19 & $19 \mathrm{e}$ & RF13 \\
\hline 6 & $6 d$ & 31 GP7478 & 13 & $13 e$ & 72JVN001 & 19 & $19 f$ & RN01 \\
\hline 6 & $6 e$ & $32 \mathrm{~EB} 0030$ & 13 & $13 \mathrm{f}$ & 72JVS002 & 19 & $19 g$ & RF15A \\
\hline 7 & $7 a$ & $37 \mathrm{BL} 1020$ & 13 & $13 \mathrm{~g}$ & $72 \mathrm{JVS} 005$ & 19 & $19 \mathrm{~h}$ & RF20A \\
\hline 7 & $7 b$ & 72POA001 & 13 & $13 \mathrm{~h}$ & 72JVT004 & 19 & $19 \mathrm{i}$ & RF20B \\
\hline 7 & $7 c$ & 72PAU005 & 14 & $14 a$ & 72BIW006 & 19 & $19 j$ & 72BHF005 \\
\hline 7 & $7 d$ & HOLBRNA & 14 & $14 \mathrm{~b}$ & 72BIW008 & 19 & $19 \mathrm{k}$ & 72BHF011 \\
\hline 7 & $7 e$ & SVHTP02 & 14 & $14 c$ & 72BIW009 & 19 & 191 & CU92 \\
\hline 8 & 8 & 72PEP001 & 15 & $15 \mathrm{a}$ & 72PGB002 & 19 & $19 \mathrm{~m}$ & CU920 \\
\hline 9 & $9 a$ & 31 GP8508 & 15 & $15 \mathrm{~b}$ & 72PGB004 & 19 & $19 n$ & 72ВЛL002 \\
\hline 9 & $9 \mathrm{~b}$ & 37EP1009 & 15 & $15 c$ & 72RBD016 & 19 & 190 & 72BJP002 \\
\hline 9 & $9 c$ & $37 \mathrm{EP} 1038$ & 15 & $15 \mathrm{~d}$ & 72RBD017 & 19 & $19 p$ & 72BTD001 \\
\hline 9 & $9 d$ & $32 \mathrm{CC} 0040$ & 15 & $15 e$ & 72RCK002 & 20 & $20 \mathrm{a}$ & 57WCA106 \\
\hline 9 & $9 e$ & 72RIE009 & 15 & $15 f$ & RR03 & 20 & $20 \mathrm{~b}$ & BR02 \\
\hline 9 & $9 f$ & $34 \mathrm{CB} 8615$ & 15 & $15 \mathrm{~g}$ & RF21B & 20 & $20 c$ & BR13 \\
\hline 9 & $9 g$ & PANT42 & 15 & $15 \mathrm{~h}$ & RR3B & 20 & $20 d$ & $94 \mathrm{IC} 8089$ \\
\hline 9 & $9 \mathrm{~h}$ & 37BF1151 & 15 & $15 \mathrm{i}$ & 72RIE008 & 20 & $20 \mathrm{e}$ & 94PA7158 \\
\hline 9 & $9 \mathrm{i}$ & 72RIE004 & 15 & $15 j$ & RF07 & 21 & $21 a$ & 32LA4001 \\
\hline 9 & $9 j$ & 72RIE026 & 15 & $15 \mathrm{k}$ & RF19 & 21 & $21 \mathrm{~b}$ & 94JC8012 \\
\hline 10 & $10 \mathrm{a}$ & 31GP8597 & 15 & 151 & RF09 & 22 & $22 a$ & 94JE8093 \\
\hline 10 & $10 \mathrm{~b}$ & 34RDP029 & 15 & $15 \mathrm{~m}$ & RF16 & 22 & $22 b$ & 94JM8094 \\
\hline 10 & $10 c$ & 34RDP036 & 15 & $15 n$ & RF17 & 23 & $23 a$ & 94LC9042 \\
\hline 10 & $10 \mathrm{~d}$ & 72RFL010 & 15 & 150 & RF2B & 23 & $23 b$ & 94SJ9036 \\
\hline
\end{tabular}




\begin{tabular}{|c|c|c|c|c|c|c|c|c|}
\hline $\begin{array}{c}\text { Cluster } \\
\text { No. }\end{array}$ & PCORD & ESIS Code & $\begin{array}{c}\text { Cluster } \\
\text { No. }\end{array}$ & PCORD & ESIS Code & $\begin{array}{c}\text { Cluster } \\
\text { No. }\end{array}$ & PCORD & ESIS Code \\
\hline 24 & $24 a$ & $32 \mathrm{~EB} 0002$ & 24 & $24 \mathrm{~V}$ & LM930 & 31 & $31 \mathrm{~b}$ & WATE5131 \\
\hline 24 & $24 \mathrm{~b}$ & 32EB0105 & 24 & $24 \mathrm{~W}$ & 72JWG121 & 31 & $31 c$ & WATE4087 \\
\hline 24 & $24 c$ & 72JEE001 & 24 & $24 X$ & 72JWG143 & 31 & $31 d$ & WATE5033 \\
\hline 24 & $24 d$ & 72JEE003 & 25 & $25 a$ & 34URD003 & 31 & $31 \mathrm{e}$ & WATE5045 \\
\hline 24 & $24 \mathrm{e}$ & 72JEE012 & 25 & $25 b$ & 34URD059 & 31 & $31 f$ & WATE 5047 \\
\hline 24 & $24 f$ & 72WMP015 & 25 & $25 c$ & 72JAF003 & 32 & $32 a$ & 72JAF002 \\
\hline 24 & $24 \mathrm{~g}$ & $\mathrm{HC} 92$ & 25 & $25 \mathrm{~d}$ & PANT03 & 32 & $32 b$ & 72JAF016 \\
\hline 24 & $24 \mathrm{~h}$ & 72BFM002 & 25 & $25 \mathrm{e}$ & PANT50 & 32 & $32 c$ & 72LAN001 \\
\hline 24 & $24 \mathrm{i}$ & 72BFM003 & 25 & $25 f$ & WATE5114 & 32 & $32 d$ & 72JAF019 \\
\hline 24 & $24 j$ & 72JVS010 & 25 & $25 \mathrm{~g}$ & $\mathrm{YC} 92 \mathrm{O}$ & 32 & $32 \mathrm{e}$ & 72JOG007 \\
\hline 24 & $24 \mathrm{k}$ & JR92 & 26 & $26 a$ & $32 \mathrm{~EB} 0051$ & 32 & $32 f$ & 72JAF006 \\
\hline 24 & 241 & $72 \mathrm{BBB} 002$ & 26 & $26 \mathrm{~b}$ & 32EB0089 & 32 & $32 \mathrm{~g}$ & 72JAF009 \\
\hline 24 & $24 \mathrm{~m}$ & 72BHF012 & 27 & $27 a$ & $34 \mathrm{CP} 2003$ & 32 & $32 \mathrm{~h}$ & 72JAF004 \\
\hline 24 & $24 n$ & 72BRA001 & 27 & $27 \mathrm{~b}$ & 72JLG007 & 32 & $32 \mathrm{i}$ & 72JAF013 \\
\hline 24 & 240 & 72JEE018 & 27 & $27 c$ & 72JLB013 & 32 & $32 j$ & 72JSS016 \\
\hline 24 & $24 p$ & MC92 & 27 & $27 d$ & 72JNT016 & 32 & $32 \mathrm{k}$ & STRBA2 \\
\hline 24 & $24 q$ & 72JLG008 & 27 & $27 e$ & 72JLB004 & 32 & 321 & 72WTR013 \\
\hline 24 & $24 r$ & PANT13 & 27 & $27 \mathrm{f}$ & 72JNT003 & 32 & $32 \mathrm{~m}$ & 72WTR017 \\
\hline 24 & $24 s$ & WATE5081 & 27 & $27 \mathrm{~g}$ & 72JNT007 & 32 & $32 n$ & 72JLG001 \\
\hline 24 & $24 t$ & WATE5140 & 27 & $27 \mathrm{~h}$ & 72JNT012 & 32 & 320 & STRBA3 \\
\hline 24 & $24 u$ & WATE5143 & 27 & $27 i$ & 72JWG010 & 32 & $32 p$ & STRBA7 \\
\hline 24 & $24 v$ & 72JEA016 & 27 & $27 j$ & 72JWG060 & 32 & $32 q$ & 72JLG009 \\
\hline 24 & $24 w$ & SCHIMIN & 27 & $27 \mathrm{k}$ & 72JWG073 & 32 & $32 r$ & 72JSSO09 \\
\hline 24 & $24 x$ & 72JOC007 & 27 & 271 & 72JWG066 & 32 & $32 \mathrm{~s}$ & 72JSS023 \\
\hline 24 & $24 y$ & 72JOC008 & 27 & $27 \mathrm{~m}$ & 72JWG104 & 32 & $32 t$ & 72JEA006 \\
\hline 24 & $24 z$ & $72 \mathrm{JOC} 009$ & 28 & $28 \mathrm{a}$ & 72JEE006 & 32 & $32 u$ & $72 \mathrm{JOC} 005$ \\
\hline 24 & $24 \mathrm{~A}$ & 34ET4425 & 28 & $28 b$ & JHEAIN & 32 & $32 v$ & 72JOC002 \\
\hline 24 & $24 B$ & 72JEA012 & 28 & $28 c$ & 72JWG067 & 32 & $32 w$ & $72 \mathrm{JEA011}$ \\
\hline 24 & $24 \mathrm{C}$ & 72JEA015 & 28 & $28 \mathrm{~d}$ & 72JWG064 & 32 & $32 x$ & 72JEA007 \\
\hline 24 & $24 D$ & $72 \mathrm{JOC} 006$ & 28 & $28 \mathrm{e}$ & 72JWG065 & 32 & $32 y$ & 72JEA009 \\
\hline 24 & $24 \mathrm{E}$ & $72 \mathrm{JOC} 010$ & 28 & $28 \mathrm{f}$ & 72JWG083 & 33 & $33 a$ & 72JOG002 \\
\hline 24 & $24 \mathrm{~F}$ & 72JOC011 & 28 & $28 \mathrm{~g}$ & 72JWG079 & 33 & $33 b$ & HS93I \\
\hline 24 & $24 \mathrm{G}$ & 72JEA004 & 28 & $28 \mathrm{~h}$ & 72JWG107 & 33 & $33 c$ & 72JVN003 \\
\hline 24 & $24 \mathrm{H}$ & 72JEA008 & 28 & $28 \mathrm{i}$ & 72JWG116 & 33 & $33 d$ & 72JVN005 \\
\hline 24 & $24 \mathrm{I}$ & 72JOG001 & 29 & $29 a$ & 72JBC 015 & 33 & $33 e$ & 72WMP016 \\
\hline 24 & $24 \mathrm{~J}$ & NROCKIN & 29 & $29 \mathrm{~b}$ & 72JWG093 & 34 & $34 a$ & 72JNC076 \\
\hline 24 & $24 \mathrm{~K}$ & 72JCC 001 & 29 & $29 c$ & 72JWE001 & 34 & $34 \mathrm{~b}$ & 72JWG014 \\
\hline 24 & $24 \mathrm{~L}$ & 72JNT017 & 29 & $29 d$ & 72JMC013 & 34 & $34 c$ & 72JWG028 \\
\hline 24 & $24 \mathrm{M}$ & 72JWG070 & 29 & $29 \mathrm{e}$ & 72JDD010 & 35 & 35 & 72PRC001 \\
\hline 24 & $24 \mathrm{~N}$ & 72JWG113 & 29 & $29 \mathrm{f}$ & TROU4B & 36 & $36 a$ & $32 \mathrm{~EB} 0003$ \\
\hline 24 & 240 & 72JWT006 & 29 & $29 \mathrm{~g}$ & 72JTC011 & 36 & $36 \mathrm{~b}$ & 32 EB 0031 \\
\hline 24 & $24 \mathrm{P}$ & 72JWG020 & 29 & $29 \mathrm{~h}$ & TRO13A & 36 & $36 c$ & 32EB0040 \\
\hline 24 & $24 Q$ & 72JWG061 & 30 & $30 a$ & $72 \mathrm{NNC} 019$ & 36 & $36 \mathrm{~d}$ & $32 \mathrm{PK} 1002$ \\
\hline 24 & $24 \mathrm{R}$ & 72JWG117 & 30 & $30 \mathrm{~b}$ & 72JNT010 & 36 & $36 \mathrm{e}$ & 32PU1021 \\
\hline 24 & $24 S$ & 72JWG077 & 30 & $30 \mathrm{c}$ & 72JWG016 & 36 & $36 f$ & 32 PU1005 \\
\hline 24 & $24 \mathrm{~T}$ & LIVING & 30 & $30 d$ & 72JWT001 & 36 & $36 \mathrm{~g}$ & $32 \mathrm{PK} 1025$ \\
\hline 24 & $24 \mathrm{U}$ & LM93I & 31 & $31 a$ & WATE 4082 & 36 & $36 \mathrm{~h}$ & 34MR0B01 \\
\hline
\end{tabular}




\begin{tabular}{|c|c|c|c|c|c|}
\hline Cluster No. & ESIS Code & Cluster No. & ESIS Code & Cluster No. & ESIS Code \\
\hline $36 \mathrm{i}$ & 34MR0Q01 & $41 \mathrm{a}$ & 72JNC043 & $48 \mathrm{c}$ & $57 \mathrm{WCA} 103$ \\
\hline $36 j$ & 34MR0C01 & $41 \mathrm{~b}$ & 94SJ9032 & $48 d$ & 57WCA107 \\
\hline $36 \mathrm{k}$ & 34MR0F01 & $42 a$ & 72JOG004 & $49 a$ & 72JNC006 \\
\hline 361 & 34MR0P01 & $42 \mathrm{~b}$ & 72JOG006 & $49 \mathrm{~b}$ & 72JNC008 \\
\hline $36 \mathrm{~m}$ & 34MR0I01 & $42 c$ & 72WTR002 & $49 c$ & TROU1A \\
\hline $36 n$ & 34MR0L01 & $42 d$ & 72WTR003 & $50 a$ & PANT04 \\
\hline 360 & 34MR0D01 & $42 e$ & 72WTR015 & $50 \mathrm{~b}$ & PANT14 \\
\hline $36 p$ & 34MR0M01 & $43 a$ & 72JBR006 & $50 c$ & PANT08 \\
\hline $36 q$ & 34MR0G01 & $43 b$ & DEEP10 & $50 \mathrm{~d}$ & PANT41 \\
\hline $36 r$ & 34MR0S01 & $43 c$ & 72JMC016 & $50 \mathrm{e}$ & PANT43 \\
\hline $36 s$ & 34MR0T01 & $43 \mathrm{~d}$ & 72JLL024 & $50 \mathrm{f}$ & PANT48 \\
\hline $36 t$ & 34MR0K01 & $43 e$ & 72JWG026 & $51 \mathrm{a}$ & $32 \mathrm{PK} 1005$ \\
\hline $37 a$ & $32 \mathrm{MI} 1016$ & $43 \mathrm{f}$ & 72JYK001 & $51 b$ & 34MR0O01 \\
\hline $37 \mathrm{~b}$ & $32 \mathrm{PK} 1023$ & $44 a$ & $32 \mathrm{~EB} 0024$ & $51 \mathrm{c}$ & 32PK1007 \\
\hline $37 c$ & 32PU1007 & $44 b$ & $34 \mathrm{KP} 0033$ & 51d & $34 \mathrm{KCG} 501$ \\
\hline $37 d$ & 32PU1016 & $44 c$ & $34 \mathrm{KP} 0041$ & $51 \mathrm{e}$ & $32 \mathrm{PU} 1006$ \\
\hline $37 e$ & 32PU1017 & $44 d$ & 94PA7048 & $51 \mathrm{f}$ & $34 \mathrm{KCK} 001$ \\
\hline $37 f$ & $34 \mathrm{KCG} 162$ & $44 \mathrm{e}$ & YE09 & $51 \mathrm{~g}$ & 34MR0H01 \\
\hline $37 \mathrm{~g}$ & $34 \mathrm{KCK} 002$ & $44 \mathrm{f}$ & $37 \mathrm{SP} 1012$ & $51 \mathrm{~h}$ & 34MR0U01 \\
\hline $37 \mathrm{~h}$ & $34 \mathrm{KCG} 301$ & $44 \mathrm{~g}$ & 94SJ9001 & $51 \mathrm{i}$ & 34MR0R01 \\
\hline $38 a$ & 32EB0013 & $44 \mathrm{~h}$ & 37 SP1028 & $52 a$ & 32PK1009 \\
\hline $38 \mathrm{~b}$ & GR92 & $44 i$ & $37 \mathrm{SP} 1013$ & $52 \mathrm{~b}$ & $32 \mathrm{PK} 1014$ \\
\hline $38 \mathrm{c}$ & RR920 & $44 j$ & $94 \mathrm{JI} 5018$ & $52 c$ & $34 \mathrm{KCG} 401$ \\
\hline $39 a$ & $32 \mathrm{~EB} 0059$ & $45 a$ & $32 \mathrm{SC} 0002$ & $52 \mathrm{~d}$ & $34 \mathrm{KCK} 005$ \\
\hline $39 \mathrm{~b}$ & $32 \mathrm{PK} 1015$ & $45 b$ & 94J19009 & $52 e$ & $32 \mathrm{PK} 1010$ \\
\hline $40 a$ & 32EB0087 & $45 c$ & 94PA7145 & $52 \mathrm{f}$ & 32PU1004 \\
\hline $40 \mathrm{~b}$ & 94JM7017 & $45 d$ & $32 S C 0007$ & $53 a$ & $34 \mathrm{KP} 0004$ \\
\hline $40 c$ & 72JAF010 & $45 e$ & 37 SP1001 & $53 \mathrm{~b}$ & $34 \mathrm{KP} 0016$ \\
\hline $40 d$ & 72JWT014 & $45 \mathrm{f}$ & $34 \mathrm{KP} 0010$ & $53 c$ & BR05 \\
\hline $40 \mathrm{e}$ & 72JWG021 & $45 \mathrm{~g}$ & $94 \mathrm{JC} 8080$ & $54 a$ & SS25 \\
\hline $40 \mathrm{f}$ & 72JWG058 & $45 \mathrm{~h}$ & $34 \mathrm{KCG} 211$ & $54 \mathrm{~b}$ & WM02 \\
\hline $40 \mathrm{~g}$ & 72JWG105 & $46 a$ & $34 \mathrm{KP} 0008$ & $54 c$ & TM08 \\
\hline $40 \mathrm{~h}$ & 72JWG037 & $46 \mathrm{~b}$ & $34 \mathrm{KP} 0014$ & $55 a$ & 72BSP003 \\
\hline $40 \mathrm{i}$ & $72 J W G 096$ & $46 c$ & $34 \mathrm{KP} 0029$ & $55 \mathrm{~b}$ & 72JAF021 \\
\hline $40 \mathrm{j}$ & 72JWG091 & $46 \mathrm{~d}$ & $34 \mathrm{KP} 0015$ & $55 c$ & 72JLB015 \\
\hline $40 \mathrm{k}$ & 72JWG101 & $46 e$ & 94 SJ7025 & $55 d$ & SCSO96 \\
\hline 401 & 72JAF014 & $46 f$ & $94 J 6052$ & $55 \mathrm{e}$ & 72JMC006 \\
\hline $40 \mathrm{~m}$ & 72LAN005 & $46 \mathrm{~g}$ & 94IC7032 & $55 f$ & 72JST001 \\
\hline $40 n$ & 72WTR011 & $46 \mathrm{~h}$ & $94 \mathrm{IC} 8087$ & $55 \mathrm{~g}$ & $72 \mathrm{JMC014}$ \\
\hline 400 & 72JSS008 & $46 \mathrm{i}$ & 94JE9151 & $55 \mathrm{~h}$ & SD30 \\
\hline $40 p$ & LRILEYI & $47 a$ & $32 \mathrm{MI} 1010$ & & \\
\hline $40 q$ & 72JOC001 & $47 \mathrm{~b}$ & $32 \mathrm{MI} 1012$ & & \\
\hline $40 \mathrm{r}$ & JRO92 & $47 c$ & $32 \mathrm{MI} 1031$ & & \\
\hline $40 s$ & MC92O & $47 d$ & $32 \mathrm{MI} 1022$ & & \\
\hline $40 \mathrm{t}$ & 72RBD018 & $47 e$ & 32MI1025 & & \\
\hline $40 u$ & RR06 & $48 a$ & $32 \mathrm{MI} 1013$ & & \\
\hline $40 \mathrm{v}$ & $72 \mathrm{WMP} 020$ & $48 \mathrm{~b}$ & $32 \mathrm{MI} 1026$ & & \\
\hline
\end{tabular}




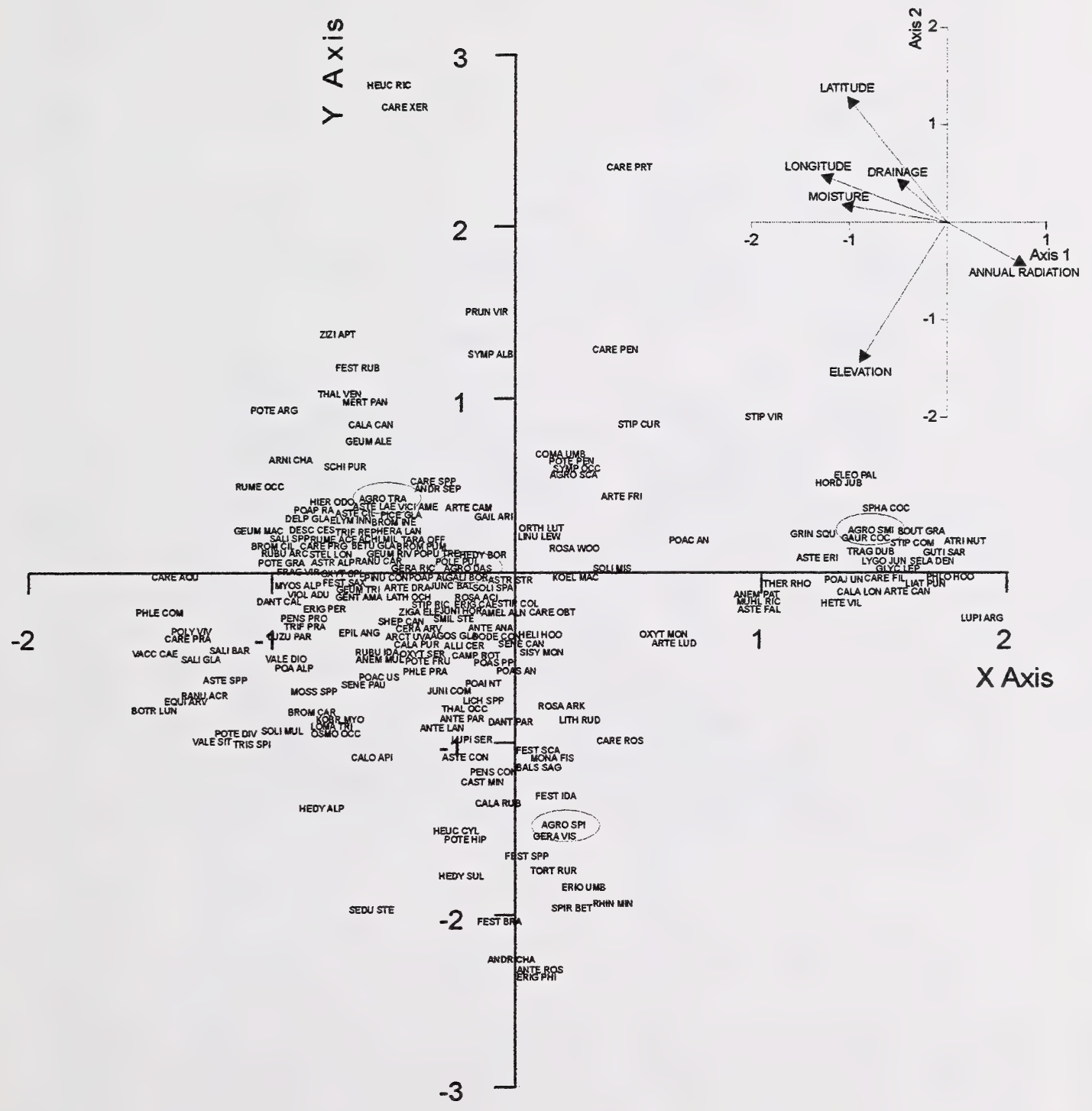

Figure 2. Ordination diagram based on Detrended Canonical Correspondence Analysis (DCCA) of 120 plots from the Ecological Site Inventory System (ESIS) database. The diagram displays all but the infrequent species from 120 plots. 


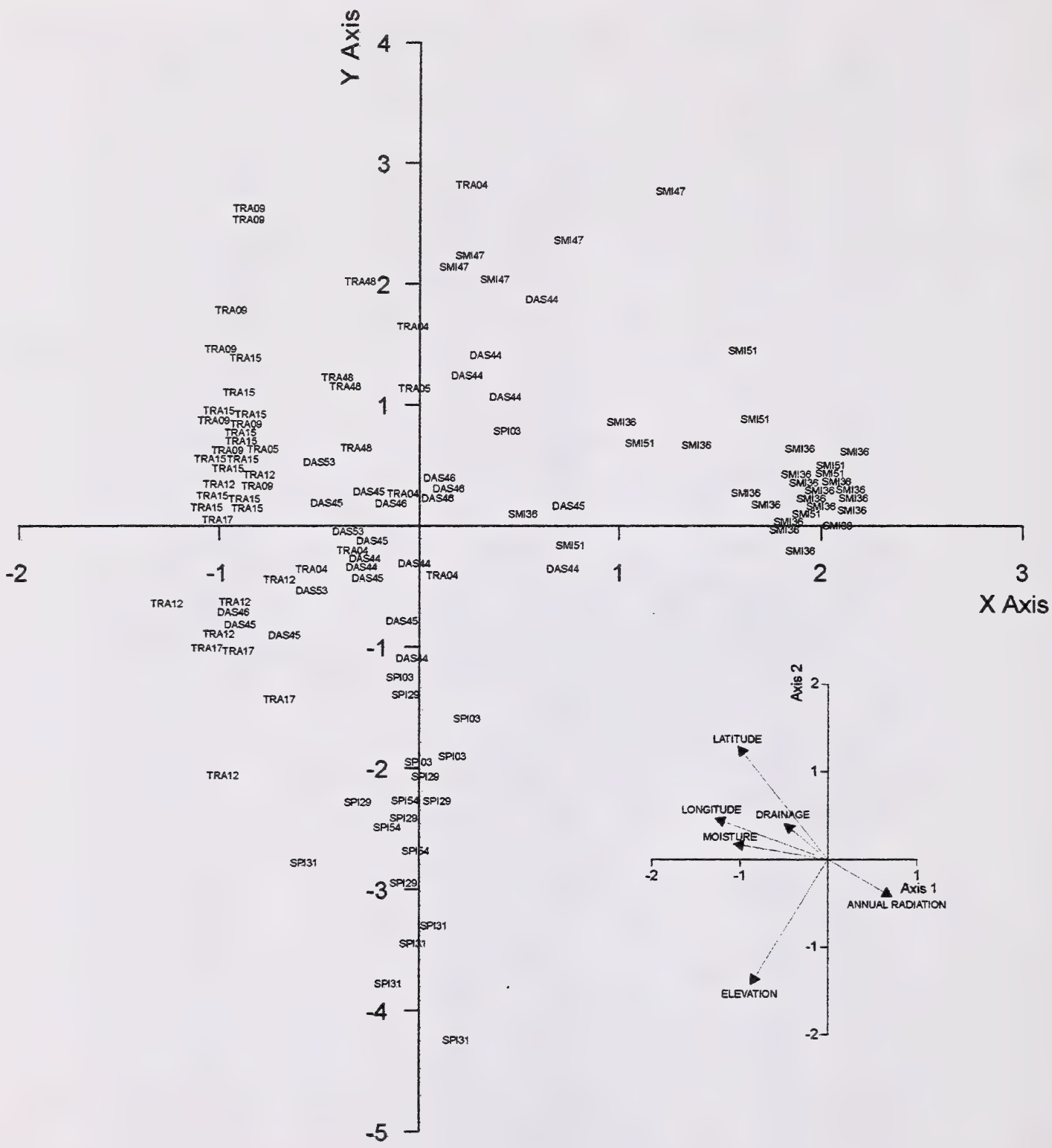

Figure 3. Ordination diagram based on Detrended Canonical Correspondence Analysis (DCCA) of 120 plots from the Ecological Site Inventory System (ESIS) database. The diagram displays plots representing 18 Agropyron community types identified by the cluster analysis. Plot labels were created by combining the first three letters of the species name of the dominant Agropyron species and the number assigned to the community (Cluster No.) from the cluster analysis (Figure 1, Table 5). 


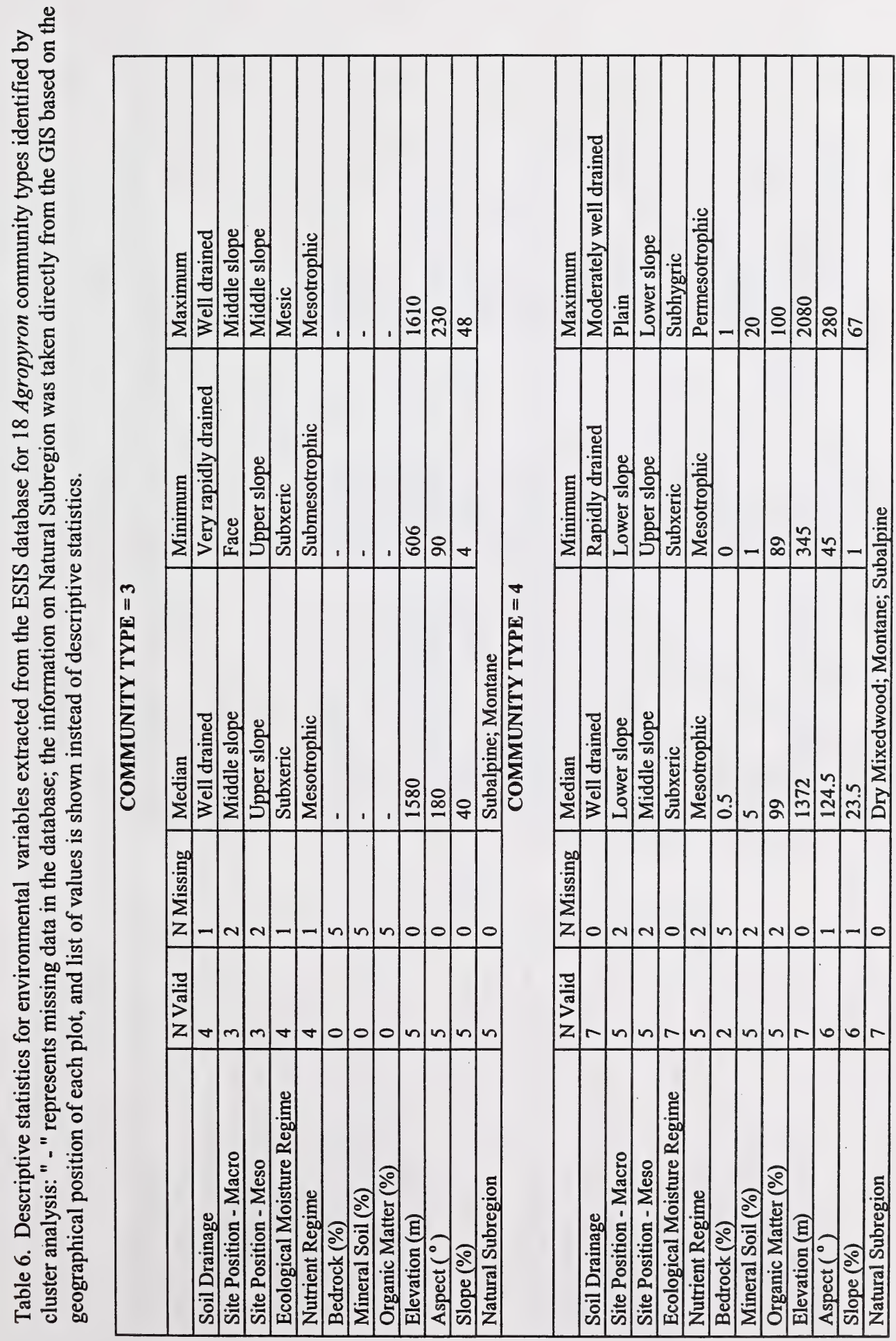

年

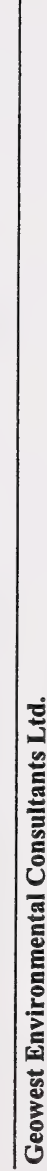




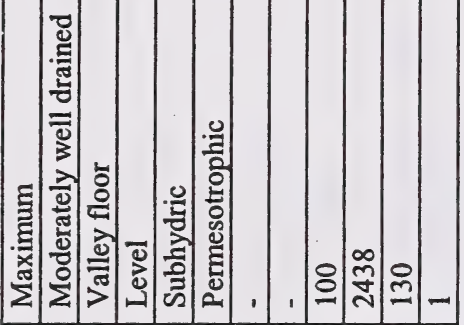

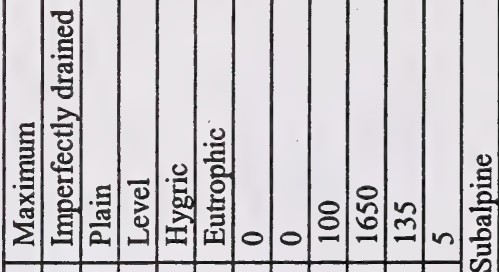

.

홇

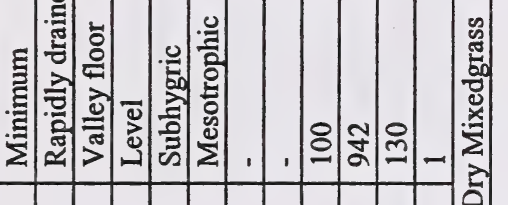

|:

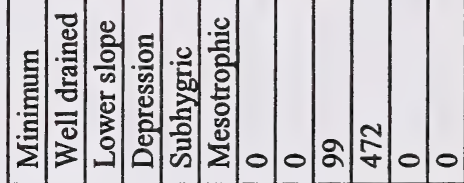

$\underset{\sim}{\infty}$

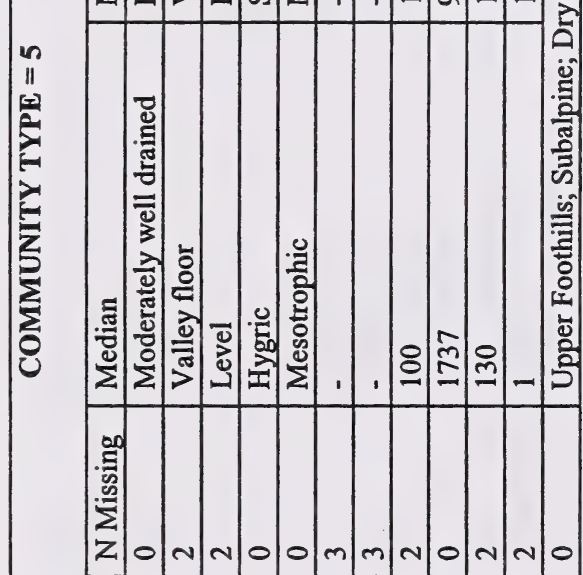

$\frac{\pi}{2}$

$\begin{aligned} & z \\ & z\end{aligned}-m m 00-m--m$

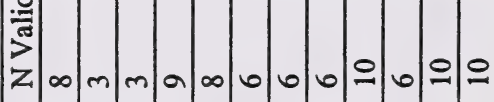
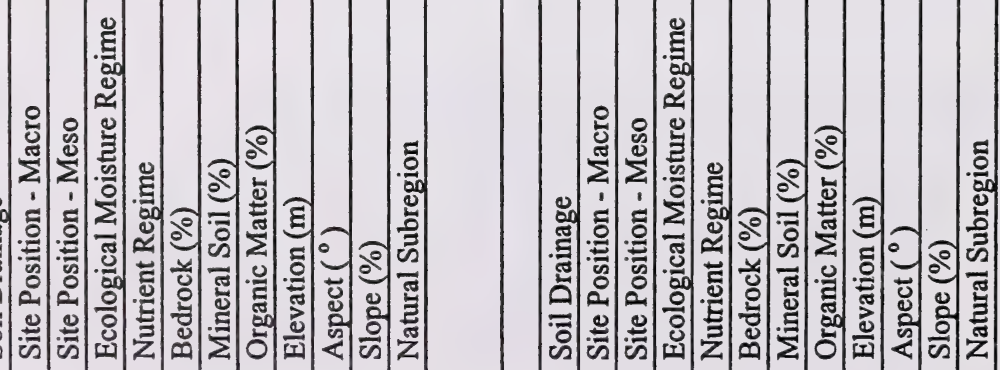


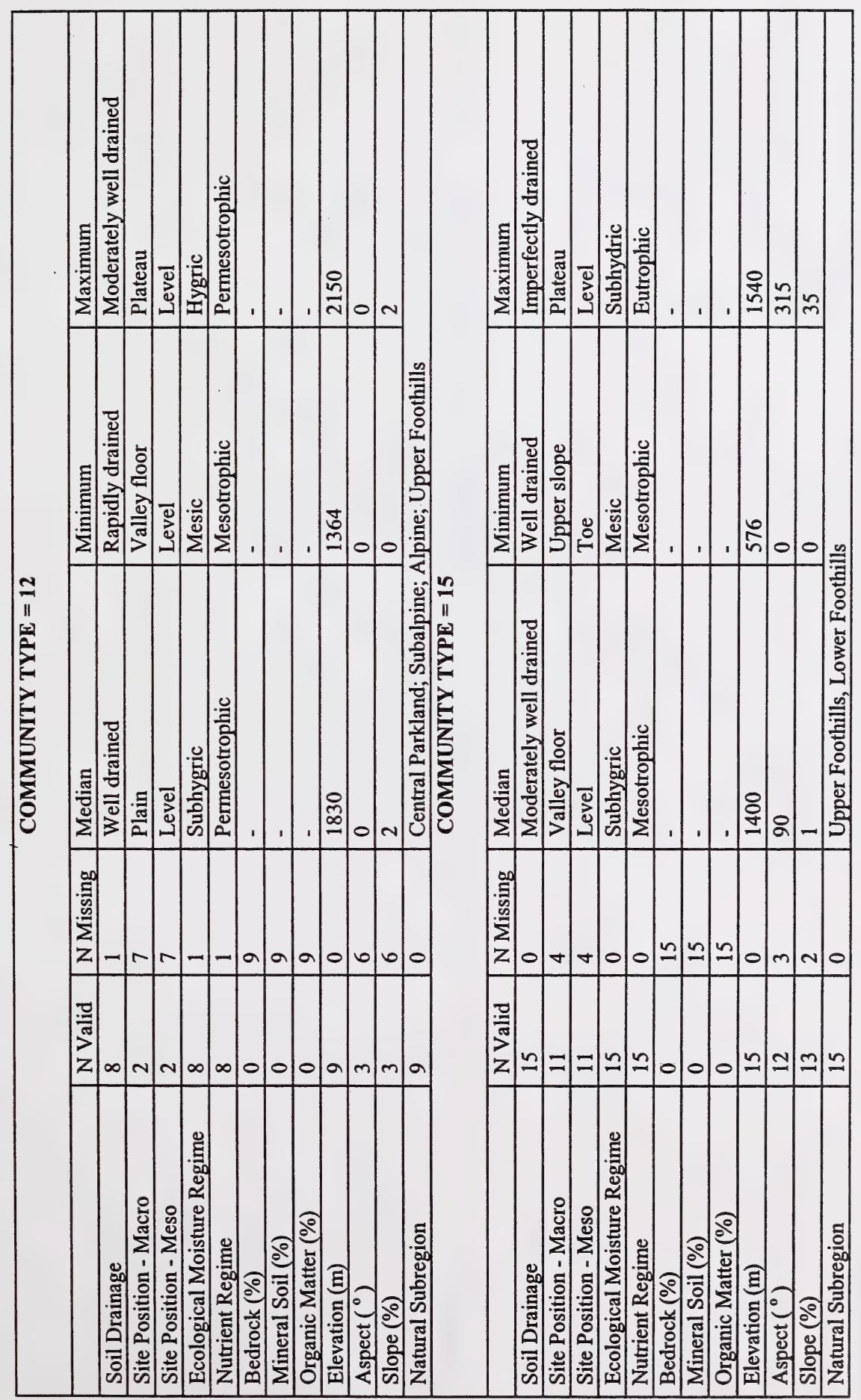




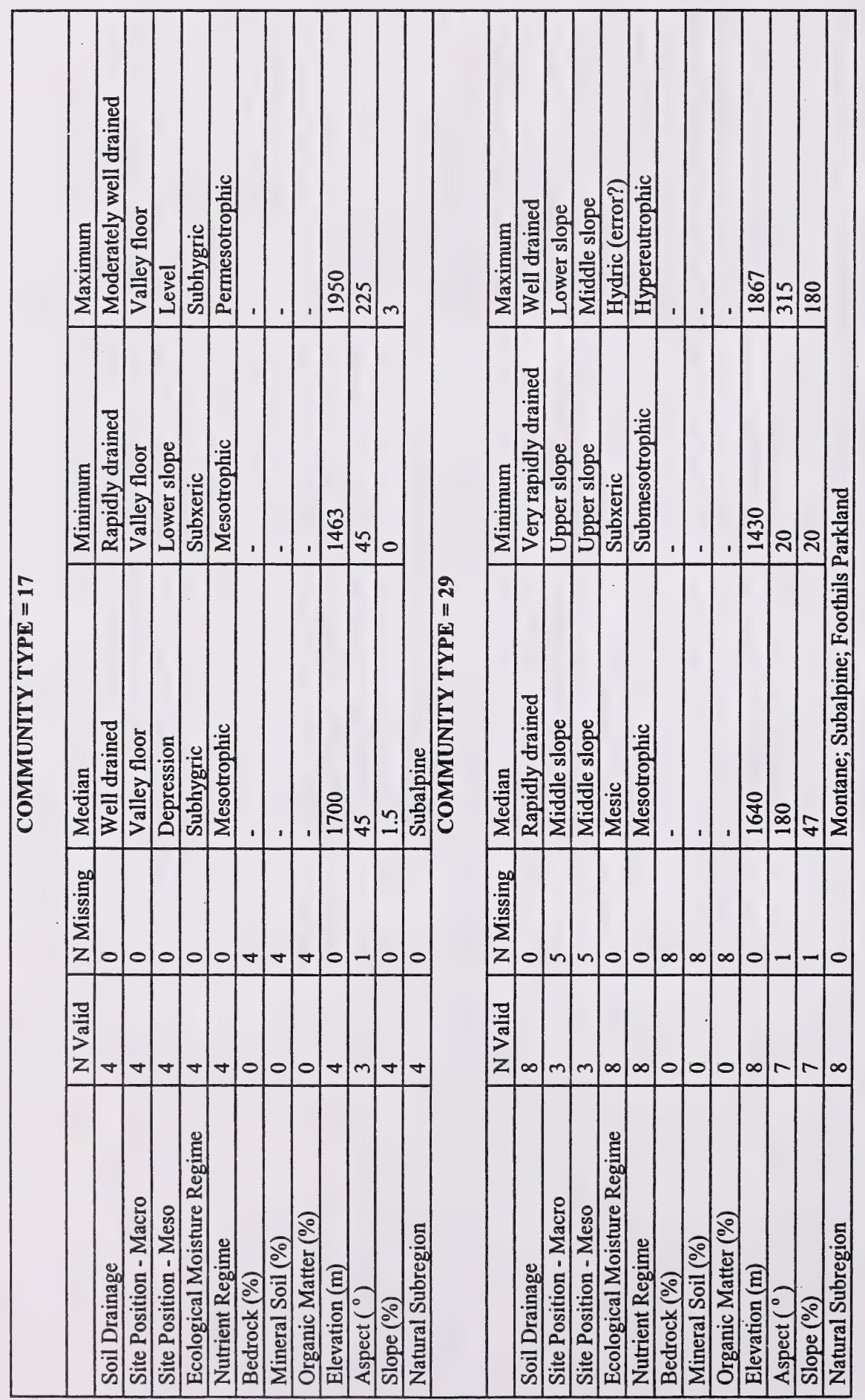




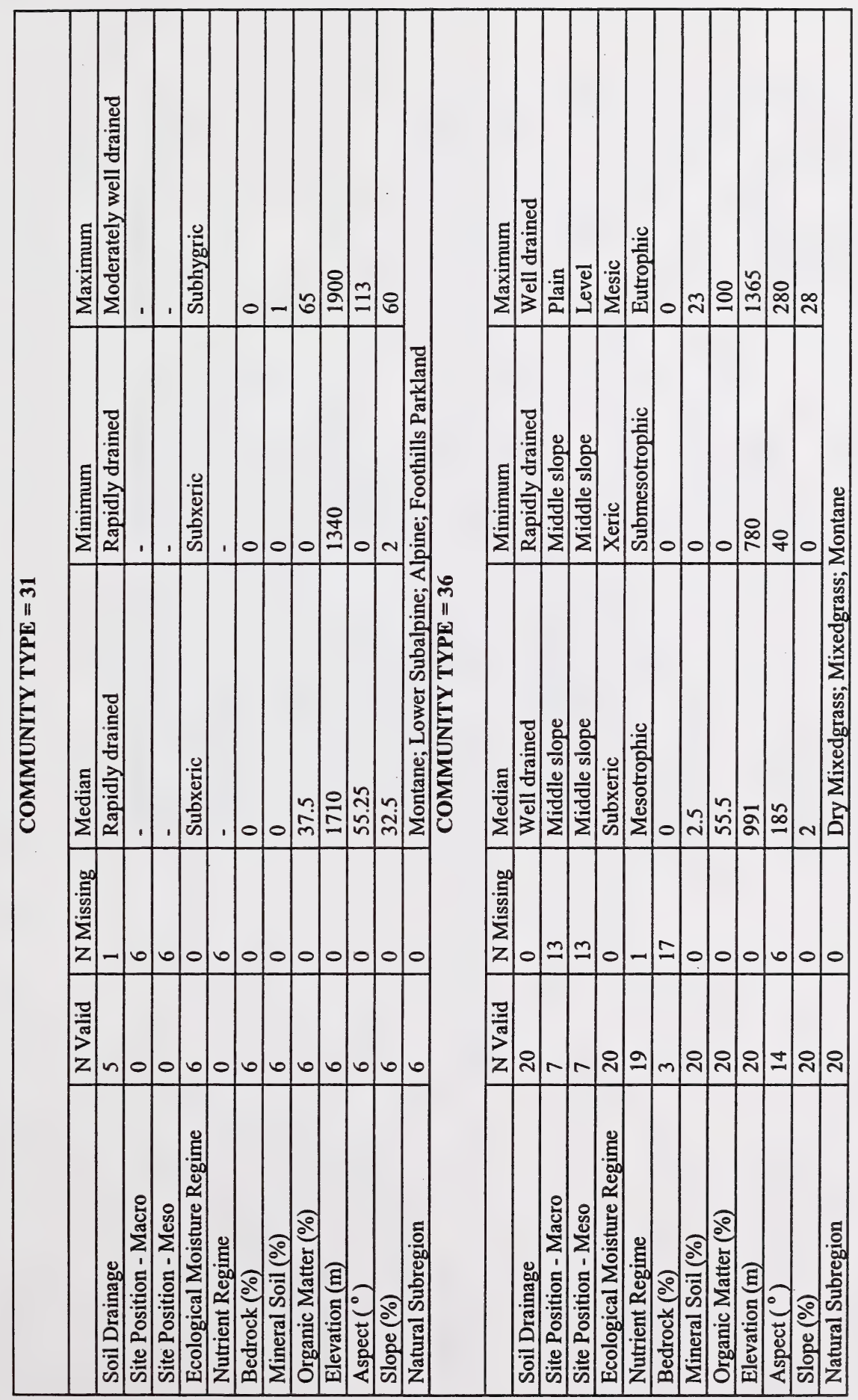

5
$\vdots$
0
0
0 


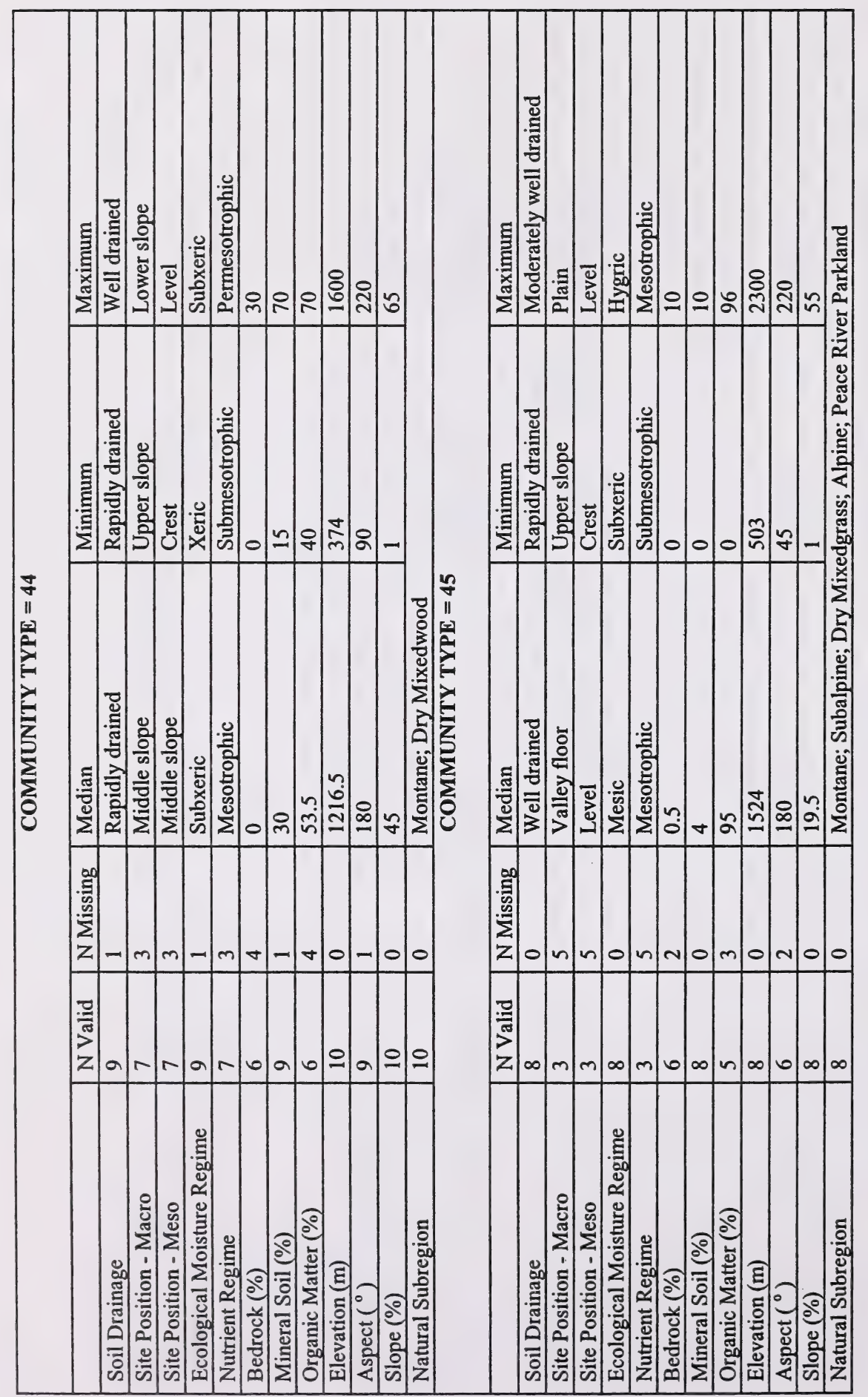




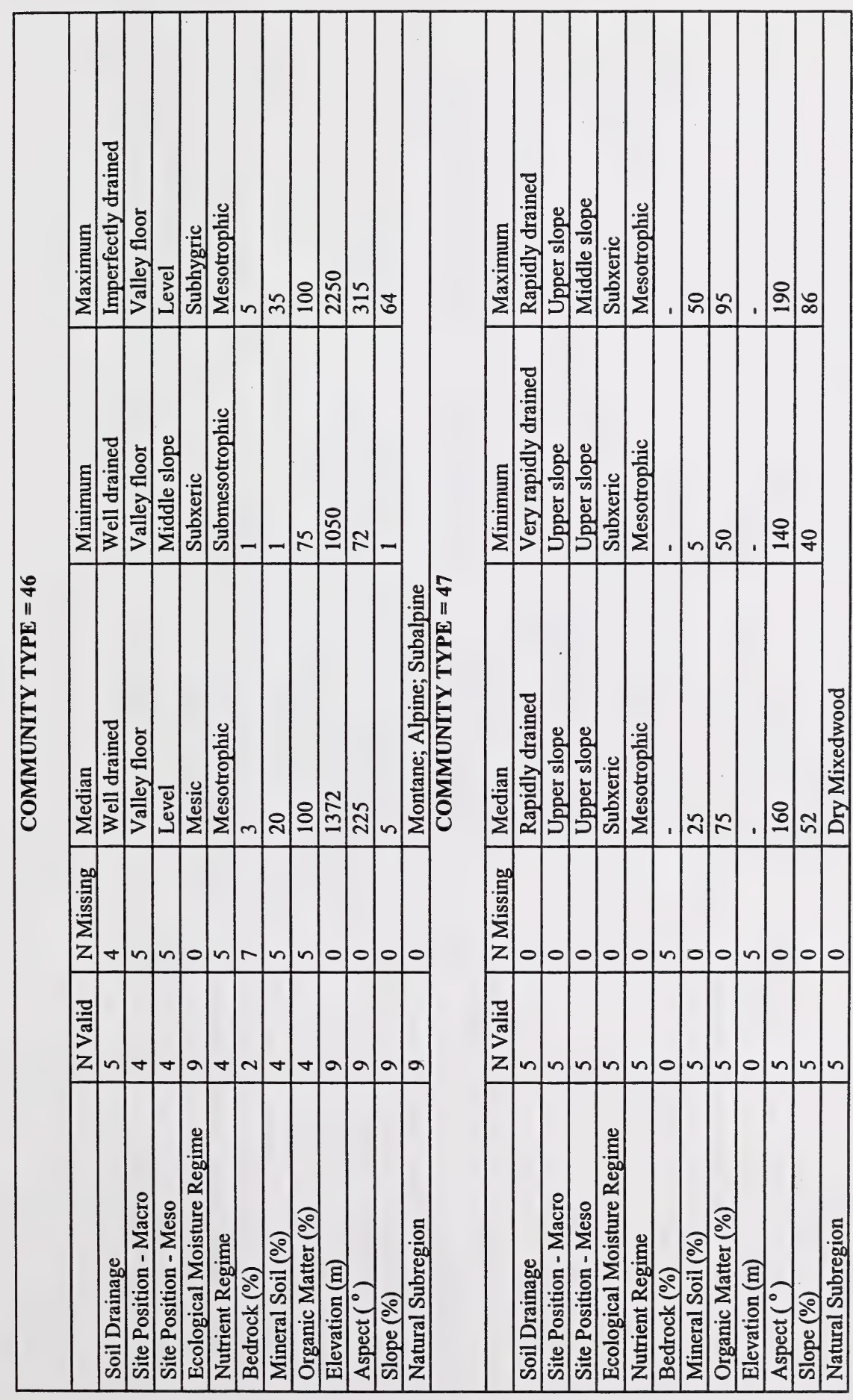

政 


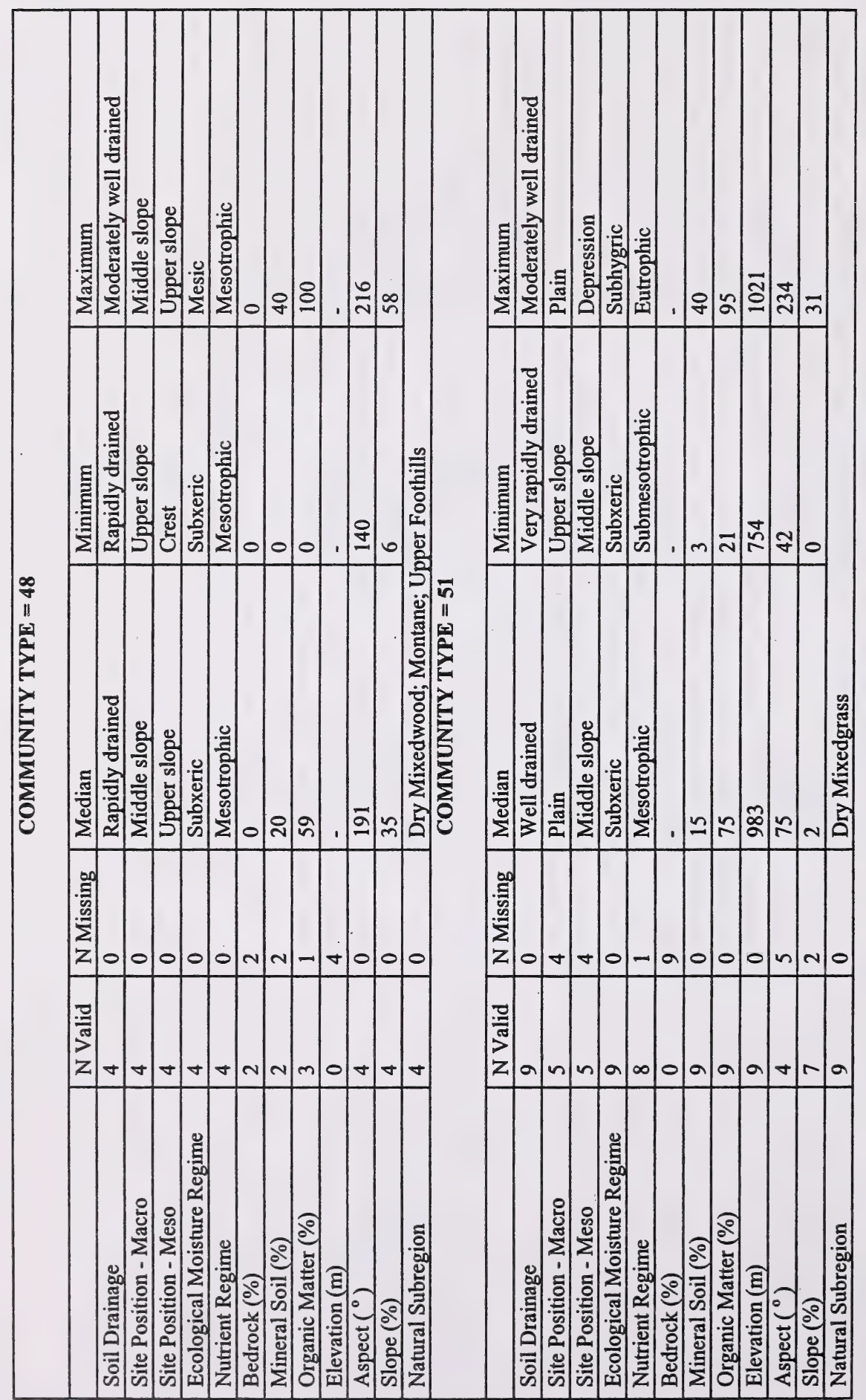




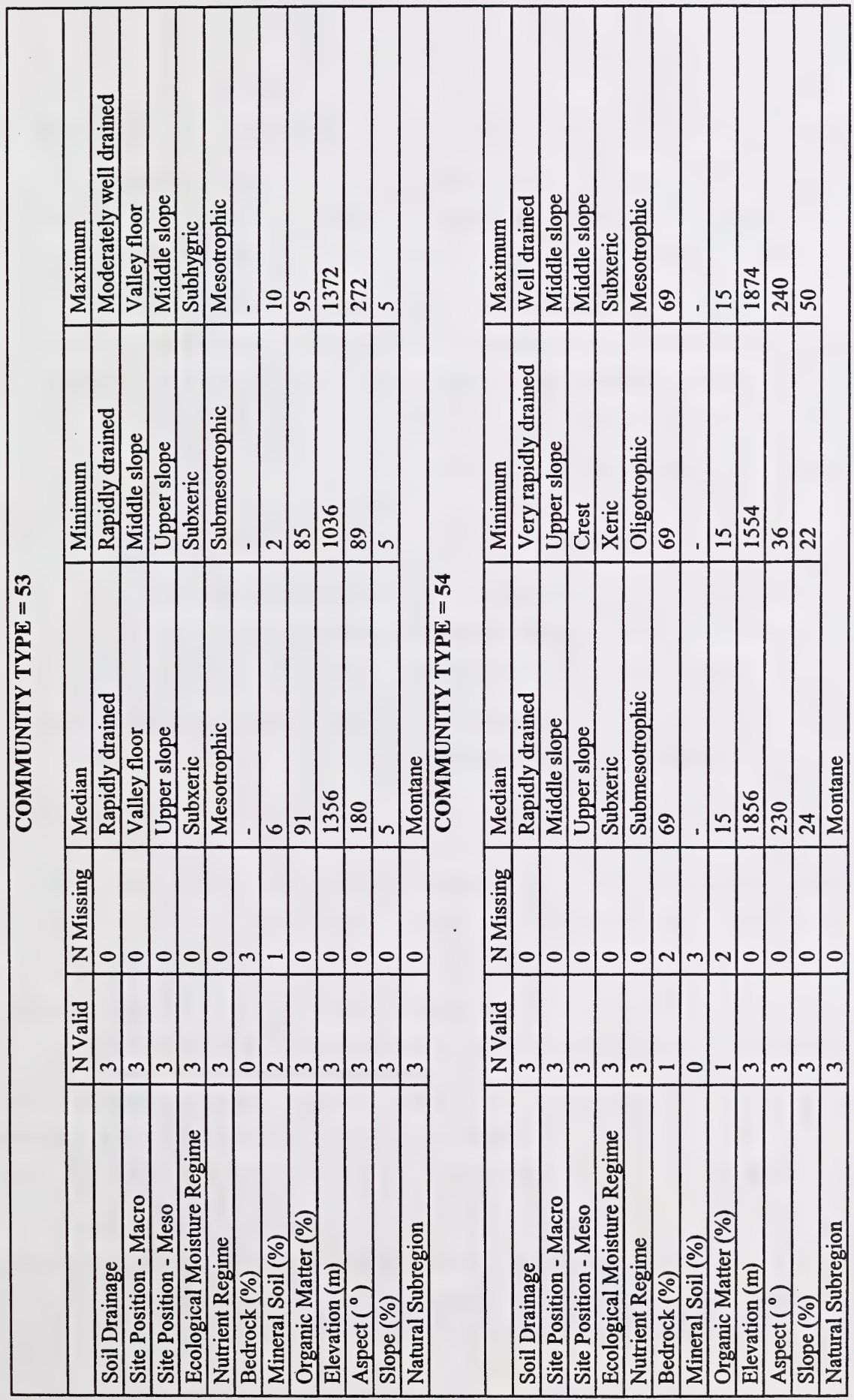


They are characterized by a number of species from moister habitats such as Zizia aptera, Schizachne purpurascens, Poa pratensis, Carex aquatilis, Deschampsia cespitosa, Hierochloe odorata, Calamagrostis canadensis, Geum aleppicum, Thalictrum venulosum, Mertensia paniculata, Arnica chamissonis and Delphinium glaucum (Figure 2).

On the other hand, communities dominated and codominated by Agropyron smithii are mostly found within the southeastern portion of the province and on drier soils than communities dominated by other Agropyron species. These communities are characterized by a number of drought-tolerant species from dry habitats such as Bouteloua gracilis, Calamovilfa longifolia, Carex filifolia, Stipa viridula, Gaura coccinea, Sphaeralcea coccinea, Tragopogon dubius, Phlox hoodii, Heterotheca villosa, Atriplex nuttallii and Selaginella densa (Figure 2). Spatially, and in relation to the soil moisture, communities dominated and codominated by Agropyron spicatum and $A$. dasystachyum fall in between the previous two groups. In addition to this, communities dominated and codominated by Agropyron spicatum generally occupy higher elevations than the other three groups. A number of species characteristic for high altitudes are found in this communities (Festuca brachyphylla, Androsace chamaejasme, Sedum stenopetalum, Antennaria lanata) (Figure 2).

Within the Agropyron trachycaulum Alliance, separation between communities can be partially explained by soil moisture conditions. Community \# 9 (Agropyron trachycaulum - Elymus innovatus - Thalictrum venulosum Herbaceous Vegetation) occupies the most moist soils, followed by communities \#15, \#12, \#17 (Agropyron trachycaulum - Carex praegracilis Fragaria virginiana Herbaceous Vegetation), \#48 (Agropyron trachycaulum Herbaceous Vegetation), and \#5 (Agropyron trachycaulum - Carex atherodes Herbaceous Vegetation). Community \#4 (Agropyron trachycaulum - Koeleria cristata Herbaceous Vegetation) occupies the driest soils of these four community types (Figure 3. Table 6).

Within the Agropyron smithii Alliance, Community \#47 (Carex stenophylla - Agropyron smithii Herbaceous Vegetation) is spatially separated from community \# 51 (Agropyron smithii Herbaceous Vegetation) and community \# 36 (Agropyron smithii - Stipa comata - Bouteloua gracilis Herbaceous Vegetation) by occurring within the northeastern portion of the province, while the later two mostly occupy sites within the southeastern portion of the province. The ordination analysis did not provide a possible explanation for the compositional difference between the Agropyron smithii Herbaceous Vegetation and the Agropyron smithii - Stipa comata - Bouteloua gracilis Herbaceous Vegetation community types (Figure 3, Table 6).

Compositional differences between communities within the Agropyron spicatum Alliance can be partially explained by elevation. Community \#31 (Agropyron spicatum Herbaceous Vegetation) occupies sites at the highest elevations, while community \#3 (Agropyron spicatum - Carex obtusata Herbaceous Vegetation) occurs at the lowest elevations of all four communities. Community \#29 (Agropyron spicatum - Festuca campestris Herbaceous Vegetation) and community \#54 (Agropyron spicatum - Festuca idahoensis Herbaceous Vegetation) occupy elevations between the previous two communities, however, the ordination analysis did not provide a possible explanation for the compositional differences between the last two communities (Figure 3 ). 
The ordination analysis did not provide a possible explanation for the compositional differences between the three communities within the Agropyron dasystachyum Alliance situated in the centre of a diagram (Figure 3) (communities \#44, \#46 (Agropyron dasystachyum - Koeleria macrantha - Artemisia frigida Herbaceous Vegetation), \#45 (Agropyron dasystachyum Herbaceous Vegetation), and \#53 (Juniperus horizontalis - Arctostaphylos uva-ursi / Agropyron dasystachyum - Elymus innovatus Dwarf Shrub Herbaceous Vegetation)).

There are two possible reasons for the inability of ordination analysis to provide more insight into the separation between Agropyron Alliances and between community types within each of Agropyron Alliances:

1) Only a limited number of environmental variables was available from the ESIS database and they did not include some of the very important variables such as soil salinity and disturbances. The geographical distribution of community types within the province (represented by the latitude and longitude variables in the analysis) is partially controlled by climatically driven moisture availability (see Strong and Legat 1992 for the overview of the general distribution of plant communities within the province). On a smaller scale, the composition of grassland communities depends not only on the general soil moisture conditions (represented by the soil moisture and drainage in the analysis), but also on the species competition with each other for available resources such as light, soil moisture, and soil nutrients. In undisturbed grassland communities, the live plant canopy of taller dominant grasses, as well as dead plant material, cause inadequate light conditions for shorter plants (Grime 1979). In addition to this, the availability of soil water, which also influences the uptake of nutrients by roots, not only depends on the competitive abilities of neighboring plants, but is also influenced by soil physical and chemical properties (Barbour et al. 1980). Chemical properties of the soil such as salinity and sodicity, are important characteristics of local soil conditions. Besides their direct toxic effect upon plants, high concentrations of soluble salts interfere with soil water availability by raising the osmotic potential of the soil solution and reducing water uptake by plant roots (Bresler et al. 1982). These soil conditions prevent successful establishment of salt-intolerant species (glycophytes), thereby allowing numerous facultative and obligate halophytic species to grow. On the other hand, in non-saline sodic soils (soils in which sodium represents the main soluble salt), high concentrations of sodium salts have a twofold effect on plants. First, they significantly influence the physical properties of the soil by causing fragmentation of silt particles into clay particles, resulting in low soil permeability to water and air, frequent puddling, and soil hardness during dry periods (Cairns and Szabolcs 1973, Bresler et al. 1982). These soil conditions limit root penetration and water and air uptake by plants. Second, high sodium concentrations interfere with the uptake of other cations from the soil solution, resulting in magnesium, calcium, and nitrogen deficiencies in plants (Cairns et al. 1962, Toogood and Cairns 1978, Bresler et al. 1982). Grazing and trampling by ungulates (both domestic and wild) also have complex effects on species composition by removing vegetation and influencing the nitrogen cycle (Hobbs 1996). A removal of live and dead vegetation lowers the competitive abilities of dominant grasses, thus allowing the invasion of inferior competitors (Weaver and Roland 1952, Harper 1977). The reverse may be true for urine addition (providing readily available nitrogen to the topsoil), which causes a switch in species composition back to a small number of competitive species (Steinauer and Collins 1995). 
2) Two of the variables extracted from the ESIS database, soil moisture and drainage, underwent revisions in coding over the years, which has resulted in an inconsistency in codes representing the same moisture/drainage level within the ESIS database (Russell Wells personal communications). Although changes may be considered minor (i.e. change of one level on the scale of 1 to 8), they do represent a source of error in the ordination analysis.

\subsubsection{Cross Referencing of Proposed Agropyron Community Types With the Literature} and Analysis of Plot Data From Alberta

In this section, the proposed 39 Agropyron dominated/codominated community types within Alberta are cross referenced with the similar community types described in the literature from Alberta and from adjacent provinces and States, and with the analysis of ESIS plot data (Tables $7,8,9,10,12,13,14$ and 15). Additional 19 communities from the Alberta's literature and from the classification of ESIS plots which do not represent Agropyron dominated/codominated community types but were examined during the classification process are organized in Table 11.

\subsubsection{Cross Reference Tables With the Literature from Alberta and Analysis of the ESIS Plot Data}

Following cross reference tables summarize proposed Agropyron community types in Alberta in relation to their literature sources from Alberta and the equivalent community types from cluster analysis of ESIS plot data. 


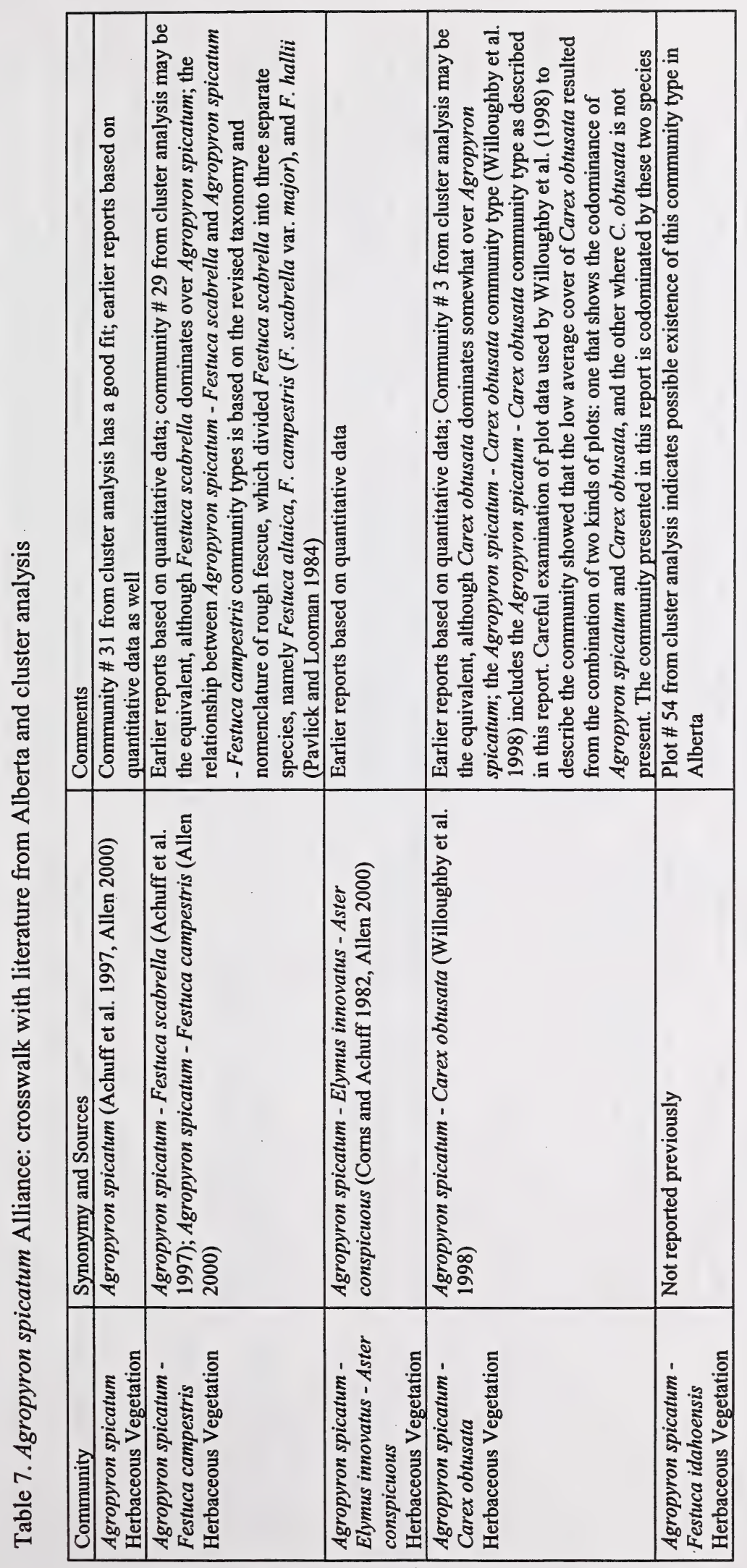




\begin{tabular}{|c|c|c|c|c|}
\hline 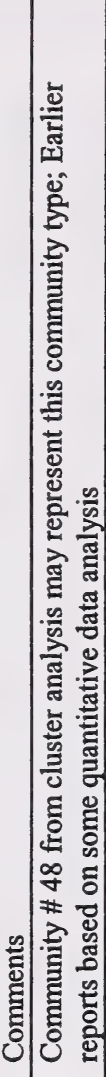 & 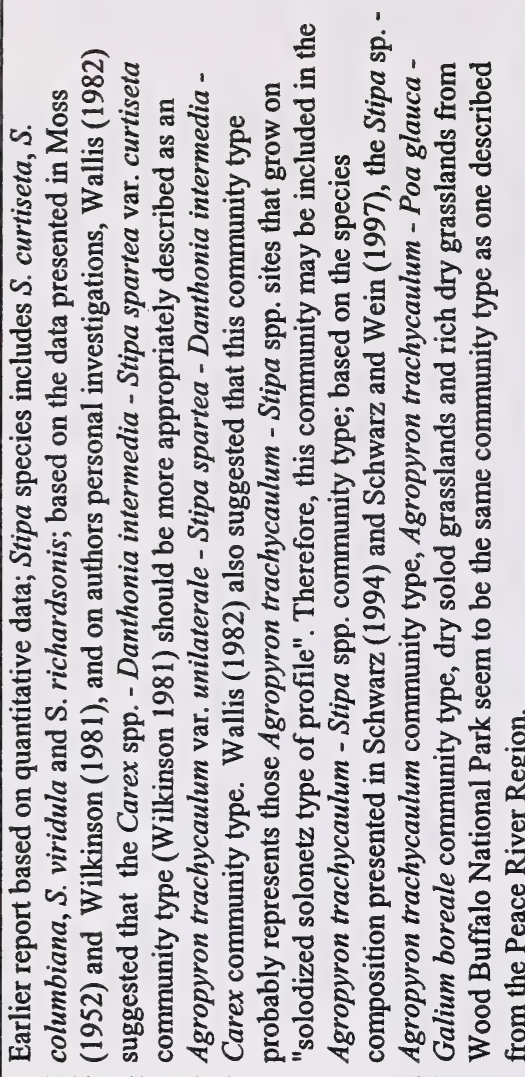 & 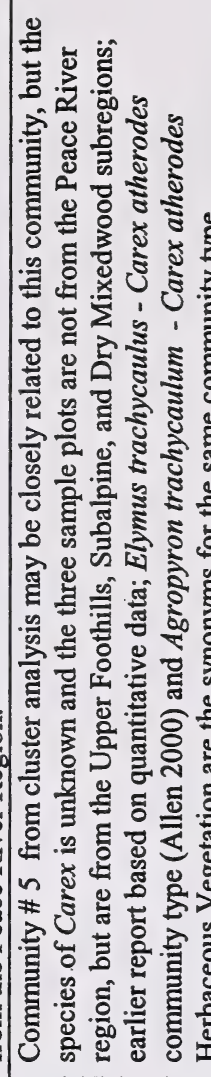 & 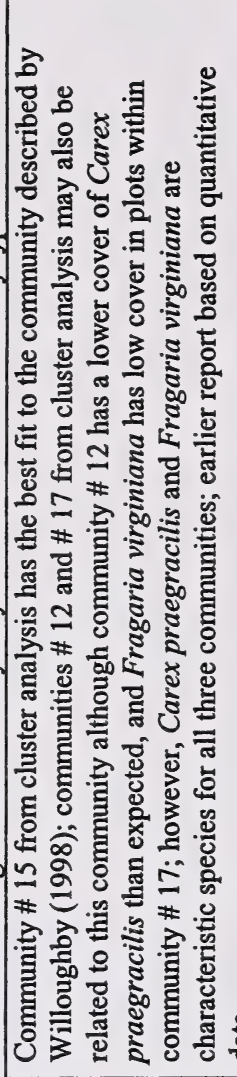 & 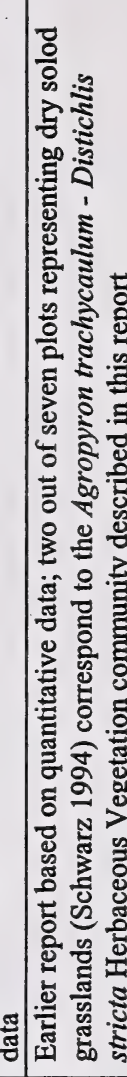 \\
\hline 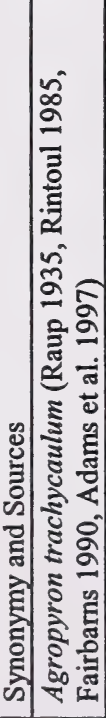 & 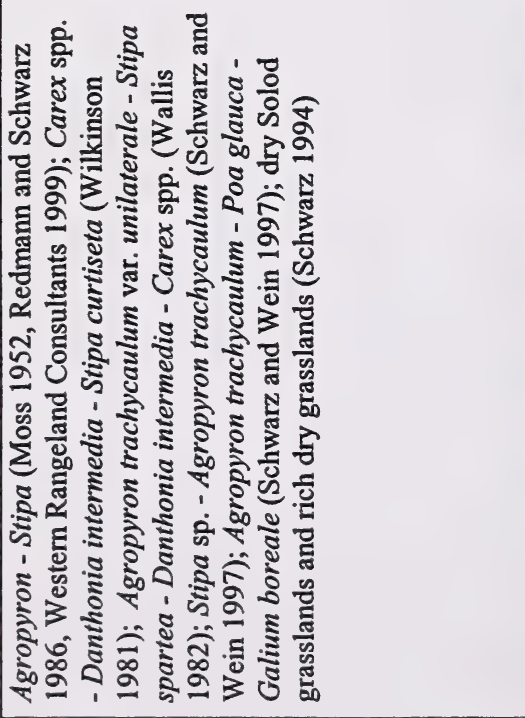 & 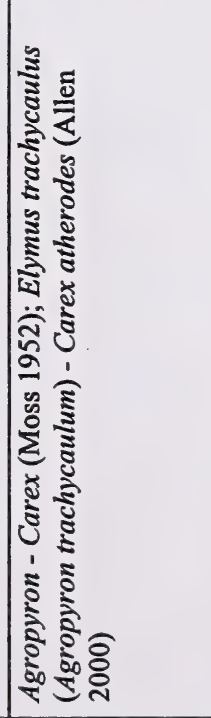 & 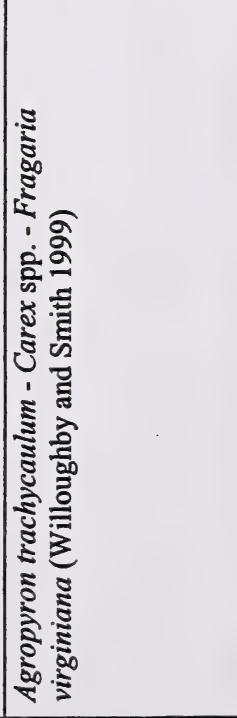 & 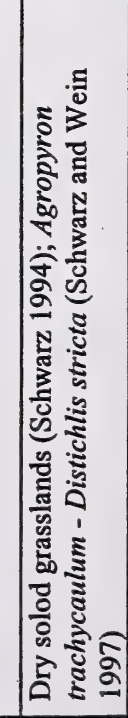 \\
\hline 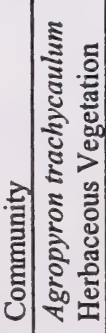 & 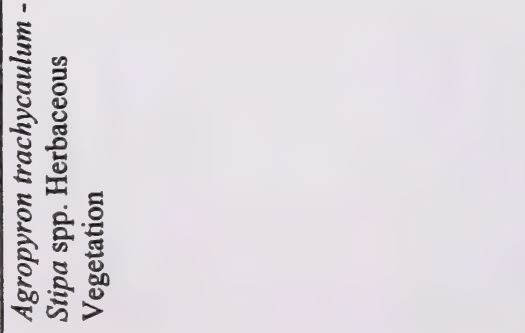 & 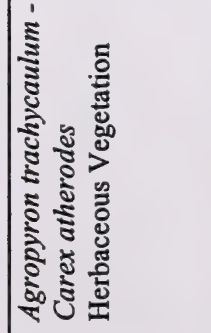 & 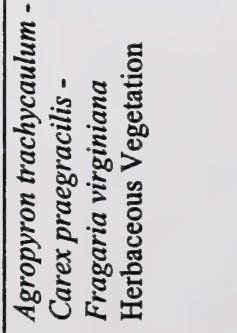 & 证 \\
\hline
\end{tabular}




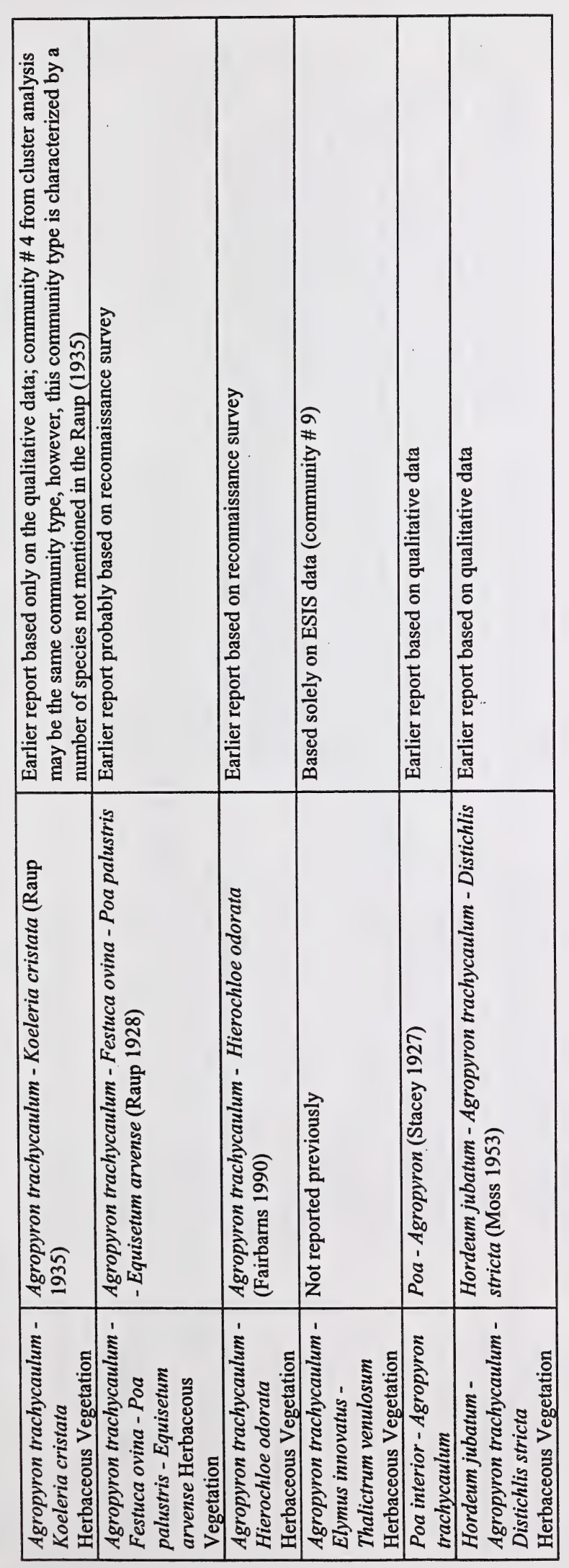




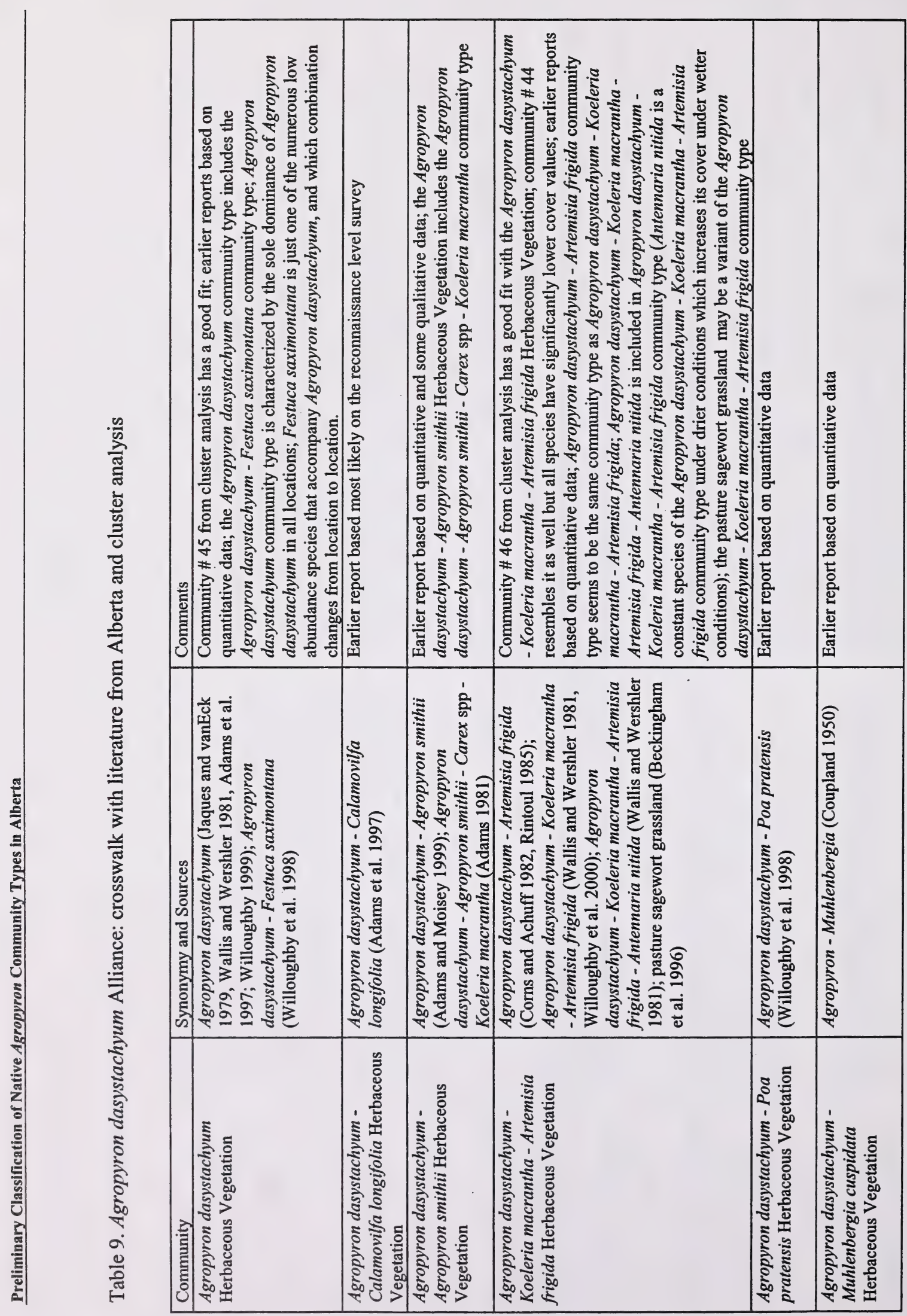




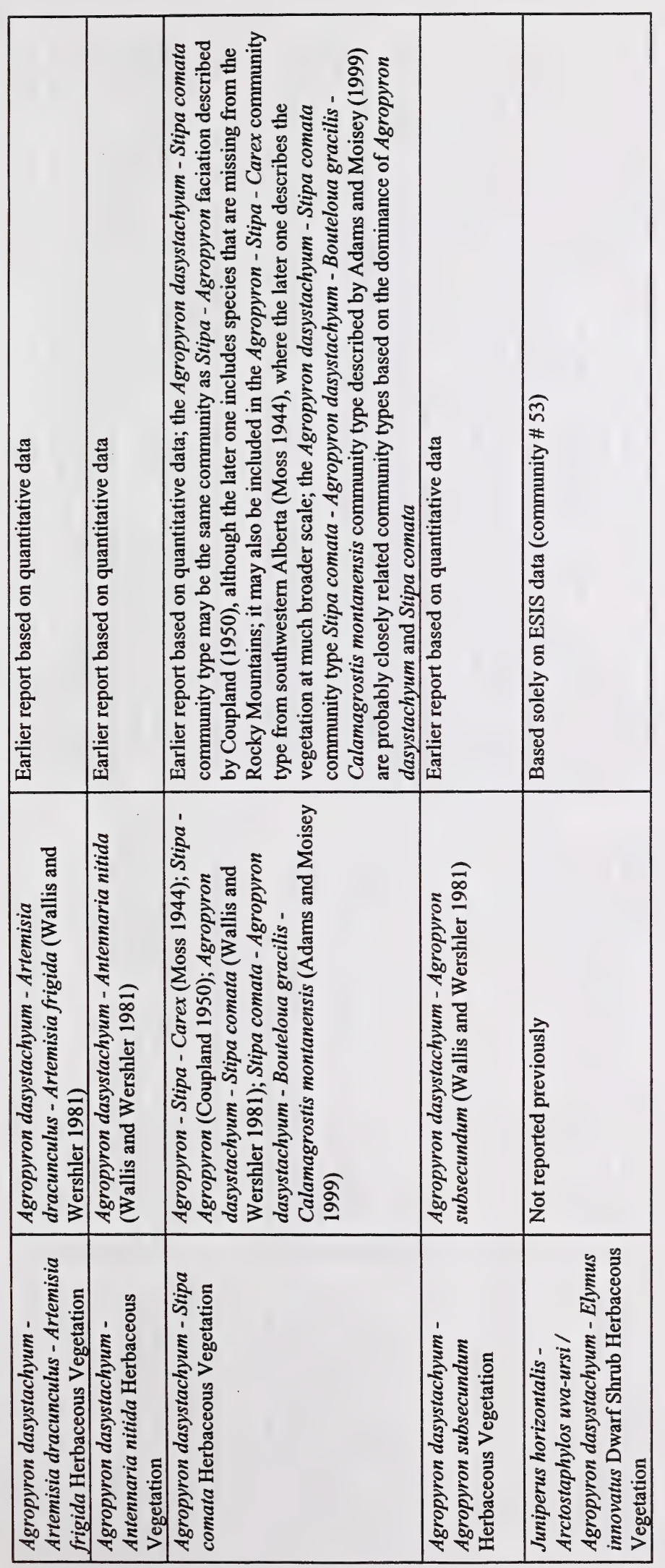




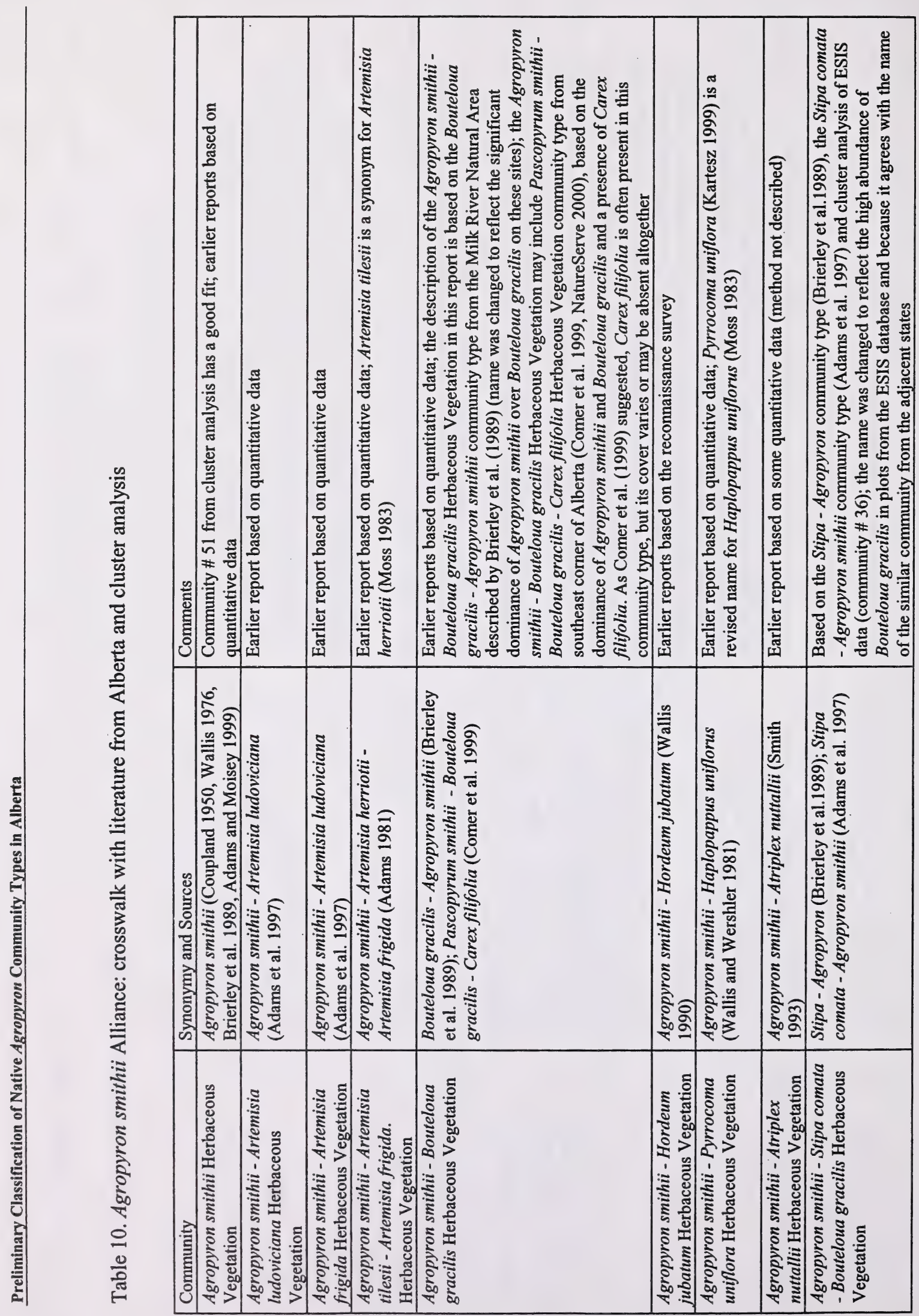




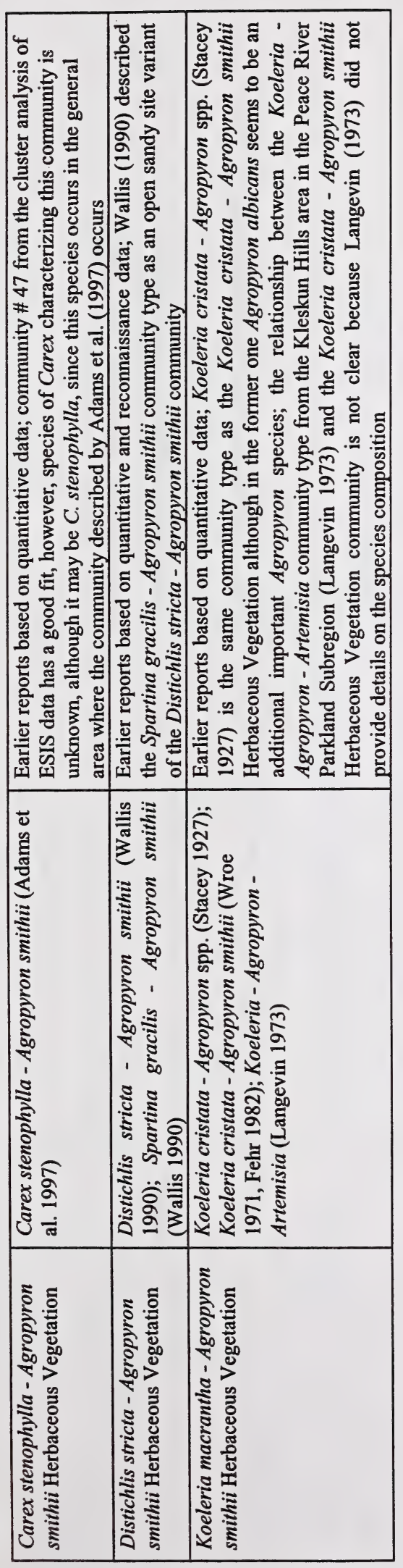




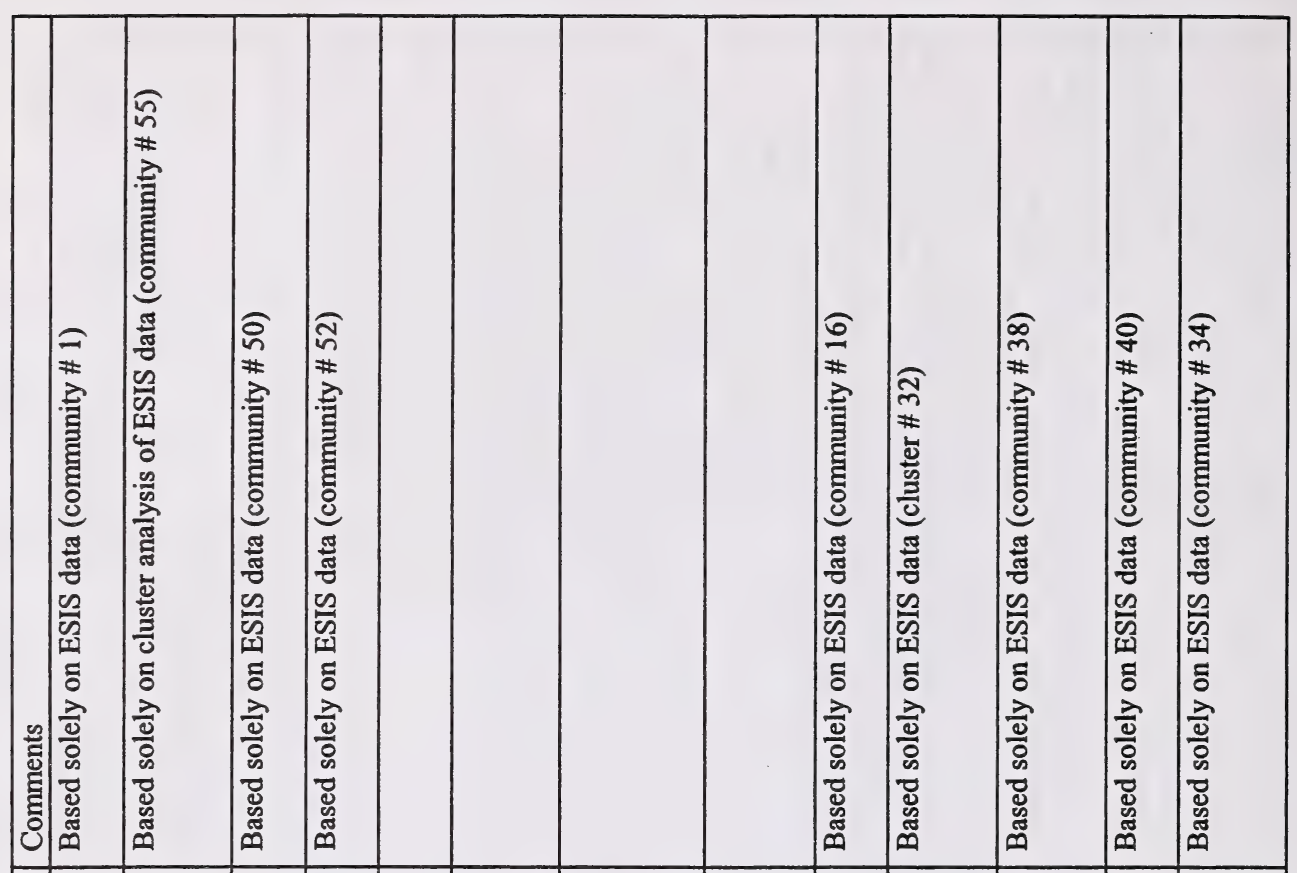

|:

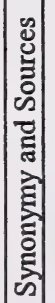

ลิำ ส

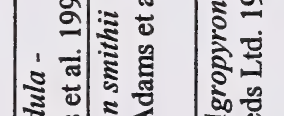

.

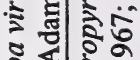

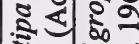

क हाँ

$\therefore$ :

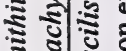

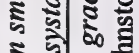

ธุำ

डे पे ले

के: $:$ :

$1: \infty$

ริ

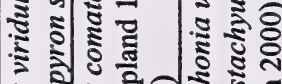

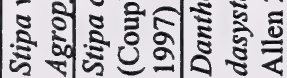

$\because$ 


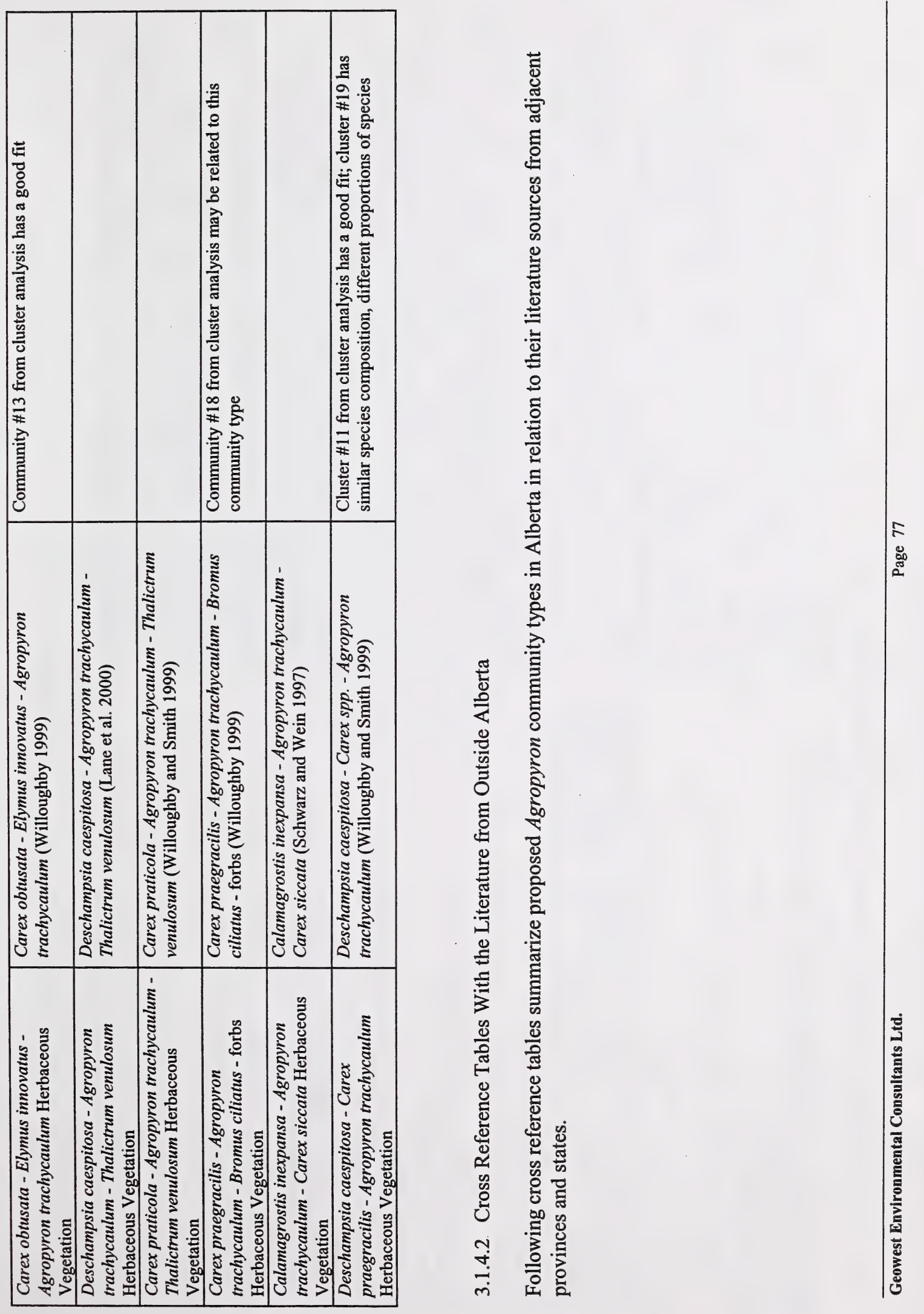




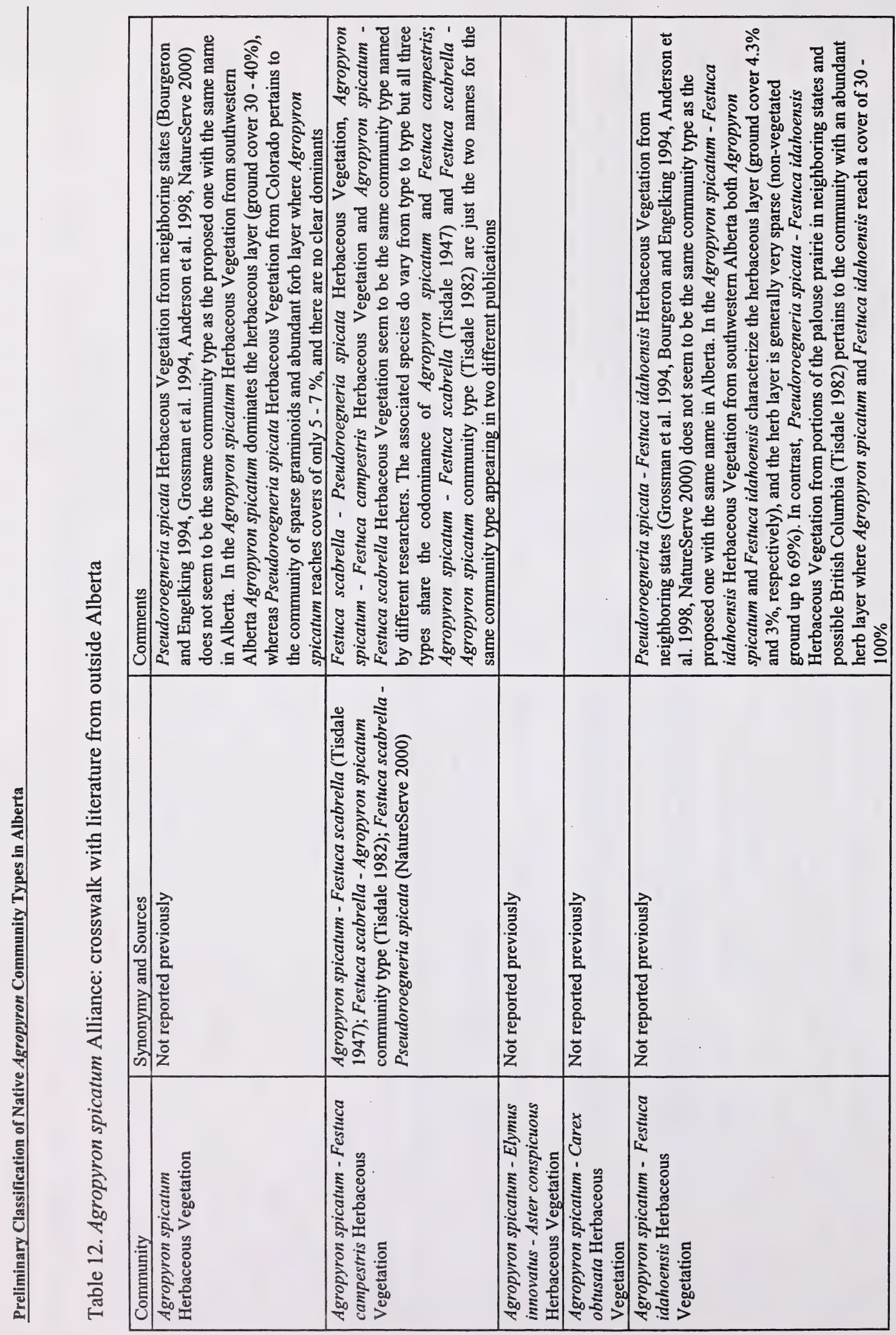




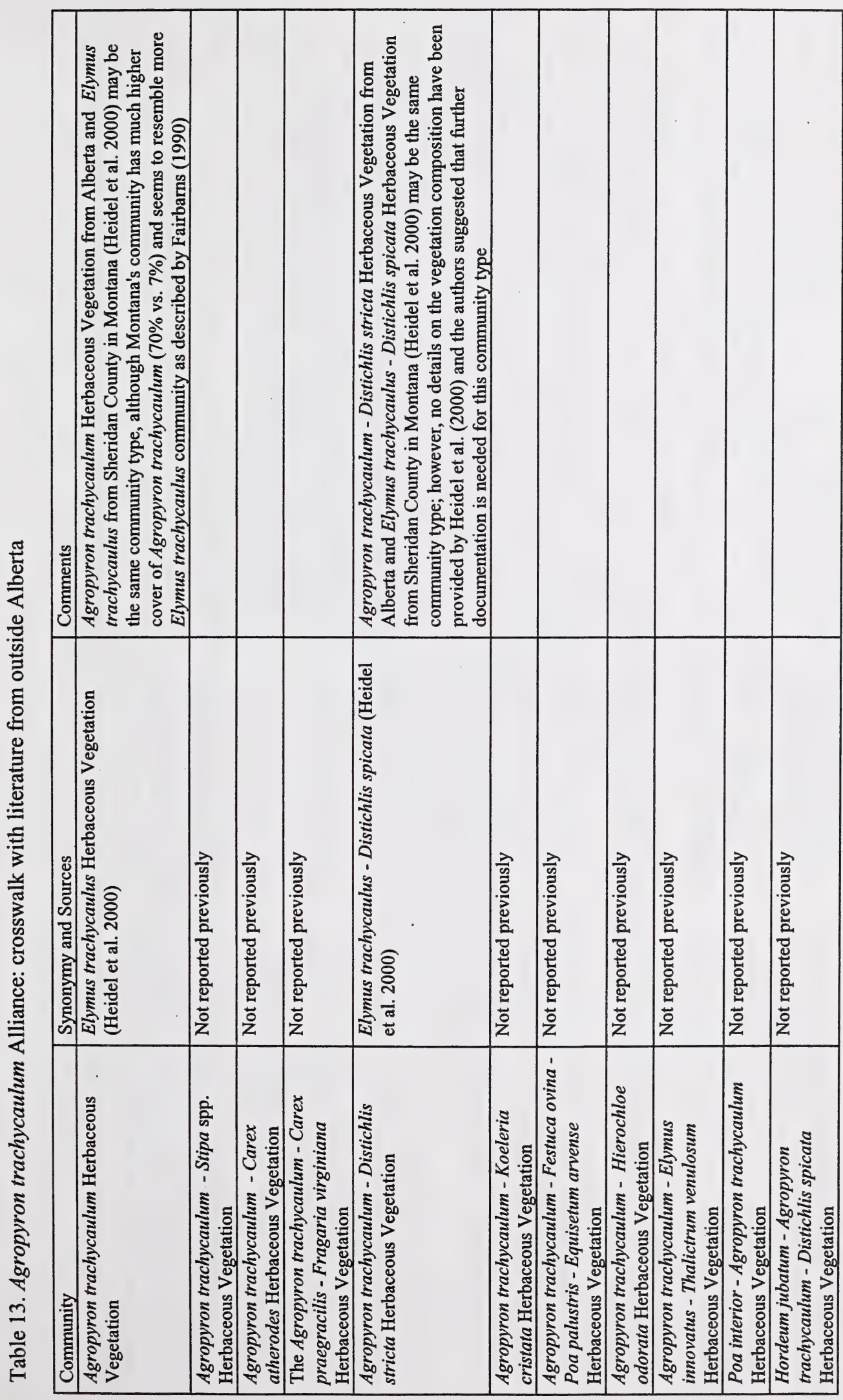

童 


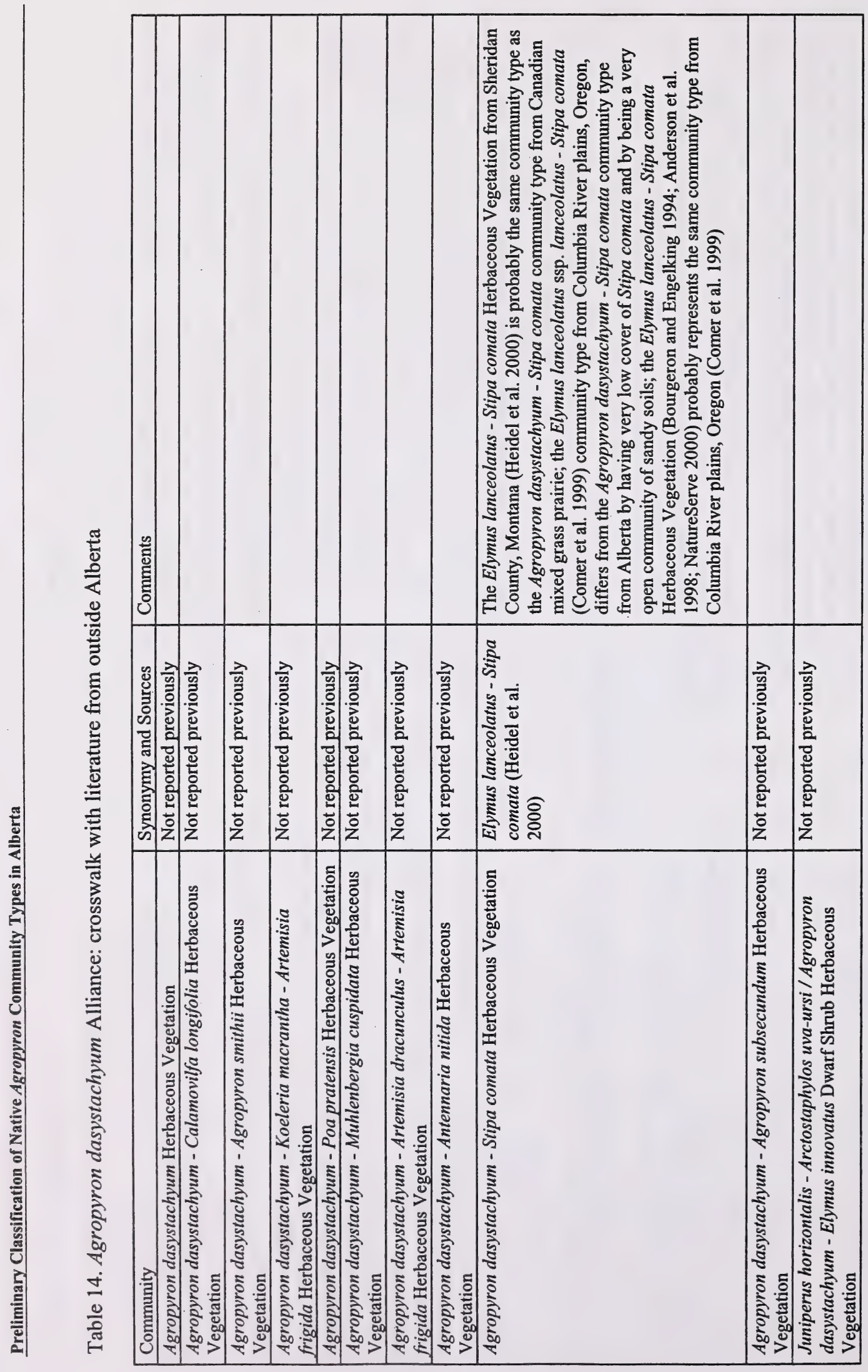




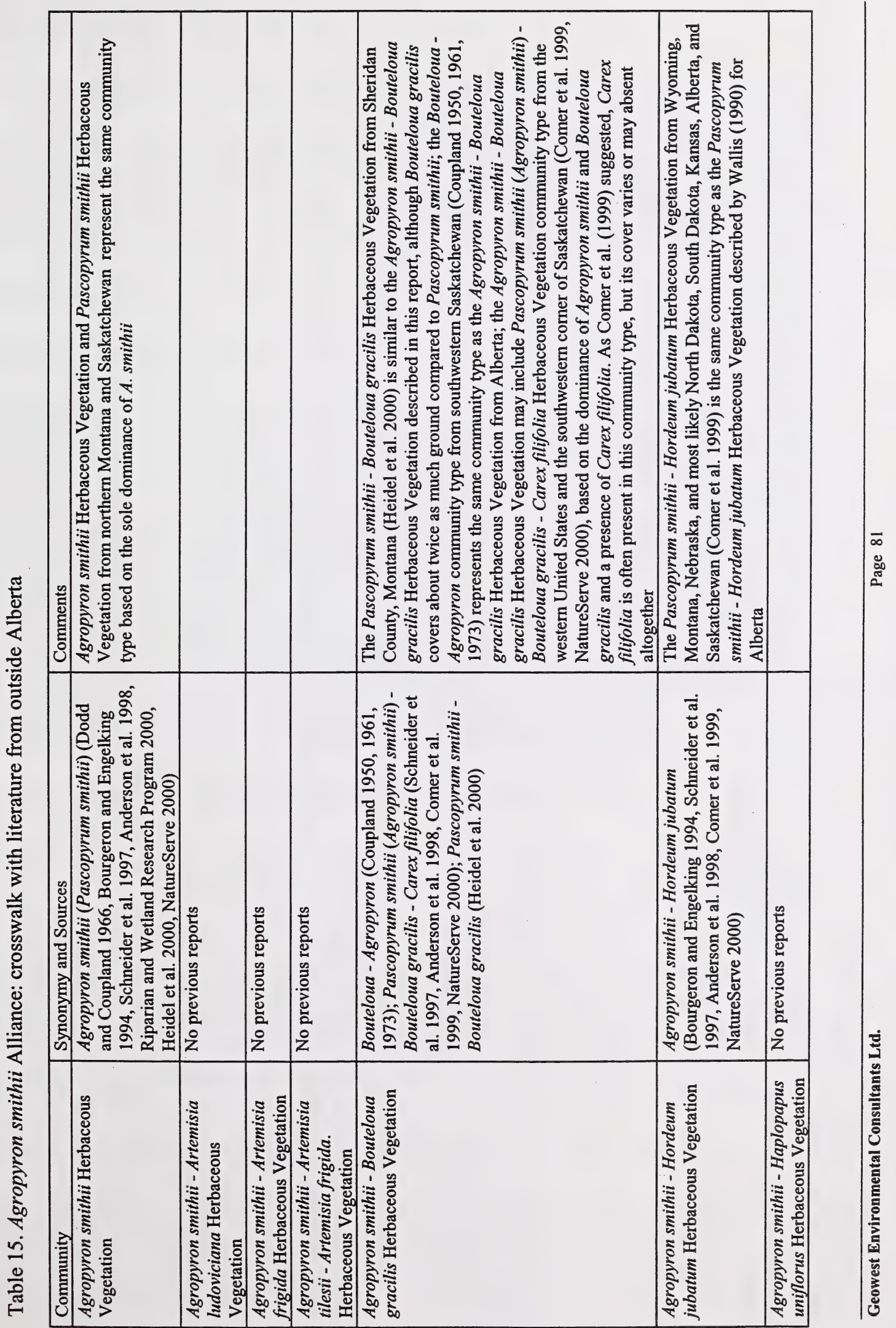




\begin{tabular}{|c|c|c|c|c|}
\hline & 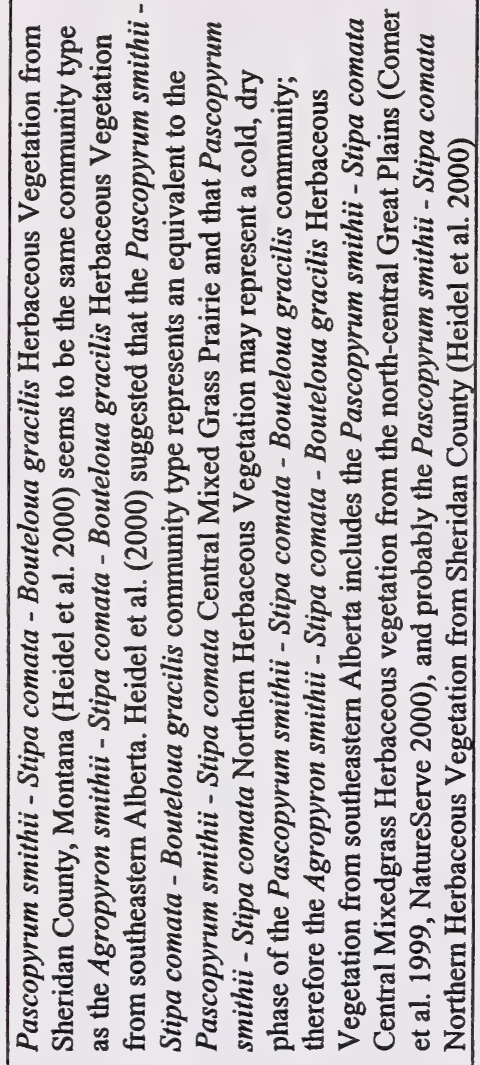 & & 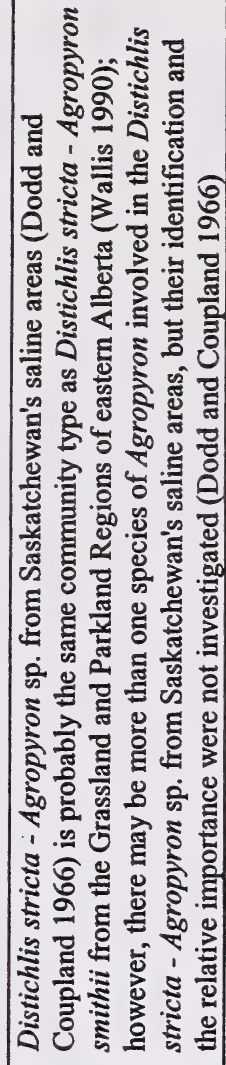 & \\
\hline 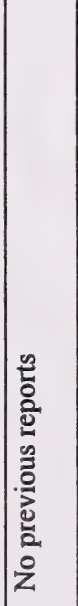 & 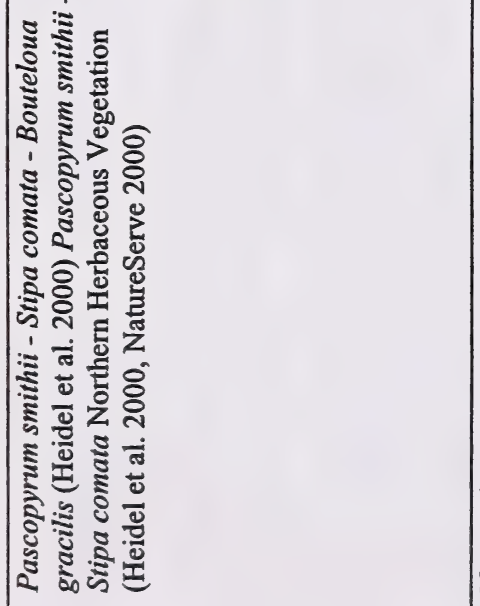 & 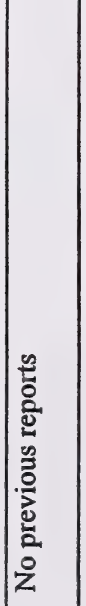 & 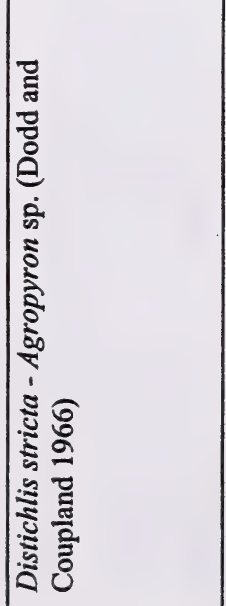 & 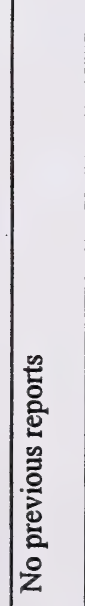 \\
\hline 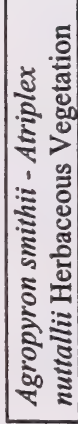 & 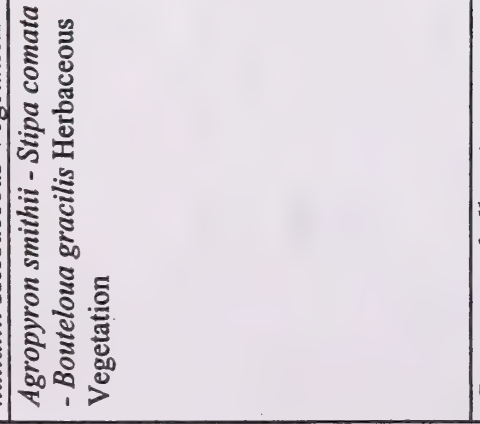 & 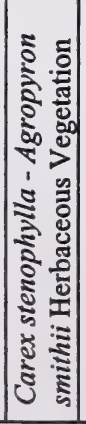 & 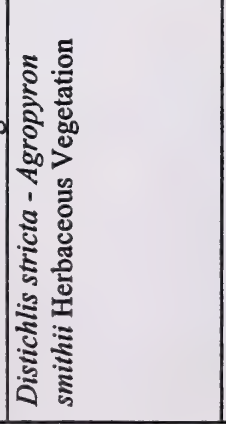 & 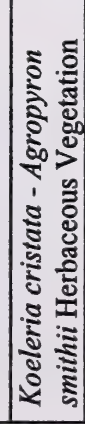 \\
\hline
\end{tabular}




\subsubsection{Description of Proposed Agropyron Community Types}

The preliminary classification of Agropyron community types based on the literature review and the cluster analysis of the ESIS database identified 39 potential Agropyron dominated/codominated community types within Alberta. They are grouped into four Herbaceous Alliances: Agropyron spicatum (5 communities), A. trachycaulum (11 communities), $A$. dasystachyum (11 communities) and $A$. smithii (12 communities).

\subsubsection{Agropyron spicatum Herbaceous Alliance}

\section{Agropyron spicatum Herbaceous Vegetation}

This community occurs within Waterton Lakes National Park (Achuff et al. (1997) (Type H42). It is associated with subxeric to mesic, moderately sloping, easterly and southerly oriented sites, mainly in the Subalpine Subregion (elevation range: 1700 - $1900 \mathrm{~m}$ ) (Achuff et al. 1997). It also occurs in Montane and Foothills Parkland, and possibly Alpine (community \#31 in this report) Subregions. Soils are well drained Brunisols and Regosols developed on fluvial, colluvial and morainal landforms. Agropyron spicatum dominates this successionally mature community (30$40 \%$ cover) accompanied by a number of common grasses such as Bromus marginatus, Phleum pratense and Poa palustris. Main forbs include Achillea millefolium, Fragaria virginiana, Galium boreale and Penstemon confertus, in addition to various other common species such as Aster conspicuous, Campanula rotundifolia, Epilobium angustifolium, Hedysarum sulphurescens, Lathyrus ochroleucus and Thalictrum occidentale. Cluster analysis and examination of environmental data by Geowest researchers indicate that Poa interior may become codominant on certain lower elevational sites while Poa palustris and Bromus carinatus may become abundant on sites with wetter soils (subhygric moisture regimes).

\section{Agropyron spicatum - Festuca campestris Herbaceous Vegetation}

This community type occurs in the area just north of the Waterton Lakes National Park (community \#29 in this report). It occurs on subxeric to mesic Foothills Parkland, Subalpine and Montane sites (elevation range: 1430 - $1867 \mathrm{~m}$ ), on gentle to steep slopes with mostly southerly aspects. Soils are well to very rapidly drained, with subxeric to mesic moisture regimes and submesotrophic to mesotrophic nutrient regimes. Agropyron spicatum and Festuca campestris dominate with $8.8 \%$ and $14.9 \%$ cover, respectively. Other common species include Festuca idahoensis (7.4\%), Koeleria macrantha (4.1\%), Danthonia parryi (3.9\%), Galium boreale (3.4\%), Aster conspicuous (3.6\%), Lupinus sericeus (2.8\%), Fragaria virginiana (2.5\%), Monarda fistulosa (2\%), Geranium viscosissimum (2\%) and Anemone multifida (1\%). Common shrub species include Amelanchier alnifolia (6.1\%), Rosa acicularis (5.5\%) and Spiraea betulifolia (3.1\%).

Agropyron spicatum - Elymus innovatus - Aster conspicuous Herbaceous Vegetation

This community type occupies small areas on dry, southwest facing slopes, with rapidly drained soils, within the Montane and Subalpine subregions of Banff National Park (Type H19 in Corns and Achuff 1982). Soils are predominantly Orthic Regosols with xeric moisture regimes, 
developed on colluvial and glacial landforms. Shrub cover is low, with Juniperus communis and Rosa acicularis occurring sporadically. Agropyron spicatum, Elymus innovatus and Koeleria cristata dominate the community $(15-30 \%, 10-30 \%$, and $3-10 \%$ cover, respectively) accompanied by various forbs such as Aster conspicuous, Oxytropis splendens, Antennaria nitida/rosea and Cerastium arvense ( $3-5 \%,<8 \%,<2 \%$, and $<2 \%$ cover, respectively). Corns and Achuff (1982) report that this successionally mature community is limited in extent to slopes above Hillsdale Meadow in Banff.

\section{Agropyron spicatum - Carex obtusata Herbaceous Vegetation}

This community type occupies middle and upper slopes with mostly southerly aspects (slope range: 4 - 48\%) within the Montane and Subalpine subregions (elevation range $606 \mathrm{~m}-1618 \mathrm{~m}$ ) in southwestern Alberta (Willoughby et al. 1998, community \#3 in this report). Soils are very rapidly to well-drained, with mostly subxeric moisture regimes and submesotrophic to mesotrophic nutrient regimes. Amelanchier alnifolia (4.2\%) and Symphoricarpos occidentalis $(6.2 \%)$ are characteristic species of the shrub layer. The dominant grass and sedge species, Agropyron spicatum, Carex obtusata, Koeleria macrantha and Festuca scabrella, make up $11.6 \%, 19.8 \%, 5.4 \%$, and $4.2 \%$ of the canopy cover, respectively. Some of the dominant forb and dwarf shrub species include Arctostaphylos uva-ursi, Rosa arkansana and Artemisia frigida. Increasing grazing pressure on the drier sites results in a decline of Agropyron spicatum and an increase of low growing forbs and sedges (Willoughby et al. 1998).

\section{Agropyron spicatum - Festuca idahoensis Herbaceous Vegetation}

This community occurs at elevations between $1554 \mathrm{~m}$ and $1874 \mathrm{~m}$, on moderately sloping sites with westerly or northerly aspects (community \#54 in this report). Sites can occupy crest to middle slope positions. Soils are very rapidly drained to well drained with xeric to subxeric moisture regimes and mesotrophic to oligotrophic nutrient regimes. The vegetation cover in this community is very thinly distributed with bare ground reaching up to $69 \%$. This community consists of a sparse collection of graminoids and forbs. Some shrub and dwarf shrub species are also present. Potentilla fruticosa, Shepherdia canadensis, Rosa acicularis and Arctostaphylos uva-ursi can occur in small amounts, but for the most part, a shrub layer is non-existent. Pseudoroegneria spicata and Festuca idahoensis occur with $4.3 \%$ and $3 \%$ cover, respectively. Other constant species include Agoseris glauca, Selaginella densa, Oxytropis sericeus, Gaillardia aristata and Anemone multifida.

\subsubsection{Agropyron trachycaulum Herbaceous Alliance}

\section{Agropyron trachycaulum Herbaceous Vegetation}

This community type occurs in Alberta under variable site conditions. It occurs on very xeric to xeric, steep to moderately steep southerly oriented slopes of the Peace River Parkland Subregion and possibly Montane and Upper Foothills subregions ((Rintoul 1985; community \#48 in this report). Soils are rapidly to moderately well drained. They include Orthic Regosols and Orthic Eutric Brunisols with clay loam to sandy loam textures. It also occurs in saline meadows of the Boreal Forest Natural Region (Fairbarns 1990). The community also inhabits lower terraces in the Suffield National Wildlife Area situated within the Dry Mixedgrass Subregion on well to 
imperfectly drained Orthic Regosols and Orthic Eutric Brunisols with sandy loam to silt loam textures (Adams et al. 1997). Small areas characterized by clay loam soils about $60 \mathrm{~cm}$ deep, with some glacial boulders support this community type in the Peace Point area of Wood Buffalo National Park (Raup 1935). Vegetation on drier sites is relatively open with unvegetated surface varying from $30-75 \%$. Agropyron trachycaulum dominates this community, while other common species include Artemisia frigida, Koeleria macrantha, Vicia americana, Achillea millefolium, Gallium boreale, and Allium cernuum. Commonly associated shrubs such as Symphoricarpos occidentalis, Rosa spp., Prunus virginiana and Amelanchier alnifolia may become dominant in some areas. Wetter sites (Boreal Region) may have a higher cover of Agropyron trachycaulum, and include species such as Symphoricarpos albus, Carex spp., Agrostis scabra, Antennaria parviflora, Astragalus dasyglottis, Geum triflorum, Hieracium umbellatum, Lactuca pulchella, Viola adunca and some halophytic species (Fairbarns 1990). Wood Buffalo National Park grasslands are characterized by an assemblage of perennial forbs such as Geum triflorum, Stachys scopulorum, Geum macrophyllum var. perincisum, and Galium boreale. Equisetum pratense, Bromus pumpellianus, Schizachne purpurascens and Calamagrostis spp. are some of the secondary species.

\section{Agropyron trachycaulum - Stipa spp. Herbaceous Vegetation}

This community occupies moderately dry slopes and certain flat mesic grasslands in the Peace River area (Moss 1952). Sites are quite variable and include rocky grounds of an old moraine, well drained alluvial soils, level areas with heavy textured black soils developed on flood plains of streams, and black loam of silty to clay mixture with a "solodized solonetz type of profile", developed on lacustrine or alluvial-lacustrine material. In the Peace Point area of Wood Buffalo National Park this community occupies relatively flat areas with Orthic Cumulic Regosols of sandy-loam texture, developed on glaciolacustrine sediments (Redmann and Schwarz 1986). The same community occurs at Salt River sites in Wood Buffalo National Park on Black Solod soils (Schwarz 1994; Schwarz and Wein 1997). Vegetation on the Peace River sites is characterized by the dominance of grass and sedge species such as Agropyron trachycaulum, Stipa curtiseta, Koeleria macrantha and Carex obtusata, accompanied by numerous forb species (e.g. Galium boreale, Achillea millefolium, Thalictrum venulosum). Stipa richardsonis, Danthonia intermedia, Agropyron dasystachyum, Carex praticola, C. siccata, and some shrubby species (e.g. Amelanchier alnifolia) may become locally abundant. Agropyron trachycaulum ( $20.8 \%$ cover) and Stipa columbiana $(9.7 \%$ cover) dominate the herb layer on the Peace Point sites described by Redmann and Schwarz (1986). S comata, S. curtiseta, Artemisia frigida, and Galium boreale are some of the additional grass and forb species characterizing these grasslands. The community described by Schwarz (1994) and Schwarz and Wein (1997) is dominated by A. trachycaulum, Stipa curtiseta ( $S$. richardsonis, $S$. viridula), accompanied by some typically southern species such as Koeleria macrantha, Carex siccata, C. xerantica, Muhlenbergia richardsonis, Geum triflorum and Potentilla hippiana. Heavy grazing in the Agropyron - Stipa community type results in a decrease of cover of the leading grass species and an increase of other species, particularly Carex obtusata (Moss 1952; Redmann and Schwarz 1986).

Agropyron trachycaulum - Carex atherodes Herbaceous Vegetation

In its unmodified condition, this community occupies only one shallow basin in the Peace River area ( $\mathrm{N}$ of Fort Vermilion and $\mathrm{E}$ of the Caribou River, near the base of the Caribou Mountains) 
of Alberta (Moss 1952). Somewhat modified versions of this community by moderate grazing and roadside ditching occur near the Boyer River on deposits of fine sand and clay, in Buffalo Prairie on silty flood plain sites with fertile black loam $(5-10 \mathrm{~cm})$ over brown silt subsoil, and near Keg River (Moss 1952). Typically, Agropyron trachycaulum and Carex atherodes dominate, accompanied by other principal grass and forb species such as Carex praticola, Calamagrostis spp., Bromus spp., Solidago lepida and Vicia americana. Symphoricarpos occidentalis, Symphoricarpos albus and Rosa woodsii are frequent species in the shrub layer, and become more abundant under modified (grazed) conditions.

Agropyron trachycaulum - Carex praegracilis - Fragaria virginiana Herbaceous Vegetation

This community occurs on mesic to subhygric, moderately well drained soils with mesotrophic nutrient regimes within the Upper Foothills Subregion (1400 - 2438 masl) (Willoughby and Smith 1999), and the Upper and Lower Foothills subregions (576 - $1540 \mathrm{~m}$ ) ((communities \#15, $\# 12$ and \#17 in this report)). The dominant grass and sedge species are Agropyron trachycaulum, Carex praegracilis, Bromus ciliatus and Elymus innovatus. On average, they contributed $26.0 \%$, $21.0 \%, 9.0 \%$ and $5.0 \%$ to the canopy cover, respectively (this report). Some of the dominant forbs, Fragaria virginiana, Potentilla gracilis, Achillea millefolium and Aster ciliolatus, make up $12.0 \%, 9.0 \%, 8.0 \%$ and $5.0 \%$ of the canopy cover, respectively (this report). At least some stands of this community represent a degradation of the Festuca scabrella - Deschampsia caespitosa community type and are very common in valley bottoms in areas with heavy grazing (Willoughby and Smith 1999).

Agropyron trachycaulum - Distichlis stricta Herbaceous Vegetation

This community type occupies small areas with eroded Solods and saline seeps on glaciolacustrine materials on the Salt River escarpment in Wood Buffalo National Park (Schwarz 1994, Schwarz and Wein 1997). Sites occur on southerly aspects at 210 masl. Soils are moderately fine textured and rapidly drained Dark Brown Solods and saline Regosols. This community is characterized by a relatively small number of species, including Symphoricarpos occidentalis, Agropyron trachycaulum, Distichlis stricta, Koeleria macrantha, Spartina gracilis, Poa juncifolia and Carex siccata.

\section{Agropyron trachycaulum - Koeleria cristata Herbaceous Vegetation}

Raup (1935) described the Agropyron trachycaulum - Koeleria cristata community type for the salt plains (level country just west of the Slave River) of Wood Buffalo National Park (Peace River Lowlands Subregion). This community was found about two miles south of Heart Lake on nearly level terrain where streams carried off the outwash and left the soil with little or no salt. Agropyron trachycaulum and Koeleria cristata dominate the community. Subdominant species include Juniperus horizontalis, Hierochloe odorata, Deschampsia caespitosa, Danthonia intermedia, Schizachne purpurascens and Agrostis scabra. Cluster analysis of the ESIS database presented in this report indicates the possible existence of this community type in the Dry Mixedwood, Subalpine and Montane subregions (community \#4). However, with the exception of the two dominant species, Agropyron trachycaulum and Koeleria cristata, few other species are shared between these two communities. Grasslands outside Wood Buffalo National Park are characterized by a number of species not mentioned in Raup (1935) such as Helictotrichon 
hookeri, Carex pensylvanica, Bromus inermis, Artemisia frigida, Stipa curtiseta, Muhlenbergia richardsonis, Festuca scabrella, and Carex obtusata.

Agropyron trachycaulum - Festuca ovina - Poa palustris - Equisetum arvense Herbaceous Vegetation

This community type occupies sandy beach deposits with few rocks in the vicinity of Shelter Point, along the north shore of Lake Athabasca (Raup 1928). Dominant species include Agropyron tenerum, Festuca ovina, Poa palustris and Equisetum arvense. Secondary species include Sisyrinchium angustifolium, Rumex altissimus, Corydalis aurea, Potentilla monspeliensis, Rubus idaeus var. canadensis, and Epilobium angustifolium.

\section{Agropyron trachycaulum - Hierochloe odorata Herbaceous Vegetation}

This community type occurs in the Boreal Region of northwestern Alberta (Child Lake, High Level and Hay River) (Fairbarns 1990). It occupies the wettest and least saline end of the moisture and salinity gradients characterizing saline meadows of northwestern Alberta. Agropyron trachycaulum and Hierochloe odorata dominate, while Carex spp., Rosa acicularis and Symphoricarpos albus represent some of the more abundant species. Achillea millefolium, Agrostis scabra, Antennaria parviflora, Astragalus dasyglottis, Galium boreale, Geum triflorum, Hieracium umbellatum, Lactuca pulchella, Viola adunca and some halophytic species are some of the less abundant species characterizing this community type.

Agropyron trachycaulum - Elymus innovatus - Thalictrum venulosum Herbaceous Vegetation

This community type occurs on lower slopes and plains of the Central Mixedwood, Dry Mixedwood, Upper Foothills and Subalpine subregions, at elevations ranging from 472 to 1650 masl (community \#9 in this report)). It occurs on level terrain and in depressions. When on sloping terrain (ca 5\%), the community occupies northerly and easterly aspects. Soils are well to imperfectly drained, with subhygric to hygric moisture regimes and mesotrophic to eutrophic nutrient regimes. Agropyron trachycaulum, Elymus innovatus, Thalictrum venulosum and Mertensia paniculata are the dominant species (average ground cover of $14 \%, 14 \%, 14 \%$, and $10 \%$, respectively). Other important species include Deschampsia caespitosa, Achillea millefolium, Carex praegracilis, Bromus inermis, B. ciliatus, Delphinium glaucum, Aster ciliolatus, Vicia americana, Epilobium angustifolium, and Schizachne purpurascens. Salix barclayi and Betula glandulosa are prominent species in the shrub layer.

\section{Poa interior - Agropyron trachycaulum Herbaceous Vegetation}

This community type was described for the Grande Prairie - Beaverlodge area by Stacey (1927). It was found, among other places, in parts of the sand ridge where the growth of pine, spruce and poplar helped the development of an inch or two of black soil. Poa interior, Agropyron tenerum, and $A$. caninum are the dominant grasses in this association. Other important species included Calamagrostis inexpansa, Agrostis hiemalis, Poa palustris, Elymus innovatus, Koeleria cristata, Carex praticola, and C. xerantica. In the numerous local depressions, Calamagrostis canadensis replaces the more xerophytic $C$. inexpansa. The author described this association as very widespread on drier habitats within the study area. 
Hordeum jubatum - Agropyron trachycaulum - Distichlis stricta Herbaceous Vegetation

This community inhabits saline meadows in areas about eight $\mathrm{km}$ west of Fort Vermilion, in northwestern Alberta (Moss 1953). Sites include pools, sinkholes, barren patches, and extensive grassy flats. In addition to the three dominant species, Hordeum jubatum, Agropyron trachycaulum, and Distichlis stricta, the author listed Elymus macounii, Muhlenbergia richardsonis, Puccinellia nuttalliana, Suaeda depressa as leading species. Aster ericoides, Grindelia squarrosa, Vicia americana, Plantago eriopoda, Aster caerulescens, Gallium boreale, Solidago lepida, Carex praticola and Carex praegracilis are just some of the additional species listed for these meadows. The Hordeum jubatum - Agropyron trachycaulum - Distichlis stricta community type (Moss 1953) may be a successional or disturbance variant of the Agropyron trachycaulum - Distichlis stricta (Schwarz and Wein 1997) community type. Hordeum jubatum invades as a result of grazing or some other low-level disturbance on saline/semi-saline Gleysolic soils (Art Schwarz - personal communications).

\subsubsection{Agropyron dasystachyum Herbaceous Alliance}

\section{Agropyron dasystachyum Herbaceous Vegetation}

This community occurs in a variety of locations including very dry and steep southeast to southwest facing slopes in the Kakwa Falls region (Jaques and vanEck 1979), steep south facing slopes with shallow, rapidly drained soils, with subxeric to xeric moisture regimes and submesotrophic nutrient regimes, at lower elevations within the Subalpine and the Montane subregions (Willoughby et al. 1998, Willoughby 1999), very steep slopes with northerly aspects in the Suffield National Wildlife Area situated within the Dry Mixedgrass Subregion (Adams et al. 1997), and one moderately well drained, mesic site at the toe position of an alluvial fan in the Kootenay Plains area (Wallis and Wershler 1981). Classification of the ESIS plots indicate the possible presence of this community in the Alpine and Peace River Parkland subregions (community \#45 in this report). Agropyron dasystachyum dominates in all sites (average cover $30-40 \%$ ) accompanied by other, less abundant species such as Symphoricarpos occidentalis, Agropyron caninum var. andinum, Carex obtusata, Calamagrostis purpurascens, Koeleria cristata, Poa interior, Stipa spartea, Stipa occidentalis var. minor, Allium cernuum, Artemisia frigida, Cerastium arvense, and Vicia americana in the Kakwa Falls (Jaques and vanEck 1979), Arctostaphylos uva-ursi, Koeleria cristata, Phleum commutatum, Carex obtusata, Elymus innovatus, Festuca saximontana, Thalictrum occidentale, Epilobium angustifolium, Antennaria parviflora and Lupinus sericeus on Montane and Subalpine sites (Willoughby et al. 1998, Willoughby 1999), Geum triflorum, Linum lewisii, Stellaria longipes, Koeleria macrantha, Agoseris glauca and Campanula rotundifolia in the Kootenay Plains (Wallis and Wershler 1981), Amelanchier alnifolia, Artemisia cana, A. frigida, Koeleria macrantha, Anemone patens, Gutierrezia sarothrae and Comandra umbellata in the Suffield National Wildlife Area (Adams et al. 1997), or Koeleria cristata, Epilobium angustifolium, Festuca spp. and Galium boreale (this report). 
Agropyron dasystachyum - Calamovilfa longifolia Herbaceous Vegetation

This community type was noted by Adams et al. (1997) for the Suffield National Wildlife Area. It represents a minor vegetation component on well drained, sandy soils developed on fluvial materials within broad ravines with relatively low-angle side slopes.

Agropyron dasystachyum - Agropyron smithii Herbaceous Vegetation

This community type occurs on moderately well to well drained Solonetzic soils in the Milk River Natural Area and the Kennedy Coulee Ecological Reserve, situated within the Dry Mixedgrass Subregion (Adams and Moisey 1999). Soils include Brown Solodized Solonetz and Brown Solonetz, with minor occurrences of Brown Solods, Brown Chernozems and Orthic Regosols. The same community type inhabits steep, unstable mid-slopes with southerly aspects in the Peace River and Clear River canyons in the Dry Mixedwood Subregion (Adams 1981). Soils are Orthic Regosols with silty loam texture, developed on morainal and colluvial materials. Besides the two dominant grasses, Agropyron dasystachyum and Agropyron smithii, additional species in the Milk River region include Artemisia frigida, Bouteloua gracilis, Stipa comata, Poa pratensis and Koeleria macrantha. Carex spp., Koeleria macrantha, Stipa curtiseta, Artemisia frigida and Stipa viridula characterize sites in the Peace River region.

\section{Agropyron dasystachyum - Koeleria macrantha - Artemisia frigida Herbaceous Vegetation}

In the Montane Subregion, this community type occurs within Jasper and Banff National Parks (elevation range $1040-1640 \mathrm{~m}$ ) on xeric, generally steeply sloping sites with southerly aspects (Corns and Achuff 1982). Soils are rapidly to well drained and include Orthic Eutric Brunisols and Orthic Regosols developed on colluvial, glacial, and fluvial materials. In the north and central portion of the Kootenay Plains area, this community occupies well drained, submesic alluvial fans (Wallis and Wershler 1981). The community occupies variety of slopes and aspects, but mainly occurs on near level terrain or on the toe or ridges of the fan. On the west and north side of the river in the south-central portion of the Kootenay Plains area, the same community occurs on moderately well to well drained, mesic to submesic depressions and nearly level sites at the toe or upper slope of the alluvial fans (Wallis and Wershler 1981). Within the Montane Subregion, this community type is also reported from areas with Cumulic Regosols and Orthic and Brunisolic Gray Luvisols (Beckginham et al. 1996). Willoughby et al. (2000) described the same community type for the south and west facing slopes (slope range $10-90 \%$ ) along the banks of the Peace, Smoky and Wapiti rivers throughout the Dry Mixedwood Subregion (elevation range $345-606 \mathrm{~m}$ ). Soils are very rapidly drained with xeric-subxeric moisture regimes and submesotrophic nutrient regimes. Within the Silver Valley area this community occurs on moderate to steep, south and southwest facing slopes with rapidly to well drained, very xeric to xeric Orthic Regosols and Orthic Eutric Brunisols of clay loam or sandy loam texture (Rintoul 1985). Cluster analysis from this report indicates that this community type may also occur within the Alpine, Subalpine and Cypress Hills Montane subregions.

Within the Montane Subregion sites are generally forb poor, moss layer covers up to $30 \%$ of the ground, and unvegetated surface reaches up to $50 \%$. Sites described by Corns and Achuff (1982) are dominated by Agropyron dasystachyum (5 - 50\% cover) with lesser amounts of Artemisia frigida (1 - 10\%), Koeleria cristata $(2-10 \%)$ and Achillea millefolium $(<5 \%)$. In the Kootenay 
Plains area, on somewhat drier stands, Agropyron dasystachyum, Koeleria macrantha and Artemisia frigida contribute $6-75 \%, 6-25 \%$ and $6-25 \%$, to the ground cover, respectively, while Antennaria nitida occurs scattered, mainly in wetter depressions (Wallis and Wershler 1981). Additional frequent species include Astragalus striatus, Linum lewisii, Orthocarpus luteus, and Erigeron caespitosus. (Wallis and Wershler 1981). In wetter sites, Artemisia frigida and Antennaria nitida become more abundant, with a lower cover of Koeleria macrantha (Wallis and Wershler 1981). Astragalus striatus and Aster alpinus may also become locally abundant. On some sites within the Montane Subregion, Artemisia frigida and Koeleria macrantha may reach higher ground cover than Agropyron dasystachyum (Beckginham et al. 1996). Calamagrostis purpurascens, Poa pratensis, Carex spp. and Linum lewisii are also found on this sites. This community type from the Dry Mixedwood Subregion seems to have a lower cover of the three dominant species. Agropyron dasystachyum, Koeleria macrantha and Artemisia frigida cover on average $10 \%, 5 \%$ and $6 \%$ of the ground, respectively (Willoughby et al. 2000). Other characteristic species include Amelanchier alnifolia (6\%), Rosa acicularis (3\%), Carex spp. Agropyron trachycaulum and Stipa richardsonis. In addition to the three dominant species, sites within the Silver Valley area include species such as Stipa spartea, Allium cernuum, Astragalus agrestis, Crepis tectorum and Linum lewisii. Cluster analysis from this report indicates that this community type may have much higher vegetation cover, especially of the three dominant species, when occurring on moister sites within Montane, Subalpine and Alpine subregions, compared to drier sites of the Montane, Cypress Hills Montane and Dry Mixedwood subregions. Noteworthy species of this community within the Silver Valley study site are Lomatium foeniculaceum and Opuntia fragilis, species more commonly found in southeastern Alberta (Rintoul 1985).

\section{Agropyron dasystachyum - Poa pratensis Herbaceous Vegetation}

This community type was described by Willoughby et al. (1998) for only one site above the Oldman River in the Outer Gap Range Allotment in the Montane Subregion of Alberta (elevation $1545 \mathrm{~m}$ ). The Outer Gap range is subjected to extremely high desiccating winds. This community occupied dry, moderately to heavily grazed south facing slopes (slope 15\%). Soils are shallow, rapidly drained, with submesic moisture regimes and submesotrophic nutrient regimes. The dominant grass and sedge species are Agropyron dasystachyum (35\%), Carex obtusata (11\%), Poa pratensis (10\%), and Poa canbyi (5\%). Taraxacum officinale, Vicia americana, Antennaria parvifolia, Oxytropis splendens and Solidago missouriensis, which made up $15.0 \%, 13.0 \%$, $10.0 \%, 8.0 \%$ and $6.0 \%$ of canopy cover, respectively, are the dominant forbs. Symphoricarpos occidentalis (12\%) and Rosa arkansana (7\%) are the dominant species in the shrub and dwarf shrub layers. The authors suggest that this community has been driven by disturbance (grazing) which favored exotic species such as Poa pratensis and Taraxacum officinale, however, relatively dry soil conditions have prevented Poa pratensis from dominating this community type. In the absence of the disturbance the community would probably more closely resemble moister sites within the Agropyron spicatum - Carex obtusata community type. (Willoughby et al. 1998).

Agropyron dasystachyum - Muhlenbergia cuspidata Herbaceous Vegetation

This community type is associated with water eroded areas scattered throughout rolling topography of the Canadian mixed prairie (Coupland 1950). Characterized by frequent areas of 
bare ground, this community is dominated by Agropyron dasystachyum and Muhlenbergia cuspidata. Agropyron smithii represents only a minor component of the wheat grass cover in this community, and together, the two wheat grass species make up $35.2 \%$ of the total basal area. The codominant species, Muhlenbergia cuspidata, contributes $18.2 \%$ of the total vegetation cover. The principal associated grasses and sedges, Koeleria cristata, Bouteloua gracilis, Stipa comata, $S$. spartea var. curtiseta, $S$. viridula, Carex eleocharis and $C$. filifolia contribute $8.1 \%, 13.0 \%, 1.4 \%, 1.4 \%, 1.2 \%, 14.9 \%$ and $1.4 \%$ of the total basal area, respectively. Artemisia frigida and Phlox hoodii were the most abundant forbs, making up $8.8 \%$ and $4.9 \%$ of the total basal area. Coupland (1950) suggested that the vegetation of these sites, in the absence of disturbance, would more closely resemble that of the Stipa-Bouteloua type, however, water erosion has modified the relative abundance of the grasses.

\section{Agropyron dasystachyum - Artemisia dracunculus - Artemisia frigida Herbaceous Vegetation}

This community type occurs on near level, well-drained, submesic sites, at the toe edge of alluvial fans in the Kootenay Plains area (Wallis and Wershler 1981). Agropyron dasystachyum, Artemisia dracunculus, and Artemisia frigida contribute about $26-50 \%, 16-25 \%$, and $16-25 \%$ to the ground cover, respectively. Agropyron subsecundum and Koeleria cristata are locally abundant. Additional species include Linum lewisii, Oxytropis campestre, Astragalus striatus, Potentilla pensylvanica, Antennaria nitida, Erigeron caespitosus, Orthocarpus luteus and Poa glauca.

\section{Agropyron dasystachyum - Antennaria nitida Herbaceous Vegetation}

This community type occupies woodland edges and former wooded sites on south or east side of river in the Kootenay Plains area, where it is a major community type (Wallis and Wershler 1981). It occupies mid slopes (3 - 5\%) with northerly and southerly aspects on alluvial fans. Soils are well drained with submesic moisture regimes. Ground cover of each of the codominant species, Agropyron dasystachyum and Antennaria nitida, generally reaches from 25 to $50 \%$, although, in certain areas cover of Antennaria reaches $75 \%$. Numerous other species characterize this community type, including Koeleria cristata, Artemisia frigida, Comandra pallida, Linum lewisii, Astragalus striatus, Anemone multifida, Androsace septentionalis, Gentianella amarella, Galium boreale, Campanula rotundifolia, Agoseris glauca, Aster alpinus, Erigeron caespitosus, Gaillardia aristata, Senecio canus, Solidago decumbens, Allium cernuum, Sysirinchium montanum, and Bromus pumpellianus. In some areas shrub species such as Rosa woodsii. and Potentilla fruticosa invade these grasslands. Some areas are more open, with the cover of bare soil and rock being up to $45 \%$ and $25 \%$, respectively. Antennaria nitida, Artemisia frigida, Agropyron dasystachyum, Koeleria cristata and lichens are locally common.

\section{Agropyron dasystachyum - Stipa comata Herbaceous Vegetation}

This community type is locally prevalent in one area on the west side of the North Saskatchewan River, in the central portion of the Kootenay Plains study site (Wallis and Wershler 1981). It occupies the toe edges of alluvial fans, with well-drained soils characterized by submesic moisture regimes. Coupland (1950) described this community type for undulating to gently rolling areas, with medium textured soils of the dark-brown soil zone in the mixed prairie of Canada. More details on this community type from the Milk River area is given by Adams and 
Moisey (1999). In the Milk River area this community occupies landscapes with well-drained soils (slope $1-4 \%$ ), situated upslope from the western wheat grass and the northern wheat grass western wheat grass community types. Soils are mainly Orthic Brown Chernozems with minor importance of Calcareous Brown and Solonetzic Brown Chernozems. The same community type may also exist in southwestern Alberta in the shallow black soil zone and on black soils when grazing pressure has allowed Agropyron species to replace more palatable fescues (Moss 1944). In the Kootenay Plains area, Agropyron dasystachyum and Stipa comata dominate, each contributing 26 - 50\% to the ground cover. Artemisia frigida (16 - 25\%), Koeleria cristata (6 $15 \%$ ), and Agropyron subsecundum (6-15\%) are the few major species in this community, while Astragalus agrestis, Linum lewisii, Antennaria nitida, Solidago decumbens, Orthocarpus luteus, Agropyron smithii, and Festuca saximontana are present with very low covers. Lichens cover up to $25 \%$ of the ground. Coupland (1950) noted that the three dominant species of this community type within the mixed grass prairie, Agropyron dasystachyum, Stipa comata, and S. spartea var. curtiseta, contribute $43 \%$ to the ground cover, while sedges make up $25.5 \%$ of the total basal area. Selaginella densa may cover up to $30 \%$ in disturbed areas. The principal subdominant graminoids are Bouteloua gracilis, Koeleria cristata, Carex filifolia, C. eleocharis and C. heliophila. Carex eleocharis may reach the same basal cover as Agropyron dasystachyum. Stipa comata, Agropyron dasystachyum, Bouteloua gracilis and Calamagrostis montanensis dominate grasslands described for the Milk River area. Grasslands in southwestern Alberta are also dominated by Agropyron dasystachyum, Stipa comata, and S. spartea var. curtiseta, but also include some A. smithii and Festuca idahoensis. Heidel et al. (2000) believe that this community represents a "missing link" between the prevailing Pascopyrum smithii - Stipa comata Bouteloua gracilis association of the U.S. Great Plains and the prevailing Elymus lanceolatus Stipa curtiseta association of the Canadian Great Plains. Heidel et al. (2000) also suggested that this association falls within the "Stipa - Agropyron faciation" of Coupland (1950).

\section{Agropyron dasystachyum - Agropyron subsecundum Herbaceous Vegetation}

This community type occurs in only one location in a depressional site with considerable bare ground (mineral soil 15\%) on a river terrace in the Kootenay Plains area (Wallis and Wershler 1981). Soils are well drained with submesic moisture regimes. Agropyron dasystachyum and Agropyron subsecundum codominate, contributing about $50-75 \%$ to the ground cover. Linum lewisii ( $5-15 \%)$ is the only abundant forb species. Additional species characterizing this community type, but with very low cover, include Astragalus striatus, A. tenellus, Oxytropis sericea, Gentianella amarella, Achillea millefolium, Artemisia dracunculus, A. frigida and Solidago decumbens.

Juniperus horizontalis - Arctostaphylos uva-ursi / Agropyron dasystachyum - Elymus innovatus Dwarf Shrub Herbaceous Vegetation

This community type occurs on nearly level terrain on valley floors and middle slope positions within the Rocky Mountain Natural Region (Montane Subregion) (elevation range of 1036 to $1372 \mathrm{~m}$ ) (community \#53 in this report). Soils are rapidly to moderately well drained, with subxeric to subhygric moisture regimes and submesotrophic to mesotrophic nutrient regimes. Juniperus horizontalis and Agropyron dasystachyum are the most abundant species; Potentilla fruticosa; Juniperus horizontalis, Arctostaphylos uva-ursi, Agropyron dasystachyum and Elymus innovatus occur in each inventoried stand of this community. Juniperus horizontalis, 
Arctostaphylos uva-ursi and Elymus innovatus are the three characteristic species; tree and shrub species such as Picea glauca, Pinus contorta, Shepherdia canadensis, and Salix spp. may reach significant covers in some stands, but none of them are constant species.

\subsubsection{Agropyron smithii Herbaceous Alliance}

\section{Agropyron smithii Herbaceous Vegetation}

This community type occupies slightly alkaline clay flats and some alluviated clay flats within the mixed grass prairie in Canada, where it is held in a subclimax stage related to the Agropyron - Koeleria faciation by the accumulation of soluble salts or by the deposition of sediments (Coupland 1950). In the Milk River Natural Area and the Kennedy Coulee Ecological Reserve, it occupies lower, swale and depressional sites with moderately well to imperfectly drained Brown Solonetz, Brown Solodized Solonetz and Brown Solods (possibly some Gleysolic soils) with clay and loam textures (Wallis 1976; Brierley et al. 1989, Adams and Moisey 1999). The same community type is documented by the cluster analysis (community \#51 in this report). This community is solely dominated by Agropyron smithii. Koeleria cristata and Poa secunda are less common grasses, while Gutierrezia diversifolia and Phlox hoodii represent the principal forbs (Coupland 1950). It may also include species such as Bouteloua gracilis, Muhlenbergia richardsonis, Carex eleocharis, C. filifolia, Gutierrezia serothrae, Phlox hoodii, Lomatium foeniculaceum, L. macrocarpum, Liatris punctata (Wallis 1976). Other species reported by Adams and Moisey (1999) include Agropyron dasystachyum, Poa pratensis, Carex stenophylla, Artemisia ludoviciana and Eleocharis palustris. It may also have Deschampsia cespitosa, Beckmannia syzigachne, and Hordeum jubatum in moister depressions in lakebeds, and Poa juncifolia, Puccinellia spp. and Distichlis stricta in association with saline depressions (Brierley et al. 1989).

\section{Agropyron smithii - Artemisia ludoviciana Herbaceous Vegetation}

This community type occurs on sand plains in the Suffield National Wildlife Area within the Dry Mixedgrass Subregion, where it occupies depressions and gentle slopes (2-9\%) with variable aspects (Adams et al. 1997). Soils are Orthic Regosols developed on morainal materials and include imperfectly to well drained sandy soils, well to rapidly drained loamy sands, or well drained sandy loams. Agropyron smithii and Artemisia ludoviciana dominate with $42 \%$ and $9 \%$ ground cover, respectively. Other notable species include Carex stenophylla (6\%), Poa pratensis (4\%), Grindelia squarrosa and Chenopodium pratericola (last two with very low covers).

\section{Agropyron smithii - Artemisia frigida Herbaceous Vegetation}

This community type occurs in the Suffield National Wildlife Area within the Dry Mixedgrass Subregion. It occupies various landform/surficial materials with various soil types. These include: sand plains and sand dunes with well drained sandy Orthic Regosols; broad ravines with well drained sandy Orthic Brown Chernozems; glacio-fluvial terraces with well drained, sandy Orthic Regosols and Rego Brown Chernozems; glacio-fluvial terraces with well drained loamy sandy Orthic Brown Chernozems; outwash plains with well drained Orthic and Rego Brown Chernozems and Orthic Regosols of sandy loam texture; undulating outwash and hummocky moraine with well drained Orthic and Rego Brown Chernozems of sandy loam texture; rolling 
moraine with well drained Orthic and Calcareous Brown Chernozems of sandy loam to loam texture; and, morainal deposits with thin eolian veneers with well to rapidly drained Orthic Brown Chernozems of sandy loam texture. No details were provided on the vegetation composition for this community type.

\section{Agropyron smithii - Artemisia tilesii - Artemisia frigida. Herbaceous Vegetation}

This community type occupies slump sites in colluvial and morainal material on steep slopes (mid-slope position) in the Peace River area within the Dry Mixedwood Subregion (Adams 1981). It occurs just upslope from the areas occupied by Agropyron dasystachyum - Agropyron smithii - Carex spp. - Koeleria macrantha community type. On the upper (less steep) slope it is bordered by the Agropyron smithii - Stipa viridula - Carex spp. - Vicia americana community type. In contrast to adjacent community types which provide primary range for livestock and primary winter range for mule deer, the steep slopes re-colonized by Agropyron smithii, Artemisia tilesii and Artemisia frigida were rarely used for grazing by either cattle or wildlife.

\section{Agropyron smithii - Bouteloua gracilis Herbaceous Vegetation}

This community type occurs in the Milk River area on well drained Brown Solonetz and Brown Solodized Solonetz soils, and occasionally Orthic Brown Chernozems with loam and clay loam texture developed on gently inclined and undulating till (Brierley et al. 1989). Comer et al. 1999 confirmed the existence of this community on gently rolling terrain with loamy, deep, fertile soils within the southeast corner of Alberta. Agropyron smithii (28.1\% composition), Poa sandbergii ( $13.1 \%$ composition), Koeleria macrantha (6.6\% composition), Stipa comata $(4.4 \%$ composition), Bouteloua gracilis (3.9\% composition), and Selaginella densa $(29.3 \%$ composition) dominate, accompanied by secondary species such as Phlox hoodii, Tragopogon dubius, Artemisia frigida, Carex filifolia, Atriplex nuttallii, Artemisia cana, Eurotia lanata, Achillea millefolium, Opuntia polyacantha and Grindelia squarrosa (Brierley et al. 1989).

\section{Agropyron smithii - Hordeum jubatum Herbaceous Vegetation}

This community occurs in the northmost portion of a large saline wetland located within the Neutral Hills area, Northern Fescue Subregion (Wallis 1990). It represents the driest vegetation component along a moisture gradient adjacent to the Distichlis stricta community type occupying somewhat wetter soils.

\section{Agropyron smithii - Pyrrocoma uniflora Sparse Herbaceous Vegetation}

This community type was found at only one site in the vicinity of alkali grass (Puccinellia nuttalliana) depressions in the vicinity of Whirlpool Point in the Kootenay Plains area (Wallis and Wershler 1981). It occurs on sites with high water tables. Vegetation has low cover values with considerable bare ground. Scattered forbs include Cerastium arvense, Anemone multifida, Astragalus agrestis, Achillea millefolium, Senecio canus, Taraxacum officinale and Aster sibiricus. 
Agropyron smithii - Atriplex nuttallii Herbaceous Vegetation

This community type occurs on moderate slopes on the northeast side of an un-named coulee in the Manyberries badlands within the Mixedgrass Subregion (elevation ranges $968-1066 \mathrm{~m}$ ) (Smith 1993). Soils of the general area are Brown Solonetz with loamy textures derived from moderately calcareous till, and overlaying shales and sandstones. This community is characterized by having $75 \%$ to $80 \%$ bare ground. Agropyron smithii and Atriplex nuttallii codominated in this community. Koeleria macrantha and Artemisia frigida are also abundant on one site inventoried. Other characteristic species include Phlox hoodii, Gutierrezia serothrae, Gaura coccinea, Grindelia squarrosa, Haplopappus nuttallii, Chrysothamnus nauseosus, Oenathera caespitosa, Erigeron caespitosus and Carex filifolia (locally abundant in sandier patches).

Agropyron smithii - Stipa comata - Bouteloua gracilis Herbaceous Vegetation

This community type occurs within the western portion of the Milk River Natural Area (elevation about $1000 \mathrm{~m}$ ) on west- and some east-facing colluvial slopes (slope $10-20 \%$ ) (Brierley et al.1989). Soils are well drained, fine to coarse textured Orthic Brown Chernozems with submesic moisture regimes. The same community type also occurs on gentle slopes $(<15 \%)$ with variable aspects within the Suffield National Wildlife Area within the Dry Mixedgrass Subregion (Adams et al. 1997). Sites occupied by this community type included: middle terraces with well drained, sandy Orthic Brown Chernozems; lower terraces with imperfectly drained, sandy loam Orthic Regosols and Orthic Gleysols; valley walls with well drained sandy Orthic Brown Chernozems; hilly outwash with well drained, loamy sand Orthic Brown Chernozems; hummocky moraine with well drained, sandy Orthic Brown Chernozems; and inclined morainal slopes with sandy loam Orthic and Rego Brown Chernozems. Finally, this community type may also occur within the Cypress Hills Montane and Mixedgrass Subregions on rapidly to well drained soils with subxeric to mesic moisture regimes (community \#36 in this report). In the Milk River Natural Area, this community is dominated by Stipa comata/S. spartea, Agropyron smithii and Selaginella densa (average percent compositional cover of $23 \%, 22 \%$, and $34 \%$, respectively), accompanied by Bouteloua gracilis, Carex spp., Koeleria macrantha, Poa sandbergii, Calamovilfa longifolia, Phlox hoodii and numerous other species (Brierley et al. 1989). Within the Suffield National Wildlife Area, Agropyron smithii, Stipa comata and Carex stenophylla dominate, contributing on average $21 \%, 31 \%$ and $19 \%$ to the ground cover, respectively. Additional species include Bouteloua gracilis (3\%), Chenopodium pratericola (4\%), Descurainia pinnata (1\%), Lactuca pulchella, Lygodesmia juncea and Opuntia polyacantha (low covers). Analysis of plots from the ESIS database (this report) indicates that this community type found within the Cypress Hills Montane, and the Dry Mixedgrass and Mixedgrass subregions of southeastern Alberta is dominated by Agropyron smithii (16\%), Stipa comata $(9.7 \%)$, Bouteloua gracilis (9.7\%) and Selaginella densa (35\%), accompanied by less abundant species such as Koeleria macrantha, Carex filifolia, Agropyron dasystachyum and Stipa viridula.

Carex stenophylla - Agropyron smithii Herbaceous Vegetation

This community type occurs on a variety of sites including depressional sites on well drained, sandy Orthic Regosols and Rego Brown Chernozems of glacio-fluvial terraces, well to rapidly drained loamy sand Orthic Brown Chernozems developed on morainal deposits, and on well 
drained, sandy loam to loam Orthic and Calcareous Brown Chernozems on morainal deposits within the Suffield National Wildlife Area within the Dry Mixedgrass Subregion (Adams et al. 1997). The same community possibly exists northwest of Fairview (Boreal Forest - Dry Mixedwood Subregion) where it occupies steep slopes (25 - 50\%) with southerly aspects, on very rapidly drained soils with subxeric moisture regimes (community \#47 in this report). In the Suffield National Wildlife Area Agropyron smithii (43\%) and Carex stenophylla (57\%) dominate, accompanied by only three additional species, Chenopodium pratericola (4\%), Vicia americana $(1 \%)$ and Taraxacum officinale $(<1 \%)$. The same community from the Boreal Forest Region is less vegetated (ca. $30 \%$ vegetation cover) dominated by $A$. smithii (7.6\%) and Carex spp. (4.6\%), and accompanied by species such as Amelanchier alnifolia, Symphoricarpos albus, Koeleria macrantha, Stipa curtiseta, and S. comata.

\section{Distichlis stricta - Agropyron smithii Herbaceous Vegetation}

This community type occurs in saline wetlands in the Grassland and Parkland Regions of eastern Alberta (Wallis 1990). This "saline dry meadow" is transitional between the driest portion of the halophytic communities and the semi-halophytic communities. Numerous upland species accompany the two dominant grasses, including Aster ericoides and Grindelia squarrosa. Locations where this community was found include Altario, Birch Lake, Capt. Eyre Lake, Sand Plain North, Irma-Jarrow Lakes, Kenilworth Lake, Neutral Hills South, Old Channel Lake Springs, and Ribstone South. Wallis (1990) described the Spartina gracilis - Agropyron smithii community type as a variant of the Distichlis stricta - Agropyron smithii community occurring on open sandy sites.

\section{$\underline{\text { Koeleria cristata - Agropyron smithii Herbaceous Vegetation }}$}

This community occurs on drier upland and exposed sites in the Grand Prairie - Beaverlodge area within the Peace River Parkland Subregion (Stacey 1927). It also occurs in the Rumsey Ecological Reserve, situated within Central Parkland Subregion, on level areas and lower slopes with xeric Brown and Black Solonetzic soils (Wroe 1971; Fehr 1982). Koeleria cristata, Agropyron albicans and A. smithii are the dominant grasses in the Grand Prairie - Beaverlodge area, accompanied by other grass and forb species such as Agrostis hiemalis, Poa interior, Stipa columbiana, S. spartea, Elymus innovatus, Agropyron tenerum, A. inerme, A. caninum, and A. albicans. Agropyron inerme, and $A$. albicans are more prominent species within the limited range of Niobe. In the Rumsey Ecological Reserve, Koeleria cristata (59\%), Agropyron smithii (46\%) Selaginella densa (59\%), Carex eleocharis (35\%), Poa secunda (15\%), Grindelia squarrosa $(15 \%)$ and Distichlis stricta $(8 \%)$ are the most abundant species. Some additional species include Achillea millefolium, Antennaria nitida, Artemisia frigida, Bouteloua gracilis and Hordeum jubatum.

\subsubsection{Agropyron albicans group}

Agropyron albicans - Artemisia frigida community type

This community type occurs on subxeric, west to southeast facing, active slopes within the Montane and Subalpine subregions. Some of the characteristic species include Prunus virginiana, Koeleria macrantha and Galium boreale (Allen 2000). This community type has no 
written documentation, and in agreement with the ANHIC personnel, no characterization abstract is prepared for it at present time.

\subsection{Assignment of Preliminary Provincial Ranking and Identification of Knowledge Gaps}

The amount and the quality of available information used to describe proposed Agropyron community types and assign provincial rankings varied from community to community. As a result, some community types were difficult to rank at present due to incomplete or insufficient data. For those that are ranked, more information is needed for confirmation of the proposed rank and to fill in the gaps in the Community Characterization Abstracts. Following are the suggested provincial ranks for each of the proposed Agropyron community types, accompanied by an explanation of information gaps and suggested strategies to address these gaps.

\section{Agropyron spicatum Herbaceous Vegetation}

This community is considered provincially rare (ranked SU) in the preliminary plant community tracking list (Allen 2000). Its provincial ranking should be changed to S1 because it is restricted to Waterton Lakes National Park, with only 6 known sites. All known sites should be revisited and the size and condition of each occurrence documented.

\section{Agropyron spicatum - Festuca campestris Herbaceous Vegetation}

This community type is considered provincially rare (ranked SU) (Allen 2000). Provincial status should be changed to $\mathrm{S} 1$ because this community is restricted to the very southwestern corner of Alberta (area just north of the Waterton Lakes National Park). Cluster analysis of the combined ESIS database and the additional plots from Waterton Lakes National Park indicated that most of the plots from Waterton Lakes National Park used by Achuff et al. (1997) to describe Agropyron spicatum - Festuca scabrella community type belong either to the Festuca scabrella community type or to the Agropyron spicatum community type. Plots indicated by cluster analysis to belong to Agropyron spicatum - Festuca campestris community type are located just north of the Waterton Lakes National Park. It seems that the inclusion of these Waterton plots into the Agropyron spicatum - Festuca scabrella community type resulted from the relatively small scale $(1: 20,000)$ at which the ecological land classification was done (see details in Achuff et al. 1997) (Peter Achuff - personal communications).All sites from Waterton Lakes National Park described as Agropyron spicatum - Festuca scabrella in Achuff et al. (1997) should be revisited to clarify their classification .

\section{Agropyron spicatum - Elymus innovatus - Aster conspicuous Herbaceous Vegetation}

This community type is considered provincially rare (ranked SU) (Allen 2000). Rank should be changed to S1 because of its small size and restricted distribution (only on slopes above Hillsdale Meadow in Banff National Park). All known sites should be revisited and the actual size of each occurrence documented. 


\section{Agropyron spicatum - Carex obtusata Herbaceous Vegetation}

This community type is probably restricted to southwestern Alberta, just north of Waterton Lakes National Park, therefore it should be placed on the provincial tracking list and ranked S1.

\section{Agropyron spicatum - Festuca idahoensis Herbaceous Vegetation}

Insufficient information exists for this community type. The classification is based on the cluster analysis of only three ESIS plots. No other provincial ranking but SU is possible until more information is collected. Known sites should be revisited and more information collected to confirm the validity of the classification for this community type.

\section{Agropyron trachycaulum Herbaceous Vegetation}

This community seems to be widespread occurring within Parkland (Peace River Parkland Subregion), Grassland (Dry Mixedgrass Subregion), Boreal Forest (Dry Mixedwood), and possibly Rocky Mountain (Montane Subregion) and Foothills (Upper Foothills Subregion) Natural Regions. although the exact number of occurrences is not known, this community may be ranked S3.

\section{Agropyron trachycaulum - Stipa spp. Herbaceous Vegetation}

Western Rangeland Consultants (1999) indicated that the majority of the grasslands northeast of Grande Prairie have been lost within the last 50 years due to farming practices. In addition, stands in Wood Buffalo National Park are very small and threatened from tree and shrub encroachment. Redmann and Schwarz 1986 compared grasslands from the Peace Point area in Wood Buffalo National Park with those described for the Peace River region by Moss (1952). They concluded that the Peace River sites are closer in species composition to the Stipa faciation than to the Agropyron - Stipa faciation, and explained it by the presence of drier, non-solonetzic soils characterizing the Peace Point grasslands. Further study is needed to confirm that the Agropyron trachycaulum and Stipa spp. dominated communities from Wood Buffalo National Park and the Peace River region represent the same community type, and to estimate their sizes and the potential threats to the communities. The Agropyron trachycaulum - Stipa spp. Herbaceous Vegetation community type is currently on community tracking list as Carex spp. Danthonia intermedia - Stipa curtiseta Herbaceous Vegetation community, and ranked S1.

\section{Agropyron trachycaulum - Carex atherodes Herbaceous Vegetation}

Because of its limited distribution (restricted to an area north of Fort Vermilion and east of the Caribou River, near the base of the Caribou Mountains within the Peace River Parkland Subregion) this community type is currently considered provincially rare (ranked S1) (Allen 2000). Three plots from the ESIS database clustered together into a "community type" that may be named "Agropyron trachycaulum - Carex spp. community type". However, the species of Carex is not known, and the three sampling plots are not from the Peace River region, but are from the Upper Foothills, Subalpine, and Dry Mixedwood subregions. More information is needed to show if these three plots represent the same community type as the one described in Moss (1952). 
Agropyron trachycaulum - Carex praegracilis - Fragaria virginiana Herbaceous Vegetation

Willoughby and Smith (1999) described this community based on 10 plots. The additional 12 plots from the ESIS database represent the same community type (community \#15 in this report includes 15 plots, of which three were used by Willoughby and Smith (1999) to describe the same community). The additional 13 plots represent communities \# 12 and \# 17 from this report. However, the relationship of these communities to the Agropyron trachycaulum - Carex praegracilis - Fragaria virginiana Herbaceous Vegetation community is not clear. Community \# 12 has a lower cover of Carex praegracilis than expected, and Fragaria virginiana has low cover in plots within community \# 17. However, Carex praegracilis and Fragaria virginiana are characteristic species for all three communities. It should also be noted that plots from community \#17 occur in Subalpine Subregion, and plots from community \#12 occupy sites within the Subalpine, Montane, Upper Foothills and Central Parkland subregions. More information is needed to understand the relationship between the Agropyron trachycaulum Carex praegracilis - Fragaria virginiana community type and the communities represented by clusters \#12 and \#17 from the ESIS database analysis. Therefore, provincial rank S2S3 is proposed until more information is collected on this community type.

\section{Agropyron trachycaulum - Distichlis stricta Herbaceous Vegetation}

This community has extremely limited in distribution and size (a few small areas in Wood Buffalo National Park), and is threatened by the aspen and shrub encroachment. Therefore, it should be placed on the provincial tracking list and ranked S1. Known sites should be revisited to assess the actual size of occurrences.

\section{Agropyron trachycaulum - Koeleria cristata Herbaceous Vegetation}

This community has limited distribution and size (most likely only a few small areas in Wood Buffalo National Park) and is threatened by aspen and shrub encroachment. Art Schwarz (personal communications) suggested that the Agropyron trachycaulum - Koeleria cristata community type from the salt plains as described by Raup (1935) may not exist any longer in Wood Buffalo National Park. The relationship between this community type described by Raup (1935), and community \#4 from this report is not clear. This community should be placed on the provincial tracking list and ranked SU. Further studies are needed to confirm the existence of this community in Wood Buffalo National Park and to examine it's relationship to the Rocky Mountain grasslands from the ESIS database.

Agropyron trachycaulum - Festuca ovina - Poa palustris - Equisetum arvense Herbaceous Vegetation

This community was described in an old report from the Boreal Forest Natural Region in the Shelter Point area near Lake Athabasca. It should be ranked SU until further information is collected on its presence, and the number and size of occurrences. 


\section{Agropyron trachycaulum - Hierochloe odorata Herbaceous Vegetation}

It is not clear at this time whether Agropyron trachycaulum dominated stands and Hierochloe odorata dominated stands mentioned in Fairbarns (1990) can be identified as separate community types, or if they just represent components of the Agropyron trachycaulum Hierochloe odorata community type. Additional detailed study is needed to examine the composition of these communities, especially with regard to the spatial distribution and size of Agropyron trachycaulum and Hierochloe odorata dominated patches. Until further information is available, this community should be placed on the provincial tracking list and ranked SU.

\section{Agropyron trachycaulum - Elymus innovatus - Thalictrum venulosum Herbaceous Vegetation}

Classification of this community type is based solely on the ESIS database analysis. Additional, more detailed study is needed to confirm the actual similarity in vegetation composition between occurrences. Until more information is available this community should be ranked SU.

\section{Poa interior - Agropyron trachycaulum Herbaceous Vegetation}

Classification of this community type was based only on the qualitative data. It should be ranked SU until more information is available.

\section{Hordeum jubatum - Agropyron trachycaulum - Distichlis stricta Herbaceous Vegetation}

Classification of this community type was based only on the qualitative data, therefore it should be ranked SU until more information is available.

\section{Agropyron dasystachyum Herbaceous Vegetation}

This community seems to be found mostly in the Rocky Mountains Region: Kakwa Falls area (study site located ca. $160 \mathrm{~km} \mathrm{~S}$ of Grand Prairie, $50 \mathrm{~km} \mathrm{NW}$ of Grand Cache), Kootenay Plains area, and other sites within the Subalpine and Montane subregions. It also exists within the Dry Mixedgrass Subregion. Its possible presence within the Alpine and Peace River Parkland subregions needs future confirmation. Based on the distributional data and approximate number of occurrences (between 20 and 100), this community type should be ranked S3.

\section{Agropyron dasystachyum - Calamovilfa longifolia Herbaceous Vegetation}

This community type was reported only from the Suffield National Wildlife Area - Grassland Natural Region (Dry Mixedgrass Subregion). No details on the community were provided, therefore, it should be ranked SU until more information is available.

\section{Agropyron dasystachyum - Agropyron smithii Herbaceous Vegetation}

This community seems to be found only in the Milk River Natural Area and the Kennedy Coulee Ecological Reserve, and along the Peace River and Clear River canyons between Bear Canyon and Many Islands. There may be more that 5 but less than 20 occurrences of this community type 
within the province, therefore, it should be placed on the provincial tracking list and ranked S2? until more information on the precise number of occurrences is available.

\section{Agropyron dasystachyum - Koeleria macrantha - Artemisia frigida Herbaceous Vegetation}

This community has been reported from Banff and Jasper National Parks (Rocky Mountains Natural Region - Montane and possibly Subalpine and Alpine subregions), the banks of the Peace, Smoky and Wapiti rivers, and the Silver Valley (Boreal Forest Natural Region - Dry Mixedwood Subregion), and it possibly exists within the Cypress Hills area (Rocky Mountains Natural Region - Montane Subregion). The exact number of sites and their sizes is not known, therefore, this community should be placed on the provincial tracking list ranked S2S3 until more information is available.

\section{Agropyron dasystachyum - Poa pratensis Herbaceous Vegetation}

Classification of this community type was based on only one sampling plot. This community potentially exists and it should be ranked SU until more information is available. The only known location should be revisited and other similar sites investigated for possible occurrences of this community. Because the exotic but naturalized and widespread species, Poa pratensis is a weak codominant in this community type, more information is needed on the ecology of this community to determine whether it should be considered native or non-native for the purposes of identifying biodiversity of communities in Alberta.

\section{Agropyron dasystachyum - Muhlenbergia cuspidata Herbaceous Vegetation}

With the exception of the Grassland Research Area at Cadillac, Saskatchewan, Coupland (1950) did not provide the precise location of sites inhabited by this community type. However, the author indicated that this community type occurs "throughout the area of rolling topography", with which the Bouteloua - Stipa faciation is associated, indicating that the Agropyron Muhlenbergia community type may exist in Alberta. Therefore, this community type should be placed on the provincial tracking list and ranked SP until further information is collected.

\section{Agropyron dasystachyum - Artemisia dracunculus - Artemisia frigida Herbaceous Vegetation}

This community type seems to be restricted to sites in the Kootenay Plains study area. Therefore, it should be placed on the provincial tracking list and ranked S1.

\section{Agropyron dasystachyum - Antennaria nitida Herbaceous Vegetation}

This community type seems to be restricted to sites in the Kootenay Plains study area. Therefore, it should be placed on the provincial tracking list and ranked S1.

\section{Agropyron dasystachyum - Stipa comata Herbaceous Vegetation}

Besides one documented site in the Kootenay plains area, and one in the Milk River Natural Area, the precise number and location of sites occupied by this community within Alberta is 
unknown. Until further sites are documented, this community should be placed on the provincial tracking list and ranked S1S2.

Agropyron dasystachyum - Agropyron subsecundum Herbaceous Vegetation

This community type occurs in only one area on a river terrace in the Kootenay Plains area; it should be placed on the community tracking list and ranked S1

Juniperus horizontalis - Arctostaphylos uva-ursi / Agropyron dasystachyum - Elymus innovatus Dwarf Shrub Herbaceous Vegetation

Classification of this community type was based solely on the ESIS database analysis. Additional, more detailed study is needed to confirm the similarity in vegetation composition between plots and the validity of the classification for this community type. Until further information is available, this community should be ranked SU.

\section{Agropyron smithii Herbaceous Vegetation}

Reported from Milk River Natural Area, the Kennedy Creek Ecological Reserve (Grassland Natural Region - Dry Mixedgrass Subregion), and east of Manyberries (Grassland Natural Region - Mixedgrass Subregion). Based on the information on this community type provided by Coupland (1950), Wallis (1976), Brierley et al. (1989), Adams and Moisey (1999), and cluster analysis from this report (community \#51), there may be about 20 individual occurrences. Therefore, this community type should be placed on the provincial tracking list and ranked S2S3 until more information on the location and size of occurrences is available.

\section{Agropyron smithii - Artemisia ludoviciana Herbaceous Vegetation}

This community type was reported from only one site within the Suffield National Wildlife Area (Grassland Natural Region, Dry Mixedgrass Subregion), but it may be more widespread. Therefore, it should be added to the community tracking list and ranked S1S2.

\section{Agropyron smithii - Artemisia frigida Herbaceous Vegetation}

This community type was reported only from the Suffield National Wildlife Area (Grassland Natural Region - Dry Mixedgrass Subregion), but with a number of occurrences. Adams et al. (1997) did not provide any details on the vegetation composition for this community type, therefore, it should be ranked SU and all known sites should be revisited to document the actual vegetation composition.

\section{Agropyron smithii - Artemisia tilesii - Artemisia frigida. Herbaceous Vegetation}

This community type was reported only from areas along the Peace River and Clear River canyons between Bear Canyon and Many Islands (Boreal forest Natural Region - Dry Mixedwood Subregion). Because of its limited distribution and presence of Herriots sage (Artemisia herriotii (Adams 1981) or A. tilesii (Moss 1983)) which is considered rare in Alberta 
(ranked S2) (ANHIC 2001), this community type should be placed on the community tracking list and ranked S1.

\section{Agropyron smithii - Bouteloua gracilis Herbaceous Vegetation}

This community type was reported with certainty only from the Milk River Natural Area (Grassland Natural Region, Dry Mixedgrass Subregion). This community type should be placed on the provincial tracking list and ranked S1 until further information is available about the distribution of this community within the province.

\section{Agropyron smithii - Hordeum jubatum Herbaceous Vegetation}

This community type was reported only from the Neutral Hills Central site (Grassland Natural Region - Northern Fescue Subregion). It should be placed on the provincial tracking list and ranked S1

\section{Agropyron smithii - Pyrrocoma uniflora Sparse Herbaceous Vegetation}

This community type was reported from only one site within the Kootenay Plains area, at Whirlpool Point (Rocky Mountain Natural Region - Montane Subregion). Pyrrocoma uniflora is ranked S3 in the province and is listed on the Alberta Natural Heritage Information Centre Vascular Plants on the Watch List (ANHIC 2001). This community type should be placed on the provincial tracking list and ranked S1.

\section{Agropyron smithii - Atriplex nuttallii Herbaceous Vegetation}

This community type seems to be restricted to the Mannyberries badlands (Grassland Natural Region - Mixedgrass Subregion), therefore it should be placed on the provincial tracking list and ranked S1.

\section{Agropyron smithii - Stipa comata - Bouteloua gracilis Herbaceous Vegetation}

This community type was reported from the western part of the Milk River Natural Area and from the Suffield National Wildlife Area (Grassland Natural Region - Dry Mixedgrass Subregion). It possibly exist in other places within the Dry Mixedgrass and Mixedgrass Subregions, and within the Rocky Mountain Natural Region (Cypress Hills Montane Subregion) in the southwestern corner of Alberta (this report). Based on the estimated number of occurrences (about 20) this community should be placed on the tracking list and ranked S2S3.

\section{Carex stenophylla - Agropyron smithii Herbaceous Vegetation}

This community type was reported only from the Suffield National Wildlife Area (Grassland Natural Region - Dry Grassland Subregion) (Adams et al. 1997). It possibly also exists northwest of Fairview (Boreal Forest - Dry Mixedwood Subregion)(this report), but this location needs to be confirmed. This community should be placed on the provincial community tracking list and ranked S1 until further information is available. 


\section{Distichlis stricta - Agropyron smithii Herbaceous Vegetation}

This community type was described for Altario, Birch Lake, Capt. Eyre Lake Sand Plain North, Irma-Jarrow Lakes, Kenilworth Lake, Neutral Hills South, Old Channel Lake Springs, and Ribstone South. Its existence is also possible in numerous other small areas characterized by solonetzic soils in the Parkland and Grassland Natural Regions (Ksenija Vujnovic - personal observations). Until more information is available on the extent of the distribution of this community type, it should be placed on the provincial community tracking list and ranked S2.

\section{Koeleria cristata - Agropyron smithii Herbaceous Vegetation}

This community seems to be limited to the Grande Prairie - Beaverlodge area (Parkland Natural Region - Peace River Parkland Subregion) and Rumsey Ecological Reserve (Parkland Natural Region - Central Parkland Subregion). Based on the estimated number of occurrences (between 5 and 20) it should be placed on the community tracking list and ranked S1S2.

\subsection{Conclusions}

The preliminary classification of Agropyron community types based on the literature review and the cluster analysis of the ESIS database identified 39 potential Agropyron dominated/codominated community types within Alberta. These were grouped into four Herbaceous Alliances: Agropyron spicatum, A. trachycaulum, A. dasystachyum and A. smithii. All proposed Agropyron community types were described and assigned a suggested preliminary provincial ranking. Cross-reference tables were created to present all the synonyms found in the literature and explain their relationship to proposed community types. Knowledge gaps were identified and strategies to address these gaps were provided. Community characterization abstracts were also compiled for each of the proposed community types. The information in this report can be used to update the preliminary community tracking list by including new community types, as well as by changing ranking for those communities that are currently on the list. It can also be used to decide which community types need further studies and to prioritize these studies. Finally, this preliminary classification of Agropyron communities in Alberta is a part of a larger project to classify and describe the vegetation of Alberta within a North American context. 


\section{LITERATURE CITED}

Achuff, L. Peter, Conservation Biologist, Jasper National Park, Box 10, Jasper, AB, T0E 1E0; tel (780) 852-6197; fax (780) 852-4775; email: peter_achuff@pch.gc.ca

Achuff, P. L., R. L. McNeil, M. L. Coleman. 1997. Ecological Land Classification of Waterton Lakes National Park, Alberta - Soil and vegetation resources. Report prepared by Waterton lakes National Park, Waterton park and Contract Pedology Services Ltd., Ledbridge, $\mathrm{AB}$

Adams, B. 1981. Range Ecology and the impact of livestock grazing on the Peace River Slopes, Alberta. Public Lands Division,

Adams, g. D., G. C. Trottier, W. L. Strong, I. D. MacDonald, S. J. Barry, P. G. Gregoire, G. W. Babish and G. Weiss. 1997. Vegetation component report: Canadian Forces Base Suffield national Wildlife area - Wildlife Inventory. Report prepared for the Canadian Wildlife service, Environment Canada, Edmonton, AB.

Adams, B and D. Moisey. 1999. Analysis of vegetation and soil monitoring records for Milk River Natural Area and Kennedy Creek Ecological Reserve. 1999. Public Lands, Alberta Agriculture, Food and Rural Development, Lethbridge

Alberta Environmental Protection (AEP). 1993. Alberta plants and fungi - master species list and species group checklist. Publ. No.; Ref. 75.Edmonton, AB.

Alberta Environmental Protection (AEP). 1994. Ecological land survey site description manual. Report prepared by the Canadian Forest Service and Alberta Land and Forest Services, Edmonton, $\mathrm{AB}$.

Allen J. Lorna, Biologist, Recreation and Protected Areas Division, Natural Heritage Planning and valuation Branch, $2^{\text {nd }}$ Floor, Oxbridge Place, 9820-106 Street, Edmonton, AB, T5K 2J6; tel: (780) 427-5209; email: lorna.allen@gov.ab.ca.

Allen, L. 2000. Alberta Natural Heritage Information Centre Preliminary Plant Community Tracking List. Alberta Environment, Edmonton, $\mathrm{AB}$

Anderson, M., P. Bougeron, M. T. Bryer, R. Crawford, L. Engelking, D. Faber-Langendoen, M. Gallyoun, K. Goodin, D. H. Grossman, S. Landaal, K. Metzler, K. D. Patterson, M. Pyne, M. Reid, L. Sneddon and A. S. Weakley. 1998. International classification of ecological communities: terrestrial vegetation of the United States, Volume II, The National Vegetation Classification System: list of types. The Nature Conservancy, Arlington, VA.

Alberta Natural Heritage Information Centre (ANHIC). 2001. Alberta Natural Heritage Information Centre Element Tracking Lists. http://www.gov.ab.ca/env/parks/anhic/trackanh.html 
Barbour, M. G., J. H. Burk, and W. D. Pitts. 1980. Terrestrial plant ecology. The Benjamin Cummings Publishing Company, Menlo Park, California, USA.

Beckingham, J.D., I. G. W. Corns and J. H. Archibald. 1996. Field Guide to Ecosites of WestCentral Alberta. Canadian Forest Service Special Report No.9, Northern Forestry Centre, Edmonton, $\mathrm{AB}$.

Bloom, S. A. 1981. Similarity indices in community studies: potential pitfalls. Marine Ecology Progress Series 5:125-128.

Bonan, G. B. 1989. A computer model of the solar radiation, soil moisture and soil thermal regime in Boreal forests. Ecological Modeling 45:275-306.

Bourgeron, P. S and L. D. Engelking. 1994. A preliminary vegetation classification of the Western United States. Unpublished report prepared by the Wetern Heritage task Force for The Nature Conservancy, Boulder, CO.

Braun-Blanquet, J. 1965. Plant sociology: the study of plant communities. English translation of Pflanzensoziologie revised and edited by G. D. Fuller and H. S. Conard. Hafner Publishing Co., London, England.

Bresler, E., B. L. McNeal, and D. L. Carter. 1982. Saline and sodic soils: principles-dynamicsmodeling. Springer-Verlag, New York, New York, USA.

Brierley, D., D. Bradshaw, and D. Downing. 1989. Milk River Natural Area - biophysical inventory - southern uplands. Report prepared for Alberta Forestry, Lands and Wildlife, land information services division, resource Information Branch, Edmonton, AB.

Cairns, R. R., R. A. Milne, and W. E. Bowser. 1962. A nutrient disorder in barley seedlings grown on an alkali solonetzic soil. Canadian Journal of Soil Science 42:1-6.

Cairns, R. R., and I. Szabolcs. 1973. Effect of sodium sulfate and sodium carbonate solutions on chemical and physical properties of a chernozem soil. Canadian Journal of Soil Science 53:399-403.

Canadian Forest Service and Alberta Land and Forest Service (CFS-LFS). 1994. Ecological land survey site description manual. Canada/Alberta Partnership Agreement in Forestry publications.

Comer P., L. Allen, Steve Cooper, D. Faber-Langendoen, and G. Jones. 1999. Selected shrubland and grassland communities of the Northern Great Plains. A Report to Nebraska National Forest.

Corns, I. G. W. and P. L. Achuff. 1982. Vegetation type descriptions in W. D. Holland and G. M. Coen (eds.). Ecological (Biophysical) Land Classification of Banff and Jasper National Parks. Alberta Institute of Pedology, Publication No. SS-82-44. 
Coupland, R. T. 1950. Ecology of mixed prairie in Canada. Ecological Monographs 20: 271315

Coupland, R. T. 1961. A reconstruction of grassland classification in the northern Great Plains of North America. Journal of Ecology 49:135-167.

Coupland, R. T. 1973. A theme study of natural grasslands in western Canada. A Report to National and Historic Parks Branch Canada, Department of Indian affairs and Northern Development.

Daubenmire, R. 1970. Steppe vegetation of Washington. Washington Agriculture Experimental Station Technical Bulletin No. 62.

Dodd, J. D. and R. T. Coupland. 1966. Vegetation of saline Areas in Saskatchewan. Ecology 47: 958-967

Eastern slopes rangeland seeds ltd. 1995. A five year summary of the range inventory and selected species monitoring on the Milk River Natural Area (1991 - 1995). Report for the Milk River Management Committee.

Fairbarns, M. 1990. The Salt Meadows of Northwestern Alberta: A Reconnaissance Biophysical Inventory. Alberta Forestry, Lands and Wildlife.

Faber-Langendoen, J. Drake, G. Jones, D. Lenz, P. Lesica and S. Rolfsmeier. 1997. Rare plant communities of the Northern Great Plains. A report to the Nebraska National Forest by the Nature Conservancy.

Fehr, A. W. 1982. The Candidate Rumsey Ecological Reserve: A Biophysical Inventory. Alberta Energy and Natural Resources.

Grime, J. P. 1979. Plant strategies and vegetation processes. John Wiley and Sons, Great Britain.

Grossman, D. H., K. L. Goodin and C. L. Reuss (editors). 1994. Rare plant communities of the conterminous United States - an initial survey. The Nature Conservancy, Arlington, VA.

Grossman, D. H., D. Faber-Langendoen, A. S. Weakley, M. Anderson, P. Bougeron, R. Crawford, K. Goodin, S. Landaal, K. Metzler, K. D. Patterson, M. Pyne, M. Reid and L. Sneddon. 1998. International classification of ecological communities: terrestrial vegetation of the United States, Volume I, The National Vegetation Classification System: development, status and applications. The Nature Conservancy, Arlington, VA.

Harper, J. L. 1977. Population biology of plants. Academic press, New York, New York, USA. 
Heidal, B., S. V. Cooper and C. Jean. 2000. Plant species of special concern and plant associations of Sheridan County, Montana. Report to the U.S. Fish and Wildlife Service. Montana Natural Heritage Program, Helena, Montana.

Hill, M. O. 1979. TWINSPAN - A FORTRAN program for arranging multivariate data in an ordered two-way table by classification of the individuals and attributes. Cornell University, Ithaca, New York.

Hill, M. O. and H. G. Gauch. 1973. Diversity and evenness: a unifying notation and its consequences. Ecology 54:427-432.

Hill, M. O. and H. G. Gauch. 1980. Detrended correspondence analysis, an improved ordination technique. Vegetatio 42: 47-58

Hobbs, N. T. 1996. Modification of ecosystems by ungulates. Journal of Wildlife Management 60:695-713.

Jaques, D. \& P. Van Eck. 1979. Biophysical Features and Recommendations for Recreational Development in the Kakwa Falls Region, Alberta. Kananaskis Center for Environmental Research, $\mathrm{U}$ of $\mathrm{C}$.

Johnston, A., S. Smoliak, L. M. Forbes, and J. A. Campbell. 1967. Alberta Range Management Guide. Albert department of Agriculture, Lands and Forests. Publication No. 134/14

Jongman, R. H. G., C. J. F. ter Braak, and O. F. van Tongeren (editors). 1987. Data analysis in community ecology. Pudoc Wageningen, Netherlands.

Kartesz, JT. 1999. A synonymized checklist and atlas with biological attributes for the vascular flora of the United States, Canada, and Greenland. 1st edition. In: Meacham, CA. Synthesis of the north American flora [computer program]. Version 1.0. North Carolina Botanical Garden, Chapel Hill ( NC).

Keddy, P. A. 1991. Working with heterogeneity: an operator's guide to environmental gradients. Pages181-201 in Kolasa, J., and S. T. A. Pickett, editors. Ecological heterogeneity. Spring-Verlag New York, Inc., New York, USA.

Kent, M., and P. Coker. 1992. Vegetation description and analysis: a practical approach. CRS Press, London, Belhaven Press.

Lane, C. T., M. G., Willoughby, M. J. Alexander and the Rangeland Health Assessment Project and Forest Rangeland Action Plan. 2000. Guide to range plant community types and carrying capacity for the Lower Foothills Subregion of Alberta - third approximation. Alberta Environment, Land and Forest Service and Alberta Agriculture, Food and Rural Development, Public Lands Division, Edmonton, AB.

Langevin, A. 1973. A preliminary paper on the Kleskun Hills Area. Report prepared by Environmental Research Station, Parks Planning, Alberta. 
Legendre, L., and P. Legendre. 1983. Numerical ecology. Elsevier, Amsterdam.

Ministry of Environment, Lands and Parks, and Ministry of Forests (MOE and MOF). 1998. Field Manual for describing terrestrial Ecosystems. British Columbia

Moss, E. H. 1944. The prairie and associated vegetation of southwestern Alberta. Canadian Journal of Research 22:11-31.

Moss, E. H. 1952. Grasslands of the Peace River Region, western Canada. Canadian Journal of Botany 30: 98-104

Moss, E. H. 1953. Marsh and bog vegetation in northwestern Alberta. Canadian Journal of Botany 31: 448-470.

Moss, E. H. 1955. The vegetation of Alberta. The Botanical Review, Vol. XXI, No. 9

Moss, E. H. 1983. The flora of Alberta. (2nd edition). Revised by J. G. Packer. University of Toronto Press, Toronto, ON.

NatureServe: An online encyclopedia of life [web application]. 2000. Version 1.0. Arlington (VA): Association for Biodiversity Information. Available: http://www.natureserve.org

Pavlick, L. E., and J. Looman. 1984. Taxonomy and nomenclature of rough fescue, Festuca altaica, $F$. campestris ( $F$. scabrella var. major), and $F$. hallii, in Canada and adjacent part of United States. Canadian Journal of Botany 62:1739-1749.

Raup, L.C. 1928. A survey of the vegetation of Shelter Point, Athabasca Lake. Doctorate thesis, University of Pittsburgh.

Raup, H. M. 1935. Botanical Investigations in Wood Buffalo Park. Bulletin No. 74, Biological Series, No. 20. Canada Dept. of Mines and National Museum of Canada. Ottawa, Ontario.

Redmann R. E. and A. G. Schwarz. 1986. Dry grassland plant communities in Wood Buffalo National park, Alberta. Canadian Field-Naturalist 100: 526-532.

Rintoul, J. 1985. Silver Valley: Biophysical Resource Analysis. Alberta Forestry, Lands and Wildlife.

Schneider, R. E., D. Faber-Langendoen, R. C. Crawford and A. S. Weakley. 1997. The status of biodiversity in the Great Plains: great Planes vegetation classification. Supplemental document 1, In: W.R. Ostlie, R. E. Schneider, J. M. Aldrich, T. M. Faust, R. L. B. McKim and S. J. Chaplin, The Status of Biodiversity in the Great Plains. The Nature Conservancy, Arlington, VA. 
Schwarz, Arthur, Rm 855, General Service Building, Department of Renewable Resources, University of Alberta; email: arthur.schwarz@ualberta.ca.

Schwarz, A. G. 1994. Inventory of dry grasslands and associated vegetation in Wood Buffalo National Park. Report prepared for Parks Canada, Wood Buffalo National Park, Fort Smith.

Schwarz, A. G. and R. W. Wein. 1997. Threatened dry grasslands in the continental boreal forests of Wood Buffalo National Park. Canadian journal of Botany 75: 1363-1370

Smith, W. 1993. An Assessment of Short-horned Lizard Habitat and Use Manyberries Badland, Alberta. Alberta Fish and Wildlife, Lethbridge, AB.

Stacey, E. C. 1927. Ecological studies on the native grasses of the Grande Prairie-Beaverlodge district. M.Sc. thesis, Department of Field Husbandry, University of Alberta, Edmonton, Alberta.

Steinauer, E. M., and S. L. Collins. 1995. Effect of urine deposition on small-scale patch structure in prairie vegetation. Ecology 76:1195-1205.

ter Braak, C. J. F. 1987. The analysis of vegetation-environmental relationships by canonical correspondence analysis. Vegetatio 69:69-77.

ter Braak, C. J. F. 1988. CANOCO: A FORTRAN program for canonical, community ordination by (partial)(detrended)(canonical) correspondence analysis, principal component analysis and redundancy analysis (Version 2.1). Technical report LWA-88-02. Agricultural Mathematics Group, Wagenien.

Thieret, J. W. 1959. Grassland vegetation near Fort Province, Northwest Territories. The Canadian field-Naturalist 73: 161-167

Timoney, P. T. 1999. Threatened dry grasslands in the continental boreal forest of Wood Buffalo National Park: commentary. Canadian Journal of Botany 77: 913-917

Tisdale, E. W. 1947. The grasslands of the southern interior of British Columbia. Ecology 28: 346-382.

Tisdale, E. W. 1982. Grasslands of western North America: the Pacific Northwest Bunchgrass. Grassland Ecology and Classification: Symposium proceeding June 1982. Ministry of Forests, BC

Toogood, J. A., and R. R. Cairns 1978. Solonetzic soils technology and management. Department of Extension, University of Alberta, Edmonton, Alberta.

Vujnovic, Ksenija, Plant Ecologist, 2608-83 Street, Edmonton, AB, T6K 2Y6; tel: (780) 4668837; email: ksenija@home.com 
Wallis, C. 1976. Milk river canyon resource evaluation. report prepared for planning and design, Alberta recreation, parks, and wildlife, Edmonton, AB.

Wallis, C. A. 1982. An overview of the mixed grasslands of North America. Grassland Ecology and Classification: Symposium proceeding June 1982. Ministry of Forests, BC

Wallis, C. 1990. Reconnaissance survey of saline wetlands and springs in the GrasslandParkland region of Eastern Alberta. World Wildlife Fund, Canada

Wallis, C. and C. Wershler. 1981. Kootenay Plains Flora and Grassland Vegetation Assessment - 1981. Alberta Energy and Natural Resources.

Weaver, J. E., and Roland. 1952. Effect of excessive natural mulch on development, yield, and structure of native grassland. Botanical Gazette 114:1-19.

Wells E. Russell, Landscape Ecologist, Resource Data Division, Alberta Environment, 12th Floor, Oxbridge Place, 9820 - 106 street, Edmonton; tel: (780) 422-0139; email: Russell.Walls@gov.ab.ca

Western Rangeland Consultants Inc. (with the assistance of Beulah Tec Limited). 1999. Mitigation measures and future recommendations for rare native grasslands on the Cochrane property and three other adjacent to Highway 43, near Grande Prairie, Alberta. Report prepared for Planning and Technical Services Division, Planning Services Branch, Alberta Transportation and Utilities, Edmonton, AB.

Wheeler, G. H. 1976. Some grasslands and shrubland communities in the parklands of central Alberta. M.Sc. thesis, Department of Plant Science, University of Alberta, Edmonton, Alberta.

Whittaker, R. H. 1967. Gradient analysis of vegetation. Biological Review 42:207-264

Whittaker, R. H. 1978. Ordination of plant communities. Dr. W. Junk Publishers, The Hague, Boston.

Wilkinson, K. 1981. Remnant and early settlement prairies and solonetzic soils in the Peace River District. M.Sc. thesis, Department of Biology, University of Calgary, Calgary, Alberta.

Willoughby M. G. 1999. Range plant community types and carrying capacity for the Subalpine and Alpine Subregions - first approximation. Environmental protection, Land and Forest Service, Edmonton, AB. 
Willoughby, M. G., M. J. Alexander and K. M. Sundquist. 1998. Range plant community types and carrying capacity for the Montane Subregion of Alberta - third approximation. Environmental Protection, Lands and Forest Services, Edmonton, AB.

Willoughby, M. G. and D. Smith. 1999. Range plant community types and carrying capacity for the Upper Foothills Subregion - third approximation. Environmental Protection, Land and Forest Service, Edmonton, AB.

Willoughby M. G. and the Rangeland Health Assessment Project and Forest Rangeland Action Plan. 2000. Guide to range plant community types and carrying capacity for the Dry and Central Mixedwood Subregions in Alberta - third approximation. Alberta Environment, Land and Forest Service and Alberta Agriculture, Food and Rural Development, Public Lands Division, Edmonton, AB.

Wroe, R. A. 1971. Synecology of a Festuca scabrella Torr. grassland. Ph.D. thesis, Department of Plant Science, University of Alberta, Edmonton, Alberta.

Zar, J. H. 1984. Biostatistical analysis. Prentice Hall, Englewood Cliffs, New Jersey, USA. 


\section{APPENDIX 1}

List of Species Assigned to the Dwarf Shrub Layer 

Appendix 1. List of species assigned to the dwarf shrub layer

\section{Species Latin name}

Arctostaphylos rubra

Arctostaphylos uva-ursi

Atriplex nuttallii

Berberis repens

Dryas drummondii

Dryas octopetala

Empetrum nigrum

Eriogonum umbellatum

Juniperus horizontalis

Linnaea borealis

Penstemon fruticosus

Phyllodoce glanduliflora

Rosa arkansana

Rubus arcticus

Rubus pubescens

Salix reticulata

Sibbaldia procumbens

Sphaeralcea coccinea

Spiraea betulifolia

Vaccinium caespitosum

Vaccinium myrtillus

Vaccinium scoparium 



\section{APPENDIX 2 \\ Detailed Description of Fields in the Community Characterization Abstract}


I

।

,

I

,

,

,

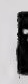

I

I

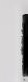

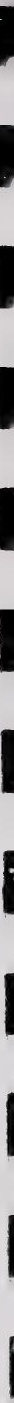


Appendix 2: TERRESTRIAI COMMTNTY CHARACTERZATION ABSTRACT SUB-NMON:I (CCAS) - DRAFT DESIG.N STRLCTCRE - JANUARY 1995

$\underline{1}$

NOTE: This document is a draft of the design for the terrestrial communty characterization abstact: global for the BCD system. It is meant only as a training tool and should not be confused with the wortprocessing version of this database (September 1992) which is currenty th use. Drfferences among these two designs will be rectified at the time the databases become available in the BCD system.

KEY:

Fields with no designated field type are single value

mv-multivalue field

amv=associated multivalue field

xx=text field

s=symbolic field: Acronyms in the left margins identify the flles from wivic s; moolic atelis are translated.

Field Name:

1.DENTIFIERS

SEL.SUTMLARY

ET SNAME (s)

ET SCOMNAME (s)

2. CLASSIFICATION

ET SYSTEM (s)

ET CLASS (s)

ET SLBCLASS(s)

ET GROUP(s)
Bret Desmorion:

A one paragraph abstart for the Conmen Elemee:

described in this reoord

Sub-uatonai Elemeut name. May be te same as SCONALAE

Sub-natonal Element sommon name. May be the same as S.AVE

Vame for System $=$ which Elemect is located TERRESTRIAL AQUATIC, SUBTERRALEAT

Physiognouic class in filch the elemed is. Based of

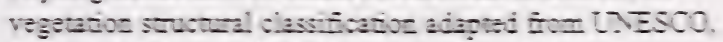
1973 and Drisoll 19:4. Deterned arge'y $\%$ Ifeform height and persect cover of each

Physiogonon subclass = nich the elemect is. Based on

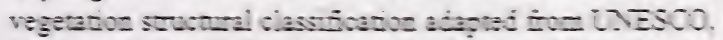
1973 and Drscoll 1954. Deternmed largely by gredon=m leaf phezology for outnondes do minated by footy oorer

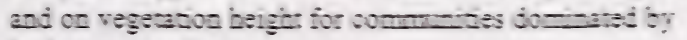
berbaceous cover.

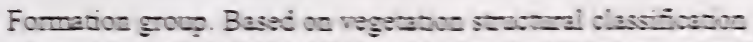

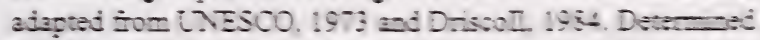
largely or a combuacun of cimate, lear morpiology, and leat poenology. 
ET FORMATION (s)

ET ALLIANCE (s)

CONFIDENCE.LEVEL

SSIMILAR.COMMUNITIES (txt)

3. RELATED NOMENCLATURE

SOTHER.NAMES (amv)

SOTHER.NAMES.RELATION (amv)

SOTHER.NAMES.RELATION.NOTE (amv) SNAMES.COM (txt)

\section{DISTRIBUTION}

EGR SRANGE (s)

EGR SRANGECOM (s)

SDISTRIBUTION.COM (txt)

\section{ENVIRONMENTAL FACTORS}

SMINELEV

SMAXELEV

SLANDFORM (mv)
Formation based on vegetation structural classification adapted from UNESCO, 1973 and Driscoll, 1984. Based on broadly defined environmental factors which are associated with structural differences in the vegetation and additional structural descriptors such as crown shape and lifeform of the dominant lower stratum

Name of alliance in which the element fits. Alliances are groups of elements sharing one or more diagnostic species which, as a rule, are found in the uppermost strata of the vegetation.

Indication of the level of confidence in the type.

List of closely related or apparently similar communities to the type at hand, and comments on how they differ.

Any other names used by other State systems or agencies. Specify the source and provide reference if available.

Indication of the relationship of the SOTHER.NAMES to the type at hand.

Brief description of the relationship to the SNAME.

Summary of related names used for the Element within the state. Also comments on the relationship of these other types to the Element.

Code indicating the estimated present size of the Elements range.

Description of the Element's present and historic range within the state. Describe the relationship of original to current range. Comment on shifting boundaries of the range and change of the extent of the occurrence of the community within the range.

Summary of the distribution of the Element, across state physiographic provinces, counties, ecoregions, watersheds, EPAEMAP hexagons, local jurisdictions, and other state distribution information not covered in the above list.

Minimum elevation at which Community Element occurs within the state.

Maximum elevation at which Community Element occurs within the state.

Landform(s) on which State Element is generally located. 
STOPO.POSITION (mv)

SSLOPE (mv)

SASPECT (mv)

SGEOLOGY.COM (txt)

SSOIL.TYPE (mv)

SSOIL.MOISTURE (mv)

SSOIL.COM (txt)

SHYDRO.INFLUENCE (txt)

SSEASONAL.VAR (txt)

SKEY.ENVIRO.FACTORS (txt)

SENVIRO.COM (txt)

\section{BIOLOGICAL AND STRUCTURAL DESCRIPTION}

6a. VEGETATION

SSTRATA.LIFEFORM (amv)

SPCT.COVER (amv)

SHEIGHT (amv)

SMOST.ABUND.SPP (amv)

SUNVEGETATED.SURFACE (amv)

SUNVEGETATED.SURFACE.COVER (amv)
Topographic position(s) of the State Element on the landscape.

Range of slopes on which State Element occurs.

Range of aspects over which State Element occurs.

Comments on geologic substrate and other important geologic features on which the State Element generally occurs.

Soil type(s) based on any level of taxonomy available: Soil survey map unit, series, great group, etc. as detailed as existing information allows.

The amount of water available to plants. Based on soil drainage, soil structure and texture, and climate.

Information on soil properties. Include information on how soil information was collected, a description of soil texture, stoniness, root penetration, notes on horizon depths, mottling, $\mathrm{pH}$ etc. Comment on the level of taxonomy of soil listed in SOILTYPE field.

Comments on hydrologic influences on the community including: zonation reflecting water level fluctuations, tidally influenced, permanent or temporary, hydrologic seasonality, standing water, etc.

Description of important seasonal influences/variations.

Comments on important environmental determinants of the biological composition or structure of this community and/or its subtypes within the state.

Summary of environmental conditions associated with the Element within the state. Include information on topographic position, landform, slope, aspect, geological substrate, soil textures and moisture, hydrologic influences, and climate, and any other important environmental factors not listed above.

Layers of vegetation occurring within the State Element.

Percent cover of each layer.

Height of each layer.

Most abundant (in terms of percent cover) plant species in each layer. Use Latin names and a comma as a delimiter.

Description of unvegetated surface.

Percent cover of substrate. 
SCONSTANT.SPP (mv)

SCHARACTERISTIC.SPP (mv)

SVEGETATION.COM (txt)

6b. OTHER SPECIES

SHIGH.RANK.SPP (mv)

SFAUNA.COM (txt)

SOTHER.SPP.COM (txt)

6c. VARIABILITY

SSPP.COMP.VAR (txt)

SPHYSIOG.VAR (txt)

SSUBTYPES (txt)

SVARIABILITY.COM (txt)

7. DYNAMIC PROCESSES

SNAT.DISTURBANCE (txt)

SSUCCESS.STATUS

SSUCCESS.DYNAM.COM (txt)
List of plant species likely to be found in every occurrence of the Element, but that can also be found in other communities.

List of key plant species which occur only in this community type in the state, but may not necessarily be found in every occurrence of the type.

Summary description of the leaf type and phenology, physiognomy and plant species composition of the Element. Include a list of strata present, height and percent cover of each strata, most abundant plant species (in terms of percent cover) in each layer as well as characteristic and constant species associated with the Element and any other relevant vegetation features not listed above.

Names of global and state high ranking plant or animal species that are expected to be found within occurrences of this State Element.

Comments on animals commonly associated with this type.

Summary of other noteworthy species associated with the Element. Include information on high ranking plant and animal species, common fauna, endemics or exotic, or any other noteworthy species commonly associated with the type.

Comments on variability in species composition within and among occurrences.

Comments on structural variation and patterns within and among occurrences.

Comments on subtypes of this Element recognized at the state level.

Summary of the variability in species composition and physiognomy within and among occurrences of the type. Note any subtypes tracked within the state. Also include any other comments on variability not outlined above.

Comments on the type and duration of natural disturbances (on any scale) particular to this Element type.

Successional status.

Summary of natural disturbance regimes, successional status, any temporal dynamics, an age structure, dispersal agents, old growth forest characteristics, etc. include any other comments on succession and dynamics not outlined above. 


\section{SPATIAL RELATIONS}

SSIZE (txt)

SSPATIAL.DISTRIBUTION (txt)

SADJACENT.COMMUNITIES (txt)

SINCLUSION.COMMUNITIES (txt)

SMOSAIC.COM (txt)

SSPATIAL.COM (txt)

\section{STATUS}

ESR SRANK (s)

ESR SREASONS (txt, s)

SEXEMPLARY.EO

SEXEMP.EO.SITENAME

SSTATCOM (txt)

10. MANAGEMENT

$\operatorname{SECONCOM}(\mathrm{txt})$

SMANAGE.COM (txt)

\section{INVENTORY AND SAMPLING \\ PROCEDURES}

SIMAGERY.COM (txt)

\section{Common size of Element occurrences.}

Comments on whether this Element is generally patchy, or often one continuous patch on the landscape.

Name(s) of other community types commonly adjacent to this Element. Comment on their spatial relationships across the landscape.

Name(s) of community types frequently occurring within this Element (i.e. heath bog within an occurrence of mixed coniferous forest).

If the Element represents a complex mosaic of subassociations such as Dune/Swale communities, or zonal coastal plain pond shores, indication of the scale and pattern of the components.

Summary of general size and shape and distribution pattern of the Element across the landscape. Note common adjacent and inclusion communities, or any other spatial relation not outlined above.

State Element rank which characterizes the relative rarity or endangerment of the Element state-wide.

Reason for assigning the State Element Rank.

Element Occurrence Code for the "bests" example of an Element Occurrence of the type within the state or province.

Sitename for the where the exemplary Element Occurrence is located within the state.

Summary and any additional comments on the conservation status of the Element state-wide.

Comments on economic uses of this type. i.e. timber and forest products usage, recreation, flood control, groundwater recharge, any other economically important species, etc.

Summary and additional comments on the management of the community including economically important species or uses, threats to the community, management strategies for exotics, animal usage, restrictions to size/shape for sustainability.
Comments on imagery that is useful for identifying the Element - Can the community be easily distinguished from 
SSAMPLE.STRATEGY (txt)

SINVENTORY.COM (txt)

12. ANALYSIS PROCEDURES AND DATA MANAGEMENT

SANALYSIS.COM (txt)

SANALYSIS.DATA.MANAGE.COM (txt) other communities on imagery? e.g. from adjacent communities and from similar communities; comments on types and scales of useful imagery.

Comments on the best way to sample this community. Describe any unusual sampling procedures that are specific to the type.

Summary and additional comments on the recommended sampling strategy for the community. Include information on the best imagery, overflight, and ground survey methods to be used for the type.

Description of the data and analysis used to determine the type.

Summary of the analysis procedures and data used to determine the type. Include information on the location of the data. If a permanent plot of the type exists within the state, give the location. provide element Occurrence numbers and State names, if available.

Any other comments about this community not covered in the fields above.

\section{REFERENCES}

SA CITATION (amv, s) 


\section{APPENDIX 3 \\ Descriptive Statistics for Species Cover Within Each Cluster (Community)}



Appendix 3. Descriptive statistics (number of plots, range, minimum, maximum, sum, mean, standard deviation and variance) for species cover within each cluster (community) derived from the Furthest Neighbor cluster analysis; to save on space, only statistics for those species with at least $1 \%$ cover are shown (the number of species that are not shown is presented at the end of each cluster).

\section{CLUSTER}

1

\begin{tabular}{|c|c|c|c|c|c|c|c|c|}
\hline & $N$ & Range & Minimum & Maximum & Sum & Mean & Std. Deviation & Variance \\
\hline STIPCOL & 5.0 & 35.0 & 0.0 & 35.0 & 85.0 & 17.0 & 17.5 & 307.5 \\
\hline KOELMAC & 5.0 & 13.0 & 7.0 & 20.0 & 69.0 & 13.8 & 4.8 & 22.7 \\
\hline AGROSPI & 5.0 & 20.0 & 0.0 & 20.0 & 48.0 & 9.6 & 7.6 & 58.3 \\
\hline LUPISER & 5.0 & 15.0 & 0.0 & 15.0 & 26.0 & 5.2 & 6.9 & 47.7 \\
\hline ARTEFRI & 5.0 & 10.0 & 0.0 & 10.0 & 17.0 & 3.4 & 4.2 & 17.3 \\
\hline SELADEN & 5.0 & 15.0 & 0.0 & 15.0 & 16.0 & 3.2 & 6.6 & 43.7 \\
\hline GALIBOR & 5.0 & 8.0 & 0.0 & 8.0 & 14.0 & 2.8 & 3.3 & 10.7 \\
\hline MONAFIS & 5.0 & 10.0 & 0.0 & 10.0 & 12.0 & 2.4 & 4.3 & 18.8 \\
\hline ANTEPAR & 5.0 & 10.0 & 0.0 & 10.0 & 11.0 & 2.2 & 4.4 & 19.2 \\
\hline ACHIMIL & 5.0 & 5.0 & 0.0 & 5.0 & 9.0 & 1.8 & 1.9 & 3.7 \\
\hline LITHRUD & 5.0 & 5.0 & 0.0 & 5.0 & 7.0 & 1.4 & 2.1 & 4.3 \\
\hline CALAPUR & 5.0 & 7.0 & 0.0 & 7.0 & 7.0 & 1.4 & 3.1 & 9.8 \\
\hline HEDYSUL & 5.0 & 5.0 & 0.0 & 5.0 & 6.0 & 1.2 & 2.2 & 4.7 \\
\hline FESTIDA & 5.0 & 5.0 & 0.0 & 5.0 & 6.0 & 1.2 & 2.2 & 4.7 \\
\hline PHLEPRA & 5.0 & 5.0 & 0.0 & 5.0 & 5.0 & 1.0 & 2.2 & 5.0 \\
\hline LINULEW & 5.0 & 2.0 & 0.0 & 2.0 & 5.0 & 1.0 & 1.0 & 1.0 \\
\hline FESTSPP & 5.0 & 5.0 & 0.0 & 5.0 & 5.0 & 1.0 & 2.2 & 5.0 \\
\hline DANTPAR & 5.0 & 5.0 & 0.0 & 5.0 & 5.0 & 1.0 & 2.2 & 5.0 \\
\hline CARESPP & 5.0 & 5.0 & 0.0 & 5.0 & 5.0 & 1.0 & 2.2 & 5.0 \\
\hline BALSSAG & 5.0 & 5.0 & 0.0 & 5.0 & 5.0 & 1.0 & 2.2 & 5.0 \\
\hline ANEMMUL & 5.0 & 2.0 & 0.0 & 2.0 & 5.0 & 1.0 & 0.7 & 0.5 \\
\hline $\begin{array}{l}\text { AGROTRA } \\
\text { (plus } 40 \text { species) }\end{array}$ & 5.0 & 5.0 & 0.0 & 5.0 & 5.0 & 1.0 & 2.2 & 5.0 \\
\hline
\end{tabular}

\section{CLUSTER}

2

\begin{tabular}{|c|c|c|c|c|c|c|c|c|}
\hline & $\mathrm{N}$ & Range & Minimum & Maximum & Sum & \multicolumn{2}{|c|}{ Mean Std. Deviation } & Variance \\
\hline SELADEN & 5.0 & 42.0 & 0.0 & 42.0 & 123.0 & 24.6 & 18.7 & 349.8 \\
\hline PHLOHOO & 5.0 & 15.0 & 6.0 & 21.0 & 65.0 & 13.0 & 5.8 & 33.5 \\
\hline CAREOBT & 5.0 & 12.0 & 8.0 & 20.0 & 61.0 & 12.2 & 4.7 & 22. \\
\hline DANTPAR & 5.0 & 17.0 & 0.0 & 17.0 & 53.0 & 10.6 & 6.5 & 41.8 \\
\hline FESTIDA & 5.0 & 25.0 & 0.0 & 25.0 & 37.0 & 7.4 & 10.5 & 109. \\
\hline KOELMAC & 5.0 & 11.0 & 3.0 & 14.0 & 33.0 & 6.6 & 4.3 & 18 \\
\hline FESTSCA & 5.0 & 5.0 & 1.0 & 6.0 & 21.0 & 4.2 & 2.2 & 4.7 \\
\hline AGRODAS & 5.0 & 14.0 & 0.0 & 14.0 & 21.0 & 4.2 & 6.3 & 39. \\
\hline ARTEFRI & 5.0 & 3.0 & 2.0 & 5.0 & 17.0 & 3.4 & 1.1 & \\
\hline AGROSPI & 5.0 & 7.0 & 0.0 & 7.0 & 17.0 & 3.4 & 3.3 & 10.8 \\
\hline ANTEPAR & 5.0 & 12.0 & 0.0 & 12.0 & 16.1 & 3.2 & 5.2 & \\
\hline POACUS & 5.0 & 12.0 & 0.0 & 12.0 & 14.1 & 2.8 & 5.2 & \\
\hline ERIGCAE & 5.0 & 5.0 & 0.0 & 5.0 & 14.0 & 2.8 & 2.3 & \\
\hline
\end{tabular}




$\begin{array}{lrrrrrrrr}\text { ASTRALP } & 5.0 & 13.0 & 0.0 & 13.0 & 14.0 & 2.8 & 5.7 & 32.7 \\ \text { ANEMPAT } & 5.0 & 7.0 & 0.0 & 7.0 & 14.0 & 2.8 & 3.0 & 8.7 \\ \text { STIPCOL } & 5.0 & 13.0 & 0.0 & 13.0 & 13.0 & 2.6 & 5.8 & 33.8 \\ \text { CERAARV } & 5.0 & 7.0 & 0.0 & 7.0 & 12.2 & 2.4 & 3.3 & 11.1 \\ \text { GALIBOR } & 5.0 & 3.0 & 1.0 & 4.0 & 12.0 & 2.4 & 1.3 & 1.8 \\ \text { GAILARI } & 5.0 & 5.0 & 0.0 & 5.0 & 8.1 & 1.6 & 2.1 & 4.2 \\ \text { ASTRSTR } & 5.0 & 8.0 & 0.0 & 8.0 & 8.0 & 1.6 & 3.6 & 12.8 \\ \text { POTEFRU } & 5.0 & 4.0 & 0.0 & 4.0 & 7.1 & 1.4 & 1.7 & 2.7 \\ \text { LUPISER } & 5.0 & 3.0 & 0.0 & 3.0 & 7.0 & 1.4 & 1.1 & 1.3 \\ \text { POACAN } & 5.0 & 6.0 & 0.0 & 6.0 & 6.0 & 1.2 & 2.7 & 7.2 \\ \text { ANEMMUL } & 5.0 & 4.0 & 0.0 & 4.0 & 5.2 & 1.0 & 1.7 & 2.9 \\ \text { LITHRUD } & 5.0 & 4.0 & 0.0 & 4.0 & 5.1 & 1.0 & 1.7 & 3.0 \\ \text { HETEVIL } & 5.0 & 5.0 & 0.0 & 5.0 & 5.1 & 1.0 & 2.2 & 5.0 \\ \text { (plus 31 species) } & & & & & & & & \end{array}$

\section{CLUSTER} 3

CAREOBT

AGROSPI

SYMPOCC

KOELMAC

ARTEFRI

AMELALN

FESTSCA

ROSAARK

MONAFIS

FESTIDA

CALARUB

STIPVIR

POACUS

GALIBOR

BROMPUM

ARTELUD

STIPCUR

SMILSTE

PHLEPRA

CERAARV

ASTECON

TARAOFF

POPUTRE

VICLAME

ANTEPAR

SOLIMIS

FRAGVIR

CAMPROT

ASTELAE

AGROSMI

(plus 35 species)
N Range Minimum Maximum

$\begin{array}{rrrr}5.0 & 34.0 & 3.0 & 37.0\end{array}$

5.0

5.0

5.0

5.0

5.0

5.0

5.0

5.0

5.0

5.0

5.0

5.0

5.0

5.0

5.0

5.0

5.0

5.0

5.0

5.0

5.0

5.0

5.0

5.0

5.0

5.0

5.0

5.0

5.0

20.0

14.0

0.0

20.0

1.0

3.0

0.0

0.1

0.0

1.0

0.0

0.0

0.0

0.0

0.0

0.0

0.0

0.0

0.0

0.0

0.0

0.0

0.0

0.0

0.0

0.0

0.0

0.0

0.0

0.0

0.0

0.0
Sum

99.0

58.0

31.0

27.0

22.0

21.1

21.0

17.0

12.0

11.0

11.0

10.0

8.0

7.1

7.1

7.1

7.0

7.0

7.0

7.0

7.0

6.1

6.0

5.1

5.1

5.0

5.0

5.0

5.0

5.0
Mean Std. Deviation Variance

19.8

14.9

221.7

11.6

6.2

5.4

4.4

4.2

4.2

3.4

2.4

2.2

2.2

2.0

1.6

1.4

1.4

1.4

1.4

1.4

1.4

1.4

1.4

1.2

1.2

1.0

1.0

1.0

1.0

1.0

1.0

1.0
9.1

5.5

1.7

5.3

4.9

7.8

2.3

3.6

3.9

4.9

2.8

3.6

1.7

2.2

3.1

3.1

3.1

3.1

0.9

3.1

2.7

1.6

2.2

1.4

2.2

2.2

1.7

2.2

2.2
82.3

30.7

2.8

28.3

24.5

61.2

5.3

12.8

15.2

24.2

8.0

12.8

2.7

4.7

9.7

9.8

9.8

9.8

0.8

9.8

7.1

2.7

5.0

2.0

5.0

5.0

3.0

5.0

5.0 


\section{CLUSTER}

4

\begin{tabular}{|c|c|c|c|c|c|c|c|c|}
\hline & $\mathrm{N}$ & Range & Minimum & Maximum & Sum & \multicolumn{2}{|c|}{ Mean Std. Deviation } & Variance \\
\hline KOELMAC & 7.0 & 47.0 & 3.0 & 50.0 & 165.0 & 23.6 & 15.2 & 230.3 \\
\hline AGROTRA & 7.0 & 27.0 & 3.0 & 30.0 & 149.0 & 21.3 & 9.7 & 93.9 \\
\hline HELIHOO & 7.0 & 26.0 & 0.0 & 26.0 & 64.0 & 9.1 & 11.7 & 135.8 \\
\hline CAREPEN & 7.0 & 30.0 & 0.0 & 30.0 & 56.0 & 8.0 & 13.7 & 188.0 \\
\hline BROMINE & 7.0 & 30.0 & 0.0 & 30.0 & 55.0 & 7.9 & 12.2 & 148.8 \\
\hline ARTEFRI & 7.0 & 20.0 & 0.0 & 20.0 & 54.0 & 7.7 & 7.7 & 59.9 \\
\hline STIPCUR & 7.0 & 26.0 & 0.0 & 26.0 & 31.0 & 4.4 & 9.7 & 94.0 \\
\hline MUHLRIC & 7.0 & 26.0 & 0.0 & 26.0 & 26.0 & 3.7 & 9.8 & 96.6 \\
\hline FESTSCA & 7.0 & 26.0 & 0.0 & 26.0 & 26.0 & 3.7 & 9.8 & 96.6 \\
\hline CAREOBT & 7.0 & 26.0 & 0.0 & 26.0 & 26.0 & 3.7 & 9.8 & 96.6 \\
\hline AGROSCA & 7.0 & 26.0 & 0.0 & 26.0 & 26.0 & 3.7 & 9.8 & 96.6 \\
\hline ANTEPAR & 7.0 & 15.0 & 0.0 & 15.0 & 26.0 & 3.7 & 6.2 & 38.2 \\
\hline SYMPOCC & 7.0 & 15.0 & 0.0 & 15.0 & 18.0 & 2.6 & 5.6 & 31.3 \\
\hline ANEMMUL & 7.0 & 10.0 & 0.0 & 10.0 & 16.0 & 2.3 & 3.5 & 12.6 \\
\hline STIPVIR & 7.0 & 15.0 & 0.0 & 15.0 & 15.0 & 2.1 & 5.7 & 32.1 \\
\hline OXYTSPL & 7.0 & 5.0 & 0.0 & 5.0 & 12.0 & 1.7 & 2.0 & 3.9 \\
\hline HEDYSUL & 7.0 & 10.0 & 0.0 & 10.0 & 10.0 & 1.4 & 3.8 & 14.3 \\
\hline CAMPROT & 7.0 & 4.0 & 0.0 & 4.0 & 9.0 & 1.3 & 1.6 & 2.6 \\
\hline ELYMINN & 7.0 & 5.0 & 0.0 & 5.0 & 8.0 & 1.1 & 2.0 & 4.1 \\
\hline CALAI UR & 7.0 & 8.0 & 0.0 & 8.0 & 8.0 & 1.1 & 3.0 & 9.1 \\
\hline GEUMTRI & 7.0 & 5.0 & 0.0 & 5.0 & 7.0 & 1.0 & 1.8 & 3.3 \\
\hline $\begin{array}{l}\text { ARTEDRA } \\
\text { (plus } 46 \text { species) }\end{array}$ & 7.0 & 6.0 & 0.0 & 6.0 & 7.0 & 1.0 & 2.2 & 5.0 \\
\hline
\end{tabular}

\section{CLUSTER}

5

$\begin{array}{lrrrrrrrr} & \mathrm{N} & \text { Range } & \text { Minimum } & \text { Maximum } & \text { Sum } & \text { Mean Std. Deviation } & \text { Variance } \\ \text { AGROTR } & 3.0 & 26.0 & 18.0 & 44.0 & 94.0 & 31.3 & 13.0 & 169.3 \\ \text { A } & & & & & & & & \\ \text { CARESPP } & 3.0 & 50.0 & 0.0 & 50.0 & 84.0 & 28.0 & 25.5 & 652.0 \\ \text { BROMCIL } & 3.0 & 57.0 & 0.0 & 57.0 & 65.0 & 21.7 & 30.9 & 952.3 \\ \text { KOELMAC } & 3.0 & 35.0 & 4.0 & 39.0 & 49.0 & 16.3 & 19.7 & 386.3 \\ \text { POTEGRA } & 3.0 & 31.0 & 0.0 & 31.0 & 36.0 & 12.0 & 16.6 & 277.0 \\ \text { ANEMMUL } & 3.0 & 27.0 & 0.0 & 27.0 & 27.1 & 9.0 & 15.6 & 242.1 \\ \text { OXYTSPL } & 3.0 & 10.0 & 0.0 & 10.0 & 18.0 & 6.0 & 5.3 & 28.0 \\ \text { ACHIMIL } & 3.0 & 8.0 & 1.0 & 9.0 & 16.0 & 5.3 & 4.0 & 16.3 \\ \text { CALALON } & 3.0 & 10.0 & 0.0 & 10.0 & 10.0 & 3.3 & 5.8 & 33.3 \\ \text { AGOSGLA } & 3.0 & 8.0 & 0.0 & 8.0 & 8.1 & 2.7 & 4.6 & 21.1 \\ \text { TARAOFF } & 3.0 & 8.0 & 0.0 & 8.0 & 8.0 & 2.7 & 4.6 & 21.3 \\ \text { RANUCAR } & 3.0 & 8.0 & 0.0 & 8.0 & 8.0 & 2.7 & 4.6 & 21.3 \\ \text { POAPAL } & 3.0 & 8.0 & 0.0 & 8.0 & 8.0 & 2.7 & 4.6 & 21.3 \\ \text { EPILANG } & 3.0 & 8.0 & 0.0 & 8.0 & 8.0 & 2.7 & 4.6 & 21.3 \\ \text { STIPCOM } & 3.0 & 4.0 & 0.0 & 4.0 & 4.0 & 1.3 & 2.3 & 5.3 \\ \text { SOLIMUL } & 3.0 & 2.0 & 0.0 & 2.0 & 4.0 & 1.3 & 1.2 & 1.3 \\ \text { POACAN } & 3.0 & 3.0 & 0.0 & 3.0 & 3.0 & 1.0 & 1.7 & 3.0\end{array}$

(plus 19 species) 


\section{CLUSTER}

6

\begin{tabular}{|c|c|c|c|c|c|c|c|c|}
\hline & $\mathrm{N}$ & Range & Minimum & Maximum & Sum & \multicolumn{2}{|c|}{ Mean Std. Deviation } & Variance \\
\hline CAREAQU & 2.0 & 12.0 & 34.0 & 46.0 & 80.0 & 40.0 & 8.5 & 72.0 \\
\hline AGROTRA & 2.0 & 2.0 & 5.0 & 7.0 & 12.0 & 6.0 & 1.4 & 2.0 \\
\hline GEUMALE & 2.0 & 7.0 & 0.0 & 7.0 & 7.0 & 3.5 & 4.9 & 24.5 \\
\hline JUNCBAL & 2.0 & 5.0 & 0.0 & 5.0 & 5.0 & 2.5 & 3.5 & 12.5 \\
\hline VALEDIO & 2.0 & 3.0 & 0.0 & 3.0 & 3.0 & 1.5 & 2.1 & 4.5 \\
\hline CALACAN & 2.0 & 3.0 & 0.0 & 3.0 & 3.0 & 1.5 & 2.1 & 4.5 \\
\hline BETUGLA & 2.0 & 3.0 & 0.0 & 3.0 & 3.0 & 1.5 & 2.1 & 4.5 \\
\hline $\begin{array}{l}\text { RUBUARC } \\
\text { (plus } 7 \text { species) }\end{array}$ & 2.0 & 2.0 & 0.0 & 2.0 & 2.0 & 1.0 & 1.4 & 2.0 \\
\hline
\end{tabular}

\section{CLUSTER}

7

\begin{tabular}{|c|c|c|c|c|c|c|c|c|}
\hline & $\mathrm{N}$ & Range & Minimum & Maximum & Sum & \multicolumn{2}{|c|}{ Mean Std. Deviation } & Variance \\
\hline CALACAN & 5.0 & 38.0 & 2.0 & 40.0 & 79.0 & 15.8 & 16.4 & 267.7 \\
\hline POAPRA & 5.0 & 19.0 & 0.0 & 19.0 & 52.0 & 10.4 & 9.2 & 83.8 \\
\hline TARAOFF & 5.0 & 16.0 & 0.0 & 16.0 & 36.0 & 7.2 & 7.4 & 54.7 \\
\hline EPILANG & 5.0 & 20.0 & 1.0 & 21.0 & 35.0 & 7.0 & 8.0 & 64.0 \\
\hline AGROTRA & 5.0 & 9.0 & 4.0 & 13.0 & 35.0 & 7.0 & 3.9 & 15.5 \\
\hline HERALAN & 5.0 & 21.0 & 0.0 & 21.0 & 34.0 & 6.8 & 9.7 & 94.7 \\
\hline MERTPAN & 5.0 & 11.0 & 0.0 & 11.0 & 30.0 & 6.0 & 4.1 & 16.5 \\
\hline CAREPRA & 5.0 & 20.0 & 0.0 & 20.0 & 25.0 & 5.0 & 8.7 & 75.0 \\
\hline BROMCIL & 5.0 & 9.0 & 1.0 & 10.0 & 25.0 & 5.0 & 3.6 & 13.0 \\
\hline THALVEN & 5.0 & 10.0 & 0.0 & 10.0 & 18.0 & 3.6 & 4.6 & 21.3 \\
\hline VICIAME & 5.0 & 10.0 & 0.0 & 10.0 & 16.0 & 3.2 & 4.0 & 15.7 \\
\hline DELPGLA & 5.0 & 8.0 & 0.0 & 8.0 & 14.0 & 2.8 & 3.6 & 12.7 \\
\hline SALISPP & 5.0 & 8.0 & 0.0 & 8.0 & 12.0 & 2.4 & 3.6 & 12.8 \\
\hline ROSAACI & 5.0 & 10.0 & 0.0 & 10.0 & 10.1 & 2.0 & 4.5 & 19.9 \\
\hline GERARIC & 5.0 & 10.0 & 0.0 & 10.0 & 10.0 & 2.0 & 4.5 & 20.0 \\
\hline FRAGVIR & 5.0 & 7.0 & 0.0 . & 7.0 & 10.0 & 2.0 & 2.9 & 8.5 \\
\hline EQUIARV & 5.0 & 6.0 & 0.0 & 6.0 & 9.0 & 1.8 & 2.7 & 7.2 \\
\hline CARESPP & 5.0 & 9.0 & 0.0 & 9.0 & 9.0 & 1.8 & 4.0 & 16.2 \\
\hline RUBUIDA & 5.0 & 4.0 & 0.0 & 4.0 & 8.1 & 1.6 & 1.8 & 3.2 \\
\hline PICEGLA & 5.0 & 5.0 & 0.0 & 5.0 & 8.0 & 1.6 & 2.3 & 5.3 \\
\hline GEUMMAC & 5.0 & 5.0 & 0.0 & 5.0 & 8.0 & 1.6 & 2.1 & 4.3 \\
\hline STELLON & 5.0 & 5.0 & 0.0 & 5.0 & 7.0 & 1.4 & 2.2 & 4.8 \\
\hline CAREATH & 5.0 & 7.0 & 0.0 & 7.0 & 7.0 & 1.4 & 3.1 & 9.8 \\
\hline LATHOCH & 5.0 & 6.0 & 0.0 & 6.0 & 6.0 & 1.2 & 2.7 & 7.2 \\
\hline ASTECIL & 5.0 & 2.0 & 0.0 & 2.0 & 6.0 & 1.2 & 0.8 & 0.7 \\
\hline ACHIMIL & 5.0 & 3.0 & 0.0 & 3.0 & 5.1 & 1.0 & 1.2 & 1.5 \\
\hline SYMPOCC & 5.0 & 4.0 & 0.0 & 4.0 & 5.0 & 1.0 & 1.7 & 3.0 \\
\hline $\begin{array}{l}\text { POPUTRE } \\
\text { (plus } 9 \text { species) }\end{array}$ & 5.0 & 5.0 & 0.0 & 5.0 & 5.0 & 1.0 & 2.2 & 5.0 \\
\hline
\end{tabular}




\section{CLUSTER}

8

\begin{tabular}{|c|c|c|c|c|c|c|c|}
\hline & $\mathrm{N}$ & Range & Minimum & Maximum & Sum & Mean Std. Deviatio & Variance \\
\hline FESTRUB & 1.0 & 0.0 & 65.0 & 65.0 & 65.0 & 65.0 & \\
\hline ROSAACI & 1.0 & 0.0 & 25.0 & 25.0 & 25.0 & 25.0 & \\
\hline TARAOFF & 1.0 & 0.0 & 8.0 & 8.0 & 8.0 & 8.0 & \\
\hline TRIFPRA & 1.0 & 0.0 & 6.0 & 6.0 & 6.0 & 6.0 & \\
\hline AGROTRA & 1.0 & 0.0 & 6.0 & 6.0 & 6.0 & 6.0 & . \\
\hline BROMINE & 1.0 & 0.0 & 2.0 & 2.0 & 2.0 & 2.0 & \\
\hline POAPRA & 1.0 & 0.0 & 1.0 & 1.0 & 1.0 & 1.0 & \\
\hline FRAGVIR & 1.0 & 0.0 & 1.0 & 1.0 & 1.0 & 1.0 & \\
\hline VICLAME & 1.0 & 0.0 & 0.1 & 0.1 & 0.1 & 0.1 & \\
\hline GALIBOR & 1.0 & 0.0 & 0.1 & 0.1 & 0.1 & 0.1 & \\
\hline ACHIMIL & 1.0 & 0.0 & 0.1 & 0.1 & 0.1 & 0.1 & \\
\hline
\end{tabular}

CLUSTER

9

AGROTRA

THALVEN

ELYMINN

MERTPAN

DESCCES

ACHIMIL

CAREPRG

BROMINE

DELPGLA

ASTECIL

VICIAME

EPILANG

BROMCIL

SCHIPUR

SALIBAR

FRAGVIR

GALIBOR

BETUGLA

POTEGRA

CAREXER

ASTELAE

CARESPP

PICEGLA

POTEDIV

(plus 45 species)

$\begin{array}{rrrr}\text { N } & \text { Range } & \text { Minimum } & \text { Maximum } \\ 10.0 & 24.0 & 5.0 & 29.0 \\ 10.0 & 28.0 & 3.0 & 31.0 \\ 10.0 & 50.0 & 0.0 & 50.0 \\ 10.0 & 30.0 & 2.0 & 32.0 \\ 10.0 & 24.0 & 0.0 & 24.0 \\ 10.0 & 15.0 & 0.0 & 15.0 \\ 10.0 & 21.0 & 0.0 & 21.0 \\ 10.0 & 20.0 & 0.0 & 20.0 \\ 10.0 & 14.0 & 0.0 & 14.0 \\ 10.0 & 13.0 & 0.0 & 13.0 \\ 10.0 & 7.0 & 0.0 & 7.0 \\ 10.0 & 11.0 & 0.0 & 11.0 \\ 10.0 & 15.0 & 0.0 & 15.0 \\ 10.0 & 9.0 & 0.0 & 9.0 \\ 10.0 & 20.0 & 0.0 & 20.0 \\ 10.0 & 8.0 & 0.0 & 8.0 \\ 10.0 & 4.0 & 0.0 & 4.0 \\ 10.0 & 10.0 & 0.0 & 10.0 \\ 10.0 & 9.0 & 0.0 & 9.0 \\ 10.0 & 10.0 & 0.0 & 10.0 \\ 10.0 & 15.0 & 0.0 & 15.0 \\ 10.0 & 6.0 & 0.0 & 6.0 \\ 10.0 & 10.0 & 0.0 & 10.0 \\ 10.0 & 11.0 & 0.0 & 11.0\end{array}$

\section{CLUSTER}

10

Sum

144.0

141.0

138.0

100.0

63.0

63.0

55.0

47.0

44.0

36.0

35.0

30.0

30.0

29.0

26.0

22.1

22.0

21.1

21.0

20.0

15.1

14.0

11.1

11.0

\section{Mean Std. Deviatio}

14.4

14.1

13.8

10.0

6.3

6.3

5.5

4.7

4.4

3.6

3.5

3.0

3.0

2.9

2.6

2.2

2.2

2.1

2.1

2.0

1.5

1.4

1.1

1.1
7.0

9.3

18.1

10.0

9.2

4.6

9.0

7.5

4.2

5.3

2.1

3.7

5.9

3.3

6.4

2.6

1.4

3.6

2.8

4.2

4.7

2.4

3.1

3.5
Variance 48.7 86.3 329.1 99.6 85.3 20.9

81.6 56.5 17.6 28.5

4.3

13.3

34.2

11.0

40.9

6.6

2.0

12.9

7.7

17.8

22.5

5.6

9.9

12.1

GEUMTRI

$\begin{array}{rrrrr}N & \text { Range } & \text { Minimum } & \text { Maximum } & \text { Sum } \\ 4.0 & 16.0 & 2.0 & 18.0 & 36.0 \\ 4.0 & 13.0 & 0.0 & 13.0 & 30.0\end{array}$

Sum

Mean Std. Deviation Variance

POTEGRA

$$
4.0
$$

30.0 


$\begin{array}{lrrrrrrrr}\text { BROMINE } & 4.0 & 20.0 & 0.0 & 20.0 & 29.0 & 7.3 & 9.5 & 90.3 \\ \text { HELIHOO } & 4.0 & 20.0 & 0.0 & 20.0 & 28.0 & 7.0 & 9.5 & 89.3 \\ \text { FESTBRA } & 4.0 & 21.0 & 0.0 & 21.0 & 21.0 & 5.3 & 10.5 & 110.3 \\ \text { AGROTRA } & 4.0 & 4.0 & 4.0 & 8.0 & 21.0 & 5.3 & 1.9 & 3.6 \\ \text { ACHIMIL } & 4.0 & 8.0 & 0.0 & 8.0 & 14.0 & 3.5 & 3.4 & 11.7 \\ \text { POTEFRU } & 4.0 & 8.0 & 0.0 & 8.0 & 13.0 & 3.3 & 3.9 & 15.6 \\ \text { DELPGLA } & 4.0 & 6.0 & 0.0 & 6.0 & 13.0 & 3.3 & 2.5 & 6.3 \\ \text { BETUGLA } & 4.0 & 10.0 & 0.0 & 10.0 & 13.0 & 3.3 & 4.7 & 22.3 \\ \text { SALISPP } & 4.0 & 10.0 & 0.0 & 10.0 & 12.0 & 3.0 & 4.8 & 22.7 \\ \text { CARESPP } & 4.0 & 8.0 & 0.0 & 8.0 & 12.0 & 3.0 & 3.8 & 14.7 \\ \text { VICIAME } & 4.0 & 5.0 & 0.0 & 5.0 & 10.1 & 2.5 & 2.9 & 8.2 \\ \text { FRAGVIR } & 4.0 & 2.0 & 2.0 & 4.0 & 10.0 & 2.5 & 1.0 & 1.0 \\ \text { THALVEN } & 4.0 & 3.0 & 0.0 & 3.0 & 9.0 & 2.3 & 1.5 & 2.3 \\ \text { GALIBOR } & 4.0 & 2.0 & 1.0 & 3.0 & 8.0 & 2.0 & 1.2 & 1.3 \\ \text { KOBRMYO } & 4.0 & 6.0 & 0.0 & 6.0 & 6.0 & 1.5 & 3.0 & 9.0 \\ \text { GENTAMA } & 4.0 & 3.0 & 0.0 & 3.0 & 6.0 & 1.5 & 1.3 & 1.7 \\ \text { DESCCES } & 4.0 & 6.0 & 0.0 & 6.0 & 6.0 & 1.5 & 3.0 & 9.0 \\ \text { ASTRALP } & 4.0 & 6.0 & 0.0 & 6.0 & 6.0 & 1.5 & 3.0 & 9.0 \\ \text { POAPRA } & 4.0 & 5.0 & 0.0 & 5.0 & 5.0 & 1.3 & 2.5 & 6.3 \\ \text { FESTSCA } & 4.0 & 5.0 & 0.0 & 5.0 & 5.0 & 1.3 & 2.5 & 6.3 \\ \text { ELYMINN } & 4.0 & 5.0 & 0.0 & 5.0 & 5.0 & 1.3 & 2.5 & 6.3 \\ \text { LATHOCH } & 4.0 & 2.0 & 0.0 & 2.0 & 4.0 & 1.0 & 1.2 & 1.3 \\ \text { DANTCAL } & 4.0 & 4.0 & 0.0 & 4.0 & 4.0 & 1.0 & 2.0 & 4.0 \\ \text { (plus 22 SPecies) } & & & & & & & & \end{array}$

\section{CLUSTER}

11

\begin{tabular}{lrrrrrrrr} 
DESCCES & 12.0 & 25.0 & 20.0 & 45.0 & 390.0 & 32.5 & 7.0 & 48.8 \\
CAREPRG & 12.0 & 31.0 & 0.0 & 31.0 & 161.0 & 13.4 & 10.8 & 115.9 \\
THALVEN & 12.0 & 24.0 & 0.0 & 24.0 & 106.0 & 8.8 & 8.5 & 71.6 \\
AGROTRA & 12.0 & 15.0 & 4.0 & 19.0 & 102.0 & 8.5 & 5.0 & 24.6 \\
ASTECIL & 12.0 & 18.0 & 0.0 & 18.0 & 92.0 & 7.7 & 6.7 & 45.3 \\
FRAGVIR & 12.0 & 23.9 & 0.1 & 24.0 & 89.1 & 7.4 & 8.0 & 64.7 \\
ACHIMIL & 12.0 & 13.0 & 3.0 & 16.0 & 88.0 & 7.3 & 4.0 & 16.1 \\
POTEGRA & 12.0 & 12.0 & 0.0 & 12.0 & 80.2 & 6.7 & 4.4 & 19.6 \\
TARAOFF & 12.0 & 14.0 & 0.0 & 14.0 & 37.5 & 3.1 & 5.0 & 25.4 \\
SALIBAR & 12.0 & 12.0 & 0.0 & 12.0 & 37.1 & 3.1 & 4.7 & 22.0 \\
FESTSAX & 12.0 & 12.0 & 0.0 & 12.0 & 36.0 & 3.0 & 4.0 & 15.8 \\
BROMPUM & 12.0 & 29.0 & 0.0 & 29.0 & 32.1 & 2.7 & 8.3 & 69.1 \\
MERTPAN & 12.0 & 8.0 & 0.0 & 8.0 & 26.0 & 2.2 & 2.2 & 4.7 \\
CALACAN & 12.0 & 23.0 & 0.0 & 23.0 & 23.5 & 2.0 & 6.6 & 43.9 \\
JUNCBAL & 12.0 & 6.0 & 0.0 & 6.0 & 22.3 & 1.9 & 2.1 & 4.2 \\
GALIBOR & 12.0 & 3.9 & 0.1 & 4.0 & 22.2 & 1.9 & 1.2 & 1.4 \\
ZIZIAPT & 12.0 & 14.0 & 0.0 & 14.0 & 21.0 & 1.8 & 4.0 & 15.7 \\
GEUMTRI & 12.0 & 14.0 & 0.0 & 14.0 & 21.2 & 1.8 & 3.9 & 15.6 \\
SCHIPUR & 12.0 & 10.0 & 0.0 & 10.0 & 21.1 & 1.8 & 3.2 & 10.5 \\
CAREAQU & 12.0 & 20.0 & 0.0 & 20.0 & 21.0 & 1.8 & 5.8 & 33.1 \\
PENSPRO & 12.0 & 6.0 & 0.0 & 6.0 & 17.2 & 1.4 & 1.9 & 3.7 \\
FESTSCA & 12.0 & 4.0 & 0.0 & 4.0 & 17.1 & 1.4 & 1.7 & 2.8 \\
\hline
\end{tabular}




$\begin{array}{lrrrrrrrr}\text { POAPRA } & 12.0 & 11.0 & 0.0 & 11.0 & 16.3 & 1.4 & 3.1 & 9.6 \\ \text { DANTCAL } & 12.0 & 5.0 & 0.0 & 5.0 & 14.2 & 1.2 & 1.6 & 2.5 \\ \text { DELPGLA } & 12.0 & 6.0 & 0.0 & 6.0 & 13.1 & 1.1 & 1.8 & 3.3 \\ \text { AGOSGLA } & 12.0 & 7.0 & 0.0 & 7.0 & 13.1 & 1.1 & 2.2 & 5.0 \\ \text { TRIFPRA } & 12.0 & 7.0 & 0.0 & 7.0 & 12.0 & 1.0 & 2.4 & 5.6 \\ \text { (plus 51 species) } & & & & & & & & \end{array}$

\section{CLUSTER}

12

\begin{tabular}{|c|c|c|c|c|c|c|c|c|}
\hline & $\mathrm{N}$ & Range & Minimum & Maximum & Sum & \multicolumn{2}{|c|}{ Mean Std. Deviation } & Variance \\
\hline AGROTRA & 9.0 & 21.0 & 4.0 & 25.0 & 118.0 & 13.1 & 6.4 & 41.1 \\
\hline FRAGVIR & 9.0 & 27.0 & 3.0 & 30.0 & 108.0 & 12.0 & 7.9 & 62.8 \\
\hline SALIBAR & 9.0 & 20.0 & 0.0 & 20.0 & 56.1 & 6.2 & 9.1 & 83.5 \\
\hline CAREPRA & 9.0 & 45.0 & 0.0 & 45.0 & 45.0 & 5.0 & 15.0 & 225.0 \\
\hline ACHIMIL & 9.0 & 6.0 & 1.0 & 7.0 & 43.0 & 4.8 & 2.1 & 4.4 \\
\hline FESTSAX & 9.0 & 11.0 & 0.0 & 11.0 & 38.0 & 4.2 & 3.5 & 12.4 \\
\hline CAREPRG & 9.0 & 17.0 & 0.0 & 17.0 & 38.0 & 4.2 & 6.4 & 41.4 \\
\hline DANTCAL & 9.0 & 19.0 & 0.0 & 19.0 & 36.0 & 4.0 & 6.1 & 36.8 \\
\hline TRIFPRA & 9.0 & 17.0 & 0.0 & 17.0 & 26.1 & 2.9 & 6.1 & 36.8 \\
\hline PENSPRO & 9.0 & 7.0 & 0.0 & 7.0 & 24.0 & 2.7 & 2.2 & 5.0 \\
\hline OXYTSER & 9.0 & 24.0 & 0.0 & 24.0 & 24.0 & 2.7 & 8.0 & 64.0 \\
\hline CERAARV & 9.0 & 3.9 & 0.1 & 4.0 & 17.1 & 1.9 & 1.3 & 1.8 \\
\hline ELYMINN & 9.0 & 9.0 & 0.0 & 9.0 & 17.1 & 1.9 & 2.9 & 8.3 \\
\hline ARCTUVA & 9.0 & 13.0 & 0.0 & 13.0 & 16.0 & 1.8 & 4.3 & 18.2 \\
\hline POAALP & 9.0 & 10.0 & 0.0 & 10.0 & 15.0 & 1.7 & 3.4 & 11.5 \\
\hline ASTRALP & 9.0 & 8.0 & 0.0 & 8.0 & 14.2 & 1.6 & 2.7 & 7.5 \\
\hline ANTEPAR & 9.0 & 6.0 & 0.0 & 6.0 & 14.1 & 1.6 & 2.1 & 4.5 \\
\hline FESTSCA & 9.0 & 8.0 & 0.0 & 8.0 & 14.0 & 1.6 & 2.7 & 7.0 \\
\hline POAPRA & 9.0 & 7.0 & 0.0 & 7.0 & 13.1 & 1.5 & 2.6 & 7.0 \\
\hline POTEGRA & 9.0 & 6.0 & 0.0 & 6.0 & 12.2 & 1.4 & 2.2 & 4.7 \\
\hline TARAOFF & 9.0 & 4.0 & 0.0 & 4.0 & 10.1 & 1.1 & 1.4 & 1.8 \\
\hline CAREOBT & 9.0 & 4.0 & 0.0 & 4.0 & 10.0 & 1.1 & 1.5 & 2.1 \\
\hline KOELMAC & 9.0 & 6.0 & 0.0 & 6.0 & 9.2 & 1.0 & 2.1 & 4.5 \\
\hline
\end{tabular}

\section{CLUSTER}

13

\begin{tabular}{|c|c|c|c|c|c|c|c|c|}
\hline & $\mathrm{N}$ & Range & Minimum & Maximum & Sum & \multicolumn{2}{|c|}{ Mean Std. Deviation } & Variance \\
\hline CAREOBT & 8.0 & 40.0 & 0.0 & 40.0 & 154.0 & 19.3 & 13.9 & 194.2 \\
\hline SOLIMIS & 8.0 & 22.0 & 4.0 & 26.0 & 108.0 & 13.5 & 7.2 & 51.4 \\
\hline ELYMINN & 8.0 & 27.0 & 1.0 & 28.0 & 101.0 & 12.6 & 10.2 & 103.1 \\
\hline AGROTRA & 8.0 & 18.0 & 4.0 & 22.0 & 98.0 & 12.3 & 6.3 & 39.4 \\
\hline FRAGVIR & 8.0 & 14.0 & 3.0 & 17.0 & 77.0 & 9.6 & 4.8 & 23.4 \\
\hline ACHIMIL & 8.0 & 10.0 & 5.0 & 15.0 & 76.0 & 9.5 & 3.3 & 10.9 \\
\hline FESTSCA & 8.0 & 24.0 & 0.0 & 24.0 & 70.0 & 8.8 & 8.0 & 64.8 \\
\hline POTEDIV & 8.0 & 23.0 & 0.0 & 23.0 & 65.0 & 8.1 & 9.2 & 85.3 \\
\hline POTEFRU & 8.0 & 15.0 & 0.0 & 15.0 & 56.0 & 7.0 & 6.0 & 35.4 \\
\hline JUNCBAL & 8.0 & 15.9 & 0.1 & 16.0 & 50.1 & 6.3 & 5.6 & 31.5 \\
\hline GEUMTRI & 8.0 & 12.0 & 0.0 & 12.0 & 49.0 & 6.1 & 3.8 & 14.4 \\
\hline TARAOFF & 8.0 & 25.9 & 0.1 & 26.0 & 44.3 & 5.5 & 8.6 & 73.2 \\
\hline DESCCES & 8.0 & 19.0 & 0.0 & 19.0 & 39.0 & 4.9 & 6.1 & 37.6 \\
\hline
\end{tabular}




\begin{tabular}{|c|c|c|c|c|c|c|c|c|}
\hline BROMCIL & 8.0 & 10.0 & 0.0 & 10.0 & 39.0 & 4.9 & 4.5 & 20.1 \\
\hline ARCTUVA & 8.0 & 18.0 & 0.0 & 18.0 & 37.0 & 4.6 & 7.5 & 56.3 \\
\hline PENSPRO & 8.0 & 12.0 & 0.0 & 12.0 & 35.0 & 4.4 & 5.3 & 28.0 \\
\hline KOELMAC & 8.0 & 13.0 & 1.0 & 14.0 & 33.0 & 4.1 & 4.2 & 17.6 \\
\hline POAALP & 8.0 & 11.0 & 0.0 & 11.0 & 31.0 & 3.9 & 4.9 & 23.6 \\
\hline FESTIDA & 8.0 & 8.9 & 0.1 & 9.0 & 29.1 & 3.6 & 3.0 & 9.0 \\
\hline DANTCAL & 8.0 & 13.0 & 0.0 & 13.0 & 28.1 & 3.5 & 4.6 & 21.0 \\
\hline POTEARG & 8.0 & 18.0 & 0.0 & 18.0 & 25.0 & 3.1 & 6.5 & 42.1 \\
\hline HEDYSUL & 8.0 & 11.0 & 0.0 & 11.0 & 23.0 & 2.9 & 4.4 & 19.3 \\
\hline PENSCON & 8.0 & 14.0 & 0.0 & 14.0 & 22.1 & 2.8 & 4.9 & 23.6 \\
\hline ASTELAE & 8.0 & 8.0 & 0.0 & 8.0 & 22.0 & 2.8 & 2.7 & 7.4 \\
\hline BROMPUM & 8.0 & 9.0 & 0.0 & 9.0 & 20.0 & 2.5 & 4.1 & 16.6 \\
\hline DANTPAR & 8.0 & 10.0 & 0.0 & 10.0 & 19.0 & 2.4 & 3.8 & 14.3 \\
\hline STIPRIC & 8.0 & 6.0 & 0.0 & 6.0 & 18.0 & 2.3 & 2.7 & 7.1 \\
\hline POACUS & 8.0 & 13.0 & 0.0 & 13.0 & 17.0 & 2.1 & 4.5 & 20.1 \\
\hline THALVEN & 8.0 & 8.0 & 0.0 & 8.0 & 16.0 & 2.0 & 2.7 & 7.4 \\
\hline POTEGRA & 8.0 & 14.0 & 0.0 & 14.0 & 16.0 & 2.0 & 4.9 & 24.0 \\
\hline CERAARV & 8.0 & 2.0 & 1.0 & 3.0 & 16.0 & 2.0 & 1.1 & 1.1 \\
\hline GALIBOR & 8.0 & 4.9 & 0.1 & 5.0 & 15.1 & 1.9 & 1.7 & 2.9 \\
\hline ANTELAN & 8.0 & 8.0 & 0.0 & 8.0 & 13.2 & 1.7 & 2.8 & 7.6 \\
\hline OXYTSPL & 8.0 & 7.0 & 0.0 & 7.0 & 13.0 & 1.6 & 3.0 & 9.1 \\
\hline AGOSGLA & 8.0 & 5.0 & 0.0 & 5.0 & 9.0 & 1.1 & 1.7 & 3.0 \\
\hline SALISPP & 8.0 & 8.0 & 0.0 & 8.0 & 8.0 & 1.0 & 2.8 & 8.0 \\
\hline $\begin{array}{l}\text { FESTRUB } \\
\text { (plus } 26 \text { species) }\end{array}$ & 8.0 & 8.0 & 0.0 & 8.0 & 8.0 & 1.0 & 2.8 & \\
\hline
\end{tabular}

CLUSTER

\begin{tabular}{lrrrrrrrr} 
ELYMINN & 3.0 & 23.0 & 23.0 & 46.0 & 99.0 & 33.0 & 11.8 & 139.0 \\
CAREPRG & 3.0 & 54.0 & 3.0 & 57.0 & 93.0 & 31.0 & 27.1 & 732.0 \\
POTEDIV & 3.0 & 26.0 & 12.0 & 38.0 & 81.0 & 27.0 & 13.5 & 181.0 \\
DANTCAL & 3.0 & 41.0 & 0.0 & 41.0 & 63.0 & 21.0 & 20.5 & 421.0 \\
BROMCIL & 3.0 & 50.0 & 0.0 & 50.0 & 50.0 & 16.7 & 28.9 & 833.3 \\
KOBRMYO & 3.0 & 20.0 & 0.0 & 20.0 & 39.0 & 13.0 & 11.3 & 127.0 \\
AGROTRA & 3.0 & 10.0 & 5.0 & 15.0 & 35.0 & 11.7 & 5.8 & 33.3 \\
SOLIMUL & 3.0 & 25.0 & 1.0 & 26.0 & 31.0 & 10.3 & 13.7 & 186.3 \\
LUZUPAR & 3.0 & 25.0 & 0.0 & 25.0 & 28.0 & 9.3 & 13.7 & 186.3 \\
FRAGVIR & 3.0 & 25.0 & 0.0 & 25.0 & 25.0 & 8.3 & 14.4 & 208.3 \\
DESCCES & 3.0 & 25.0 & 0.0 & 25.0 & 25.0 & 8.3 & 14.4 & 208.3 \\
ARNICHA & 3.0 & 25.0 & 0.0 & 25.0 & 25.0 & 8.3 & 14.4 & 208.3 \\
ANTEPAR & 3.0 & 25.0 & 0.0 & 25.0 & 25.0 & 8.3 & 14.4 & 208.3 \\
THALVEN & 3.0 & 22.0 & 0.0 & 22.0 & 22.0 & 7.3 & 12.7 & 161.3 \\
ACHIMIL & 3.0 & 10.0 & 0.0 & 10.0 & 16.0 & 5.3 & 5.0 & 25.3 \\
DELPGLA & 3.0 & 13.0 & 0.0 & 13.0 & 15.0 & 5.0 & 7.0 & 49.0 \\
PENSPRO & 3.0 & 11.0 & 0.0 & 11.0 & 14.0 & 4.7 & 5.7 & 32.3 \\
FESTBRA & 3.0 & 13.0 & 0.0 & 13.0 & 14.0 & 4.7 & 7.2 & 52.3 \\
TARAOFF & 3.0 & 13.0 & 0.0 & 13.0 & 13.0 & 4.3 & 7.5 & 56.3 \\
HEDYBOR & 3.0 & 13.0 & 0.0 & 13.0 & 13.0 & 4.3 & 7.5 & 56.3 \\
CALACAN & 3.0 & 5.0 & 0.0 & 5.0 & 9.0 & 3.0 & 2.6 & 7.0 \\
TRISSPI & 3.0 & 2.0 & 1.0 & 3.0 & 6.0 & 2.0 & 1.0 & 1.0 \\
POLYVIV & 3.0 & 6.0 & 0.0 & 6.0 & 6.0 & 2.0 & 3.5 & 12.0 \\
\hline GEWESE & & & & & & & $P a g e$
\end{tabular}




$\begin{array}{lllllllll}\text { POAPRA } & 3.0 & 2.0 & 1.0 & 3.0 & 5.0 & 1.7 & 1.2 & 1.3 \\ \text { GALIBOR } & 3.0 & 4.0 & 0.0 & 4.0 & 5.0 & 1.7 & 2.1 & 4.3 \\ \text { BETUGLA } & 3.0 & 5.0 & 0.0 & 5.0 & 5.0 & 1.7 & 2.9 & 8.3 \\ \text { SALIBAR } & 3.0 & 4.0 & 0.0 & 4.0 & 4.0 & 1.3 & 2.3 & 5.3 \\ \text { STELLON } & 3.0 & 0.0 & 1.0 & 1.0 & 3.0 & 1.0 & 0.0 & 0.0 \\ \text { SISYMON } & 3.0 & 3.0 & 0.0 & 3.0 & 3.0 & 1.0 & 1.7 & 3.0 \\ \text { RUMEACE } & 3.0 & 2.0 & 0.0 & 2.0 & 3.0 & 1.0 & 1.0 & 1.0 \\ \text { POTEGRA } & 3.0 & 3.0 & 0.0 & 3.0 & 3.0 & 1.0 & 1.7 & 3.0 \\ \text { POTEFRU } & 3.0 & 2.0 & 0.0 & 2.0 & 3.0 & 1.0 & 1.0 & 1.0 \\ \text { OXYTSPL } & 3.0 & 3.0 & 0.0 & 3.0 & 3.0 & 1.0 & 1.7 & 3.0 \\ \text { AGROSCA } & 3.0 & 3.0 & 0.0 & 3.0 & 3.0 & 1.0 & 1.7 & 3.0 \\ \text { (plus 7 species) } & & & & & & & & \end{array}$

\section{CLUSTER}

15

\begin{tabular}{|c|c|c|c|c|c|c|c|c|}
\hline & $\mathrm{N}$ & Range & Minimum & Maximum & Sum & \multicolumn{2}{|c|}{ Mean Std. Deviation } & Variance \\
\hline AGROTRA & 15.0 & 53.0 & 6.0 & 59.0 & 304.0 & 20.3 & 15.1 & 227.4 \\
\hline FRAGVIR & 15.0 & 23.0 & 7.0 & 30.0 & 268.0 & 17.9 & 7.2 & 51.8 \\
\hline CAREPRG & 15.0 & 38.0 & 0.0 & 38.0 & 251.0 & 16.7 & 12.2 & 147.8 \\
\hline DESCCES & 15.0 & 46.0 & 0.0 & 46.0 & 172.0 & 11.5 & 15.8 & 249.6 \\
\hline ACHIMIL & 15.0 & 19.0 & 2.0 & 21.0 & 163.0 & 10.9 & 5.6 & 30.8 \\
\hline DANTCAL & 15.0 & 58.0 & 0.0 & 58.0 & 155.2 & 10.3 & 15.6 & 244.5 \\
\hline SCHIPUR & 15.0 & 33.0 & 0.0 & 33.0 & 127.0 & 8.5 & 7.9 & 62.7 \\
\hline TARAOFF & 15.0 & 31.0 & 0.0 & 31.0 & 115.1 & 7.7 & 11.1 & 123.8 \\
\hline ASTECIL & 15.0 & 18.0 & 0.0 & 18.0 & 115.1 & 7.7 & 6.8 & 45.6 \\
\hline THALVEN & 15.0 & 12.0 & 2.0 & 14.0 & 86.0 & 5.7 & 3.2 & 10.4 \\
\hline POTEGRA & 15.0 & 16.0 & 0.0 & 16.0 & 84.1 & 5.6 & 5.4 & 29.2 \\
\hline FESTSAX & 15.0 & 21.0 & 0.0 & 21.0 & 71.0 & 4.7 & 6.6 & 44.1 \\
\hline GEUMTRI & 15.0 & 46.0 & 0.0 & 46.0 & 62.2 & 4.1 & 11.7 & 137.7 \\
\hline BROMPUM & 15.0 & 41.0 & 0.0 & 41.0 & 61.2 & 4.1 & 10.4 & 108.8 \\
\hline ELYMNNN & 15.0 & 15.0 & 0.0 & 15.0 & 49.1 & 3.3 & 4.8 & 23.3 \\
\hline ASTRALP & 15.0 & 18.0 & 0.0 & 18.0 & 49.1 & 3.3 & 5.0 & 24.9 \\
\hline POAPRA & 15.0 & 12.0 & 0.0 & 12.0 & 47.1 & 3.1 & 3.7 & 13.9 \\
\hline VICIAME & 15.0 & 12.0 & 0.0 & 12.0 & 44.1 & 2.9 & 3.1 & 9.5 \\
\hline GALIBOR & 15.0 & 6.0 & 1.0 & 7.0 & 40.0 & 2.7 & 2.0 & 4.0 \\
\hline GENTAMA & 15.0 & 10.0 & 0.0 & 10.0 & 37.3 & 2.5 & 3.3 & 10.9 \\
\hline ARCTUVA & 15.0 & 15.0 & 0.0 & 15.0 & 35.0 & 2.3 & 5.2 & 26.8 \\
\hline STIPCOL & 15.0 & 21.0 & 0.0 & 21.0 & 28.0 & 1.9 & 5.6 & 31.3 \\
\hline GEUMALE & 15.0 & 8.0 & 0.0 & 8.0 & 26.2 & 1.7 & 2.4 & 5.9 \\
\hline CERAARV & 15.0 & 17.0 & 0.0 & 17.0 & 24.1 & 1.6 & 4.4 & 19.1 \\
\hline ERIGPER & 15.0 & 10.0 & 0.0 & 10.0 & 23.0 & 1.5 & 3.3 & 11.0 \\
\hline AGROSCA & 15.0 & 10.0 & 0.0 & 10.0 & 22.2 & 1.5 & 2.6 & 6.9 \\
\hline CAREPRA & 15.0 & 11.0 & 0.0 & 11.0 & 21.0 & 1.4 & 3.7 & 13.7 \\
\hline KOELMAC & 15.0 & 7.0 & 0.0 & 7.0 & 20.3 & 1.4 & 2.2 & 5.0 \\
\hline MERTPAN & 15.0 & 9.0 & 0.0 & 9.0 & 19.4 & 1.3 & 2.5 & 6.4 \\
\hline BROMINE & 15.0 & 10.0 & 0.0 & 10.0 & 18.1 & 1.2 & 2.9 & 8.4 \\
\hline PHLEPRA & 15.0 & 17.0 & 0.0 & 17.0 & 17.0 & 1.2 & 4.4 & 19.2 \\
\hline ROSAACI & 15.0 & 16.0 & 0.0 & 16.0 & 17.1 & 1.1 & 4.1 & 17.0 \\
\hline $\begin{array}{l}\text { CALACAN } \\
\text { (plus } 47 \text { species) }\end{array}$ & 15.0 & 5.0 & 0.0 & 5.0 & 15.2 & 1.0 & 1.8 & 3.1 \\
\hline
\end{tabular}




\section{CLUSTER}

16

\begin{tabular}{|c|c|c|c|c|c|c|c|c|}
\hline & $\mathrm{N}$ & Range & Minimum & Maximum & Sum & \multicolumn{2}{|c|}{ Mean Std. Deviation } & Variance \\
\hline FESTSPP & 10.0 & 43.0 & 0.0 & 43.0 & 120.0 & 12.0 & 14.9 & 221.6 \\
\hline FESTIDA & 10.0 & 24.0 & 0.0 & 24.0 & 119.0 & 11.9 & 7.5 & 57.0 \\
\hline GEUMTRI & 10.0 & 20.0 & 0.0 & 20.0 & 88.0 & 8.8 & 7.3 & 54.0 \\
\hline POAPRA & 10.0 & 21.0 & 0.0 & 21.0 & 78.0 & 7.8 & 8.6 & 74.0 \\
\hline DANTPAR & 10.0 & 17.0 & 0.0 & 17.0 & 55.0 & 5.5 & 6.3 & 39.6 \\
\hline AGROTRA & 10.0 & 6.0 & 4.0 & 10.0 & 54.0 & 5.4 & 2.1 & 4.3 \\
\hline FESTSCA & 10.0 & 22.0 & 0.0 & 22.0 & 52.0 & 5.2 & 8.4 & 71.1 \\
\hline POTEFRU & 10.0 & 14.0 & 1.0 & 15.0 & 43.0 & 4.3 & 4.1 & 17.1 \\
\hline ACHIMIL & 10.0 & 7.0 & 1.0 & 8.0 & 42.0 & 4.2 & 2.8 & 7.7 \\
\hline DODECON & 10.0 & 12.0 & 0.0 & 12.0 & 39.0 & 3.9 & 4.6 & 20.8 \\
\hline GALIBOR & 10.0 & 5.0 & 0.0 & 5.0 & 29.0 & 2.9 & 1.9 & 3.7 \\
\hline POTEGRA & 10.0 & 5.0 & 1.0 & 6.0 & 29.0 & 2.9 & 1.7 & 2.8 \\
\hline TARAOFF & 10.0 & 5.0 & 1.0 & 6.0 & 28.0 & 2.8 & 2.0 & 4.2 \\
\hline ANEMMUL & 10.0 & 4.0 & 1.0 & 5.0 & 26.0 & 2.6 & 1.7 & 2.9 \\
\hline PENSPRO & 10.0 & 9.0 & 0.0 & 9.0 & 23.0 & 2.3 & 3.7 & 14.0 \\
\hline CARESPP & 10.0 & 14.0 & 0.0 & 14.0 & 23.0 & 2.3 & 4.5 & 20.5 \\
\hline VICIAME & 10.0 & 3.0 & 0.0 & 3.0 & 18.0 & 1.8 & 1.2 & 1.5 \\
\hline STIPRIC & 10.0 & 8.0 & 0.0 & 8.0 & 18.0 & 1.8 & 3.3 & 10.8 \\
\hline PENSCON & 10.0 & 5.0 & 0.0 & 5.0 & 17.0 & 1.7 & 2.1 & 4.5 \\
\hline KOELMAC & 10.0 & 1.0 & 1.0 & 2.0 & 17.0 & 1.7 & 0.5 & 0.2 \\
\hline MYOSALP & 10.0 & 4.0 & 0.0 & 4.0 & 15.0 & 1.5 & 1.5 & 2.3 \\
\hline CAREPRA & 10.0 & 15.0 & 0.0 & 15.0 & 15.0 & 1.5 & 4.7 & 22.5 \\
\hline AGOSGLA & 10.0 & 3.0 & 0.0 & 3.0 & 15.0 & 1.5 & 1.1 & 1.2 \\
\hline CAREOBT & 10.0 & 4.0 & 0.0 & 4.0 & 13.0 & 1.3 & 1.7 & 2.9 \\
\hline CERAARV & 10.0 & 3.0 & 0.0 & 3.0 & 12.0 & 1.2 & 0.8 & 0.6 \\
\hline CAREXER & 10.0 & 5.0 & 0.0 & 5.0 & 12.0 & 1.2 & 2.0 & 4.2 \\
\hline FRAGVIR & 10.0 & 4.0 & 0.0 & 4.0 & 10.2 & 1.0 & 1.4 & 2.0 \\
\hline LUPISER & 10.0 & 4.0 & 0.0 & 4.0 & 10.1 & 1.0 & 1.6 & 2.6 \\
\hline ROSAACI & 10.0 & 4.0 & 0.0 & 4.0 & 10.0 & 1.0 & 1.6 & 2.7 \\
\hline ASTESPP & 10.0 & 6.0 & 0.0 & 6.0 & 10.0 & 1.0 & 2.0 & 4.0 \\
\hline
\end{tabular}

\section{CLUSTER}

17

MOSSSPP
CAREPRG
AGROTRA
KOBRMYO
ARCTUVA
GEUMTRI
DESCCES
FESTSAX
BETUGLA
SOLIMUL
POASAN
THALVEN

$\begin{array}{rrrr}\text { N } & \text { Range } & \text { Minimum } & \text { Maximum } \\ 4.0 & 6.0 & 24.0 & 30.0 \\ 4.0 & 40.0 & 0.0 & 40.0 \\ 4.0 & 7.0 & 6.0 & 13.0 \\ 4.0 & 23.0 & 0.0 & 23.0 \\ 4.0 & 17.0 & 0.0 & 17.0 \\ 4.0 & 17.0 & 0.0 & 17.0 \\ 4.0 & 13.0 & 0.0 & 13.0 \\ 4.0 & 11.0 & 0.0 & 11.0 \\ 4.0 & 20.0 & 0.0 & 20.0 \\ 4.0 & 13.0 & 0.0 & 13.0 \\ 4.0 & 19.0 & 0.0 & 19.0 \\ 4.0 & 15.0 & 0.0 & 15.0\end{array}$

Sum

108.0

58.0

43.0

33.0

29.0

25.0

25.0

23.0

20.0

19.0

19.0

15.0
Mean Std. Deviation Variance

27.0

2.9

18.0

3.2

10.9

8.6

7.6

7.2

4.8

10.0

6.2

$\begin{array}{lll}4.8 & 9.5 & 90.3\end{array}$

$\begin{array}{lll}3.8 & 7.5 & 56.3\end{array}$

8.7

323.7

10.3

118.9

74.3

57.6

52.3

22.9

100.0

37.9 


$\begin{array}{lrlllllrr}\text { POTEFRU } & 4.0 & 3.0 & 1.0 & 4.0 & 10.0 & 2.5 & 1.3 & 1.7 \\ \text { POTEGRA } & 4.0 & 8.0 & 0.0 & 8.0 & 9.0 & 2.3 & 3.9 & 14.9 \\ \text { POAINT } & 4.0 & 9.0 & 0.0 & 9.0 & 9.0 & 2.3 & 4.5 & 20.3 \\ \text { PENSPRO } & 4.0 & 5.0 & 0.0 & 5.0 & 9.0 & 2.3 & 2.1 & 4.3 \\ \text { DANTPAR } & 4.0 & 9.0 & 0.0 & 9.0 & 9.0 & 2.3 & 4.5 & 20.3 \\ \text { ACHIMIL } & 4.0 & 2.0 & 1.0 & 3.0 & 8.0 & 2.0 & 0.8 & 0.7 \\ \text { POLYVIV } & 4.0 & 7.0 & 0.0 & 7.0 & 7.1 & 1.8 & 3.5 & 12.1 \\ \text { FESTSCA } & 4.0 & 7.0 & 0.0 & 7.0 & 7.0 & 1.8 & 3.5 & 12.3 \\ \text { AGOSGLA } & 4.0 & 3.0 & 1.0 & 4.0 & 7.0 & 1.8 & 1.5 & 2.3 \\ \text { THALOCC } & 4.0 & 6.0 & 0.0 & 6.0 & 6.0 & 1.5 & 3.0 & 9.0 \\ \text { CERAARV } & 4.0 & 3.0 & 0.0 & 3.0 & 6.0 & 1.5 & 1.3 & 1.7 \\ \text { PINUCON } & 4.0 & 5.0 & 0.0 & 5.0 & 5.0 & 1.3 & 2.5 & 6.3 \\ \text { VALEDIO } & 4.0 & 3.0 & 0.0 & 3.0 & 4.0 & 1.0 & 1.4 & 2.0\end{array}$

\section{CLUSTER}

18

BROMCIL

CAREPRG

FESTSCA

AGROTRA

GEUMTRI

ACHIMIL

HEDYALP

POAPRA

BETUGLA

POTEDIV

ELYMINN

AGRODAS

ARCTUVA

CAREFIL

VICIAME

SOLIMUL

POLYVIV

FRAGVIR

DANTCAL

OXYTMON

AGOSGLA

THALVEN

POTEFRU

FESTIDA

(plus 38 species)
N

6.0

6.0

6.0

6.0

6.0

6.0

6.0

6.0

6.0

6.0

6.0

6.0

6.0

6.0

6.0

6.0

6.0

6.0

6.0

6.0

6.0

6.0

6.0

6.0
Range Minimum Maximum 35.0

7.0

13.0

13.0

14.0

8.0

5.0

14.0

16.0

8.0

11.0

11.0

15.0

15.0

5.0

12.0

7.0

7.0

4.0

8.0

1.9

3.0

3.0

5.0
0.0

7.0

0.0

0.0

0.0

1.0

1.0

0.0

0.0

0.0

0.0

0.0

0.0

0.0

0.0

0.0

0.0

0.0

0.0

0.0

0.1

0.0

0.0

0.0
35.0

14.0

13.0

13.0

14.0

9.0

6.0

14.0

16.0

8.0

11.0

11.0

15.0

15.0

5.0

12.0

7.0

7.0

4.0

8.0

2.0

3.0

3.0

5.0
Sum

57.0

55.0

30.0

30.0

26.0

22.0

22.0

20.0

20.0

18.0

18.0

18.0

17.0

16.0

14.0

13.0

12.0

11.0

9.0

8.0

7.1

6.0

6.0

6.0
Mean Std. Deviation Variance

9.5

. $13.1 \quad 171.1$

9.2

5.0

5.0

4.3

3.7

3.7

3.3

3.3

3.0

3.0

3.0

2.8

2.7

2.3

2.2

2.0

1.8

1.5

1.3

1.2

1.0

1.0

1.0
2.8

5.7

4.9

5.9

2.8

1.8

5.8

6.4

4.0

4.6

4.8

6.0

6.1

2.6

4.8

2.9

2.6

1.6

3.3

0.7

1.3

1.1

2.0
7.8

32.8

24.0

34.7

7.9

3.1

33.1

41.1

15.6

20.8

23.2

36.2

36.6

6.7

23.3

8.4

7.0

2.7

10.7

0.5

1.6

1.2

4.0

\section{CLUSTER}

19

N

16.0

16.0

16.0

16.0
Range Minimum Maximum

$$
56.0
$$

29.0

31.0

40.0

$$
23.0
$$

4.0

0.0

1.0

\section{0}

33.0

31.0

41.0
Sum 717.0

232.0

171.0

155.0
Mean Std. Deviation Variance 44.8

14.5

10.7

9.7
15.6

9.1

10.2

9.8
243.5

82.4 


\begin{tabular}{|c|c|c|c|c|c|c|c|c|}
\hline ASTECIL & 16.0 & 45.0 & 0.0 & 45.0 & 149.0 & 9.3 & 14.5 & 210.9 \\
\hline THALVEN & 16.0 & 37.0 & 0.0 & 37.0 & 146.0 & 9.1 & 11.5 & 131.6 \\
\hline JUNCBAL & 16.0 & 37.0 & 0.0 & 37.0 & 128.0 & 8.0 & 10.9 & 119.2 \\
\hline GEUMTRI & 16.0 & 20.0 & 0.0 & 20.0 & 110.0 & 6.9 & 7.6 & 57.1 \\
\hline BROMCIL & 16.0 & 31.0 & 0.0 & 31.0 & 103.1 & 6.4 & 11.1 & 123.5 \\
\hline FESTSAX & 16.0 & 34.0 & 0.0 & 34.0 & 91.0 & 5.7 & 10.2 & 103.4 \\
\hline FRAGVIR & 16.0 & 19.0 & 0.0 & 19.0 & 87.3 & 5.5 & 6.9 & 47.2 \\
\hline DANTCAL & 16.0 & 25.0 & 0.0 & 25.0 & 77.1 & 4.8 & 7.9 & 62.9 \\
\hline FESTSCA & 16.0 & 31.0 & 0.0 & 31.0 & 75.0 & 4.7 & 9.1 & 82.9 \\
\hline POAPRA & 16.0 & 36.0 & 0.0 & 36.0 & 61.2 & 3.8 & 8.9 & 79.8 \\
\hline POTEGRA & 16.0 & 13.0 & 0.0 & 13.0 & 56.0 & 3.5 & 4.2 & 18.0 \\
\hline ELYMINN & 16.0 & 29.0 & 0.0 & 29.0 & 48.0 & 3.0 & 7.8 & 60.4 \\
\hline CAREPRT & 16.0 & 26.0 & 0.0 & 26.0 & 48.0 & 3.0 & 8.2 & 67.7 \\
\hline TARAOFF & 16.0 & 18.0 & 0.0 & 18.0 & 47.0 & 2.9 & 4.5 & 20.3 \\
\hline POLYVIV & 16.0 & 18.0 & 0.0 & 18.0 & 44.0 & 2.8 & 6.0 & 36.3 \\
\hline GALIBOR & 16.0 & 14.0 & 0.0 & 14.0 & 43.2 & 2.7 & 3.5 & 12.2 \\
\hline CERAARV & 16.0 & 12.0 & 0.0 & 12.0 & 39.3 & 2.5 & 3.3 & 11.1 \\
\hline ASTRALP & 16.0 & 24.0 & 0.0 & 24.0 & 38.3 & 2.4 & 6.0 & 35.6 \\
\hline VICIAME & 16.0 & 18.0 & 0.0 & 18.0 & 35.0 & 2.2 & 4.8 & 23.4 \\
\hline PENSPRO & 16.0 & 9.0 & 0.0 & 9.0 & 34.1 & 2.1 & 3.2 & 10.4 \\
\hline SOLIMUL & 16.0 & 14.0 & 0.0 & 14.0 & 29.0 & 1.8 & 3.8 & 14.1 \\
\hline RUMEACE & 16.0 & 9.0 & 0.0 & 9.0 & 27.0 & 1.7 & 3.0 & 8.9 \\
\hline POTEDIV & 16.0 & 13.0 & 0.0 & 13.0 & 26.0 & 1.6 & 3.8 & 14.4 \\
\hline KOBRMYO & 16.0 & 25.0 & 0.0 & 25.0 & 25.0 & 1.6 & 6.3 & 39.1 \\
\hline HEDYALP & 16.0 & 13.0 & 0.0 & 13.0 & 24.0 & 1.5 & 3.6 & 12.8 \\
\hline POTEFRU & 16.0 & 14.0 & 0.0 & 14.0 & 21.1 & 1.3 & 3.5 & 12.1 \\
\hline SALIBAR & 16.0 & 16.0 & 0.0 & 16.0 & 18.1 & 1.1 & 4.0 & 16.0 \\
\hline DELPGLA & 16.0 & 8.0 & 0.0 & 8.0 & 17.1 & 1.1 & 2.3 & 5.1 \\
\hline AGOSGLA & 16.0 & 4.0 & 0.0 & 4.0 & 16.3 & 1.0 & 1.1 & 1.2 \\
\hline $\begin{array}{l}\text { OXYTSPL } \\
\text { (plus } 47 \text { species) }\end{array}$ & 16.0 & 9.0 & 0.0 & 9.0 & 15.2 & 1.0 & 2.4 & 5.6 \\
\hline
\end{tabular}

\section{CLUSTER}

20

\begin{tabular}{|c|c|c|c|c|c|c|c|c|}
\hline & $\mathrm{N}$ & Range & Minimum & Maximum & Sum & \multicolumn{2}{|c|}{ Mean Std. Deviation } & Variance \\
\hline ELYMINN & 5.0 & 17.0 & 15.0 & 32.0 & 122.0 & 24.4 & 7.0 & 49.3 \\
\hline BROMINE & 5.0 & 15.0 & 0.0 & 15.0 & 19.0 & 3.8 & 6.4 & 40.7 \\
\hline POAPRA & 5.0 & 8.0 & 0.0 & 8.0 & 17.0 & 3.4 & 4.2 & 17.8 \\
\hline SHEPCAN & 5.0 & 16.0 & 0.0 & 16.0 & 16.0 & 3.2 & 7.1 & 51.0 \\
\hline AGROTRA & 5.0 & 6.0 & 0.0 & 6.0 & 16.0 & 3.2 & 2.9 & 8.7 \\
\hline HEDYALP & 5.0 & 8.0 & 0.0 & 8.0 & 14.0 & 2.8 & 3.3 & 11.1 \\
\hline PICEGLA & 5.0 & 10.0 & 0.0 & 10.0 & 14.0 & 2.8 & 4.4 & 19.2 \\
\hline FRAGVIR & 5.0 & 5.0 & 0.0 & 5.0 & 13.0 & 2.6 & 2.3 & 5.3 \\
\hline CARESPP & 5.0 & 6.0 & 0.0 & 6.0 & 12.0 & 2.4 & 3.3 & 10.8 \\
\hline ASTRALP & 5.0 & 8.0 & 0.0 & 8.0 & 12.0 & 2.4 & 3.4 & 11.3 \\
\hline TARAOFF & 5.0 & 7.0 & 0.0 & 7.0 & 11.0 & 2.2 & 2.9 & 8.7 \\
\hline ROSAACI & 5.0 & 8.0 & 0.0 & 8.0 & 11.0 & 2.2 & 3.5 & 12.2 \\
\hline SALISPP & 5.0 & 10.1 & 0.0 & 10.1 & 10.2 & 2.0 & 4.5 & 20.3 \\
\hline PHLECOM & 5.0 & 10.0 & 0.0 & 10.0 & 10.0 & 2.0 & 4.5 & 20.0 \\
\hline ASTECIL & 5.0 & 10.0 & 0.0 & 10.0 & 10.0 & 2.0 & 4.5 & 20.0 \\
\hline ACHIMIL & 5.0 & 4.0 & 1.0 & 5.0 & 10.0 & 2.0 & 1.7 & 3.0 \\
\hline TRISSPI & 5.0 & 5.0 & 0.0 & 5.0 & 9.0 & 1.8 & 2.5 & 6.2 \\
\hline
\end{tabular}




$\begin{array}{llllllllr}\text { GALIBOR } & 5.0 & 5.0 & 0.0 & 5.0 & 9.0 & 1.8 & 2.2 & 4.7 \\ \text { EPILANG } & 5.0 & 5.0 & 0.0 & 5.0 & 8.0 & 1.6 & 2.1 & 4.3 \\ \text { CAREPEN } & 5.0 & 8.0 & 0.0 & 8.0 & 8.0 & 1.6 & 3.6 & 12.8 \\ \text { SYMPOCC } & 5.0 & 7.0 & 0.0 & 7.0 & 7.0 & 1.4 & 3.1 & 9.8 \\ \text { KOELMAC } & 5.0 & 5.0 & 0.0 & 5.0 & 6.0 & 1.2 & 2.2 & 4.7 \\ \text { POASAN } & 5.0 & 4.0 & 0.0 & 4.0 & 5.0 & 1.0 & 1.7 & 3.0 \\ \text { CAMPROT } & 5.0 & 2.0 & 0.0 & 2.0 & 5.0 & 1.0 & 0.7 & 0.5\end{array}$

CLUSTER

21

$\begin{array}{rrrr}\text { N } & \text { Range } & \text { Minimum } & \text { Maximum } \\ 2.0 & 30.0 & 0.0 & 30.0 \\ 2.0 & 20.0 & 0.0 & 20.0 \\ 2.0 & 0.0 & 10.0 & 10.0 \\ 2.0 & 7.0 & 0.0 & 7.0 \\ 2.0 & 7.0 & 0.0 & 7.0 \\ 2.0 & 5.0 & 0.0 & 5.0 \\ 2.0 & 5.0 & 0.0 & 5.0 \\ 2.0 & 3.0 & 1.0 & 4.0 \\ 2.0 & 4.0 & 0.0 & 4.0 \\ 2.0 & 3.0 & 0.0 & 3.0 \\ 2.0 & 3.0 & 0.0 & 3.0 \\ 2.0 & 2.0 & 0.0 & 2.0 \\ 2.0 & 2.0 & 0.0 & 2.0 \\ 2.0 & 2.0 & 0.0 & 2.0 \\ 2.0 & 1.0 & 0.0 & 1.0 \\ 2.0 & 1.0 & 0.0 & 1.0 \\ 2.0 & 1.0 & 0.0 & 1.0 \\ 2.0 & 1.0 & 0.0 & 1.0 \\ 2.0 & 1.0 & 0.0 & 1.0 \\ 2.0 & 1.0 & 0.0 & 1.0 \\ 2.0 & 1.0 & 0.0 & 1.0 \\ 2.0 & 1.0 & 0.0 & 1.0 \\ 2.0 & 1.0 & 0.0 & 1.0\end{array}$

$\begin{array}{rrrrrrrr}N & \text { Range } & \text { Minimum } & \text { Maximum } & \text { Sum } & \text { Mean Std. Deviation } & \text { Variance } \\ 2.0 & 50.0 & 30.0 & 80.0 & 110.0 & 55.0 & 35.4 & 1250.0 \\ 2.0 & 25.0 & 0.0 & 25.0 & 25.0 & 12.5 & 17.7 & 312.5 \\ 2.0 & 17.0 & 3.0 & 20.0 & 23.0 & 11.5 & 12.0 & 144.5 \\ 2.0 & 1.0 & 2.0 & 3.0 & 5.0 & 2.5 & 0.7 & 0.5 \\ 2.0 & 5.0 & 0.0 & 5.0 & 5.0 & 2.5 & 3.5 & 12.5 \\ 2.0 & 3.0 & 0.0 & 3.0 & 3.0 & 1.5 & 2.1 & 4.5 \\ 2.0 & 3.0 & 0.0 & 3.0 & 3.0 & 1.5 & 2.1 & 4.5 \\ 2.0 & 2.0 & 0.0 & 2.0 & 2.0 & 1.0 & 1.4 & 2.0 \\ 2.0 & 2.0 & 0.0 & 2.0 & 2.0 & 1.0 & 1.4 & 2.0 \\ 2.0 & 2.0 & 0.0 & 2.0 & 2.0 & 1.0 & 1.4 & 2.0 \\ 2.0 & 2.0 & 0.0 & 2.0 & 2.0 & 1.0 & 1.4 & 2.0 \\ 2.0 & 0.0 & 1.0 & 1.0 & 2.0 & 1.0 & 0.0 & 0.0\end{array}$

\begin{tabular}{rrrr} 
Sum & \multicolumn{2}{c}{ Mean Std. Deviation } & Variance \\
30.0 & 15.0 & 21.2 & 450.0 \\
20.0 & 10.0 & 14.1 & 200.0 \\
20.0 & 10.0 & 0.0 & 0.0 \\
7.0 & 3.5 & 5.0 & 24.5 \\
7.0 & 3.5 & 5.0 & 24.5 \\
5.0 & 2.5 & 3.5 & 12.5 \\
5.0 & 2.5 & 3.5 & 12.5 \\
5.0 & 2.5 & 2.1 & 4.5 \\
4.0 & 2.0 & 2.8 & 8.0 \\
3.0 & 1.5 & 2.1 & 4.5 \\
3.0 & 1.5 & 2.1 & 4.5 \\
2.0 & 1.0 & 1.4 & 2.0 \\
2.0 & 1.0 & 1.4 & 2.0 \\
2.0 & 1.0 & 1.4 & 2.0 \\
1.0 & 0.5 & 0.7 & 0.5 \\
1.0 & 0.5 & 0.7 & 0.5 \\
1.0 & 0.5 & 0.7 & 0.5 \\
1.0 & 0.5 & 0.7 & 0.5 \\
1.0 & 0.5 & 0.7 & 0.5 \\
1.0 & 0.5 & 0.7 & 0.5 \\
1.0 & 0.5 & 0.7 & 0.5 \\
1.0 & 0.5 & 0.7 & 0.5 \\
1.0 & 0.5 & 0.7 & 0.5
\end{tabular}

KOBRMYO

AGROSPP

KOELMAC

ELYMINN

CERAARV

ARCTUVA

ACHIMIL

MYOSALP

JUNIHOR

DELPGLA

POTEFRU

ANEMPAT

ANEMMUL

PENSPRO

HETEVIL

GUTISAR

ERIGCAE

BROMINE

BOTRLUN

ARTECAN

AGROSCA

FRAGVIR

CAREXER

TORTRUR

DESCCES

PHLECOM

HERALAN

EPILANG

ARCTUVA

ACHIMIL
AGROSPP

ELYMINN

SALIGLA

\section{CLUSTER \\ CLUSTER
22}

Geowest Environmental Consultants Ltd. 


\begin{tabular}{|c|c|c|c|c|c|c|c|}
\hline TARAOFF & 2.0 & 1.0 & 0.0 & 1.0 & 1.0 & 0.5 & 0.7 \\
\hline POTEFRU & 2.0 & 1.0 & 0.0 & 1.0 & 1.0 & 0.5 & 0.7 \\
\hline POTEDIV & 2.0 & 1.0 & 0.0 & 1.0 & 1.0 & 0.5 & 0.7 \\
\hline POLYVIV & 2.0 & 1.0 & 0.0 & 1.0 & 1.0 & 0.5 & 0.7 \\
\hline POASPP & 2.0 & 1.0 & 0.0 & 1.0 & 1.0 & 0.5 & 0.7 \\
\hline PENSPRO & 2.0 & 1.0 & 0.0 & 1.0 & 1.0 & 0.5 & 0.7 \\
\hline MYOSALP & 2.0 & 1.0 & 0.0 & 1.0 & 1.0 & 0.5 & 0.7 \\
\hline HEDYSUL & 2.0 & 1.0 & 0.0 & 1.0 & 1.0 & 0.5 & 0.7 \\
\hline GERARIC & 2.0 & 1.0 & 0.0 & 1.0 & 1.0 & 0.5 & 0.7 \\
\hline GENTAMA & 2.0 & 1.0 & 0.0 & 1.0 & 1.0 & 0.5 & 0.7 \\
\hline ERIOUMB & 2.0 & 1.0 & 0.0 & 1.0 & 1.0 & 0.5 & 0.7 \\
\hline DELPGLA & 2.0 & 1.0 & 0.0 & 1.0 & 1.0 & 0.5 & 0.7 \\
\hline CARESPP & 2.0 & 1.0 & 0.0 & 1.0 & 1.0 & 0.5 & 0.7 \\
\hline CAMPROT & 2.0 & 1.0 & 0.0 & 1.0 & 1.0 & 0.5 & 0.7 \\
\hline BOTRLUN & 2.0 & 1.0 & 0.0 & 1.0 & 1.0 & 0.5 & 0.7 \\
\hline AGOSGLA & 2.0 & 1.0 & 0.0 & 1.0 & 1.0 & 0.5 & 0.7 \\
\hline
\end{tabular}

DANTCAL

PENSPRO

AGROSPP

TRISSPI

PHLECOM

VALEDIO

FRAGVIR

TORTRUR

DELPGLA

CARESPP

GALIBOR

FESTSPP

BETUGLA

ACHIMIL

VICIAME

POTEFRU

EPILANG

THALOCC

POTEDIV

GENTAMA

ELYMINN

ASTECIL

ARCTUVA

ANTEPAR
N

\section{0}

2.0

2.0

2.0

2.0

2.0

2.0

2.0

2.0

2.0

2.0

2.0

2.0

2.0

2.0

2.0

2.0

2.0

2.0

2.0

2.0

2.0

2.0

2.0

Range
5.0
30.0
7.0
10.0
10.0
7.0
7.0
4.0
6.0
4.0
5.0
5.0
5.0
0.0
1.0
3.0
3.0
2.0
2.0
2.0
1.0
1.0
1.0
1.0

\section{CLUSTER \\ 23}

$\begin{array}{rr}\text { Minimum } & \text { Maximum } \\ 15.0 & 20.0 \\ 0.0 & 30.0 \\ 5.0 & 12.0 \\ 0.0 & 10.0 \\ 0.0 & 10.0 \\ 1.0 & 8.0 \\ 1.0 & 8.0 \\ 1.0 & 5.0 \\ 0.0 & 6.0 \\ 1.0 & 5.0 \\ 0.0 & 5.0 \\ 0.0 & 5.0 \\ 0.0 & 5.0 \\ 2.0 & 2.0 \\ 1.0 & 2.0 \\ 0.0 & 3.0 \\ 0.0 & 3.0 \\ 0.0 & 2.0 \\ 0.0 & 2.0 \\ 0.0 & 2.0 \\ 0.0 & 1.0 \\ 0.0 & 1.0 \\ 0.0 & 1.0 \\ 0.0 & 1.0 \\ & \end{array}$

Sum

Mean Std. Deviation

Variance

35.0

17.5

3.5

12.5

30.0

15.0

21.2

450.0

17.0

8.5

5.0

24.5

10.0

5.0

$7.1 \quad 50.0$

10.0

5.0

7.1

50.0

9.0

4.5

4.9

24.5

4.5

4.9

24.5

6.0

3.0

2.8

8.0

6.0

3.0

4.2

18.0

6.0

3.0

2.8

8.0

$5.0 \quad 5.0$

2.5

3.5

12.5

5.0

2.5

3.5

12.5

2.5

3.5

12.5

2.0

0.0

0.0

4.0
3.0

1.5

0.7

0.5

1.5

2.1

4.5

3.0

1.5

2.1

4.5

2.0

1.0

1.4

2.0

1.0

1.4

2.0

1.0

1.4

2.0

2.0
1.0

0.5

0.7

0.5

1.0

0.5

0.7

0.5

1.0

0.5

0.7

0.5

1.0

0.5

0.7

0.5

\section{CLUSTER}

24

N Range Minimum Maximum

Sum Mean Std. Deviation Variance

FESTSCA

50.0

44.0

16.0

$\begin{array}{rrrr}44.0 & 16.0 & 60.0 & 1890.0 \\ 41.0 & 0.0 & 41.0 & 296.0\end{array}$

1890.0

13.4

180.2

50.0

Geowest Environmental Consultants Ltd. 


$\begin{array}{lrrrrrrrr}\text { AGROTRA } & 50.0 & 23.0 & 0.0 & 23.0 & 295.0 & 5.9 & 4.4 & 19.3 \\ \text { GEUMTRI } & 50.0 & 29.0 & 0.0 & 29.0 & 252.1 & 5.0 & 7.1 & 51.0 \\ \text { FESTIDA } & 50.0 & 48.0 & 0.0 & 48.0 & 250.3 & 5.0 & 9.4 & 88.3 \\ \text { CAREOBT } & 50.0 & 22.0 & 0.0 & 22.0 & 239.0 & 4.8 & 6.4 & 41.3 \\ \text { PENSCON } & 50.0 & 39.0 & 0.0 & 39.0 & 224.2 & 4.5 & 8.5 & 73.0 \\ \text { ACHIMIL } & 50.0 & 38.0 & 0.0 & 38.0 & 183.3 & 3.7 & 5.4 & 28.7 \\ \text { FRAGVIR } & 50.0 & 40.0 & 0.0 & 40.0 & 138.1 & 2.8 & 6.3 & 39.5 \\ \text { GALIBOR } & 50.0 & 11.0 & 0.0 & 11.0 & 133.2 & 2.7 & 2.8 & 7.7 \\ \text { STIPRIC } & 50.0 & 28.0 & 0.0 & 28.0 & 131.3 & 2.6 & 5.4 & 29.6 \\ \text { POAPRA } & 50.0 & 23.0 & 0.0 & 23.0 & 127.3 & 2.5 & 5.1 & 25.8 \\ \text { ARCTUVA } & 50.0 & 23.0 & 0.0 & 23.0 & 116.0 & 2.3 & 5.4 & 29.2 \\ \text { POTEFRU } & 50.0 & 23.0 & 0.0 & 23.0 & 111.1 & 2.2 & 4.0 & 16.3 \\ \text { POTEGRA } & 50.0 & 11.0 & 0.0 & 11.0 & 93.4 & 1.9 & 2.8 & 7.7 \\ \text { MOSSSPP } & 50.0 & 20.0 & 0.0 & 20.0 & 87.0 & 1.7 & 4.5 & 20.0 \\ \text { ELYMINN } & 50.0 & 34.0 & 0.0 & 34.0 & 79.2 & 1.6 & 5.5 & 30.6 \\ \text { DANTCAL } & 50.0 & 16.0 & 0.0 & 16.0 & 74.2 & 1.5 & 3.5 & 12.1 \\ \text { POACOM } & 50.0 & 24.0 & 0.0 & 24.0 & 67.0 & 1.3 & 4.9 & 23.9 \\ \text { ANEMMUL } & 50.0 & 11.0 & 0.0 & 11.0 & 65.6 & 1.3 & 2.4 & 5.6 \\ \text { LUPISER } & 50.0 & 23.0 & 0.0 & 23.0 & 64.1 & 1.3 & 3.9 & 15.6 \\ \text { AGOSGLA } & 50.0 & 9.0 & 0.0 & 9.0 & 59.0 & 1.2 & 1.7 & 2.8 \\ \text { KOBRMYO } & 50.0 & 37.0 & 0.0 & 37.0 & 57.0 & 1.1 & 5.6 & 31.1 \\ \text { AGROSPI } & 50.0 & 21.0 & 0.0 & 21.0 & 56.0 & 1.1 & 3.8 & 14.4 \\ \text { GERAVIS } & 50.0 & 9.0 & 0.0 & 9.0 & 54.0 & 1.1 & 2.0 & 4.1 \\ \text { POAPAL } & 50.0 & 41.0 & 0.0 & 41.0 & 51.0 & 1.0 & 5.9 & 34.9 \\ \text { TARAOFF } & 50.0 & 15.0 & 0.0 & 15.0 & 51.0 & 1.0 & 2.6 & 6.5 \\ \text { PHLEPRA } & 50.0 & 25.0 & 0.0 & 25.0 & 50.0 & 1.0 & 4.0 & 16.1 \\ \text { EPILANG } & 50.0 & 23.0 & 0.0 & 23.0 & 48.2 & 1.0 & 3.5 & 12.1 \\ \text { KOELMAC } & 50.0 & 7.0 & 0.0 & 7.0 & 47.7 & 1.0 & 1.6 & 2.6 \\ \text { (plus 118 species) } & & & & & & & & \end{array}$

\section{CLUSTER}

25

\begin{tabular}{|c|c|c|c|c|c|c|c|c|}
\hline & $N$ & Range & Minimum & Maximum & Sum & Mean & ation & Vanance \\
\hline FESTSCA & 7.0 & 24.0 & 11.0 & 35.0 & 159.0 & 22.7 & 8.0 & 63. \\
\hline GEUMTRI & 7.0 & 35.0 & 0.0 & 35.0 & 75.0 & 10.7 & 12.2 & 147. \\
\hline CARESPP & 7.0 & 25.0 & 0.0 & 25.0 & 72.0 & 10.3 & 9.6 & 92. \\
\hline EPILANG & 7.0 & 35.0 & 0.0 & 35.0 & 68.0 & 9.7 & 14.1 & 197 \\
\hline POTEDIV & 7.0 & 25.0 & 0.0 & 25.0 & 45.0 & 6.4 & 11.1 & 122. \\
\hline ACHIMIL & 7.0 & 14.0 & 2.0 & 16.0 & 44.0 & 6.3 & 4.8 & 22 \\
\hline POTEFRU & 7.0 & 15.0 & 0.0 & 15.0 & 38.0 & 5.4 & 5.0 & 25.3 \\
\hline ELYMINN & 7.0 & 18.0 & 0.0 & 18.0 & 38.0 & 5.4 & 8.3 & 69. \\
\hline FRAGVIR & 7.0 & 10.0 & 0.0 & 10.0 & 35.0 & 5.0 & 4.5 & 20.7 \\
\hline TARAOFF & 7.0 & 12.0 & 0.0 & 12.0 & 34.0 & 4.9 & 4.9 & 24.1 \\
\hline AGROTRA & 7.0 & 14.0 & 0.0 & 14.0 & 29.0 & 4.1 & 4.9 & 24 \\
\hline CAREPRA & 7.0 & 25.0 & 0.0 & 25.0 & 25.0 & 3.6 & 9.4 & 89. \\
\hline GALIBOR & 7.0 & 10.0 & 0.0 & 10.0 & 25.0 & 3.6 & 3.2 & 10.3 \\
\hline POAPRA & 7.0 & 19.0 & 0.0 & 19.0 & 24.1 & 3.4 & 7.1 & 50. \\
\hline SALIGLA & 7.0 & 20.0 & 0.0 & 20.0 & 20.0 & 2.9 & 7.6 & 57 \\
\hline POTEGRA & 7.0 & 6.0 & 0.0 & 6.0 & 20.0 & 2.9 & 2.3 & \\
\hline DESCCES & 7.0 & 20.0 & 0.0 & 20.0 & 20.0 & 2.9 & 7.6 & 57.1 \\
\hline
\end{tabular}




$\begin{array}{lrrrrrrrr}\text { VICIAME } & 7.0 & 8.0 & 0.0 & 8.0 & 18.0 & 2.6 & 3.0 & 9.0 \\ \text { THALVEN } & 7.0 & 10.0 & 0.0 & 10.0 & 17.1 & 2.4 & 3.8 & 14.5 \\ \text { AGROSPP } & 7.0 & 10.0 & 0.0 & 10.0 & 17.0 & 2.4 & 4.2 & 18.0 \\ \text { POASPP } & 7.0 & 5.0 & 0.0 & 5.0 & 11.0 & 1.6 & 2.4 & 5.6 \\ \text { DANTCAL } & 7.0 & 11.0 & 0.0 & 11.0 & 11.0 & 1.6 & 4.2 & 17.3 \\ \text { CAMPROT } & 7.0 & 3.0 & 0.0 & 3.0 & 11.0 & 1.6 & 1.0 & 1.0 \\ \text { SMILSTE } & 7.0 & 7.0 & 0.0 & 7.0 & 9.0 & 1.3 & 2.6 & 6.9 \\ \text { FESTIDA } & 7.0 & 8.0 & 0.0 & 8.0 & 8.0 & 1.1 & 3.0 & 9.1 \\ \text { CERAARV } & 7.0 & 7.0 & 0.0 & 7.0 & 7.1 & 1.0 & 2.6 & 7.0 \\ \text { (plus 39 species) } & & & & & & & & \end{array}$

CLUSTER

26

\begin{tabular}{|c|c|c|c|c|c|c|c|c|}
\hline & $\mathrm{N}$ & Range & Minimum & Maximum & Sum & \multicolumn{2}{|c|}{ Mean Std. Deviation } & Variance \\
\hline STIPCUR & 2.0 & 37.0 & 23.0 & 60.0 & 83.0 & 41.5 & 26.2 & 684.5 \\
\hline KOELMAC & 2.0 & 10.0 & 0.0 & 10.0 & 10.0 & 5.0 & 7.1 & 50.0 \\
\hline FESTSCA & 2.0 & 3.0 & 2.0 & 5.0 & 7.0 & 3.5 & 2.1 & 4.5 \\
\hline HETEVIL & 2.0 & 6.0 & 0.0 & 6.0 & 6.0 & 3.0 & 4.2 & 18.0 \\
\hline AGROTRA & 2.0 & 5.0 & 0.0 & 5.0 & 5.0 & 2.5 & 3.5 & 12.5 \\
\hline VICLAME & 2.0 & 0.0 & 2.0 & 2.0 & 4.0 & 2.0 & 0.0 & 0.0 \\
\hline AGRODAS & 2.0 & 4.0 & 0.0 & 4.0 & 4.0 & 2.0 & 2.8 & 8.0 \\
\hline POAPRA & 2.0 & 2.0 & 0.0 & 2.0 & 2.0 & 1.0 & 1.4 & 2.0 \\
\hline ASTEFAL & 2.0 & 2.0 & 0.0 & 2.0 & 2.0 & 1.0 & 1.4 & 2.0 \\
\hline ARTELUD & 2.0 & 2.0 & 0.0 & 2.0 & 2.0 & 1.0 & 1.4 & 2.0 \\
\hline ARTEFRI & 2.0 & 0.0 & 1.0 & 1.0 & 2.0 & 1.0 & 0.0 & 0.0 \\
\hline ACHIMIL & 2.0 & 0.0 & 1.0 & 1.0 & 2.0 & 1.0 & 0.0 & 0.0 \\
\hline TRAGDUB & 2.0 & 1.0 & 0.0 & 1.0 & 1.0 & 0.5 & 0.7 & 0.5 \\
\hline SYMPOCC & 2.0 & 1.0 & 0.0 & 1.0 & 1.0 & 0.5 & 0.7 & 0.5 \\
\hline STIPCOL & 2.0 & 1.0 & 0.0 & 1.0 & 1.0 & 0.5 & 0.7 & 0.5 \\
\hline ROSAWOO & 2.0 & 1.0 & 0.0 & 1.0 & 1.0 & 0.5 & 0.7 & 0.5 \\
\hline MUHLRIC & 2.0 & 1.0 & 0.0 & 1.0 & 1.0 & 0.5 & 0.7 & 0.5 \\
\hline GUTISAR & 2.0 & 1.0 & 0.0 & 1.0 & 1.0 & 0.5 & 0.7 & 0.5 \\
\hline GAILARI & 2.0 & 1.0 & 0.0 & 1.0 & 1.0 & 0.5 & 0.7 & 0.5 \\
\hline ARTECAN & 2.0 & 1.0 & 0.0 & 1.0 & 1.0 & 0.5 & 0.7 & 0.5 \\
\hline ANTEPAR & 2.0 & 1.0 & 0.0 & 1.0 & 1.0 & 0.5 & 0.7 & 0.5 \\
\hline
\end{tabular}

CLUSTER

27

\begin{tabular}{|c|c|c|c|c|c|c|c|c|}
\hline FESTIDA & 13.0 & 25.0 & 13.0 & 38.0 & 289.0 & 22.2 & 7.4 & 54.0 \\
\hline MOSSSPP & 13.0 & 74.0 & 0.0 & 74.0 & 231.0 & 17.8 & 22.3 & 499.2 \\
\hline KOELMAC & 13.0 & 18.0 & 0.0 & 18.0 & 131.0 & 10.1 & 4.4 & 19.6 \\
\hline LUPISER & 13.0 & 26.0 & 0.0 & 26.0 & 86.0 & 6.6 & 7.5 & 56.6 \\
\hline FESTSCA & 13.0 & 25.0 & 0.0 & 25.0 & 76.1 & 5.9 & 7.5 & 56.4 \\
\hline STIPRIC & 13.0 & 22.0 & 0.0 & 22.0 & 59.0 & 4.5 & 7.8 & 61.1 \\
\hline GALIBOR & 13.0 & 11.0 & 1.0 & 12.0 & 50.0 & 3.8 & 3.1 & 9.6 \\
\hline AGROTRA & 13.0 & 16.0 & 0.0 & 16.0 & 43.0 & 3.3 & 4.7 & 22.4 \\
\hline AGROSPI & 13.0 & 14.0 & 0.0 & 14.0 & 43.0 & 3.3 & 4.6 & 20.7 \\
\hline ACHIMIL & 13.0 & 11.0 & 0.0 & 11.0 & 42.0 & 3.2 & 3.0 & 9.2 \\
\hline CARESPP & 13.0 & 12.0 & 0.0 & 12.0 & 37.0 & 2.8 & 4.2 & 17.3 \\
\hline ANTEPAR & 13.0 & 20.0 & 0.0 & 20.0 & 35.0 & 2.7 & 5.7 & 32.6 \\
\hline
\end{tabular}




\begin{tabular}{|c|c|c|c|c|c|c|c|c|}
\hline CERAARV & 13.0 & 9.0 & 0.0 & 9.0 & 34.1 & 2.6 & 3.1 & 9.5 \\
\hline ANEMMUL & 13.0 & 8.0 & 0.0 & 8.0 & 33.0 & 2.5 & 2.6 & 6.9 \\
\hline POASAN & 13.0 & 30.0 & 0.0 & 30.0 & 32.0 & 2.5 & 8.3 & 68.8 \\
\hline PHLEPRA & 13.0 & 21.0 & 0.0 & 21.0 & 31.0 & 2.4 & 6.1 & 37.4 \\
\hline DANTPAR & 13.0 & 17.0 & 0.0 & 17.0 & 31.0 & 2.4 & 5.7 & 32.1 \\
\hline SYMPOCC & 13.0 & 15.0 & 0.0 & 15.0 & 31.0 & 2.4 & 4.9 & 23.9 \\
\hline AMELALN & 13.0 & 14.0 & 0.0 & 14.0 & 30.3 & 2.3 & 4.0 & 15.8 \\
\hline CAREROS & 13.0 & 9.0 & 0.0 & 9.0 & 27.0 & 2.1 & 3.3 & 10.9 \\
\hline POAPRA & 13.0 & 12.0 & 0.0 & 12.0 & 26.0 & 2.0 & 3.6 & 13.2 \\
\hline FRAGVIR & 13.0 & 21.0 & 0.0 & 21.0 & 24.0 & 1.8 & 5.8 & 33.8 \\
\hline SOLIMIS & 13.0 & 5.0 & 0.0 & 5.0 & 21.0 & 1.6 & 1.9 & 3.8 \\
\hline ROSAARK & 13.0 & 11.0 & 0.0 & 11.0 & 21.0 & 1.6 & 3.4 & 11.8 \\
\hline OXYTSPL & 13.0 & 16.0 & 0.0 & 16.0 & 19.0 & 1.5 & 4.4 & 19.4 \\
\hline FESTSAX & 13.0 & 11.0 & 0.0 & 11.0 & 19.0 & 1.5 & 3.3 & 10.6 \\
\hline BROMCIL & 13.0 & 13.0 & 0.0 & 13.0 & 19.0 & 1.5 & 3.6 & 13.3 \\
\hline BALSSAG & 13.0 & 12.0 & 0.0 & 12.0 & 19.0 & 1.5 & 3.5 & 12.1 \\
\hline AGOSGLA & 13.0 & 5.0 & 0.0 & 5.0 & 18.0 & 1.4 & 1.8 & 3.3 \\
\hline GEUMTRI & 13.0 & 9.0 & 0.0 & 9.0 & 17.1 & 1.3 & 2.7 & 7.4 \\
\hline STIPCOL & 13.0 & 7.0 & 0.0 & 7.0 & 15.0 & 1.2 & 2.0 & 3.8 \\
\hline AGROSMI & 13.0 & 11.0 & 0.0 & 11.0 & 15.0 & 1.2 & 3.2 & 10.0 \\
\hline $\begin{array}{l}\text { TARAOFF } \\
\text { (plus } 60 \text { species) }\end{array}$ & 13.0 & 4.0 & 0.0 & 4.0 & 13.2 & 1.0 & 1.6 & 2.5 \\
\hline
\end{tabular}

\section{CLUSTER}

28

Descriptive Statistics(a)

\begin{tabular}{|c|c|c|c|c|c|c|c|c|}
\hline & $\mathrm{N}$ & Range & Minimum & Maximum & Sum & \multicolumn{2}{|c|}{ Mean Std. Deviation } & Variance \\
\hline FESTIDA & 9.0 & 42.0 & 14.0 & 56.0 & 240.0 & 26.7 & 12.7 & 160.5 \\
\hline GEUMTRI & 9.0 & 23.0 & 0.0 & 23.0 & 145.0 & 16.1 & 7.2 & 52.4 \\
\hline DANTPAR & 9.0 & 23.0 & 2.0 & 25.0 & 128.0 & 14.2 & 8.7 & 76.4 \\
\hline FESTSCA & 9.0 & 21.0 & 0.0 & 21.0 & 116.0 & 12.9 & 7.4 & 55.1 \\
\hline STIPRIC & 9.0 & 28.0 & 0.0 & 28.0 & 88.0 & 9.8 & 9.8 & 96.4 \\
\hline POAPRA & 9.0 & 19.0 & 0.0 & 19.0 & 51.1 & 5.7 & 7.8 & 60.1 \\
\hline FRAGVIR & 9.0 & 17.0 & 0.0 & 17.0 & 49.1 & 5.5 & 7.0 & 49.6 \\
\hline MOSSSPP & 9.0 & 29.0 & 0.0 & 29.0 & 49.0 & 5.4 & 9.5 & 90.5 \\
\hline AGRODAS & 9.0 & 12.0 & 0.0 & 12.0 & 45.0 & 5.0 & 5.1 & 25.8 \\
\hline STIPVIR & 9.0 & 42.0 & 0.0 & 42.0 & 42.0 & 4.7 & 14.0 & 196.0 \\
\hline POTEDIV & 9.0 & 19.0 & 0.0 & 19.0 & 39.0 & 4.3 & 6.2 & 38.8 \\
\hline ACHIMIL & 9.0 & 8.9 & 0.1 & 9.0 & 33.1 & 3.7 & 3.0 & 8.9 \\
\hline PENSCON & 9.0 & 6.9 & 0.1 & 7.0 & 33.1 & 3.7 & 2.0 & 3.9 \\
\hline CARESPP & 9.0 & 10.0 & 0.0 & 10.0 & 29.1 & 3.2 & 3.4 & 11.6 \\
\hline GERAVIS & 9.0 & 13.0 & 0.0 & 13.0 & 28.0 & 3.1 & 4.3 & 18.4 \\
\hline JUNCBAL & 9.0 & 26.0 & 0.0 & 26.0 & 26.1 & 2.9 & 8.7 & 75.0 \\
\hline POTEFRU & 9.0 & 19.0 & 0.0 & 19.0 & 26.0 & 2.9 & 6.1 & 37.4 \\
\hline DESCCES & 9.0 & 24.0 & 0.0 & 24.0 & 24.0 & 2.7 & 8.0 & 64.0 \\
\hline CAREOBT & 9.0 & 21.0 & 0.0 & 21.0 & 24.0 & 2.7 & 6.9 & 48.3 \\
\hline KOELMAC & 9.0 & 7.0 & 0.0 & 7.0 & 19.0 & 2.1 & 2.1 & 4.4 \\
\hline AGROSPI & 9.0 & 10.0 & 0.0 & 10.0 & 19.0 & 2.1 & 4.2 & 17.6 \\
\hline ASTECIL & 9.0 & 12.0 & 0.0 & 12.0 & 18.1 & 2.0 & 4.0 & 15.7 \\
\hline ROSAACI & 9.0 & 14.0 & 0.0 & 14.0 & 16.1 & 1.8 & 4.6 & 21.4 \\
\hline GALIBOR & 9.0 & 6.0 & 0.0 & 6.0 & 15.1 & 1.7 & 1.9 & 3.5 \\
\hline POTEGRA & 9.0 & 7.0 & 0.0 & 7.0 & 14.2 & 1.6 & 2.4 & 6.0 \\
\hline
\end{tabular}




$\begin{array}{lrrrrrrrr}\text { POASPP } & 9.0 & 13.0 & 0.0 & 13.0 & 13.0 & 1.4 & 4.3 & 18.8 \\ \text { AGROTRA } & 9.0 & 9.0 & 0.0 & 9.0 & 13.0 & 1.4 & 3.1 & 9.8 \\ \text { VACCCAE } & 9.0 & 13.0 & 0.0 & 13.0 & 13.0 & 1.4 & 4.3 & 18.8 \\ \text { THALOCC } & 9.0 & 8.0 & 0.0 & 8.0 & 12.0 & 1.3 & 2.7 & 7.3 \\ \text { SOLIMUL } & 9.0 & 10.0 & 0.0 & 10.0 & 12.0 & 1.3 & 3.3 & 11.0 \\ \text { BROMCIL } & 9.0 & 11.0 & 0.0 & 11.0 & 11.1 & 1.2 & 3.7 & 13.4 \\ \text { VICIAME } & 9.0 & 7.0 & 0.0 & 7.0 & 9.2 & 1.0 & 2.3 & 5.2\end{array}$

\section{CLUSTER}

29

$\begin{array}{lrr} & \text { N } & \text { Rang } \\ \text { FESTSCA } & 8.0 & 24.0 \\ \text { AGROSPI } & 8.0 & 23.0 \\ \text { FESTIDA } & 8.0 & 13.0 \\ \text { AMELALN } & 8.0 & 13.0 \\ \text { ROSAACI } & 8.0 & 9.0 \\ \text { KOELMAC } & 8.0 & 17.0 \\ \text { DANTPAR } & 8.0 & 12.0 \\ \text { ASTECON } & 8.0 & 29.0 \\ \text { GALIBOR } & 8.0 & 5.0 \\ \text { SPIRBET } & 8.0 & 11.0 \\ \text { LUPISER } & 8.0 & 8.0 \\ \text { FRAGVIR } & 8.0 & 20.0 \\ \text { MONAFIS } & 8.0 & 12.0 \\ \text { GERAVIS } & 8.0 & 14.0 \\ \text { CERAARV } & 8.0 & 5.0 \\ \text { CAREOBT } & 8.0 & 13.0 \\ \text { ACHIMIL } & 8.0 & 2.9 \\ \text { ANTEROS } & 8.0 & 10.0 \\ \text { SOLIMUL } & 8.0 & 8.0 \\ \text { EPILANG } & 8.0 & 7.0 \\ \text { LATHOCH } & 8.0 & 4.0 \\ \text { ANEMMUL } & 8.0 & 2.0 \\ \text { (PlU 69 SP } & & \end{array}$

(plus 69 species)
0.0

2.0

2.0

0.0

0.0

0.0

0.0

1.0

0.0

0.0

0.0

0.0

0.0

0.0

0.0

0.1

0.0

0.0

0.0

0.0

0.0 .
27.0

23.0

15.0

15.0

9.0

17.0

12.0

29.0

6.0

11.0

8.0

20.0

12.0

14.0

5.0

13.0

3.0

10.0

8.0

7.0

4.0

2.0
Sum Mean Std. Deviation Variance

$\begin{array}{rrrr}119.0 & 14.9 & 9.4 & 87.6 \\ 70.0 & 8.8 & 7.9 & 62.8 \\ 59.0 & 7.4 & 3.7 & 13.7 \\ 49.0 & 6.1 & 4.2 & 17.6 \\ 44.0 & 5.5 & 2.7 & 7.4 \\ 33.1 & 4.1 & 6.1 & 37.4 \\ 31.0 & 3.9 & 4.7 & 22.4 \\ 29.0 & 3.6 & 10.3 & 105.1 \\ 27.0 & 3.4 & 2.0 & 4.0 \\ 25.0 & 3.1 & 4.6 & 21.3 \\ 22.0 & 2.8 & 3.1 & 9.6 \\ 20.1 & 2.5 & 7.1 & 49.9 \\ 16.1 & 2.0 & 4.1 & 16.8 \\ 16.0 & 2.0 & 4.9 & 24.0 \\ 13.0 & 1.6 & 2.2 & 4.8 \\ 13.0 & 1.6 & 4.6 & 21.1 \\ 10.2 & 1.3 & 1.0 & 1.0 \\ 10.0 & 1.3 & 3.5 & 12.5 \\ 9.0 & 1.1 & 2.8 & 7.8 \\ 8.1 & 1.0 & 2.4 & 6.0 \\ 8.0 & 1.0 & 1.9 & 3.4 \\ 8.0 & 1.0 & 0.8 & 0.6\end{array}$

CLUSTER

30

N Range Minimum Maximum

4.0

4.0

4.0

4.0

4.0

4.0

4.0

4.0

4.0

4.0

4.0

4.0

50.0

52.0

12.0

14.0

10.0

13.9

9.0

17.0

7.0

5.0

9.9

6.0
25.0

0.0

7.0

3.0

3.0

0.1

1.0

0.0

1.0

0.0

0.1

0.0
75.0

52.0

19.0

17.0

13.0

14.0

10.0

17.0

8.0

5.0

10.0

6.0
Sum

175.0

52.0

43.0

34.0

31.0

17.1

17.0

17.0

15.0

14.0

13.1

13.0
Mean Std. Deviation Variance

43.8

13.0

10.8

8.5

7.8

4.3

4.3

4.3

3.8

3.5

3.3

3.3
23.0

26.0

5.7

6.0

4.6

6.5

4.0

8.5

3.0

2.4

4.6

2.8
528.9

676.0

32.3

36.3

20.9

42.6

16.3

72.3

8.9

5.7

20.7

7.6 


\begin{tabular}{|c|c|c|c|c|c|c|c|c|}
\hline ANTEPAR & 4.0 & 6.9 & 0.1 & 7.0 & 12.1 & 3.0 & 3.1 & 9.8 \\
\hline ASTELAE & 4.0 & 11.0 & 0.0 & 11.0 & 11.2 & 2.8 & 5.5 & 29.9 \\
\hline STIPCOL & 4.0 & 5.0 & 0.0 & 5.0 & 10.0 & 2.5 & 2.1 & 4.3 \\
\hline DANTPAR & 4.0 & 10.0 & 0.0 & 10.0 & 10.0 & 2.5 & 5.0 & 25.0 \\
\hline CARESPP & 4.0 & 5.0 & 0.0 & 5.0 & 10.0 & 2.5 & 2.9 & 8.3 \\
\hline OXYTSPL & 4.0 & 9.0 & 0.0 & 9.0 & 9.0 & 2.3 & 4.5 & 20.3 \\
\hline GAIlLARI & 4.0 & 8.0 & 0.0 & 8.0 & 8.0 & 2.0 & 4.0 & 16.0 \\
\hline GEUMTRI & 4.0 & 4.0 & 0.0 & 4.0 & 7.0 & 1.8 & 2.1 & 4.3 \\
\hline FESTSAX & 4.0 & 7.0 & 0.0 & 7.0 & 7.0 & 1.8 & 3.5 & 12.3 \\
\hline AGROTRA & 4.0 & 7.0 & 0.0 & 7.0 & 7.0 & 1.8 & 3.5 & 12.3 \\
\hline ROSAACI & 4.0 & 5.0 & 0.0 & 5.0 & 6.1 & 1.5 & 2.4 & 5.6 \\
\hline AMELALN & 4.0 & 6.0 & 0.0 & 6.0 & 6.1 & 1.5 & 3.0 & 8.9 \\
\hline AGOSGLA & 4.0 & 5.0 & 0.0 & 5.0 & 6.1 & 1.5 & 2.4 & 5.6 \\
\hline SOLIMIS & 4.0 & 6.0 & 0.0 & 6.0 & 6.0 & 1.5 & 3.0 & 9.0 \\
\hline ANEMMUL & 4.0 & 1.9 & 0.1 & 2.0 & 5.1 & 1.3 & 0.9 & 0.8 \\
\hline POTEFRU & 4.0 & 3.0 & 0.0 & 3.0 & 5.0 & 1.3 & 1.5 & 2.3 \\
\hline PHLEPRA & 4.0 & 5.0 & 0.0 & 5.0 & 5.0 & 1.3 & 2.5 & 6.3 \\
\hline OXYTSER & 4.0 & 3.0 & 0.0 & 3.0 & 5.0 & 1.3 & 1.5 & 2.3 \\
\hline HETEVIL & 4.0 & 3.0 & 0.0 & 3.0 & 5.0 & 1.3 & 1.5 & 2.3 \\
\hline BROMINE & 4.0 & 5.0 & 0.0 & 5.0 & 5.0 & 1.3 & 2.5 & 6.3 \\
\hline SMILSTE & 4.0 & 4.0 & 0.0 & 4.0 & 4.0 & 1.0 & 2.0 & 4.0 \\
\hline CAREROS & 4.0 & 4.0 & 0.0 & 4.0 & 4.0 & 1.0 & 2.0 & 4.0 \\
\hline BROMPUM & 4.0 & 4.0 & 0.0 & 4.0 & 4.0 & 1.0 & 2.0 & 4.0 \\
\hline
\end{tabular}

(plus 29 species)

CLUSTER

31

\begin{tabular}{|c|c|c|c|c|c|c|c|c|}
\hline & $\mathrm{N}$ & Range & Minimum & Maximum & Sum & \multicolumn{2}{|c|}{ Mean Std. Deviation } & Variance \\
\hline AGROSPI & 6.0 & 25.0 & 15.0 & 40.0 & 190.0 & 31.7 & 9.3 & 86.7 \\
\hline BROMCAR & 6.0 & 25.0 & 0.0 & 25.0 & 40.0 & 6.7 & 10.8 & 116.7 \\
\hline FESTIDA & 6.0 & 25.0 & 0.0 & 25.0 & 35.0 & 5.8 & 9.7 & 94.2 \\
\hline HEDYSUL & 6.0 & 25.0 & 0.0 & 25.0 & 31.0 & 5.2 & 9.9 & 98.2 \\
\hline PHLEPRA & 6.0 & 15.0 & 0.0 & 15.0 & 28.0 & 4.7 & 6.3 & 39.9 \\
\hline FESTSCA & 6.0 & 25.0 & 0.0 & 25.0 & 27.0 & 4.5 & 10.1 & 101.5 \\
\hline LOMATRI & 6.0 & 15.0 & 0.0 & 15.0 & 26.0 & 4.3 & 6.5 & 42.7 \\
\hline POAPAL & 6.0 & 15.0 & 0.0 & 15.0 & 25.0 & 4.2 & 6.7 & 44.2 \\
\hline POAINT & 6.0 & 20.0 & 0.0 & 20.0 & 20.0 & 3.3 & 8.2 & 66.7 \\
\hline ANTEPAR & 6.0 & 15.0 & 0.0 & 15.0 & 20.0 & 3.3 & 6.1 & 36.7 \\
\hline GERAVIS & 6.0 & 10.0 & 0.0 & 10.0 & 19.0 & 3.2 & 3.9 & 15.0 \\
\hline GALIBOR & 6.0 & 4.0 & 1.0 & 5.0 & 19.0 & 3.2 & 1.6 & 2.6 \\
\hline SPIRBET & 6.0 & 10.0 & 0.0 & 10.0 & 17.0 & 2.8 & 4.0 & 15.8 \\
\hline FRAGVIR & 6.0 & 5.0 & 0.0 & 5.0 & 17.0 & 2.8 & 2.5 & 6.2 \\
\hline ASTECON & 6.0 & 15.0 & 0.0 & 15.0 & 17.0 & 2.8 & 6.0 & 35.8 \\
\hline LUPISER & 6.0 & 10.0 & 0.0 & 10.0 & 15.0 & 2.5 & 3.8 & 14.7 \\
\hline BROMINE & 6.0 & 10.0 & 0.0 & 10.0 & 15.0 & 2.5 & 4.2 & 17.5 \\
\hline ARTELUD & 6.0 & 15.0 & 0.0 & 15.0 & 15.0 & 2.5 & 6.1 & 37.5 \\
\hline ACHIMIL & 6.0 & 4.0 & 1.0 & 5.0 & 14.0 & 2.3 & 2.1 & 4.3 \\
\hline EPILANG & 6.0 & 5.0 & 0.0 & 5.0 & 13.0 & 2.2 & 1.8 & 3.4 \\
\hline OSMOOCC & 6.0 & 10.0 & 0.0 & 10.0 & 12.0 & 2.0 & 4.0 & 15.6 \\
\hline MONAFIS & 6.0 & 10.0 & 0.0 & 10.0 & 11.0 & 1.8 & 4.0 & 16.2 \\
\hline AMELALN & 6.0 & 10.0 & 0.0 & 10.0 & 11.0 & 1.8 & 4.0 & 16.2 \\
\hline ERIGPER & 6.0 & 10.0 & 0.0 & 10.0 & 11.0 & 1.8 & 4.0 & 16.2 \\
\hline
\end{tabular}




$\begin{array}{lllllllrr}\text { PENSCON } & 6.0 & 4.0 & 1.0 & 5.0 & 10.0 & 1.7 & 1.6 & 2.7 \\ \text { CALOAPI } & 6.0 & 8.0 & 0.0 & 8.0 & 10.0 & 1.7 & 3.1 & 9.9 \\ \text { VALEDIO } & 6.0 & 8.0 & 0.0 & 8.0 & 9.0 & 1.5 & 3.2 & 10.3 \\ \text { AGROTRA } & 6.0 & 8.0 & 0.0 & 8.0 & 8.0 & 1.3 & 3.3 & 10.7 \\ \text { ZIGAELE } & 6.0 & 5.0 & 0.0 & 5.0 & 7.0 & 1.2 & 1.9 & 3.8 \\ \text { THALOCC } & 6.0 & 5.0 & 0.0 & 5.0 & 7.0 & 1.2 & 1.9 & 3.8 \\ \text { ROSAWOO } & 6.0 & 5.0 & 0.0 & 5.0 & 7.0 & 1.2 & 1.9 & 3.8 \\ \text { (plus 37 species) } & & & & & & & & \end{array}$

\section{CLUSTER}

32

FESTIDA

FESTSCA

AGROTRA

CAREOBT

DANTPAR

MONAFIS

ACHIMIL

GALIBOR

POAPRA

KOELMAC

GERAVIS

VICIAME

PHLEPRA

POACOM

ROSAACI

POTEFRU

ASTELAE

POTEGRA

LUPISER

AGOSGLA

SOLIMIS

DANTCAL

FRAGVIR

SYMPOCC

STIPVIR

GEUMTRI

SMILSTE

BROMCIL

ANEMMUL

POACAN

TARAOFF

CARESPP

AGROSMI

LITHRUD

ARCTUVA

EPILANG

AGROSPI

LATHOCH

LUPIARG

(plus 74 species)
N

25.0

25.0

25.0

25.0

25.0

25.0

25.0

25.0

25.0

25.0

25.0

25.0

25.0

25.0

25.0

25.0

25.0

25.0

25.0

25.0

25.0

25.0

25.0

25.0

25.0

25.0

25.0

25.0

25.0

25.0

25.0

25.0

25.0

25.0

25.0

25.0

25.0

25.0

25.0
Range

$$
64.0
$$

23.0

32.0

21.0

44.0

30.0

15.0

12.0

20.0

14.0

10.0

7.0

32.0

27.0

12.0

12.0

13.0

15.0

18.0

8.0

7.0

21.0

11.0

8.0

8.0

7.0

13.0

7.0

7.0

14.0

9.0

9.0

9.0

5.0

15.0

8.0

13.0

7.0

8.0
Minimum Maximum

0.0

2.0

0.0

0.0

0.0

0.0

0.0

0.0

0.0

0.0

0.0

0.0

0.0

0.0

0.0

0.0

0.0

0.0

0.0

0.0

0.0

0.0

0.0

0.0

0.0

0.0

0.0

0.0

0.0

0.0

0.0

0.0

0.0

0.0

0.0

0.0

0.0

0.0

0.0
64.0

25.0

32.0

21.0

44.0

30.0

15.0

12.0

20.0

14.0

10.0

7.0

32.0

27.0

12.0

12.0

13.0

15.0

18.0

8.0

7.0

21.0

11.0

8.0

8.0

7.0

13.0

7.0

7.0

14.0

9.0

9.0

9.0

5.0

15.0

8.0

13.0

7.0

8.0
Sum

269.1

246.0

235.0

215.0

204.1

138.1

118.2

115.1

109.1

101.1

93.0

86.1

83.0

82.0

74.0

73.0

66.1

63.8

61.0

55.3

46.5

41.0

40.2

39.0

37.0

37.0

36.2

34.4

31.2

27.0

26.6

26.0

26.0

25.2

25.0

25.0

25.0

24.2

24.0
Mean Std. Deviation

10.8

9.8

9.4

8.6

8.2

5.5

4.7

4.6

4.4

4.0

3.7

3.4

3.3

3.3

3.0

2.9

2.6

2.6

2.4

2.2

1.9

1.6

1.6

1.6

1.5

1.5

1.4

1.4

1.2

1.1

1.1

1.0

1.0

1.0

1.0

1.0

1.0

1.0

1.0 


\section{CLUSTER}

33

DANTCAL

FESTSCA

CAREOBT

STIPRIC

SOLIMIS

AGROTRA

PENSPRO

FESTIDA

FRAGVIR

LUPISER

VACCCAE

POTEARG

SOLIMUL

TARAOFF

ACHIMIL

CERAARV

SELADEN

ELYMINN

GALIBOR

PENSCON

JUNCBAL

DANTPAR

AGRODAS

POTEFRU

FESTSAX

(plus 49 species)
N Range Minimum Maximum

$$
5.0
$$

5.0

5.0

5.0

5.0

5.0

5.0

5.0

5.0

5.0

5.0

5.0

5.0

5.0

5.0

5.0

5.0

5.0

5.0

5.0

5.0

5.0

5.0

5.0

5.0

30.0

41.0

18.0

22.0

23.0

6.0

17.0

17.0

8.0

12.0

8.0

8.0

9.0

7.0

3.9

4.0

4.0

6.0

3.9

3.0

5.0

6.0

6.0

3.0

5.0
13.0

2.0

6.0

0.0

0.0

0.0

0.0

0.0

0.0

0.0

0.0

0.0

0.0

0.0

0.1

0.0

0.0

0.0

0.1

0.0

0.0

0.0

0.0

0.0

0.0

\section{0}

43.0

24.0

22.0

23.0

6.0

17.0

17.0

8.0

12.0

8.0

8.0

9.0

7.0

4.0

4.0

4.0

6.0

4.0

3.0

5.0

6.0

6.0

3.0

5.0
Sum

159.0

106.0

60.0

51.0

23.0

22.0

20.0

18.1

16.0

15.0

13.0

13.0

11.0

10.0

9.2

9.1

8.0

8.0

6.3

6.2

6.1

6.0

6.0

5.1

5.0
Mean Std. Deviation Variance

31.8

11.6

14.6

134.7

21.2

12.0

10.2

4.6

4.4

4.0

3.6

3.2

3.0

2.6

2.6

2.2

2.0

1.8

1.8

1.6

1.6

1.3

1.2

1.2

1.2

1.2

1.0

1.0
7.4

10.8

10.3

2.6

7.4

7.5

3.6

5.2

3.7

3.7

3.9

2.9

1.7

1.8

2.2

2.5

1.7

1.6

2.2

2.7

2.7

1.4

2.2
212.7

54.5

117.2

105.8

6.8

54.5

56.1

13.2

27.0

13.8

13.8

15.2

8.5

3.0

3.1

4.8

6.3

3.0

2.6

4.6

7.2

7.2

2.0

5.0

\section{CLUSTER}

34

N Range Minimum Maximum

Sum

Mean Std. Deviation Variance

FESTSAX

CARESPP

AGROTRA

KOELMAC

FESTSCA

HELIHOO

ACHIMIL

GALIBOR

SYMPOCC

3.0

1.0 16.0

17.0

50.0

16.7

0.6

0.3

3.0

3.0

16.0

27.0

9.0

6.6

43.0

$3.0 \quad 13.0$

0.0

13.0

21.0

7.0

6.6

43.0

$3.0 \quad 12.0$

0.0

12.0

19.0

6.3

6.0

36.3

$3.0 \quad 13.0$

1.0

14.0

17.0 


$\begin{array}{lllllllrr}\text { CERAARV } & 3.0 & 6.0 & 0.0 & 6.0 & 9.0 & 3.0 & 3.0 & 9.0 \\ \text { POLYVIV } & 3.0 & 8.0 & 0.0 & 8.0 & 8.0 & 2.7 & 4.6 & 21.3 \\ \text { POTEGRA } & 3.0 & 7.0 & 0.0 & 7.0 & 8.0 & 2.7 & 3.8 & 14.3 \\ \text { LATHOCH } & 3.0 & 7.0 & 0.0 & 7.0 & 7.0 & 2.3 & 4.0 & 16.3 \\ \text { AGOSGLA } & 3.0 & 6.0 & 0.0 & 6.0 & 6.0 & 2.0 & 3.5 & 12.0 \\ \text { TARAOFF } & 3.0 & 2.9 & 0.1 & 3.0 & 4.1 & 1.4 & 1.5 & 2.2 \\ \text { POACOM } & 3.0 & 3.0 & 0.0 & 3.0 & 4.0 & 1.3 & 1.5 & 2.3 \\ \text { FESTIDA } & 3.0 & 4.0 & 0.0 & 4.0 & 4.0 & 1.3 & 2.3 & 5.3 \\ \text { OXYTSER } & 3.0 & 4.0 & 0.0 & 4.0 & 4.0 & 1.3 & 2.3 & 5.3 \\ \text { TRAGDUB } & 3.0 & 3.0 & 0.0 & 3.0 & 3.0 & 1.0 & 1.7 & 3.0 \\ \text { THALOCC } & 3.0 & 3.0 & 0.0 & 3.0 & 3.0 & 1.0 & 1.7 & 3.0 \\ \text { POAPRA } & 3.0 & 3.0 & 0.0 & 3.0 & 3.0 & 1.0 & 1.7 & 3.0 \\ \text { BROMCAR } & 3.0 & 3.0 & 0.0 & 3.0 & 3.0 & 1.0 & 1.7 & 3.0 \\ \text { ASTECIL } & 3.0 & 3.0 & 0.0 & 3.0 & 3.0 & 1.0 & 1.7 & 3.0 \\ \text { (plus 20 species) } & & & & & & & & \end{array}$

CLUSTER

35

FESTSAX

ARTECAM

CAREPRA

ERIGPHI

PICEGLA

AGROTRA

TRIFREP

POAPRA

AMELALN

GALIBOR

VICIAME

TARAOFF

ROSAACI

AGROSCA
N

1.0

1.0

1.0

1.0

1.0

1.0

1.0

1.0

1.0

1.0

1.0

1.0

1.0

1.0
Range Minimum Maximum

$$
0.0 \quad 10.0
$$

$0.0 \quad 10.0$

$0.0 \quad 7.0$

$0.0 \quad 6.0$

$0.0 \quad 5.0$

0.0

0.0

0.0

0.0

0.0

0.0

0.0

0.0

0.0
10.0

10.0

7.0

6.0

5.0

5.0

4.0

4.0

4.0

1.0

0.1

0.1

0.1

0.1
Sum

10.0

10.0

7.0

6.0

5.0

5.0

4.0

4.0

4.0

1.0

0.1

0.1

0.1

0.1
Mean Std. Deviation Variance 10.0

10.0

7.0

6.0

5.0

5.0

4.0

4.0

4.0

1.0

0.1

0.1

0.1

0.1

\section{CLUSTER}

36

Descriptive Statistics(a)

SELADEN
AGROSMI
BOUTGRA
STIPCOM
KOELMAC
ARTEFRI
CAREFIL
CALALON
STIPVIR
AGRODAS
(plus 50 species)

N

20.0

20.0

20.0

20.0

20.0

20.0

20.0

20.0

20.0

20.0
Range Minimum Maximum 50.0

50.0

45.0

33.0

26.0

18.0

27.0

34.0

22.0

11.0

$$
7.0
$$

0.0

0.0

0.0

0.0

0.0

0.0

0.0

0.0

0.0

\section{0}

50.0

45.0

33.0

26.0

18.0

27.0

34.0

22.0

11.0
Sum

708.0

326.0

194.0

193.0

115.0

66.0

60.0

41.0

38.0

27.0
Mean Std. Deviation Variance

35.4

$14.1 \quad 200.1$

16.3

$14.6 \quad 212.7$

9.7

9.7

$12.4 \quad 153.8$

5.8

3.3

3.0

2.1

1.9

1.4

8.7

75.4

$6.1 \quad 37.4$

$4.1 \quad 16.7$

$\begin{array}{ll}6.4 & 40.8\end{array}$

$7.6 \quad 57.8$

$5.3 \quad 28.0$

3.2

10.2 


\begin{tabular}{|c|c|c|c|c|c|c|c|c|}
\hline & & & & & & & \\
\hline STIPCOM & 8.0 & 48.0 & 10.0 & 58.0 & 306.0 & 38.3 & 14.9 . & 221.9 \\
\hline BOUTGRA & 8.0 & 20.0 & 0.0 & 20.0 & 99.0 & 12.4 & 6.4 & 41.1 \\
\hline CAREFIL & 8.0 & 20.0 & 0.0 & 20.0 & 48.0 & 6.0 & 8.5 & 72.0 \\
\hline CALALON & 8.0 & 30.0 & 0.0 & 30.0 & 45.0 & 5.6 & 10.1 & 102.6 \\
\hline AGROSMI & 8.0 & 10.0 & 0.0 & 10.0 & 42.0 & 5.3 & 4.6 & 21.4 \\
\hline KOELMAC & 8.0 & 10.0 & 0.0 & 10.0 & 22.0 & 2.8 & 3.6 & 13.1 \\
\hline AGRODAS & 8.0 & 10.0 & 0.0 & 10.0 & 16.0 & 2.0 & 3.9 & 14.9 \\
\hline ARTEFRI & 8.0 & 3.0 & 0.0 & 3.0 & 13.0 & 1.6 & 1.1 & 1.1 \\
\hline AGROTRA & 8.0 & 12.0 & 0.0 & 12.0 & 12.0 & 1.5 & 4.2 & 18.0 \\
\hline CARESPP & 8.0 & 7.0 & 0.0 & 7.0 & 10.0 & 1.3 & 2.6 & 6.5 \\
\hline HETEVIL & 8.0 & 3.0 & 0.0 & 3.0 & 7.2 & 0.9 & 1.1 & 1.2 \\
\hline ARTELUD & 8.0 & 7.0 & 0.0 & 7.0 & 7.0 & 0.9 & 2.5 & 6.1 \\
\hline ARTECAN & 8.0 & 4.0 & 0.0 & 4.0 & 7.0 & 0.9 & 1.5 & 2.1 \\
\hline PHLOHOO & 8.0 & 5.0 & 0.0 & 5.0 & 6.1 & 0.8 & 1.7 & 3.1 \\
\hline SELADEN & 8.0 & 3.0 & 0.0 & 3.0 & 6.0 & 0.8 & 1.4 & 1.9 \\
\hline VICLAME & 8.0 & 2.0 & 0.0 & 2.0 & 5.1 & 0.6 & 0.9 & 0.8 \\
\hline ROSAWOO & 8.0 & 3.0 & 0.0 & 3.0 & 4.0 & 0.5 & 1.1 & 1.1 \\
\hline LIATPUN & 8.0 & 1.0 & 0.0 & 1.0 & 3.1 & 0.4 & 0.5 & 0.3 \\
\hline GLYCLEP & 8.0 & 2.0 & 0.0 & 2.0 & 3.0 & 0.4 & 0.7 & 0.6 \\
\hline ASTEERI & 8.0 & 2.0 & 0.0 & 2.0 & 3.0 & 0.4 & 0.7 & 0.6 \\
\hline THERRHO & 8.0 & 1.0 & 0.0 & 1.0 & 2.0 & 0.3 & 0.5 & 0.2 \\
\hline POASAN & 8.0 & 2.0 & 0.0 & 2.0 & 2.0 & 0.3 & 0.7 & 0.5 \\
\hline LYGOJUN & 8.0 & 1.0 & 0.0 & 1.0 & 2.0 & 0.3 & 0.5 & 0.2 \\
\hline SOLIMIS & 8.0 & 1.0 & 0.0 & 1.0 & 2.0 & 0.3 & 0.5 & 0.2 \\
\hline GUTISAR & 8.0 & 2.0 & 0.0 & 2.0 & 2.0 & 0.3 & 0.7 & 0.5 \\
\hline GAURCOC & 8.0 & 1.0 & 0.0 & 1.0 & 2.0 & 0.3 & 0.5 & 0.2 \\
\hline SYMPOCC & 8.0 & 1.0 & 0.0 & 1.0 & 1.0 & 0.1 & 0.4 & 0.1 \\
\hline SYMPALB & 8.0 & 1.0 & 0.0 & 1.0 & 1.0 & 0.1 & 0.4 & 0.1 \\
\hline SPHACOC & 8.0 & 1.0 & 0.0 & 1.0 & 1.0 & 0.1 & 0.4 & 0.1 \\
\hline CERAARV & 8.0 & 1.0 & 0.0 & 1.0 & 1.0 & 0.1 & 0.4 & 0.1 \\
\hline ASTEFAL & 8.0 & 1.0 & 0.0 & 1.0 & 1.0 & 0.1 & 0.4 & 0.1 \\
\hline ANTEPAR & 8.0 . & 1.0 & 0.0 & 1.0 & 1.0 & 0.1 & 0.4 & 0.1 \\
\hline ANEMMUL & 8.0 & 1.0 & 0.0 & 1.0 & 1.0 & 0.1 & 0.4 & 0.1 \\
\hline ACHIMIL & 8.0 & 1.0 & 0.0 & 1.0 & 1.0 & 0.1 & 0.4 & 0.1 \\
\hline \multirow[t]{3}{*}{ COMAUMB } & 8.0 & 0.1 & 0.0 & 0.1 & 0.2 & 0.0 & 0.0 & 0.0 \\
\hline & \multicolumn{5}{|c|}{$\begin{array}{c}\text { CLUSTER } \\
38\end{array}$} & & & \\
\hline & $\mathrm{N}$ & Range & Minimum & Maximum & Sum & \multicolumn{2}{|c|}{ Mean Std. Deviation } & Variance \\
\hline DESCCES & 3.0 & 62.0 & 6.0 & 68.0 & 142.0 & 47.3 & 35.8 & 1281.3 \\
\hline POAPRA & 3.0 & 7.0 & 12.0 & 19.0 & 44.0 & 14.7 & 3.8 & 14.3 \\
\hline AGROTRA & 3.0 & 3.0 & 8.0 & 11.0 & 28.0 & 9.3 & 1.5 & 2.3 \\
\hline TARAOFF & 3.0 & 17.0 & 1.0 & 18.0 & 23.0 & 7.7 & 9.1 & 82.3 \\
\hline PENSCON & 3.0 & 13.0 & 0.0 & 13.0 & 14.0 & 4.7 & 7.2 & 52.3 \\
\hline ASTEERI & 3.0 & 13.0 & 0.0 & 13.0 & 13.0 & 4.3 & 7.5 & 56.3 \\
\hline GRINSQU & 3.0 & 8.0 & 0.0 & 8.0 & 8.0 & 2.7 & 4.6 & 21.3 \\
\hline ACHIMIL & 3.0 & 5.0 & 0.0 & 5.0 & 8.0 & 2.7 & 2.5 & 6.3 \\
\hline POTEGRA & 3.0 & 8.0 & 0.0 & 8.0 & 8.0 & 2.7 & 4.6 & 21.3 \\
\hline POTEFRU & 3.0 & 5.0 & 0.0 & 5.0 & 5.0 & 1.7 & 2.9 & 8.3 \\
\hline
\end{tabular}

\section{CLUSTER}

37

N Range Minimum Maximum

8.0

8.0

8.0

8.0

8.0

8.0

8.0

8.0

\section{0}

8.0

8.0

8.

8.0

\section{0}

8.0

\section{0}

8

\section{8}

8

8.0 


$\begin{array}{lllllllll}\text { ASTELAE } & 3.0 & 2.9 & 0.1 & 3.0 & 4.1 & 1.4 & 1.5 & 2.2 \\ \text { THALVEN } & 3.0 & 2.0 & 0.0 & 2.0 & 4.0 & 1.3 & 1.2 & 1.3 \\ \text { RUMEACE } & 3.0 & 3.0 & 0.0 & 3.0 & 3.0 & 1.0 & 1.7 & 2.9 \\ \text { VICIAME } & 3.0 & 0.0 & 1.0 & 1.0 & 3.0 & 1.0 & 0.0 & 0.0 \\ \text { HORDJUB } & 3.0 & 3.0 & 0.0 & 3.0 & 3.0 & 1.0 & 1.7 & 3.0 \\ \text { CAREPRT } & 3.0 & 3.0 & 0.0 & 3.0 & 3.0 & 1.0 & 1.7 & 3.0 \\ \text { CAREATH } & 3.0 & 3.0 & 0.0 & 3.0 & 3.0 & 1.0 & 1.7 & 3.0 \\ \text { (plus } 18 \text { species) } & & & & & & & & \end{array}$

CLUSTER 39

\begin{tabular}{|c|c|c|c|c|c|c|c|c|}
\hline & $\mathrm{N}$ & Range & Minimum & Maximum & Sum & \multicolumn{2}{|c|}{ Mean Std. Deviation } & Variance \\
\hline POAPAL & 2.0 & 50.0 & 0.0 & 50.0 & 50.0 & 25.0 & 35.4 & 1250.0 \\
\hline POAPRA & 2.0 & 10.0 & 5.0 & 15.0 & 20.0 & 10.0 & 7.1 & 50.0 \\
\hline MUHLRIC & 2.0 & 13.0 & 2.0 & 15.0 & 17.0 & 8.5 & 9.2 & 84.5 \\
\hline ACHIMIL & 2.0 & 12.0 & 0.0 & 12.0 & 12.0 & 6.0 & 8.5 & 72.0 \\
\hline SYMPOCC & 2.0 & 9.0 & 1.0 & 10.0 & 11.0 & 5.5 & 6.4 & 40.5 \\
\hline ARTELUD & 2.0 & 7.0 & 1.0 & 8.0 & 9.0 & 4.5 & 4.9 & 24.5 \\
\hline AGROTRA & 2.0 & 5.0 & 2.0 & 7.0 & 9.0 & 4.5 & 3.5 & 12.5 \\
\hline ROSAWOO & 2.0 & 6.0 & 1.0 & 7.0 & 8.0 & 4.0 & 4.2 & 18.0 \\
\hline AGROSMI & 2.0 & 4.0 & 0.0 & 4.0 & 4.0 & 2.0 & 2.8 & 8.0 \\
\hline STIPCUR & 2.0 & 3.0 & 0.0 & 3.0 & 3.0 & 1.5 & 2.1 & 4.5 \\
\hline POACOM & 2.0 & 3.0 & 0.0 & 3.0 & 3.0 & 1.5 & 2.1 & 4.5 \\
\hline GLYCLEP & 2.0 & 3.0 & 0.0 & 3.0 & 3.0 & 1.5 & 2.1 & 4.5 \\
\hline VICLAME & 2.0 & 0.0 & 1.0 & 1.0 & 2.0 & 1.0 & 0.0 & 0.0 \\
\hline STIPCOM & 2.0 & 2.0 & 0.0 & 2.0 & 2.0 & 1.0 & 1.4 & 2.0 \\
\hline SOLIMIS & 2.0 & 0.0 & 1.0 & 1.0 & 2.0 & 1.0 & 0.0 & 0.0 \\
\hline SELADEN & 2.0 & 2.0 & 0.0 & 2.0 & 2.0 & 1.0 & 1.4 & 2.0 \\
\hline KOELMAC & 2.0 & 2.0 & 0.0 & 2.0 & 2.0 & 1.0 & 1.4 & 2.0 \\
\hline BROMINE & 2.0 & 2.0 & 0.0 & 2.0 & 2.0 & 1.0 & 1.4 & 2.0 \\
\hline ASTESPP & 2.0 & 2.0 & 0.0 & 2.0 & 2.0 & 1.0 & 1.4 & 2.0 \\
\hline ARTEFRI & 2.0 & 0.0 & 1.0 & 1.0 & 2.0 & 1.0 & 0.0 & 0.0 \\
\hline STIPVIR & 2.0 & 1.0 & 0.0 & 1.0 & 1.0 & 0.5 & 0.7 & 0.5 \\
\hline SPHACOC & 2.0 & 1.0 & 0.0 & 1.0 & 1.0 & 0.5 & 0.7 & 0.5 \\
\hline LINULEW & 2.0 & 1.0 & 0.0 & 1.0 & 1.0 & 0.5 & 0.7 & 0.5 \\
\hline HETEVIL & 2.0 & 1.0 & 0.0 & 1.0 & 1.0 & 0.5 & 0.7 & 0.5 \\
\hline CAREOBT & 2.0 & 1.0 & 0.0 & 1.0 & 1.0 & 0.5 & 0.7 & 0.5 \\
\hline BOUTGRA & 2.0 & 1.0 & 0.0 & 1.0 & 1.0 & 0.5 & 0.7 & 0.5 \\
\hline ARTECAN & 2.0 & 1.0 & 0.0 & 1.0 & 1.0 & 0.5 & 0.7 & 0.5 \\
\hline ANTEPAR & 2.0 & 1.0 & 0.0 & 1.0 & 1.0 & 0.5 & 0.7 & 0.5 \\
\hline AGROSCA & 2.0 & 1.0 & 0.0 & 1.0 & 1.0 & 0.5 & 0.7 & 0.5 \\
\hline
\end{tabular}

\section{CLUSTER}

40

N Range Minimum Maximum

POAPRA

TARAOFF

AGROTRA

ACHIMIL

GEUMTRI

FRAGVIR

22.0

$\begin{array}{rrr}43.0 & 19.0 & 62.0 \\ 32.0 & 0.0 & 32.0 \\ 30.0 & 0.0 & 30.0 \\ 20.0 & 0.0 & 20.0 \\ 41.0 & 0.0 & 41.0 \\ 26.0 & 0.0 & 26.0\end{array}$

22.0

22.0

22.0

22.0

22.0
Sum

818.0

233.2

204.0

161.1

159.1

121.1
Mean Std. Deviation Variance

37.2

10.6

9.3

7.3

7.2

5.5
11.1

10.9

8.5

6.0

12.2

7.0
124.2

117.9

72.1

36.2

148.6

49.6 


$\begin{array}{lrrrrrrrr}\text { POTEGRA } & 22.0 & 24.0 & 0.0 & 24.0 & 113.0 & 5.1 & 6.7 & 44.3 \\ \text { STIPRIC } & 22.0 & 43.0 & 0.0 & 43.0 & 109.1 & 5.0 & 11.4 & 130.5 \\ \text { PHLEPRA } & 22.0 & 31.0 & 0.0 & 31.0 & 93.0 & 4.2 & 8.5 & 71.7 \\ \text { PENSCON } & 22.0 & 30.0 & 0.0 & 30.0 & 77.0 & 3.5 & 7.3 & 52.6 \\ \text { FESTIDA } & 22.0 & 18.0 & 0.0 & 18.0 & 67.2 & 3.1 & 5.5 & 30.8 \\ \text { FESTSCA } & 22.0 & 20.0 & 0.0 & 20.0 & 58.0 & 2.6 & 5.2 & 26.5 \\ \text { GERAVIS } & 22.0 & 13.0 & 0.0 & 13.0 & 47.0 & 2.1 & 4.3 & 18.2 \\ \text { DANTPAR } & 22.0 & 16.0 & 0.0 & 16.0 & 47.0 & 2.1 & 3.8 & 14.5 \\ \text { VICIAME } & 22.0 & 11.0 & 0.0 & 11.0 & 45.2 & 2.1 & 3.1 & 9.9 \\ \text { POTEDIV } & 22.0 & 15.0 & 0.0 & 15.0 & 45.1 & 2.1 & 4.5 & 19.8 \\ \text { CAREPRG } & 22.0 & 12.0 & 0.0 & 12.0 & 45.0 & 2.0 & 4.5 & 19.9 \\ \text { CAREOBT } & 22.0 & 15.0 & 0.0 & 15.0 & 44.0 & 2.0 & 3.8 & 14.4 \\ \text { GALIBOR } & 22.0 & 20.0 & 0.0 & 20.0 & 43.3 & 2.0 & 4.4 & 19.7 \\ \text { CERAARV } & 22.0 & 22.0 & 0.0 & 22.0 & 42.2 & 1.9 & 5.0 & 24.9 \\ \text { BROMCIL } & 22.0 & 17.0 & 0.0 & 17.0 & 38.1 & 1.7 & 3.9 & 15.2 \\ \text { KOELMAC } & 22.0 & 10.0 & 0.0 & 10.0 & 33.2 & 1.5 & 2.9 & 8.2 \\ \text { DANTCAL } & 22.0 & 18.0 & 0.0 & 18.0 & 29.1 & 1.3 & 4.0 & 15.9 \\ \text { TRIFREP } & 22.0 & 27.0 & 0.0 & 27.0 & 29.0 & 1.3 & 5.8 & 33.1 \\ \text { AGOSGLA } & 22.0 & 10.0 & 0.0 & 10.0 & 28.1 & 1.3 & 2.7 & 7.1 \\ \text { CAREPRA } & 22.0 & 24.0 & 0.0 & 24.0 & 26.0 & 1.2 & 5.1 & 26.2 \\ \text { THALVEN } & 22.0 & 9.0 & 0.0 & 9.0 & 26.0 & 1.2 & 2.5 & 6.3 \\ \text { (plus 96 species) } & & & & & & & \end{array}$

\section{CLUSTER}

41

$\mathrm{N}$

POAPRA

FRAGVIR

TRIFREP

ANEMMUL

PENSPRO

LICHSPP

PHLEPRA

ACHIMIL

POTEFRU

GEUMRIV

GENTAMA

SALIGLA

CAREOBT

AGRODAS

TARAOFF

POLEPUL

GALIBOR

BROMINE

ASTECIL

ARCTUVA

FESTSAX

POTEGRA

ELYMINN

CARESPP

ROSAACI

KOELMAC
Range Minimum Maximum

$$
9.0
$$

3.0

16.0

8.0

11.0

11.0

9.0

1.0

6.0

6.0

6.0

5.0

4.0

4.0

3.0

3.0

1.0

3.0

3.0

3.0

2.0

2.0

2.0

2.0

1.0

1.0

$$
5.0
$$

7.0

0.0

2.0

0.0

0.0

0.0

4.0

0.0

0.0

0.0

0.0

0.0

0.0

0.0

0.0

1.0

0.0

0.0

0.0

0.0

0.0

0.0

0.0

0.0

0.0
14.0

10.0

16.0

10.0

11.0

11.0

9.0

5.0

6.0

6.0

6.0

5.0

4.0

4.0

3.0

3.0

2.0

3.0

3.0

3.0

2.0

2.0

2.0

2.0

1.0

1.0
Sum

19.0

17.0

16.0

12.0

11.0

11.0

9.0

9.0

6.0

6.0

6.0

5.0

4.0

4.0

3.0

3.0

3.0

3.0

3.0

3.0

2.0

2.0

2.0

2.0

1.0

1.0
Mean Std. Deviation

9.5

6.4
2.1

2.1
11.3

11.3
5.7

7.8

7.8

7.8

6.4

0.7

4.2

4.2

4.2

3.5

2.8

2.8

2.1

2.1

0.7

2.1

2.1

2.1

1.3

1.4

1.4

1.4

0.7

0.7

1.0

0.5

0.5
Variance 40.5

28.0

32.0

60.5

60.5

40.5

0.5

18.0

18.0

18.0

12.5

8.0

8.0

4.5

4.5

0.5

4.5

4.5

4.5

1.8

2.0

2.0 


\begin{tabular}{|c|c|c|c|c|c|c|c|c|}
\hline DELPGLA & 2.0 & 1.0 & 0.0 & 1.0 & 1.0 & 0.5 & 0.7 & 0.5 \\
\hline ANDRSEP & 2.0 & 1.0 & 0.0 & 1.0 & 1.0 & 0.5 & 0.7 & 0.5 \\
\hline \multirow[t]{3}{*}{ AGOSGLA } & 2.0 & 1.0 & 0.0 & 1.0 & 1.0 & 0.5 & 0.7 & 0.5 \\
\hline & \multicolumn{7}{|c|}{$\begin{array}{c}\text { CLUSTER } \\
42\end{array}$} & \\
\hline & $\mathrm{N}$ & Range & Minimum & Maximum & Sum & \multicolumn{2}{|c|}{ Mean Std. Deviation } & Variance \\
\hline POAPRA & 5.0 & 10.0 & 14.0 & 24.0 & 91.0 & 18.2 & 3.8 & 14.2 \\
\hline LUPISER & 5.0 & 29.0 & 0.0 & 29.0 & 42.0 & 8.4 & 11.9 & 142.3 \\
\hline AGRODAS & 5.0 & 35.0 & 0.0 & 35.0 & 35.0 & 7.0 & 15.7 & 245.0 \\
\hline CAREOBT & 5.0 & 20.0 & 0.0 & 20.0 & 34.0 & 6.8 & 8.3 & 69.7 \\
\hline TARAOFF & 5.0 & 14.0 & 1.0 & 15.0 & 28.0 & 5.6 & 5.9 & 35.3 \\
\hline VICIAME & 5.0 & 13.0 & 0.0 & 13.0 & 26.1 & 5.2 & 5.4 & 29.4 \\
\hline KOELMAC & 5.0 & 10.0 & 1.0 & 11.0 & 26.0 & 5.2 & 4.5 & 20.2 \\
\hline THERRHO & 5.0 & 8.0 & 0.0 & 8.0 & 21.0 & 4.2 & 4.0 & 16.2 \\
\hline GALIBOR & 5.0 & 8.0 & 1.0 & 9.0 & 20.0 & 4.0 & 3.2 & 10.0 \\
\hline ANTEPAR & 5.0 & 10.0 & 0.0 & 10.0 & 20.0 & 4.0 & 5.5 & 30.0 \\
\hline SOLIMIS & 5.0 & 8.0 & 1.0 & 9.0 & 18.0 & 3.6 & 3.7 & 13.8 \\
\hline SYMPOCC & 5.0 & 12.0 & 0.0 & 12.0 & 17.0 & 3.4 & 5.0 & 24.8 \\
\hline SELADEN & 5.0 & 15.0 & 0.0 & 15.0 & 15.0 & 3.0 & 6.7 & 45.0 \\
\hline AGROSPI & 5.0 & 14.0 & 0.0 & 14.0 & 14.0 & 2.8 & 6.3 & 39.2 \\
\hline ACHIMIL & 5.0 & 4.0 & 0.0 & 4.0 & 12.0 & 2.4 & 1.8 & 3.3 \\
\hline GAILARI & 5.0 & 8.0 & 0.0 & 8.0 & 11.1 & 2.2 & 3.5 & 12.1 \\
\hline STIPCOL & 5.0 & 4.0 & 0.0 & 4.0 & 11.0 & 2.2 & 2.0 & 4.2 \\
\hline ANDRSEP & 5.0 & 7.0 & 0.0 & 7.0 & 11.0 & 2.2 & 3.2 & 10.2 \\
\hline SISYMON & 5.0 & 6.0 & 0.0 & 6.0 & 9.1 & 1.8 & 2.5 & 6.1 \\
\hline CAMPROT & 5.0 & 6.0 & 0.0 & 6.0 & 9.1 & 1.8 & 2.5 & 6.1 \\
\hline FESTIDA & 5.0 & 4.0 & 0.0 & 4.0 & 9.0 & 1.8 & 1.6 & 2.7 \\
\hline DANTCAL & 5.0 & 9.0 & 0.0 & 9.0 & 9.0 & 1.8 & 4.0 & 16.2 \\
\hline AGOSGLA & 5.0 & 5.0 & 0.0 & 5.0 & 9.0 & 1.8 & 2.0 & 4.2 \\
\hline OXYTSER & 5.0 & 7.0 & 0.0 & 7.0 & 8.1 & 1.6 & 3.0 & 9.2 \\
\hline POACAN & 5.0 & 6.0 & 0.0 & 6.0 & 8.0 & 1.6 & 2.6 & 6.8 \\
\hline OXYTSPL & 5.0 & 8.0 & 0.0 & 8.0 & 8.0 & 1.6 & 3.6 & 12.8 \\
\hline ANEMMUL & 5.0 & 5.0 & 0.0 & 5.0 & 8.0 & 1.6 & 1.9 & 3.8 \\
\hline AGROTRA & 5.0 & 4.0 & 0.0 & 4.0 & 8.0 & 1.6 & 2.2 & 4.8 \\
\hline ROSAARK & 5.0 & 7.0 & 0.0 & 7.0 & 7.0 & 1.4 & 3.1 & 9.8 \\
\hline ROSAACI & 5.0 & 3.0 & 0.0 & 3.0 & 6.0 & 1.2 & 1.3 & 1.7 \\
\hline POTEFRU & 5.0 & 5.0 & 0.0 & 5.0 & 5.1 & 1.0 & 2.2 & 5.0 \\
\hline VIOLADU & 5.0 & 5.0 & 0.0 & 5.0 & 5.0 & 1.0 & 2.2 & 5.0 \\
\hline SMILSTE & 5.0 & 5.0 & 0.0 & 5.0 & 5.0 & 1.0 & 2.2 & 5.0 \\
\hline CALARUB & 5.0 & 5.0 & 0.0 & 5.0 & 5.0 & 1.0 & 2.2 & 5.0 \\
\hline AMELALN & 5.0 & 2.0 & 0.0 & 2.0 & 5.0 & 1.0 & 1.0 & 1.0 \\
\hline AGROSMI & 5.0 & 4.0 & 0.0 & 4.0 & 5.0 & 1.0 & 1.7 & 3.0 \\
\hline
\end{tabular}

\section{CLUSTER}

43

\begin{tabular}{|c|c|c|c|c|c|c|c|c|}
\hline & $N$ & Range & Minimum & Maximum & Sum & Mean & lation & Variance \\
\hline FRAGVIR & 6.0 & 26.0 & 10.0 & 36.0 & 125.0 & 20.8 & 9.7 & 93.8 \\
\hline CAREPRA & 6.0 & 88.0 & 0.0 & 88.0 & 101.0 & 16.8 & 35.3 & 1242.6 \\
\hline MOSSSPP & 6.0 & 36.0 & 0.0 & 36.0 & 73.0 & 12.2 & 16.0 & 257.4 \\
\hline
\end{tabular}




\begin{tabular}{|c|c|c|c|c|c|c|c|c|}
\hline POAPRA & 6.0 & 20.0 & 0.0 & 20.0 & 59.0 & 9.8 & 8.3 & 69.4 \\
\hline ACHIMIL & 6.0 & 26.0 & 0.0 & 26.0 & 56.0 & 9.3 & 11.3 & 127.1 \\
\hline PHLEPRA & 6.0 & 17.0 & 0.0 & 17.0 & 47.0 & 7.9 & 6.9 & 47.5 \\
\hline POTEGRA & 6.0 & 46.0 & 0.0 & 46.0 & 46.0 & 7.7 & 18.8 & 352.7 \\
\hline POPUTRE & 6.0 & 20.0 & 0.0 & 20.0 & 45.0 & 7.5 & 8.8 & 77.5 \\
\hline GALIBOR & 6.0 & 27.0 & 0.0 & 27.0 & 42.0 & 7.0 & 10.7 & 114.4 \\
\hline VICLAME & 6.0 & 26.0 & 0.0 & 26.0 & 39.1 & 6.5 & 10.0 & 99.6 \\
\hline EPILANG & 6.0 & 21.0 & 0.0 & 21.0 & 39.0 & 6.5 & 8.4 & 70.3 \\
\hline ASTESPP & 6.0 & 38.0 & 0.0 & 38.0 & 39.0 & 6.5 & 15.4 & 238.3 \\
\hline GERARIC & 6.0 & 20.0 & 0.0 & 20.0 & 38.0 & 6.3 & 8.2 & 67.9 \\
\hline CALARUB & 6.0 & 22.0 & 0.0 & 22.0 & 37.0 & 6.2 & 9.8 & 96.2 \\
\hline PENSCON & 6.0 & 28.0 & 0.0 & 28.0 & 36.0 & 6.0 & 11.2 & 126.4 \\
\hline AGROTRA & 6.0 & 11.0 & 0.0 & 11.0 & 28.0 & 4.7 & 4.3 & 18.3 \\
\hline MERTPAN & 6.0 & 24.0 & 0.0 & 24.0 & 27.0 & 4.5 & 9.6 & 92.7 \\
\hline THALOCC & 6.0 & 24.0 & 0.0 & 24.0 & 24.0 & 4.0 & 9.8 & 95.8 \\
\hline LATHOCH & 6.0 & 12.0 & 0.0 & 12.0 & 24.0 & 4.0 & 5.1 & 25.6 \\
\hline CARESPP & 6.0 & 14.0 & 0.0 & 14.0 & 19.0 & 3.2 & 5.5 & 30.6 \\
\hline ASTECON & 6.0 & 13.0 & 0.0 & 13.0 & 19.0 & 3.2 & 5.1 & 25.8 \\
\hline ASTELAE & 6.0 & 8.0 & 0.0 & 8.0 & 18.0 & 3.0 & 3.7 & 13.6 \\
\hline LUPISER & 6.0 & 17.0 & 0.0 & 17.0 & 17.0 & 2.8 & 6.9 & 48.2 \\
\hline SYMPOCC & 6.0 & 14.0 & 0.0 & 14.0 & 17.0 & 2.8 & 5.6 & 31.4 \\
\hline CALACAN & 6.0 & 16.0 & 0.0 & 16.0 & 16.0 & 2.7 & 6.5 & 42.7 \\
\hline TARAOFF & 6.0 & 4.0 & 0.0 & 4.0 & 16.0 & 2.7 & 1.5 & 2.3 \\
\hline FESTSAX & 6.0 & 12.0 & 0.0 & 12.0 & 12.0 & 2.0 & 4.9 & 24.0 \\
\hline PHLECOM & 6.0 & 11.0 & 0.0 & 11.0 & 11.0 & 1.8 & 4.5 & 20.2 \\
\hline AGROSCA & 6.0 & 11.0 & 0.0 & 11.0 & 11.0 & 1.8 & 4.5 & 20.2 \\
\hline SYMPALB & 6.0 & 10.0 & 0.0 & 10.0 & 10.0 & 1.7 & 4.1 & 16.7 \\
\hline RUBUIDA & 6.0 & 9.0 & 0.0 & 9.0 & 9.0 & 1.5 & 3.7 & 13.5 \\
\hline ROSAACI & 6.0 & 5.0 & 0.0 & 5.0 & 9.0 & 1.5 & 2.3 & 5.5 \\
\hline MONAFIS & 6.0 & 9.0 & 0.0 & 9.0 & 9.0 & 1.5 & 3.7 & 13.5 \\
\hline ANTEPAR & 6.0 & 8.0 & 0.0 & 8.0 & 9.0 & 1.5 & 3.2 & 10.3 \\
\hline RHINMIN & 6.0 & 8.0 & 0.0 & 8.0 & 8.0 & 1.3 & 3.3 & 10.7 \\
\hline ELYMINN & 6.0 & 5.0 & 0.0 & 5.0 & 7.0 & 1.2 & 2.0 & 4.2 \\
\hline BROMINE & 6.0 & 4.0 & 0.0 & 4.0 & 7.0 & 1.2 & 1.8 & 3.4 \\
\hline SENEPAU & 6.0 & 6.0 & 0.0 & 6.0 & 6.0 & 1.0 & 2.5 & 6.0 \\
\hline GEUMTRI & 6.0 & 6.0 & 0.0 & 6.0 & 6.0 & 1.0 & 2.4 & 6.0 \\
\hline FESTRUB & 6.0 & 6.0 & 0.0 & 6.0 & 6.0 & 1.0 & 2.4 & 6.0 \\
\hline $\begin{array}{l}\text { AGROSMI } \\
\text { (plus } 32 \text { species) }\end{array}$ & 6.0 & 6.0 & 0.0 & 6.0 & 6.0 & 1.0 & 2.5 & 6.0 \\
\hline
\end{tabular}

$\begin{array}{rrrrrrrr}\text { N } & \text { Range } & \text { Minimum } & \text { Maximum } & \text { Sum } & \text { Mean Std. Deviation } & \text { Variance } \\ 10.0 & 22.0 & 0.0 & 22.0 & 86.0 & 8.6 & 7.5 & 56.0 \\ 10.0 & 11.0 & 4.0 & 15.0 & 83.0 & 8.3 & 3.6 & 12.9 \\ 10.0 & 15.0 & 0.0 & 15.0 & 54.1 & 5.4 & 6.1 & 37.3 \\ 10.0 & 12.0 & 0.0 & 12.0 & 22.0 & 2.2 & 4.7 & 21.7 \\ 10.0 & 20.0 & 0.0 & 20.0 & 20.0 & 2.0 & 6.3 & 40.0 \\ 10.0 & 7.0 & 0.0 & 7.0 & 20.0 & 2.0 & 2.8 & 8.0 \\ 10.0 & 7.0 & 0.0 & 7.0 & 14.0 & 1.4 & 2.1 & 4.3 \\ 10.0 & 10.0 & 0.0 & 10.0 & 11.0 & 1.1 & 3.1 & 9.9\end{array}$

KOELMAC

AGRODAS

ARTEFRI

ARCTUVA

STIPVIR

POTEFRU

COMAUMB

ALLICER

\section{CLUSTER \\ CLUSTER
44}

Geowest Environmental Consultants Ltd. 
OXYTSER

JUNICOM

(plus 48 species)
10.0

10.0

8.0
10.0

0.0

0.0

$$
8.0
$$

10.0
10.0

10.0
1.0

1.0
2.5

3.2
6.2

10.0

\section{CLUSTER}

45

AGRODAS
DANTCAL
STIPCOM
JUNIHOR
AMELALN
EPILANG
KOELMAC
FESTSPP
GALIBOR
SALISPP
LUPISER
FRAGVIR
SYMPALB
ARTEFRI
(plus 63 species)

N

8.0

8.0

8.0

8.0

8.0

8.0

8.0

8.0

8.0

8.0

8.0

8.0

8.0

8.0
Range Minimum Maximum

$$
55.0
$$

40.0

23.0

$$
18.0
$$

$$
18.0
$$

10.0

8.0

7.0

5.0

10.0

10.0

4.0

5.0

5.0

15.0

0.0

0.0

0.0

0.0

0.0

0.0

0.0

0.0

0.0

0.0

0.0

0.0

0.0
70.0

40.0

23.0

18.0

18.0

10.0

8.0

7.0

5.0

10.0

10.0

4.0

5.0

5.0
Sum

334.0

41.0

23.0

20.0

18.0

15.0

12.0

12.0

11.0

10.0

10.0

10.0

8.0

8.0

\section{CLUSTER}

46

Descriptive Statistics(a)

AGRODAS

KOELMAC

ARTEFRI

ELYMINN

FESTSAX

LINULEW

THALOCC

CALAPUR

FRAGVIR

ASTESPP

ARTEDRA

SMILSTE

POPUTRE

DESCCES

AGROSMI

(plus 60 species)
N

9.0

9.0

9.0

9.0

9.0

9.0

9.0

9.0

9.0

9.0

9.0

9.0

9.0

9.0

9.0
Range Minimum Maximum

29.0

60.0

28.0

25.0

22.0

20.0

18.0

15.0

8.0

15.0

8.0

12.0

10.0

10.0

5.0
10.0

0.0

0.0

0.0

0.0

0.0

0.0

0.0

0.0

0.0

0.0

0.0

0.0

0.0

0.0
Sum

229.0

215.0

91.0

45.0

26.0

22.0

18.0

17.0

15.0

15.0

14.0

12.0

10.0

10.0

9.0
Mean Std. Deviation Variance

25.4

23.9

10.1

5.0

2.9

2.4

2.0

1.9

1.7

1.7

1.6

1.3

1.1

1.1

1.0
9.3

20.1

11.6

8.7

$7.2 \quad 52.4$

$6.6 \quad 43.5$

$6.0 \quad 36.0$

$5.0 \quad 24.6$

$2.9 \quad 8.3$

$5.0 \quad 25.0$

$2.7 \quad 7.5$

$4.0 \quad 16.0$

$3.3 \quad 11.1$

$3.3 \quad 11.1$

$\begin{array}{ll}1.7 & 2.8\end{array}$

\section{CLUSTER}

47

AGROSMI
CARESPP
AMELALN

\section{N}

Range

11.0

Minimum Maximum

5.0

5.0

4.0

0.0

15.0

10.0

1.0
Sum

38.0

23.0

22.0
Mean Std. Deviation Variance 7.6

4.3

3.7

18.8

4.6

4.3

$\begin{array}{lll}4.4 & 4.3 & 18.3\end{array}$




$\begin{array}{lllllllll}\text { SYMPALB } & 5.0 & 3.0 & 1.0 & 4.0 & 15.0 & 3.0 & 1.4 & 2.0 \\ \text { KOELMAC } & 5.0 & 5.0 & 0.0 & 5.0 & 10.0 & 2.0 & 1.9 & 3.5 \\ \text { STIPCUR } & 5.0 & 5.0 & 0.0 & 5.0 & 9.0 & 1.8 & 2.0 & 4.2 \\ \text { ARTEFRI } & 5.0 & 3.0 & 0.0 & 3.0 & 8.0 & 1.6 & 1.1 & 1.3 \\ \text { PRUNVIR } & 5.0 & 3.0 & 0.0 & 3.0 & 4.0 & 0.8 & 1.3 & 1.7 \\ \text { VICIAME } & 5.0 & 1.0 & 0.0 & 1.0 & 3.0 & 0.6 & 0.5 & 0.3 \\ \text { STIPVIR } & 5.0 & 2.0 & 0.0 & 2.0 & 3.0 & 0.6 & 0.9 & 0.8 \\ \text { STIPCOM } & 5.0 & 3.0 & 0.0 & 3.0 & 3.0 & 0.6 & 1.3 & 1.8 \\ \text { ROSAACI } & 5.0 & 2.0 & 0.0 & 2.0 & 3.0 & 0.6 & 0.9 & 0.8 \\ \text { STIPCOL } & 5.0 & 2.0 & 0.0 & 2.0 & 2.0 & 0.4 & 0.9 & 0.8 \\ \text { LINULEW } & 5.0 & 1.0 & 0.0 & 1.0 & 2.0 & 0.4 & 0.5 & 0.3 \\ \text { GALIBOR } & 5.0 & 1.0 & 0.0 & 1.0 & 2.0 & 0.4 & 0.5 & 0.3 \\ \text { COMAUMB } & 5.0 & 1.0 & 0.0 & 1.0 & 2.0 & 0.4 & 0.5 & 0.3 \\ \text { ASTELAE } & 5.0 & 1.0 & 0.0 & 1.0 & 2.0 & 0.4 & 0.5 & 0.3 \\ \text { OXYTSPL } & 5.0 & 1.0 & 0.0 & 1.0 & 1.0 & 0.2 & 0.4 & 0.2 \\ \text { GEUMTRI } & 5.0 & 1.0 & 0.0 & 1.0 & 1.0 & 0.2 & 0.4 & 0.2 \\ \text { FESTRUB } & 5.0 & 1.0 & 0.0 & 1.0 & 1.0 & 0.2 & 0.4 & 0.2 \\ \text { ARTECAM } & 5.0 & 1.0 & 0.0 & 1.0 & 1.0 & 0.2 & 0.5 & 0.2 \\ \text { ANEMMUL } & 5.0 & 1.0 & 0.0 & 1.0 & 1.0 & 0.2 & 0.4 & 0.2 \\ \text { ACHIMIL } & 5.0 & 1.0 & 0.0 & 1.0 & 1.0 & 0.2 & 0.4 & 0.2\end{array}$

CLUSTER

48

Descriptive Statistics(a)

AGROTRA
AMELALN
GAILARI
ROSAACI
PRUNVIR
ARTEFRI
KOELMAC
VICIAME

SYMPOCC

GALIBOR

BROMCII

ACHIMIL

plus 31 species

$\begin{array}{rrrr}\text { N } & \text { Range } & \text { Minimum } & \text { Maximum } \\ 4.0 & 12.0 & 0.0 & 12.0 \\ 4.0 & 3.0 & 2.0 & 5.0 \\ 4.0 & 10.0 & 0.0 & 10.0 \\ 4.0 & 4.0 & 1.0 & 5.0 \\ 4.0 & 3.0 & 0.0 & 3.0 \\ 4.0 & 3.0 & 0.0 & 3.0 \\ 4.0 & 1.0 & 1.0 & 2.0 \\ 4.0 & 0.0 & 1.0 & 1.0 \\ 4.0 & 2.0 & 0.0 & 2.0 \\ 4.0 & 0.0 & 1.0 & 1.0 \\ 4.0 & 2.0 & 0.0 & 2.0 \\ 4.0 & 2.0 & 0.0 & 2.0\end{array}$

\section{CLUSTER}

49

Descriptive Statistics(a)

DANTPAR

CAREROS

KOELMAC

FESTSAX

ROSAACI

GALIBOR

LICHSPP

AGROSMI
N Range Minimum Maximum

$\begin{array}{llll}3.0 & 36.0 & 0.0 & 36.0\end{array}$

$3.0 \quad 12.0$

$3.0 \quad 13.0$

$3.0 \quad 12.0$

$3.0 \quad 14.0$

$3.0 \quad 1.0$

$3.0 \quad 17.0$

3.0
$0.0 \quad 12.0$

$1.0 \quad 14.0$

$\begin{array}{ll}0.0 & 12.0\end{array}$

$\begin{array}{ll}1.0 & 15.0\end{array}$

$5.0 \quad 6.0$

$0.0 \quad 17.0$

$4.0 \quad 6.0$
Sum

27.0

16.0

11.0

9.0

6.0

6.0

5.0

4.0

4.0

4.0

4.0

4.0
Mean Std.

$$
6.8
$$

4.0

2.8

2.3

1.5

1.5

1.3

1.0

1.0

1.0

1.0

1.0

$\begin{array}{rr}\text { Deviation } & \text { Variance } \\ 5.4 & 28.9 \\ 1.4 & 2.0 \\ 4.9 & 23.6 \\ 1.9 & 3.6 \\ 1.7 & 3.0 \\ 1.3 & 1.7 \\ 0.5 & 0.3 \\ 0.0 & 0.0 \\ 1.2 & 1.3 \\ 0.0 & 0.0 \\ 1.2 & 1.3 \\ 0.8 & 0.7\end{array}$

Sum Mean Std. Deviation Variance $\begin{array}{llll}36.0 & 12.0 & 20.8 & 432.0\end{array}$

$\begin{array}{llll}23.0 & 7.7 & 6.7 & 44.3\end{array}$

$\begin{array}{llll}20.0 & 6.7 & 6.7 & 44.3\end{array}$

$\begin{array}{llll}18.0 & 6.0 & 6.0 & 36.0\end{array}$

$\begin{array}{llll}17.0 & 5.7 & 8.1 & 65.3\end{array}$

$\begin{array}{llll}17.0 & 5.7 & 0.6 & 0.3\end{array}$

$\begin{array}{llll}17.0 & 5.7 & 9.8 & 96.3\end{array}$

$\begin{array}{llll}15.0 & 5.0 & 1.0 & 1.0\end{array}$

5
.2
3
7
3
8
8
8
.8
3
3
3
3
.2
.2
.2




\begin{tabular}{|c|c|c|c|c|c|c|c|c|}
\hline PRUNVIR & 3.0 & 10.0 & 0.0 & 10.0 & 11.0 & 3.7 & 5.5 & 30.3 \\
\hline MOSSSPP & 3.0 & 11.0 & 0.0 & 11.0 & 11.0 & 3.7 & 6.4 & 40.3 \\
\hline POAINT & 3.0 & 11.0 & 0.0 & 11.0 & 11.0 & 3.7 & 6.4 & 40.3 \\
\hline LUPISER & 3.0 & 5.0 & 2.0 & 7.0 & 11.0 & 3.7 & 2.9 & 8.3 \\
\hline STIPCOL & 3.0 & 7.0 & 0.0 & 7.0 & 10.0 & 3.3 & 3.5 & 12.3 \\
\hline HELIHOO & 3.0 & 4.0 & 1.0 & 5.0 & 7.0 & 2.3 & 2.3 & 5.3 \\
\hline CERAARV & 3.0 & 2.0 & 1.0 & 3.0 & 7.0 & 2.3 & 1.2 & 1.3 \\
\hline SYMPALB & 3.0 & 5.0 & 0.0 & 5.0 & 6.0 & 2.0 & 2.7 & 7.0 \\
\hline OXYTSPL & 3.0 & 6.0 & 0.0 & 6.0 & 6.0 & 2.0 & 3.5 & 12.0 \\
\hline HETEVIL & 3.0 & 2.0 & 1.0 & 3.0 & 6.0 & 2.0 & 1.0 & 1.0 \\
\hline ACHIMIL & 3.0 & 3.9 & 0.1 & 4.0 & 5.1 & 1.7 & 2.0 & 4.2 \\
\hline ARTEFRI & 3.0 & 3.0 & 0.0 & 3.0 & 5.0 & 1.7 & 1.5 & 2.3 \\
\hline LITHRUD & 3.0 & 4.0 & 0.0 & 4.0 & 5.0 & 1.7 & 2.1 & 4.3 \\
\hline AMELALN & 3.0 & 5.0 & 0.0 & 5.0 & 5.0 & 1.7 & 2.9 & 8.3 \\
\hline STIPRIC & 3.0 & 4.0 & 0.0 & 4.0 & 4.0 & 1.3 & 2.3 & 5.3 \\
\hline MONAFIS & 3.0 & 4.0 & 0.0 & 4.0 & 4.0 & 1.3 & 2.3 & 5.3 \\
\hline FESTSCA & 3.0 & 3.0 & 0.0 & 3.0 & 4.0 & 1.3 & 1.5 & 2.3 \\
\hline CAREXER & 3.0 & 4.0 & 0.0 & 4.0 & 4.0 & 1.3 & 2.3 & 5.3 \\
\hline THERRHO & 3.0 & 3.0 & 0.0 & 3.0 & 3.0 & 1.0 & 1.7 & 3.0 \\
\hline COMAUMB & 3.0 & 2.0 & 0.0 & 2.0 & 3.0 & 1.0 & 1.0 & 1.0 \\
\hline
\end{tabular}

CLUSTER

50

CAREXER

$\mathrm{N}$

Range Minimum Maximum

Sum

Mean Std. Deviation Variance

MOSSSPP

6.0

5.0

7.0

12.0

56.0

9.3

2.1

4.3

6.0

10.0

14.0

51.0

8.5

4.1

17.1

GEUMTRI

6.0

0.0

19.0

35.0

5.8

8.1

66.2

AGROSMI

6.0

0.0

9.0

26.0

GALIBOR

6.0

13.9

14.0

25.1

4.4

3.6

12.9

FESTSCA

KOELMAC

6.0

0.0

12.0

24.0

4.2

5.2

26.8

STIPVIR

6.0

1.0

7.0

23.0

4.0

4.2

18.0

6.0

13.0

13.0

22.0

3.8

2.3

5.4

6.0

0.0

3.7

5.8

33.9

POTEFRU

6.0

9.0

21.0

3.5

3.3

10.7

AGROTRA

6.0

1.0

7.0

20.0

3.3

2.3

5.5

VICLAME

6.0

7.0

7.0

2.9

3.2

10.5

ARTEFRI

6.0

0.0

15.0

2.5

3.5

12.3

ROSAACI

6.0

6.0

14.1

2.4

2.0

4.2

ASTRALP

6.0

8.0

0.0

2.2

3.2

10.5

HELIHOO

6.0

7.0

7.0

13.0

2.2

2.6

7.0

DANTPAR

6.0

0.1

12.1

2.0

1.6

2.7

BROMINE

7.0

7.0

1.8

3.0

9.0

POASPP

6.0

0.0

8.0

1.3

2.1

4.3

(plus 25 species)

3.0

0.0

3.0

6.0

1.0

1.5

2.4

\section{CLUSTER}

51

N Range Minimum Maximum

Sum

Mean Std. Deviation

Variance

$\begin{array}{llll}9.0 & 70.0 & 10.0 & 80.0\end{array}$

300.0 33.3

20.6

423.0

ARTEFRI

$\begin{array}{llll}9.0 & 16.0 & 0.0 & 16.0\end{array}$

41.1

4.6

6.6

43.9 


$\begin{array}{lrrrrrrrr}\text { STIPCOM } & 9.0 & 11.0 & 0.0 & 11.0 & 32.0 & 3.6 & 3.6 & 13.0 \\ \text { SELADEN } & 9.0 & 17.0 & 0.0 & 17.0 & 31.0 & 3.4 & 6.6 & 44.0 \\ \text { STIPVIR } & 9.0 & 30.0 & 0.0 & 30.0 & 30.0 & 3.3 & 10.0 & 100.0 \\ \text { CARESPP } & 9.0 & 25.0 & 0.0 & 25.0 & 25.0 & 2.8 & 8.3 & 69.4 \\ \text { ARTECAN } & 9.0 & 14.0 & 0.0 & 14.0 & 24.0 & 2.7 & 5.4 & 29.0 \\ \text { BOUTGRA } & 9.0 & 8.0 & 0.0 & 8.0 & 22.0 & 2.4 & 3.3 & 10.8 \\ \text { GRINSQU } & 9.0 & 15.0 & 0.0 & 15.0 & 18.0 & 2.0 & 5.0 & 24.8 \\ \text { CALALON } & 9.0 & 16.0 & 0.0 & 16.0 & 16.0 & 1.8 & 5.3 & 28.4 \\ \text { KOELMAC } & 9.0 & 6.0 & 0.0 & 6.0 & 15.0 & 1.7 & 2.1 & 4.3 \\ \text { AGROTRA } & 9.0 & 14.0 & 0.0 & 14.0 & 15.0 & 1.7 & 4.6 & 21.5 \\ \text { PHLOHOO } & 9.0 & 7.0 & 0.0 & 7.0 & 9.1 & 1.0 & 2.3 & 5.2 \\ \text { (plus 32 species) } & & & & & & & & \end{array}$

\section{CLUSTER}

52

HORDJUB
AGROSMI
POAPAL
ELEOPAL
CARESPP
POAPRA
PUCCHAU
ARTELUD
DESCCES
AGROSCA
GRINSQU
POACAN
AGROTRA
ROSAWOO
TARAOFF
ACHIMIL
ARTECAM
SOLIMIS
GLYCLEP
ASTEFAL
ARTEFRI
ARTECAN
$\mathrm{N}$

6.0

6.0

6.0

6.0

6.0

6.0

6.0

6.0

6.0

6.0

6.0

6.0

6.0

6.0

6.0

6.0

6.0

6.0

6.0

6.0

6.0

6.0
Range Minimum Maximum

$$
50.0
$$

33.0

20.0

26.0

15.0

10.0

20.0

15.0

15.0

10.0

3.0

5.0

5.0

3.0

2.0

2.0

1.0

1.0

1.0

1.0

1.0

1.0
10.0

2.0

0.0

0.0

0.0

0.0

0.0

0.0

0.0

0.0

0.0

0.0

0.0

0.0

0.0

0.0

0.0

0.0

0.0

0.0

0.0

0.0

\section{0}

35.0

20.0

26.0

15.0

10.0

20.0

15.0

15.0

10.0

3.0

5.0

5.0

3.0

2.0

2.0

1.0

1.0

1.0

1.0

1.0

1.0
Sum

181.0

81.0

63.0

44.0

25.0

23.0

20.0

18.1

15.0

10.0

8.0

5.0

5.0

5.0

3.0

2.0

1.0

1.0

1.0

1.0

1.0

1.0
Mean Std. Deviation 30.2

13.5

10.5

7.3

4.2

3.8

3.3

3.0

2.5

1.7

1.3

0.9

0.8

0.8

0.5

0.3

0.2

0.2

0.2

0.2

0.2

0.2
23.7

14.8

8.8

11.6

6.6

4.9

8.2

6.0

6.1

4.1

1.4

2.0

2.0

1.3

0.8

0.8

0.4

0.4

0.4

0.4

0.4

0.4
Variance

562.2

220.3

77.5

135.5

44.2

24.2

66.7

35.9

37.5

16.7

1.9

4.1

4.2

1.8

0.7

0.7

0.2

0.2

0.2

0.2

0.2

0.2

\section{CLUSTER}

53

\begin{tabular}{lrrrrrrrr} 
& N & Range & Minimum & Maximum & Sum & Mean Std. Deviation & Variance \\
AGRODAS & 3.0 & 33.0 & 2.0 & 35.0 & 52.0 & 17.3 & 16.6 & 276.3 \\
JUNIHOR & 3.0 & 12.0 & 8.0 & 20.0 & 40.0 & 13.3 & 6.1 & 37.3 \\
CALAPUR & 3.0 & 23.0 & 0.0 & 23.0 & 23.0 & 7.7 & 13.3 & 176.3 \\
PICEGLA & 3.0 & 12.0 & 0.0 & 12.0 & 22.0 & 7.3 & 6.4 & 41.3 \\
SHEPCAN & 3.0 & 20.0 & 0.0 & 20.0 & 21.0 & 7.0 & 11.3 & 127.0 \\
ELYMINN & 3.0 & 9.0 & 3.0 & 12.0 & 18.0 & 6.0 & 5.2 & 27.0 \\
CARESPP & 3.0 & 16.0 & 0.0 & 16.0 & 16.0 & 5.3 & 9.2 & 85.3 \\
ARCTUVA & 3.0 & 4.0 & 4.0 & 8.0 & 16.0 & 5.3 & 2.3 & 5.3 \\
SALISPP & 3.0 & 15.0 & 0.0 & 15.0 & 15.0 & 5.0 & 8.7 & 75.0 \\
\hline
\end{tabular}




$\begin{array}{lrrrrrrrr}\text { PINUCON } & 3.0 & 8.0 & 0.0 & 8.0 & 12.0 & 4.0 & 4.0 & 16.0 \\ \text { OXYTSER } & 3.0 & 6.0 & 0.0 & 6.0 & 11.0 & 3.7 & 3.2 & 10.3 \\ \text { ROSAACI } & 3.0 & 10.0 & 0.0 & 10.0 & 11.0 & 3.7 & 5.5 & 30.3 \\ \text { GALIBOR } & 3.0 & 10.0 & 0.0 & 10.0 & 11.0 & 3.7 & 5.5 & 30.3 \\ \text { HEDYBOR } & 3.0 & 8.0 & 0.0 & 8.0 & 10.0 & 3.3 & 4.2 & 17.3 \\ \text { POTEFRU } & 3.0 & 5.0 & 1.0 & 6.0 & 9.0 & 3.0 & 2.6 & 7.0 \\ \text { KOELMAC } & 3.0 & 4.0 & 0.0 & 4.0 & 6.0 & 2.0 & 2.0 & 4.0 \\ \text { AGROTRA } & 3.0 & 4.0 & 0.0 & 4.0 & 5.0 & 1.7 & 2.1 & 4.3 \\ \text { SOLISPA } & 3.0 & 3.0 & 0.0 & 3.0 & 5.0 & 1.7 & 1.5 & 2.3 \\ \text { ARTEFRI } & 3.0 & 5.0 & 0.0 & 5.0 & 5.0 & 1.7 & 2.9 & 8.3 \\ \text { OXYTSPL } & 3.0 & 3.0 & 0.0 & 3.0 & 4.0 & 1.3 & 1.5 & 2.3 \\ \text { ZIGAELE } & 3.0 & 3.0 & 0.0 & 3.0 & 3.0 & 1.0 & 1.7 & 3.0 \\ \text { JUNICOM } & 3.0 & 3.0 & 0.0 & 3.0 & 3.0 & 1.0 & 1.7 & 3.0 \\ \text { CAMPROT } & 3.0 & 2.0 & 0.0 & 2.0 & 3.0 & 1.0 & 1.0 & 1.0 \\ \text { plus 12 Species } & & & & & & & & \end{array}$

CLUSTER

54

$\mathrm{N}$

3.0

3.0

3.0

3.0

3.0

3.0

3.0

3.0

3.0

3.0

3.0

AGOSGLA

(plus 22 species)

$\begin{array}{rrr}\text { Range } & \text { Minimum } & \text { Maximum } \\ 1.0 & 4.0 & 5.0 \\ 7.0 & 0.0 & 7.0 \\ 4.0 & 0.0 & 4.0 \\ 5.0 & 0.0 & 5.0 \\ 1.0 & 1.0 & 2.0 \\ 1.0 & 1.0 & 2.0 \\ 1.0 & 1.0 & 2.0 \\ 1.0 & 1.0 & 2.0 \\ 1.9 & 0.1 & 2.0 \\ 2.0 & 0.0 & 2.0 \\ 0.0 & 1.0 & 1.0\end{array}$

\section{CLUSTER}

55

$\mathrm{N}$
8.0

ARCTUVA

AGROSPI

AMELALN

FESTSCA

ROSAACI

FESTIDA

OXYTSPL

AGROTRA

GEUMTRI

CAREOBT

ANDRCHA

FRAGVIR

KOELMAC

POAPRA

GALIBOR

ACHIMIL
8.0

8.0

8.0

8.0

8.0

8.0

8.0

8.0

8.0

8.0

8.0

8.0

8.0

8.0

8.0
Range Minimum Maximum

13.0

16.0

12.0

13.0

8.0

9.0

10.0

8.0

14.0

7.0

20.0

14.0

6.0

9.0

5.0

5.0

8.0
0.0
0.0
0.0
0.0
0.0
0.0
0.0
0.0
0.0
0.0
0.0
0.0
0.0
0.0
0.0

8.0
0.0

21.0

16.0

12.0

13.0

8.0

9.0

10.0

8.0

14.0

7.0

20.0

14.0

6.0

9.0

5.0

5.0
Sum

13.0

9.0

6.0

5.0

4.0

4.0

4.0

4.0

3.1

3.0

3.0
Mean Std. Deviation

4.3

3.0

2.0

1.7

1.3

1.3

1.3

1.3

1.0

1.0

1.0
0.6

3.6

2.0

2.9

0.6

0.6

0.6

0.6

1.0

1.0

0.0
Variance

0.3

13.0

4.0

8.3

0.3

0.3

0.3

0.3

0.9

1.0

0.0
Sum

130.0

47.0

36.0

29.0

27.0

27.0

25.1

24.0

22.0

21.0

20.0

19.0

17.1

17.0

15.2

14.1
Mean Std. Deviation Variance

16.3

4.1

16.5

5.9

6.2

38.7

4.5

5.3

27.7

3.6

4.6

21.1

3.4

3.5

12.6

3.4

3.5

12.3

3.1

3.2

10.3

3.0

3.5

12.3

2.8

2.6

5.3

28.5

3.0

9.1

7.1

50.0

2.5

4.8

23.4

2.1

2.9

8.6

2.1

3.2

10.1

1.9

1.9

3.7

1.8 


$\begin{array}{lllllllrr}\text { CERAARV } & 8.0 & 5.0 & 0.0 & 5.0 & 14.0 & 1.8 & 1.7 & 2.8 \\ \text { POTEFRU } & 8.0 & 5.0 & 0.0 & 5.0 & 13.2 & 1.7 & 1.9 & 3.6 \\ \text { DANTCAL } & 8.0 & 9.0 & 0.0 & 9.0 & 13.0 & 1.6 & 3.2 & 10.0 \\ \text { PENSCON } & 8.0 & 5.0 & 0.0 & 5.0 & 12.1 & 1.5 & 1.9 & 3.7 \\ \text { FESTSAX } & 8.0 & 8.0 & 0.0 & 8.0 & 11.0 & 1.4 & 2.8 & 7.7 \\ \text { MONAFIS } & 8.0 & 9.0 & 0.0 & 9.0 & 11.0 & 1.4 & 3.2 & 10.0 \\ \text { ANTEPAR } & 8.0 & 7.0 & 0.0 & 7.0 & 11.0 & 1.4 & 2.3 & 5.4 \\ \text { SPIRBET } & 8.0 & 6.0 & 0.0 & 6.0 & 10.1 & 1.3 & 2.1 & 4.5 \\ \text { PHLEPRA } & 8.0 & 6.0 & 0.0 & 6.0 & 10.0 & 1.3 & 2.4 & 5.6 \\ \text { ANEMMUL } & 8.0 & 3.0 & 0.0 & 3.0 & 10.0 & 1.3 & 1.2 & 1.4 \\ \text { SELADEN } & 8.0 & 6.0 & 0.0 & 6.0 & 8.1 & 1.0 & 2.1 & 4.3 \\ \text { SHEPCAN } & 8.0 & 4.0 & 0.0 & 4.0 & 8.0 & 1.0 & 1.9 & 3.4\end{array}$

(plus 64 species) 



\section{APPENDIX 4 \\ Summary of Detrended Canonocal Correspondence Analysis (DCCA) of 120 Plots From ESIS Database}



Appendix 4: Summary of Detrended Canonocal Correspondence Analysis (DCCA) of 120 plots from ESIS database.

[Mon Jan 01 17:54:26 2001] Log file created [Mon Jan 01 17:56:21 2001] Settings changed

[Mon Jan 01 17:56:41 2001] CON file [C:LMy Documentsizadnjire.con] saved [Mon Jan 01 17:56:44 2001] Running CANOCO:

[Mon Jan 01 17:56:44 2001] CON file [C:My Documentslzadnjire.con] saved Program CANOCO Version 4.0 April 1998 - written by Cajo J.F. Ter Braak

Copyright (c) 1988-1998 Centre for Biometry Wageningen, CPRO-DLO Box 100, 6700 AC Wageningen, the Netherlands.

CANOCO performs (partial) (detrended) (canonical) correspondence analysis, principal components analysis and redundancy analysis.

CANOCO is an extension of Cornell Ecology program DECORANA (Hill,1979)

For explanation of the input/output see the manual or

Ter Braak, C.J.F. (1995) Ordination. Chapter 5 in:

Data Analysis in Community and Landscape Ecology

(Jongman, R.H.G., Ter Braak, C.J.F. and Van Tongeren, O.F.R., Eds)

Cambridge University Press, Cambridge, UK, 91-173 pp.

\begin{tabular}{|c|c|c|c|}
\hline \multicolumn{4}{|c|}{$* * *$ Type of analysis *** } \\
\hline Model & $\begin{array}{l}\text { Gradien } \\
\text { indirect }\end{array}$ & $\begin{array}{r}\text { analysis } \\
\text { direct }\end{array}$ & hybrid \\
\hline linear & $1=\mathrm{PCA}$ & $2=\mathrm{RDA}$ & 3 \\
\hline unimodal & $4=\mathrm{CA}$ & $5=\mathrm{CCA}$ & 6 \\
\hline$"$ & $\begin{array}{c}7=\text { DCA } \\
10=\text { non-st }\end{array}$ & $\begin{array}{c}\text { 8=DCCA } \\
\text { dard analys }\end{array}$ & is 9 \\
\hline
\end{tabular}

Type analysis number

Answer $=8$

$* * *$ Data files $* * *$

Species data $\quad$ C:LMYDOCU 1 1KSENIJAISPECIE 1.DAT

Covariable data :

Environmental data : C:LMYDOCU 1 1KSENIJALENVIRO_4.DAT

Initialization file:

Forward selection of envi. variables $=0$

Scaling of ordination scores $=2$

Diagnostics $=3$

File : C:LMYDOCU 1LKSENIJAISPECIE 1.DAT

Title : WCanoImp produced data file

Format : (I5,1X,6(I6,F5.1))

No. of couplets of species number and abundance per line : 6 
Sample 13 to be omitted
Sample 25 to be omitted
Sample 28 to be omitted
Sample 32 to be omitted
Sample 41 to be omitted
Sample 53 to be omitted
Sample 54 to be omitted
Number of samples 120
Number of species 209
Number of occurrences 2612

File : C:LMYDOCU 1LKSENIJALENVIRO_4.DAT

Title: WCanoImp produced data file

Format : (I5,1X,3(I6,F13.7))

No. of environmental variables : 6

No interaction terms defined

No transformation of species data

No species-weights specified

No sample-weights specified

downweighting of rare species

Final species weights applied (weight*downweight)

$\begin{array}{llllllllllll}1.0 & 1.000 & 1.000 & .417 & 1.000 & 1.000 & .000 & 1.000 & .742 & 1.000 & .000\end{array}$

$2.0 \quad 1.000 .142 \quad 256.1621 .000 .1451 .000$

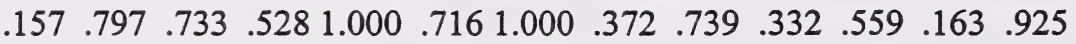

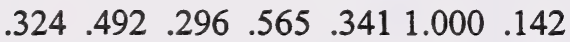

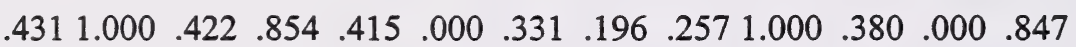

.870 .356 .2611 .000 .142 .142 .924

$.380 .4171 .0001 .000 .843 .7371 .0001 .000 \quad 285.1421 .0001 .000 .509$

$\begin{array}{llllll}1.000 .661 .234 & 1.000 & .239\end{array}$

$\begin{array}{lllllllllll}1.0 & 1.000 .277 & 1.000 & 1.000 & 1.000 & .025 & 1.000 & .559 & .572 & .528 & .427\end{array}$

$\begin{array}{lllllll}2.0 & .654 .142 .228 & .359 & .404 & .339 & .389\end{array}$

$\begin{array}{llllllll}.432 .653 .247 & 1.000 & 1.000\end{array}$

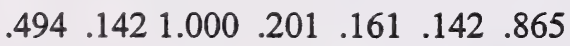

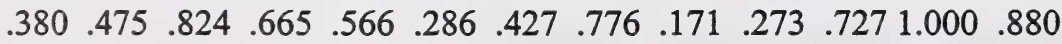

$\begin{array}{llllllll}1.000 & .517 & .524 & 1.000 & .587 & .535 & .309\end{array}$

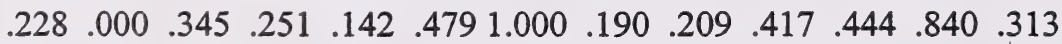

$1.0001 .0001 .000 .2561 .000 \quad 833 \quad 285$

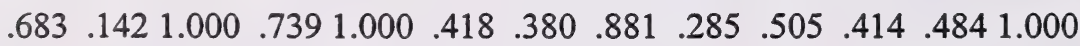

$.4271 .0001 .000 \quad .483 .342 .803 \quad .500$

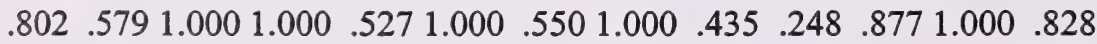

$\begin{array}{lllll}1.000 & 2401.000 .509 .2591 .000 .146\end{array}$

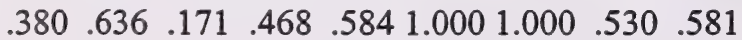

No rescaling 
No. of active samples: 120

No. of passive samples: 0

No. of active species: 204

Total inertia in species data $=$

Sum of all eigenvalues of $\mathrm{CA}=9.74620$

$* * * * * *$ Check on influence in covariable/environment data **

The following sample(s) have extreme values

Sample Environmental Covariable + Environment space

variable Influence influence influence

$\begin{array}{rr}24 & 3.1 \mathrm{x} \\ 26 & 4.6 \mathrm{x} \\ 27 & 4.3 \mathrm{x} \\ * * * * * * & \text { End of check } * * * * * *\end{array}$

***MESSAGE***

No detrending with respect to term $\mathrm{AX} 3{ }^{* *} 2$

$* * *$ MESSAGE***

No detrending with respect to term $\mathrm{AX} 1 * \mathrm{AX} 3$

\section{MESSAGE***}

No detrending with respect to term $\mathrm{AX} 2 * \mathrm{AX} 3$

1

$* * * *$ Weighted correlation matrix (weight $=$ sample total) $* * * *$

$\begin{array}{lccccccccc}\text { SPEC AX1 } & 1.0000 & & 1000 & \\ \text { SPEC AX2 } & .0218 & 1.0000 & & & & & & \\ \text { SPEC AX3 } & -.0519 & -.0169 & 1.0000 & & & & & \\ \text { SPEC AX4 } & .1099 & .1249 & -.5026 & & 1.0000 & & & \\ \text { ENVI AX1 } & .9334 & .0000 & .0000 & .0000 & 1.0000 & & & \\ \text { ENVI AX2 } & .0000 & .7882 & .0000 & .0000 & .0000 & 1.0000 & & \\ \text { ENVI AX3 } & .0000 & .0000 & .6833 & .0000 & .0000 & .0000 & 1.0000 & \\ \text { ENVI AX4 } & .0000 & .0000 & .0000 & .0000 & .0000 & .0000 & .0000 & .0000 \\ \text { Drainage } & -.3428 & .1945 & -.2079 & .0000 & -.3673 & .2467 & -.3042 & .0000 \\ \text { E. Mosit } & -.6296 & .0952 & .2476 & .0000 & -.6745 & .1208 & .3624 & .0000 \\ \text { Annual R } & .1383 & -.2107 & -.1105 & .0000 & .1482 & -.2673 & -.1617 & .0000 \\ \text { Elevatio } & -.5310 & -.6114 & -.0480 & .0000 & -.5689 & -.7757 & -.0703 & .0000 \\ \text { LATITUDE } & -.5594 & .5343 & -.0246 & .0000 & -.5993 & .6779 & -.0359 & .0000 \\ \text { LONGITUD } & -.7205 & .2168 & -.1865 & .0000 & -.7720 & .2750 & -.2729 & .0000\end{array}$

SPEC AX1 SPEC AX2 SPEC AX3 SPEC AX4 ENVI AX1 ENVI AX2 ENVI AX3 ENVI AX4 
Drainage $\quad 1.0000$

E. Mosit $\quad .6515$

Annual R $\quad-.2887$

Elevatio $\quad .2229$

LATITUDE $\quad .0909$

LONGITUD $\quad .0401$

1.0000

$-.2713$

.3619

.2074

.2335

LONGITUD
E. Mosit
Drainage

$\mathrm{N}$ name (weighted) mean stand. dev. inflation factor

$\begin{array}{llccl}1 & \text { SPEC AX1 } & .0000 & 1.0714 & \\ 2 & \text { SPEC AX2 } & .0000 & 1.2687 & \\ 3 & \text { SPEC AX3 } & .0000 & 1.4634 & \\ 4 & \text { SPEC AX4 } & .0000 & 1.0000 & \\ 5 & \text { ENVI AX1 } & .0000 & 1.0000 & \\ 6 & \text { ENVI AX2 } & .0000 & 1.0000 & \\ 7 & \text { ENVI AX3 } & .0000 & 1.0000 & \\ 8 & \text { ENVI AX4 } & .0000 & .0000 & \\ 1 & \text { Drainage } & 3.0453 & .8157 & 1.8352 \\ 2 & \text { E. Mosit } & 3.9143 & 1.3160 & 2.1423 \\ 3 & \text { Annual R } & 743.2941 & 77.0216 & 1.2120 \\ 4 & \text { Elevatio } & 1304.3050 & 385.6898 & 1.8056 \\ 5 & \text { LATITUDE } & 51.4198 & 2.1104 & 4.1719 \\ 6 & \text { LONGITUD } & 114.4941 & 2.5598 & 3.7886\end{array}$

$* * * *$ Summary $* * * *$

\begin{tabular}{|c|c|c|c|c|}
\hline Axes & 1 & 2 & 3 & 4 \\
\hline Eigenvalues : & .701 & .251 & .119 & .511 \\
\hline $\begin{array}{l}\text { Species-environment correlations : } \\
\text { Cumulative percentage variance }\end{array}$ & .933 & .788 & .683 & .000 \\
\hline $\begin{array}{l}\text { of species data : } \\
\text { of species-environment relation: }\end{array}$ & $\begin{array}{c}7.2 \\
45.5\end{array}$ & $\begin{array}{l}9.8 \\
61.9\end{array}$ & $\begin{array}{l}11.0 \\
69.6\end{array}$ & $\begin{array}{c}16.2 \\
.0\end{array}$ \\
\hline
\end{tabular}

Sum of all unconstrained eigenvalues 9.746

Sum of all canonical eigenvalues

*** Unrestricted permutation ***

Seeds: 23239945 
**** Summary of Monte Carlo test ****

Test of significance of first canonical axis: eigenvalue $=\quad .701$

$$
\begin{aligned}
& \text { F-ratio }=8.761 \\
& \mathrm{P} \text {-value }=.0050
\end{aligned}
$$

Test of significance of all canonical axes : Trace $=1.540$

$$
\begin{aligned}
& \text { F-ratio }=3.533 \\
& \mathrm{P} \text {-value }=.0050
\end{aligned}
$$

( 199 permutations under reduced model)

***MESSAGE***

No detrending with respect to term $\mathrm{AX} 3 * * 2$

***MESSAGE***

No detrending with respect to term $\mathrm{AX} 1 * \mathrm{AX} 3$

***MESSAGE***

No detrending with respect to term $\mathrm{AX} 2 * \mathrm{AX} 3$

[Mon Jan 01 17:57:02 2001] CANOCO call succeeded 



\begin{abstract}
APPENDIX 5
Statistics for Environmental Variables Used in Detrended Canonical Correspondence Analysis (DCCA)
\end{abstract}



Appendix 5: Statistics for environmental variables used in detrended canonical correspondence analysis (DCCA) of 120 plots from ESIS database. Bold values in "Regression/canonical coefficients" table are important values based on significant canonical coefficients $(\mathrm{P}<0.05, \mathrm{DF}$ $=113)(Z a r 1984$, p. 371-377). Bold values in "t-values of regression coefficients" table indicate significant regression coefficients $(\mathrm{P}<0.05, \mathrm{DF}=113)$. Bold values in "Inter set correlations of environmental variables" table represent truly significant variables (significant in both aforementioned tables).

WCanoImp produced data file

DCCA Canonical axes:

DETR-POLY2 Downweight

No transformation

Regr: Regression/canonical coefficients for standardized variables

\begin{tabular}{rrrrrr}
$\mathrm{N}$ & \multicolumn{1}{c}{ NAME } & AX1 & AX2 & AX3 & AX4 \\
& \multicolumn{1}{c}{ EIG } & .7012 & .2514 & .1191 & .5106 \\
& & & & & \\
1 & Drainage & .0303 & .4990 & -.8710 & .0000 \\
2 & E. Mosit & $\mathbf{- . 3 3 8 5}$ & .0627 & $\mathbf{1 . 2 4 7 7}$ & .0000 \\
3 & Annual R & .0538 & -.0720 & -.0375 & .0000 \\
4 & Elevatio & $\mathbf{- . 5 1 0 5}$ & $\mathbf{- . 6 3 8 1}$ & -.0023 & .0000 \\
5 & LATITUDE & $\mathbf{- . 3 7 8 2}$ & $\mathbf{. 6 6 7 3}$ & $\mathbf{. 5 1 6 2}$ & .0000 \\
6 & LONGITUD & $\mathbf{- . 3 3 3 8}$ & $\mathbf{- . 3 5 3 8}$ & $\mathbf{- 1 . 0 8 2 0}$ & .0000
\end{tabular}

WCanoImp produced data file

DCCA Canonical axes: 3 Covariables: 0 Scaling: 2

DETR-POLY2 Downweight

No transformation

tVal: t-values of regression coefficients

\begin{tabular}{llcccc} 
N & \multicolumn{1}{c}{ NAME } & AX1 & AX2 & AX3 & AX4 \\
& & & & & \\
& FR EXPLAINED & .4554 & .1633 & .0774 & .0000 \\
1 & Drainage & .6183 & $\mathbf{5 . 0 1 4 9}$ & $-\mathbf{- 6 . 3 9 6 5}$ & .0000 \\
2 & E. Mosit & $\mathbf{- 6 . 3 9 2 4}$ & .5834 & $\mathbf{8 . 4 8 1 4}$ & .0000 \\
3 & Annual R & 1.3511 & -.8909 & -.3390 & .0000 \\
4 & Elevatio & $\mathbf{- 1 0 . 5 0 1 7}$ & $-\mathbf{6 . 4 6 5 7}$ & -.0169 & .0000 \\
5 & LATITUDE & $\mathbf{- 5 . 1 1 8 4}$ & $\mathbf{4 . 4 4 8 0}$ & $\mathbf{2 . 5 1 4 2}$ & .0000 \\
6 & LONGITUD & $\mathbf{- 4 . 7 4 0 8}$ & $\mathbf{- 2 . 4 7 4 7}$ & $\mathbf{- 5 . 5 3 0 6}$ & .0000
\end{tabular}


WCanoImp produced data file

DCCA Canonical axes:

DETR-POLY2 Downweight

3 Covariables: 0 Scaling:

2

No transformation

CorE: Inter set correlations of environmental variables with axes

\begin{tabular}{llllll} 
N & \multicolumn{1}{c}{ NAME } & \multicolumn{1}{c}{ AX1 } & AX2 & AX3 & AX4 \\
& & & & & \\
& FR EXTRACTED & .2745 & .1329 & .0257 & .0000 \\
1 & Drainage & -.3428 & .1945 & -.2079 & .0000 \\
2 & E. Mosit & -.6296 & .0952 & .2476 & .0000 \\
3 & Annual R & .1383 & -.2107 & -.1105 & .0000 \\
4 & Elevatio & -.5310 & -.6114 & -.0480 & .0000 \\
5 & LATITUDE & $\mathbf{- . 5 5 9 4}$ & $\mathbf{. 5 3 4 3}$ & -.0246 & .0000 \\
6 & LONGITUD & $\mathbf{- . 7 2 0 5}$ &. $\mathbf{2 1 6 8}$ & $\mathbf{- . 1 8 6 5}$ & .0000
\end{tabular}




\section{APPENDIX 6 \\ Community Characterization Abstracts}





\section{COMMUNITY CHARACTERIZATION ABSTRACT Agropyron spicatum Herbaceous Vegetation}

\section{IDENTIFIERS}

SEL.SUMMARY: The Agropyron spicatum community type was described for the Waterton Lakes National Park by Achuff et al. (1997) (Type H42). This community is associated with subxeric to mesic, moderately sloping, easterly and southerly oriented sites, in the lower Subalpine Subregion (elevation range: 1700 - $1900 \mathrm{~m}$ ) within the park (Achuff et al. 1997). Soils are well drained Brunisols and Regosols developed on fluvial, colluvial and morainal landforms. Agropyron spicatum dominates this successionally mature community (30-40\% cover) accompanied with some common grasses, such as Bromus marginatus, Phleum pratense and Poa palustris. Main forbs include Achillea millefolium, Fragaria virginiana, Galium boreale and Penstemon confertus, in addition to various other common species, such as Aster conspicuous, Campanula rotundifolia, Epilobium angustifolium, Hedysarum sulphurescens, Lathyrus ochroleucus and Thalictrum occidentale.

SNAME: Agropyron spicatum Herbaceous Vegetation

SCOMNAME: Bluebunch wheat grass Herbaceous Vegetation

\section{CLASSIFICATION}

SYSTEM: Terrestrial

CLASS: Herbaceous vegetation

SUBCLASS: Perennial graminoid vegetation (grasslands)

GROUP: Temperate or subpolar grasslands

FORMATION: Medium-tall sod temperate or subpolar grasslands

ALLIANCE: Agropyron spicatum Herbaceous Alliance

\section{CLASSIFICATION CONFIDENCE LEVEL: 1}

SSIMILAR COMMUNITIES: Lack of codominants separates this community from most other Agropyron spicatum community types. Although Aster conspicuous is common, lack of Elymus innovatus separates this type from the Agropyron spicatum - Elymus innovatus - Aster conspicuous community type from Banff National Park (Corns and Achuff 1982). In the Agropyron spicatum Herbaceous Vegetation community from southwestern Alberta, Agropyron spicatum dominates the herbaceous layer (ground cover 30 - 40\%), whereas the Pseudoroegneria spicata Herbaceous Vegetation community from Colorado (NatureServe 2000) pertains to a community of sparse graminoids and abundant forb layer, where Agropyron spicatum (Pseudoroegneria spicata) reaches covers of only $5-7 \%$, and there are no clear dominants. The 
Agropyron spicatum community type occupies the highest elevations of all four types described within the Agropyron spicatum alliance in Alberta.

\section{DISTRIBUTION}

SNATREG: Mainly Rocky Mountain, some Parkland

SSUBREG: Mainly lower Subalpine, some Montane and Foothills Parkland, possibly Alpine (community \#31 in this report)

SRANGECOM: Presently known only from the Waterton Lakes National Park in southwestern Alberta (Achuff et al. 1997).

SDISTRIBUTION.COM: Presently known only from the Waterton Lakes National Park in southwestern Alberta (Achuff et al. 1997); mainly in Rocky Mountain Natural Region (lower Subalpine, some Montane and possibly Alpine Subregions), some in Parkland Natural Region (Foothills Parkland Subregion).

\section{ENVIRONMENTAL FACTORS}

SMINELEV: $1700 \mathrm{~m}$

SMAXELEV: $1900 \mathrm{~m}$

SLANDFORM: Fluvial, colluvial and morainal

STOP.POSITION: Generally midslope position

SSLOPE: Median: $32.5 \%(2-60 \%)$

SASPECT: Median: $55.3^{\circ}\left(0-113^{\circ}\right)$

SSOIL.TYPE: Brunisols and Regosols

SSOIL.MOSTURE: Subxeric to mesic

SSOIL.COM: Well to rapidly drained soils

SKEY.ENVIRO.FACTORS: Most likely droughty conditions on subxeric to mesic, moderately sloping, easterly and southerly oriented sites, as well as the high elevation $(1700-1900 \mathrm{~m})$.

SENVIRO.COM: Subxeric to mesic, moderately sloping, easterly and southerly oriented sites, in the lower Subalpine Subregion (elevation range: 1700 - $1900 \mathrm{~m}$ ) within the Waterton Lakes National Park. Soils are well to rapidly drained Brunisols and Regosols developed on fluvial, colluvial and morainal landforms. (Achuff et al. 1997). Cluster analysis and environmental data examination by Geowest researchers indicate that this community type may occur on lower elevations (one plot at $1340 \mathrm{~m}$ ) and on moister (subhygric) soils. 


\section{BIOLOGICAL AND STRUCTURAL DESCRIPTION}

\section{6a VEGETATION}

SSTRATA LIFEFORM: Shrub; dwarf shrub; herb; moss

SPCT.COVER: Shrub 4.5\%; dwarf shrub 3.1\% ; herb $123 \%$; moss $17 \%$

SMOST.ABUND.SPP: Agropyron spicatum

SUNVEGETATED.SURFACE: None

SUNVEGETATED.SURFACE COVER: 0\%

SCONSTANT.SPP: Bromus marginatus, Phleum pratense, Poa palustris, Achillea millefolium, Galium boreale and Penstemon confertus

SCHARACTERISTIC.SPP: Agropyron spicatum

SVEGETATION.COM: Four strata include: shrub (4.5\%), dwarf shrub (3.1\%), herb(123\%), and moss (17\%); Agropyron spicatum is the most abundant and a characteristic species; there is no unvegetated surface; constant species include Bromus marginatus, Phleum pratense, Poa palustris, Achillea millefolium, Galium boreale and Penstemon confertus

\section{6c VARIABILITY}

SSPP.COMP.VAR: Cluster analysis and environmental data examination by Geowest researchers indicate that Poa interior may become codominant on certain lower elevational sites while Poa palustris and Bromus carinatus may become abundant on sites with wetter soils (subhygric moisture regimes).

SVARIABILITY.COM: Cluster analysis and environmental data examination by Geowest researchers indicate that Poa interior may become codominant on certain lower elevational sites while Poa palustris and Bromus carinatus may become abundant on sites with wetter soils (subhygric moisture regimes).

\section{DYNAMIC PROCESSES}

SSUCCESS.STATUS: Mature

9. STATUS

SRANK: S1

SREASONS: Restricted to the Waterton Lakes National Park with only 6 known sites 
SSTATCOM: This community is presently considered provincially rare (ranked SU) in the Preliminary Plant Community Tracking List (Allen 2000); its provincial ranking should be changed to S1 because it is restricted to the Waterton Lakes National Park with only 6 known sites.

\section{ANALYSIS PROCEDURES AND DATA MANAGEMENT}

SANALYSIS.COM: Within each of the 5 sampling plots $(10 \mathrm{~m} \times 10 \mathrm{~m})$ canopy cover was estimated visually to the nearest percent. Plants with less than $1 \%$ were assigned $0.5 \%$ cover. Noted environmental factors included elevation, slope, aspect, topographic position, relief shape, landform, soil group, drainage class and moisture regimes. A Global Positioning System (GPS) instrument was used to define the precise location of each plot. Data was analyzed by tabular comparison, and both indirect and direct ordination (Achuff et al. 1997). Waterton Lakes plot data was also used in the cluster and ordination analysis of combined ESIS database and Waterton Lakes database performed by the Geowest personnel. Cluster analysis included species data from 416 plots. Ordination analysis related vegetation data from 120 plots to the following environmental variables: solar radiation (combines slope, aspect, and latitude), drainage class, moisture regimes, elevation, latitude, and longitude (last two variables represent macroclimatic variables - NW position in the province coincides with cooler and wetter climate as opposed to the $\mathrm{SE}$ end of the province). In addition to ordination, descriptive statistics (median, minimum, maximum) were calculated for environmental variables. These calculations were done in SPSS for Windows and included both variables used in the ordination and variables with a lot of missing data (soil drainage, site position - macro, site position - meso, nutrient regimes, \% bedrock, $\%$ mineral soil, and $\%$ organic material). The information on Natural Subregion was taken from the GIS based on the geographical position of each plot.

SANALYSIS.DATA.MANAGE.COM: Within each of the 5 sampling plots $(10 \mathrm{~m} \times 10 \mathrm{~m})$ canopy cover was estimated visually to the nearest percent. Plants with less than $1 \%$ were assigned $0.5 \%$ cover. Noted environmental factors included elevation, slope, aspect, topographic position, relief shape, landform, soil group, drainage class and moisture regimes. A Global Positioning System (GPS) instrument was used to define the precise location of each plot. Data was analyzed by tabular comparison, and both indirect and direct ordination (Achuff et al. 1997). Waterton Lakes plot data was also used in the cluster and ordination analysis of combined ESIS database and Waterton Lakes database performed by the Geowest personnel. Cluster analysis included species data from 416 plots. Ordination analysis related vegetation data from 120 plots to the following environmental variables: solar radiation (combines slope, aspect, and latitude), drainage class, moisture regimes, elevation, latitude, and longitude (last two variables represent macroclimatic variables - NW position in the province coincides with cooler and wetter climate as oppose to the SE end of the province). In addition to ordination, descriptive statistics (median, minimum, maximum) were calculated for environmental variables. These calculations were done in SPSS for Windows and included both variables used in the ordination and variables with a lot of missing data (soil drainage, site position - macro, site position - meso, nutrient regimes, \% bedrock, $\%$ mineral soil, and $\%$ organic material). The information on Natural Subregion was taken from the GIS based on the geographical position of each plot. Waterton Lakes plot data (both vegetation and environmental files) are available from Dr. Peter Achuff. The Ecological Site Inventory System (ESIS) electronic database is stored in the Resource Data Division of Alberta Environment, Edmonton. 


\section{REFERENCES}

\section{CITATION:}

Achuff, P. L., R. L. McNeil, M. L. Coleman. 1997. Ecological Land Classification of Waterton Lakes National Park, Alberta - Soil and vegetation resources. Report prepared by Waterton lakes National Park, Waterton park and Contract Pedology Services Ltd., Ledbridge, $\mathrm{AB}$

Allen, L. 2000. Alberta Natural Heritage Information Centre Preliminary Plant Community Tracking List. Alberta Environment, Edmonton, $\mathrm{AB}$

Corns, I. G. W. and P. L. Achuff. 1982. Vegetation type descriptions in W. D. Holland and G. M. Coen (eds.). Ecological (Biophysical) Land Classification of Banff and Jasper National Parks. Alberta Institute of Pedology, Publication No. SS-82-44.

NatureServe: An online encyclopedia of life [web application]. 2000. Version 1.0. Arlington (VA): Association for Biodiversity Information. Available: http://www.natureserve.org 


\section{COMMUNITY CHARACTERIZATION ABSTRACT}

Agropyron spicatum - Festuca campestris Herbaceous Vegetation

\section{IDENTIFIERS}

SEL.SUMMARY: The Agropyron spicatum - Festuca campestris community type occurs in the area just north of the Waterton Lakes National Park (community \#29 in this report). It occurs on subxeric to mesic Foothills Parkland, Subalpine and Montane sites (elevation range: 1430 - 1867 $\mathrm{m}$ ), on gentle to steep slopes with mostly southerly aspects. Soils are well to very rapidly drained, with subxeric to mesic moisture regimes and submesotrophic to mesotrophic nutrient regimes. Agropyron spicatum and Festuca campestris dominate with $8.8 \%$ and $14.9 \%$ cover, respectively. Other common species include Festuca idahoensis (7.4\%), Koeleria macrantha (4.1\%), Danthonia parryi (3.9\%), Galium boreale (3.4\%), Aster conspicuous (3.6\%), Lupinus sericeus (2.8\%), Fragaria virginiana (2.5\%), Monarda fistulosa (2\%), Geranium viscosissimum (2\%) and Anemone multifida (1\%). Common shrub species include Amelanchier alnifolia (6.1\%), Rosa acicularis (5.5\%) and Spiraea betulifolia (3.1\%).

SNAME: Agropyron spicatum - Festuca campestris Herbaceous Vegetation

SCOMNAME: Bluebunch wheat grass - bluebunch fescue Herbaceous Vegetation

\section{CLASSIFICATION}

SYSTEM: Terrestrial

CLASS: Herbaceous vegetation

SUBCLASS: Perennial graminoid vegetation (grasslands)

GROUP: Temperate or subpolar grasslands

FORMATION: Medium-tall sod temperate or subpolar grasslands

ALLIANCE: Agropyron spicatum Herbaceous Alliance

\section{CLASSIFICATION CONFIDENCE LEVEL: 1}

SSIMILAR COMMUNITIES: The Agropyron spicatum Herbaceous Vegetation community lacks codominants and Festuca campestris is only present in low cover, if at all. The Danthonia spp. - Festuca scabrella - Koeleria macrantha community type from Waterton Lakes National Park (Achuff et al. 1997) (H25) has little or no Agropyron spicatum, and Festuca campestris is instead codominant with Danthonia spp., which has low cover in the Agropyron spicatum Festuca campestris community type. The Agropyron spicatum - Festuca idahoensis Herbaceous Vegetation community type (this report) is a more sparsely vegetated type, with bare ground up to $69 \%$. Festuca campestris is generally lacking. Although Aster conspicuous is common, lack of Elymus innovatus and the codominance of Agropyron spicatum and Festuca campestris separate this type from the Agropyron spicatum - Elymus innovatus - Aster conspicuous community type 
from Banff National Park (Corns and Achuff 1982). The Pseudoroegneria spicata - Koeleria macrantha Herbaceous Vegetation community from Montana (Comer et al. 1999) is also similar to the Agropyron spicatum - Festuca campestris community type, but it lacks Festuca campestris. The Pseudoroegneria spicata - Festuca idahoensis Herbaceous Vegetation community from portions of the palouse prairie in Montana, Idaho, Washington, Oregon and possibly British Columbia (Grossman et al. 1994) also generally lacks Festuca campestris. The Pseudoroegneria spicata - Festuca idahoensis Canyon Herbaceous Vegetation community (Idaho, Oregon, Washington) (Anderson et al. 1998) is another potentially similar community type, but a detailed vegetation description was not available, therefore no direct comparison with the Agropyron spicatum - Festuca campestris Herbaceous Vegetation community is possible at this time.

Cluster analysis of the combined ESIS database and the additional plots from Waterton Lakes National Park indicated that most of the plots from Waterton Lakes National Park used by Achuff et al. (1997) to describe the Agropyron spicatum - Festuca scabrella community type belong either to the Festuca scabrella community type or to the Agropyron spicatum community type. Plots indicated by cluster analysis to belong to the Agropyron spicatum - Festuca campestris community type are located just north of Waterton Lakes National Park. It seems that the inclusion of these Waterton plots into the Agropyron spicatum - Festuca scabrella community type resulted from the relatively small scale $(1: 20,000)$ at which the ecological land classification was done (see details in Achuff et al. 1997) and the necessity to combine the two communities into one more generalised community (Peter Achuff - personal communications).

\section{RELATED NOMENCLATURE}

SOTHER.NAMES: Festuca scabrella - Pseudoroegneria spicata Herbaceous Vegetation (NatureServe 2000); Agropyron spicatum - Festuca scabrella (Tisdale 1947); and Festuca scabrella - Agropyron spicatum community type (Tisdale 1982).

SOTHER.NAMES.RELATION.NOTE: The relationship between Agropyron spicatum - Festuca scabrella and Agropyron spicatum - Festuca campestris community types is based on the revised taxonomy and nomenclature of rough fescue, which divided Festuca scabrella into three separate species, namely Festuca altaica, F. campestris ( $F$. scabrella var. major), and $F$. hallii (Pavlick and Looman 1984). Festuca scabrella - Pseudoroegneria spicata Herbaceous Vegetation and Festuca scabrella-Agropyron spicatum community type seem to be the same community type named by different researchers.

SNAMES.COM: The relationship between Agropyron spicatum - Festuca scabrella and Agropyron spicatum - Festuca campestris community types is based on the revised taxonomy and nomenclature of rough fescue, which divided Festuca scabrella into three separate species, namely Festuca altaica, $F$. campestris ( $F$. scabrella var. major), and $F$. hallii (Pavlick and Looman 1984). Festuca scabrella - Pseudoroegneria spicata Herbaceous Vegetation and Agropyron spicatum - Festuca scabrella Herbaceous Vegetation seem to be the same community type named by different researchers. The associated species do vary from type to type but all three types share the codominance of Agropyron spicatum and Festuca campestris. Agropyron spicatum - Festuca scabrella (Tisdale 1947) and Festuca scabrella - Agropyron spicatum 
community type (Tisdale 1982) are just the two names for the same community type appearing in two different publications.

\section{DISTRIBUTION}

SNATREG: Rocky Mountain, Parkland

SSUBREG: Mainly Montane, some Subalpine, some Foothills Parkland

SRANGECOM: Restricted to the southwestern corner of Alberta (area just north of the Waterton Lakes National Park)

SDISTRIBUTION.COM: Restricted to the southwestern corner of Alberta(area just north of the Waterton Lakes National Park); Rocky Mountain Natural Region (mainly Montane and some Subalpine Subregions) and some in Parkland Natural Region (Foothills Parkland).

\section{ENVIRONMENTAL FACTORS}

SMINELEV: $1430 \mathrm{~m}$

SMAXELEV: $1867 \mathrm{~m}$

STOP.POSITION: Generally midslope position

SSLOPE: Median: $47 \%(20-180 \%)$

SASPECT: Median: $180^{\circ}\left(20-315^{\circ}\right)$

SSOIL.MOSTURE: Subxeric to mesic

SSOIL.COM: Well to very rapidly drained soils with submesotrophic to mesotrophic nutrient regimes

SKEY.ENVIRO.FACTORS: Most likely droughty conditions on subxeric to mesic sites

SENVIRO.COM: Subxeric to mesic Foothills Parkland, Montane and Subalpine sites in the park (elevation range: $1430-1867 \mathrm{~m}$ ), on gentle to steep slopes with mostly southerly aspects. Soils are well to very rapidly drained, with subxeric to mesic moisture regimes and submesotrophic to mesotrophic nutrient regimes.

\section{BIOLOGICAL AND STRUCTURAL DESCRIPTION}

\section{6a VEGETATION}

SSTRATA LIFEFORM: Shrub; dwarf shrub; herb

SPCT.COVER: Shrub 12\%; dwarf shrub 3.4\%; herb $84.7 \%$ 
SMOST.ABUND.SPP: Amelanchier alnifolia, Rosa acicularis, Agropyron spicatum, Festuca campestris, Festuca idahoensis

SUNVEGETATED.SURFACE: None

SUNVEGETATED.SURFACE COVER: $0 \%$

SCONSTANT.SPP: Amelanchier alnifolia, Agropyron spicatum, Festuca campestris, Festuca idahoensis, Galium boreale, Achillea millefolium

SVEGETATION.COM: Three strata include: shrub (12\%), dwarf shrub (3.4\%), and herb(84.7\%); Agropyron spicatum, Festuca campestris and Festuca idahoensis are the dominant species in the herb layer $(8.8 \%, 14.9 \%$ and $7.4 \%$, respectively); there is no unvegetated surface; constant species include Amelanchier alnifolia, Agropyron spicatum, Festuca campestris, Festuca idahoensis, Galium boreale, Achillea millefolium.

\section{STATUS}

SRANK: S1

SREASONS: Restricted to the southwestern corner of Alberta

SSTATCOM: This community type is presently considered provincially rare (ranked SU) (Allen 2000). Provincial status should be changed to $S 1$ because this community is restricted to the southwestern corner of Alberta (area just north of the Waterton Lakes National Park).

\section{ANALYSIS PROCEDURES AND DATA MANAGEMENT}

SANALYSIS.COM: Cluster and ordination analysis of the combined ESIS database and Waterton Lakes database was performed by the Geowest personnel. Cluster analysis included species data from 416 plots. Ordination analysis related vegetation data from 120 plots to the following environmental variables: solar radiation (combines slope, aspect, and latitude), drainage class, moisture regimes, elevation, latitude, and longitude (last two variables represent macroclimatic variables - NW position in the province coincides with cooler and wetter climate as oppose to the SE end of the province). In addition to ordination, descriptive statistics (median, minimum, maximum) were calculated for environmental variables. These calculations were done in SPSS for Windows and included both variables used in the ordination and variables with a lot of missing data (soil drainage, site position - macro, site position - meso, nutrient regimes, \% bedrock, $\%$ mineral soil, and \% organic material. The information on Natural Subregion was taken from the GIS based on the geographical position of each plot. List of values was presented instead of statistics for the natural Subregion.

SANALYSIS.DATA.MANAGE.COM: Cluster and ordination analysis of the combined ESIS database and Waterton Lakes database was performed by the Geowest personnel. Cluster analysis included species data from 416 plots. Ordination analysis related vegetation data from 120 plots to the following environmental variables: solar radiation (combines slope, aspect, and latitude), 
drainage class, moisture regimes, elevation, latitude, and longitude (last two variables represent macroclimatic variables - NW position in the province coincides with cooler and wetter climate as oppose to the SE end of the province). In addition to ordination, descriptive statistics (median, minimum, maximum) were calculated for environmental variables. These calculations were done in SPSS for Windows and included both variables used in the ordination and variables with a lot of missing data (soil drainage, site position - macro, site position - meso, nutrient regimes, $\%$ bedrock, \% mineral soil, and \% organic material. The information on Natural Subregion was taken from the GIS based on the geographical position of each plot. List of values was presented instead of statistics for the natural Subregion. Waterton Lakes plot data (both vegetation and environmental files) is available from Dr. Peter Achuff. Ecological Site Inventory System (ESIS) electronic database is stored in the Resource Data Division of Alberta Environment, Edmonton.

\section{GENERAL COMMENTS}

SCOMMUNITY.COM: Cluster analysis of the combined ESIS database and the additional plots from Waterton Lakes National Park indicated that most of the plots from Waterton Lakes National Park used by Achuff et al. (1997) to describe Agropyron spicatum - Festuca scabrella community type belong either to the Festuca scabrella community type or to the Agropyron spicatum community type. Plots indicated by cluster analysis to belong to Agropyron spicatum Festuca campestris community type are located just north of the Waterton Lakes National Park. It seems that the inclusion of these Waterton plots into the Agropyron spicatum - Festuca scabrella community type resulted from the relatively small scale $(1: 20,000)$ at which the ecological land classification was done (see details in Achuff et al. 1997) (Peter Achuff personal communications).

\section{REFERENCES}

\section{CITATION:}

Achuff, L. Peter, Conservation Biologist, Jasper National Park, Box 10, Jasper, AB, TOE 1E0; tel (780) 852-6197; fax (780) 852-4775; email: peter_achuff@pch.gc.ca

Achuff, P. L., R. L. McNeil, M. L. Coleman. 1997. Ecological Land Classification of Waterton Lakes National Park, Alberta - Soil and vegetation resources. Report prepared by Waterton lakes National Park, Waterton park and Contract Pedology Services Ltd., Ledbridge, $\mathrm{AB}$

Allen, L. 2000. Alberta Natural Heritage Information Centre Preliminary Plant Community Tracking List. Alberta Environment, Edmonton, AB

Anderson, M., P. Bougeron, M. T. Bryer, R. Crawford, L. Engelking, D. Faber-Langendoen, M. Gallyoun, K. Goodin, D. H. Grossman, S. Landaal, K. Metzler, K. D. Patterson, M. Pyne, M. Reid, L. Sneddon and A. S. Weakley. 1998. International classification of ecological communities: terrestrial vegetation of the United States, Volume II, The National Vegetation Classification System: list of types. The Nature Conservancy, Arlington, VA. 
Corns, I. G. W. and P. L. Achuff. 1982. Vegetation type descriptions in W. D. Holland and G. M. Coen (eds.). Ecological (Biophysical) Land Classification of Banff and Jasper National Parks. Alberta Institute of Pedology, Publication No. SS-82-44.

Comer, P., L. Allen, Steve Cooper, D. Faber-Langendoen, and G. Jones. 1999. Selected shrubland and grassland communities of the Northern Great Plains. A Report to Nebraska National Forest.

Grossman, D. H., K. L. Goodin and C. L. Reuss (editors). 1994. Rare plant communities of the conterminous United States - an initial survey. The Nature Conservancy, Arlington, VA.

NatureServe: An online encyclopedia of life [web application]. 2000. Version 1.0. Arlington (VA): Association for Biodiversity Information. Available: http://www.natureserve.org

Pavlick, L. E., and J. Looman. 1984. Taxonomy and nomenclature of rough fescue, Festuca altaica, $F$. campestris ( $F$. scabrella var. major), and $F$. hallii, in Canada and adjacent part of United States. Canadian Journal of Botany 62:1739-1749.

Tisdale, E. W. 1947. The grasslands of the southern interior of British Columbia. Ecology 28: 346-382.

Tisdale, E. W. 1982. Grasslands of western North America: the Pacific Northwest Bunchgrass. Grassland Ecology and Classification: Symposium proceeding June 1982. Ministry of Forests, BC 
COMMUNITY CHARACTERIZATION ABSTRACT

Agropyron spicatum - Elymus innovatus - Aster conspicuous

Herbaceous Vegetation

\section{DENTIFIERS}

SEL.SUMMARY: The Agropyron spicatum - Elymus innovatus - Aster conspicuous community type occupies small areas on dry, southwest facing slopes, with rapidly drained soils, within the Montane and Lower Subalpine Subregions of the Banff National Park (Type H19 in Corns and Achuff 1982). Soils are predominantly Orthic Regosols with xeric moisture regimes, developed on colluvial and glacial landforms. Shrub cover is low, with Juniperus communis and Rosa acicularis occurring sporadically. Agropyron spicatum, Elymus innovatus and Koeleria cristata dominate the community $(15-30 \%, 10-30 \%$, and $3-10 \%$ cover, respectively) accompanied by some common forbs, such as Aster conspicuous, Oxytropis splendens, Antennaria nitida/rosea and Cerastium arvense ( $3-5 \%,<8 \%,<2 \%$, and $<2 \%$ cover, respectively). Corns and Achuff (1982) report that this successionally mature community is limited in extent to slopes above Hillsdale meadow in Banff.

SNAME: Agropyron spicatum - Elymus innovatus - Aster conspicuous Herbaceous Vegetation

SCOMNAME: Bluebunch wheatgrass - hairy wild rye - showy aster Herbaceous Vegetation

\section{CLASSIFICATION}

SYSTEM: Terrestrial

CLASS: Herbaceous vegetation

SUBCLASS: Perennial graminoid vegetation (grasslands)

GROUP: Temperate or subpolar grasslands

FORMATION: Medium-tall sod temperate or subpolar grasslands

ALLIANCE: Agropyron spicatum Herbaceous Alliance

\section{CLASSIFICATION CONFIDENCE LEVEL: 1}

SSIMILAR COMMUNITIES: Aster conspicuous is common in the Agropyron spicatum Herbaceous Vegetation community type from southwestern Alberta (Achuff et al. 1997), but lack of Elymus innovatus separates this type from the Agropyron spicatum - Elymus innovatus - Aster conspicuous community type. Pseudoroegneria spicata Herbaceous Vegetation from Colorado (NatureServe 2000) and Pseudoroegneria spicata - Koeleria macrantha Herbaceous Vegetation from Montana (Comer et al. 1999) generally lack both Elymus innovatus and Aster conspicuous.

\section{DISTRIBUTION}


SNATREG: Rocky Mountain

SSUBREG: Montane and lower Subalpine

SRANGECOM: Restricted to the slopes above Hillsdale meadow in Banff National Park

SDISTRIBUTION.COM: Restricted to the slopes above Hillsdale meadow in Banff National Park (Achuff et al. 1997); Rocky Mountain Natural Region, Montane and some lower Subalpine Subregions.

\section{ENVIRONMENTAL FACTORS}

SMINELEV: $1400 \mathrm{~m}$

SMAXELEV: $1700 \mathrm{~m}$

SLANDFORM: Colluvial and glacial

SSLOPE: Moderately steep

SASPECT: Southwest

SSOIL.TYPE: Orthic Regosols

SSOIL.MOSTURE: Xeric

SSOIL.COM: Rapidly drained soils

SKEY.ENVIRO.FACTORS: Dry conditions on southerly aspects.

SENVIRO.COM: Dry, moderately steep southwest facing slopes, within the Montane and Lower Subalpine Subregions (elevation $1400 \mathrm{~m}-1700 \mathrm{~m}$ ) of Banff National Park; soils are predominantly rapidly drained Orthic Regosols with xeric moisture regimes, developed on colluvial and glacial landforms (Corns and Achuff 1982)

\section{BIOLOGICAL AND STRUCTURAL DESCRIPTION}

6a VEGETATION

SSTRATA LIFEFORM: Shrub; herb-dwarf shrub

SPCT.COVER: Shrub (2\%); herb-dwarf shrub (50 - 85\%)

SMOST.ABUND.SPP: Juniperus communis, Rosa acicularis; Agropyron spicatum, Elymus innovatus, Koeleria cristata

SCONSTANT.SPP: Antennaria nitida/rosea, Achillea millefolium, Koeleria cristata 


\section{SCHARACTERISTIC.SPP: Aster conspicuous}

SVEGETATION.COM: two strata include: shrub (2\%), herb - dwarf shrub (50 - 85\%); Juniperus communis and Rosa acicularis are the dominant species in the shrub layer; Agropyron spicatum, Elymus innovatus, Koeleria cristata dominate the herb layer; constant species include Antennaria nitida/rosea, Achillea millefolium, Koeleria cristata; Aster conspicuous is the characteristic species.

\section{DYNAMIC PROCESSES}

\section{SSUCCESS.STATUS: Mature}

\section{STATUS}

SRANK: S1

SREASONS: Small size and restriction in distribution

SSTATCOM: This community type is presently considered provincially rare (ranked SU) (Allen 2000); rank should be changed to $S 1$ because of its small size and restriction in distribution (only on slopes above Hillsdale meadow in Banff National Park)

\section{ANALYSIS PROCEDURES AND DATA MANAGEMENT}

SANALYSIS.COM: Within each of the 5 sampling plots $(10 \mathrm{~m} \times 10 \mathrm{~m})$ canopy cover was estimated visually to the nearest percent. Plants with less than $1 \%$ were assigned $0.5 \%$ cover. Noted environmental factors included elevation, slope, aspect, topographic position, relief shape, landform, soil group, drainage class and moisture regimes. Data was analyzed by tabular comparison, and both indirect and direct ordination (Corns and Achuff 1982).

SANALYSIS.DATA.MANAGE.COM: Within each of the 5 sampling plots $(10 \mathrm{~m} \times 10 \mathrm{~m})$ canopy cover was estimated visually to the nearest percent. Plants with less than $1 \%$ were assigned $0.5 \%$ cover. Noted environmental factors included elevation, slope, aspect, topographic position, relief shape, landform, soil group, drainage class and moisture regimes. Data was analyzed by tabular comparison, and both indirect and direct ordination (Corns and Achuff 1982). It was also entered into the Ecological Site Inventory System (ESIS) electronic database which is stored in the Resource Data Division of Alberta Environment, Edmonton.

\section{REFERENCES}

\section{CITATION:}

Achuff, P. L., R. L. McNeil, M. L. Coleman. 1997. Ecological Land Classification of Waterton Lakes National Park, Alberta - Soil and vegetation resources. Report prepared by Waterton lakes National Park, Waterton park and Contract Pedology Services Ltd., Ledbridge, $\mathrm{AB}$ 
Allen, L. 2000. Alberta Natural Heritage Information Centre Preliminary Plant Community Tracking List. Alberta Environment, Edmonton, AB

Corns, I. G. W. and P. L. Achuff. 1982. Vegetation type descriptions in W. D. Holland and G. M. Coen (eds.). Ecological (Biophysical) Land Classification of Banff and Jasper National Parks. Alberta Institute of Pedology, Publication No. SS-82-44.

Comer, P., L. Allen, Steve Cooper, D. Faber-Langendoen, and G. Jones. 1999. Selected shrubland and grassland communities of the Northern Great Plains. A Report to Nebraska National Forest.

NatureServe: An online encyclopedia of life [web application]. 2000. Version 1.0. Arlington (VA): Association for Biodiversity Information. Available: http://www.natureserve.org 


\section{COMMUNITY CHARACTERIZATION ABSTRACT \\ Agropyron spicatum - Carex obtusata Herbaceous Vegetation}

\section{IDENTIFIERS}

SEL.SUMMARY: This community type occupies middle and upper slopes with mostly southerly aspects (slope range: 4 - 48\%) within the Montane and Subalpine subregions (elevation range $606 \mathrm{~m} \mathrm{-1618} \mathrm{m)} \mathrm{in} \mathrm{southwestern} \mathrm{Alberta} \mathrm{(Willoughby} \mathrm{et} \mathrm{al.} \mathrm{1998,} \mathrm{community} \mathrm{\# 3} \mathrm{in} \mathrm{this} \mathrm{report).}$ Soils are very rapidly to well-drained, with mostly subxeric moisture regimes and submesotrophic to mesotrophic nutrient regimes. Amelanchier alnifolia (4.2\%) and Symphoricarpos occidentalis $(6.2 \%)$ are characteristic species of the shrub layer. The dominant grass and sedge species, Agropyron spicatum, Carex obtusata, Koeleria macrantha and Festuca campestris, make up $11.6 \%, 19.8 \%, 5.4 \%$, and $4.2 \%$ of the canopy cover, respectively. Some of the dominant forb and dwarf shrub species include Arctostaphylos uva-ursi, Rosa arkansana and Artemisia frigida.

SNAME: Agropyron spicatum - Carex obtusata Herbaceous Vegetation

SCOMNAME: Bluebunch wheatgrass - blunt sedge Herbaceous Vegetation

\section{CLASSIFICATION}

SYSTEM: Terrestrial

CLASS: Herbaceous vegetation

SUBCLASS: Perennial graminoid vegetation (grasslands)

GROUP: Temperate or subpolar grasslands

FORMATION: Medium-tall sod temperate or subpolar grasslands

ALLIANCE: Agropyron spicatum Herbaceous Alliance

\section{CLASSIFICATION CONFIDENCE LEVEL: 1}

SSIMILAR COMMUNITIES: The Agropyron spicatum Herbaceous Vegetation community type from southwestern Alberta (Achuff et al. 1997) has no codominants and lacks a significant Carex obtusata component. The Agropyron spicatum - Festuca campestris Herbaceous Vegetation community (this report) has a much higher ground cover of Festuca campestris, and Carex obtusata is not a significant component. The Pseudoroegneria spicata Herbaceous Vegetation community from Colorado (NatureServe 2000) and the Pseudoroegneria spicata - Koeleria macrantha Herbaceous Vegetation community from Montana (Comer et al. 1999) generally lack a significant Carex obtusata component.

\section{RELATED NOMENCLATURE}


SOTHER.NAMES: Agropyron spicatum - Carex obtusata community type (Willoughby et al. 1998)

SOTHER.NAMES.RELATION.NOTE: The Agropyron spicatum - Carex obtusata community type (Willoughby et al. 1998) includes the Agropyron spicatum - Carex obtusata community type as described in this report.

SNAMES.COM: Willoughby et al. (1998) described the Agropyron spicatum - Carex obtusata community type at a broader level, including sites that represent the Agropyron spicatum - Carex obtusata community type as is described in this report, as well as sites with very low covers of Carex obtusata, or with high shrub covers.

\section{DISTRIBUTION}

SNATREG: Rocky Mountain

SSUBREG: Montane and Subalpine (community \#3 in this report)

SRANGECOM: Restricted to southwestern Alberta (just north of Waterton National Park)

SDISTRIBUTION.COM: Restricted to the southwestern Alberta (just north of Waterton National Park); Rocky Mountain Natural Region (Montane and Subalpine subregions)

\section{ENVIRONMENTAL FACTORS}

SMINELEV: $606 \mathrm{~m}$

SMAXELEV: $1610 \mathrm{~m}$

STOP.POSITION: Middle to upper slopes

SSLOPE: Median 40\% (4 - 48\%)

SASPECT: Median $180^{\circ}\left(90-230^{\circ}\right)$

SSOIL.MOSTURE: Mostly subxeric

SSOIL.COM: Very rapidly to well-drained soils with submesotrophic to mesotrophic nutrient regimes

SKEY.ENVIRO.FACTORS: Droughty conditions on southerly slopes

6. BIOLOGICAL AND STRUCTURAL DESCRIPTION

6a VEGETATION

SSTRATA LIFEFORM: Shrub; dwarf shrub; herb 
SPCT.COVER: Shrub 10\%; dwarf shrub 4\%; herb $83 \%$

SMOST.ABUND.SPP: Symphoricarpos occidentalis, Amelanchier alnifolia; Rosa arkansana; Agropyron spicatum, Carex obtusata, Koeleria macrantha

SCONSTANT.SPP: Symphoricarpos occidentalis, Amelanchier alnifolia; Rosa arkansana; Agropyron spicatum, Carex obtusata, Koeleria macrantha

SCHARACTERISTIC.SPP: Carex obtusata

SVEGETATION.COM: Three strata include: shrub (10\%), dwarf shrub (4\%) and herb(83\%); Symphoricarpos occidentalis and Amelanchier alnifolia are the dominant species in the shrub layer; Rosa arkansana dominates the dwarf shrub layer; Agropyron spicatum, Carex obtusata and Koeleria macrantha are the most abundant herbs; constant species include Symphoricarpos occidentalis, Amelanchier alnifolia, Rosa arkansana, Agropyron spicatum, Carex obtusata, Koeleria macrantha; Carex obtusata is the characteristic species.

6c VARIABILITY

SSPP.COMP.VAR: Increased grazing pressure on drier sites results in a decline of Agropyron spicatum and an increase of low growing forbs and sedges (Willoughby et al. 1998).

SVARIABILITY.COM: Increased grazing pressure on drier sites results in a decline of Agropyron spicatum and an increase of low growing forbs and sedges (Willoughby et al. 1998).

\section{STATUS}

SRANK: S1

SREASONS: Probably restricted to southwestern Alberta, just north of Waterton Lakes National Park

SSTATCOM: It is probably restricted to southwestern Alberta, just north of Waterton Lakes National Park, therefore it should be placed on the provincial tracking list and ranked S1.

\section{MANAGEMENT}

SECONCOM: Grazing

SMANAGECOM: Increased grazing pressure on the drier sites results in a decline of Agropyron spicatum and an increase of low growing forbs and sedges (Willoughby et al. 1998).

\section{ANALYSIS PROCEDURES AND DATA MANAGEMENT}

SANALYSIS.COM: Within each of the $10 \mathrm{~m} \times 10 \mathrm{~m}$ sampling plots, canopy cover was estimated using ten randomly selected $1 \times 1 \mathrm{~m}$ microplots for shrubs, and $20 \times 50 \mathrm{~cm}$ microplots 
for herbs. Noted environmental factors included elevation, slope, aspect, soil drainage, nutrient regimes, and moisture regimes. Data was analyzed by both cluster and both indirect and ordination analyses (Willoughby et al. 1998). Additional cluster and ordination analysis of the combined ESIS database (including most of the plots analyzed by M. Willoughby) and the Waterton Lakes database was performed by Geowest personnel. Cluster analysis included species data from 416 plots. Ordination analysis related vegetation data from 120 plots to the following environmental variables: solar radiation (combines slope, aspect, and latitude), drainage class, moisture regimes, elevation, latitude, and longitude (last two variables represent macroclimatic variables - NW position in the province coincides with cooler and wetter climate as oppose to the $\mathrm{SE}$ end of the province). In addition to ordination, descriptive statistics (median, minimum, maximum) were calculated for environmental variables. These calculations were done in SPSS for Windows and included both variables used in the ordination and variables with a lot of missing data (soil drainage, site position - macro, site position - meso, nutrient regimes, $\%$ bedrock, $\%$ mineral soil, and $\%$ organic material. The information on Natural Subregion was taken from the GIS based on the geographical position of each plot.

SANALYSIS.DATA.MANAGE.COM: Within each of the $10 \mathrm{~m} \times 10 \mathrm{~m}$ sampling plots, canopy cover was estimated using ten randomly selected $1 \times 1 \mathrm{~m}$ microplots for shrubs, and $20 \times 50 \mathrm{~cm}$ microplots for herbs. Noted environmental factors included elevation, slope, aspect, soil drainage, nutrient regimes, and moisture regimes. Data was analyzed by both cluster and both indirect and ordination analyses (Willoughby et al. 1998). Additional cluster and ordination analysis of the combined ESIS database (including most of the plots analyzed by $\mathrm{M}$. Willoughby) and the Waterton Lakes database was performed by Geowest personnel. Cluster analysis included species data from 416 plots. Ordination analysis related vegetation data from 120 plots to the following environmental variables: solar radiation (combines slope, aspect, and latitude), drainage class, moisture regimes, elevation, latitude, and longitude (last two variables represent macroclimatic variables - NW position in the province coincides with cooler and wetter climate as oppose to the SE end of the province). In addition to ordination, descriptive statistics (median, minimum, maximum) were calculated for environmental variables. These calculations were done in SPSS for Windows and included both variables used in the ordination and variables with a lot of missing data (soil drainage, site position - macro, site position - meso, nutrient regimes, \% bedrock, $\%$ mineral soil, and $\%$ organic material. The information on Natural Subregion was taken from the GIS based on the geographical position of each plot. Subregion. Ecological Site Inventory System (ESIS) electronic database is stored in the Resource Data Division of Alberta Environment, Edmonton.

\section{REFERENCES}

\section{CITATION:}

Achuff, P. L., R. L. McNeil, M. L. Coleman. 1997. Ecological Land Classification of Waterton Lakes National Park, Alberta - Soil and vegetation resources. Report prepared by Waterton lakes National Park, Waterton park and Contract Pedology Services Ltd., Ledbridge, $A B$ 
Comer, P., L. Allen, Steve Cooper, D. Faber-Langendoen, and G. Jones. 1999. Selected shrubland and grassland communities of the Northern Great Plains. A Report to Nebraska National Forest.

NatureServe: An online encyclopedia of life [web application]. 2000. Version 1.0. Arlington (VA): Association for Biodiversity Information. Available: http://www.natureserve.org

Willoughby, M. G., M. J. Alexander and K. M. Sundquist. 1998. Range plant community types and carrying capacity for the Montane Subregion of Alberta - third approximation. Environmental Protection, Lands and Forest Services, Edmonton, AB. 


\section{COMMUNITY CHARACTERIZATION ABSTRACT} Agropyron spicatum - Festuca idahoensis Herbaceous Vegetation

\section{IDENTIFIERS}

SEL.SUMMARY: This community occurs at elevations between $1554 \mathrm{~m}$ and $1874 \mathrm{~m}$, on moderately sloping sites with westerly or northerly aspects (community \#54 in this report). Sites can occupy crest to middle slope positions. Soils are very rapidly drained to well drained with xeric to subxeric moisture regimes and mesotrophic to oligotrophic nutrient regimes. The vegetation cover in this association is very thinly distributed with bare ground reaching up to $69 \%$. This community consists of a sparse collection of graminoids and forbs. Some shrub and dwarf shrub species are also present. Potentilla fruticosa, Shepherdia canadensis, Rosa acicularis and Arctostaphylos uva-ursi can occur in small amounts, but for the most part a shrub layer is non-existent. Agropyron spicatum and Festuca idahoensis occur with $4.3 \%$ and $3 \%$ cover, respectively. Other constant species include Agoseris glauca, Selaginella densa, Oxytropis sericeus, Gaillardia aristata and Anemone multifida.

SNAME: Agropyron spicatum - Festuca idahoensis Herbaceous Vegetation

SCOMNAME: Bluebunch wheat grass - bluebunch fescue Herbaceous Vegetation

\section{CLASSIFICATION}

SYSTEM: Terrestrial

CLASS: Herbaceous vegetation

SUBCLASS: Perennial graminoid vegetation (grasslands)

GROUP: Temperate or subpolar grasslands

FORMATION: Medium-tall sod temperate or subpolar grasslands

ALLIANCE: Agropyron spicatum Herbaceous Alliance

\section{CLASSIFICATION CONFIDENCE LEVEL: 2}

SSIMILAR COMMUNITIES: The Agropyron spicatum - Festuca campestris community type from southwestern Alberta (this report) has a greater overall ground cover and Festuca campestris codominates. Festuca idahoensis is present, but with lower cover than Festuca campestris. The Pseudoroegneria spicata - Festuca idahoensis Herbaceous Vegetation community type from portions of the palouse prairie in Montana, Idaho, Washington, Oregon and possible British Columbia (Grossman et al. 1994) represents a community of abundant herbs where Agropyron spicatum (Pseudoroegneria spicata) and Festuca idahoensis reach a cover of $30-100 \%$. In contrast, in the Agropyron spicatum - Festuca idahoensis Herbaceous Vegetation community type from southwestern Alberta, Agropyron spicatum and Festuca idahoensis contribute only $4.3 \%$ and $3 \%$ to the ground cover, respectively, and the herb layer is generally 
very sparse (non-vegetated ground up to 69\%). The Pseudoroegneria spicata Herbaceous Vegetation community type from Colorado (NatureServe 2000) resembles the Agropyron spicatum - Festuca idahoensis community type from southwestern Alberta by its sparse vegetation cover and diverse forb layer, however, it generally lacks the presence of Festuca idahoensis.

The Pseudoroegneria spicata - Festuca idahoensis Canyon Herbaceous Vegetation community (Idaho, Oregon, Washington) (Anderson et al. 1998) is another potentially similar community type, but a detailed vegetation description was not available, therefore no direct comparison with the Agropyron spicatum - Festuca idahoensis Herbaceous Vegetation community is possible at this time.

\section{DISTRIBUTION}

SNATREG: Rocky Mountain

SSUBREG: Montane

SRANGECOM: Presently known only from the area just north of Waterton Lakes National Park

SDISTRIBUTION.COM: Presently known only from the area just north of Waterton Lakes National Park (Rocky Mountain Natural Region - Montane Subregion).

\section{ENVIRONMENTAL FACTORS}

SMINELEV: $1554 \mathrm{~m}$

SMAXELEV: $1874 \mathrm{~m}$

STOP.POSITION: crest to middle slope

SSLOPE: Median: 24\% (22 - 50\%)

SASPECT: Median: $230^{\circ}\left(36-240^{\circ}\right)$

SSOIL.MOSTURE: Xeric to subxeric

SSOIL.COM: Very rapidly drained to well drained, with mesotrophic to oligotrophic nutrient regimes

SENVIRO.COM: Moderately sloping sites with westerly or northerly aspects; can occupy crest to middle slope positions; soils very rapidly drained to well drained with xeric to subxeric moisture regimes and mesotrophic to oligotrophic nutrient regimes.

\section{BIOLOGICAL AND STRUCTURAL DESCRIPTION}

\section{6a VEGETATION}


SSTRATA LIFEFORM: Shrub; dwarf shrub; herb

SPCT.COVER: Shrub 5.3\%; dwarf shrub 1.7\%; herb 20\%

SMOST.ABUND.SPP: Potentilla fruticosa, Shepherdia canadensis, Rosa acicularis; Arctostaphylos uva-ursi; Pseudoroegneria spicata, Festuca idahoensis

SUNVEGETATED.SURFACE: bedrock, organic matter

SUNVEGETATED.SURFACE COVER: Bedrock $69 \%$, organic matter $15 \%$

SCONSTANT.SPP: Pseudoroegneria spicata, Agoseris glauca, Selaginella densa, Oxytropis sericeus, Gaillardia aristata, Anemone multifida.

SCHARACTERISTIC.SPP: Festuca idahoensis

SVEGETATION.COM: The vegetation cover is very thinly distributed with unvegetated surface reaching up to $69 \%$. This community consists of a sparse collection of graminoids and forbs. Some shrub and dwarf shrub species are also present. Potentilla fruticosa, Shepherdia canadensis, Rosa acicularis and Arctostaphylos uva-ursi can occur in small amounts, but for the most part a shrub layer is non-existent. Agropyron spicatum and Festuca idahoensis occur with 4.3\% and 3\% cover, respectively. Other constant species include Agoseris glauca, Selaginella densa, Oxytropis sericeus, Gaillardia aristata and Anemone multifida.

\section{STATUS}

SRANK: SU

SREASONS: Insufficient information - the classification of this community is based on the cluster analysis of only three ESIS plots

SSTATCOM: Insufficient information - the classification of this community is based on the cluster analysis of only three ESIS plots; this community should be placed on the provincial tracking list and ranked SU until more information is collected

\section{MANAGEMENT}

SMANAGECOM: Generally low vegetation cover and a diverse forb layer probably indicate a degraded occurrence that may have resulted from the heavy grazing or wind/water caused soil erosion.

\section{ANALYSIS PROCEDURES AND DATA MANAGEMENT}

SANALYSIS.COM: Cluster and ordination analysis of the combined ESIS database and Waterton Lakes database was performed by the Geowest personnel. Cluster analysis included species data from 416 plots. Ordination analysis related vegetation data from 120 plots to the 
following environmental variables: solar radiation (combines slope, aspect, and latitude), drainage class, moisture regimes, elevation, latitude, and longitude (last two variables represent macroclimatic variables - NW position in the province coincides with cooler and wetter climate as opposed to the SE end of the province). In addition to ordination, descriptive statistics (median, minimum, maximum) were calculated for environmental variables. These calculations were done in SPSS for Windows and included both variables used in the ordination and variables with a lot of missing data (soil drainage, site position - macro, site position - meso, nutrient regimes, $\%$ bedrock, $\%$ mineral soil, and $\%$ organic material. The information on Natural Subregion was taken from the GIS based on the geographical position of each plot.

SANALYSIS.DATA.MANAGE.COM: Cluster and ordination analysis of the combined ESIS database and Waterton Lakes database performed by Geowest personnel. Cluster analysis included species data from 416 plots. Ordination analysis related vegetation data from 120 plots to the following environmental variables: solar radiation (combines slope, aspect, and latitude), drainage class, moisture regimes, elevation, latitude, and longitude (last two variables represent macroclimatic variables - NW position in the province coincides with cooler and wetter climate as opposed to the SE end of the province). In addition to ordination, descriptive statistics (median, minimum, maximum) were calculated for environmental variables. These calculations were done in SPSS for Windows and included both variables used in the ordination and variables with a lot of missing data (soil drainage, site position - macro, site position - meso, nutrient regimes, $\%$ bedrock, $\%$ mineral soil, and $\%$ organic material. The information on Natural Subregion was taken from the GIS based on the geographical position of each plot. the ecological Site Inventory System (ESIS) electronic database is stored in the Resource Data Division of Alberta Environment, Edmonton.

\section{REFERENCES}

\section{CITATION:}

Anderson, M., P. Bougeron, M. T. Bryer, R. Crawford, L. Engelking, D. Faber-Langendoen, M. Gallyoun, K. Goodin, D. H. Grossman, S. Landaal, K. Metzler, K. D. Patterson, M. Pyne, M. Reid, L. Sneddon and A. S. Weakley. 1998. International classification of ecological communities: terrestrial vegetation of the United States, Volume II, The National Vegetation Classification System: list of types. The Nature Conservancy, Arlington, VA.

Grossman, D. H., K. L. Goodin and C. L. Reuss (editors). 1994. Rare plant communities of the conterminous United States - an initial survey. The Nature Conservancy, Arlington, VA.

NatureServe: An online encyclopedia of life [web application]. 2000. Version 1.0. Arlington (VA): Association for Biodiversity Information. Available: http://www.natureserve.org 


\section{COMMUNITY CHARACTERIZATION ABSTRACT Agropyron trachycaulum Herbaceous Vegetation}

\section{IDENTIFIERS}

SEL.SUMMARY: The Agropyron trachycaulum community type occurs in Alberta under variable site conditions. It occurs on very xeric to xeric, steep to moderately steep southerly oriented slopes of the Peace River Parkland Subregion and possibly Montane and Upper Foothills subregions (Rintoul 1985; community \#48 in this report). Soils are rapidly to moderately well drained. They include Orthic Regosols and Orthic Eutric Brunisols with clay loam to sandy loam texture. It also occurs in saline meadows of the Boreal Forest Natural Region (Fairbarns 1990). The community also inhabits lower terraces in the Suffield National Wildlife Area situated within the Dry Mixedgrass Subregion on well to imperfectly drained Orthic Regosols and Orthic Eutric Brunisols with sandy loam to silty loam texture (Adams et al. 1997). Small areas characterized by clay loam soils about $60 \mathrm{~cm}$ deep, with some glacial boulders support this community type in the Peace Point area of Wood Buffalo National Park (Raup 1935). Vegetation on drier sites is relatively open with unvegetated surface varying from 30 75\%. Agropyron trachycaulum dominates this community, while other common species include Artemisia frigida, Koeleria macrantha, Vicia americana, Achillea millefolium, Gallium boreale, and Allium cernuum. Commonly associated shrubs, such as Symphoricarpos occidentalis, Rosa spp., Prunus virginiana or Amelanchier alnifolia may become dominant in some areas. Wetter sites (Boreal Region) may have a higher cover of Agropyron trachycaulum, and include species such as Symphoricarpos albus, Carex spp., Agrostis scabra, Antennaria parviflora, Astragalus dasyglottis, Geum triflorum, Hieracium umbellatum, Lactuca pulchella, Viola adunca and some halophytic species (Fairbarns 1990). Wood Buffalo National Park grasslands are characterized by an assemblage of perennial forbs, such as Geum triflorum, Stachys scopulorum, Geum macrophyllum var. perincisum, and Galium boreale. Equisetum pratense, Bromus pumpellianus, Schizachne purpurascens and Calamagrostis spp. are some of the secondary species.

SNAME: Agropyron trachycaulum Herbaceous Vegetation

SCOMNAME: Slender wheat grass Herbaceous Vegetation

\section{CLASSIFICATION}

SYSTEM: Terrestrial

CLASS: Herbaceous vegetation

SUBCLASS: Perennial graminoid vegetation (grasslands)

GROUP: Temperate or subpolar grasslands

FORMATION: Medium-tall sod temperate or subpolar grasslands

ALLIANCE: Agropyron trachycaulum Herbaceous Alliance 


\section{CLASSIFICATION CONFDENCE LEVEL: 2}

SSIMILAR COMMUNITIES: Lack of codominants separates this community from most other Agropyron trachycaulum community types. Agropyron trachycaulum - Koeleria macrantha Herbaceous Vegetation (Raup 1935, this report) is a similar community type, however, although Koeleria macrantha may be present in the Agropyron trachycaulum Herbaceous Vegetation community, it never codominates.

The Agropyron trachycaulum Herbaceous Vegetation community also seems to occur on drier soils than the Agropyron trachycaulum - Elymus innovatus - Thalictrum venulosum and Agropyron trachycaulum - Carex praegracilis - Fragaria virginiana community types (this report).

\section{RELATED NOMENCLATURE}

SOTHER.NAMES: Elymus trachycaulus Herbaceous Vegetation

SOTHER.NAMES.RELATION.NOTE: The Agropyron trachycaulum Herbaceous Vegetation from Alberta and Elymus trachycaulus Herbaceous Vegetation from Sheridan County in Montana (Heidel et al. 2000) may be the same community type.

SNAMES.COM: The Agropyron trachycaulum Herbaceous Vegetation from Alberta and Elymus trachycaulus Herbaceous Vegetation from Sheridan County in Montana (Heidel et al. 2000) may be the same community type, although Montana's community has a higher cover of Agropyron trachycaulum (70\%) and seems to resemble more those sites in Alberta described by Fairbarns (1990). More information is needed to better understand variability in the cover of the dominant species and in the community composition between the Alberta's and Montana's sites.

\section{DISTRIBUTION}

SNATREG: Parkland, Grassland, Boreal Forest, possibly Rocky Mountain and Foothills

SSUBREG: Peace River Parkland, Dry Mixedgrass, Dry Mixedwood, and possibly Montane and Upper Foothills

SRANGE: Seems to be widespread

SDISTRIBUTION.COM: Seems to be widespread; occurs within Parkland (Peace River Parkland Subregion), Grassland (Dry Mixedgrass Subregion), Boreal Forest (Dry Mixedwood), and possibly Rocky Mountain (Montane Subregion) and Foothills (Upper Foothills Subregion) Natural Regions

\section{ENVIRONMENTAL FACTORS}

SLANDFORM: Occurs on, but is probably not restricted to lower terraces (Adams et al. 1997)

SSLOPE: Median: 35\% (6 - 58\%) (this report) 
SASPECT: Median: $191^{\circ}\left(140-216^{\circ}\right)$ (this report)

SSOIL.TYPE: Orthic Regosols and Orthic Eutric Brunisols (Adams et al. 1997)

SSOIL.MOSTURE: Very xeric to mesic (this report)

SSOIL.COM: Rapidly to imperfectly drained, with clay loam, silty loam, and sandy loam texture; some clay loam soils about $60 \mathrm{~cm}$ deep, with some glacial boulders; soils include those with mesotrophic nutrient regimes

SENVIRO.COM: This community type occurs under variable site conditions. It occurs on very xeric to xeric, steep to moderately steep southerly oriented slopes of the Peace River Parkland Subregion and possibly Montane and Upper Foothills subregions. Soils are rapidly to moderately well drained. They include Orthic Regosols and Orthic Eutric Brunisols with clay loam to sandy loam texture. The community also occurs in saline meadows of the Boreal Region. It also inhabits lower terraces within the Dry Mixedgrass Subregion on well to imperfectly drained Orthic Regosols and Orthic Eutric Brunisols with sandy loam to silty loam texture.

\section{BIOLOGICAL AND STRUCTURAL DESCRIPTION}

\section{6a VEGETATION}

SSTRATA LIFEFORM: Shrub; herb

SPCT.COVER: Shrub 9.6\%; herb 28\% (this report)

SMOST.ABUND.SPP: Symphoricarpos occidentalis, Rosa spp., Amelanchier alnifolia; Agropyron trachycaulum

SUNVEGETATED.SURFACE: Mineral soils and organic matter (this report)

SUNVEGETATED.SURFACE COVER: Generally $30-75 \%$, much lower on wetter sites

SCONSTANT.SPP: Rosa spp.; Agropyron trachycaulum, Koeleria macrantha, Vicia americana, Achillea millefolium, Gallium boreale

SVEGETATION.COM: Vegetation is relatively open with unvegetated surface varying from 30 $75 \%$ on drier sites to much lower on wetter sites. Agropyron trachycaulum dominates this community, while other common species include Artemisia frigida, Koeleria macrantha, Vicia americana, Achillea millefolium, Galium boreale, and Allium cernuum. Commonly associated shrub species, such as Symphoricarpos occidentalis, Rosa spp., Prunus virginiana or Amelanchier alnifolia may become dominant in some areas.

6c VARIABILITY 
SSUBTYPES: Similar community occurs on well-drained moderately steep, south facing slopes, where it becomes dominated by low shrub, such as Symphoricarpos occidentalis, Rosa spp. and Prunus virginiana (Rintoul 1985). The author considered this community a subtype of the Agropyron trachycaulum community type in his study area.

SVARIABIITY.COM: Commonly associated shrub species, such as Symphoricarpos occidentalis, Rosa spp., Prunus virginiana or Amelanchier alnifolia may become dominant in some areas. Wetter sites, such as slightly saline areas described by Fairbarns (1990), may have a higher cover of Agropyron trachycaulum compared to the community on drier soils described by Rintoul (1985) and in this report. Wetter sites also include species such as Symphoricarpos albus, Carex spp., Agrostis scabra, Antennaria parviflora, Astragalus dasyglottis, Geum triflorum, Hieracium umbellatum, Lactuca pulchella, Viola adunca and some halophytic species. Wetter sites from Wood Buffalo National Park are characterized by an assemblage of perennial forbs, such as Geum triflorum, Stachys scopulorum, Geum macrophyllum var. perincisum, and Galium boreale.

\section{SPATIAL RELATIONS}

SADJACENT.COMMUNITIES: In Wood Buffalo National Park, grasslands are surrounded by aspen stands.

SSPATIAL.COM: In Wood Buffalo National Park, grasslands are surrounded by aspen stands.

\section{STATUS}

SRANK: S3

SREASONS: Fairly widespread

SSTATCOM: This community seems to be fairly widespread, therefore it should be ranked S3

\section{MANAGEMENT}

SMANAGECOM: Prescribed burning or natural fires would help prevent aspen and shrub encroachment into grassland areas of the Wood Buffalo National Park (Schwarz and Wein 1997).

\section{ANALYSIS PROCEDURES AND DATA MANAGEMENT}

SANALYSIS.COM: Rintoul (1985) used tabular comparisons of vegetation cover data and environmental data to describe the community. Adams et al. (1997) collected the vegetation data (percent cover for each species) from a number of subsamples $(15-20 \mathrm{~cm} \times 50 \mathrm{~cm})$ located within the circular ( $200 \mathrm{~m}$ diameter) plots. Their vegetation classification was based on the manual grouping of subsamples using the cluster analysis dendrogram as a general guide. Plant communities were also associated with environmental factors, such as slope and aspect. Fairbarns (1990) based the vegetation description only on the reconnaissance level survey. Cluster and ordination analyses of the combined ESIS database and Waterton Lakes database were performed by Geowest personnel. Cluster analysis included species data from 416 plots. 
Ordination analysis related vegetation data from 120 plots to the following environmental variables: solar radiation (combines slope, aspect, and latitude), drainage class, moisture regimes, elevation, latitude, and longitude (last two variables represent macroclimatic variables - NW position in the province coincides with cooler and wetter climate as oppose to the SE end of the province). In addition to ordination, descriptive statistics (median, minimum, maximum) were calculated for environmental variables. These calculations were done in SPSS for Windows and included both variables used in the ordination and variables with a lot of missing data (soil drainage, site position - macro, site position - meso, nutrient regimes, $\%$ bedrock, $\%$ mineral soil, and $\%$ organic material. The information on Natural Subregion was taken from the GIS based on the geographical position of each plot.

SANALYSIS.DATA.MANAGE.COM: Rintoul (1985) used tabular comparisons of vegetation cover data and environmental data to describe the community. Adams et al. (1997) collected the vegetation data (percent cover for each species) from a number of subsamples $(15-20 \mathrm{~cm} \times 50$ $\mathrm{cm}$ ) located within the circular (200 m diameter) plots. Their vegetation classification was based on the manual grouping of subsamples using the cluster analysis dendrogram as a general guide. Plant communities were also associated with environmental factors, such as slope and aspect. Fairbarns (1990) based his vegetation description only on the reconnaissance level survey. Cluster and ordination analysis of combined ESIS database and Waterton Lakes database performed by the Geowest personnel. Cluster analysis included species data from 416 plots. Ordination analysis related vegetation data from 120 plots to the following environmental variables: solar radiation (combines slope, aspect, and latitude), drainage class, moisture regimes, elevation, latitude, and longitude (last two variables represent macroclimatic variables - NW position in the province coincides with cooler and wetter climate as oppose to the SE end of the province). In addition to ordination, descriptive statistics (median, minimum, maximum) were calculated for environmental variables. These calculations were done in SPSS for Windows and included both variables used in the ordination and variables with a lot of missing data (soil drainage, site position - macro, site position - meso, nutrient regimes, $\%$ bedrock, $\%$ mineral soil, and $\%$ organic material. The information on Natural Subregion was taken from the GIS based on the geographical position of each plot. The Ecological Site Inventory System (ESIS) electronic database is stored in the Resource Data Division of Alberta Environment, Edmonton.

\section{GENERAL COMMENTS}

SCOMMUNITY.COM: Further studies are needed to assess if this community should be split up into two community types (open community on dry sites and the community on wetter-solonetzic sites).

\section{REFERENCES}

\section{CITATION:}

Adams, G. D., G. C. Trottier, W. L. Strong, I. D. MacDonald, S. J. Barry, P. G. Gregoire, G. W. Babish and G. Weiss. 1997. Vegetation component report: Canadian Forces Base Suffield national Wildlife area - Wildlife Inventory. Report prepared for the Canadian Wildlife Service, Environment Canada, Edmonton, AB. 
Fairbarns, M. 1990. The Salt Meadows of Northwestern Alberta: A Reconnaissance Biophysical Inventory. Alberta Forestry, Lands and Wildlife.

Heidal, B., S. V. Cooper and C. Jean. 2000. Plant species of special concern and plant associations of Sheridan County, Montana. Report to the U.S. Fish and Wildlife Service. Montana Natural Heritage Program, Helena, Montana.

Rintoul, J. 1985. Silver Valley: Biophysical Resource Analysis. Alberta Forestry, Lands and Wildlife.

Raup, H. M. 1935. Botanical Investigations in Wood Buffalo Park. Bulletin No. 74, Biological Series, No. 20. Canada Dept. of Mines and National Museum of Canada. Ottawa, Ontario. 174 pp.

Schwarz, A. G. and R. W. Wein. 1997. Threatened dry grasslands in the continental boreal forests of Wood Buffalo National Park. Canadian journal of Botany 75: 1363-1370 


\section{COMMUNITY CHARACTERIZATION ABSTRACT}

\section{Agropyron trachycaulum - Stipa spp. Herbaceous Vegetation}

\section{IDENTIFIERS}

SEL.SUMMARY: This community occupies moderately dry slopes and certain flat mesic grasslands in the Peace River Region (Moss 1952). Sites are quite variable and include rocky grounds of an old moraine, well drained alluvial soils, level areas with heavy textured black soils developed on flood plains of streams, and black loam of silty to clay mixture with a "solodized solonetz type of profile", developed on lacustrine or alluvial-lacustrine material. In the Peace Point area of Wood Buffalo National Park this community occupies relatively flat areas with Orthic Cumulic Regosols of sandy-loam texture, developed on glaciolacustrine sediments (Redmann and Schwarz 1986). It also occurs at Salt River sites in the Wood Buffalo National Park on Black Sold soils (Schwarz 1994; Schwarz and Wein 1997). Vegetation on Peace River sites is characterized by the dominance of grass and sedge species such as Agropyron trachycaulum, Stipa curtiseta, Koeleria macrantha and Carex obtusata, accompanied by numerous forb species (e.g. Galium boreale, Achillea millefolium, Thalictrum venulosum). Stipa richardsonis, Danthonia intermedia, Agropyron dasystachyum, Carex praticola, C. siccata, and some shrubby species (e.g. Amelanchier alnifolia) may become locally abundant. Agropyron trachycaulum (20.8\% cover) and Stipa columbiana $(9.7 \%$ cover) dominate the herb layer on the Peace Point sites described by Redmann and Schwarz (1986). S comata, S. curtiseta, Artemisia frigida, and Galium boreale are some of the additional grass and forb species characterizing these grasslands. The community described by Schwarz (1994) and Schwarz and Wein (1997) is dominated by $A$. trachycaulum, Stipa curtiseta (S. richardsonis, S. viridula), accompanied by some typically southern species, such as Koeleria macrantha, Carex siccata, C. xerantica, Muhlenbergia richardsonis, Geum triflorum and Potentilla hippiana.

SNAME: Agropyron trachycaulum - Stipa spp. Herbaceous Vegetation

SCOMNAME: Slender wheat grass - needle grass Herbaceous Vegetation

\section{CLASSIFICATION}

\section{SYSTEM: Terrestrial}

CLASS: Herbaceous vegetation

SUBCLASS: Perennial graminoid vegetation (grasslands)

GROUP: Temperate or subpolar grasslands

FORMATION: Medium-tall sod temperate or subpolar grasslands

ALLIANCE: Agropyron trachycaulum Herbaceous Alliance

CLASSIFICATION CONFIDENCE LEVEL: 1 
SSIMILAR COMMUNITIES: The Agropyron trachycaulum Herbaceous Vegetation community (Raup 1935, Rintoul 1985, Fairbarns 1990, Adams et al. 1997, this report) lacks codominants and Stipa spp. is sparse to absent. The Agropyron trachycaulum - Koeleria cristata Herbaceous Vegetation (Raup 1935, this report) is a similar community type, however, Stipa species are either absent or present in low cover. The Elymus trachycaulus - Muhlenbergia richardsonis Herbaceous Vegetation community from Fort Providence (Northwest Territories) and Saskatchewan (Thieret 1959, Dodd and Coupland 1966) is another similar community type. Muhlenbergia richardsonis can be present in the Agropyron trachycaulum - Stipa spp. Herbaceous Vegetation community type, but it never codominates. In addition, the Elymus trachycaulus - Muhlenbergia richardsonis Herbaceous Vegetation community lacks a significant Stipa spp. component.

\section{RELATED NOMENCLATURE}

SOTHER.NAMES: Carex spp. - Danthonia intermedia - Stipa spartea var. curtiseta (Wilkinson 1981); Agropyron trachycaulum var. unilaterale - Stipa spartea - Danthonia intermedia - Carex community type (Wallis 1982); Stipa sp. - Agropyron trachycaulum community type (Schwarz and Wein 1997); Agropyron trachycaulum - Poa glauca - Galium boreale community type (Schwarz and Wein 1997); dry solod grasslands and rich dry grasslands (Schwarz 1994).

SOTHER.NAMES.RELATION.NOTE: Based on the data presented in Moss (1952) and Wilkinson (1981), and on authors personal investigations, Wallis (1982) suggested that the Carex spp. - Danthonia intermedia - Stipa spartea var. curtiseta community type should be more appropriately described as an Agropyron trachycaulum var. unilaterale - Stipa spartea Danthonia intermedia - Carex community type. Wallis (1982) also suggested that this community type probably represents those Agropyron trachycaulum - Stipa spp. sites that grow on "solodized solonetz type of profile". Based on the species composition presented in Schwarz (1994) and Schwarz and Wein (1997), the Stipa sp. - Agropyron trachycaulum community type, Agropyron trachycaulum - Poa glauca - Galium boreale community type, dry solod grasslands and rich dry grasslands from the Wood Buffalo National Park seem to be the same community type as one described from the Peace River region by Moss (1952).

SNAMES.COM: Based on the data presented in Moss (1952) and Wilkinson (1981), and on authors personal investigations, Wallis (1982) suggested that the Carex spp. - Danthonia intermedia - Stipa spartea var. curtiseta community type (Wilkinson 1981) should be more appropriately described as an Agropyron trachycaulum var. unilaterale - Stipa spartea Danthonia intermedia - Carex community type. Wallis (1982) also suggested that this community type probably represents those Agropyron trachycaulum - Stipa spp. sites that grow on "solodized solonetz type of profile". Therefore, this community may be included in the Agropyron trachycaulum - Stipa spp. community type. Based on the species composition presented in Schwarz (1994) and Schwarz and Wein (1997), the Stipa sp. - Agropyron trachycaulum community type, Agropyron trachycaulum - Poa glauca - Galium boreale community type, dry solod grasslands and rich dry grasslands from the Wood Buffalo National Park seem to be the same community type as one described from the Peace River region by Moss (1952). Further studies are needed to assess whether communities occurring on the solonetzic soils should be separated from the Agropyron trachycaulum - Stipa spp. community type. 


\section{DISTRIBUTION}

SNATREG: Parkland, Boreal Forest

SSUBREG: Peace River Parkland, Peace River Lowlands

SRANGE: Northern Alberta (Peace River Parkland, immediately adjacent areas, south base of the Caribou Mountains, a number of smaller areas in the NW corner of Alberta, Wood Buffalo National Park - Peace Point, Salt River and Square Lake sites)

SRANGECOM: Restricted to the northern portion of Alberta

SDISTRIBUTION.COM: Northern Alberta (Peace River Parkland, immediately adjacent areas, south base of the Caribou Mountains, a number of smaller areas in the NW corner of Alberta, Wood Buffalo National Park - Peace Point, Salt River and Square Lake sites); Parkland Natural Region (Peace River Parkland Subregion), Boreal Forest Natural Region (Peace River Lowlands Subregion)

\section{ENVIRONMENTAL FACTORS}

SMINELEV: $200 \mathrm{~m}$ (Wood Buffalo National Park)

SMAXELEV: $220 \mathrm{~m}$ (Wood Buffalo National Park)

SLANDFORM: Alluvial, lacustrine, alluvial-lacustrine, glaciolacustrine

STOP.POSITION: Variable (level areas, flood plains of streams, middle slope, crest)

SSLOPE: 0 - 30\% (Wood Buffalo National Park)

SASPECT: Southerly (Wood Buffalo National Park)

SSOIL.TYPE: Variable; in the Peace River region it includes rocky grounds of an old moraine, well drained alluvial soils, heavy textured black soils developed on silty flood plain, black loam of silty to clay mixture with a "solodized solonetz type of profile", developed on lacustrine or alluvial-lacustrine material; in the Peace Point area occurs on coarse textured, rapidly drained Orthic Cumulic Regosols, developed on glaciolacustrine sediments; it also occupies Black Solod, Dark Gray Solod and Humic Folisol soils in Wood Buffalo National Park.

SSOIL.MOSTURE: Includes mesic soils

SENVIRO.COM: In Wood Buffalo National Park sites range in elevation from $200 \mathrm{~m}$ to $220 \mathrm{~m}$; community occurs under variable soil conditions: in the Peace River region it includes rocky grounds of an old moraine, well drained alluvial soils, heavy textured black soils developed on flood plain, black loam of silty to clay mixture with a "solodized solonetz type of profile", developed on lacustrine or alluvial-lacustrine material; the Peace Point community occurs on coarse textured, rapidly drained Orthic Cumulic Regosols of sandy-loam texture, developed on 
glaciolacustrine sediments; it also occupies Black Solod, Dark Gray Solod and Humic Folisol soils in Wood Buffalo National Park.

\section{BIOLOGICAL AND STRUCTURAL DESCRIPTION}

\section{6a VEGETATION}

SSTRATA LIFEFORM: Shrub; herb

SPCT.COVER: Shrub (0 - 14\%); herb (75 - 105\%) (Wood Buffalo National Park)

SHEIGHT: Shrub (0 - $1.4 \mathrm{~m})$ (Wood Buffalo National Park)

SMOST.ABUND.SPP: Agropyron trachycaulum, Stipa curtiseta and/or S. columbiana/S. richardsonis/S. viridula, Koeleria cristata and Carex obtusata/C. siccata

SCONSTANT.SPP: Agropyron trachycaulum, Galium boreale, Achillea millefolium, Thalictrum venulosum

SCHARACTERISTIC.SPP: Stipa curtiseta, S. columbiana, S. richardsonis, or S. viridula

SVEGETATION.COM: Shrub layer not prominent but some shrubby species (e.g. Amelanchier alnifolia) may become locally abundant; herb layer abundant, with Agropyron trachycaulum, Stipa curtiseta, S. columbiana, S. richardsonis, or S. viridula, Koeleria macrantha and Carex obtusata/C. siccata being the most abundant species; Agropyron trachycaulum, Galium boreale, Achillea millefolium, Thalictrum venulosum are the constant species; Stipa curtiseta/S. columbiana/S. richardsonis/S. viridula are the characteristic species.

\section{6b OTHER SPECIES}

SOTHERSPP.COM: A number of species which are characteristic for more southern regions of Alberta are present in stands from Wood Buffalo National Park: Stipa curtiseta, S. richardsonis, S. viridula, Koeleria macrantha, Geum triflorum, Carex siccata, C. xerantica, C. filifolia, Muhlenbergia richardsonis, Comandra umbellata, Potentilla hippiana, Orthocarpus luteus, Poa arida, P. juncifolia, Ranunculus cardiophyllus, Solidago missouriensis, Silene drummondii and Anemone cylindrica, A. patens. S. viridula, S. comata and Ranunculus cardiophyllus are thought to be uncommon in the boreal forest region (Schwarz and Wein 1997).

\section{6c VARIABILITY}

SSPP.COMP.VAR: In the Wood Buffalo National Park sites, Stipa columbiana, Stipa richardsonis or $S$. viridula replace or accompany Stipa curtiseta which characterizes the Peace River community. The same stands at Peace Point may have higher covers of Stipa viridula and Poa glauca. 
SVARIABIITY.COM: In the Wood Buffalo sites Stipa columbiana, Stipa richardsonis and $S$. viridula are more characteristic than Stipa curtiseta, which is more typical for Peace River communities.

\section{SPATIAL RELATIONS}

SSIZE: A few hectares in the Wood Buffalo National Park; limited extend in the Peace River region

SADJACENT.COMMUNITIES: Agropyron trachycaulum - Carex atherodes Herbaceous Vegetation occupies moister areas adjacent to the Agropyron trachycaulum - Stipa spp. Community in the Peace River Region. Grasslands of the Peace Point area in Wood Buffalo National Park are surrounded by aspen stands.

\section{STATUS}

\section{SRANK: S1}

SREASONS: Western Rangeland Consultants (1999) indicated that the majority of the grasslands NE from Grande Prairie have been lost within the last 50 years due to farming practices; also, very small size of stands in Wood Buffalo National Park, along with the threat from the tree and shrub encroachment.

SSTATCOM: Western Rangeland Consultants (1999) indicated that the majority of the grasslands NE from Grande Prairie have been lost within the last 50 years due to farming practices; stands in Wood Buffalo National Park are very small and threatened from the tree and shrub encroachment; this community type is currently on the community tracking list as Carex spp. - Danthonia intermedia - Stipa curtiseta community (ranked S1).

\section{MANAGEMENT}

SECONCOM: Grazed by cattle in the Peace River and by bison in Wood Buffalo National Park

SMANAGECOM: Heavy grazing in the Agropyron - Stipa community type results in a decrease of cover of the leading grass species and on increase of other species, particularly Carex obtusata (Moss 1952; Redmann and Schwarz 1986); prescribed burning or natural fires would help prevent aspen and shrub encroachment into grassland areas of Wood Buffalo National Park (Schwarz and Wein 1997).

\section{ANALYSIS PROCEDURES AND DATA MANAGEMENT}

SANALYSIS.COM: Moss (1952) recorded species abundance, frequency and, for some sites, relative coverage of the species. Sampling areas varied in size from a few square "rods" to several acres. Redmann and Schwarz (1986) performed baseline sampling of vegetation at $5 \mathrm{~m}$ intervals using $50 \times 25 \mathrm{~cm}$ quadrats. Species cover was estimated using a five-point scale. Comparison with the Peace River grasslands described by Moss (1952) was done by ranking the eight most dominant graminoids and 8 most dominant forb species in each grassland type. 
Dominance similarity index was calculated to assess the similarity between different grassland types. Schwarz (1994) and Schwarz and Wein (1997) assigned the percent cover classes to all vascular plants within $25 \mathrm{~m}^{2}$ circular plots. Ordination (DCA) and cluster (TWINSPAN) analyses were perfumed to classify grassland communities.

SANALYSIS.DATA.MANAGE.COM: Moss (1952) recorded species abundance, frequency and, for some sites, relative coverage of the species. Sampling areas varied in size from a few square "rods" to several acres. Redmann and Schwarz (1986) performed baseline sampling of vegetation at $5 \mathrm{~m}$ intervals using $50 \times 25 \mathrm{~cm}$ quadrats. Species cover was estimated using a fivepoint scale. Comparison with the Peace River grasslands described by Moss (1952) was done by ranking the eight most dominant graminoids and 8 most dominant forb species in each grassland type. Dominance similarity index was calculated to assess the similarity between different grassland types. Schwarz (1994) and Schwarz and Wein (1997) assigned the percent cover classes to all vascular plants within $25 \mathrm{~m}^{2}$ circular plots. Ordination (DCA) and cluster (TWINSPAN) analyses were perfumed to classify grassland communities. Vegetation data used in Redmann and Schwarz (1986), Schwarz (1994) and in Schwarz and Wein (1996) is in the possession of A.G. Schwarz (see the reference section of this report).

\section{GENERAL COMMENTS}

SCOMMUNITY.COM: Redmann and Schwarz 1986 compared grasslands from the Peace Point area in Wood Buffalo National Park with those described for the Peace River region by Moss (1952). They concluded that the Peace River sites are closer in species composition to the Stipa faciation than to the Agropyron - Stipa faciation, and explained it by the presence of drier and non-solonetzic soils characterizing the Peace Point grasslands. Further study is needed to confirm that the Agropyron trachycaulum and Stipa spp. dominated communities from Wood Buffalo National Park and the Peace River region represent the same community type, and to estimate their sizes and potential threats to the communities.

\section{REFERENCES}

\section{CITATION:}

Adams, G. D., G. C. Trottier, W. L. Strong, I. D. MacDonald, S. J. Barry, P. G. Gregoire, G. W. Babish and G. Weiss. 1997. Vegetation component report: Canadian Forces Base Suffield national Wildlife area - Wildlife Inventory. Report prepared for the Canadian Wildlife Service, Environment Canada, Edmonton, AB.

Dodd, J. D. and R. T. Coupland. 1966. Vegetation of saline Areas in Saskatchewan. Ecology 47: 958-967

Fairbarns, M. 1990. The Salt Meadows of Northwestern Alberta: A Reconnaissance Biophysical Inventory. Alberta Forestry, Lands and Wildlife.

Moss, E. H. 1952. Grasslands of the Peace River Region, western Canada. Canadian Journal of Botany 30: 98-104 
Redmann, R. E. and A. G. Schwarz. 1986. Dry grassland plant communities in Wood Buffalo National park, Alberta. Canadian Field-Naturalist 100: 526-532.

Rintoul, J. 1985. Silver Valley: Biophysical Resource Analysis. Alberta Forestry, Lands and Wildlife.

Raup, H. M. 1935. Botanical Investigations in Wood Buffalo Park. Bulletin No. 74, Biological Series, No. 20. Canada Dept. of Mines and National Museum of Canada. Ottawa, Ontario. $174 \mathrm{pp}$.

Schwarz, A. G. 1994. Inventory of dry grasslands and associated vegetation in Wood Buffalo National Park. Report prepared for Parks Canada, Wood Buffalo National Park, Fort Smith.

Schwarz, A. G. and R. W. Wein. 1997. Threatened dry grasslands in the continental boreal forests of Wood Buffalo National Park. Canadian journal of Botany 75: 1363-1370

Thieret, J. W. 1959. Grassland vegetation near Fort Province, Northwest Territories. The Canadian field-Naturalist 73: 161-167

Wallis, C. A. 1982. An overview of the mixed grasslands of North America. Grassland Ecology and Classification: Symposium proceeding June 1982. Ministry of Forests, BC

Western Rangeland Consultants Inc. (with the assistance of Beulah Tec Limited). 1999. Mitigation measures and future recommendations for rare native grasslands on the Cochrane property and three other adjacent to Highway 43, near Grande Prairie, Alberta. Report prepared for Planning and Technical Services Division, Planning Services Branch, Alberta Transportation and Utilities, Edmonton, AB.

Wilkinson, K. 1981. Remnant and early settlement prairies and solonetzic soils in the Peace River District. M.Sc. thesis, Department of Biology, University of Calgary, Calgary, Alberta. 


\section{COMMUNITY CHARACTERIZATION ABSTRACT}

Agropyron trachycaulum - Carex atherodes Herbaceous Vegetation

\section{IDENTIFIERS}

SEL.SUMMARY: In its unmodified condition this community occupies only one shallow basin in the Peace River Region ( $N$ of Fort Vermilion and $\mathrm{E}$ of the Caribou River, near the base of the Caribou Mountains) of Alberta (Moss 1952). Somewhat modified versions of this community occur on the Boyer River site on deposits of fine sand and clay, in Buffalo Prairie on silty flood plain sites with fertile black loam $(5-10 \mathrm{~cm})$ over brown silt subsoil, and near Keg River (Moss 1952). Typically, Agropyron trachycaulum and Carex atherodes dominate, accompanied by other principal grass and forb species, such as Carex praticola, Calamagrostis spp., Bromus spp, Solidago lepida and Vicia americana. Symphoricarpos occidentalis, Symphoricarpos albus and Rosa woodsii are frequent species in the shrub layer, and become more abundant under modified (grazed) conditions.

SNAME: Agropyron trachycaulum - Carex atherodes Herbaceous Vegetation

SCOMNAME: Slender wheat grass - awned sedge Herbaceous Vegetation

\section{CLASSIFICATION}

SYSTEM: Terrestrial

CLASS: Herbaceous vegetation

SUBCLASS: Perennial graminoid vegetation (grasslands)

GROUP: Temperate or subpolar grasslands

FORMATION: Medium-tall sod temperate or subpolar grasslands

ALLIANCE: Agropyron trachycaulum Herbaceous Alliance

\section{CLASSIFICATION CONFIDENCE LEVEL: 1}

SSIMILAR COMMUNITIES: The Agropyron trachycaulum Herbaceous Vegetation community type (Rintoul 1985, Fairbarns 1990, Adams et al. 1997, this report) lacks codominants and Carex species are mostly absent.

\section{RELATED NOMENCLATURE}

SOTHER.NAMES: Elymus trachycaulus - Carex atherodes community type (Allen 2000).

SOTHER.NAMES.RELATION. NOTE: Elymus trachycaulus - Carex atherodes community type (Allen 2000) and Agropyron trachycaulum - Carex atherodes Herbaceous Vegetation are the synonyms for the same community type. 
SNAMES.COM: Elymus trachycaulus - Carex atherodes community type (Allen 2000) and Agropyron trachycaulum - Carex atherodes Herbaceous Vegetation are the synonyms for the same community type; Elymus trachycaulus (Kartesz 1999) is a synonym for Agropyron trachycaulum (Moss 1983).

\section{DISTRIBUTION}

SNATREG: Parkland

SSUBREG: Peace River Parkland

SRANGECOM: Restricted to an area north of the Fort Vermilion and east of the Caribou River, near the base of the Caribou Mountains

SDISTRIBUTION.COM: Restricted to an area north of Fort Vermilion and east of the Caribou River, near the base of the Caribou Mountains (Parkland Natural Region - Peace River Parkland Subregion)

\section{ENVIRONMENTAL FACTORS}

STOP.POSITION: Mainly in low areas

SSLOPE: Level

SSOIL.COM: Somewhat modified versions of this community occur on the Boyer River site on deposits of fine sand and clay, and in Buffalo Prairie on silty flood plain sites with fertile black loam $(5-10 \mathrm{~cm})$ over the brown silt subsoil, and near the Keg River.

SENVIRO.COM: Somewhat modified versions of this community occur on the Boyer River site on deposits of fine sand and clay, and in Buffalo Prairie on silty flood plain sites with fertile black loam $(5-10 \mathrm{~cm})$ over the brown silt subsoil, and near the Keg River.

\section{BIOLOGICAL AND STRUCTURAL DESCRIPTION}

\section{6a VEGETATION}

SSTRATA LIFEFORM: Shrub; herb

SMOST.ABUND.SPP: Symphoricarpos occidentalis, Symphoricarpos albus, Rosa woodsii: Agropyron trachycaulum, Carex atherodes

SCONSTANT.SPP: Agropyron trachycaulum, Carex atherodes, Carex praticola, Calamagrostis spp., Bromus spp, Solidago lepida, Gallium boreale, Vicia americana

SCHARACTERISTIC.SPP: Carex atherodes 
SVEGETATION.COM: Symphoricarpos occidentalis, Symphoricarpos albus and Rosa woodsii dominate the shrub layer; Agropyron trachycaulum, Carex atherodes are the dominant herbs; Agropyron trachycaulum, Carex atherodes, Carex praticola, Calamagrostis spp., Bromus spp, Solidago lepida, Gallium boreale, and Vicia americana are some of the constant species; Carex atherodes is the characteristic species.

\section{6c VARIABIITY}

SSPP.COMP.VAR: Symphoricarpos occidentalis, Rosa woodsii and Carex atherodes become more abundant under grazed conditions.

SVARIABILITY.COM: Symphoricarpos occidentalis, Rosa woodsii and Carex atherodes become more abundant under grazed conditions

\section{SPATIAL RELATIONS}

SADJACENT.COMMUNITIES: Agropyron trachycaulum - Stipa spp. Herbaceous Vegetation occupies drier areas adjacent to the Agropyron trachycaulum - Carex atherodes community type

SSPATIAL.COM: Agropyron trachycaulum - Stipa spp. Herbaceous Vegetation occupies drier areas adjacent to the Agropyron trachycaulum - Carex atherodes community type

\section{STATUS}

SRANK: S1

SREASONS: Very limited distribution (Restricted to an area north of Fort Vermilion and east of the Caribou River, near the base of the Caribou Mountains, Parkland Natural Region - Peace River Parkland Subregion)

SSTATCOM: Very limited distribution (Restricted to an area north of Fort Vermilion and east of the Caribou River, near the base of the Caribou Mountains, Parkland Natural Region - Peace River Parkland Subregion); this community is presently considered provincially rare (ranked S1) in the Preliminary Plant Community Tracking List (Allen 2000)

\section{ANALYSIS PROCEDURES AND DATA MANAGEMENT}

SANALYSIS.COM: Moss (1952) recorded species abundance, frequency and, for some sites, relative coverage of the species. Sampling areas varied in size from a few square "rods" to several acres. Cluster and ordination analysis of the combined ESIS database and Waterton Lakes database was performed by Geowest personnel. Cluster analysis included species data from 416 plots. Ordination analysis related vegetation data from 120 plots to the following environmental variables: solar radiation (combines slope, aspect, and latitude), drainage class, moisture regimes, elevation, latitude, and longitude (last two variables represent macroclimatic variables - NW position in the province coincides with cooler and wetter climate as oppose to the SE end of the province). In addition to ordination, descriptive statistics (median, minimum, maximum) were calculated for environmental variables. These calculations were done in SPSS for Windows and 
included both variables used in the ordination and variables with a lot of missing data (soil drainage, site position - macro, site position - meso, nutrient regimes, $\%$ bedrock, $\%$ mineral soil, and $\%$ organic material. The information on Natural Subregion was taken from the GIS based on the geographical position of each plot.

SANALYSIS.DATA.MANAGE.COM: Moss (1952) recorded species abundance, frequency and, for some sites, relative coverage of the species. Sampling areas varied in size from a few square rods to several acres. Cluster and ordination analysis of the combined ESIS database and Waterton Lakes database was performed by Geowest personnel. Cluster analysis included species data from 416 plots. Ordination analysis related vegetation data from 120 plots to the following environmental variables: solar radiation (combines slope, aspect, and latitude), drainage class, moisture regimes, elevation, latitude, and longitude (last two variables represent macroclimatic variables - NW position in the province coincides with cooler and wetter climate as oppose to the $\mathrm{SE}$ end of the province). In addition to ordination, descriptive statistics (median, minimum, maximum) were calculated for environmental variables. These calculations were done in SPSS for Windows and included both variables used in the ordination and variables with a lot of missing data (soil drainage, site position - macro, site position - meso, nutrient regimes, $\%$ bedrock, \% mineral soil, and \% organic material. The information on Natural Subregion was taken from the GIS based on the geographical position of each plot. The Ecological Site Inventory System (ESIS) electronic database is stored in the Resource Data Division of Alberta Environment, Edmonton.

\section{GENERAL COMMENTS}

SCOMMUNITY.COM: Three plots from the ESIS database clustered together into a "community type" that may be named "Agropyron trachycaulum - Carex spp. community type" (community \#5 in this report). However, the species of Carex is not known, and the three sampling plots are not from the Peace River region, but are from Upper Foothills, Subalpine, and Dry Mixedwood subregions. More information is needed to show if these three plots represent the same community type as the one described in Moss (1952).

\section{REFERENCES}

\section{CITATION:}

Adams, G. D., G. C. Trottier, W. L. Strong, I. D. MacDonald, S. J. Barry, P. G. Gregoire, G. W. Babish and G. Weiss. 1997. Vegetation component report: Canadian Forces Base Suffield national Wildlife area - Wildlife Inventory. Report prepared for the Canadian Wildlife Service, Environment Canada, Edmonton, AB.

Allen, L. 2000. Alberta Natural Heritage Information Centre Preliminary Plant Community Tracking List. Alberta Environment, Edmonton, AB

Fairbarns, M. 1990. The Salt Meadows of Northwestern Alberta: A Reconnaissance Biophysical Inventory. Alberta Forestry, Lands and Wildlife. 
Kartesz, JT. 1999. A synonymized checklist and atlas with biological attributes for the vascular flora of the United States, Canada, and Greenland. 1st edition. In: Meacham, CA. Synthesis of the north American flora [computer program]. Version 1.0. North Carolina Botanical Garden, Chapel Hill ( NC).

Moss, E. H. 1952. Grasslands of the Peace River Region, western Canada. Canadian Journal of Botany 30: 98-104

Moss, E. H. 1983. The flora of Alberta. (2nd edition). Revised by J. G. Packer. University of Toronto Press, Toronto, ON.

Rintoul, J. 1985. Silver Valley: Biophysical Resource Analysis. Alberta Forestry, Lands and Wildlife. 
COMMUNITY CHARACTERIZATION ABSTRACT

Agropyron trachycaulum - Carex praegracilis - Fragaria virginiana Herbaceous Vegetation

\section{DENTIFIERS}

SEL.SUMMARY: This community occurs on mesic to subhygric, moderately well drained soils with mesotrophic nutrient regimes within the Upper Foothills Subregion (elevation ranges 1400 $2438 \mathrm{~m}$ ) (Willoughby and Smith 1999), and the Upper and Lower Foothills (576 - $1540 \mathrm{~m}$ ) (communities \#15, \#12 and \#17 in this report). The dominant grass and sedge species are Agropyron trachycaulum, Carex praegracilis, Bromus ciliatus and Elymus innovatus. On average, they contributed $26.0 \%, 21.0 \%, 9.0 \%$ and $5.0 \%$ to the canopy cover, respectively (this report). Some of the dominant forbs, Fragaria virginiana, Potentilla gracilis, Achillea millefolium and Aster ciliolatus, make up $12.0 \%, 9.0 \%, 8.0 \%$ and $5.0 \%$ of the canopy cover, respectively (this report). At least some stands of this community represent a degradation of the Festuca scabrella - Deschampsia caespitosa community type and is very common in valley bottoms in areas with heavy grazing (Willoughby and Smith 1999).

SNAME: Agropyron trachycaulum - Carex praegracilis - Fragaria virginiana Herbaceous Vegetation

SCOMNAME: Slender wheat grass - graceful sedge - wild strawberry Herbaceous Vegetation

\section{CLASSIFICATION}

SYSTEM: Terrestrial

CLASS: Herbaceous vegetation

SUBCLASS: Perennial graminoid vegetation (grasslands)

GROUP: Temperate or subpolar grasslands

FORMATION: Medium-tall sod temperate or subpolar grasslands

ALLIANCE: Agropyron trachycaulum Herbaceous Alliance

\section{CLASSIFICATION CONFIDENCE LEVEL: 1}

SSIMILAR COMMUNITIES: The Agropyron trachycaulum Herbaceous Vegetation community type (Rintoul 1985, Fairbarns 1990, Adams et al. 1997, this report) lacks codominants. Carex spp and Fragaria virginiana are also generally absent. The Agropyron trachycaulum - Elymus innovatus - Thalictrum venulosum Herbaceous Vegetation community type (this report) is also similar to the Agropyron trachycaulum - Carex praegracilis - Fragaria virginiana Herbaceous Vegetation community, but, in the former community, Carex praegracilis does not codominate and Fragaria virginiana is generally absent. 
The Agropyron trachycaulum - Carex praegracilis - Fragaria virginiana community type also seems to occur on drier soils than the Agropyron trachycaulum - Elymus innovatus - Thalictrum venulosum community type, and on wetter soils than the Agropyron trachycaulum and Agropyron trachycaulum - Koeleria cristata community types (this report).

\section{DISTRIBUTION}

SNATREG: Foothills

SSUBREG: Upper Foothills, Lower Foothills

SDISTRIBUTION.COM: Foothills Natural Region (Upper and Lower Foothills Subregions)

\section{ENVIRONMENTAL FACTORS}

SMINELEV: $576 \mathrm{~m}$ (this report)

SMAXELEV: 2438 m (Willoughby and Smith 1999)

STOP.POSITION: Toe, level (this report)

SSLOPE: Median 1\% (0 - 35\%) (this report)

SASPECT: Median $90^{\circ}\left(0-315^{\circ}\right)$ (this report)

SSOIL.MOSTURE: Mesic to subhygric (this report)

SSOIL.COM: Moderately well drained soils with mesotrophic nutrient regimes; some well to imperfectly drained soils (this report)

SENVIRO.COM: This community occurs on mostly level terrain with mesic to subhygric, moderately well drained soils with mesotrophic nutrient regimes. Elevation ranges from $576 \mathrm{~m}$ to $2438 \mathrm{~m}$.

\section{BIOLOGICAL AND STRUCTURAL DESCRIPTION}

\section{6a VEGETATION}

SSTRATA LIFEFORM: Shrub; dwarf shrub; herb; moss

SPCT.COVER: Shrub 3.5\%; dwarf shrub 2.5\%; herb 180\%; moss $0-27 \%$ (this report)

SMOST.ABUND.SPP: Salix barclayi; Arctostaphylos uva-ursi; Agropyron trachycaulum, Carex praegracilis, Fragaria virginiana

SCONSTANT.SPP: Agropyron trachycaulum, Fragaria virginiana, Achillea millefolium 
SCHARACTERISTIC.SPP: Carex praegracilis, Fragaria virginiana

SVEGETATION.COM: The four strata include shrub 3.5\%, dwarf shrub $2.5 \%$, herb $180 \%$, and moss 0 - 27\%; the most abundant species per strata include Salix barclayi; Arctostaphylos uvaursi; Agropyron trachycaulum, Carex praegracilis, Fragaria virginiana; moss (unidentified) may be abundant in some stands; Agropyron trachycaulum, Fragaria virginiana and Achillea millefolium are constant species; Carex praegracilis and Fragaria virginiana are characteristic species.

\section{STATUS}

SRANK: S2S3

SREASONS: Willoughby and Smith (1999) described this community based on 10 plots; the additional 12 plots from the ESIS database represent the same community type (community \#15 in this report includes 15 plots, out of which three were used by Willoughby and Smith (1999) to describe the same community); additional 13 plots represent communities \# 12 and \# 17 from this report which relationship with the Agropyron trachycaulum - Carex praegracilis - Fragaria virginiana Herbaceous Vegetation community is not clear.

SSTATCOM: Willoughby and Smith (1999) described this community based on 10 plots; the additional 12 plots from the ESIS database represent the same community type (community \#15 in this report includes 15 plots, out of which three were used by Willoughby and Smith (1999) to describe the same community); additional 13 plots represent communities \# 12 and \# 17 from this report which relationship with the Agropyron trachycaulum - Carex praegracilis - Fragaria virginiana Herbaceous Vegetation community is not clear; Provincial rank S2S3 is proposed until more information is collected on this community type.

\section{MANAGEMENT}

SECONCOM: Used for cattle grazing

SMANAGECOM: At least some stands within this community appear to be a result of moderate to heavy grazing of the Festuca scabrella - Deschampsia caespitosa community type. Without moderate to heavy grazing, they would most likely revert to the original grassland community type.

\section{ANALYSIS PROCEDURES AND DATA MANAGEMENT}

SANALYSIS.COM: Within each of the $10 \mathrm{~m} \times 10 \mathrm{~m}$ sampling plots, canopy cover was estimated using ten randomly selected $1 \times 1 \mathrm{~m}$ microplots for shrubs, and $20 \times 50 \mathrm{~cm}$ microplots for herbs. Noted environmental factors included elevation, slope, aspect, soil drainage, nutrient regimes, and moisture regimes. Data was analyzed by both cluster and ordination analyses (Willoughby and Smith 1999). Additional cluster and ordination analysis of the combined ESIS database (including a number of plots analyzed by $\mathrm{M}$. Willoughby) and Waterton Lakes database was performed by Geowest personnel. Cluster analysis included species data from 416 plots. Ordination analysis related vegetation data from 120 plots to the following environmental 
variables: solar radiation (combines slope, aspect, and latitude), drainage class, moisture regimes, elevation, latitude, and longitude (last two variables represent macroclimatic variables - NW position in the province coincides with cooler and wetter climate as oppose to the SE end of the province). In addition to ordination, descriptive statistics (median, minimum, maximum) were calculated for environmental variables. These calculations were done in SPSS for Windows and included both variables used in the ordination and variables with a lot of missing data (soil drainage, site position - macro, site position - meso, nutrient regimes, $\%$ bedrock, $\%$ mineral soil, and $\%$ organic material. The information on Natural Subregion was taken from the GIS based on the geographical position of each plot.

SANALYSIS.DATA.MANAGE.COM: Within each of the $10 \mathrm{~m} \times 10 \mathrm{~m}$ sampling plots, canopy cover was estimated using ten randomly selected $1 \times 1 \mathrm{~m}$ microplots for shrubs, and $20 \times 50 \mathrm{~cm}$ microplots for herbs. Noted environmental factors included elevation, slope, aspect, soil drainage, nutrient regimes, and moisture regimes. Data was analyzed by both cluster and ordination analyses (Willoughby and Smith 1999). Additional cluster and ordination analysis of the combined ESIS database (including a number of plots analyzed by $\mathrm{M}$. Willoughby) and Waterton Lakes database was performed by Geowest personnel. Cluster analysis included species data from 416 plots. Ordination analysis related vegetation data from 120 plots to the following environmental variables: solar radiation (combines slope, aspect, and latitude), drainage class, moisture regimes, elevation, latitude, and longitude (last two variables represent macroclimatic variables - NW position in the province coincides with cooler and wetter climate as oppose to the $\mathrm{SE}$ end of the province). In addition to ordination, descriptive statistics (median, minimum, maximum) were calculated for environmental variables. These calculations were done in SPSS for Windows and included both variables used in the ordination and variables with a lot of missing data (soil drainage, site position - macro, site position - meso, nutrient regimes, $\%$ bedrock, \% mineral soil, and \% organic material. The information on Natural Subregion was taken from the GIS based on the geographical position of each plot. The Ecological Site Inventory System (ESIS) electronic database is stored in the Resource Data Division of Alberta Environment, Edmonton.

\section{GENERAL COMMENTS}

SCOMMUNITY.COM: The classification analysis of the ESIS data performed by Geowest personnel showed three similar clusters (community types) (\# 12, \#15, \#17), out of which one (\# $15)$ has the best fit to the community described by Willoughby (1998). Cluster group \#15 was used to describe environmental conditions under which the community occurs. The other two clusters may represent the same type, although cluster \# 12 has a lower cover of Carex praegracilis than expected, and Fragaria virginiana has low cover in plots within cluster \# 17. However, Carex praegracilis and Fragaria virginiana are characteristic species for all three clusters. It should also be noted that plots from cluster \#17 occur in Subalpine Subregion, and plots from cluster \#12 occupy sites within the Subalpine, Montane, Upper Foothills and Central Parkland subregions. More information is needed to understand the relationship between Agropyron trachycaulum - Carex praegracilis - Fragaria virginiana community type and the communities represented by clusters \#12 and \#17 from the ESIS database analysis.

\section{REFERENCES}




\section{CITATION:}

Adams, G. D., G. C. Trottier, W. L. Strong, I. D. MacDonald, S. J. Barry, P. G. Gregoire, G. W. Babish and G. Weiss. 1997. Vegetation component report: Canadian Forces Base Suffield national Wildlife area - Wildlife Inventory. Report prepared for the Canadian Wildlife Service, Environment Canada, Edmonton, AB.

Fairbarns, M. 1990. The Salt Meadows of Northwestern Alberta: A Reconnaissance Biophysical Inventory. Alberta Forestry, Lands and Wildlife.

Rintoul, J. 1985. Silver Valley: Biophysical Resource Analysis. Alberta Forestry, Lands and Wildlife.

Willoughby, M. G. and D. Smith. 1999. Range plant community types and carrying capacity for the Upper Foothills Subregion - third approximation. Environmental Protection, Land and Forest Service, Edmonton, $\mathrm{AB}$. 


\section{COMMUNITY CHARACTERIZATION ABSTRACT}

Agropyron trachycaulum - Distichlis stricta Herbaceous Vegetation

\section{IDENTIFIERS}

SEL.SUMMARY: This community type occupies small areas with eroded Solods and saline seeps on glaciolacustrine materials on the Salt River escarpment in Wood Buffalo National Park (Schwarz 1994, Schwarz and Wein 1997). Sites occur on southerly aspects at $210 \mathrm{~m}$ elevation. Soils are moderately fine textured and rapidly drained Dark Brown Solods and saline Regosols. This community is characterized by relatively small number of species, including Symphoricarpos occidentalis, Agropyron trachycaulum, Distichlis stricta, Koeleria macrantha, Spartina gracilis, Poa juncifolia and Carex siccata.

SNAME: Agropyron trachycaulum - Distichlis stricta Herbaceous Vegetation

SCOMNAME: Slender wheat grass - salt grass Herbaceous Vegetation

\section{CLASSIFICATION}

SYSTEM: Terrestrial

CLASS: Herbaceous vegetation

SUBCLASS: Perennial graminoid vegetation (grasslands)

GROUP: Temperate or subpolar grasslands

FORMATION: Medium-tall sod temperate or subpolar grasslands

ALLIANCE: Agropyron trachycaulum Herbaceous Alliance

\section{CLASSIFICATION CONFIDENCE LEVEL: 1}

SSIMILAR COMMUNITIES: The Agropyron trachycaulum Herbaceous Vegetation community type (Rintoul 1985, Fairbarns 1990, Adams et al. 1997, this report) is dominated solely by Agropyron trachycaulum, and Distichlis stricta is generally absent. Agropyron trachycaulum Koeleria macrantha Herbaceous Vegetation (Raup 1935, this report) is another similar community type, but it generally lacks Distichlis stricta. The difference between the Hordeum jubatum - Agropyron trachycaulum - Distichlis stricta community from the Peace River area, and the Agropyron trachycaulum - Distichlis stricta community from Wood Buffalo National Park, is based on the much greater prevalence of Hordeum jubatum in the composition of the former community. The Elymus trachycaulus - Spartina gracilis Herbaceous Vegetation community type from Sheridan County, Montana (Heidel et al. 2000) may differ from the Agropyron trachycaulum - Distichlis stricta Herbaceous Vegetation community type by a much greater prevalence of Spartina gracilis in the species composition, but a detailed vegetation description was not available, therefore no direct comparison with the Agropyron trachycaulum - Distichlis stricta Herbaceous Vegetation community is possible at this time. 


\section{RELATED NOMENCLATURE}

SOTHER.NAMES: Dry solod grasslands (Schwarz 1994); Elymus trachycaulus - Distichlis spicata Herbaceous Vegetation (Heidel et al. 2000)

SOTHER.NAMES.RELATION.NOTE: Two plots from the dry solod grasslands (Schwarz 1994) represent the Agropyron trachycaulum - Distichlis stricta Herbaceous Vegetation community described in this report. The Agropyron trachycaulum - Distichlis stricta Herbaceous Vegetation from Alberta and Elymus trachycaulus - Distichlis spicata Herbaceous Vegetation from Sheridan County in Montana (Heidel et al. 2000) may be the same community type.

SNAMES.COM: Two plots from the dry solod grasslands (Schwarz 1994) represent the Agropyron trachycaulum - Distichlis stricta Herbaceous Vegetation community described in this report. The Agropyron trachycaulum - Distichlis stricta Herbaceous Vegetation from Alberta and Elymus trachycaulus - Distichlis spicata Herbaceous Vegetation from Sheridan County in Montana (Heidel et al. 2000) may be the same community type. However, no details on the vegetation composition have been provided by Heidel et al. (2000) and the authors suggested that further documentation is needed for this community type.

\section{DISTRIBUTION}

SNATREG: Boreal Forest

SSUBREG: Peace River Lowlands

SRANGECOM: Limited to small openings in the boreal forest of Wood Buffalo National Park

SDISTRIBUTION.COM: Limited to small forest openings in Wood Buffalo National Park, Boreal Forest Natural Region

\section{ENVIRONMENTAL FACTORS}

SMINELEV: $210 \mathrm{~m}$

SMAXELEV: $210 \mathrm{~m}$

SLANDFORM: Glaciofluvia!

STOP.POSITION: Upper slopes

SSLOPE: $30-33 \%$

SASPECT: $133-159^{\circ}$

SSOIL.TYPE: Dark Brown Solod and saline Regosols

SSOIL.COM: Moderately fine textured and rapidly drained soils 
SENVIRO.COM: Community occurs on southerly aspects at $210 \mathrm{~m}$ elevation; soils are moderately fine textured and rapidly drained Dark Brown Solods and saline Regosols on glaciolacustrine sediments.

\section{BIOLOGICAL AND STRUCTURAL DESCRIPTION}

\section{6a VEGETATION}

SSTRATA LIFEFORM: Shrub; herb

SPCT.COVER: Shrub (1.5 - 2.5\%); herb (98 - 100\%)

SMOST.ABUND.SPP: Agropyron trachycaulum, Distichlis stricta

SUNVEGETATED.SURFACE: Probably mineral soils

SUNVEGETATED.SURFACE COVER: Probably mineral soils (1 - 5\%)

SCHARACTERISTIC.SPP: Distichlis stricta

SVEGETATION.COM: A relatively small number of species characterizes this community. Dominant species are Agropyron trachycaulum and Distichlis stricta. Distichlis stricta is also the characteristic species of this community. Koeleria macrantha, Spartina gracilis, Poa juncifolia and Carex siccata are some of the additional important species.

\section{6b OTHER SPECIES}

SOTHERSPP.COM: A number of species which are characteristic for more southern regions of Alberta are present in this community: Koeleria macrantha, Geum triflorum, Carex siccata, $C$. xerantica, Muhlenbergia richardsonis, Poa juncifolia, Spartina gracilis, Distichlis stricta and Poa arida. Distichlis stricta is thought to be uncommon in the Boreal Forest Region (Schwarz and Wein 1997).

\section{SPATIAL RELATIONS}

SSIZE: Less than 1 ha

SADJACENT.COMMUNITIES: Grasslands in Wood Buffalo National Park are surrounded by aspen stands.

\section{STATUS}

\section{SRANK: S1}

SREASONS: Extremely limited distribution and size (few small areas in Wood Buffalo National Park), as well as the threat from the aspen and shrub encroachment. 
SSTATCOM: Extremely limited distribution and size (few small areas in Wood Buffalo National Park), as well as the threat from the aspen and shrub encroachment; this community should be placed on the provincial tracking list and ranked S1

\section{MANAGEMENT}

SMANAGECOM: Prescribed burning or natural fires would help prevent aspen and shrub encroachment into grassland areas of Wood Buffalo National Park (Schwarz and Wein 1997).

\section{ANALYSIS PROCEDURES AND DATA MANAGEMENT}

SANALYSIS.COM: Schwarz 1994 and Schwarz and Wein (1997) assigned percent cover classes to all vascular plants within $25 \mathrm{~m}^{2}$ circular plots. Ordination (DCA) and cluster (TWINSPAN) analyses were performed to classify grassland communities.

SANALYSIS.DATA.MANAGE.COM: Schwarz 1994 and Schwarz and Wein (1997) assigned percent cover classes to all vascular plants within $25 \mathrm{~m}^{2}$ circular plots. Ordination (DCA) and cluster (TWINSPAN) analyses were performed to classify grassland communities. Vegetation data used in Schwarz 1994 and Schwarz and Wein (1997) is in the possession of A.G. Schwarz (see the reference section of this report).

\section{GENERAL COMMENTS}

SCOMMUNITY.COM: Timoney (1999) commented on the classification of dry grasslands within Wood Buffalo National Park by Schwartz and Wein (1997), and suggested that the dominant dry grasslands in Wood Buffalo National Park belong predominantly to the Agropyron - Stipa association (Peace River Prairie) as classified by Moss $(1952,1955)$. Authors of this report believe that the Agropyron trachycaulum - Distichlis stricta community type should be accepted as a separate community type because of the general lack of Stipa species and the dominance of Distichlis stricta.

\section{REFERENCES}

\section{CITATION:}

Adams, G. D., G. C. Trottier, W. L. Strong, I. D. MacDonald, S. J. Barry, P. G. Gregoire, G. W. Babish and G. Weiss. 1997. Vegetation component report: Canadian Forces Base Suffield national Wildlife area - Wildlife Inventory. Report prepared for the Canadian Wildlife Service, Environment Canada, Edmonton, AB.

Fairbarns, M. 1990. The Salt Meadows of Northwestern Alberta: A Reconnaissance Biophysical Inventory. Alberta Forestry, Lands and Wildlife.

Heidal, B., S. V. Cooper and C. Jean. 2000. Plant species of special concern and plant associations of Sheridan County, Montana. Report to the U.S. Fish and Wildlife Service. Montana Natural Heritage Program, Helena, Montana. 
Moss, E. H. 1952. Grasslands of the Peace River Region, western Canada. Canadian Journal of Botany 30: 98-104

Moss, E. H. 1955. The vegetation of Alberta. The Botanical Review, Vol. XXI, No. 9

Rintoul, J. 1985. Silver Valley: Biophysical Resource Analysis. Alberta Forestry, Lands and Wildlife.

Raup, H. M. 1935. Botanical Investigations in Wood Buffalo Park. Bulletin No. 74, Biological Series, No. 20. Canada Dept. of Mines and National Museum of Canada. Ottawa, Ontario. 174 pp.

Schwarz, A. G. 1994. Inventory of dry grasslands and associated vegetation in Wood Buffalo National Park. Report prepared for Parks Canada, Wood Buffalo National Park, Fort Smith.

Schwarz, A. G. and R. W. Wein. 1997. Threatened dry grasslands in the continental boreal forests of Wood Buffalo National Park. Canadian journal of Botany 75: 1363-1370

Timoney, P. T. 1999. Threatened dry grasslands in the continental boreal forest of Wood Buffalo National Park: commentary. Canadian Journal of Botany 77: 913-917 
COMMUNITY CHARACTERIZATION ABSTRACT

Agropyron trachycaulum - Koeleria macrantha Herbaceous Vegetation

\section{IDENTIFIERS}

SEL.SUMMARY: This community type occupies salt plains (level country just west of the Slave River) of Wood Buffalo National Park (Peace River Lowlands Subregion) (Raup 1935). It is located about 2 miles south of Heart Lake on nearly level terrain where streams carried off the outwash and left the soil with little or no salt. Cluster analysis of the ESIS database presented in this report (community \#4) indicates the possible existence of this community type in the Dry Mixedwood, Subalpine and Montane subregions on level to steeply sloping areas of variable aspects. Soils are moderately well to rapidly drained with mostly subxeric moisture regimes. Agropyron trachycaulum and Koeleria macrantha dominate the community described by Raup (1935). Subdominant species include Juniperus horizontalis, Hierochloe odorata, Deschampsia caespitosa, Danthonia intermedia, Schizachne purpurascens and Agrostis scabra. With the exception of the two dominant species, Agropyron trachycaulum and Koeleria macrantha, few other species are shared between this community described by Raup (1935) and one based on the cluster analysis (this report). Grasslands outside Wood Buffalo National Park are characterized by a number of species not mentioned in the Raup (1935), such as Helictotrichon hookeri, Carex pensylvanica, Bromus inermis, Artemisia frigida, Stipa curtiseta, Muhlenbergia richardsonis, Festuca scabrella, and Carex obtusata.

The Agropyron trachycaulum - Koeleria macrantha community type also seems to occur on drier soils than the Agropyron trachycaulum - Elymus innovatus - Thalictrum venulosum and Agropyron trachycaulum - Carex praegracilis - Fragaria virginiana community types (this report).

SNAME: Agropyron trachycaulum - Koeleria macrantha Herbaceous Vegetation

SCOMNAME: Slender wheat grass - June grass Herbaceous Vegetation

\section{CLASSIFICATION}

SYSTEM: Terrestrial

CLASS: Herbaceous vegetation

SUBCLASS: Perennial graminoid vegetation (grasslands)

GROUP: Temperate or subpolar grasslands

FORMATION: Medium-tall sod temperate or subpolar grasslands

ALLIANCE: Agropyron trachycaulum Herbaceous Alliance

CLASSIFICATION CONFIDENCE LEVEL: 2 
SSIMILAR COMMUNITIES: Koeleria macrantha is a component of the Agropyron trachycaulum - Stipa spp. Herbaceous Vegetation (Moss 1952, Redmann and Schwarz 1986, Schwarz 1994, Schwarz and Wein 1997), Poa interior - Agropyron trachycaulum Herbaceous Vegetation (Stacey 1927) and the Agropyron trachycaulum Herbaceous Vegetation (Rintoul 1985, Fairbarns 1990, Adams et al. 1997, this report) community types, but is not a codominant species. In addition, Stipa spp. and Poa interior are generally not a significant component of the Agropyron trachycaulum - Koeleria macrantha Herbaceous Vegetation community. The Agropyron trachycaulum - Hierochloe odorata Herbaceous Vegetation community (Fairbarns 1990) differs from the Agropyron trachycaulum - Koeleria macrantha Herbaceous Vegetation community by a much greater importance of Hierochloe odorata in the vegetation cover. The Elymus trachycaulus - Muhlenbergia richardsonis Herbaceous Vegetation community from Fort Providence (Northwest Territories) and Saskatchewan (Thieret 1959, Dodd and Coupland 1966) differs from the Agropyron trachycaulum - Koeleria macrantha Herbaceous Vegetation community by a much greater importance of Muhlenbergia richardsonis in the vegetation cover, and by an absence of Koeleria macrantha.

\section{DISTRIBUTION}

SNATREG: Boreal Forest, possibly Rocky Mountain

SSUBREG: Peace River Lowlands, possibly Dry Mixedwood, Subalpine and Montane

SRANGECOM: Possibly limited to the salt plains of Wood Buffalo National Park (Boreal Forest Natural Region - Peace River Lowlands Subregion); may be present in the Rocky Mountain Natural Region (Montane and Subalpine Subregions) and in the Dry Mixedwood Subregion of the Boreal Forest Natural Region.

SDISTRIBUTION.COM: Most likely limited to the Boreal Forest Natural Region on the salt plains of Wood Buffalo National Park; may also be present in the Rocky Mountain Natural Region.

\section{ENVIRONMENTAL FACTORS}

SMINELEV: $345 \mathrm{~m}$ (this report)

SMAXELEV: $2080 \mathrm{~m}$ (this report)

STOP.POSITION: Lower to upper slopes (this report)

SSLOPE: $1-67 \%$

SASPECT: Variable

SSOIL.MOSTURE: Subxeric (some subhygric) (this report)

SSOIL.COM: Moderately well to rapidly drained soils (this report) 
SENVIRO.COM: It occurs on level to steeply sloping areas of variable aspects; soils are moderately well to rapidly drained with mostly subxeric moisture regimes (this report)

\section{BIOLOGICAL AND STRUCTURAL DESCRIPTION}

\section{6a VEGETATION}

SSTRATA LIFEFORM: Shrub; herb

SMOST.ABUND.SPP: Agropyron trachycaulum, Koeleria macrantha

SCONSTANT.SPP: Probably Juniperus horizontalis; Hierochloe odorata, Deschampsia caespitosa, Danthonia intermedia, Schizachne purpurascens and Agrostis scabra

SVEGETATION.COM: Agropyron trachycaulum and Koeleria macrantha dominate the community; subdominant species include Juniperus horizontalis, Hierochloe odorata, Deschampsia caespitosa, Danthonia intermedia, Schizachne purpurascens and Agrostis scabra (Raup 1935).

\section{6c VARIABILITY}

SSPP.COMP.VAR: Grasslands outside Wood Buffalo National Park, which are described in this report based on the cluster analysis of the ESIS database, are characterized by a number of species not mentioned in Raup (1935), such as Helictotrichon hookeri, Carex pensylvanica, Bromus inermis, Artemisia frigida, Stipa curtiseta, Muhlenbergia richardsonis, Festuca scabrella, and Carex obtusata.

SVARIABIITY.COM: Grasslands outside Wood Buffalo National Park, which are described in this report based on cluster analysis of the ESIS database, are characterized by a number of species not mentioned in Raup (1935), such as Helictotrichon hookeri, Carex pensylvanica, Bromus inermis, Artemisia frigida, Stipa curtiseta, Muhlenbergia richardsonis, Festuca scabrella, and Carex obtusata.

\section{SPATIAL RELATIONS}

SSIZE: Small

SADJACENT.COMMUNITIES: The Hordeum jubatum community type occurs down slope from the Agropyron trachycaulum - Koeleria macrantha community type on more saline soils, in Wood Buffalo National Park.

SSPATIAL.COM: The Hordeum jubatum community type occurs down slope from the Agropyron trachycaulum - Koeleria macrantha community type on more saline soils, in Wood Buffalo National Park.

9. STATUS 


\section{SRANK: SU}

SREASONS: Limited distribution and size (few small areas in Wood Buffalo National Park), as well as the threat from aspen and shrub encroachment; the Agropyron trachycaulum - Koeleria macrantha community type from the salt plains as described by Raup (1935) may not exist any longer in Wood Buffalo National Park (Art Schwarz - personal communications); relationship between this community type described by Raup (1935) and from this report (community \#4) is not clear.

SSTATCOM: Limited distribution and size (few small areas in Wood Buffalo National Park), as well as the threat from aspen and shrub encroachment; the Agropyron trachycaulum - Koeleria macrantha community type from the salt plains as described by Raup (1935) may not exist any longer in Wood Buffalo National Park (Arts Schwarz - personal communications); relationship between this community type described by Raup (1935) and from this report (community \#4) is not clear; this community should be placed on the provincial tracking list and ranked SU until further information is collected.

\section{MANAGEMENT}

SMANAGECOM: Prescribed burning or natural fires would help prevent aspen and shrub encroachment into grassland areas of Wood Buffalo National Park (Schwarz and Wein 1997).

\section{GENERAL COMMENTS}

SCOMMUNITY.COM: Raup (1935) emphasized the striking similarity of this prairie community to the Peace Point prairie, described by Raup (1935) as Stipa comata - Koeleria cristata community, and to a prairie found at the base of Caribou Mountains. In a few places, Calamagrostis canadensis - Carex trichocarpa community type from the base of the Caribou Mountains was characterized by the nearly pure stands of Agropyron trachycaulum. It is not clear at the present time whether the Agropyron trachycaulum - Koeleria macrantha community described in this report based on the cluster analysis of ESIS data represents the same community type as the one described by Raup (1935). Further studies are needed to confirm the existence of this community in Wood Buffalo National Park and to examine it's similarity to the Rocky Mountain grasslands from the ESIS database.

\section{REFERENCES}

\section{CITATION:}

Adams, G. D., G. C. Trottier, W. L. Strong, I. D. MacDonald, S. J. Barry, P. G. Gregoire, G. W. Babish and G. Weiss. 1997. Vegetation component report: Canadian Forces Base Suffield national Wildlife area - Wildlife Inventory. Report prepared for the Canadian Wildlife Service, Environment Canada, Edmonton, AB.

Dodd, J. D. and R. T. Coupland. 1966. Vegetation of saline Areas in Saskatchewan. Ecology 47: $958-967$ 
Fairbarns, M. 1990. The Salt Meadows of Northwestern Alberta: A Reconnaissance Biophysical Inventory. Alberta Forestry, Lands and Wildlife.

Moss, E. H. 1952. Grasslands of the Peace River Region, western Canada. Canadian Journal of Botany 30: 98-104

Redmann, R. E. and A. G. Schwarz. 1986. Dry grassland plant communities in Wood Buffalo National park, Alberta. Canadian Field-Naturalist 100: 526-532.

Rintoul, J. 1985. Silver Valley: Biophysical Resource Analysis. Alberta Forestry, Lands and Wildlife.

Raup, H. M. 1935. Botanical Investigations in Wood Buffalo Park. Bulletin No. 74, Biological Series, No. 20. Canada Dept. of Mines and National Museum of Canada. Ottawa, Ontario. 174 pp.

Schwarz, Arthur, Rm 855, General Service Building, Department of Renewable Resources, University of Alberta; email: arthur.schwarz@ualberta.ca;

Schwarz, A. G. 1994. Inventory of dry grasslands and associated vegetation in Wood Buffalo National Park. Report prepared for Parks Canada, Wood Buffalo National Park, Fort Smith.

Schwarz, A. G. and R. W. Wein. 1997. Threatened dry grasslands in the continental boreal forests of Wood Buffalo National Park. Canadian journal of Botany 75: 1363-1370

Thieret, J. W. 1959. Grassland vegetation near Fort Province, Northwest Territories. The Canadian field-Naturalist 73: 161-167 


\section{COMMUNITY CHARACTERIZATION ABSTRACT}

Agropyron trachycaulum - Festuca ovina - Poa palustris - Equisetum arvense Herbaceous Vegetation

\section{IDENTIFIERS}

SEL.SUMMARY: This community type occupies sand beaches with few rocks at Shelter Point, Athabasca Lake (Raup 1928). Dominant species include Agropyron tenerum (Agropyron trachycaulum), Festuca ovina, Poa palustris and Equisetum arvense. Secondary species include Sisyrinchium angustifolium, Rumex altissimus, Corydalis aurea, Potentilla monspeliensis, Rubus idaeus var. canadensis, and Epilobium angustifolium.

SNAME: Agropyron trachycaulum - Festuca ovina - Poa palustris - Equisetum arvense Herbaceous Vegetation

SCOMNAME: slender wheat grass - sheep fescue - fowl bluegrass - common horsetail Herbaceous Vegetation

\section{CLASSIFICATION}

SYSTEM: Terrestrial

CLASS: Herbaceous vegetation

SUBCLASS: Perennial graminoid vegetation (grasslands)

GROUP: Temperate or subpolar grasslands

FORMATION: Medium-tall sod temperate or subpolar grasslands

ALLIANCE: Agropyron trachycaulum Herbaceous Alliance

\section{CLASSIFICATION CONFIDENCE LEVEL: 2}

SSIMILAR COMMUNITIES: The Agropyron trachycaulum Herbaceous Vegetation community type (Rintoul 1985, Fairbarns 1990, Adams et al. 1997, this report) is dominated solely by Agropyron trachycaulum. In addition, Festuca ovina, Poa palustris and Equisetum arvense do not represent a significant component of the above community.

\section{DISTRIBUTION}

SNATREG: Boreal Forest

SSUBREG: Peace River Lowlands

SRANGECOM: Limited to the Shelter Point area near Lake Athabasca 
SDISTRIBUTION.COM: Limited to the Boreal Forest Natural Region at Shelter Point area near Lake Athabasca

\section{ENVIRONMENTAL FACTORS}

SSLOPE: Near level

SSOIL.COM: Sandy soils with few rocks

SENVIRO.COM: Sandy soils with few rocks

\section{BIOLOGICAL AND STRUCTURAL DESCRIPTION}

\section{6a VEGETATION}

SMOST.ABUND.SPP: SEL.SUMMARY: Agropyron tenerum, Festuca ovina, Poa palustris, Equisetum arvense

\section{SUNVEGETATED.SURFACE: Sand}

SVEGETATION.COM: Dominant species include Agropyron tenerum, Festuca ovina, Poa palustris, Equisetum arvense. Secondary species include Sisyrinchium angustifolium, Rumex altissimus, Corydalis aurea, Potentilla monspeliensis, Rubus idaeus var. canadensis, and Epilobium angustifolium.

9. STATUS

SRANK: SU

SREASONS: Old report of a community; reported only for the Boreal Forest Natural Region at Shelter Point area near Lake Athabasca

SSTATCOM: Old report of a community; reported only for the Boreal Forest Natural Region at Shelter Point area near Lake Athabasca, this community should be ranked SU until further information is collected.

\section{ANALYSIS PROCEDURES AND DATA MANAGEMENT}

SANALYSIS.COM: Probably only the reconnaissance survey

SANALYSIS.DATA.MANAGE.COM: Probably only the reconnaissance survey

\section{GENERAL COMMENTS}

SCOMMUNITY.COM: Future study is needed to confirm the existence of this community at the reported site. 


\section{REFERENCES}

\section{CITATION:}

Adams, G. D., G. C. Trottier, W. L. Strong, I. D. MacDonald, S. J. Barry, P. G. Gregoire, G. W. Babish and G. Weiss. 1997. Vegetation component report: Canadian Forces Base Suffield national Wildlife area - Wildlife Inventory. Report prepared for the Canadian Wildlife Service, Environment Canada, Edmonton, AB.

Fairbarns, M. 1990. The Salt Meadows of Northwestern Alberta: A Reconnaissance Biophysical Inventory. Alberta Forestry, Lands and Wildlife.

Rintoul, J. 1985. Silver Valley: Biophysical Resource Analysis. Alberta Forestry, Lands and Wildlife.

Raup, L.C. 1928. A survey of the vegetation of Shelter Point, Athabasca Lake. Doctorate thesis, University of Pittsburgh. 


\section{COMMUNITY CHARACTERIZATION ABSTRACT}

Agropyron trachycaulum - Hierochloe odorata Herbaceous Vegetation

\section{IDENTIFIERS}

SEL.SUMMARY: This community type occurs in the Boreal Region of northwestern Alberta (Child Lake, High Level and Hay River) (Fairbarns 1990). It occupies the wettest and least saline end of the moisture and salinity gradients characterizing saline meadows of northwestern Alberta. Agropyron trachycaulum and Hierochloe odorata dominate, while Carex spp., Rosa acicularis and Symphoricarpos albus represent some of the more abundant species. Achillea millefolium, Agrostis scabra, Antennaria parviflora, Astragalus dasyglottis, Galium boreale, Geum triflorum, Hieracium umbellatum, Lactuca pulchella, Viola adunca and some halophytic species are some of the less abundant species characterizing this community type.

SNAME: Agropyron trachycaulum - Hierochloe odorata Herbaceous Vegetation

SCOMNAME: Slender wheat grass - sweet grass Herbaceous Vegetation

\section{CLASSIFICATION}

SYSTEM: Terrestrial

CLASS: Herbaceous vegetation

SUBCLASS: Perennial graminoid vegetation (grasslands)

GROUP: Temperate or subpolar grasslands

FORMATION: Medium-tall sod temperate or subpolar grasslands

ALLIANCE: Agropyron trachycaulum Herbaceous Alliance

\section{CLASSIFICATION CONFIDENCE LEVEL: 3}

SSIMILAR COMMUNITIES: The Agropyron trachycaulum Herbaceous Vegetation community type (Rintoul 1985, Fairbarns 1990, Adams et al. 1997, this report) has no codominants and generally lacks a significant Hierochloe odorata component. The Agropyron trachycaulum Hierochloe odorata Herbaceous Vegetation community differs from the Agropyron trachycaulum - Koeleria macrantha Herbaceous Vegetation community (Raup 1935, this report) by the much greater importance of Hierochloe odorata in the vegetation cover.

\section{DISTRIBUTION}

SNATREG: Boreal Forest

SSUBREG: Dry Mixedwood 
SRANGECOM: Child Lake, High Level and Hay River areas

SDISTRIBUTION.COM: Child Lake, High Level and Hay River areas in the Boreal Forest Natural Region (Dry Mixedwood Subregion)

\section{ENVIRONMENTAL FACTORS}

SENVIRO.COM: It occupies the wettest and least saline end of the moisture and salinity gradients characterizing saline meadows of northwestern Alberta.

\section{BIOLOGICAL AND STRUCTURAL DESCRIPTION}

6a VEGETATION

SSTRATA LIFEFORM: shrub, herb

SMOST.ABUND.SPP: Rosa acicularis, Symphoricarpos albus; Agropyron trachycaulum, Hierochloe odorata; Carex spp.

SVEGETATION.COM: Agropyron trachycaulum and Hierochloe odorata dominate the community; Rosa acicularis and Symphoricarpos albus are some of the more abundant shrub species; Achillea millefolium, Agrostis scabra, Antennaria parviflora, Astragalus dasyglottis, Galium boreale, Geum triflorum, Hieracium umbellatum, Lactuca Pulchella, Viola adunca are less abundant species in this community type.

6c VARIABILITY

SSPP.COMP.VAR: Agropyron trachycaulum and/or Hierochloe odorata may dominate in certain areas

SVARIABILITY.COM: Agropyron trachycaulum and/or Hierochloe odorata may dominate in certain areas

\section{SPATIAL RELATIONS}

SADJACENT.COMMUNITIES: Vegetation on moderately saline sites adjacent to the sites occupied by the Agropyron trachycaulum - Hierochloe odorata community type are often dominated by Aster ericoides, Deschampsia caespitosa, Grindelia squarrosa and Hordeum jubatum.

SSPATIAL.COM: Vegetation on moderately saline sites adjacent to the sites occupied by the Agropyron trachycaulum - Hierochloe odorata community type are often dominated by Aster ericoides, Deschampsia caespitosa, Grindelia squarrosa and Hordeum jubatum.

\section{STATUS}

\section{SRANK: SU}


SREASONS: Not enough information about this community type to assess the rank; it should be placed on the provincial tracking list and assigned rank SP until more information is collected

SSTATCOM: Not enough information about this community type to assess the rank; it should be placed on the provincial tracking list and assigned rank SP until more information is collected

\section{ANALYSIS PROCEDURES AND DATA MANAGEMENT}

SANALYSIS.COM: Reconnaissance survey

SANALYSIS.DATA.MANAGE.COM: Reconnaissance survey

\section{GENERAL COMMENTS}

SCOMMUNITY.COM: It is not clear at this time whether Agropyron trachycaulum dominated stands and Hierochloe odorata dominated stands mentioned in Fairbarns (1990) can be identified as a separate community types, or if they just represent components of the Agropyron trachycaulum - Hierochloe odorata community type. Additional detailed study is needed to examine the composition of these communities, especially with regard to the spatial distribution and size of Agropyron trachycaulum and Hierochloe odorata dominated patches.

\section{REFERENCES}

\section{CITATION:}

Adams, G. D., G. C. Trottier, W. L. Strong, I. D. MacDonald, S. J. Barry, P. G. Gregoire, G. W. Babish and G. Weiss. 1997. Vegetation component report: Canadian Forces Base Suffield national Wildlife area - Wildlife Inventory. Report prepared for the Canadian Wildlife Service, Environment Canada, Edmonton, AB.

Fairbarns, M. 1990. The Salt Meadows of Northwestern Alberta: A Reconnaissance Biophysical Inventory. Alberta Forestry, Lands and Wildlife.

Rintoul, J. 1985. Silver Valley: Biophysical Resource Analysis. Alberta Forestry, Lands and Wildlife.

Raup, H. M. 1935. Botanical Investigations in Wood Buffalo Park. Bulletin No. 74, Biological Series, No. 20. Canada Dept. of Mines and National Museum of Canada. Ottawa, Ontario. 174 pp. 


\section{COMMUNITY CHARACTERIZATION ABSTRACT \\ Agropyron trachycaulum - Elymus innovatus - Thalictrum venulosum Herbaceous Vegetation}

\section{IDENTIFIERS}

SEL.SUMMARY: This community type occurs on lower slopes and plains of the Central Mixedwood, Dry Mixedwood, Upper Foothills and Subalpine Subregions, at elevations ranging from 472 to $1650 \mathrm{~m}$ (community \#9 in this report). It occurs on level terrain and in depressions. When on slopping terrain (ca 5\%), community occupies northerly and easterly aspects. Soils are well to imperfectly drained, with subhygric to hygric moisture regimes and mesotrophic to eutrophic nutrient regimes. Agropyron trachycaulum, Elymus innovatus, Thalictrum venulosum and Mertensia paniculata are the dominant species (average ground cover of $14 \%, 14 \%, 14 \%$, and $10 \%$, respectively). Other important species include Deschampsia caespitosa, Achillea millefolium, Carex praegracilis, Bromus inermis, B. ciliatus, Delphinium glaucum, Aster ciliolatus, Vicia americana, Epilobium angustifolium, and Schizachne purpurascens. Salix barclayi and Betula glandulosa are prominent species in the shrub layer.

SNAME: Agropyron trachycaulum - Elymus innovatus - Thalictrum venulosum Herbaceous Vegetation

SCOMNAME: Slender wheat grass - hairy wild rye - veiny meadow rue Herbaceous Vegetation

\section{CLASSIFICATION}

SYSTEM: Terrestrial

CLASS: Herbaceous vegetation

SUBCLASS: Perennial graminoid vegetation (grasslands)

GROUP: Temperate or subpolar grasslands

FORMATION: Medium-tall sod temperate or subpolar grasslands

ALLIANCE: Agropyron trachycaulum Herbaceous Alliance

\section{CLASSIFICATION CONFIDENCE LEVEL: 2}

SSIMILAR COMMUNITIES: The Agropyron trachycaulum Herbaceous Vegetation community type (Rintoul 1985, Fairbarns 1990, Adams et al. 1997, this report) has no codominants and generally lacks significant Elymus innovatus and Thalictrum venulosum components. The Agropyron trachycaulum - Elymus innovatus - Thalictrum venulosum Herbaceous Vegetation community is also similar to the Agropyron trachycaulum - Carex praegracilis - Fragaria virginiana Herbaceous Vegetation community (Willoughby and Smith 1999, this report), but, in the former community, Carex praegracilis does not codominate and Fragaria virginiana is generally absent. Although Elymus innovatus is an important species in the Poa interior - 
Agropyron trachycaulum Herbaceous Vegetation community (Stacey 1927), it doesn't codominate. Poa interior is also generally lacking in the Agropyron trachycaulum - Elymus innovatus - Thalictrum venulosum Herbaceous Vegetation community type.

The Agropyron trachycaulum - Elymus innovatus - Thalictrum venulosum community type also seems to occur on wetter sites than the Agropyron trachycaulum - Carex praegracilis - Fragaria virginiana, Agropyron trachycaulum and Agropyron trachycaulum - Koeleria macrantha community types (this report).

\section{DISTRIBUTION}

SNATREG: Boreal Forest, Foothills, Rocky Mountain

SSUBREG: Central Mixedwood, Dry Mixedwood, Upper Foothills and Subalpine Subregions

SDISTRIBUTION.COM: Boreal Forest (Central Mixedwood, Dry Mixedwood Subregions), Foothills (Upper Foothills Subregion), and Rocky Mountain (Subalpine Subregion) Natural Regions.

\section{ENVIRONMENTAL FACTORS}

SMINELEV: $472 \mathrm{~m}$

SMAXELEV: $1650 \mathrm{~m}$

STOP.POSITION: lower slopes and plains

SSLOPE: Median 0\% (0 - 5\%)

SASPECT: Median $45^{\circ}\left(0-135^{\circ}\right)$

SSOIL.MOSTURE: Subhygric to hygric

SSOIL.COM: Well to imperfectly drained soils with mesotrophic to eutrophic nutrient regimes

SENVIRO.COM: This community type occurs on lower slopes and plains at elevations ranging from 472 to $1650 \mathrm{~m}$. It occurs on level terrain and in depressions. When on sloping terrain (ca $5 \%)$, community occupies northerly and easterly aspects. Soils are well to imperfectly drained, with subhygric to hygric moisture regimes and mesotrophic to eutrophic nutrient regimes.

\section{BIOLOGICAL AND STRUCTURAL DESCRIPTION}

\section{6a VEGETATION}

SSTRATA LIFEFORM: shrub; herb

SPCT.COVER: shrub 5\%; herb $120 \%$ 
SMOST.ABUND.SPP: Salix barclayi, Betula glandulosa; Agropyron trachycaulum, Elymus innovatus, Thalictrum venulosum, Mertensia paniculata

SCONSTANT.SPP: Agropyron trachycaulum, Thalictrum venulosum, Mertensia paniculata

\section{SCHARACTERISTIC.SPP: Elymus innovatus}

SVEGETATION.COM: Agropyron trachycaulum, Elymus innovatus, Thalictrum venulosum and Mertensia paniculata are the dominant species (average ground cover of $14 \%, 14 \%, 14 \%$, and $10 \%$, respectively). Other important species include Deschampsia caespitosa, Achillea millefolium, Carex praegracilis, Bromus inermis, B. ciliatus, Delphinium glaucum, Aster ciliolatus, Vicia americana, Epilobium angustifolium, and Schizachne purpurascens. Agropyron trachycaulum, Thalictrum venulosum, and Mertensia paniculata are constant species. Elymus innovatus is a characteristic species. Salix barclayi and Betula glauca are prominent species in the shrub layer.

\section{STATUS}

\section{SRANK: SU}

SREASONS: Classification based solely on the ESIS database analysis; additional, more detailed study is needed to confirm the similarity in vegetation composition between plots (occurrences).

SSTATCOM: Classification based solely on the ESIS database analysis; additional, more detailed study is needed to confirm the actual similarity in vegetation composition between occurrences; until more information is available this community should be ranked SU.

\section{ANALYSIS PROCEDURES AND DATA MANAGEMENT}

SANALYSIS.COM: Cluster and ordination analysis of the combined ESIS database and Waterton Lakes database was performed by Geowest personnel. Cluster analysis included species data from 416 plots. Ordination analysis related vegetation data from 120 plots to the following environmental variables: solar radiation (combines slope, aspect, and latitude), drainage class, moisture regimes, elevation, latitude, and longitude (last two variables represent macroclimatic variables - NW position in the province coincides with cooler and wetter climate as oppose to the $\mathrm{SE}$ end of the province). In addition to ordination, descriptive statistics (median, minimum, maximum) were calculated for environmental variables. These calculations were done in SPSS for Windows and included both variables used in the ordination and variables with a lot of missing data (soil drainage, site position - macro, site position - meso, nutrient regimes, $\%$ bedrock, $\%$ mineral soil, and $\%$ organic material. The information on Natural Subregion was taken from the GIS based on the geographical position of each plot.

SANALYSIS.DATA.MANAGE.COM: Cluster and ordination analysis of the combined ESIS database and Waterton Lakes database was performed by Geowest personnel. Cluster analysis included species data from 416 plots. Ordination analysis related vegetation data from 120 plots to the following environmental variables: solar radiation (combines slope, aspect, and latitude), 
drainage class, moisture regimes, elevation, latitude, and longitude (last two variables represent macroclimatic variables - NW position in the province coincides with cooler and wetter climate as oppose to the SE end of the province). In addition to ordination, descriptive statistics (median, minimum, maximum) were calculated for environmental variables. These calculations were done in SPSS for Windows and included both variables used in the ordination and variables with a lot of missing data (soil drainage, site position - macro, site position - meso, nutrient regimes, $\%$ bedrock, \% mineral soil, and \% organic material. The information on Natural Subregion was taken from the GIS based on the geographical position of each plot. The Ecological Site Inventory System (ESIS) electronic database is stored in the Resource Data Division of Alberta Environment, Edmonton.

\section{REFERENCES}

\section{CITATION:}

Adams, G. D., G. C. Trottier, W. L. Strong, I. D. MacDonald, S. J. Barry, P. G. Gregoire, G. W. Babish and G. Weiss. 1997. Vegetation component report: Canadian Forces Base Suffield national Wildlife area - Wildlife Inventory. Report prepared for the Canadian Wildlife Service, Environment Canada, Edmonton, AB.

Fairbarns, M. 1990. The Salt Meadows of Northwestern Alberta: A Reconnaissance Biophysical Inventory. Alberta Forestry, Lands and Wildlife.

Rintoul, J. 1985. Silver Valley: Biophysical Resource Analysis. Alberta Forestry, Lands and Wildlife.

Stacey, E. C. 1927. Ecological studies on the native grasses of the Grande Prairie-Beaverlodge district. M.Sc. thesis, Department of Field Husbandry, University of Alberta, Edmonton, Alberta.

Willoughby, M. G. and D. Smith. 1999. Range plant community types and carrying capacity for the Upper Foothills Subregion - third approximation. Environmental Protection, Land and Forest Service, Edmonton, $\mathrm{AB}$. 


\section{COMMUNITY CHARACTERIZATION ABSTRACT}

\section{Poa interior - Agropyron trachycaulum Herbaceous Vegetation}

\section{IDENTIFIERS}

SEL.SUMMARY: This community type was described for the Grande Prairie - Beaverlodge area by Stacey (1927). It was found, among other places, in parts of the sand ridge where the growth of pine, spruce and poplar helped the development of an inch or two of black soil. Poa interior, Agropyron tenerum, and A. caninum are the dominant grasses in this association. Other important species included Calamagrostis inexpansa, Agrostis hiemalis, Poa palustris, Elymus innovatus, Koeleria macrantha, Carex praticola, and C. xerantica. In the numerous local depressions, Calamagrostis canadensis replaces the more xerophytic $C$. inexpansa. The author described this association as very widespread on drier habitats within the study area.

SNAME: Poa interior - Agropyron trachycaulum Herbaceous Vegetation

SCOMNAME: Inland bluegrass - slender wheat grass Herbaceous Vegetation

\section{CLASSIFICATION}

SYSTEM: Terrestrial

CLASS: Herbaceous vegetation

SUBCLASS: Perennial graminoid vegetation (grasslands)

GROUP: Temperate or subpolar grasslands

FORMATION: Medium-tall sod temperate or subpolar grasslands

ALLIANCE: Agropyron trachycaulum Herbaceous Alliance

\section{CLASSIFICATION CONFIDENCE LEVEL: 3}

SSIMILAR COMMUNITIES: The General lack of a significant Poa interior component separates the Agropyron trachycaulum - Koeleria macrantha Herbaceous Vegetation community (Raup 1935, this report) and the Agropyron trachycaulum - Elymus innovatus - Thalictrum venulosum Herbaceous Vegetation (this report) from this community type. The Agropyron trachycaulum Herbaceous Vegetation community type (Rintoul 1985, Fairbarns 1990, Adams et al. 1997, this report) is dominated solely by Agropyron trachycaulum and generally lacks a significant Poa interior component.

\section{DISTRIBUTION}

SNATREG: Parkland

SSUBREG: Peace River Parkland 
SRANGECOM: Grande Prairie - Beaverlodge district

SDISTRIBUTION.COM: Grande Prairie - Beaverlodge area; Parkland Natural Region (Peace River Parkland)

\section{ENVIRONMENTAL FACTORS}

SSOIL.COM: Among other places, parts of the sand ridge where the growth of pine, spruce and poplar helped the development of an inch or two of black soil.

SENVIRO.COM: Among other places, parts of the sand ridge where the growth of pine, spruce and poplar helped the development of an inch or two of black soil.

\section{BIOLOGICAL AND STRUCTURAL DESCRIPTION}

\section{6a VEGETATION}

SMOST.ABUND.SPP: Poa interior, Agropyron trachycaulum (Agropyron tenerum and A. caninum)

SUNVEGETATED.SURFACE: Probably sandy soil

SCHARACTERISTIC.SPP: Poa interior

SVEGETATION.COM: Poa interior, Agropyron trachycaulum (Agropyron tenerum, and A. caninum) are the dominant grasses; other important species included Calamagrostis inexpansa, Agrostis hiemalis, Poa palustris, Elymus innovatus, Koeleria macrantha, Carex praticola, and C. xerantica.

\section{6c VARIABILITY}

SSPP.COMP.VAR: In the numerous local depressions, Calamagrostis canadensis replaces the more xerophytic $C$. inexpansa.

SVARIABILITY.COM: In the numerous local depressions, Calamagrostis canadensis replaces the more xerophytic $C$. inexpansa.

\section{SPATIAL RELATIONS}

SADJACENT.COMMUNITIES: Poa pratensis community type grows in moister areas SSPATIAL.COM: Poa pratensis community type grows in moister areas

\section{STATUS}

SRANK: SU 
SREASONS: Classification based on the qualitative data;

SSTATCOM: Classification based on the qualitative data; should be ranked SU until more information is available.

\section{ANALYSIS PROCEDURES AND DATA MANAGEMENT}

SANALYSIS.COM: Classification based only on qualitative data; little attention given to forb species.

SANALYSIS.DATA.MANAGE.COM: Classification based only on qualitative data; little attention given to forb species.

\section{GENERAL COMMENTS}

SCOMMUNITY.COM: Revisit to the described sites and more detailed study on the actual species composition is needed.

\section{REFERENCES}

\section{CITATION:}

Adams, G. D., G. C. Trottier, W. L. Strong, I. D. MacDonald, S. J. Barry, P. G. Gregoire, G. W. Babish and G. Weiss. 1997. Vegetation component report: Canadian Forces Base Suffield national Wildlife area - Wildlife Inventory. Report prepared for the Canadian Wildlife Service, Environment Canada, Edmonton, AB.

Fairbarns, M. 1990. The Salt Meadows of Northwestern Alberta: A Reconnaissance Biophysical Inventory. Alberta Forestry, Lands and Wildlife.

Rintoul, J. 1985. Silver Valley: Biophysical Resource Analysis. Alberta Forestry, Lands and Wildlife.

Raup, H. M. 1935. Botanical Investigations in Wood Buffalo Park. Bulletin No. 74, Biological Series, No. 20. Canada Dept. of Mines and National Museum of Canada. Ottawa, Ontario. $174 \mathrm{pp}$.

Stacey, E. C. 1927. Ecological studies on the native grasses of the Grande Prairie-Beaverlodge district. M.Sc. thesis, Department of Field Husbandry, University of Alberta, Edmonton, Alberta. 


\section{COMMUNITY CHARACTERIZATION ABSTRACT}

Hordeum jubatum - Agropyron trachycaulum - Distichlis stricta Herbaceous Vegetation

\section{IDENTIFIERS}

SEL.SUMMARY: This community inhabits saline meadows in areas about $8 \mathrm{~km}$ west of Fort Vermilion, northwestern Alberta (Moss 1953). Sites include pools, sinkholes, barren patches, and extensive grassy flats. In addition to the three dominant species, Hordeum jubatum, Agropyron trachycaulum, and Distichlis stricta, the author listed Elymus macounii, Muhlenbergia richardsonis, Puccinellia nuttalliana and Suaeda depressa as leading species. Aster ericoides, Grindelia squarrosa, Vicia americana, Plantago eriopoda, Aster caerulescens, Gallium boreale, Solidago lepida, Carex praticola and Carex praegracilis are just some of the additional species listed for these meadows.

SNAME: Hordeum jubatum - Agropyron trachycaulum - Distichlis stricta Herbaceous Vegetation

SCOMNAME: Foxtail barley - slender wheat grass Herbaceous Vegetation

\section{CLASSIFICATION}

SYSTEM: Terrestrial

CLASS: Herbaceous vegetation

SUBCLASS: Perennial graminoid vegetation (grasslands)

GROUP: Temperate or subpolar grasslands

FORMATION: Medium-tall sod temperate or subpolar grasslands

ALLIANCE: Agropyron trachycaulum Herbaceous Alliance

\section{CLASSIFICATION CONFIDENCE LEVEL: 3}

SSIMILAR COMMUNITIES: The Agropyron trachycaulum Herbaceous Vegetation community type (Rintoul 1985, Fairbarns 1990, Adams et al. 1997, this report) is dominated solely by Agropyron trachycaulum and generally lacks significant Hordeum jubatum and Distichlis stricta components. The difference between the Hordeum jubatum - Agropyron trachycaulum Distichlis stricta community and the Agropyron trachycaulum - Distichlis stricta community from Wood Buffalo National Park (Schwarz and Wein 1997), is based on the much greater prevalence of Hordeum jubatum in the composition of the former community. Although Carex praegracilis occurs in the Hordeum jubatum - Agropyron trachycaulum - Distichlis stricta community, a general lack of both Hordeum jubatum and Distichlis stricta in the Agropyron trachycaulum - Carex praegracilis - Fragaria virginiana Herbaceous Vegetation community (Willoughby and Smith 1999, this report) separates this community type from the former one. The Elymus trachycaulus - Muhlenbergia richardsonis Herbaceous Vegetation community from 
Fort Providence (Northwest Territories) and Saskatchewan (Thieret 1959, Dodd and Coupland 1966) differs from the Hordeum jubatum - Agropyron trachycaulum - Distichlis stricta Herbaceous Vegetation community by the much greater importance of Muhlenbergia richardsonis in the vegetation cover, and the lower cover of Hordeum jubatum and Distichlis stricta.

\section{DISTRIBUTION}

SNATREG: Boreal Forest

SSUBREG: Dry Mixedwood

SRANGECOM: Limited in distribution to saline soils of the area west of Fort Vermilion, northwestern Alberta

SDISTRIBUTION.COM: Limited in distribution to saline soils of the area west of Fort Vermilion, northwestern Alberta; Boreal Forest Natural Region (Dry Mixedwood Subregion)

\section{ENVIRONMENTAL FACTORS}

SSOIL.COM: Saline soils

SENVIRO.COM: Saline soils

\section{BIOLOGICAL AND STRUCTURAL DESCRIPTION}

\section{6a VEGETATION}

SMOST.ABUND.SPP: Hordeum jubatum, Agropyron trachycaulum, and Distichlis stricta

SVEGETATION.COM: Hordeum jubatum, Agropyron trachycaulum, and Distichlis stricta are the dominant species; Elymus macounii, Muhlenbergia richardsonis, Puccinellia nuttalliana, Suaeda depressa are other leading species. Aster ericoides, Grindelia squarrosa, Vicia americana, Plantago eriopoda, Aster caerulescens, Galium boreale, Solidago lepida, Carex praticola and Carex praegracilis are some of the additional species listed for this community.

\section{STATUS}

SRANK: SU

SREASONS: Classification based on the qualitative data;

SSTATCOM: Classification based on the qualitative data; it should be ranked SU until more information is available. 
SMANAGECOM: Hordeum jubatum - Agropyron trachycaulum - Distichlis stricta community type (Moss 1953) may be a successional or disturbance variant of Agropyron trachycaulum Distichlis stricta (Schwarz and Wein 1997) community type. Hordeum jubatum invades as a result of grazing or some other low-level disturbance on saline/semi-saline Gleysols (Art Schwarz - personal communications).

\section{ANALYSIS PROCEDURES AND DATA MANAGEMENT}

SANALYSIS.COM: Classification based mostly on qualitative data

SANALYSIS.DATA.MANAGE.COM: Classification based mostly on qualitative data

\section{GENERAL COMMENTS}

SCOMMUNITY.COM: Revisit to the described sites and more detailed study on the actual species composition is needed

\section{REFERENCES}

\section{CITATION:}

Adams, G. D., G. C. Trottier, W. L. Strong, I. D. MacDonald, S. J. Barry, P. G. Gregoire, G. W. Babish and G. Weiss. 1997. Vegetation component report: Canadian Forces Base Suffield national Wildlife area - Wildlife Inventory. Report prepared for the Canadian Wildlife Service, Environment Canada, Edmonton, AB.

Fairbarns, M. 1990. The Salt Meadows of Northwestern Alberta: A Reconnaissance Biophysical Inventory. Alberta Forestry, Lands and Wildlife.

Dodd, J. D. and R. T. Coupland. 1966. Vegetation of saline Areas in Saskatchewan. Ecology 47: $958-967$

Moss, E. H. 1953. Marsh and bog vegetation in northwestern Alberta. Canadian Journal of Botany 31: 448-470.

Rintoul, J. 1985. Silver Valley: Biophysical Resource Analysis. Alberta Forestry, Lands and Wildlife.

Schwarz, Arthur. Rm 855, General Service Building, Department of Renewable Resources, University of Alberta; E-mail: arthur.schwarz@ualberta.ca;

Schwarz, A. G. and R. W. Wein. 1997. Threatened dry grasslands in the continental boreal forests of Wood Buffalo National Park. Canadian journal of Botany 75: 1363-1370

Thieret, J. W. 1959. Grassland vegetation near Fort Province, Northwest Territories. The Canadian field-Naturalist 73: 161-167 
Willoughby, M. G. and D. Smith. 1999. Range plant community types and carrying capacity for the Upper Foothills Subregion - third approximation. Environmental Protection, Land and Forest Service, Edmonton, AB. 


\section{COMMUNITY CHARACTERIZATION ABSTRACT} Agropyron dasystachyum Herbaceous Vegetation

\section{IDENTIFIERS}

SEL.SUMMARY: This community has been reported from a variety of locations in the province including very dry and steep southeast to southwest facing slopes in the Kakwa Falls area (Jaques and vanEck 1979), steep south facing slopes with shallow, rapidly drained soils, with subxeric to xeric moisture regimes and submesotrophic nutrient regimes, at lower elevations within the Subalpine and the Montane Subregions (Willoughby et al. 1998, Willoughby 1999), very steep slopes with northerly aspects in the Suffield National Wildlife Area situated within the Dry Mixedgrass Subregion (Adams et al. 1997), and one moderately well drained, mesic site at the toe position of an alluvial fan in the Kootenay Plains area (Wallis and Wershler 1981). Classification of ESIS plots also indicates the possible presence of this community (community \#45 in this report) in the Alpine and Peace River Parkland Subregions. Agropyron dasystachyum dominates in all sites (average cover 30 - 40\%) accompanied by other, less abundant species, such as Symphoricarpos occidentalis, Agropyron caninum var. andinum, Carex obtusata, Calamagrostis purpurascens, Koeleria macrantha, Poa interior, Stipa spartea, Stipa occidentalis var. minor, Allium cernuum, Artemisia frigida, Cerastium arvense, and Vicia americana in the Kakwa Falls area (Jaques and vanEck 1979), Arctostaphylos uva-ursi, Koeleria macrantha, Phleum commutatum, Carex obtusata, Elymus innovatus, Festuca saximontana, Thalictrum occidentale, Epilobium angustifolium, Antennaria parviflora and Lupinus sericeus in the Subalpine and Montane sites (Willoughby et al. 1998, Willoughby 1999), Geum triflorum, Linum lewisii, Stellaria longipes, Koeleria macrantha, Agoseris glauca and Campanula rotundifolia in the Kootenay Pass site (Wallis and Wershler 1981), Amelanchier alnifolia, Artemisia cana, A. frigida, Koeleria macrantha, Anemone patens, Gutierrezia sarothrae and Comandra umbellata Suffield National Wildlife Area (Adams et al. 1997), and Koeleria macrantha, Epilobium angustifolium, Festuca spp. and Galium boreale (this report).

SNAME: Agropyron dasystachyum Herbaceous Vegetation

SCOMNAME: Northern wheat grass Herbaceous Vegetation

\section{CLASSIFICATION}

SYSTEM: Terrestrial

CLASS: Herbaceous vegetation

SUBCLASS: Perennial graminoid vegetation (grasslands)

GROUP: Temperate or subpolar grasslands

FORMATION: Medium-tall sod temperate or subpolar grasslands

ALLIANCE: Agropyron dasystachyum Herbaceous Alliance 


\section{CLASSIFICATION CONFIDENCE LEVEL: 1}

SSIMILAR COMMUNITIES: Although Koeleria macrantha is generally present in the Agropyron dasystachyum Herbaceous Vegetation community type, this type differs from the Agropyron dasystachyum - Koeleria macrantha - Artemisia frigida (Wallis and Wershler 1981, Corns and Achuff 1982, Rintoul 1985, Beckginham et al. 1996, Willoughby et al. 2000, this report), Elymus lanceolatus - Koeleria macrantha from Saskatchewan (Coupland 1950) and the Elymus lanceolatus - (Koeleria macrantha) from Sheridan County, Montana (Heidel et al. 2000) Herbaceous Vegetation community types by the lack of codominants. In addition, the last two communities differ from the Agropyron dasystachyum Herbaceous Vegetation community type by having high cover values of Carex eleocharis and by the presence of Bouteloua gracilis. The Juniperus horizontalis - Arctostaphylos uva-ursi / Agropyron dasystachyum - Elymus innovatus dwarf shrub Herbaceous Vegetation community type (this report) separates from the Agropyron dasystachyum Herbaceous Vegetation community type described by Willoughby et al. (1998) and Willoughby (1999) by having much higher cover of Arctostaphylos uva-ursi and Elymus innovatus, and by the presence of Juniperus horizontalis. The Elymus lanceolatus - Stipa comata community type from Oregon is also dominated solely by Agropyron dasystachyum, however, it is a very open community type (usually less than $50 \%$ vegetation ground cover) occurring only on sandy soils.

\section{RELATED NOMENCLATURE}

SOTHER.NAMES: Agropyron dasystachyum - Festuca saximontana (Willoughby et al. 1998)

SOTHER.NAMES.RELATION.NOTE: Agropyron dasystachyum community type includes Agropyron dasystachyum - Festuca saximontana community type (Willoughby et al. 1998)

SNAMES.COM: Agropyron dasystachyum community type includes Agropyron dasystachyum Festuca saximontana community type (Willoughby et al. 1998); Agropyron dasystachyum community type is characterized by the sole dominance of Agropyron dasystachyum in all locations; Festuca saximontana is just one of the numerous low abundance species that accompany Agropyron dasystachyum, and which vary in prominence from location to location.

\section{DISTRIBUTION}

SNATREG: Rocky Mountains; possibly Parkland and Grassland

SSUBREG: Subalpine, Montane; possibly Alpine, Peace River Parkland and Dry Mixedgrass

SRANGECOM: Mostly found in Rocky Mountains Region: Kakwa Falls area (study site located ca. $160 \mathrm{~km} \mathrm{~S}$ of Grand Prairie, $50 \mathrm{~km} \mathrm{NW}$ of Grand Cache), Kootenay Plains area, and other sites within Subalpine and Montane Subregions

SDISTRIBUTION.COM: Mostly found in Rocky Mountains Natural Region: Kakwa Falls area (study site located ca. $160 \mathrm{~km} \mathrm{~S}$ of Grand Prairie, $50 \mathrm{~km} \mathrm{NW}$ of Grand Cache), Kootenay Plains area, and other sites within Subalpine and Montane Subregions; possibly exists within the 
Alpine, Peace River Parkland and Dry Mixedgrass Subregions (this report), but more information is needed to confirm these locations.

\section{ENVIRONMENTAL FACTORS}

SMINELEV: 1220 m (Willoughby et al. 1998, Willoughby 1999)

SMAXELEV: 1859 m (Willoughby et al. 1998, Willoughby 1999)

SSLOPE: Mostly on steep slopes, occasionally on level terrain

SASPECT: Southerly (Rocky Mountains) to northerly (Dry Mixedgrass)

SSOIL.MOSTURE: Subxeric to xeric, occasionally mesic

SSOIL.COM: Rapidly drained soils, with submesotrophic nutrient regimes; occasionally on moderately well drained soils

SENVIRO.COM: This community mainly occupies very dry and steep southeast to southwest facing slopes. Soils are mainly shallow and rapidly drained, with subxeric to xeric moisture regimes and submesotrophic nutrient regimes; it may also occur on moderately well drained, level, mesic site, at toe position of the alluvial fan.

\section{BIOLOGICAL AND STRUCTURAL DESCRIPTION}

6a VEGETATION

SSTRATA LIFEFORM: Shrub; dwarf shrub; herb

SPCT.COVER: Shrub 5.9\%; dwarf shrub 3.4\%; herb 76.6\% (this report)

SMOST.ABUND.SPP: Agropyron dasystachyum

SUNVEGETATED.SURFACE: Organic matter (this report)

SUNVEGETATED.SURFACE COVER: Organic matter (0 - 95\%) (this report)

SCONSTANT.SPP: Koeleria macrantha

SCHARACTERISTIC.SPP: Agropyron dasystachyum

SVEGETATION.COM: There are three main vegetation strata in this community: shrub (5.9\%), dwarf shrub (3.4\%) and herb (76.6\%); Agropyron dasystachyum dominates on all locations; Koeleria macrantha is the only constant species, while the combination of numerous low abundance species that accompany Agropyron dasystachyum changes from location to location. 
SSPP.COMP.VAR: The combination of numerous low abundance species that accompany Agropyron dasystachyum varies from location to location: Symphoricarpos occidentalis, Agropyron caninum var. andinum, Carex obtusata, Calamagrostis purpurascens, Poa interior, Stipa spartea, Stipa occidentalis var. minor, Allium cernuum, Artemisia frigida, Cerastium arvense, and Vicia americana characterize the community in the Kakwa Falls region; Arctostaphylos uva-ursi, Phleum commutatum, Carex obtusata, Elymus innovatus, Festuca saximontana, Thalictrum occidentale, Epilobium angustifolium, Antennaria parviflora and Lupinus sericeus are characteristic for sites described by Willoughby et al. (1998) and Willoughby (1999); Geum triflorum, Linum lewisii, Stellaria longipes, Koeleria macrantha, Agoseris glauca and Campanula rotundifolia are found in the Kootenay Plains area; and Amelanchier alnifolia, Artemisia cana, A. frigida, Anemone patens, Gutierrezia sarothrae and Comandra umbellata are found on sites in the Dry Mixedgrass Subregion.

SVARIABILITY.COM: The combination of numerous low abundance species that accompany Agropyron dasystachyum changes from location to location: Symphoricarpos occidentalis, Agropyron caninum var. andinum, Carex obtusata, Calamagrostis purpurascens, Poa interior, Stipa spartea, Stipa occidentalis var. minor, Allium cernuum, Artemisia frigida, Cerastium arvense, and Vicia americana characterize the community in the Kakwa Falls region; Arctostaphylos uva-ursi, Phleum commutatum, Carex obtusata, Elymus innovatus, Festuca saximontana, Thalictrum occidentale, Epilobium angustifolium, Antennaria parviflora and Lupinus sericeus are characteristic for sites described by Willoughby et al. (1998) and Willoughby (1999); Geum triflorum, Linum lewisii, Stellaria longipes, Koeleria macrantha, Agoseris glauca and Campanula rotundifolia are found in Kootenay Plains area; and Amelanchier alnifolia, Artemisia cana, A. frigida, Anemone patens, Gutierrezia sarothrae and Comandra umbellata are found on sites in the Dry Mixedgrass Subregion.

\section{STATUS}

\section{SRANK: S3}

SREASONS: This community seems to be found mostly in the Rocky Mountains Region: Kakwa Falls area (study site located ca. $160 \mathrm{~km} \mathrm{~S}$ of Grand Prairie, $50 \mathrm{~km} \mathrm{NW}$ of Grand Cache), Kootenay Plains area, and other sites within Subalpine and Montane Subregions; it also exists within the Dry Mixedgrass Subregion; possible presence within the Alpine and Peace River Parkland Subregions needs future confirmation.

SSTATCOM: This community seems to be found mostly in the Rocky Mountains region: Kakwa Falls area (study site located ca. $160 \mathrm{~km} \mathrm{~S}$ from Grand Prairie, $50 \mathrm{~km} \mathrm{NW}$ of Grand Cache), Kootenay Plains area, and other sites within Subalpine and Montane Subregions; it also exists within the Dry Mixedgrass Subregions; possible presence within the Alpine and Peace River Parkland Subregions needs future confirmation; based on the distributional data, this community type should be ranked S3.

\section{ANALYSIS PROCEDURES AND DATA MANAGEMENT}


SANALYSIS.COM: Within each of the $10 \mathrm{~m} \times 10 \mathrm{~m}$ sampling plots, canopy cover was estimated using ten randomly selected $1 \times 1 \mathrm{~m}$ microplots for shrubs, and $20 \times 50 \mathrm{~cm}$ microplots for herbs. Noted environmental factors included elevation, slope, aspect, soil drainage, nutrient regimes, and moisture regimes. Data was analyzed by both cluster and ordination analyses (Willoughby et al. 1998, Willoughby 1999). Additional cluster and ordination analysis of combined ESIS database (including a number of plots analyzed by $\mathrm{M}$. Willoughby) and Waterton Lakes database was performed by Geowest personnel. Cluster analysis included species data from 416 plots. Ordination analysis related vegetation data from 120 plots to the following environmental variables: solar radiation (combines slope, aspect, and latitude), drainage class, moisture regimes, elevation, latitude, and longitude (last two variables represent macroclimatic variables - NW position in the province coincides with cooler and wetter climate as oppose to the $\mathrm{SE}$ end of the province). In addition to ordination, descriptive statistics (median, minimum, maximum) were calculated for environmental variables. These calculations were done in SPSS for Windows and included both variables used in the ordination and variables with a lot of missing data (soil drainage, site position - macro, site position - meso, nutrient regimes, $\%$ bedrock, $\%$ mineral soil, and $\%$ organic material). The information on Natural Subregion was taken from the GIS based on the geographical position of each plot. Ecological Site Inventory System (ESIS) electronic database is stored in the Resource Data Division of the Alberta Environment, Edmonton. Wallis and Wershler (1981) recorded detailed canopy coverage within representative $1 \times 1 \mathrm{~m}$ plots, which were nested within $15 \mathrm{~m}$ diameter sampling areas. Additional information on species presence was collected within $15 \mathrm{~m}$ diameter sampling areas. Jaques and vanEck (1979) determined vegetation cover within ten $20 \times 50 \mathrm{~cm}$ micro plots located at $10 \mathrm{~m}$ intervals along the upper and lower boundary of $50 \times 15 \mathrm{~m}$ macro plots. Jaques and vanEck (1979) and Wallis and Wershler (1981) did not perform any cluster or ordination analyses on their data. Adams et al. (1997) collected vegetation data (percent cover for each species) from a number of subsamples $(15-20 \mathrm{~cm} \times 50 \mathrm{~cm})$ located within circular ( $200 \mathrm{~m}$ diameter) plots. Their vegetation classification was based on the manual grouping of subsamples using a cluster analysis dendrogram as a general guide. Plant communities were also associated with environmental factors, such as slope and aspect.

SANALYSIS.DATA.MANAGE.COM: Within each of the $10 \mathrm{~m} \times 10 \mathrm{~m}$ sampling plots, canopy cover was estimated using ten randomly selected $1 \times 1 \mathrm{~m}$ microplots for shrubs, and $20 \times 50 \mathrm{~cm}$ microplots for herbs. Noted environmental factors included elevation, slope, aspect, soil drainage, nutrient regimes, and moisture regimes. Data was analyzed by both cluster and ordination analyses (Willoughby et al. 1998, Willoughby 1999). Additional cluster and ordination analysis of combined ESIS database (including a number of plots analyzed by $\mathrm{M}$. Willoughby) and Waterton Lakes database was performed by Geowest personnel. Cluster analysis included species data from 416 plots. Ordination analysis related vegetation data from 120 plots to the following environmental variables: solar radiation (combines slope, aspect, and latitude), drainage class, moisture regimes, elevation, latitude, and longitude (last two variables represent macroclimatic variables - NW position in the province coincides with cooler and wetter climate as oppose to the SE end of the province). In addition to ordination, descriptive statistics (median, minimum, maximum) were calculated for environmental variables. These calculations were done in SPSS for Windows and included both variables used in the ordination and variables with a lot of missing data (soil drainage, site position - macro, site position - meso, nutrient regimes, $\%$ bedrock, $\%$ mineral soil, and $\%$ organic material). The information on Natural Subregion was taken from the GIS based on the geographical position of each plot. List of values 
was presented instead of statistics for the natural Subregion. Ecological Site Inventory System (ESIS) electronic database is stored in the Resource Data Division of the Alberta Environment, Edmonton. Wallis and Wershler (1981) recorded detailed canopy coverage within representative $1 \times 1 \mathrm{~m}$ plots, which were nested within $15 \mathrm{~m}$ diameter sampling areas. Additional information on species presence was collected within $15 \mathrm{~m}$ diameter sampling areas. Jaques and vanEck (1979) determined vegetation cover within ten $20 \times 50 \mathrm{~cm}$ micro plots located at $10 \mathrm{~m}$ intervals along the upper and lower boundary of each $50 \times 15 \mathrm{~m}$ macro plots. Jaques and vanEck (1979) and Wallis and Wershler (1981) did not perform any cluster or ordination analyses on their data. Adams et al. (1997) collected vegetation data (percent cover for each species) from a number of subsamples $(15-20 \mathrm{~cm} \times 50 \mathrm{~cm})$ located within circular $(200 \mathrm{~m}$ diameter) plots. Their vegetation classification was based on the manual grouping of subsamples using a cluster analysis dendrogram as a general guide. Plant communities were also associated with environmental factors, such as slope and aspect.

\section{REFERENCES}

\section{CITATION:}

Adams, G. D., G. C. Trottier, W. L. Strong, I. D. MacDonald, S. J. Barry, P. G. Gregoire, G. W. Babish and G. Weiss. 1997. Vegetation component report: Canadian Forces Base Suffield national Wildlife area - Wildlife Inventory. Report prepared for the Canadian Wildlife Service, Environment Canada, Edmonton, AB.

Beckingham, J.D., I. G. W. Corns and J. H. Archibald. 1996. Field Guide to Ecosites of WestCentral Alberta. Canadian Forest Service Special Report No.9, Northern Forestry Centre, Edmonton, $\mathrm{AB}$.

Corns, I. G. W. and P. L. Achuff. 1982. Vegetation type descriptions in W. D. Holland and G. M. Coen (eds.). Ecological (Biophysical) Land Classification of Banff and Jasper National Parks. Alberta Institute of Pedology, Publication No. SS-82-44.

Coupland, R. T. 1950. Ecology of mixed prairie in Canada. Ecological Monographs 20: 271315

Heidal, B., S. V. Cooper and C. Jean. 2000. Plant species of special concern and plant associations of Sheridan County, Montana. Report to the U.S. Fish and Wildlife Service. Montana Natural Heritage Program, Helena, Montana.

Jaques, D. \& P. Van Eck. 1979. Biophysical Features and Recommendations for Recreational Development in the Kakwa Falls Region, Alberta. Kananaskis Center for Environmental Research, U of C.

Rintoul, J. 1985. Silver Valley: Biophysical Resource Analysis. Alberta Forestry, Lands and Wildlife.

Wallis, C. and C. Wershler. 1981. Kootenay Plains Flora and Grassland Vegetation Assessment - 1981. Alberta Energy and Natural Resources. 
Willoughby, M. G. 1999. Range plant community types and carrying capacity for the Subalpine and Alpine Subregions - first approximation. Environmental protection, Land and Forest Service, Edmonton, $\mathrm{AB}$.

Willoughby, M. G., M. J. Alexander and K. M. Sundquist. 1998. Range plant community types and carrying capacity for the Montane Subregion of Alberta - third approximation. Environmental Protection, Lands and Forest Services, Edmonton, AB.

Willoughby, M. G. and the Rangeland Health Assessment Project and Forest Rangeland Action Plan. 2000. Guide to range plant community types and carrying capacity for the Dry and Central Mixedwood Subregions in Alberta - third approximation. Alberta Environment, Land and Forest Service and Alberta Agriculture, Food and Rural Development, Public Lands Division, Edmonton, $\mathrm{AB}$. 


\section{COMMUNITY CHARACTERIZATION ABSTRACT}

\section{Agropyron dasystachyum - Calamovilfa longifolia Herbaceous Vegetation}

\section{IDENTIFIERS}

SEL.SUMMARY: This community type was noted by Adams et al. (1997) for the Suffield National Wildlife Area. It represents a minor vegetation component on well drained, sandy soils developed on fluvial materials within broad ravines with relatively low-angle side slopes.

SNAME: Agropyron dasystachyum - Calamovilfa longifolia Herbaceous Vegetation

SCOMNAME: Northern Wheat Grass - Sand Grass Herbaceous Vegetation

\section{CLASSIFICATION}

SYSTEM: Terrestrial

CLASS: Herbaceous vegetation

SUBCLASS: Perennial graminoid vegetation (grasslands)

GROUP: Temperate or subpolar grasslands

FORMATION: Medium-tall sod temperate or subpolar grasslands

ALLIANCE: Agropyron dasystachyum Herbaceous Alliance

\section{CLASSIFICATION CONFIDENCE LEVEL: 3}

SSIMILAR COMMUNITIES: This community type differs from the Agropyron dasystachyum Herbaceous Vegetation community type (Jaques and vanEck 1979, Wallis and Wershler 1981, Adams et al. 1997, Willoughby et al. 1998, Willoughby 1999) by the importance of Calamovilfa longifolia. However, Adams et al. (1997) did not provide sufficient details on the species composition to enable direct comparison of these two community types.

\section{DISTRIBUTION}

SNATREG: Grassland

SSUBREG: Dry Mixedgrass

SRANGECOM: Reported only from the Suffield National Wildlife Area

SDISTRIBUTION.COM: Reported only from the Suffield National Wildlife Area Grassland Natural Region (Dry Mixedgrass Subregion)

\section{ENVIRONMENTAL FACTORS}


SLANDFORM: Fluvial materials

SSLOPE: $15-45 \%$

SSOIL.COM: Well drained, sandy soils

SENVIRO.COM: It occurs on well drained, sandy soils developed on fluvial materials within broad ravine with relatively low-angle side slopes

\section{BIOLOGICAL AND STRUCTURAL DESCRIPTION}

\section{6a VEGETATION}

SMOST.ABUND.SPP: Agropyron dasystachyum and Calamovilfa longifolia

\section{6b OTHER SPECIES}

\section{STATUS}

SRANK: SU

SREASONS: Reported only from the Suffield National Wildlife Area - Grassland Natural Region (Dry Mixedgrass Subregion); no details on the community provided

SSTATCOM: Reported only from the Suffield National Wildlife Area - Grassland Natural Region (Dry Mixedgrass Subregion); no details on the community provided, therefore, it should be ranked SU until more information is available.

\section{ANALYSIS PROCEDURES AND DATA MANAGEMENT}

SANALYSIS.COM: Adams et al. (1997) collected vegetation data (percent cover for each species) from a number of subsamples $(15-20 \mathrm{~cm} \times 50 \mathrm{~cm})$ located within circular $(200 \mathrm{~m}$ diameter) plots. The vegetation classification was based on the manual grouping of subsamples using cluster analysis dendrogram as a general guide. Plant communities were also associated with environmental factors, such as slope and aspect. Since no details were provided on the vegetation composition for this community type, it is most likely that this community type was named based on the reconnaissance level survey that preceded more detailed collection of the vegetation data.

SANALYSIS.DATA.MANAGE.COM: Adams et al. (1997) collected vegetation data (percent cover for each species) from a number of subsamples $(15-20 \mathrm{~cm} \times 50 \mathrm{~cm})$ located within circular ( $200 \mathrm{~m}$ diameter) plots. The vegetation classification was based on the manual grouping of subsamples using cluster analysis dendrogram as a general guide. Plant communities were also associated with environmental factors, such as slope and aspect. Since no details were provided on the vegetation composition for this community type, it is most likely that this community type 
was named based on the reconnaissance level survey that preceded more detailed collection of the vegetation data.

\section{GENERAL COMMENTS}

SCOMMUNITY.COM: More information is needed to confirm the existence of this community type in Alberta.

\section{REFERENCES}

\section{CITATION:}

Adams, G. D., G. C. Trottier, W. L. Strong, I. D. MacDonald, S. J. Barry, P. G. Gregoire, G. W. Babish and G. Weiss. 1997. Vegetation component report: Canadian Forces Base Suffield national Wildlife area - Wildlife Inventory. Report prepared for the Canadian Wildlife Service, Environment Canada, Edmonton, AB.

Jaques, D. \& P. Van Eck. 1979. Biophysical Features and Recommendations for Recreational Development in the Kakwa Falls Region, Alberta. Kananaskis Center for Environmental Research, U of C.

Wallis, C. and C. Wershler. 1981. Kootenay Plains Flora and Grassland Vegetation Assessment - 1981. Alberta Energy and Natural Resources.

Willoughby, M. G. 1999. Range plant community types and carrying capacity for the Subalpine and Alpine Subregions - first approximation. Environmental protection, Land and Forest Service, Edmonton, $\mathrm{AB}$.

Willoughby, M. G., M. J. Alexander and K. M. Sundquist. 1998. Range plant community types and carrying capacity for the Montane Subregion of Alberta - third approximation. Environmental Protection, Lands and Forest Services, Edmonton, AB. 


\section{COMMUNITY CHARACTERIZATION ABSTRACT}

Agropyron dasystachyum - Agropyron smithii Herbaceous Vegetation

\section{IDENTIFIERS}

SEL.SUMMARY: This community type occurs on moderately well to well drained Solonetzic soils in the Milk River Natural Area and the Kennedy Coulee Ecological Reserve, situated within the Dry Mixedgrass Subregion (Adams and Moisey 1999). Soils include Brown Solodized Solonetz and Brown Solonetz, with minor occurrences of Brown Solods, Brown Chernozems and Orthic Regosols. The same community type inhabits steep, unstable mid-slopes with southerly aspects in the Peace River and Clear River canyons in the Dry Mixedwood Subregion (Adams 1981). Soils are Orthic Regosols with silty loamy texture, developed on morainal and colluvial materials. Besides the two dominant grasses, Agropyron dasystachyum and Agropyron smithii, additional species in the Milk River region include Artemisia frigida, Bouteloua gracilis, Stipa comata, Poa pratensis and Koeleria macrantha. Carex spp., Koeleria macrantha, Stipa curtiseta, Artemisia frigida and Stipa viridula characterize sites in the Peace River region.

SNAME: Agropyron dasystachyum - Agropyron smithii Herbaceous Vegetation

SCOMNAME: Northern wheat grass - Western wheat grass Herbaceous Vegetation

\section{CLASSIFICATION}

SYSTEM: Terrestrial

CLASS: Herbaceous vegetation

SUBCLASS: Perennial graminoid vegetation (grasslands)

GROUP: Temperate or subpolar grasslands

FORMATION: Medium-tall sod temperate or subpolar grasslands

ALLIANCE: Agropyron dasystachyum Herbaceous Alliance

\section{CLASSIFICATION CONFIDENCE LEVEL: 1}

SSIMILAR COMMUNITIES: Similar community types include: Agropyron dasystachyum Herbaceous Vegetation (Jaques and vanEck 1979, Wallis and Wershler 1981, Adams et al. 1997, Willoughby et al. 1998, Willoughby 1999), Agropyron dasystachyum - Koeleria macrantha Artemisia frigida Herbaceous Vegetation (Wallis and Wershler 1981, Corns and Achuff 1982, Rintoul 1985, Beckginham et al. 1996, Willoughby et al. 2000, this report), Agropyron dasystachyum - Poa pratensis Herbaceous Vegetation (Willoughby et al. 1998), and Agropyron dasystachyum - Stipa comata Herbaceous Vegetation (Moss 1944, Coupland 1950, Wallis and Wershler 1981, Adams and Moisey 1999) from Alberta, as well as Elymus lanceolatus - Stipa comata Herbaceous Vegetation from Oregon and Montana (Heidel et al. 2000, NatureServe 2000), Elymus lanceolatus -Koeleria macrantha community from Saskatchewan (Coupland 
1950), Elymus lanceolatus - (Koeleria macrantha) Herbaceous Vegetation from Sheridan County, Montana (Heidel et al. 2000), and Elymus lanceolatus - Bouteloua gracilis Herbaceous Vegetation from Sheridan County, Montana (Heidel et al. 2000). All of the aforementioned community types differ from the Agropyron dasystachyum - Agropyron smithii Herbaceous Vegetation community by having little or no Agropyron smithii. Although Koeleria macrantha, Artemisia frigida, Poa pratensis and Stipa comata may be present in the Agropyron dasystachyum - Agropyron smithii Herbaceous Vegetation community type, they never codominate.

\section{RELATED NOMENCLATURE}

SOTHER.NAMES: Agropyron dasystachyum - Agropyron smithii - Carex spp - Koeleria macrantha (Adams 1981)

SOTHER.NAMES.RELATION.NOTE: The Agropyron dasystachyum - Agropyron smithii Herbaceous Vegetation includes the Agropyron dasystachyum - Agropyron smithii - Carex spp Koeleria macrantha community type (Adams 1981)

SNAMES.COM: The Agropyron dasystachyum - Agropyron smithii Herbaceous Vegetation includes the Agropyron dasystachyum - Agropyron smithii - Carex spp - Koeleria macrantha community type (Adams 1981).

\section{DISTRIBUTION}

SNATREG: Grassland, Boreal Forest

SSUBREG: Dry Mixedgrass, Dry Mixedwood

SRANGECOM: Milk River Natural Area and the Kennedy Coulee Ecological Reserve, and along the Peace River and Clear River canyons between Bear Canyon and Many Islands.

SDISTRIBUTION.COM: Milk River Natural Area and the Kennedy Coulee Ecological Reserve (Grassland Natural Region - Dry Mixedgrass Subregion), and along the Peace River and Clear River (Boreal Forest Natural Region - Dry Mixedwood Subregion)

\section{ENVIRONMENTAL FACTORS}

SMINELEV: $950 \mathrm{~m}$ (Adams and Moisey 1999)

SLANDFORM: Includes morainal and colluvial materials

STOP.POSITION: Midslopes (Adams 1981)

SSLOPE: 1 - $4 \%$ in Milk River sites to steep slopes in the Peace River region

SASPECT: Southerly aspects (Adams 1981) 
SSOIL.TYPE: Major soil types are Brown Solodized Solonetz and Brown Solonetz, with minor importance of Brown Solods, Brown Chernozems and Orthic Regosols.

SSOIL.COM: Soils characterizing Milk River sites are moderately well to well drained

SENVIRO.COM: This community type occurs on moderately well to well drained Solonetzic soils in the Milk River Natural Area and the Kennedy Creek Ecological. Soils include Brown Solodized Solonetz and Brown Solonetz, with minor importance of Brown Solods, Brow Chernozems and Orthic Regosols. The same community type inhabits steep, unstable mid-slopes with southerly aspects along the Peace River and Clear River in Dry Mixedwood Subregion. Soils are Orthic Regosols with silty loamy texture, developed on morainal and colluvial materials.

\section{BIOLOGICAL AND STRUCTURAL DESCRIPTION}

\section{6a VEGETATION}

SMOST.ABUND.SPP: Agropyron dasystachyum and Agropyron smithii

SCONSTANT.SPP: Koeleria macrantha

SCHARACTERISTIC.SPP: One, or the combination of different Stipa species (Stipa curtiseta, S. comata, S. viridula)

SVEGETATION.COM: Besides the two dominant grasses, Agropyron dasystachyum and Agropyron smithii, additional species in the Milk River region include Artemisia frigida, Bouteloua gracilis, Stipa comata, Poa pratensis and Koeleria macrantha. Carex spp., Koeleria macrantha, Stipa curtiseta, Artemisia frigida and Stipa viridula characterize sites in the Peace River region.

\section{6b OTHER SPECIES}

SFAUNA.COM: Winter range for Mule deer

SOTHERSPP.COM: Prickly pear cactus may still occur in the community from the Peace River region; it is a decreaser in the study area on this site type, because of its sensitivity to trampling (Adams 1981)

\section{6c VARIABILITY}

SSPP.COMP.VAR: In the Peace River region Stipa curtiseta and $S$. viridula replace $S$. comata from the Milk River region

SVARIABILITY.COM: In the Peace River region Stipa curtiseta and $S$. viridula replace $S$. comata from the Milk River region

\section{DYNAMIC PROCESSES}


SNAT.DISTURBANCE: Soil erosion

SSUCCESS.DYNAM.COM: Natural soil erosion is further enhanced by livestock and wildlife trampling

\section{STATUS}

SRANK: S2?

SREASONS: This community seems to be found only in the Milk River Natural Area and the Kennedy Coulee Ecological Reserve, and along the Peace River and Clear River canyons between Bear Canyon and Many Islands.

SSTATCOM: This community seems to be found only in the Milk River Natural Area and the Kennedy Coulee Ecological Reserve, and along the Peace River and Clear River canyons between Bear Canyon and Many Islands. There may be more that 5 but less than 20 occurrences of this community type within the province, therefore, it should be placed on the provincial tracking list and ranked S2? until more information on the precise number of occurrences is available.

\section{MANAGEMENT}

SECONCOM: Grazed by cattle at Peace River sites

SMANAGECOM: Adams (1981) noted that this type within the Peace River region represents rangeland in good condition, whereas the same vegetation community became dominated by western porcupine grass, green needle grass, and upland sedge, when in excellent condition (lower grazing pressure).

\section{ANALYSIS PROCEDURES AND DATA MANAGEMENT}

SANALYSIS.COM: For their vegetation classification, Adams and Moisey (1999) used estimated percent cover of vascular plant species, mosses, lichens and exposed mineral soil in 20 $\times 50 \mathrm{~cm}$ plots located along transects at about $5 \mathrm{~m}$ intervals. Vegetation was classified based on classification and ordination analyses using PC-ORD software. Adams (1981) combined transect sampling of representative sites with reconnaissance observations and more detailed site sampling, such as recording species crown cover and various site factors. No classification or ordination analyses were used to classify vegetation communities.

SANALYSIS.DATA.MANAGE.COM: For their vegetation classification, Adams and Moisey (1999) used estimated percent cover of vascular plant species, mosses, lichens and exposed mineral soil in $20 \times 50 \mathrm{~cm}$ plots located along transects at about $5 \mathrm{~m}$ intervals. Vegetation was classified based on classification and ordination analyses using PC-ORD software. Plot data is stored in the Prairie Data Base (PLD - AAFRD), Public Lands - Alberta Agriculture, Food and Rural Development, Lethbridge. Adams (1981) combined transect sampling of representative sites with reconnaissance observations and more detailed site sampling, such as recording 
species crown cover and various site factors. No classification or ordination analyses were used to classify vegetation communities.

\section{REFERENCES}

\section{CITATION:}

Adams, B. 1981. Range Ecology and the impact of livestock grazing on the Peace River Slopes, Alberta. Public Lands Division,

Adams, G. D., G. C. Trottier, W. L. Strong, I. D. MacDonald, S. J. Barry, P. G. Gregoire, G. W. Babish and G. Weiss. 1997. Vegetation component report: Canadian Forces Base Suffield national Wildlife area - Wildlife Inventory. Report prepared for the Canadian Wildlife Service, Environment Canada, Edmonton, AB.

Adams, B and D. Moisey. 1999. Analysis of vegetation and soil monitoring records for Milk River Natural Area and Kennedy Creek Ecological Reserve. 1999. Public Lands, Alberta Agriculture, Food and Rural Development, Lethbridge

Beckingham, J.D., I. G. W. Corns and J. H. Archibald. 1996. Field Guide to Ecosites of WestCentral Alberta. Canadian Forest Service Special Report No.9, Northern Forestry Centre, Edmonton, $\mathrm{AB}$.

Corns, I. G. W. and P. L. Achuff. 1982. Vegetation type descriptions in W. D. Holland and G. M. Coen (eds.). Ecological (Biophysical) Land Classification of Banff and Jasper National Parks. Alberta Institute of Pedology, Publication No. SS-82-44.

Coupland, R. T. 1950. Ecology of mixed prairie in Canada. Ecological Monographs 20: 271315

Heidal, B., S. V. Cooper and C. Jean. 2000. Plant species of special concern and plant associations of Sheridan County, Montana. Report to the U.S. Fish and Wildlife Service. Montana Natural Heritage Program, Helena, Montana.

Jaques, D. \& P. Van Eck. 1979. Biophysical Features and Recommendations for Recreational Development in the Kakwa Falls Region, Alberta. Kananaskis Center for Environmental Research, $\mathrm{U}$ of $\mathrm{C}$.

Moss, E. H. 1944. The prairie and associated vegetation of southwestern Alberta. Canadian Journal of Research 22:11-31.

NatureServe 2000. An online encyclopedia of life [web application]. 2000. Version 1.0. Arlington (VA): Association for Biodiversity Information. Available: http://www.natureserve.org

Rintoul, J. 1985. Silver Valley: Biophysical Resource Analysis. Alberta Forestry, Lands and Wildlife. 
Wallis, C. and C. Wershler. 1981. Kootenay Plains Flora and Grassland Vegetation Assessment - 1981. Alberta Energy and Natural Resources.

Willoughby, M. G. 1999. Range plant community types and carrying capacity for the Subalpine and Alpine Subregions - first approximation. Environmental protection, Land and Forest Service, Edmonton, $\mathrm{AB}$.

Willoughby, M. G., M. J. Alexander and K. M. Sundquist. 1998. Range plant community types and carrying capacity for the Montane Subregion of Alberta - third approximation. Environmental Protection, Lands and Forest Services, Edmonton, AB.

Willoughby, M. G. and the Rangeland Health Assessment Project and Forest Rangeland Action Plan. 2000. Guide to range plant community types and carrying capacity for the Dry and Central Mixedwood Subregions in Alberta - third approximation. Alberta Environment, Land and Forest Service and Alberta Agriculture, Food and Rural Development, Public Lands Division, Edmonton, $\mathrm{AB}$. 


\section{COMMUNITY CHARACTERIZATION ABSTRACT}

Agropyron dasystachyum - Koeleria macrantha - Artemisia frigida Herbaceous Vegetation

\section{DENTIFIERS}

SEL.SUMMARY: In the Montane Subregion this community type occurs within Jasper and Banff National Parks (elevation range $1040-1640 \mathrm{~m}$ ) on xeric, generally steeply sloping sites with southerly aspects (Corns and Achuff 1982). Soils are rapidly to well drained and include Orthic Eutric Brunisols and Orthic Regosols developed on colluvial, glacial, and fluvial materials. In the north and central portion of the Kootenay Plains area, this community occurs on well drained, submesic alluvial fans on a variety of slopes and aspects, but mainly on near level terrain at the toe or ridges of the fan (Wallis and Wershler 1981). In the south-central portion of the Kootenay Plains area, this community occurs on moderately well to well drained, mesic to submesic depressions and nearly level sites at the toe or upper slope of the alluvial fans (Wallis and Wershler 1981). Within the Montane Subregion this community type is also reported for areas with Cumulic Regosols and Orthic and Brunisolic Gray Luvisols (Beckginham et al. 1996). Willoughby et al. (2000) described this community type for the south and west facing slopes (slope range $10-90 \%$ ) along the banks of the Peace, Smoky and Wapiti rivers throughout the Dry Mixedwood Subregion (elevation range $345-606 \mathrm{~m}$ ). Soils are very rapidly drained with xeric-subxeric moisture regimes and submesotrophic nutrient regimes. Within the Silver Valley area this community occurs on moderate to steep, south and southwest facing slopes with rapidly to well drained, very xeric to xeric Orthic Regosols and Orthic Eutric Brunisols of clay loam or sandy loam texture (Rintoul 1985). Cluster analysis from this report indicates that this community type (communities \#4 and \#44) may also occur within the Alpine and Subalpine subregions, and the Montane Subregion within the Cypress Hills.

Within the Montane Subregion, sites are generally forb poor, the moss layer covers up to $30 \%$ of the ground, and the unvegetated ground surface reaches up to $50 \%$. Sites described by Corns and Achuff (1982) are dominated by Agropyron dasystachyum (5 - 50\% cover) with lesser amounts of Artemisia frigida (1 - 10\%), Koeleria macrantha (2 - 10\%) and Achillea millefolium ( $<5 \%)$. In the Kootenay Plains area, on somewhat drier sites, Agropyron dasystachyum, Koeleria macrantha and Artemisia frigida contribute $6-75 \%, 6-25 \%$ and $6-25 \%$ to the ground cover, respectively, while Antennaria nitida occurs sporadically, mainly in wetter depressions (Wallis and Wershler 1981). Additional frequent species include Astragalus striatus, Linum lewisii, Orthocarpus luteus, and Erigeron caespitosus. (Wallis and Wershler 1981). In wetter sites, Artemisia frigida and Antennaria nitida become more abundant, while Koeleria macrantha is lower in cover (Wallis and Wershler 1981). Astragalus striatus and Aster alpinus may also become locally abundant. On some sites within the Montane Subregion, Artemisia frigida and Koeleria macrantha may reach higher ground cover than Agropyron dasystachyum (Beckginham et al. 1996). Calamagrostis purpurascens, Poa pratensis, Carex spp. and Linum lewisii are also found on these sites. This community type from the Dry Mixedwood Subregion seems to have lower cover values for the three dominant species. Agropyron dasystachyum, Koeleria macrantha and Artemisia frigida cover an average of $10 \%, 5 \%$ and $6 \%$ of the ground, respectively (Willoughby et al. 2000). Other characteristic species include Amelanchier alnifolia (6\%), Rosa acicularis (3\%), Carex spp., Agropyron trachycaulum and Stipa richardsonis. In addition to the three dominant species, sites within the Silver Valley include species such as 
Stipa spartea, Allium cernuum, Astragalus agrestis, Crepis tectorum and Linum lewisii. Cluster analysis from this report indicates that this community type may have much higher cover, especially of the three dominant species, when occurring on moister sites within the Montane, Subalpine and Alpine Subregions, as compared to cover values on drier sites in the Montane (Cypress Hills), and Dry Mixedwood Subregions.

SNAME: Agropyron dasystachyum - Koeleria macrantha - Artemisia frigida Herbaceous Vegetation

SCOMNAME: Northern wheat grass - June grass - pasture sagewort Herbaceous Vegetation

\section{CLASSIFICATION}

SYSTEM: Terrestrial

CLASS: Herbaceous vegetation

SUBCLASS: Perennial graminoid vegetation (grasslands)

GROUP: Temperate or subpolar grasslands

FORMATION: Medium-tall sod temperate or subpolar grasslands

ALLIANCE: Agropyron dasystachyum Herbaceous Alliance

\section{CLASSIFICATION CONFIDENCE LEVEL: 1}

SSIMILAR COMMUNITIES: Similar community types include: Agropyron dasystachyum Herbaceous Vegetation (Jaques and vanEck 1979, Wallis and Wershler 1981, Adams et al. 1997, Willoughby et al. 1998, Willoughby 1999), Agropyron dasystachyum - Poa pratensis Herbaceous Vegetation (Willoughby et al. 1998), Agropyron dasystachyum - Artemisia dracunculus - Artemisia frigida Herbaceous Vegetation (Wallis and Wershler 1981), Agropyron dasystachyum - Antennaria nitida Herbaceous Vegetation (Wallis and Wershler 1981) from Alberta, as well as Elymus lanceolatus - (Koeleria macrantha) Herbaceous Vegetation from Sheridan County, Montana (Heidel et al. 2000) and Elymus lanceolatus - Koeleria macrantha from Saskatchewan (Coupland 1950). The last two communities differ from the Agropyron dasystachyum - Koeleria macrantha - Artemisia frigida Herbaceous Vegetation community by having very low cover of Artemisia frigida and by the high cover values of Carex eleocharis, and the presence of Bouteloua gracilis. The Agropyron dasystachyum - Koeleria macrantha Artemisia frigida Herbaceous Vegetation community differs from the rest of the aforementioned communities by a greater cover of Koeleria macrantha and Artemisia frigida, and a generally low importance (or absence) of species such as Poa pratensis, Artemisia dracunculus and Antennaria nitida .

\section{RELATED NOMENCLATURE}


SOTHER.NAMES: Agropyron dasystachyum - Artemisia frigida (Corns and Achuff 1982; Rintoul 1985); Agropyron dasystachyum - Koeleria macrantha - Artemisia frigida - Antennaria nitida (Wallis and Wershler 1981); pasture sagewort grassland (Beckingham et al. 1996)

SOTHER.NAMES.RELATION.NOTE: The Agropyron dasystachyum - Artemisia frigida community type seems to be the same community type as Agropyron dasystachyum - Koeleria macrantha - Artemisia frigida (Wallis and Wershler 1981, Beckginham et al. 1996, Willoughby et al. 2000); The Agropyron dasystachyum - Koeleria macrantha - Artemisia frigida - Antennaria nitida community type (Wallis and Wershler 1981) is included within the Agropyron dasystachyum - Koeleria macrantha - Artemisia frigida community type. The pasture sagewort grassland (Beckingham et al. 1996) may be a variant of the Agropyron dasystachyum - Koeleria macrantha - Artemisia frigida community type.

SNAMES.COM: The Agropyron dasystachyum - Artemisia frigida community type seems to be the same community type as Agropyron dasystachyum - Koeleria macrantha - Artemisia frigida (Wallis and Wershler 1981, Beckginham et al. 1996, Willoughby et al. 2000); The Agropyron dasystachyum - Koeleria macrantha - Artemisia frigida - Antennaria nitida community type (Wallis and Wershler 1981) is included within the Agropyron dasystachyum - Koeleria macrantha-Artemisia frigida community type. Antennaria nitida is a constant species of the Agropyron dasystachyum - Koeleria macrantha - Artemisia frigida community type under drier conditions, and increases its cover under wetter conditions. The pasture sagewort grassland (Beckingham et al. 1996) may be a variant of the Agropyron dasystachyum - Koeleria macrantha - Artemisia frigida community type.

\section{DISTRIBUTION}

SNATREG: Rocky Mountain, Boreal Forest

SSUBREG: Montane, Dry Mixedwood (possibly Subalpine, Alpine and Cypress Hills Montane)

SRANGECOM: This community has been reported from the Banff and Jasper National Parks, the banks of the Peace, Smoky and Wapiti rivers, and the Silver Valley; it also possibly exist within the Cypress Hills area.

SDISTRIBUTION.COM: This community has been reported from the Banff and Jasper National Parks (Rocky Mountains Natural Region - Montane and possibly Subalpine and Alpine Subregions), the banks of the Peace, Smoky and Wapiti rivers, and the Silver Valley (Boreal Forest Natural Region - Dry Mixedwood Subregion); it also possibly exists within the Cypress Hills area (Rocky Mountains Natural Region - Montane Subregion).

\section{ENVIRONMENTAL FACTORS}

SMINELEV: $345 \mathrm{~m}$

SMAXELEV: $1640 \mathrm{~m}$ (possibly $2250 \mathrm{~m}$ )

SLANDFORM: Colluvial, glacial, and fuivial, alluvial 
STOP.POSITION: Toe slopes, upper slopes, and ridges of the alluvial fans;

SSLOPE: Variable (0 - 90\%)

SASPECT: Variable

SSOIL.TYPE: Mostly Orthic Eutric Brunisols and Orthic Regosols; also on Cumulic Regosols and Orthic and Brunisolic Gray Luvisols (Beckginham et al. 1996).

SSOIL.MOSTURE: Very xeric to mesic (possibly subhygric)

SSOIL.COM: Soils are mostly rapidly to well drained; also on very rapidly drained and possibly imperfectly drained

SENVIRO.COM: Occurs at elevations between $345 \mathrm{~m}$ and $1640 \mathrm{~m}$ (possibly as high as $2250 \mathrm{~m}$ ) on variable slopes (0 - 90\%) on all aspects; on the alluvial fans it occupies toe, upper slopes or ridge positions; soils are mostly Orthic Eutric Brunisols and Orthic Regosols (also on Cumulic Regosols and Orthic Gray Luvisols) developed on colluvial, glacial, and fluvial, and alluvial materials; soils are commonly rapidly to well drained, but community also occurs on very rapidly drained and possibly imperfectly drained soils; soil moisture regimes ranges from very xeric to mesic, and possibly subhygric;

\section{BIOLOGICAL AND STRUCTURAL DESCRIPTION}

\section{6a VEGETATION}

SSTRATA LIFEFORM: Shrub; dwarf shrub; herb; moss

SPCT.COVER: Shrub; dwarf shrub; herb; moss

SHEIGHT: Shrub (wetter sites $2 \%$, drier sites $3.5 \%$ - this report); dwarf shrub (wetter sites $0.3 \%$, drier sites $2.5 \%$ this report); herb (wetter sites $98 \%$, drier sites $41 \%$ this report); moss layer may reach up to $30 \%$ in certain areas (Wallis and Wershler 1981)

SMOST.ABUND.SPP: Agropyron dasystachyum, Koeleria macrantha, Artemisia frigida

SUNVEGETATED.SURFACE: Mineral soil and angular detritus (rock particles)

SUNVEGETATED.SURFACE COVER: Up to 50\% (mineral soil 0 - 40\%, angular detritus 5 $50 \%$ ) (Wallis and Wershler 1981)

SCONSTANT.SPP: Agropyron dasystachyum, Koeleria macrantha, Artemisia frigida, Linum lewisii

SVEGETATION.COM: Sites are generally forb poor, moss layer covers up to $30 \%$ of the ground, and unvegetated surface (mineral soil and angular detritus) reaches up to $50 \%$. 
Agropyron dasystachyum, Koeleria macrantha, and Artemisia frigida dominate on all sites, and Antennaria nitida increases its abundance under certain wetter conditions. The three dominant species are also the only constant species. Frequent species that occur in different combinations include Astragalus striatus, Linum lewisii, Orthocarpus luteus, Erigeron caespitosus, Aster alpinus, Calamagrostis purpurascens, Poa pratensis, Carex spp., Agropyron trachycaulum, Stipa richardsonis, Stipa spartea, Allium cernuum, Astragalus agrestis and Crepis tectorum. Amelanchier alnifolia, Rosa acicularis, Juniperus communis and Arctostaphylos uva-ursi are the important shrubs and dwarf shrubs species on some sites.

\section{6b OTHER SPECIES}

SHIGH.RANK.SPP: Noteworthy species of this community within the Silver Valley study site include Lomatium foeniculaceum and Opuntia fragilis, species found primarily in southeastern Alberta (Rintoul 1985).

SOTHERSPP.COM: Noteworthy species of this community within the Silver Valley study site are Lomatium foeniculaceum and Opuntia fragilis, species found primarily in southeastern Alberta (Rintoul 1985).

\section{6c VARIABILITY}

SSPP.COMP.VAR: Antennaria nitida increases its abundance under certain wetter conditions in the Kootenay Plains area (Wallis and Wershler 1981).

SVARIABILITY.COM: Antennaria nitida increases its abundance under certain wetter conditions in the Kootenay Plains area (Wallis and Wershler 1981); cluster analysis from this report indicates that this community type may have much higher vegetation cover, especially of the three dominant species, when occurring on moister sites within Montane, Subalpine and Alpine subregions, as compared to drier sites of the Montane, Cypress Hills Montane and Dry Mixedwood subregions.

\section{STATUS}

\section{SRANK: S2S3}

SREASONS: This community has been reported from the Banff and Jasper National Parks (Rocky Mountains Natural Region - Montane and possibly Subalpine and Alpine Subregions), the banks of the Peace, Smoky and Wapiti rivers, and the Silver Valley (Boreal Forest Natural Region - Dry Mixedwood Subregion), and it possibly exists within the Cypress Hills area (Rocky Mountains Natural Region - Montane Subregion); however, the exact number of sites and their size is not known; more information is needed to assign the proper provincial rank for this community.

SSTATCOM: This community has been reported from the Banff and Jasper National Parks (Rocky Mountains Natural Region - Montane and possibly Subalpine and Alpine Subregions), the banks of the Peace, Smoky and Wapiti rivers, and the Silver Valley (Boreal Forest Natural Region - Dry Mixedwood Subregion), and it possibly exists within the Cypress Hills area (Rocky 
Mountains Natural Region - Montane Subregion); however, the exact number of sites and their size is not known; this community should be placed on the provincial tracking list ranked S2S3 until more information is available.

\section{MANAGEMENT}

SMANAGECOM: This community is frequently grazed by wapiti and horses in the Kootenay Plains area; it is possible that this community occurs as a result of grazing pressure.

\section{ANALYSIS PROCEDURES AND DATA MANAGEMENT}

SANALYSIS.COM: Within each of the $10 \mathrm{~m} \times 10 \mathrm{~m}$ sampling plots, canopy cover was estimated using ten randomly selected $1 \times 1 \mathrm{~m}$ microplots for shrubs, and $20 \times 50 \mathrm{~cm}$ microplots for herbs. Noted environmental factors included elevation, slope, aspect, soil drainage, nutrient regimes, and moisture regimes. Data was analyzed by both cluster and ordination analyses (Willoughby et al. 2000). Additional cluster and ordination analysis of the combined ESIS database (including a number of plots analyzed by $M$. Willoughby) and the Waterton Lakes database was performed by Geowest personnel. Cluster analysis included species data from 416 plots. Ordination analysis related vegetation data from 120 plots to the following environmental variables: solar radiation (combines slope, aspect, and latitude), drainage class, moisture regimes, elevation, latitude, and longitude (last two variables represent macroclimatic variables - NW position in the province coincides with cooler and wetter climate as oppose to the SE end of the province). In addition to ordination, descriptive statistics (median, minimum, maximum) were calculated for environmental variables. These calculations were done in SPSS for Windows and included both variables used in the ordination and variables with a lot of missing data (soil drainage, site position - macro, site position - meso, nutrient regimes, $\%$ bedrock, $\%$ mineral soil, and $\%$ organic material. The information on Natural Subregion was taken from the GIS based on the geographical position of each plot. Wallis and Wershler (1981) recorded detailed canopy coverage within representative $1 \times 1 \mathrm{~m}$ plots, which were nested within $15 \mathrm{~m}$ diameter sampling areas. Additional information on species presence was collected within $15 \mathrm{~m}$ diameter sampling areas. The authors did not perform any cluster or ordination analyses on their data. Corns and Achuff (1982) visually estimated canopy cover to the nearest percent within each $10 \mathrm{~m} \times 10 \mathrm{~m}$ sampling plot. Plants with less than $1 \%$ were assigned $0.5 \%$ cover. Noted environmental factors included elevation, slope, aspect, topographic position, relief shape, landform, soil group, drainage class and moisture regimes. Data was analyzed by tabular comparison, and both indirect and direct ordination. Rintoul (1985) used tabular comparisons of vegetation cover data and environmental data to describe the community.

SANALYSIS.DATA.MANAGE.COM: Within each of the $10 \mathrm{~m} \times 10 \mathrm{~m}$ sampling plots, canopy cover was estimated using ten randomly selected $1 \times 1 \mathrm{~m}$ microplots for shrubs, and $20 \times 50 \mathrm{~cm}$ microplots for herbs. Noted environmental factors included elevation, slope, aspect, soil drainage, nutrient regimes, and moisture regimes. Data was analyzed by both cluster and ordination analyses (Willoughby et al. 2000). Additional cluster and ordination analysis of the combined ESIS database (including a number of plots analyzed by $\mathrm{M}$. Willoughby) and the Waterton Lakes database was performed by Geowest personnel. Cluster analysis included species data from 416 plots. Ordination analysis related vegetation data from 120 plots to the following environmental variables: solar radiation (combines slope, aspect, and latitude), drainage class, 
moisture regimes, elevation, latitude, and longitude (last two variables represent macroclimatic variables - NW position in the province coincides with cooler and wetter climate as oppose to the $\mathrm{SE}$ end of the province). In addition to ordination, descriptive statistics (median, minimum, maximum) were calculated for environmental variables. These calculations were done in SPSS for Windows and included both variables used in the ordination and variables with a lot of missing data (soil drainage, site position - macro, site position - meso, nutrient regimes, $\%$ bedrock, $\%$ mineral soil, and \% organic material. The information on Natural Subregion was taken from the GIS based on the geographical position of each plot. Ecological Site Inventory System (ESIS) electronic database is stored in the Resource Data Division of the Alberta Environment, Edmonton. Wallis and Wershler (1981) recorded detailed canopy coverage within representative $1 \times 1 \mathrm{~m}$ plots, which were nested within $15 \mathrm{~m}$ diameter sampling areas. Additional information on species presence was collected within $15 \mathrm{~m}$ diameter sampling areas. The authors did not perform any cluster or ordination analyses on their data. Corns and Achuff (1982) visually estimated canopy cover to the nearest percent within each $10 \mathrm{~m} \times 10 \mathrm{~m}$ sampling plot. Plants with less than $1 \%$ were assigned $0.5 \%$ cover. Noted environmental factors included elevation, slope, aspect, topographic position, relief shape, landform, soil group, drainage class and moisture regimes. Data was analyzed by tabular comparison, and both indirect and direct ordination It was also entered into the Ecological Site Inventory System (ESIS) electronic database which is stored in the Resource Data Division of Alberta Environment, Edmonton. Rintoul (1985) used tabular comparisons of vegetation cover data and environmental data to describe the community.

\section{REFERENCES}

\section{CITATION:}

Adams, G. D., G. C. Trottier, W. L. Strong, I. D. MacDonald, S. J. Barry, P. G. Gregoire, G. W. Babish and G. Weiss. 1997. Vegetation component report: Canadian Forces Base Suffield national Wildlife area - Wildlife Inventory. Report prepared for the Canadian Wildlife Service, Environment Canada, Edmonton, AB.

Beckingham, J.D., I. G. W. Corns and J. H. Archibald. 1996. Field Guide to Ecosites of WestCentral Alberta. Canadian Forest Service Special Report No.9, Northern Forestry Centre, Edmonton, $\mathrm{AB}$.

Corns, I. G. W. and P. L. Achuff. 1982. Vegetation type descriptions in W. D. Holland and G. M. Coen (eds.). Ecological (Biophysical) Land Classification of Banff and Jasper National Parks. Alberta Institute of Pedology, Publication No. SS-82-44.

Coupland, R. T. 1950. Ecology of mixed prairie in Canada. Ecological Monographs 20: 271315

Heidal, B., S. V. Cooper and C. Jean. 2000. Plant species of special concern and plant associations of Sheridan County, Montana. Report to the U.S. Fish and Wildlife Service. Montana Natural Heritage Program, Helena, Montana. 
Jaques, D. \& P. Van Eck. 1979. Biophysical Features and Recommendations for Recreational Development in the Kakwa Falls Region, Alberta. Kananaskis Center for Environmental Research, U of C.

Rintoul, J. 1985. Silver Valley: Biophysical Resource Analysis. Alberta Forestry, Lands and Wildlife.

Wallis, C. and C. Wershler. 1981. Kootenay Plains Flora and Grassland Vegetation Assessment - 1981. Alberta Energy and Natural Resources.

Willoughby, M. G. 1999. Range plant community types and carrying capacity for the Subalpine and Alpine Subregions - first approximation. Environmental protection, Land and Forest Service, Edmonton, AB.

Willoughby, M. G., M. J. Alexander and K. M. Sundquist. 1998. Range plant community types and carrying capacity for the Montane Subregion of Alberta - third approximation. Environmental Protection, Lands and Forest Services, Edmonton, AB.

Willoughby, M. G. and the Rangeland Health Assessment Project and Forest Rangeland Action Plan. 2000. Guide to range plant community types and carrying capacity for the Dry and Central Mixedwood Subregions in Alberta - third approximation. Alberta Environment, Land and Forest Service and Alberta Agriculture, Food and Rural Development, Public Lands Division, Edmonton, $\mathrm{AB}$. 


\section{COMMUNITY CHARACTERIZATION ABSTRACT Agropyron dasystachyum - Poa pratensis Herbaceous Vegetation}

\section{IDENTIFIERS}

SEL.SUMMARY: This community type was described by Willoughby et al. (1998) for only one site located above the Oldman River in the Outer Gap Range Allotment in the Montane Subregion of Alberta (elevation $1545 \mathrm{~m}$ ). The Outer Gap Range is subjected to extremely high desiccating winds. This community occupies dry, moderately to heavily grazed, south facing slopes (slope $15 \%$ ). Soils are shallow, rapidly drained, with submesic moisture regimes and submesotrophic nutrient regimes. The dominant grass and sedge species are Agropyron dasystachyum (35\%), Carex obtusata (11\%), Poa pratensis (10\%), and Poa canbyi (5\%). Taraxacum officinale, Vicia americana, Antennaria parvifolia, Oxytropis splendens and Solidago missouriensis, which made up $15.0 \%, 13.0 \%, 10.0 \%, 8.0 \%$ and $6.0 \%$ of canopy cover, respectively, are the dominant forbs. Symphoricarpos occidentalis (12\%) and Rosa arkansana (7\%) are the dominant species in the shrub and dwarf shrub layers. The authors suggested that this community has been driven by disturbance (grazing) which has favored exotic species such as Poa pratensis and Taraxacum officinale, however, relatively dry soil conditions have prevented Poa pratensis from dominating this community type. In the absence of the disturbance, the community would probably resemble moister sites within the Agropyron spicatum - Carex obtusata community type. (Willoughby et al. 1998).

SNAME: Agropyron dasystachyum - Poa pratensis Herbaceous Vegetation

SCOMNAME: Northern wheat grass - Kentucky bluegrass Herbaceous Vegetation

\section{CLASSIFICATION}

SYSTEM: Terrestrial

CLASS: Herbaceous vegetation

SUBCLASS: Perennial graminoid vegetation (grasslands)

GROUP: Temperate or subpolar grasslands

FORMATION: Medium-tall sod temperate or subpolar grasslands

ALLIANCE: Agropyron dasystachyum Herbaceous Alliance

\section{CLASSIFICATION CONFIDENCE LEVEL: 2}

SSIMILAR COMMUNITIES: The Agropyron dasystachyum Herbaceous Vegetation community type (Jaques and vanEck 1979, Wallis and Wershler 1981, Adams et al. 1997, Willoughby et al. 1998, Willoughby 1999) is dominated solely by Agropyron dasystachyum, and generally lacks a significant Poa pratensis component. 


\section{DISTRIBUTION}

SNATREG: Rocky Mountain

SSUBREG: Montane

SDISTRIBUTION.COM: Rocky Mountains Natural Region (Montane Subregion)

\section{ENVIRONMENTAL FACTORS}

SMINELEV: $1545 \mathrm{~m}$

SMAXELEV: $1545 \mathrm{~m}$

SSLOPE: $15 \%$

SASPECT: Southerly

SSOIL.MOSTURE: Submesic

SSOIL.COM: Rapidly to well drained, shallow soils with submesotrophic nutrient regimes

SKEY.ENVIRO.FACTORS: The authors suggested that this community has been driven by disturbance (grazing) which has favored exotic species such as Poa pratensis and Taraxacum officinale, however, relatively dry soil conditions have prevented Poa pratensis from dominating this community type. In the absence of the disturbance, the community would probably resemble moister sites within the Agropyron spicatum - Carex obtusata community type. (Willoughby et al. 1998).

SENVIRO.COM: The Outer Gap range where this community occurs is subjected to extremely strong desiccating winds. This community occupies dry, moderately to heavily grazed, south facing slopes (slope 15\%). Soils are shallow, rapidly drained, with submesic moisture regimes and submesotrophic nutrient regimes.

\section{BIOLOGICAL AND STRUCTURAL DESCRIPTION}

\section{6a VEGETATION}

SSTRATA LIFEFORM: Shrub; dwarf shrub; herb

SPCT.COVER: Shrub (12\%); dwarf shrub (7\%); herb (113\%)

SMOST.ABUND.SPP: Agropyron dasystachyum, Carex obtusata, Poa pratensis

SCHARACTERISTIC.SPP: Poa pratensis 
SVEGETATION.COM: The dominant grass and sedge species are Agropyron dasystachyum (35\%), Carex obtusata (11\%), Poa pratensis (10\%), and Poa canbyi (5\%). Taraxacum officinale, Vicia americana, Antennaria parvifolia, Oxytropis splendens and Solidago missouriensis, which made up $15.0 \%, 13.0 \%, 10.0 \%, 8.0 \%$ and $6.0 \%$ of the canopy cover, respectively, are the dominant forbs. Symphoricarpos occidentalis (12\%) and Rosa arkansana $(7 \%)$ are the dominant species in the shrub and dwarf shrub layers.

\section{STATUS}

SRANK: SU

SREASONS: Classification of this community type was based on only one sampling plot

SSTATCOM: Classification of this community type was based on only one sampling plot; this community potentially exists and it should be ranked SU until more information is available.

\section{MANAGEMENT}

\section{SECONCOM: Grazed}

SMANAGECOM: The authors suggested that this community has been driven by disturbance (grazing) which has favored exotic species such as Poa pratensis_and Taraxacum officinale, however, relatively dry soil conditions have prevented Poa pratensis from dominating this community type. In the absence of the disturbance, the community would probably resemble moister sites within the Agropyron spicatum - Carex obtusata community type. (Willoughby et al. 1998).

\section{ANALYSIS PROCEDURES AND DATA MANAGEMENT}

SANALYSIS.COM: Within each of the $10 \mathrm{~m} \times 10 \mathrm{~m}$ sampling plots, canopy cover was estimated using ten randomly selected $1 \times 1 \mathrm{~m}$ microplots for shrubs, and $20 \times 50 \mathrm{~cm}$ microplots for herbs. Noted environmental factors included elevation, slope, aspect, soil drainage, nutrient regimes, and moisture regimes. Data was analyzed by cluster and ordination analyses (Willoughby et al. 1998).

SANALYSIS.DATA.MANAGE.COM: Within each of the $10 \mathrm{~m} \times 10 \mathrm{~m}$ sampling plots, canopy cover was estimated using ten randomly selected $1 \times 1 \mathrm{~m}$ microplots for shrubs, and $20 \times 50 \mathrm{~cm}$ microplots for herbs. Noted environmental factors included elevation, slope, aspect, soil drainage, nutrient regimes, and moisture regimes. Data was analyzed by cluster and ordination analyses (Willoughby et al. 1998). Data analyzed by Willoughby et al. (1998) is part of the Ecological Site Inventory System (ESIS) electronic database, which is stored in the Resource Data Division of Alberta Environment, Edmonton.

\section{GENERAL COMMENTS}

SCOMMUNITY.COM: Only one site was described. More information is needed to show if this community type repeats over the landscape. 


\section{REFERENCES}

\section{CITATION:}

Adams, G. D., G. C. Trottier, W. L. Strong, I. D. MacDonald, S. J. Barry, P. G. Gregoire, G. W. Babish and G. Weiss. 1997. Vegetation component report: Canadian Forces Base Suffield national Wildlife area - Wildlife Inventory. Report prepared for the Canadian Wildlife Service, Environment Canada, Edmonton, AB.

Jaques, D. \& P. Van Eck. 1979. Biophysical Features and Recommendations for Recreational Development in the Kakwa Falls Region, Alberta. Kananaskis Center for Environmental Research, U of C.

Wallis, C. and C. Wershler. 1981. Kootenay Plains Flora and Grassland Vegetation Assessment - 1981. Alberta Energy and Natural Resources.

Willoughby, M. G. 1999. Range plant community types and carrying capacity for the Subalpine and Alpine Subregions - first approximation. Environmental protection, Land and Forest Service, Edmonton, AB.

Willoughby, M. G., M. J. Alexander and K. M. Sundquist. 1998. Range plant community types and carrying capacity for the Montane Subregion of Alberta - third approximation. Environmental Protection, Lands and Forest Services, Edmonton, AB. 


\section{COMMUNITY CHARACTERIZATION ABSTRACT}

Agropyron dasystachyum - Muhlenbergia cuspidata Herbaceous Vegetation

\section{IDENTIFIERS}

SEL.SUMMARY: This community type is associated with water eroded areas scattered throughout rolling topography of the Canadian mixed prairie (Coupland 1950). Characterized by frequent bare spots, this community is dominated by Agropyron dasystachyum and Muhlenbergia cuspidata. Agropyron smithii represents only a minor component of wheat grass' cover in this community, and together, the two wheat grass species make up $35.2 \%$ of the total basal area. Codominant species, Muhlenbergia cuspidata, contributes $18.2 \%$ of the total species cover. The principal associated grasses and sedges, Koeleria macrantha, Bouteloua gracilis, Stipa comata, S. spartea var. curtiseta, S. viridula, Carex eleocharis and C. filifolia contribute $8.1 \%, 13.0 \%$, $1.4 \%, 1.4 \%, 1.2 \%, 14.9 \%$ and $1.4 \%$ of the total basal area, respectively. Artemisia frigida and Phlox hoodii were the most abundant forbs, making up $8.8 \%$ and $4.9 \%$ of the total basal area.

SNAME: Agropyron dasystachyum - Muhlenbergia cuspidata Herbaceous Vegetation

SCOMNAME: Northern wheat grass - plains muhly Herbaceous Vegetation

\section{CLASSIFICATION}

SYSTEM: Terrestrial

CLASS: Herbaceous vegetation

SUBCLASS: Perennial graminoid vegetation (grasslands)

GROUP: Temperate or subpolar grasslands

FORMATION: Medium-tall sod temperate or șubpolar grasslands

ALLIANCE: Agropyron dasystachyum Herbaceous Alliance

\section{CLASSIFICATION CONFIDENCE LEVEL: 3}

SSIMILAR COMMUNITIES: Similar community types include: Agropyron dasystachyum Herbaceous Vegetation (Jaques and vanEck 1979, Wallis and Wershler 1981, Adams et al. 1997, Willoughby et al. 1998, Willoughby 1999), Agropyron dasystachyum - Agropyron smithii Herbaceous Vegetation (Adams 1981, Adams and Moisey 1999), Agropyron dasystachyum Koeleria macrantha - Artemisia frigida Herbaceous Vegetation (Wallis and Wershler 1981, Corns and Achuff 1982, Rintoul 1985, Beckginham et al. 1996, Willoughby et al. 2000, this report), and Agropyron dasystachyum - Stipa comata Herbaceous Vegetation (Moss 1944, Coupland 1950, Wallis and Wershler 1981, Adams and Moisey 1999) from Alberta, as well as Elymus lanceolatus - Stipa comata Herbaceous Vegetation from Oregon and Montana (Heidel et al. 2000, NatureServe 2000), Elymus lanceolatus - Koeleria macrantha from Saskatchewan (Coupland 1950), Elymus lanceolatus - (Koeleria macrantha) Herbaceous Vegetation from 
Sheridan County, Montana (Heidel et al. 2000), and Elymus lanceolatus - Bouteloua gracilis Herbaceous Vegetation from Sheridan County, Montana (Heidel et al. 2000). The general absence of Muhlenbergia cuspidata in the aforementioned community types separate these types from the Agropyron dasystachyum -Muhlenbergia cuspidata Herbaceous Vegetation community.

\section{DISTRIBUTION}

SNATREG: Grasslands

SSUBREG: Probably Dry Mixedgrass

SRANGECOM: May be scattered through the area of rolling topography in southeastern Alberta SDISTRIBUTION.COM: This community possibly exists within the Grassland Natural Region, scattered within the rolling topography of southeastern Alberta.

\section{ENVIRONMENTAL FACTORS}

SLANDFORM: Glacial till

SSOIL.TYPE: Chernozems

SENVIRO.COM: This community type is associated with water eroded areas scattered throughout rolling topography

\section{BIOLOGICAL AND STRUCTURAL DESCRIPTION}

6a VEGETATION

SMOST.ABUND.SPP: Agropyron dasystachyum, Muhlenbergia cuspidata, Carex eleocharis

SUNVEGETATED.SURFACE: Mineral soil

SUNVEGETATED.SURFACE COVER: Mineral soil (86\%)

\section{SCHARACTERISTIC.SPP: Muhlenbergia cuspidata}

SVEGETATION.COM: This community is dominated by Agropyron dasystachyrum and Muhlenbergia cuspidata. Agropyron smithii represents only a minor component of wheat grass' cover in this community, and together, the two wheat grass species make up $35.2 \%$ of the total basal area. Codominant species, Muhlenbergia cuspidata, contributes $18.2 \%$ of the total species cover. The principal associated grasses and sedges, Koeleria macrantha, Bouteloua gracilis, Stipa comata, S. spartea var. curtiseta, S. viridula, Carex eleocharis and C. filifolia contribute $8.1 \%, 13.0 \%, 1.4 \%, 1.4 \%, 1.2 \%, 14.9 \%$ and $1.4 \%$ of the total basal area, respectively. Artemisia frigida and Phlox hoodii were the most abundant forbs, making up $8.8 \%$ and $4.9 \%$ of the total basal area. 


\section{DYNAMIC PROCESSES}

SNAT.DISTURBANCE: Water erosion

SSUCCESS.DYNAM.COM: Coupland (1950) suggested that the vegetation of these sites, in the absence of disturbance, would be that of the Stipa - Bouteloua type, however, water erosion has modified the relative abundance of the grasses.

\section{STATUS}

SRANK: SP

SREASONS: Other than the Grassland Research Area at Cadillac, Saskatchewan, Coupland (1950) did not provide the precise location of sites supporting this community type. However, the author indicated that this community type occurred throughout the area of rolling topography, with which the Bouteloua - Stipa faciation is associated, indicating that the Agropyron Muhlenbergia community type may exist in Alberta.

SSTATCOM: Other than the Grassland Research Area at Cadillac, Saskatchewan, Coupland (1950) did not provide the precise location of sites supporting this community type. However, the author indicated that this community type occurred throughout the area of rolling topography, with which the Bouteloua - Stipa faciation is associated, indicating that the Agropyron Muhlenbergia community type may exist in Alberta. Therefore, this community type should be placed on the provincial tracking list and ranked SP until further information is collected.

\section{ANALYSIS PROCEDURES AND DATA MANAGEMENT}

SANALYSIS.COM: Coupland (1950) collected vegetation data by point transects (for basal area and percent composition) and list quadrats (for the relative abundance of subdominant species). In addition to total basal area, the distribution of subdominant species was used to differentiate subtypes within major communities.

SANALYSIS.DATA.MANAGE.COM: Coupland (1950) collected vegetation data by point transects (for basal area and percent composition) and list quadrats (for the relative abundance of subdominant species). In addition to total basal area, the distribution of subdominant species was used to differentiate subtypes within major communities

\section{GENERAL COMMENTS}

SCOMMUNITY.COM: Other than the Grassland Research Area at Cadillac, Coupland (1950) did not provide the precise location of sites supporting this community type. However, the author indicated that this community type occurred throughout the area of rolling topography, with which the Bouteloua - Stipa faciation is associated, indicating that the Agropyron - Muhlenbergia community type may exist in Alberta. Future study is needed to show whether this community type occurs within Alberta.

\section{REFERENCES}




\section{CITATION:}

Adams, B. 1981. Range Ecology and the impact of livestock grazing on the Peace River Slopes, Alberta. Public Lands Division,

Adams, G. D., G. C. Trottier, W. L. Strong, I. D. MacDonald, S. J. Barry, P. G. Gregoire, G. W. Babish and G. Weiss. 1997. Vegetation component report: Canadian Forces Base Suffield national Wildlife area - Wildlife Inventory. Report prepared for the Canadian Wildlife Service, Environment Canada, Edmonton, AB.

Adams, B and D. Moisey. 1999. Analysis of vegetation and soil monitoring records for Milk River Natural Area and Kennedy Creek Ecological Reserve. 1999. Public Lands, Alberta Agriculture, Food and Rural Development, Lethbridge

Beckingham, J.D., I. G. W. Corns and J. H. Archibald. 1996. Field Guide to Ecosites of WestCentral Alberta. Canadian Forest Service Special Report No.9, Northern Forestry Centre, Edmonton, $\mathrm{AB}$.

Corns, I. G. W. and P. L. Achuff. 1982. Vegetation type descriptions in W. D. Holland and G. M. Coen (eds.). Ecological (Biophysical) Land Classification of Banff and Jasper National Parks. Alberta Institute of Pedology, Publication No. SS-82-44.

Coupland, R. T. 1950. Ecology of mixed prairie in Canada. Ecological Monographs 20: 271315

Heidal, B., S. V. Cooper and C. Jean. 2000. Plant species of special concern and plant associations of Sheridan County, Montana. Report to the U.S. Fish and Wildlife Service. Montana Natural Heritage Program, Helena, Montana.

Jaques, D. \& P. Van Eck. 1979. Biophysical Features and Recommendations for Recreational Development in the Kakwa Falls Region, Alberta. Kananaskis Center for Environmental Research, $\mathrm{U}$ of $\mathrm{C}$.

Moss, E. H. 1944. The prairie and associated vegetation of southwestern Alberta. Canadian Journal of Research 22:11-31.

NatureServe 2000. An online encyclopedia of life [web application]. 2000. Version 1.0. Arlington (VA): Association for Biodiversity Information. Available: http://www.natureserve.org

Rintoul, J. 1985. Silver Valley: Biophysical Resource Analysis. Alberta Forestry, Lands and Wildlife.

Wallis, C. and C. Wershler. 1981. Kootenay Plains Flora and Grassland Vegetation Assessment - 1981. Alberta Energy and Natural Resources. 
Willoughby, M. G. 1999. Range plant community types and carrying capacity for the Subalpine and Alpine Subregions - first approximation. Environmental protection, Land and Forest Service, Edmonton, AB.

Willoughby, M. G., M. J. Alexander and K. M. Sundquist. 1998. Range plant community types and carrying capacity for the Montane Subregion of Alberta - third approximation. Environmental Protection, Lands and Forest Services, Edmonton, AB.

Willoughby, M. G. and the Rangeland Health Assessment Project and Forest Rangeland Action Plan. 2000. Guide to range plant community types and carrying capacity for the Dry and Central Mixedwood Subregions in Alberta - third approximation. Alberta Environment, Land and Forest Service and Alberta Agriculture, Food and Rural Development, Public Lands Division, Edmonton, $\mathrm{AB}$. 


\section{COMMUNITY CHARACTERIZATION ABSTRACT}

\section{Agropyron dasystachyum - Artemisia dracunculus - Artemisia frigida}

Herbaceous Vegetation

\section{IDENTIFIERS}

SEL.SUMMARY: This community type occurs on nearly level, well-drained, submesic sites, at the toe edge of an alluvial fan in Kootenay Plains area (Wallis and Wershler 1981). Agropyron dasystachyum, Artemisia dracunculus, and Artemisia frigida contribute about 26 - 50\%, 16 $25 \%$, and $16-25 \%$ to the ground cover, respectively. Agropyron subsecundum and Koeleria macrantha are locally abundant. Additional species include Linum lewisii, Oxytropis campestre, Astragalus striatus, Potentilla pensylvanica, Antennaria nitida, Erigeron caespitosus, Orthocarpus luteus and Poa glauca.

SNAME: Agropyron dasystachyum - Artemisia dracunculus - Artemisia frigida Herbaceous Vegetation

SCOMNAME: Northern wheat grass - sagewort - pasture sagewort Herbaceous Vegetation

\section{CLASSIFICATION}

SYSTEM: Terrestrial

CLASS: Herbaceous vegetation

SUBCLASS: Perennial graminoid vegetation (grasslands)

GROUP: Temperate or subpolar grasslands

FORMATION: Medium-tall sod temperate or subpolar grasslands

ALLIANCE: Agropyron dasystachyum Herbaceous Alliance

\section{CLASSIFICATION CONFIDENCE LEVEL: 1}

SSIMILAR COMMUNITIES: Similar community types include: Agropyron dasystachyum Herbaceous Vegetation (Jaques and vanEck 1979, Wallis and Wershler 1981, Adams et al. 1997, Willoughby et al. 1998, Willoughby 1999), Agropyron dasystachyum - Koeleria macrantha Artemisia frigida Herbaceous Vegetation (Wallis and Wershler 1981, Corns and Achuff 1982, Rintoul 1985, Beckginham et al. 1996, Willoughby et al. 2000, this report), and Agropyron dasystachyum - Antennaria nitida Herbaceous Vegetation (Wallis and Wershler 1981) from Alberta, as well as Elymus lanceolatus - Koeleria macrantha from Saskatchewan (Coupland 1950) and Elymus lanceolatus - (Koeleria macrantha) Herbaceous Vegetation from Sheridan County, Montana (Heidel et al. 2000). The general lack of Artemisia dracunculus separates the aforementioned communities from the Agropyron dasystachyum - Artemisia dracunculus Artemisia frigida Herbaceous Vegetation community type. 


\section{DISTRIBUTION}

SNATREG: Rocky Mountain

SSUBREG: Montane

SRANGECOM: This community type seems to be restricted to the Kootenay Plains study area.

SDISTRIBUTION.COM: This community type seems to be restricted to the Kootenay Plains study area (Rocky Mountains Natural Region - Montane Subregion)

\section{ENVIRONMENTAL FACTORS}

SLANDFORM: Alluvial fan

STOP.POSITION: Toe

SSLOPE: 0 - $1 \%$

SSOIL.MOSTURE: Submesic

SSOIL.COM: Well-drained soils

SENVIRO.COM: This community type occurs on near level, well-drained, submesic sites, at the toe edge of alluvial fan in the Kootenay Plains area.

\section{BIOLOGICAL AND STRUCTURAL DESCRIPTION}

6a VEGETATION

SSTRATA LIFEFORM: Shrub; herb; moss

SPCT.COVER:

SHEIGHT: Herb $20-80 \mathrm{~cm}$

SMOST.ABUND.SPP: Agropyron dasystachyum, Artemisia dracunculus, and Artemisia frigida contribute about $26-50 \%, 16-25 \%$, and $16-25 \%$ to the ground cover, respectively. Agropyron subsecundum and Koeleria macrantha are locally abundant. Additional species include Linum lewisii, Oxytropis campestre, Astragalus striatus, Potentilla pensylvanica, Antennaria nitida, Erigeron caespitosus, Orthocarpus luteus and Poa glauca.

SUNVEGETATED.SURFACE: Stones; mineral soil

SUNVEGETATED.SURFACE COVER: Stones 5 - 50\%; mineral soil 0 - 10\% 
SCHARACTERISTIC.SPP: Agropyron dasystachyum, Artemisia dracunculus, Artemisia frigida, Astragalus striatus, Antennaria nitida, Erigeron caespitosus, Orthocarpus luteus, Koeleria macrantha

SVEGETATION.COM: Agropyron dasystachyum, Artemisia dracunculus, and Artemisia frigida contribute about $26-50 \%, 16-25 \%$, and $16-25 \%$ to the ground cover, respectively. Agropyron subsecundum and Koeleria macrantha are locally abundant. Additional species include Linum lewisii, Oxytropis campestre, Astragalus striatus, Potentilla pensylvanica, Antennaria nitida, Erigeron caespitosus, Orthocarpus luteus and Poa glauca.

\section{STATUS}

SRANK: S1

SREASONS: This community type seems to be restricted to sites southeast of the North Saskatchewan River in the Kootenay Plains study area

SSTATCOM: This community type seems to be restricted to sites southeast of the North Saskatchewan River in the Kootenay Plains study area; it should be placed on the provincial tracking list and ranked S1

\section{MANAGEMENT}

SECONCOM: Grazed by horses

SMANAGECOM: Some aspen invasion observed

\section{ANALYSIS PROCEDURES AND DATA MANAGEMENT}

SANALYSIS.COM: Wallis and Wershler (1981) recorded detailed canopy coverage within representative $1 \times 1 \mathrm{~m}$ plots, which were nested within $15 \mathrm{~m}$ diameter sampling areas. Additional information on species presence was collected within $15 \mathrm{~m}$ diameter sampling areas. The authors did not perform any cluster or ordination analyses on their data.

SANALYSIS.DATA.MANAGE.COM: Wallis and Wershler (1981) recorded detailed canopy coverage within representative $1 \times 1 \mathrm{~m}$ plots, which were nested within $15 \mathrm{~m}$ diameter sampling areas. Additional information on species presence was collected within $15 \mathrm{~m}$ diameter sampling areas. The authors did not perform any cluster or ordination analyses on their data.

\section{REFERENCES}

\section{CITATION:}

Adams, G. D., G. C. Trottier, W. L. Strong, I. D. MacDonald, S. J. Barry, P. G. Gregoire, G. W. Babish and G. Weiss. 1997. Vegetation component report: Canadian Forces Base Suffield national Wildlife area - Wildlife Inventory. Report prepared for the Canadian Wildlife Service, Environment Canada, Edmonton, AB. 
Beckingham, J.D., I. G. W. Corns and J. H. Archibald. 1996. Field Guide to Ecosites of WestCentral Alberta. Canadian Forest Service Special Report No.9, Northern Forestry Centre, Edmonton, $\mathrm{AB}$.

Corns, I. G. W. and P. L. Achuff. 1982. Vegetation type descriptions in W. D. Holland and G. M. Coen (eds.). Ecological (Biophysical) Land Classification of Banff and Jasper National Parks. Alberta Institute of Pedology, Publication No. SS-82-44.

Coupland, R. T. 1950. Ecology of mixed prairie in Canada. Ecological Monographs 20: 271315

Heidal, B., S. V. Cooper and C. Jean. 2000. Plant species of special concern and plant associations of Sheridan County, Montana. Report to the U.S. Fish and Wildlife Service. Montana Natural Heritage Program, Helena, Montana.

Jaques, D. \& P. Van Eck. 1979. Biophysical Features and Recommendations for Recreational Development in the Kakwa Falls Region, Alberta. Kananaskis Center for Environmental Research, $\mathrm{U}$ of $\mathrm{C}$.

Rintoul, J. 1985. Silver Valley: Biophysical Resource Analysis. Alberta Forestry, Lands and Wildlife.

Wallis, C. and C. Wershler. 1981. Kootenay Plains Flora and Grassland Vegetation Assessment - 1981. Alberta Energy and Natural Resources.

Willoughby, M. G. 1999. Range plant community types and carrying capacity for the Subalpine and Alpine Subregions - first approximation. Environmental protection, Land and Forest Service, Edmonton, AB.

Willoughby, M. G., M. J. Alexander and K. M. Sundquist. 1998. Range plant community types and carrying capacity for the Montane Subregion of Alberta - third approximation. Environmental Protection, Lands and Forest Services, Edmonton, AB.

Willoughby, M. G. and the Rangeland Health Assessment Project and Forest Rangeland Action Plan. 2000. Guide to range plant community types and carrying capacity for the Dry and Central Mixedwood Subregions in Alberta - third approximation. Alberta Environment, Land and Forest Service and Alberta Agriculture, Food and Rural Development, Public Lands Division, Edmonton, $\mathrm{AB}$. 


\section{COMMUNITY CHARACTERIZATION ABSTRACT \\ Agropyron dasystachyum - Antennaria nitida Herbaceous Vegetation}

\section{IDENTIFIERS}

SEL.SUMMARY: This community type occupies woodland edges and former wooded sites on the southeast side of the North Saskatchewan River in the Kootenay Plains area where it is a major community type (Wallis and Wershler 1981). It occupies mid slopes (3 - 5\%) with northerly and southerly aspects on alluvial fans. Soils are well drained with submesic moisture regimes. Ground cover of each of the codominant species, Agropyron dasystachyum and Antennaria nitida, generally reaches from 25 to $50 \%$, although, in certain areas cover of Antennaria reaches $75 \%$. Numerous other species characterize this community type, including Koeleria macrantha, Artemisia frigida, Comandra pallida, Linum lewisii, Astragalus striatus, Anemone multifida, Androsace septentionalis, Gentianella amarella, Galium boreale, Campanula rotundifolia, Agoseris glauca, Aster alpinus, Erigeron caespitosus, Gaillardia aristata, Senecio canus, Solidago decumbens, Allium cernuum, Sisyrinchium montanum, and Bromus pumpellianus. In some areas shrub species such as Rosa woodsii and Potentilla fruticosa have invaded these grasslands. Some areas are more open with bare soil and rock covering up to $45 \%$ and $25 \%$, respectively. Antennaria nitida, Artemisia frigida, Agropyron dasystachyum, Koeleria macrantha or lichens are locally common.

SNAME: Agropyron dasystachyum - Antennaria nitida Herbaceous Vegetation

SCOMNAME: Northern wheat grass - small-leaved everlasting Herbaceous Vegetation

\section{CLASSIFICATION}

SYSTEM: Terrestrial

CLASS: Herbaceous vegetation

SUBCLASS: Perennial graminoid vegetation (grasslands)

GROUP: Temperate or subpolar grasslands

FORMATION: Medium-tall sod temperate or subpolar grasslands

ALLIANCE: Agropyron dasystachyum Herbaceous Alliance

\section{CLASSIFICATION CONFIDENCE LEVEL: 1}

SSIMILAR COMMUNITIES: Similar community types include: Agropyron dasystachyum Herbaceous Vegetation (Jaques and vanEck 1979, Wallis and Wershler 1981, Adams et al. 1997, Willoughby et al. 1998, Willoughby 1999) and Agropyron dasystachyum - Koeleria macrantha Artemisia frigida Herbaceous Vegetation (Wallis and Wershler 1981, Corns and Achuff 1982, Rintoul 1985, Beckginham et al. 1996, Willoughby et al. 2000, this report) from Alberta, as well as Elymus lanceolatus - Koeleria macrantha from Saskatchewan (Coupland 1950) and Elymus 
lanceolatus - (Koeleria macrantha) Herbaceous Vegetation from Sheridan County, Montana (Heidel et al. 2000). The Agropyron dasystachyum - Antennaria nitida Herbaceous Vegetation community differs from the aforementioned communities by the combined dominance of Agropyron dasystachyum and Antennaria nitida, and generally low cover of other species, including Koeleria macrantha and Artemisia frigida. In addition, Antennaria nitida is generally absent in the aforementioned communities, or present with very low cover.

\section{DISTRIBUTION}

SNATREG: Rocky Mountain

SSUBREG: Montane

SRANGECOM: This community type seems to be restricted to sites on the southeast side of the North Saskatchewan River in the Kootenay Plains study area.

SDISTRIBUTION.COM: This community type seems to be restricted to sites on the southeast side of the North Saskatchewan River in the Kootenay Plains study area (rocky Mountains Natural Region - Montane Subregion)

\section{ENVIRONMENTAL FACTORS}

SLANDFORM: Alluvial fan

STOP.POSITION: Middle

SSLOPE: $3-5 \%$

SASPECT: Northerly and southerly

SSOIL.MOSTURE: Submesic

SSOIL.COM: Well drained soils

SENVIRO.COM: This community occupies gentle slopes (3 - 5\%) with northerly and southerly aspects on alluvial fans. Soils are well drained with submesic moisture regimes.

\section{BIOLOGICAL AND STRUCTURAL DESCRIPTION}

6a VEGETATION

SSTRATA LIFEFORM: Shrub; herb; moss/lichens

SHEIGHT: Shrub ; herb 20 - $40 \mathrm{~cm}$; moss/lichens $2-3 \mathrm{~cm}$

SMOST.ABUND.SPP: Agropyron dasystachyum and Antennaria nitida 
SUNVEGETATED.SURFACE: bare soil, rock

SUNVEGETATED.SURFACE COVER: bare soil $45 \%$; rock $25 \%$

SCONSTANT.SPP: Agropyron dasystachyum, Antennaria nitida, Koeleria macrantha, Linum lewisii, Anemone multifida, Galium boreale, Campanula rotundifolia, Erigeron caespitosus, Allium cernuum, and Bromus pumpellianus

\section{SCHARACTERISTIC.SPP:}

SVEGETATION.COM: Agropyron dasystachyum and Antennaria nitida dominate this community; Koeleria macrantha, Linum lewisii, Anemone multifida, Galium boreale, Campanula rotundifolia, Erigeron caespitosus, Allium cernuum, and Bromus pumpelianus are the constant species; other species include Koeleria macrantha, Artemisia frigida, Comandra pallida, Linum lewisii, Astragalus striatus, Anemone multifida, Androsace septentionalis, Gentianella amarella, Galium boreale, Campanula rotundifolia, Agoseris glauca, Aster alpinus, Erigeron caespitosus, Gaillardia aristata, Senecio canus, Solidago decumbens, Allium cernuum, Sisyrinchium montanum, and Bromus pumpelianus.

\section{6c VARIABILITY}

SSPP.COMP.VAR: In some areas shrub species, such as Rosa woodsii and Potentilla fruticosa have invaded these grasslands. Some areas are more open with bare soil and rock covering up to $45 \%$ and $25 \%$, respectively. Antennaria nitida, Artemisia frigida, Agropyron dasystachyum, Koeleria macrantha or lichens are locally common.

SVARIABILITY.COM: In some areas shrub species, such as Rosa woodsii and Potentilla fruticosa have invaded these grasslands. Some areas are more open with bare soil and rock covering up to $45 \%$ and $25 \%$, respectively. Antennaria nitida, Artemisia frigida, Agropyron dasystachyum, Koeleria macrantha or lichens are locally common

\section{SPATIAL RELATIONS}

SSPATIAL DISTRIBUTION: This community type occupies woodland edges and former wooded sites on south or east side of river

SADJACENT.COMMUNITIES: General area is wooded (balsam poplar and spruce mentioned)

SSPATIAL.COM: This community type occupies woodland edges and former wooded sites on the southeast side of the North Saskatchewan River in the Kootenay Plains study area; general area is wooded (balsam poplar and spruce mentioned)

\section{STATUS}

SRANK: S1 
SREASONS: This community type seems to be restricted to sites on the southeast side of the North Saskatchewan River in the Kootenay Plains study area.

SSTATCOM: This community type seems to be restricted to sites on the southeast side of the North Saskatchewan River in the Kootenay Plains study area; it should be placed on the provincial tracking list and ranked S1

\section{ANALYSIS PROCEDURES AND DATA MANAGEMENT}

SANALYSIS.COM: Wallis and Wershler (1981) recorded detailed canopy coverage within representative $1 \times 1 \mathrm{~m}$ plots, which were nested within $15 \mathrm{~m}$ diameter sampling areas. Additional information on species presence was collected within $15 \mathrm{~m}$ diameter sampling areas. The authors did not perform any cluster or ordination analyses on their data.

SANALYSIS.DATA.MANAGE.COM: Wallis and Wershler (1981) recorded detailed canopy coverage within representative $1 \times 1 \mathrm{~m}$ plots, which were nested within $15 \mathrm{~m}$ diameter sampling areas. Additional information on species presence was collected within $15 \mathrm{~m}$ diameter sampling areas. The authors did not perform any cluster or ordination analyses on their data.

\section{REFERENCES}

\section{CITATION:}

Adams, G. D., G. C. Trottier, W. L. Strong, I. D. MacDonald, S. J. Barry, P. G. Gregoire, G. W. Babish and G. Weiss. 1997. Vegetation component report: Canadian Forces Base Suffield national Wildlife area - Wildlife Inventory. Report prepared for the Canadian Wildlife Service, Environment Canada, Edmonton, AB.

Beckingham, J.D., I. G. W. Corns and J. H. Archibald. 1996. Field Guide to Ecosites of WestCentral Alberta. Canadian Forest Service Special Report No.9, Northern Forestry Centre, Edmonton, $\mathrm{AB}$.

Corns, I. G. W. and P. L. Achuff. 1982. Vegetation type descriptions in W. D. Holland and G. M. Coen (eds.). Ecological (Biophysical) Land Classification of Banff and Jasper National Parks. Alberta Institute of Pedology, Publication No. SS-82-44.

Coupland, R. T. 1950. Ecology of mixed prairie in Canada. Ecological Monographs 20: 271315

Heidal, B., S. V. Cooper and C. Jean. 2000. Plant species of special concern and plant associations of Sheridan County, Montana. Report to the U.S. Fish and Wildlife Service. Montana Natural Heritage Program, Helena, Montana.

Rintoul, J. 1985. Silver Valley: Biophysical Resource Analysis. Alberta Forestry, Lands and Wildlife. 
Wallis, C. and C. Wershler. 1981. Kootenay Plains Flora and Grassland Vegetation Assessment - 1981. Alberta Energy and Natural Resources.

Willoughby, M. G. 1999. Range plant community types and carrying capacity for the Subalpine and Alpine Subregions - first approximation. Environmental protection, Land and Forest Service, Edmonton, AB.

Willoughby, M. G., M. J. Alexander and K. M. Sundquist. 1998. Range plant community types and carrying capacity for the Montane Subregion of Alberta - third approximation. Environmental Protection, Lands and Forest Services, Edmonton, AB.

Willoughby, M. G. and the Rangeland Health Assessment Project and Forest Rangeland Action Plan. 2000. Guide to range plant community types and carrying capacity for the Dry and Central Mixedwood Subregions in Alberta - third approximation. Alberta Environment, Land and Forest Service and Alberta Agriculture, Food and Rural Development, Public Lands Division, Edmonton, AB. 


\section{COMMUNITY CHARACTERIZATION ABSTRACT}

Agropyron dasystachyum - Stipa comata Herbaceous Vegetation

\section{IDENTIFIERS}

SEL.SUMMARY: This community type is locally prevalent in one area on the west side of the North Saskatchewan River, in the central portion of the Kootenay Plains area (Wallis and Wershler 1981). It occupies the toe edge of alluvial fans, with well-drained soils characterized by submesic moisture regimes. Coupland (1950) described this community for undulating to gently rolling areas with medium textured soils of dark-brown soil zone in the mixed prairie of Canada. More details on this community type from the Milk River area are given by Adams and Moisey (1999). In the Milk River area this community occupies landscapes with well-drained soils (slope $1-4 \%$ ), situated on sites upslope from the western wheat grass and the northern wheat grass western wheat grass community types. Soils are mainly Orthic Brown Chernozems with minor components of Calcareous Brown and Solonetzic Brown Chernozems. The same community type may also exist in the southwestern Alberta in shallow black soil zone and on black soils when grazing pressure allowed Agropyron species to replace more palatable fescues (Moss 1944). In the Kootenay Plains area, Agropyron dasystachyum and Stipa comata dominate, contributing 26 $50 \%$ to the ground cover each. Artemisia frigida (16 - 25\%), Koeleria macrantha (6 - 15\%), and Agropyron subsecundum (6-15\%) are the few major species in this community, while Astragalus agrestis, Linum lewisii, Antennaria nitida, Solidago decumbens, Orthocarpus luteus, Agropyron smithii, and Festuca saximontana are present with very low covers. Lichens cover up to $25 \%$ of the ground. Coupland (1950) noted that the three dominant specie of this community type within the mixed grass prairie, Agropyron dasystachyum, Stipa comata, and S. spartea var. curtiseta, contribute $43 \%$ to the ground cover, while sedges make up $25.5 \%$ of the total basal aria. Selaginella densa may cover up to $30 \%$ in disturbed areas. The principal subdominant grasses and sedges are Bouteloua gracilis, Koeleria macrantha, Carex filifolia, C. eleocharis and C. heliophila. Carex eleocharis may reach the same basal cover as Agropyron dasystachyum. Needle and thread, northern wheat grass, blue grama and plains reed grass dominate grasslands described for the Milk River area. Grasslands in the southwestern Alberta are also dominated by Agropyron dasystachyum, Stipa comata, and S. spartea var. curtiseta but also include some A. smithii and Festuca idahoensis.

SNAME: Agropyron dasystachyum - Stipa comata Herbaceous Vegetation

SCOMNAME: Northern wheat grass - needle-and-thread Herbaceous Vegetation

\section{CLASSIFICATION}

SYSTEM: Terrestrial

CLASS: Herbaceous vegetation

SUBCLASS: Perennial graminoid vegetation (grasslands)

GROUP: Temperate or subpolar grasslands 
FORMATION: Medium-tall sod temperate or subpolar grasslands

ALLIANCE: Agropyron dasystachyum Herbaceous Alliance

\section{CLASSIFICATION CONFIDENCE LEVEL: 2}

SSIMILAR COMMUNITIES: There are several similar community types from Alberta with Agropyron and Stipa components, but they differ from the Agropyron dasystachyum - Stipa comata community type by having a much higher importance of Agropyron smithii. In addition, Stipa curtiseta frequently replaces Stipa comata as a codominant species. Examples are: Agropyron smithii - Stipa curtiseta Herbaceous Vegetation (Wheeler 1976), Stipa curtiseta Agropyron smithii/A. dasystachyum Herbaceous Vegetation (Johnston et al. 1967), Stipa comata - Bouteloua gracilis - Agropyron smithii Herbaceous Vegetation (Coupland 1961, 1973 Johnston et al. 1967; Adams et al. 1997), Stipa - Agropyron Herbaceous Vegetation (Brierley et al.1989), and Stipa comata - Agropyron smithii Herbaceous Vegetation (Adams et al. 1997). The Elymus lanceolatus - Stipa comata community type from the Columbia River plains, Oregon (NatureServe 2000) differs from the Agropyron dasystachyum - Stipa comata community type from Alberta by its very low cover of Stipa comata, and by being a very open community of sandy soils.

Other similar communities include: Agropyron dasystachyum - Agropyron smithii Herbaceous Vegetation (Adams 1981, Adams and Moisey 1999), Agropyron dasystachyum - Koeleria macrantha - Artemisia frigida Herbaceous Vegetation (Wallis and Wershler 1981, Corns and Achuff 1982, Rintoul 1985, Beckginham et al. 1996, Willoughby et al. 2000, this report), Agropyron dasystachyum - Agropyron subsecundum Herbaceous Vegetation (Wallis and Wershler 1981) and Agropyron dasystachyum - Antennaria nitida Herbaceous Vegetation (Wallis and Wershler 1981) from Alberta, as well as Elymus lanceolatus - Koeleria macrantha from Saskatchewan (Coupland 1950), Elymus lanceolatus - (Koeleria macrantha) Herbaceous Vegetation from Sheridan County, Montana (Heidel et al. 2000), and Elymus lanceolatus Bouteloua gracilis Herbaceous Vegetation from Sheridan County, Montana (Heidel et al. 2000). Although Koeleria macrantha, Agropyron subsecundum and Bouteloua gracilis may occasionally attain significant ground cover, these species, as well as Agropyron smithii and Antennaria nitida, never codominate in the Agropyron dasystachyum - Stipa comata Herbaceous Vegetation community type. In addition, generally low cover or absence of Stipa comata separates the aforementioned communities from the Agropyron dasystachyum - Stipa comata Herbaceous Vegetation community type.

\section{RELATED NOMENCLATURE}

SOTHER.NAMES: Stipa - Agropyron faciation of Mixed Prairie (Stipa - Bouteloua) association Coupland (1950); needle and thread - northern wheat grass - blue grama - plains reed grass (Adams and Moisey 1999); Agropyron - Stipa - Carex associes of southwestern Alberta (Moss 1944); and Elymus lanceolatus - Stipa comata Herbaceous Vegetation from Sheridan County, Montana (Heidel et al. 2000).

SOTHER.NAMES.RELATION.NOTE: The Agropyron dasystachyum - Stipa comata community type may be the same community as Stipa - Agropyron faciation of the Mixed Prairie 
(Stipa - Bouteloua) association described by Coupland (1950); it may also be included in the Agropyron - Stipa - Carex associes of southwestern Alberta (Moss 1944); the Agropyron dasystachyum - Stipa comata community type and needle and thread - northern wheat grass blue grama - plains reed grass community type described by Adams and Moisey (1999) are probably closely related community types based on the dominance of Agropyron dasystachyum and Stipa comata; the Elymus lanceolatus - Stipa comata Herbaceous Vegetation from Sheridan County, Montana (Heidel et al. 2000) is probably the same community type as the Agropyron dasystachyum - Stipa comata community type from Canadian mixed grass prairie.

SNAMES.COM: Agropyron dasystachyum - Stipa comata community type may be the same community as Stipa - Agropyron faciation of Mixed Prairie (Stipa - Bouteloua) association described by Coupland (1950), although the later one includes species that are missing from the Rocky Mountain community such as Selaginella densa and Carex eleocharis; it may also be included in the Agropyron - Stipa - Carex associes of southwestern Alberta (Moss 1944), where the later community type describes the vegetation at much broader scale and includes areas with significant covers of Agropyron smithii, Stipa curtiseta, Bouteloua gracilis and Cares eleocharis; the Agropyron dasystachyum - Stipa comata community type and needle and thread - northern wheat grass - blue grama - plains reed grass community type described by Adams and Moisey (1999) are probably closely related community types based on the dominance of Agropyron dasystachyum and Stipa comata; the Elymus lanceolatus - Stipa comata Herbaceous Vegetation from Sheridan County, Montana (Heidel et al. 2000) is probably the same community type as the Agropyron dasystachyum - Stipa comata community type from Canadian mixed grass prairie.

\section{DISTRIBUTION}

SNATREG: Rocky Mountains, Grasslands

SSUBREG: Montane, Dry Mixedgrass, possibly Foothills Fescue (Moss 1994)

SRANGE: This community is limited in distribution to southern Alberta and the Montane Subregion of westcentral Alberta

SRANGECOM: Besides one documented site in the Kootenay Plains area, and one in the Milk River Natural Area, the precise location of other sites occupied by this community within Alberta is unknown.

SDISTRIBUTION.COM: This community occurs within the Rocky Mountains Natural Region (Montane Subregion) and the Grasslands Natural Region (Dry Mixedgrass and possibly Foothills Fescue Subregions). Besides one location documented site in the Kootenay plains area, and one in the Milk River Natural Area, the precise location of other sites occupied by this community within Alberta is unknown.

\section{ENVIRONMENTAL FACTORS}

STOP.POSITION: Toe edge of an alluvial fan site (Wallis and Wershler 1981)

SSLOPE: 1 - 4\% (Adams and Moisey 1999) 
SSOIL.TYPE: Orthic Brown Chernozems with minor importance of Calcareous Brown and Solonetzic Brown Chernozems (Adams and Moisey 1999), possibly on shallow black and black soils (Moss 1944)

SSOIL.MOSTURE: Submesic moisture regimes(Wallis and Wershler 1981)

SSOIL.COM: Well-drained soils

SENVIRO.COM: This community type occupies the toe edge of an alluvial fan, with welldrained soils characterized by submesic moisture regimes in the Kootenay Plains study site (Wallis and Wershler 1981). It is also known from undulating to gently rolling areas with medium textured soils of the dark-brown soil zone in the mixed prairie of Saskatchewan and possibly Alberta (Coupland 1950). In the Milk River area this community occupies gentle slopes ( 1 - 4\%) with well-drained Orthic Brown Chernozems, Calcareous Brown and Solonetzic Brown Chernozems (Adams and Moisey 1999). The same community type may also exist in the southwestern Alberta on shallow black or black soils.

\section{BIOLOGICAL AND STRUCTURAL DESCRIPTION}

\section{6a VEGETATION}

SMOST.ABUND.SPP: Agropyron dasystachyum, Stipa comata

SCONSTANT.SPP: Agropyron dasystachyum, Stipa comata, possibly Koeleria macrantha

SVEGETATION.COM: In the Kootenay Plains area, Agropyron dasystachyum and Stipa comata dominate, contributing $26-50 \%$ to the ground cover each. Artemisia frigida (16-25\%), Koeleria macrantha (6-15\%), and Agropyron subsecundum (6 - 15\%) are the few major species in this community, while Astragalus agrestis, Linum lewisii, Antennaria nitida, Solidago decumbens, Orthocarpus luteus, Agropyron smithii, and Festuca saximontana are present with very low covers. Lichens cover up to $25 \%$ of the ground. Within the mixed grass prairie, the three dominant species of this community, Agropyron dasystachyum, Stipa comata, and S. spartea var. curtiseta, contribute $43 \%$ to the ground cover, while sedges make up $25.5 \%$ of the total basal area (Coupland 1950). Selaginella densa may cover up to $30 \%$ in disturbed areas. The principal subdominant grasses and sedges are Bouteloua gracilis, Koeleria macrantha, Carex filifolia, $C$. eleocharis and C. heliophila. Carex eleocharis may reach the same basal cover as Agropyron dasystachyum. Needle and thread, northern wheat grass, blue grama and plains reed grass dominate grasslands described for the Milk River area. Grasslands in the southwestern Alberta are also dominated by Agropyron dasystachyum, Stipa comata, and S. spartea var. curtiseta but also include some A. smithii and Festuca idahoensis.

\section{6c VARIABILITY}

SSPP.COMP.VAR: In addition to the two dominant species, Artemisia frigida, Koeleria macrantha, and Agropyron subsecundum are additional major species of this community in the Kootenay Plains area. Lichens also cover up to $25 \%$ of the ground. Within the mixed grass 
prairie, Stipa curtiseta becomes codominant with Stipa comata and Agropyron dasystachyum. Sedges (especially C. eleocharis), Selaginella densa (mostly in disturbed areas), and Bouteloua gracilis, are also important components of this community type in the Grassland Natural Region. Calamagrostis montanensis is a prominent component of this community described for the Milk River area. A. smithii and Festuca idahoensis are some of the additional species in grasslands from the southwestern Alberta

SVARIABIITY.COM: In addition to the two dominant species, Artemisia frigida, Koeleria macrantha, and Agropyron subsecundum are additional major species of this community in the Kootenay Plains area. Lichens also cover up to $25 \%$ of the ground. Within the mixed grass prairie, Stipa curtiseta becomes codominant with Stipa comata and Agropyron dasystachyum. Sedges (especially C. eleocharis), Selaginella densa (mostly in disturbed areas), and Bouteloua gracilis, are also important components of community type in the Grassland Natural Region. Calamagrostis montanensis is a prominent component of this community described for the Milk River area. It is also important to note that Coupland $(1950,1961)$ reported that changes in soil moisture conditions over the landscape dictated the shift in species composition; the abundance of Agropyron smithii and Stipa comata increased at the expense of $A$. dasystachyum and $S$. spartea var. curtiseta under drier local conditions and/or as a result of disturbances. A. smithii and Festuca idahoensis are some of the additional species in grasslands from the southwestern Alberta. Moss (1944) also noted that in this community from the southwestern Alberta Agropyron species dominated over Stipa species on heavier lowland soils, while the opposite situation occurred under lighter and better drained soils.

\section{DYNAMIC PROCESSES}

SNAT.DISTURBANCE: Drought

SSUCCESS.DYNAM.COM: Drought

\section{SPATIAL RELATIONS}

SADJACENT.COMMUNITIES: In the Milk River area this community is situated on slopes above the western wheat grass and the northern wheat grass - western wheat grass community types.

SSPATIAL.COM: In the Milk River area this community is situated above the western wheat grass and the northern wheat grass - western wheat grass community types.

\section{STATUS}

SRANK: S1S2

SREASONS: Besides one documented site in the Kootenay plains area, and one in the Milk River Natural Area, the precise number and location of other sites occupied by this community within Alberta is unknown. 
SSTATCOM: Besides one documented site in the Kootenay plains area, and one in the Milk River Natural Area, the precise number and location of sites occupied by this community within Alberta is unknown. until further sites are documented, this community should be placed on the provincial tracking list and ranked S1S2.

\section{ANALYSIS PROCEDURES AND DATA MANAGEMENT}

SANALYSIS.COM: Coupland (1950) collected vegetation data by point transects (for basal area and percent composition) and list quadrats (for the relative abundance of subdominant species). In addition to total basal area, the distribution of subdominant species was used to differentiate subtypes within major communities. Wallis and Wershler (1981) recorded detailed canopy coverage within representative $1 \times 1 \mathrm{~m}$ plots, which were nested within $15 \mathrm{~m}$ diameter sampling areas. Additional information on species presence was collected within $15 \mathrm{~m}$ diameter sampling areas. The authors did not perform any cluster or ordination analyses on their data. For their vegetation classification, Adams and Moisey (1999) used estimated percent cover of vascular plant species, mosses, lichens and exposed mineral soil in $20 \times 50 \mathrm{~cm}$ plots located along transects at about $5 \mathrm{~m}$ intervals. Vegetation was classified based on classification and ordination analyses using PC-ORD software. Moss (1944) listed plant species, their relative coverage and frequency, and noted environmental conditions influencing different community types.

SANALYSIS.DATA.MANAGE.COM: Coupland (1950) collected vegetation data by point transects (for basal area and percent composition) and list quadrats (for the relative abundance of subdominant species). In addition to total basal area, the distribution of subdominant species was used to differentiate subtypes within major communities. Wallis and Wershler (1981) recorded detailed canopy coverage within representative $1 \times 1 \mathrm{~m}$ plots, which was nested within $15 \mathrm{~m}$ diameter sampling areas. Additional information on species presence was collected within $15 \mathrm{~m}$ diameter sampling areas. The authors did not perform any cluster or ordination analyses on their data. For their vegetation classification, Adams and Moisey (1999) used estimated percent cover of vascular plant species, mosses, lichens and exposed mineral soil in $20 \times 50 \mathrm{~cm}$ plots located along transects at about $5 \mathrm{~m}$ intervals. Vegetation was classified based on classification and ordination analyses using PC-ORD software. Plot data is stored in the Prairie Data Base (PLD AAFRD), Public Lands - Alberta Agriculture, Food and Rural Development, Lethbridge. Moss (1944) listed plant species, their relative coverage and frequency, and noted environmental conditions influencing different community types.

\section{GENERAL COMMENTS}

SCOMMUNITY.COM: Heidel et al. (2000) believe that this community represents the "missing link" between the prevailing Pascopyrum smithii - Stipa comata - Bouteloua gracilis association of the U.S. Great Plains and the prevailing Elymus lanceolatus - Stipa curtiseta association of the Canadian Great Plains. Heidel et al. (2000) also suggested that this association falls within the "Stipa - Agropyron faciation" of Coupland (1950).

\section{REFERENCES}

\section{CITATION:}


Adams, B. 1981. Range Ecology and the impact of livestock grazing on the Peace River Slopes, Alberta. Public Lands Division,

Adams, G. D., G. C. Trottier, W. L. Strong, I. D. MacDonald, S. J. Barry, P. G. Gregoire, G. W. Babish and G. Weiss. 1997. Vegetation component report: Canadian Forces Base Suffield national Wildlife area - Wildlife Inventory. Report prepared for the Canadian Wildlife Service, Environment Canada, Edmonton, AB.

Adams, B and D. Moisey. 1999. Analysis of vegetation and soil monitoring records for Milk River Natural Area and Kennedy Creek Ecological Reserve. 1999. Public Lands, Alberta Agriculture, Food and Rural Development, Lethbridge

Beckingham, J.D., I. G. W. Corns and J. H. Archibald. 1996. Field Guide to Ecosites of WestCentral Alberta. Canadian Forest Service Special Report No.9, Northern Forestry Centre, Edmonton, $\mathrm{AB}$.

Brierley, D., D. Bradshaw, and D. Downing. 1989. Milk River Natural Area - biophysical inventory - southern uplands. Report prepared for Alberta Forestry, Lands and Wildlife, land information services division, resource Information Branch, Edmonton, AB.

Corns, I. G. W. and P. L. Achuff. 1982. Vegetation type descriptions in W. D. Holland and G. M. Coen (eds.). Ecological (Biophysical) Land Classification of Banff and Jasper National Parks. Alberta Institute of Pedology, Publication No. SS-82-44.

Coupland, R. T. 1950. Ecology of mixed prairie in Canada. Ecological Monographs 20: 271315

Coupland, R. T. 1961. A reconstruction of grassland classification in the northern Great Plains of North America. Journal of Ecology 49:135-167.

Coupland, R. T. 1973. A theme study of natural grasslands in western Canada. A Report to National and Historic Parks Branch Canada, Department of Indian affairs and Northern Development.

Heidal, B., S. V. Cooper and C. Jean. 2000. Plant species of special concern and plant associations of Sheridan County, Montana. Report to the U.S. Fish and Wildlife Service. Montana Natural Heritage Program, Helena, Montana.

Johnston, A., S. Smoliak, L. M. Forbes, and J. A. Campbell. 1967. Alberta Range Management Guide. Albert department of Agriculture, Lands and Forests. Publication No. 134/14

Moss, E. H. 1944. The prairie and associated vegetation of southwestern Alberta. Canadian Journal of Research 22:11-31.

NatureServe 2000. An online encyclopedia of life [web application]. 2000. Version 1.0. Arlington (VA): Association for Biodiversity Information. Available: http://www.natureserve.org 
Rintoul, J. 1985. Silver Valley: Biophysical Resource Analysis. Alberta Forestry, Lands and Wildlife.

Wallis, C. and C. Wershler. 1981. Kootenay Plains Flora and Grassland Vegetation Assessment - 1981. Alberta Energy and Natural Resources.

Willoughby, M. G. and the Rangeland Health Assessment Project and Forest Rangeland Action Plan. 2000. Guide to range plant community types and carrying capacity for the Dry and Central Mixedwood Subregions in Alberta - third approximation. Alberta Environment, Land and Forest Service and Alberta Agriculture, Food and Rural Development, Public Lands Division, Edmonton, AB.

Wheeler, G. H. 1976. Some grasslands and shrubland communities in the parklands of central Alberta. M.Sc. thesis, Department of Plant Science, University of Alberta, Edmonton, Alberta. 
COMMUNITY CHARACTERIZATION ABSTRACT

Agropyron dasystachyum - Agropyron subsecundum Herbaceous Vegetation

\section{IDENTIFIERS}

SEL.SUMMARY: This community type was described for only one location on a river terrace in the Kootenay Plains area (Wallis and Wershler 1981). Soils are well drained with submesic moisture regimes. Agropyron dasystachyum and Agropyron subsecundum codominate contributing about $50-75 \%$ to the ground cover. Linum lewisii $(5-15 \%)$ is the only abundant forb species. The additional species characterizing this community type (with very low cover) include Astragalus striatus, A. tenellus, Oxytropis sericea, Gentianella amarella, Achillea millefolium, Artemisia dracunculus, A. frigida, and Solidago decumbens.

SNAME: Agropyron dasystachyum - Agropyron subsecundum Herbaceous Vegetation

SCOMNAME: Northern wheat grass - slender wheat grass Herbaceous Vegetation

\section{CLASSIFICATION}

SYSTEM: Terrestrial

CLASS: Herbaceous vegetation

SUBCLASS: Perennial graminoid vegetation (grasslands)

GROUP: Temperate or subpolar grasslands

FORMATION: Medium-tall sod temperate or subpolar grasslands

ALLIANCE: Agropyron dasystachyum Herbaceous Alliance

\section{CLASSIFICATION CONFIDENCE LEVEL: 1}

SSIMILAR COMMUNITIES: The Agropyron dasystachyum Herbaceous Vegetation community (Jaques and vanEck 1979, Wallis and Wershler 1981, Adams et al. 1997, Willoughby et al. 1998, Willoughby 1999) is solely dominated by Agropyron dasystachyum and generally lacks Agropyron subsecundum. Although Agropyron subsecundum may be locally abundant in the Agropyron dasystachyum - Artemisia dracunculus - Artemisia frigida Herbaceous Vegetation community (Wallis and Wershler 1981), this community separates from the Agropyron dasystachyum - Agropyron subsecundum Herbaceous Vegetation community by having a much higher ground cover of Artemisia dracunculus and Artemisia frigida.

\section{DISTRIBUTION}

SNATREG: Rocky Mountain

SSUBREG: Montane 
SRANGECOM: This community type occurs only on one site on a river terrace in the Kootenay Plains area.

SDISTRIBUTION.COM: This community type occurs only in one area on a river terrace in the Kootenay Plains area (Rocky Mountain Natural Region - Montane Subregion)

\section{ENVIRONMENTAL FACTORS}

SLANDFORM: River terrace

STOP.POSITION: Depressional site

SENVIRO.COM: This community type occurs in depression on a river terrace.

6. BIOLOGICAL AND STRUCTURAL DESCRIPTION

6a VEGETATION

SSTRATA LIFEFORM: Herb

SPCT.COVER: Herb (51 - 75\%)

SHEIGHT: $30-80 \mathrm{~cm}$

SMOST.ABUND.SPP: Agropyron dasystachyum and Agropyron subsecundum

SVEGETATION.COM: Agropyron dasystachyum and Agropyron subsecundum codominate contributing about $50-75 \%$ to the ground cover. Linum lewisii $(5-15 \%)$ is the only abundant forb species. The additional species characterizing this community type, but with very low covers, include Astragalus striatus, A. tenellus, Oxytropis sericea, Gentianella amarella, Achillea millefolium, Artemisia dracunculus, A. frigida, and Solidago decumbens. Scattered patches of shrub species, Juniperus horizontalis and Shepherdia canadensis, occur within the community.

\section{SPATIAL RELATIONS}

SSIZE: Probably less than 1 ha

SSPATIAL.COM: Probably less than 1 ha

\section{STATUS}

SRANK: S1

SREASONS: This community type occurs only in one area on a river terrace in the Kootenay Plains area (Rocky Mountain Natural Region - Montane Subregion) 
SSTATCOM: This community type occurs only in one area on a river terrace in the Kootenay Plains area (Rocky Mountain Natural Region - Montane Subregion); it should be placed on the community tracking list and ranked S1

\section{MANAGEMENT}

SECONCOM: Grazing noted

SMANAGECOM: Grazing noted

\section{ANALYSIS PROCEDURES AND DATA MANAGEMENT}

SANALYSIS.COM: Wallis and Wershler (1981) recorded detailed canopy coverage within representative $1 \times 1 \mathrm{~m}$ plots, which were nested within $15 \mathrm{~m}$ diameter sampling areas. Additional information on species presence was collected within $15 \mathrm{~m}$ diameter sampling areas. The authors did not perform any cluster or ordination analyses on their data.

SANALYSIS.DATA.MANAGE.COM: Wallis and Wershler (1981) recorded detailed canopy coverage within representative $1 \times 1 \mathrm{~m}$ plots, which were nested within $15 \mathrm{~m}$ diameter sampling areas. Additional information on species presence was collected within $15 \mathrm{~m}$ diameter sampling areas. The authors did not perform any cluster or ordination analyses on their data.

\section{REFERENCES}

\section{CITATION:}

Adams, G. D., G. C. Trottier, W. L. Strong, I. D. MacDonald, S. J. Barry, P. G. Gregoire, G. W. Babish and G. Weiss. 1997. Vegetation component report: Canadian Forces Base Suffield national Wildlife area - Wildlife Inventory. Report prepared for the Canadian Wildlife Service, Environment Canada, Edmonton, AB.

Jaques, D. \& P. Van Eck. 1979. Biophysical Features and Recommendations for Recreational Development in the Kakwa Falls Region, Alberta. Kananaskis Center for Environmental Research, U of C.

Wallis, C. and C. Wershler. 1981. Kootenay Plains Flora and Grassland Vegetation Assessment - 1981. Alberta Energy and Natural Resources.

Willoughby, M. G. 1999. Range plant community types and carrying capacity for the Subalpine and Alpine Subregions - first approximation. Environmental protection, Land and Forest Service, Edmonton, AB.

Willoughby, M. G., M. J. Alexander and K. M. Sundquist. 1998. Range plant community types and carrying capacity for the Montane Subregion of Alberta - third approximation.

Environmental Protection, Lands and Forest Services, Edmonton, AB. 


\section{COMMUNITY CHARACTERIZATION ABSTRACT}

Juniperus horizontalis - Arctostaphylos uva-ursi / Agropyron dasystachyum - Elymus innovatus Dwarf Shrub Herbaceous Vegetation

\section{IDENTIFIERS}

SEL.SUMMARY: This community type occurs on nearly level terrain on valley floors to middle slope positions within Rocky Mountain Natural Region (Montane Subregion) (elevation range of 1036 to $1372 \mathrm{~m}$ ) (community \#53 in this report). Soils are rapidly to moderately well drained soils with subxeric to subhygric moisture regimes and submesotrophic to mesotrophic nutrient regimes. Juniperus horizontalis and Agropyron dasystachyum are the most abundant species; Potentilla fruticosa; Juniperus horizontalis, Arctostaphylos uva-ursi, Agropyron dasystachyum and Elymus innovatus occur in each stand of this community. Juniperus horizontalis, Arctostaphylos uva-ursi and Elymus innovatus are the three characteristic species; tree and shrub species such as Picea glauca, Pinus contorta, Shepherdia canadensis and Salix spp. may reach significant cover in some stands, but none of them are constant species.

SNAME: Juniperus horizontalis - Arctostaphylos uva-ursi / Agropyron dasystachyum - Elymus innovatus Dwarf Shrub Herbaceous Vegetation

SCOMNAME: Creeping juniper - common bearberry / northern wheat grass - hairy wild rye Dwarf Shrub Herbaceous Vegetation

\section{CLASSIFICATION}

SYSTEM: Terrestrial

CLASS: Herbaceous vegetation

SUBCLASS: Perennial graminoid vegetation (grasslands)

GROUP: Temperate or subpolar grassland with a sparse dwarf-shrub layer

FORMATION: Short temperate or subpolar lowland grassland with a sparse needle-leaved or microphyllous dwarf-shrub layer

ALLIANCE: Agropyron dasystachyum Herbaceous Alliance

CLASSIFICATION CONFIDENCE LEVEL: 2

\section{DISTRIBUTION}

SNATREG: Rocky Mountain 


\section{ENVIRONMENTAL FACTORS}

SMINELEV: $1036 \mathrm{~m}$

SMAXELEV: $1372 \mathrm{~m}$

\section{SLANDFORM:}

STOP.POSITION: Valley floor to middle slope macro site positions; middle slope to upper slope meso site positions

SSLOPE: $5 \%$

SASPECT: Median $180^{\circ}\left(89-272^{\circ}\right)$

SSOIL.MOSTURE: Subxeric to subhygric

SSOIL.COM: Rapidly to moderately well drained soils with submesotrophic to mesotrophic nutrient regimes

SENVIRO.COM: This community type occurs on nearly level terrain on valley floors to middle slope positions within elevation range of 1036 to $1372 \mathrm{~m}$. Soils are rapidly to moderately well drained with subxeric to subhygric moisture regimes and submesotrophic to mesotrophic nutrient regimes.

\section{BIOLOGICAL AND STRUCTURAL DESCRIPTION}

\section{6a VEGETATION}

SSTRATA LIFEFORM: tree; shrub; dwarf shrub; herb

SPCT.COVER: tree $11 \%$; shrub $18.7 \%$; dwarf shrub $18.6 \%$; herb $63.7 \%$

SMOST.ABUND.SPP: Juniperus occidentalis, Agropyron dasystachyum

SUNVEGETATED.SURFACE: Mineral soil, organic matter

SUNVEGETATED.SURFACE COVER: Mineral soil (2 - 10\%), organic matter (85 - 95\%)

SCONSTANT.SPP: Potentilla fruticosa; Juniperus occidentalis, Arctostaphylos uva-ursi; Agropyron dasystachyum, Elymus innovatus

SCHARACTERISTIC.SPP: Juniperus occidentalis, Arctostaphylos uva-ursi; Elymus innovatus

SVEGETATION.COM: Juniperus occidentalis and Agropyron dasystachyum are the most abundant species; Potentilla fruticosa; Juniperus occidentalis, Arctostaphylos uva-ursi, 
Agropyron dasystachyrm and Elymus innovatus occur in each stand of this community; Juniperus occidentalis, Arctostaphylos uva-ursi and Elymus innovatus are the three characteristic species; tree and shrub species, such as Picea glauca, Pinus contorta, Shepherdia canadensis, and Salix spp. may reach significant cover in some stands, but none of them are constant species.

\section{SPATIAL RELATIONS}

SADJACENT.COMMUNITIES: Probably Picea glauca and Pinus contorta dominated stands SSPATIAL.COM: Picea glauca and Pinus contorta dominated stands may be the adjacent stands

\section{STATUS}

SRANK: SU

SREASONS: Classification based solely on the ESIS database analysis; additional, more detailed study is needed to confirm the similarity in vegetation composition between plots and the validity of the classification for this community type.

SSTATCOM: Classification based solely on the ESIS database analysis; additional, more detailed study is needed to confirm the similarity in vegetation composition between plots and the validity of the classification for this community type; until further information is available, this community should be ranked SU.

\section{ANALYSIS PROCEDURES AND DATA MANAGEMENT}

SANALYSIS.COM: Cluster and ordination analysis of the combined ESIS database and the Waterton Lakes database was performed by Geowest personnel. Cluster analysis included species data from 416 plots. Ordination analysis related vegetation data from 120 plots to the following environmental variables: solar radiation (combines slope, aspect, and latitude), drainage class, moisture regimes, elevation, latitude, and longitude (last two variables represent macroclimatic variables - NW position in the province coincides with cooler and wetter climate as oppose to the $\mathrm{SE}$ end of the province). In addition to ordination, descriptive statistics (median, minimum, maximum) were calculated for environmental variables. These calculations were done in SPSS for Windows and included both variables used in the ordination and variables with a lot of missing data (soil drainage, site position - macro, site position - meso, nutrient regimes, $\%$ bedrock, $\%$ mineral soil, and \% organic material. The information on Natural Subregion was taken from the GIS based on the geographical position of each plot.

SANALYSIS.DATA.MANAGE.COM: Cluster and ordination analysis of the combined ESIS database and Waterton Lakes database was performed by Geowest personnel. Cluster analysis included species data from 416 plots. Ordination analysis related vegetation data from 120 plots to the following environmental variables: solar radiation (combines slope, aspect, and latitude), drainage class, moisture regimes, elevation, latitude, and longitude (last two variables represent macroclimatic variables - NW position in the province coincides with cooler and wetter climate as oppose to the SE end of the province). In addition to ordination, descriptive statistics (median, minimum, maximum) were calculated for environmental variables. These calculations were done 
in SPSS for Windows and included both variables used in the ordination and variables with a lot of missing data (soil drainage, site position - macro, site position - meso, nutrient regimes, \% bedrock, \% mineral soil, and \% organic material. The information on Natural Subregion was taken from the GIS based on the geographical position of each plot. Ecological Site Inventory System (ESIS) electronic database is stored in the Resource Data Division of the Alberta Environment, Edmonton.

\section{GENERAL COMMENTS}

SCOMMUNITY.COM: Classification based solely on the ESIS database analysis; additional, more detailed study is needed to confirm the similarity in vegetation composition between plots and the validity of the classification for this community type. 


\section{COMMUNITY CHARACTERIZATION ABSTRACT Agropyron smithii Herbaceous Vegetation}

\section{IDENTIFIERS}

SEL.SUMMARY: This community type occupies slightly alkaline clay flats and some alluviated clay flats within the mixed grass prairie in Canada, where it is held in a subclimax stage in relation to the Agropyron-Koeleria faciation by the accumulation of soluble salts or by the deposition of sediments (Coupland 1950). In the Milk River Natural Area and the Kennedy Coulee Ecological Reserve, it occupies lower swale and depressional sites, with moderately well to imperfectly drained Brown Solonetz, Brown Solodized Solonetz and Brown Solods (possibly some Gleysolic soils) with clay and loamy textures (Wallis 1976; Brierley et al. 1989, Adams and Moisey 1999). This community is dominated solely by Agropyron smithii. Koeleria macrantha and Poa secunda are less common grasses, while Gutierrezia diversifolia and Phlox hoodii represent the principal forbs (Coupland 1950). It may also include species such as Bouteloua gracilis, Muhlenbergia richardsonis, Carex eleocharis, C. filifolia, Gutierrezia sarothrae, Phlox hoodii, Lomatium foeniculaceum, L. macrocarpum, Liatris punctata (Wallis 1976), Agropyron dasystachyum, Poa pratensis, Carex stenophylla, Artemisia ludoviciana and Eleocharis palustris (Adams and Moisey 1999). It may also have Deschampsia cespitosa, Beckmannia syzigachne, and Hordeum jubatum in moister depressions in lakebeds, and Poa juncifolia, Puccinellia spp. and Distichlis stricta in association with saline depressions (Brierley et al. 1989).

SNAME: Agropyron smithii Herbaceous Vegetation

SCOMNAME: Western wheat grass Herbaceous Vegetation

\section{CLASSIFICATION}

SYSTEM: Terrestrial

CLASS: Herbaceous vegetation

SUBCLASS: Perennial graminoid vegetation (grasslands)

GROUP: Temperate or subpolar grasslands

FORMATION: Medium-tall sod temperate or subpolar grasslands

ALLIANCE: Agropyron smithii Herbaceous Alliance

CLASSIFICATION CONFIDENCE LEVEL: 1

SSIMILAR COMMUNITIES: Similar community types include: Agropyron smithii - Artemisia ludoviciana Herbaceous Vegetation (Adams et al. 1997), Agropyron smithii - Bouteloua gracilis Herbaceous Vegetation (Brierley et al 1989, Comer et al. 1999), Agropyron smithii - Hordeum jubatum Herbaceous Vegetation (Wallis 1990), Distichlis stricta - Agropyron smithii Herbaceous Vegetation (Wallis 1990), Carex stenophylla - Agropyron smithii Herbaceous Vegetation 
(Adams et al. 1997, this report), and Koeleria cristata - Agropyron smithii Herbaceous Vegetation (Stacey 1927; Wroe 1971, Fehr 1982) community types (all from Alberta), as well as Distichlis stricta - Agropyron sp. Herbaceous Vegetation from Saskatchewan (Dodd and Coupland 1966) and Agropyron smithii - Bouteloua gracilis Herbaceous Vegetation from Saskatchewan and Montana (Coupland 1950, Comer et al. 1999, Heidel et al. 2000). Although Artemisia ludoviciana, Bouteloua gracilis, Distichlis stricta, Carex stenophylla (C. eleocharis) and Koeleria macrantha are frequently present in the Agropyron smithii Herbaceous Vegetation community, this community type differs from the aforementioned communities by the sole dominance of Agropyron smithii.

\section{RELATED NOMENCLATURE}

SOTHER.NAMES: Agropyron smithii Herbaceous Vegetation (Dodd and Coupland 1966); Pascopyrum smithii Herbaceous Vegetation (Heidel et al. 2000, NatureServe 2000).

SOTHER.NAMES.RELATION.NOTE: The Agropyron smithii Herbaceous Vegetation from Saskatchewan (Dodd and Coupland 1966) and the Pascopyrum smithii Herbaceous Vegetation from northern Montana (Heidel et al. 2000, NatureServe 2000) represent the same community type based on the sole dominance of $A$. smithii.

SNAMES.COM: The Agropyron smithii Herbaceous Vegetation from Saskatchewan (Dodd and Coupland 1966) and the Pascopyrum smithii Herbaceous Vegetation from northern Montana (Heidel et al. 2000, NatureServe 2000) represent the same community type based on the sole dominance of $A$. smithii.

\section{DISTRIBUTION}

SNATREG: Grassland

SSUBREG: Dry Mixedgrass, Mixedgrass

SRANGECOM: Reported from Milk River Natural Area, the Kennedy Coulee Ecological Reserve, and east of Manyberries

SDISTRIBUTION.COM: Reported from Milk River Natural Area, the Kennedy Coulee Ecological Reserve (Grassland Natural Region - Dry Mixedgrass Subregion), and east of Manyberries (Grassland Natural Region - Mixedgrass Subregion).

\section{ENVIRONMENTAL FACTORS}

SMINELEV: $754 \mathrm{~m}$ (this report)

SMAXELEV: $1066 \mathrm{~m}$

SLANDFORM: Include alluviated flats

STOP.POSITION: Lower, swale and depressional sites 
SSLOPE: Near level

SSOIL.TYPE: Brown Solonetz, Brown Solodized Solonetz and Brown Solods (possibly some Gleysolic soils)

SSOIL.COM: Soils are moderately well to imperfectly drained with clay and loam textures

SKEY.ENVIRO.FACTORS: Salinity seems to be the main factor influencing the dominance by Agropyron smithii

SENVIRO.COM: This community type occupies slightly alkaline clay flats and some alluviated clay flats within mixed grass prairie in Canada; in the Milk River Natural Area and the Kennedy Coulee Ecological Reserve it occupies lower, swale and depressional sites with moderately well to imperfectly drained Brown Solonetz, Brown Solodized Solonetz and Brown Solods (possibly some Gleysolic soils) with clay and loam textures (Wallis 1976; Brierley et al. 1989)

\section{BIOLOGICAL AND STRUCTURAL DESCRIPTION}

6a VEGETATION

SSTRATA LIFEFORM: Herb

SMOST.ABUND.SPP: Agropyron smithii.

SUNVEGETATED.SURFACE: Probably mineral soil

SUNVEGETATED.SURFACE COVER: Up to $50 \%$

\section{SCONSTANT.SPP: Agropyron smithii}

SVEGETATION.COM: This community is solely dominated by Agropyron smithii. Koeleria macrantha and Poa secunda are less common grasses, while Gutierrezia diversifolia and Phlox hoodii represent the principal forbs (Coupland 1950). It may also include species such as Bouteloua gracilis, Muhlenbergia richardsonis, Carex eleocharis, C. filifolia, Gutierrezia sarothrae, Phlox hoodii, Lomatium foeniculaceum, L. macrocarpum, Liatris punctata (Wallis 1976), Agropyron dasystachyum, Poa pratensis, Carex stenophylla, Artemisia ludoviciana and Eleocharis palustris (Adams and Moisey 1999). It may also have Deschampsia cespitosa, Beckmannia syzigachne, and Hordeum jubatum in moister depressions in lakebeds, and Poa juncifolia, Puccinellia spp. and Distichlis stricta in association with saline depressions (Brierley et al. 1989).

9. STATUS

SRANK: S2S3 
SREASONS: Reported from the Milk River Natural Area, the Kennedy Coulee Ecological Reserve (Grassland Natural Region - Dry Mixedgrass Subregion), and east of Manyberries (Grassland Natural Region - Mixedgrass Subregion). Based on the information on this community type provided by Coupland (1950), Wallis (1976), Brierley et al. (1989), Adams and Moisey (1999) and the cluster analysis from this report (community \#51), there may be about 20 individual occurrences.

SSTATCOM: Reported from the Milk River Natural Area, the Kennedy Coulee Ecological Reserve (Grassland Natural Region - Dry Mixedgrass Subregion), and east of Manyberries (Grassland Natural Region - Mixedgrass Subregion). Based on the information on this community type provided by Coupland (1950), Wallis (1976), Brierley et al. (1989), Adams and Moisey (1999) and the cluster analysis from this report (community \#51), there may be about 20 individual occurrences. Therefore, this community type should be placed on the provincial tracking list and ranked S2S3.

\section{ANALYSIS PROCEDURES AND DATA MANAGEMENT}

SANALYSIS.COM: Brierley et al. (1989) based their classification on both detailed and reconnaissance site information. On detailed sites they estimated vegetation cover within five to eight $20 \times 50 \mathrm{~cm}$ microplots arranged at a fixed distance $(100 \mathrm{~m})$ along transects. Vegetation data from detailed plots were grouped by species composition according to tabular methods described in Muller-Dombois and Ellenberg (1974). Plots with similar vegetation structure were grouped into plant communities. Coupland (1950) collected vegetation data by point transects (for basal area and percent composition) and list quadrats (for the relative abundance of subdominant species). In addition to total basal area, the distribution of subdominant species was used to differentiate subtypes within major communities. Wallis (1976) based his vegetation description on the reconnaissance survey. For their vegetation classification, Adams and Moisey (1999) used estimated percent cover of vascular plant species, mosses, lichen and exposed mineral soil in 20 $\times 50 \mathrm{~cm}$ plots located along transects at about $5 \mathrm{~m}$ intervals. Vegetation was classified based on classification and ordination analyses using PC-ORD software. Plot data is stored in the Prairie Data Base (PLD - AAFRD), Public Lands - Alberta Agriculture, Food and Rural Development, Lethbridge.

Cluster and ordination analysis of the combined ESIS database and Waterton Lakes database was performed by Geowest personnel. Cluster analysis included species data from 416 plots. Ordination analysis related vegetation data from 120 plots to the following environmental variables: solar radiation (combines slope, aspect, and latitude), drainage class, moisture regimes, elevation, latitude, and longitude (last two variables represent macroclimatic variables - NW position in the province coincides with cooler and wetter climate as oppose to the SE end of the province). In addition to ordination, descriptive statistics (median, minimum, maximum) were calculated for environmental variables. These calculations were done in SPSS for Windows and included both variables used in the ordination and variables with a lot of missing data (soil drainage, site position - macro, site position - meso, nutrient regimes, $\%$ bedrock, $\%$ mineral soil, and $\%$ organic material. The information on Natural Subregion was taken from the GIS based on the geographical position of each inventory plot. 
SANALYSIS.DATA.MANAGE.COM: Brierley et al. (1989) based their classification on both detailed and reconnaissance site information. On detailed sites they estimated vegetation cover within five to eight $20 \times 50 \mathrm{~cm}$ microplots arranged at a fixed distance $(100 \mathrm{~m})$ along transects. Vegetation data from detailed plots were grouped by species composition according to tabular methods described in Muller-Dombois and Ellenberg (1974). Plots with similar vegetation structure were grouped into plant communities. Coupland (1950) collected vegetation data by point transects (for basal area and percent composition) and list quadrats (for the relative abundance of subdominant species). In addition to total basal area, the distribution of subdominant species was used to differentiate subtypes within major communities. Wallis (1976) based his vegetation description on the reconnaissance survey. For their vegetation classification, Adams and Moisey (1999) used estimated percent cover of vascular plant species, mosses, lichens and exposed mineral soil in $20 \times 50 \mathrm{~cm}$ plots located along transects at about $5 \mathrm{~m}$ intervals. Vegetation was classified based on classification and ordination analyses using PCORD software. Plot data is stored in the Prairie Data Base (PLD - AAFRD), Public Lands Alberta Agriculture, Food and Rural Development, Lethbridge.

Cluster and ordination analysis of the combined ESIS database and Waterton Lakes database was performed by Geowest personnel. Cluster analysis included species data from 416 plots. Ordination analysis related vegetation data from 120 plots to the following environmental variables: solar radiation (combines slope, aspect, and latitude), drainage class, moisture regimes, elevation, latitude, and longitude (last two variables represent macroclimatic variables - NW position in the province coincides with cooler and wetter climate as oppose to the SE end of the province). In addition to ordination, descriptive statistics (median, minimum, maximum) were calculated for environmental variables. These calculations were done in SPSS for Windows and included both variables used in the ordination and variables with a lot of missing data (soil drainage, site position - macro, site position - meso, nutrient regimes, $\%$ bedrock, $\%$ mineral soil, and $\%$ organic material. The information on Natural Subregion was taken from the GIS based on the geographical position of each inventory plot. The Ecological Site Inventory System (ESIS) electronic database is stored in the Resource Data Division of Alberta Environment, Edmonton.

\section{REFERENCES}

\section{CITATION:}

Adams, G. D., G. C. Trottier, W. L. Strong, I. D. MacDonald, S. J. Barry, P. G. Gregoire, G. W. Babish and G. Weiss. 1997. Vegetation component report: Canadian Forces Base Suffield national Wildlife area - Wildlife Inventory. Report prepared for the Canadian Wildlife Service, Environment Canada, Edmonton, AB.

Adams, B and D. Moisey. 1999. Analysis of vegetation and soil monitoring records for Milk River Natural Area and Kennedy Creek Ecological Reserve. 1999. Public Lands, Alberta Agriculture, Food and Rural Development, Lethbridge

Brierley, D., D. Bradshaw, and D. Downing. 1989 Milk River Natural Area - biophysical inventory - southern uplands. Report prepared for Alberta Forestry, Lands and Wildlife, land information services division, resource Information Branch, Edmonton, AB. 
Comer, P., L. Allen, Steve Cooper, D. Faber-Langendoen, and G. Jones. 1999. Selected shrubland and grassland communities of the Northern Great Plains. A Report to Nebraska National Forest.

Coupland, R. T. 1950. Ecology of mixed prairie in Canada. Ecological Monographs 20: 271315

Dodd, J. D. and R. T. Coupland. 1966. Vegetation of saline Areas in Saskatchewan. Ecology 47: $958-967$

Fehr, Alan W. 1982. The Candidate Rumsey Ecological Reserve: A Biophysical Inventory. Alberta Energy and Natural Resources.

Heidal, B., S. V. Cooper and C. Jean. 2000. Plant species of special concern and plant associations of Sheridan County, Montana. Report to the U.S. Fish and Wildlife Service. Montana Natural Heritage Program, Helena, Montana.

Muller-Dombois, D., and H. Ellenberg. 1974. Aims and methods of vegetation ecology. Wiley, New York.

NatureServe: An online encyclopedia of life [web application]. 2000. Version 1.0. Arlington (VA): Association for Biodiversity Information. Available: http://www.natureserve.org

Stacey, E. C. 1927. Ecological studies on the native grasses of the Grande Prairie-Beaverlodge district.

Wallis, C. 1976. Milk River canyon resource evaluation. Report prepared for Planning and Design, Alberta Recreation, Parks, and Wildlife, Edmonton, AB.

Wallis, C. 1990. Reconnaissance survey of saline wetlands and springs in the GrasslandParkland region of Eastern Alberta. World Wildlife Fund, Canada

Wroe, R. A. 1971. Synecology of a Festuca scabrella Torr. grassland. Ph.D. thesis, Department of Plant Science, University of Alberta, Edmonton, Alberta. 


\section{COMMUNITY CHARACTERIZATION ABSTRACT \\ Agropyron smithii - Artemisia ludoviciana Herbaceous Vegetation}

\section{IDENTIFIERS}

SEL.SUMMARY: This community type occurs on sand plains in the Suffield National Wildlife Area, Dry Mixedgrass Subregion, where it occupies depressions and gentle slopes (2-9\%) with variable aspects (Adams et al. 1997). Soils are Orthic Regosols developed on morainal materials and include imperfectly to well drained sandy soils, well to rapidly drained loamy sands and well drained sandy loams. Agropyron smithii and Artemisia ludoviciana dominate with $42 \%$ and $9 \%$ ground cover, respectively. Other notable species include Carex stenophylla (6\%), Poa pratensis (4\%), Grindelia squarrosa and Chenopodium pratericola (last two with very low covers).

SNAME: Agropyron smithii - Artemisia ludoviciana Herbaceous Vegetation

SCOMNAME: Western wheat grass - prairie sagewort Herbaceous Vegetation

\section{CLASSIFICATION}

SYSTEM: Terrestrial

CLASS: Herbaceous vegetation

SUBCLASS: Perennial graminoid vegetation (grasslands)

GROUP: Temperate or subpolar grasslands

FORMATION: Medium-tall sod temperate or subpolar grasslands

ALLIANCE: Agropyron smithii Herbaceous Alliance

\section{CLASSIFICATION CONFIDENCE LEVEL: 1}

SSIMILAR COMMUNITIES: SSIMILAR COMMUNITIES: Although Artemisia ludoviciana may be present, the Agropyron smithii Herbaceous Vegetation community from Alberta (Coupland 1950, Wallis 1976, Brierley et al. 1989, Adams and Moisey 1999) and the Agropyron smithii Herbaceous Vegetation community from Saskatchewan and Montana (Dodd and Coupland 1966, Heidel et al. 2000, NatureServe 2000) differ from the Agropyron smithii Artemisia ludoviciana Herbaceous Vegetation community type by the sole dominance of Agropyron smithii. Much higher ground cover of Carex stenophylla and a general absence of Artemisia ludoviciana separate the Carex stenophylla - Agropyron smithii Herbaceous Vegetation community type (Adams et al. 1997, this report) from the Agropyron smithii Artemisia ludoviciana Herbaceous Vegetation community.

\section{DISTRIBUTION}

SNATREG: Grassland 
SSUBREG: Dry Mixedgrass

SRANGECOM: Reported only for the Suffield National Wildlife Area

SDISTRIBUTION.COM: Reported only from the Suffield National Wildlife Area (Grassland Natural Region, Dry Mixedgrass Subregion)

\section{ENVIRONMENTAL FACTORS}

SLANDFORM: Morainal

STOP.POSITION: Depressions

SSLOPE: $2-9 \%$

SASPECT: Variable

SSOIL.TYPE: Orthic Regosols

SSOIL.COM: Include imperfectly to well drained sandy soils, well to rapidly drained loamy sands and well drained sandy loams.

SENVIRO.COM: This community type occupies depressions and gentle slopes (2-9\%) with variable aspects; soils are Orthic Regosols developed on morainal materials and include imperfectly to well drained sandy soils, well to rapidly drained loamy sands and well drained sandy loams.

\section{BIOLOGICAL AND STRUCTURAL DESCRIPTION}

6a VEGETATION

SSTRATA LIFEFORM: Herb

SPCT.COVER: Herb $61 \%$

SMOST.ABUND.SPP: Agropyron smithii, Artemisia ludoviciana, Carex stenophylla

SCHARACTERISTIC.SPP: Artemisia ludoviciana

SVEGETATION.COM: Agropyron smithii and Artemisia ludoviciana dominate with $42 \%$ and $9 \%$ ground cover, respectively. Other notable species include Carex stenophylla (6\%), Poa pratensis (4\%), Grindelia squarrosa and Chenopodium pratericola (last two with very low covers).

\section{STATUS}




\section{SRANK: S1S2}

SREASONS: Reported only from one site within the Suffield National Wildlife Area (Grassland Natural Region, Dry Mixedgrass Subregion)

SSTATCOM: Reported only from one site within the Suffield National Wildlife Area (Grassland Natural Region, Dry Mixedgrass Subregion), but it may be more widespread; should be added to the community tracking list and ranked S1S2.

\section{ANALYSIS PROCEDURES AND DATA MANAGEMENT}

SANALYSIS.COM: Adams et al. (1997) collected the vegetation data (percent cover for each species) from a number of subsamples $(15-20 \mathrm{~cm} \times 50 \mathrm{~cm})$ located within circular $(200 \mathrm{~m}$ diameter) plots. Their vegetation classification was based on the manual grouping of subsamples using a cluster analysis dendrogram as a general guide. Plant communities were also associated with environmental factors, such as slope and aspect.

SANALYSIS.DATA.MANAGE.COM: Adams et al. (1997) collected the vegetation data (percent cover for each species) from a number of subsamples $(15-20 \mathrm{~cm} \times 50 \mathrm{~cm})$ located within circular ( $200 \mathrm{~m}$ diameter) plots. Their vegetation classification was based on the manual grouping of subsamples using a cluster analysis dendrogram as a general guide. Plant communities were also associated with environmental factors, such as slope and aspect.

\section{REFERENCES}

\section{CITATION:}

Adams, G. D., G. C. Trottier, W. L. Strong, I. D. MacDonald, S. J. Barry, P. G. Gregoire, G. W. Babish and G. Weiss. 1997. Vegetation component report: Canadian Forces Base Suffield national Wildlife area - Wildlife Inventory. Report prepared for the Canadian Wildlife Service, Environment Canada, Edmonton, AB.

Adams, B and D. Moisey. 1999. Analysis of vegetation and soil monitoring records for Milk River Natural Area and Kennedy Creek Ecological Reserve. 1999. Public Lands, Alberta Agriculture, Food and Rural Development, Lethbridge

Brierley, D., D. Bradshaw, and D. Downing. 1989 Milk River Natural Area - biophysical inventory - southern uplands. Report prepared for Alberta Forestry, Lands and Wildlife, land information services division, resource Information Branch, Edmonton, AB.

Coupland, R. T. 1950. Ecology of mixed prairie in Canada. Ecological Monographs 20: 271315

Dodd, J. D. and R. T. Coupland. 1966. Vegetation of saline Areas in Saskatchewan. Ecology 47: 958-967 
Heidal, B., S. V. Cooper and C. Jean. 2000. Plant species of special concern and plant associations of Sheridan County, Montana. Report to the U.S. Fish and Wildlife Service. Montana Natural Heritage Program, Helena, Montana.

NatureServe: An online encyclopedia of life [web application]. 2000. Version 1.0. Arlington (VA): Association for Biodiversity Information. Available: http://www.natureserve.org

Wallis, C. 1976. Milk River canyon resource evaluation. Report prepared for Planning and Design, Alberta Recreation, Parks, and Wildlife, Edmonton, AB. 


\section{COMMUNITY CHARACTERIZATION ABSTRACT \\ Agropyron smithii - Artemisia frigida Herbaceous Vegetation}

\section{IDENTIFIERS}

SEL.SUMMARY: This community type occurs in the Suffield National Wildlife Area, Dry Mixedgrass Subregion (Adams et al. 1997). It occupies various landforms/surficial materials with various soil types. These include: sand plains and sand dunes with well drained sandy Orthic Regosols; broad ravines with well drained sandy Orthic Brown Chernozems; glacio-fluvial terraces with well drained sand Orthic Regosols and Rego Brown Chernozems; glacio-fluvial terraces with well drained loamy sand Orthic Brown Chernozems; outwash plains with well drained Orthic and Rego Brown Chernozems and Orthic Regosols of loamy sand texture; undulating outwash and hummocky moraine with well drained Orthic and Rego Brown Chernozems of sandy loam texture; rolling moraine with well drained Orthic and Calcareous Brown Chernozems of sandy loam to loam texture; and, morainal deposits with thin eolian veneers with well to rapidly drained Orthic Brown Chernozems of loamy sand texture. No details were provided on the vegetation composition of this community type.

SNAME: Agropyron smithii - Artemisia frigida Herbaceous.Vegetation

SCOMNAME: Western wheat grass - pasture sagewort Herbaceous Vegetation

\section{CLASSIFICATION}

SYSTEM: Terrestrial

CLASS: Herbaceous vegetation

SUBCLASS: Perennial graminoid vegetation (grasslands)

GROUP: Temperate or subpolar grasslands

FORMATION: Medium-tall sod temperate or subpolar grasslands

ALLIANCE: Agropyron smithii Herbaceous Alliance

\section{CLASSIFICATION CONFDENCE LEVEL: 3}

SSIMILAR COMMUNITIES: Current information suggests that the codominance of Agropyron smithii and Artemisia frigida separates the Agropyron smithii - Artemisia frigida Herbaceous Vegetation community from other Agropyron smithii community types. However, lack of details on vegetation composition means no other comparisons can be made at this time.

\section{DISTRIBUTION}

SNATREG: Grassland 
SSUBREG: Dry Mixedgrass

SRANGECOM: Reported only for the Suffield National Wildlife Area

SDISTRIBUTION.COM: Reported only from the Suffield National Wildlife Area (Grassland Natural Region, Dry Mixedgrass Subregion)

\section{ENVIRONMENTAL FACTORS}

SLANDFORM: It occupies various landform/surficial materials, including: sand plains and sand dunes; broad ravines; glacio-fluvial terraces; outwash plains; undulating outwash and hummocky moraine; morainal deposits with thin eolian veneers.

SSLOPE: $0-45 \%$ (mostly $<10 \%)$

SSOIL.TYPE: Orthic Regosols, Orthic Brown Chernozems, Rego Brown Chernozems, Calcareous Brown Chernozems

SSOIL.COM: Well drained sandy Orthic Regosols; well drained sandy Orthic Brown Chernozems; well drained sandy Orthic Regosols and Rego Brown Chernozems; well drained loamy sand Orthic Brown Chernozems; well drained Orthic and Rego Brown Chernozems and Orthic Regosols of loamy sand texture; well drained Orthic and Rego Brown Chernozems of sandy loam texture; well drained Orthic and Calcareous Brown Chernozems of sandy loam to loam texture; well to rapidly drained Orthic Brown Chernozems of loamy sand texture.

SENVIRO.COM: It occupies various landform/surficial materials and various soil types. These include: sand plains and sand dunes with well drained sandy Orthic Regosols; broad ravines with well drained sandy Orthic Brown Chernozems; glacio-fluvial terrace with well drained sandy Orthic Regosols and Rego Brown Chernozems; glacio-fluvial terrace with well drained loamy sand Orthic Brown Chernozems; outwash plains with well drained Orthic and Rego Brown Chernozems and Orthic Regosols of loamy sand texture; undulating outwash and hummocky moraine with well drained Orthic and Rego Brown Chernozems of sandy loam texture; rolling moraine with well drained Orthic and Calcareous Brown Chernozems of sandy loam to loam texture; and, morainal deposits with thin eolian veneer with well to rapidly drained, Orthic Brown Chernozems of loamy sand texture.

\section{BIOLOGICAL AND STRUCTURAL DESCRIPTION}

6a VEGETATION

SMOST.ABUND.SPP: Agropyron smithii, Artemisia frigida

SVEGETATION.COM Agropyron smithii and Artemisia frigida are the most abundant species

9. STATUS

SRANK: SU 
SREASONS: Reported only from the Suffield National Wildlife Area (Grassland Natural Region, Dry Mixedgrass Subregion) but with a number of occurrences

SSTATCOM: Reported only from the Suffield National Wildlife Area (Grassland Natural Region, Dry Mixedgrass Subregion) but with a number of occurrences; Adams et al. (1997) did not provide any details on the vegetation composition for this community type, therefore, it should be ranked SU and all known sites should be revisited to document the actual vegetation composition.

\section{ANALYSIS PROCEDURES AND DATA MANAGEMENT}

SANALYSIS.COM: Adams et al. (1997) collected the vegetation data (percent cover for each species) from a number of subsamples $(15-20 \mathrm{~cm} \times 50 \mathrm{~cm})$ located within circular $(200 \mathrm{~m}$ diameter) plots. Their vegetation classification was based on the manual grouping of subsamples using cluster analysis dendrogram as a general guide. Plant communities were also associated with environmental factors such as slope and aspect. Since no details on vegetation composition were provided, this community type is probably based on a reconnaissance survey only.

SANALYSIS.DATA.MANAGE.COM: Adams et al. (1997) collected the vegetation data (percent cover for each species) from a number of subsamples $(15-20 \mathrm{~cm} \times 50 \mathrm{~cm})$ located within circular (200 $\mathrm{m}$ diameter) plots. Their vegetation classification was based on the manual grouping of subsamples using cluster analysis dendrogram as a general guide. Plant communities were also associated with environmental factors such as slope and aspect. Since no details on vegetation composition were provided, this community type is probably based on a reconnaissance survey only.

\section{REFERENCES}

\section{CITATION:}

Adams, G. D., G. C. Trottier, W. L. Strong, I. D. MacDonald, S. J. Barry, P. G. Gregoire, G. W. Babish and G. Weiss. 1997. Vegetation component report: Canadian Forces Base Suffield national Wildlife area - Wildlife Inventory. Report prepared for the Canadian Wildlife Service, Environment Canada, Edmonton, AB. 


\section{COMMUNITY CHARACTERIZATION ABSTRACT}

Agropyron smithii - Artemisia tilesii - Artemisia frigida. Herbaceous Vegetation

\section{IDENTIFIERS}

SEL.SUMMARY: This community type occupies slump sites on colluvial and morainal materials on steep slopes (mid-slope position) in the Peace River area (Dry Mixedwood Subregion) (Adams 1981). It occurs just upslope of areas occupied by the Agropyron dasystachyum - Agropyron smithii - Carex spp. - Koeleria macrantha community type. On the upper (less steep) slope it is bordered by the Agropyron smithii - Stipa viridula - Carex spp. Vicia americana community type. In contrast to the adjacent community types, which are primary range for livestock and primary winter range for mule deer, these steep slopes recolonized by Agropyron smithii, Artemisia tilesii and Artemisia frigida were rarely used for grazing by either cattle or wildlife.

SNAME: Agropyron smithii - Artemisia tilesii - Artemisia frigida Herbaceous Vegetation

SCOMNAME: Western wheat grass - Herriot's sage - pasture sagewort Herbaceous Vegetation

\section{CLASSIFICATION}

SYSTEM: Terrestrial

CLASS: Herbaceous vegetation

SUBCLASS: Perennial graminoid vegetation (grasslands)

GROUP: Temperate or subpolar grasslands

FORMATION: Medium-tall sod temperate or subpolar grasslands

ALLIANCE: Agropyron smithii Herbaceous Alliance

\section{CLASSIFICATION CONFIDENCE LEVEL: 3}

SSIMILAR COMMUNITIES: This community most likely differs from the Agropyron smithii Artemisia frigida Herbaceous Vegetation community (Adams et al. 1997) by the combined dominance of Agropyron smithii and Artemisia tilesii as well as by occurring primarily on very steep, eroded slopes. However, lack of details on vegetation composition of the Agropyron smithii - Artemisia frigida Herbaceous Vegetation type means no other comparisons can be made at this time.

\section{RELATED NOMENCLATURE}

SOTHER.NAMES: Agropyron smithii - Artemisia herriotii - Artemisia frigida (Adams 1981) 
SOTHER.NAMES.RELATION.NOTE: The Agropyron smithii - Artemisia herriotii - Artemisia frigida community (Adams 1981) is the same community type as the Agropyron smithii Artemisia tilesii - Artemisia frigida Herbaceous Vegetation community.

SNAMES.COM: The Agropyron smithii - Artemisia herriotii - Artemisia frigida (Adams 1981) is the same community type as the Agropyron smithii - Artemisia tilesii - Artemisia frigida Herbaceous Vegetation community. Artemisia tilesii (Kartesz 1999) is a synonym for Artemisia herriotii (Moss 1983).

\section{DISTRIBUTION}

SNATREG: Boreal forest

SSUBREG: Dry Mixedwood

SRANGECOM: Reported only from areas along the Peace River and Clear River canyons between Bear Canyon and Many Islands.

SDISTRIBUTION.COM: Reported only from areas along the Peace River and Clear River canyons between Bear Canyon and Many Islands (Boreal Forest Natural Region - Dry Mixedwood Subregion)

\section{ENVIRONMENTAL FACTORS}

SLANDFORM: Colluvial and morainal materials

STOP.POSITION: Mid-slope position

SSLOPE: Steep (probably closer to $90 \%$ )

SSOIL.MOSTURE: Probably xeric to very xeric

SKEY.ENVIRO.FACTORS: Probably dry soil conditions and soil erosion (low competition from other vegetation)

SENVIRO.COM: This community type occupies slump sites on colluvial and morainal materials on steep slopes (mid-slope position).

\section{BIOLOGICAL AND STRUCTURAL DESCRIPTION}

\section{6a VEGETATION}

SSTRATA LIFEFORM: Herb

SMOST.ABUND.SPP: Agropyron smithii, Artemisia tilesii, Artemisia frigida

SUNVEGETATED.SURFACE: Bedrock, probably some mineral soil 
SCONSTANT.SPP: Probably Agropyron smithii, Artemisia tilesii

SCHARACTERISTIC.SPP: Artemisia tilesii

SVEGETATION.COM: This community type is characterized by the dominance of Agropyron smithii, Artemisia tilesii, and Artemisia frigida.

\section{6b OTHER SPECIES}

SFAUNA.COM: Mule deer

\section{DYNAMIC PROCESSES}

SNAT.DISTURBANCE: Soil erosion

SSUCCESS.DYNAM.COM: Because of the steep slopes and unstable subsoil, these sites are constantly exposed to soil erosion.

\section{SPATIAL RELATIONS}

SADJACENT.COMMUNITIES: It occurs just above the areas occupied by the northern wheat grass - western wheat grass - upland sedge - June grass community type; on the upper (less steep) slope it is bordered by the western porcupine grass - green needle grass - upland sedge - milk vetch community type.

SSPATIAL.COM: It occurs just above the areas occupied by northern wheat grass - western wheat grass - upland sedge - June grass community type; on the upper (less steep) slope it is bordered by the western porcupine grass - green needle grass - upland sedge - milk vetch community type.

\section{STATUS}

\section{SRANK: S1}

SREASONS: Reported only from areas along the Peace River and Clear River canyons between Bear Canyon and Many Islands (Boreal forest Natural Region - Dry Mixedwood Subregion); because of its limited distribution and presence of Herriots sage (Artemisia herriotii (Adams 1981) or A. tilesii (Moss 1983) which is considered rare in Alberta (ranked S2) (ANHIC 2001), this community type should be placed on the community tracking list and ranked S1.

SSTATCOM: Reported only from areas along the Peace River and Clear River canyons between Bear Canyon and Many Islands (Boreal forest Natural Region - Dry Mixedwood Subregion); because of its limited distribution and presence of Herriots sage (Artemisia herriotii (Adams 1981) or A. tilesii (Moss 1983) which is considered rare in Alberta (ranked S2) (ANHIC 2001), this community type should be placed on the community tracking list and ranked S1. 


\section{MANAGEMENT}

SMANAGECOM: In contrast to the adjacent community types which are primary range for livestock and primary winter range for mule deer, steep slopes re-colonized by western wheat grass, Herriots sage and fringed sage are rarely used for grazing by either cattle or wildlife.

\section{ANALYSIS PROCEDURES AND DATA MANAGEMENT}

SANALYSIS.COM: Adams (1981) combined transect sampling of representative sites with reconnaissance observations and more detailed site sampling, such as recording species crown cover and various site factors. No classification or ordination analyses were used to classify vegetation communities.

SANALYSIS.DATA.MANAGE.COM: Adams (1981) combined transect sampling of representative sites with reconnaissance observations and more detailed site sampling, such as recording species crown cover and various site factors. No classification or ordination analyses were used to classify vegetation communities.

\section{GENERAL COMMENTS}

SCOMMUNITY.COM: More information is need on the actual composition and ground covers of plant species for this community; actual size of the occurrences also needs to be assessed; considering that both Agropyron smithii and Artemisia tilesii occur along the Peace and North Saskatchewan Rivers (distribution maps in Moss 1983), all potential sites (steep, eroded slopes) should be visited to check for additional occurrences of this community type.

\section{REFERENCES}

\section{CITATION:}

Adams, B. 1981. Range Ecology and the impact of livestock grazing on the Peace River Slopes, Alberta. Public Lands Division,

Adams, G. D., G. C. Trottier, W. L. Strong, I. D. MacDonald, S. J. Barry, P. G. Gregoire, G. W. Babish and G. Weiss. 1997. Vegetation component report: Canadian Forces Base Suffield national Wildlife area - Wildlife Inventory. Report prepared for the Canadian Wildlife Service, Environment Canada, Edmonton; AB.

Alberta Natural Heritage Information Centre (ANHIC). 2001. Alberta Natural Heritage Information Centre Element Tracking Lists.

http://www.gov.ab.ca/env/parks/anhic/trackanh.html

Kartesz, JT. 1999. A synonymized checklist and atlas with biological attributes for the vascular flora of the United States, Canada, and Greenland. 1st edition. In: Meacham, CA. Synthesis of the north American flora [computer program]. Version 1.0. North Carolina Botanical Garden, Chapel Hill (NC). 
Moss, E. H. 1983. The flora of Alberta. (2nd edition). Revised by J. G. Packer. University of Toronto Press, Toronto, ON. 


\section{COMMUNITY CHARACTERIZATION ABSTRACT} Agropyron smithii - Bouteloua gracilis Herbaceous Vegetation

\section{IDENTIFIERS}

SEL.SUMMARY: This community type occurs in the Milk River area on well drained Brown Solonetz and Brown Solodized Solonetz soils, and occasionally Orthic Brown Chernozems with loam and clay loam textures developed on gently inclined and undulating moraine (Brierley et al. 1989). Comer (1999) confirmed the existence of this community on gently rolling terrain with loamy, deep fertile soils within the southeast comer of Alberta. Agropyron smithii (28.1\% composition), Poa sandbergii (13.1\% composition), Koeleria macrantha (6.6\% composition), Stipa comata (4.4\% composition), Bouteloua gracilis (3.9\% composition), and Selaginella densa ( $29.3 \%$ composition) dominate, accompanied by secondary species such as Phlox hoodii, Tragopogon dubius, Artemisia frigida, Carex filifolia, Atriplex nuttallii, Artemisia cana, Eurotia lanata, Achillea millefolium, Opuntia polyacantha and Grindelia squarrosa (Brierley et al. 1989).

SNAME: Agropyron smithii - Bouteloua gracilis Herbaceous Vegetation

SCOMNAME: Western wheat grass - blue grama Herbaceous Vegetation

\section{CLASSIFICATION}

SYSTEM: Terrestrial

CLASS: Herbaceous vegetation

SUBCLASS: Perennial graminoid vegetation (grasslands)

GROUP: Temperate or subpolar grasslands

FORMATION: Medium-tall sod temperate or subpolar grasslands

ALLIANCE: Agropyron smithii Herbaceous Alliance

\section{CLASSIFICATION CONFIDENCE LEVEL: 2}

SSIMILAR COMMUNITIES: The Agropyron smithii Herbaceous Vegetation community from Alberta (Coupland 1950, Wallis 1976, Brierley et al. 1989, Adams and Moisey 1999) and the Agropyron smithii (Pascopyrum smithii) Herbaceous Vegetation community from Saskatchewan and Montana (Dodd and Coupland 1966, Heidel et al. 2000, NatureServe 2000) separate from the Agropyron smithii - Bouteloua gracilis Herbaceous Vegetation community by being solely dominated by Agropyron smithii and by having much lower cover of species such as Poa sandbergii, Koeleria macrantha and Bouteloua gracilis. The Agropyron smithii - Atriplex nuttallii Herbaceous Vegetation community (Smith 1993) is a much more open community (up to $80 \%$ bare ground), and generally lacks a significant Bouteloua gracilis component. The Agropyron smithii - Stipa comata - Bouteloua gracilis Herbaceous Vegetation community from 
Alberta (Brierley et al. 1989, Adams et al. 1997, this report) and the Pascopyrum smithii - Stipa comata - Bouteloua gracilis Herbaceous Vegetation community from Montana (Heidel et al. 2000) differ from the Agropyron smithii - Bouteloua gracilis Herbaceous Vegetation community by having a much higher component of Stipa comata, and by occurring on soils of coarser texture. A much higher importance of Koeleria macrantha in vegetation composition, as well as low cover of Bouteloua gracilis, and general lack of Stipa comata separate the Koeleria cristata Agropyron smithii Herbaceous Vegetation community (Stacey 1927; Wroe 1971, Fehr 1982) from the Agropyron smithii - Bouteloua gracilis Herbaceous Vegetation community type.

\section{RELATED NOMENCLATURE}

SOTHER.NAMES: Bouteloua gracilis -Agropyron smithii community type from the Milk River Natural Area (Brierley et al. 1989); Bouteloua-Agropyron faciation of Mixed Prairie (Stipa Bouteloua) association in Coupland (1950); Pascopyrum smithii (Agropyron smithii) - Bouteloua gracilis - Carex filifolia Herbaceous Vegetation community type from the western United States, southeast corner of Alberta and the southwestern corner of Saskatchewan (Comer et al. 1999, NatureServe 2000); and, Pascopyrum smithii - Bouteloua gracilis Herbaceous Vegetation from Sheridan County, Montana (Heidel et al. 2000).

SOTHER.NAMES.RELATION.NOTE: Bouteloua gracilis -Agropyron smithii community type (Brierley et al. 1989); Bouteloua-Agropyron faciation of Mixed Prairie Coupland (1950), Pascopyrum smithii (Agropyron smithii) - Bouteloua gracilis - Carex filifolia Herbaceous Vegetation (Comer et al. 1999, NatureServe 2000); and, Pascopyrum smithii - Bouteloua gracilis Herbaceous Vegetation (Heidel et al. 2000) are the most likely names for the same community type.

SNAMES.COM: The description of the Agropyron smithii - Bouteloua gracilis Herbaceous Vegetation community in this report is based on the Bouteloua gracilis-Agropyron smithii community type from the Milk River Natural Area described by Brierley et al. (1989). The name was changed to more accurately reflect the significant dominance of Agropyron smithii over Bouteloua gracilis on these sites. In the Bouteloua-Agropyron faciation of the Mixed Prairie (Stipa - Bouteloua) association from Saskatchewan, Agropyron also has a tendency to dominate over Bouteloua under moister conditions (Coupland 1950), and in a later publication, Coupland (1973) discussed the possibility of renaming this plant community the Agropyron - Bouteloua community. However, the author concluded that these "burn-outs" should be considered a natural disturbance feature dictating the species composition, and that the original community name should remain. The Agropyron smithii - Bouteloua gracilis Herbaceous Vegetation community may include the Pascopyrum smithii (Agropyron smithii) - Bouteloua gracilis - Carex filifolia Herbaceous Vegetation community type from the western United States, southeast corner of Alberta, and the southwestern comer of Saskatchewan (Comer et al. 1999, NatureServe 2000), based on the dominance of Agropyron smithii and Bouteloua gracilis, and the presence of Carex filifolia. As Comer et al. (1999) suggested, Carex filifolia is often present in this community type, but its cover varies, or it may absent altogether. The Pascopyrum smithii - Bouteloua gracilis Herbaceous Vegetation community from Sheridan County, Montana (Heidel et al. 2000) is probably the same community type as the Agropyron smithii - Bouteloua gracilis Herbaceous Vegetation described in this report, although Bouteloua gracilis covers about twice as much 
ground compared to Pascopyrum smithii. Finally, it should be noted that all of the aforementioned communities occupy soils with finer textures.

\section{DISTRIBUTION}

SNATREG: Grassland

SSUBREG: Dry Mixedgrass

SRANGECOM: Reported with certainty only from the Milk River Natural Area

SDISTRIBUTION.COM: Reported with certainty only from the Milk River Natural Area (Grassland Natural Region, Dry Mixedgrass Subregion)

\section{ENVIRONMENTAL FACTORS}

SMINELEV: Around $1000 \mathrm{~m}$ (Brierley et al. 1989)

SSLOPE: $0-2 \%$

SSOIL.TYPE: Brown Solonetz, Brown Solodized Solonetz, and occasionally Orthic Brown Chernozems (Brierley et al. 1989)

SSOIL.MOSTURE: Very xeric to subxeric

SSOIL.COM: Well drained soils (Brierley et al. 1989)

SENVIRO.COM: This community type occurs in the Milk River area on well drained Brown Solonetz and Brown Solodized Solonetz, and occasionally Orthic Brown Chernozems with loam and clay loam textures developed on gently inclined and undulating moraine (Brierley et al. 1989); may also exist in some other areas within southeast corner of Alberta on gently rolling terrain with loamy, deep fertile soils (Comer et al. 1999)

\section{BIOLOGICAL AND STRUCTURAL DESCRIPTION}

6a VEGETATION

SMOST.ABUND.SPP: Agropyron smithii, Poa sandbergii, Selaginella densa

SUNVEGETATED.SURFACE: Mineral soil

SUNVEGETATED.SURFACE COVER: Mineral soil (up to 40\%)

SCONSTANT.SPP: Probably Agropyron smithii and Bouteloua gracilis

SVEGETATION.COM: Agropyron smithii (28.1\% composition), Poa sandbergii (13.1\% composition), Koeleria macrantha (6.6\% composition), Stipa comata ( $4.4 \%$ composition), 
Bouteloua gracilis ( $3.9 \%$ composition), and Selaginella densa ( $29.3 \%$ composition) dominate, accompanied by secondary species such as Phlox hoodii, Tragopogon dubius, Artemisia frigida, Carex filifolia, Atriplex nuttallii, Artemisia cana, Eurotia lanata, Achillea millefolium, Opuntia polyacantha and Grindelia squarrosa (Brierley et al. 1989).

\section{STATUS}

\section{SRANK: S1}

SREASONS: Reported with certainty only from the Milk River Natural Area (Grassland Natural Region, Dry Mixedgrass Subregion); this community should be placed on the provincial tracking list and ranked S1 until further information is available about the distribution of this community within the province.

SSTATCOM: Reported with certainty only from the Milk River Natural Area (Grassland Natural Region, Dry Mixedgrass Subregion); this community should be placed on the provincial tracking list and ranked S1 until further information is available about the distribution of this community within the province.

\section{INVENTORY AND SAMPLING PROCEDURES}

SSAMPLE.STRATEGY: Comer et al. (1999) suggested that almost any combination of Agropyron smithii/Elymus lanceolatus, Bouteloua gracilis, Carex filifolia and Stipa comata is found in the northern and northwestern Great Plains, depending partially on climatic conditions (wet or dry weather), soil texture and grazing history. This consequently makes differentiating plant associations based only on the relative species abundance very difficult. As well, any of these species may be absent from certain areas, so an area of at least several acres should be examined to determine the community type (Comer et al. 1999).

SINVENTORY.COM: Comer et al. (1999) suggested that almost any combination of Agropyron smithii/Elymus lanceolatus, Bouteloua gracilis, Carex filifolia and Stipa comata is found in the northern and northwestern Great Plains, depending partially on climatic conditions (wet or dry weather), soil texture and grazing history. This consequently makes differentiating plant associations based only on the relative species abundance very difficult. As well, any of these species may be absent from certain areas, so an area of at least several acres should be examined to determine the community type (Comer et al. 1999).

\section{ANALYSIS PROCEDURES AND DATA MANAGEMENT}

SANALYSIS.COM: Brierley et al. (1989) based their classification on both detailed and reconnaissance site information. On detailed sites they estimated vegetation cover within five to eight $20 \times 50 \mathrm{~cm}$ microplots arranged at a fixed distance $(100 \mathrm{~m})$ along transects. Vegetation data from detailed plots were grouped by species composition according to tabular methods described in Muller-Dombois and Ellenberg (1974). Plots with similar vegetation structure were grouped into plant communities. 
SANALYSIS.DATA.MANAGE.COM: Brierley et al. (1989) based their classification on both detailed and reconnaissance site information. On detailed sites they estimated vegetation cover within five to eight $20 \times 50 \mathrm{~cm}$ microplots arranged at a fixed distance $(100 \mathrm{~m})$ along transects. Vegetation data from detailed plots were grouped by species composition according to tabular methods described in Muller-Dombois and Ellenberg (1974). Plots with similar vegetation structure were grouped into plant communities.

\section{REFERENCES}

\section{CITATION:}

Adams, G. D., G. C. Trottier, W. L. Strong, I. D. MacDonald, S. J. Barry, P. G. Gregoire, G. W. Babish and G. Weiss. 1997. Vegetation component report: Canadian Forces Base Suffield national Wildlife area - Wildlife Inventory. Report prepared for the Canadian Wildlife Service, Environment Canada, Edmonton, AB.

Adams, B and D. Moisey. 1999. Analysis of vegetation and soil monitoring records for Milk River Natural Area and Kennedy Creek Ecological Reserve. 1999. Public Lands, Alberta Agriculture, Food and Rural Development, Lethbridge

Brierley, D., D. Bradshaw, and D. Downing. 1989 Milk River Natural Area - biophysical inventory - southern uplands. Report prepared for Alberta Forestry, Lands and Wildlife, land information services division, resource Information Branch, Edmonton, AB.

Comer, P., L. Allen, Steve Cooper, D. Faber-Langendoen, and G. Jones. 1999. Selected shrubland and grassland communities of the Northern Great Plains. A Report to Nebraska National Forest.

Coupland, R. T. 1950. Ecology of mixed prairie in Canada. Ecological Monographs 20: 271315

Coupland, R. T. 1973. A theme study of natural grasslands in western Canada. A Report to National and Historic Parks Branch Canada, Department of Indian affairs and Northern Development.

Dodd, J. D. and R. T. Coupland. 1966. Vegetation of saline Areas in Saskatchewan. Ecology 47: 958-967

Fehr, Alan W. 1982. The Candidate Rumsey Ecological Reserve: A Biophysical Inventory. Alberta Energy and Natural Resources.

Heidal, B., S. V. Cooper and C. Jean. 2000. Plant species of special concern and plant associations of Sheridan County, Montana. Report to the U.S. Fish and Wildlife Service. Montana Natural Heritage Program, Helena, Montana.

Muller-Dombois, D., and H. Ellenberg. 1974. Aims and methods of vegetation ecology. Wiley, New York. 
NatureServe: An online encyclopedia of life [web application]. 2000. Version 1.0. Arlington (VA): Association for Biodiversity Information. Available: http://www.natureserve.org

Smith, W. 1993. An Assessment of Short-horned Lizard Habitat and Use Manyberries Badland, Alberta. Alberta Fish and Wildlife, Lethbridge, AB.

Stacey, E. C. 1927. Ecological studies on the native grasses of the Grande Prairie-Beaverlodge district.

Wallis, C. 1976. Milk River canyon resource evaluation. Report prepared for Planning and Design, Alberta Recreation, Parks, and Wildlife, Edmonton, AB.

Wroe, R. A. 1971. Synecology of a Festuca scabrella Torr. grassland. Ph.D. thesis, Department of Plant Science, University of Alberta, Edmonton, Alberta. 


\section{COMMUNITY CHARACTERIZATION ABSTRACT} Agropyron smithii - Hordeum jubatum Herbaceous Vegetation

\section{IDENTIFIERS}

SEL.SUMMARY: This community occurs in the northernmost portion of a large saline wetland located within the Neutral Hills Central site, Northern Fescue Subregion (Wallis 1990). It represents the driest vegetation sequence along a moisture gradient adjacent to the Distichlis stricta community type, which occupies somewhat wetter soils.

SNAME: Agropyron smithii - Hordeum jubatum Herbaceous Vegetation

SCOMNAME: Western wheat grass - foxtail barley Herbaceous Vegetation

\section{CLASSIFICATION}

SYSTEM: Terrestrial

CLASS: Herbaceous vegetation

SUBCLASS: Perennial graminoid vegetation (grasslands)

GROUP: Temperate or subpolar grasslands

FORMATION: Medium-tall sod temperate or subpolar grasslands

ALLIANCE: Agropyron smithii Herbaceous Alliance

\section{CLASSIFICATION CONFIDENCE LEVEL: 3}

SSIMILAR COMMUNITIES: Although Hordeum jubatum may occur in the Agropyron smithii Herbaceous Vegetation community from Alberta (Coupland 1950, Wallis 1976, Brierley et al. 1989, Adams and Moisey 1999), and possibly in the Agropyron smithii (Pascopyrum smithii) Herbaceous Vegetation from Saskatchewan and Montana (Dodd and Coupland 1966, Heidel et al. 2000, NatureServe 2000), these community types separate from the Agropyron smithii Hordeum jubatum Herbaceous Vegetation community by being solely dominated by Agropyron smithii. The Distichlis stricta - Agropyron smithii Herbaceous Vegetation community from Alberta (Wallis 1990) and the Distichlis stricta - Agropyron sp. Herbaceous Vegetation community from Saskatchewan (Dodd and Coupland 1966) generally occur on somewhat wetter soils where Distichlis stricta replaces Hordeum jubatum.

\section{RELATED NOMENCLATURE}

SOTHER.NAMES: Pascopyrum smithii - Hordeum jubatum Herbaceous Vegetation (Comer et al. 1999) 
SOTHER.NAMES.RELATION.NOTE: The Pascopyrum smithii - Hordeum jubatum Herbaceous Vegetation community from Wyoming, Montana, Nebraska, and most likely North Dakota, South Dakota, Kansas, Alberta, and Saskatchewan (Comer et al. 1999) is the same community type as the Agropyron smithii - Hordeum jubatum Herbaceous Vegetation community described by Wallis (1990) for Alberta.

SNAMES.COM: The Pascopyrum smithii - Hordeum jubatum Herbaceous Vegetation community from Wyoming, Montana, Nebraska, and most likely North Dakota, South Dakota, Kansas, Alberta, and Saskatchewan (Comer et al. 1999) is the same community type as the Agropyron smithii - Hordeum jubatum Herbaceous Vegetation community described by Wallis (1990) for Alberta.

\section{DISTRIBUTION}

SNATREG: Grassland

SSUBREG: Northern Fescue

SRANGE: Reported only from the Neutral Hills Central site

SDISTRIBUTION.COM: Reported only from the Neutral Hills Central site (Grassland Natural Region - Northern Fescue Subregion)

\section{ENVIRONMENTAL FACTORS}

\section{SKEY.ENVIRO.FACTORS: Soil salinity}

SENVIRO.COM: Soil salinity is certainly one of the factors responsible for the existence of this community type

\section{SPATIAL RELATIONS}

SADJACENT.COMMUNITIES: Adjacent to the Distichlis stricta community type, which occupies somewhat wetter soils.

SSPATIAL.COM: Adjacent to the Distichlis stricta community type, which occupies somewhat wetter soils.

9. STATUS

SRANK: S1

SREASONS: Reported only from the Neutral Hills Central area (Grassland Natural Region Northern Fescue Subregion)

SSTATCOM: Reported only from the Neutral Hills Central area (Grassland Natural Region Northern Fescue Subregion); it should be placed on the provincial tracking list and ranked S1 


\section{ANALYSIS PROCEDURES AND DATA MANAGEMENT}

SANALYSIS.COM: Wallis (1990) based the vegetation description only on a reconnaissance level survey.

SANALYSIS.DATA.MANAGE.COM: Wallis (1990) based the vegetation description only on a reconnaissance level survey.

\section{REFERENCES}

\section{CITATION:}

Adams, B and D. Moisey. 1999. Analysis of vegetation and soil monitoring records for Milk River Natural Area and Kennedy Creek Ecological Reserve. 1999. Public Lands, Alberta Agriculture, Food and Rural Development, Lethbridge

Brierley, D., D. Bradshaw, and D. Downing. 1989 Milk River Natural Area - biophysical inventory - southern uplands. Report prepared for Alberta Forestry, Lands and Wildlife, land information services division, resource Information Branch, Edmonton, $\mathrm{AB}$.

Comer, P., L. Allen, Steve Cooper, D. Faber-Langendoen, and G. Jones. 1999. Selected shrubland and grassland communities of the Northern Great Plains. A Report to Nebraska National Forest.

Coupland, R. T. 1950. Ecology of mixed prairie in Canada. Ecological Monographs 20: 271315

Dodd, J. D. and R. T. Coupland. 1966. Vegetation of saline Areas in Saskatchewan. Ecology 47: $958-967$

Heidal, B., S. V. Cooper and C. Jean. 2000. Plant species of special concern and plant associations of Sheridan County, Montana. Report to the U.S. Fish and Wildlife Service. Montana Natural Heritage Program, Helena, Montana.

NatureServe: An online encyclopedia of life [web application]. 2000. Version 1.0. Arlington (VA): Association for Biodiversity Information. Available: http://www.natureserve.org

Wallis, C. 1976. Milk River canyon resource evaluation. Report prepared for Planning and Design, Alberta Recreation, Parks, and Wildlife, Edmonton, AB.

Wallis, C. 1990. Reconnaissance survey of saline wetlands and springs in the GrasslandParkland region of Eastern Alberta. World Wildlife Fund, Canada 


\section{COMMUNITY CHARACTERIZATION ABSTRACT}

Agropyron smithii - Pyrrocoma uniflora Sparse Herbaceous Vegetation

\section{IDENTIFIERS}

SEL.SUMMARY: This community type was found only at one site in the vicinity of alkali grass (Puccinellia nuttalliana) depressions at Whirlpool Point in the Kootenay Plains area (Wallis and Wershler 1981). It occurs in areas with high water tables. Vegetation cover is low, with considerable bare ground. Scattered forbs include Cerastium arvense, Anemone multifida, Astragalus agrestis, Achillea millefolium, Senecio canus, Taraxacum officinale and Aster sibiricus.

SNAME: Agropyron smithii - Pyrrocoma uniflora Sparse Herbaceous Vegetation

SCOMNAME: Western wheat grass - one-flowered ironplant Sparse Herbaceous Vegetation

\section{CLASSIFICATION}

SYSTEM: Terrestrial

CLASS: Herbaceous vegetation

SUBCLASS: Perennial graminoid vegetation (grasslands)

GROUP: Temperate or subpolar grasslands

FORMATION: Medium-tall sod temperate or subpolar grasslands

ALLIANCE: Agropyron smithii Herbaceous Alliance

CLASSIFICATION CONFIDENCE LEVEL: 2

SSIMILAR COMMUNITIES The Agropyron smithii Herbaceous Vegetation community from Alberta (Coupland 1950, Wallis 1976, Brierley et al. 1989, Adams and Moisey 1999) and the Agropyron smithii (Pascopyrum smithii) Herbaceous Vegetation community type from Saskatchewan and Montana (Dodd and Coupland 1966, Heidel et al. 2000, NatureServe 2000) separate from the Agropyron smithii - Pyrrocoma uniflora sparse Herbaceous Vegetation community by being solely dominated by Agropyron smithii and by a general lack of Pyrrocoma uniflora. The Agropyron smithii - Pyrrocoma uniflora Herbaceous Vegetation community differs from the other Agropyron smithii communities by the combined dominance of Pyrrocoma uniflora and Agropyron smithii, and by its very open, sparsely vegetated appearance.

\section{RELATED NOMENCLATURE}

SOTHER.NAMES: Agropyron smithii - Haplopappus uniflorus community (Wallis and Wershler 1981) 
SOTHER.NAMES.RELATION.NOTE: The Agropyron smithii - Haplopappus uniflorus community (Wallis and Wershler 1981) is the same community as the Agropyron smithii Pyrrocoma uniflora Sparse Herbaceous Vegetation community.

SNAMES.COM: The Agropyron smithii - Haplopappus uniflorus community (Wallis and Wershler 1981) is the same community as the Agropyron smithii - Pyrrocoma uniflora Sparse Herbaceous Vegetation community. Pyrrocoma uniflora (Kartesz 1999) is a revised name for Haplopappus uniflorus (Moss 1983).

\section{DISTRIBUTION}

SNATREG: Rocky Mountain

SSUBREG: Montane

SRANGECOM: Reported only from one site in the Kootenay Plains area, at Whirlpool Point

SDISTRIBUTION.COM: Reported only from one site in the Kootenay Plains area, at Whirlpool Point (Rocky Mountain Natural Region - Montane Subregion)

\section{ENVIRONMENTAL FACTORS}

STOP.POSITION: Depressions

SSLOPE: $0 \%$

SSOIL.MOSTURE: Mesic

\section{BIOLOGICAL AND STRUCTURAL DESCRIPTION}

6a VEGETATION

SSTRATA LIFEFORM: Herb

SPCT.COVER: Herb (20\%)

SHEIGHT: $20 \mathrm{~cm}$

SMOST.ABUND.SPP: Agropyron smithii and Pyrrocoma uniflora

SUNVEGETATED.SURFACE: Mineral soil

SUNVEGETATED.SURFACE COVER: Mineral soil (80\%)

SCHARACTERISTIC.SPP: Agropyron smithii and Pyrrocoma uniflora 
SVEGETATION.COM: Agropyron smithii and Pyrrocoma uniflora dominate; scattered forbs include Cerastium arvense, Anemone multifida, Astragalus agrestis, Achillea millefolium, Senecio canus, Taraxacum officinale and Aster sibiricus.

\section{SPATIAL RELATIONS}

SADJACENT.COMMUNITIES: Puccinellia nuttalliana community type

SSPATLAL.COM: Adjacent to the Puccinellia nuttalliana community type

9. STATUS

SRANK: S1

SREASONS: Reported only from one site within the Kootenay Plains area, at Whirlpool Point (Rocky Mountain Natural Region - Montane Subregion)

SSTATCOM: Reported only from one site within the Kootenay Plains area, at Whirlpool Point (Rocky Mountain Natural Region - Montane Subregion); Pyrrocoma uniflora is ranked S3 in the province and is listed on the Alberta Natural Heritage Information Centre Vascular Plants on the Watch List (ANHIC 2001); this community type should be placed on the provincial tracking list and ranked $\mathrm{S} 1$

\section{ANALYSIS PROCEDURES AND DATA MANAGEMENT}

SANALYSIS.COM: Wallis and Wershler (1981) recorded detailed canopy coverage within representative $1 \times 1 \mathrm{~m}$ plots, which were nested within $15 \mathrm{~m}$ diameter sampling areas. Additional information on species presence was collected within $15 \mathrm{~m}$ diameter sampling areas. The authors did not perform any cluster or ordination analyses on their data.

SANALYSIS.DATA.MANAGE.COM: Wallis and Wershler (1981) recorded detailed canopy coverage within representative $1 \times 1 \mathrm{~m}$ plots, which were nested within $15 \mathrm{~m}$ diameter sampling areas. Additional information on species presence was collected within $15 \mathrm{~m}$ diameter sampling areas. The authors did not perform any cluster or ordination analyses on their data.

\section{REFERENCES}

\section{CITATION:}

Adams, B and D. Moisey. 1999. Analysis of vegetation and soil monitoring records for Milk River Natural Area and Kennedy Creek Ecological Reserve. 1999. Public Lands, Alberta Agriculture, Food and Rural Development, Lethbridge

Alberta Natural Heritage Information Centre (ANHIC). 2001. Alberta Natural Heritage Information Centre Element Tracking Lists. http://www.gov.ab.ca/env/parks/anhic/trackanh.html 
Brierley, D., D. Bradshaw, and D. Downing. 1989 Milk River Natural Area - biophysical inventory - southern uplands. Report prepared for Alberta Forestry, Lands and Wildlife, land information services division, resource Information Branch, Edmonton, AB.

Coupland, R. T. 1950. Ecology of mixed prairie in Canada. Ecological Monographs 20: 271315

Dodd, J. D. and R. T. Coupland. 1966. Vegetation of saline Areas in Saskatchewan. Ecology 47: 958-967

Heidal, B., S. V. Cooper and C. Jean. 2000. Plant species of special concern and plant associations of Sheridan County, Montana. Report to the U.S. Fish and Wildlife Service. Montana Natural Heritage Program, Helena, Montana.

Kartesz, JT. 1999. A synonymized checklist and atlas with biological attributes for the vascular flora of the United States, Canada, and Greenland. 1st edition. In: Meacham, CA. Synthesis of the north American flora [computer program]. Version 1.0. North Carolina Botanical Garden, Chapel Hill ( NC).

Moss, E. H. 1983. The flora of Alberta. (2nd edition). Revised by J. G. Packer. University of Toronto Press, Toronto, ON.

NatureServe: An online encyclopedia of life [web application]. 2000. Version 1.0. Arlington (VA): Association for Biodiversity Information. Available: http://www.natureserve.org

Wallis, C. 1976. Milk River canyon resource evaluation. Report prepared for Planning and Design, Alberta Recreation, Parks, and Wildlife, Edmonton, AB.

Wallis, C. and C. Wershler. 1981. Kootenay Plains Flora and Grassland Vegetation Assessment - 1981. Alberta Energy and Natural Resources. 
COMMUNITY CHARACTERIZATION ABSTRACT

Agropyron smithii - Atriplex nuttallii Herbaceous Vegetation

\section{IDENTIFIERS}

SEL.SUMMARY: This community type occurs on moderate slopes on the northeast side of an un-named coulee in the Manyberries badlands (Mixedgrass Subregion) (elevation ranges 968 $1066 \mathrm{~m}$ ) (Smith 1993). Soils of the general area are Brown Solonetz with loam textures derived from moderately calcareous till, overlaying shales and sandstones. This community is characterized by having $75 \%$ to $80 \%$ bare ground. Agropyron smithii and Atriplex nuttallii codominant in this community. Koeleria macrantha and Artemisia frigida are also abundant on one site sampled. Other characteristic species included Phlox hoodii, Gutierrezia sarothrae, Gaura coccinea, Grindelia squarrosa, Haplopappus nuttallii, Chrysothamnus nauseosus, Oenothera caespitosa, Erigeron caespitosus, and Carex filifolia (locally abundant in sandier patches).

SNAME: Agropyron smithii - Atriplex nuttallii Herbaceous Vegetation

SCOMNAME: Western wheat grass - Nuttall's atriplex Herbaceous Vegetation

\section{CLASSIFICATION}

SYSTEM: Terrestrial

CLASS: Herbaceous vegetation

SUBCLASS: Perennial graminoid vegetation (grasslands)

GROUP: Temperate or subpolar grasslands

FORMATION: Medium-tall sod temperate or subpolar grasslands

\section{CLASSIFICATION CONFIDENCE LEVEL: 2}

ALLIANCE: Agropyron smithii Herbaceous Alliance

SSIMILAR COMMUNITIES: The Agropyron smithii Herbaceous Vegetation community from Alberta (Coupland 1950, Wallis 1976, Brierley et al. 1989, Adams and Moisey 1999) and the Agropyron smithii Herbaceous Vegetation community from Saskatchewan and Montana (Dodd and Coupland 1966, Heidel et al. 2000, NatureServe 2000) separate from the Agropyron smithii Atriplex nuttallii Herbaceous Vegetation community by being solely dominated by Agropyron smithii and by the lack of a significant Atriplex nuttallii component. The codominance of Agropyron smithii and Artemisia frigida most likely separates the Agropyron smithii - Artemisia frigida Herbaceous Vegetation community (Adams et al. 1997) from the Agropyron smithii Atriplex nuttallii Herbaceous Vegetation community type. However, lack of details on the vegetation composition of the Agropyron smithii - Artemisia frigida Herbaceous Vegetation type means no other comparisons can be made at this time. The general lack of a significant Atriplex 
nuttallii component separates the Koeleria cristata - Agropyron smithii Herbaceous Vegetation community type (Stacey 1927; Wroe 1971, Fehr 1982) from the Agropyron smithii - Atriplex nuttallii Herbaceous Vegetation community.

\section{DISTRIBUTION}

SNATREG: Grassland

SSUBREG: Mixedgrass

SRANGE: Reported only from Mannyberries badlands

SDISTRIBUTION.COM: Reported only from Mannyberries badlands (Grassland Natural Region - Mixedgrass Subregion)

\section{ENVIRONMENTAL FACTORS}

SMINELEV: $968 \mathrm{~m}$

SMAXELEV: $1066 \mathrm{~m}$

STOP.POSITION: Toe to mid-slope

SSLOPE: Moderate slopes

SGEOLOGY.COM: Shales and sandstones of the Bearpaw and Oldman formations

SSOIL.TYPE: Brown Solonetz

SSOIL.COM: Gravel-clay pavement and some sandier patches

SENVIRO.COM: This community type occurs on moderate slopes. Soils of the general area are Brown Solonetz with loam textures derived from moderately calcareous till, and overlaying shales and sandstones. This community was found mostly on gravel-clay pavement with some sandier patches.

\section{BIOLOGICAL AND STRUCTURAL DESCRIPTION}

6a VEGETATION

SMOST.ABUND.SPP: Agropyron smithii and Atriplex nuttallii

SUNVEGETATED.SURFACE: Mineral soil, gravel

SUNVEGETATED.SURFACE COVER: Mineral soil, gravel (75 - 80\%)

SCONSTANT.SPP: Agropyron smithii and Atriplex nuttallii 


\section{SCHARACTERISTIC.SPP: Atriplex nuttallii}

SVEGETATION.COM: Agropyron smithii and Atriplex nuttallii codominate in this community. Koeleria macrantha and Artemisia frigida are also abundant on one site. Other characteristic species include Phlox hoodii, Gutierrezia sarothrae, Gaura coccinea, Grindelia squarrosa, Haplopappus nuttallii, Chrysothamnus nauseosus, Oenothera caespitosa, Erigeron caespitosus, and Carex filifolia (locally abundant in sandier patches).

\section{6b OTHER SPECIES}

SHIGH.RANK.SPP: One of the two sampling sites is the most important habitat for the Shorthorned Lizard (Phrynosoma douglassii ssp. brevirostre), both in the study area and in Alberta (Smith 1993).

SOTHERSPP.COM: One of the two sampling sites is the most important habitat for the Shorthorned Lizard (Phrynosoma douglassi ssp. brevirostre), both in the study area and in Alberta (Smith 1993).

6c VARIABILITY

SVARIABIITY.COM: Koeleria macrantha and Artemisia frigida are more abundant on one of the two studied sites.

\section{STATUS}

SRANK: S1

SREASONS: Seems to be restricted to Mannyberries badlands (Grassland Natural Region Mixedgrass Subregion)

SSTATCOM: Seems to be restricted to Mannyberries badlands (Grassland Natural Region Mixedgrass Subregion); it should be placed on the provincial tracking list and ranked S1.

\section{ANALYSIS PROCEDURES AND DATA MANAGEMENT}

SANALYSIS.COM: Mostly reconnaissance vegetation survey with some vegetation cover data.

SANALYSIS.DATA.MANAGE.COM: Mostly reconnaissance vegetation survey with some vegetation cover data.

\section{REFERENCES}

CITATION:

Adams, G. D., G. C. Trottier, W. L. Strong, I. D. MacDonald, S. J. Barry, P. G. Gregoire, G. W. Babish and G. Weiss. 1997. Vegetation component report: Canadian Forces Base 
Suffield national Wildlife area - Wildlife Inventory. Report prepared for the Canadian Wildlife Service, Environment Canada, Edmonton, AB.

Adams, B and D. Moisey. 1999. Analysis of vegetation and soil monitoring records for Milk River Natural Area and Kennedy Creek Ecological Reserve. 1999. Public Lands, Alberta Agriculture, Food and Rural Development, Lethbridge

Brierley, D., D. Bradshaw, and D. Downing. 1989 Milk River Natural Area - biophysical inventory - southern uplands. Report prepared for Alberta Forestry, Lands and Wildlife, land information services division, resource Information Branch, Edmonton, AB.

Coupland, R. T. 1950. Ecology of mixed prairie in Canada. Ecological Monographs 20: 271315

Dodd, J. D. and R. T. Coupland. 1966. Vegetation of saline Areas in Saskatchewan. Ecology 47: $958-967$

Fehr, Alan W. 1982. The Candidate Rumsey Ecological Reserve: A Biophysical Inventory. Alberta Energy and Natural Resources.

Heidal, B., S. V. Cooper and C. Jean. 2000. Plant species of special concern and plant associations of Sheridan County, Montana. Report to the U.S. Fish and Wildlife Service. Montana Natural Heritage Program, Helena, Montana.

NatureServe: An online encyclopedia of life [web application]. 2000. Version 1.0. Arlington (VA): Association for Biodiversity Information. Available: http://www.natureserve.org

Smith, W. 1993. An Assessment of Short-horned Lizard Habitat and Use Manyberries Badland, Alberta. Alberta Fish and Wildlife, Lethbridge, AB.

Stacey, E. C. 1927. Ecological studies on the native grasses of the Grande Prairie-Beaverlodge district.

Wallis, C. 1976. Milk River canyon resource evaluation. Report prepared for Planning and Design, Alberta Recreation, Parks, and Wildlife, Edmonton, AB.

Wroe, R. A. 1971. Synecology of a Festuca scabrella Torr. grassland. Ph.D. thesis, Department of Plant Science, University of Alberta, Edmonton, Alberta. 


\section{COMMUNITY CHARACTERIZATION ABSTRACT Agropyron smithii - Stipa comata - Bouteloua gracilis Herbaceous Vegetation}

\section{IDENTIFIERS}

SEL.SUMMARY: This community type occurs in the western portion of the Milk River Natural Area (elevation about $1000 \mathrm{~m}$ ) on west- and some east-facing colluvial slopes (slope $10-20 \%$ ) (Brierley et al.1989). Soils are well drained, fine to coarse textured, Orthic Brown Chernozems with submesic moisture regimes. The same community type also occurs on gentle slopes $(<15 \%)$ with variable aspects within the Suffield National Wildlife Area (Dry Mixedgrass Subregion) (Adams et al. 1997). Sites supporting this community type include: middle terraces with well drained, sandy Orthic Brown Chernozems; lower terraces with imperfectly drained, sandy loam Orthic Regosols and Orthic Gleysols; valley walls with well drained sandy Orthic Brown Chernozems; hilly outwash deposits with well drained, loamy sand Orthic Brown Chernozems; hummocky moraine with well drained, loam sandy textured Orthic Brown Chernozems; and, inclined morainal slopes with sandy loam Orthic and Rego Brown Chernozems. Finally, this community type may also occur within the Cypress Hills Montane and Mixedgrass Subregions on rapidly to well drained soils with subxeric to mesic moisture regimes (community \#36 in this report). In the Milk River Natural Area this community is dominated by Stipa comata/S. spartea, Agropyron smithii and Selaginella densa (average percent compositional cover of 23\%, 22\%, and $34 \%$, respectively), accompanied by Bouteloua gracilis, Carex spp., Koeleria macrantha, Poa sandbergii, Calamovilfa longifolia, Phlox hoodii and numerous other species (Brierley et al.1989). Within the Suffield National Wildlife Area, Agropyron smithii, Stipa comata and Carex stenophylla dominate, contributing on average $21 \%, 31 \%$ and $19 \%$ to the ground cover, respectively. Additional species include Bouteloua gracilis (3\%), Chenopodium pratericola (4\%), Descurainia pinnata (1\%), Lactuca pulchella, Lygodesmia juncea and Opuntia polyacantha (low covers). Analysis of plots from the ESIS database (this report) indicates that this community type found within the Cypress Hills Montane, Dry Mixedgrass and Mixedgrass Subregions of southeastern Alberta is dominated by Agropyron smithii (16\%), Stipa comata (9.7\%), Bouteloua gracilis (9.7\%) and Selaginella densa (35\%), accompanied by less abundant species such as Koeleria macrantha, Carex filifolia, Agropyron dasystachyum and Stipa viridula.

SNAME: Agropyron smithii - Stipa comata - Bouteloua gracilis Herbaceous Vegetation

SCOMNAME: Western wheat grass - needle-and-thread - blue grama Herbaceous Vegetation

\section{CLASSIFICATION}

SYSTEM: Terrestrial

CLASS: Herbaceous vegetation

SUBCLASS: Perennial graminoid vegetation (grasslands)

GROUP: Temperate or subpolar grasslands

FORMATION: Medium-tall sod temperate or subpolar grasslands 
ALLIANCE: Agropyron smithii Herbaceous Alliance

\section{CLASSIFICATION CONFIDENCE LEVEL: 1}

SSIMILAR COMMUNITIES: The Agropyron smithii Herbaceous Vegetation community from Alberta (Coupland 1950, Wallis 1976, Brierley et al. 1989, Adams and Moisey 1999) and the Agropyron smithii (Pascopyrum smithii) Herbaceous Vegetation community type from Saskatchewan and Montana (Dodd and Coupland 1966, Heidel et al. 2000, NatureServe 2000) separate from the Agropyron smithii - Stipa comata - Bouteloua gracilis Herbaceous Vegetation community by being solely dominated by Agropyron smithii and by having much lower cover of species such as Koeleria macrantha, Stipa comata and Bouteloua gracilis. The Agropyron smithii - Stipa comata - Bouteloua gracilis Herbaceous Vegetation community differs from the Agropyron smithii - Bouteloua gracilis Herbaceous Vegetation from Alberta (Brierley et al 1989, Comer et al. 1999) and the Agropyron smithii (Pascopyrum smithii) - Bouteloua gracilis Herbaceous Vegetation community from Saskatchewan and Montana (Coupland 1950, Comer et al. 1999, Heidel et al. 2000) by generally occurring on coarser soils, and by having higher ground cover of Stipa comata. Although Bouteloua gracilis may be present in the Koeleria cristata Agropyron smithii Herbaceous Vegetation community (Stacey 1927, Wroe 1971, Fehr 1982), the much higher importance of Koeleria macrantha and the general lack of a significant Stipa comata component separate this community type from the Agropyron smithii - Stipa comata Bouteloua gracilis Herbaceous Vegetation community.

\section{RELATED NOMENCLATURE}

SOTHER.NAMES: Stipa - Agropyron (Brierley et al.1989); Stipa comata - Agropyron smithii (Adams et al. 1997); Pascopyrum smithii - Stipa comata - Bouteloua gracilis Herbaceous Vegetation from Sheridan County, Montana (Heidel et al. 2000); Pascopyrum smithii - Stipa comata Northern Herbaceous Vegetation from Sheridan County (Heidel et al. 2000); Pascopyrum smithii - Stipa comata Central Mixedgrass Herbaceous vegetation from the northcentral Great Plains (Comer et al. 1999, NatureServe 2000).

SOTHER.NAMES.RELATION.NOTE: Stipa - Agropyron (Brierley et al.1989) and Stipa comata - Agropyron smithii (Adams et al. 1997) are the two community types used to describe the Agropyron smithii - Stipa comata - Bouteloua gracilis Herbaceous Vegetation from this report; Pascopyrum smithii - Stipa comata - Bouteloua gracilis Herbaceous Vegetation from Sheridan County, Montana (Heidel et al. 2000) seems to be the same community type as the Agropyron smithii - Stipa comata - Bouteloua gracilis Herbaceous Vegetation from southeastern Alberta; the Agropyron smithii - Stipa comata - Bouteloua gracilis Herbaceous Vegetation from southeastern Alberta also includes the Pascopyrum smithii - Stipa comata Northern Herbaceous Vegetation community from Sheridan County (Heidel et al. 2000) and the Pascopyrum smithii Stipa comata Central Mixedgrass Herbaceous Vegetation community from the north-central Great Plains (Comer et al. 1999, NatureServe 2000).

SNAMES.COM: Stipa - Agropyron (Brierley et al.1989) and Stipa comata - Agropyron smithii (Adams et al. 1997) are the two community types used to describe the Agropyron smithii - Stipa comata - Bouteloua gracilis Herbaceous Vegetation community from this report. The name was 
changed to reflect the high abundance of Bouteloua gracilis in plots from the ESIS database, and because it agrees with the name of the same community from the adjacent States; Pascopyrum smithii - Stipa comata - Bouteloua gracilis Herbaceous Vegetation community from Sheridan County, Montana (Heidel et al. 2000) seems to be the same community type as the Agropyron smithii - Stipa comata - Bouteloua gracilis Herbaceous Vegetation from southeastern Alberta. Heidel et al. (2000) suggested that this association falls within the "Stipa - Bouteloua Agropyron faciation" of Coupland (1950). Heidel et al. (2000) also suggested that the Pascopyrum smithii - Stipa comata - Bouteloua gracilis community type represents an equivalent to the Pascopyrum smithii - Stipa comata Central Mixed Grass Prairie community, and that the Pascopyrum smithii - Stipa comata Northern Herbaceous Vegetation community may represent a cold, dry phase of the Pascopyrum smithii - Stipa comata - Bouteloua gracilis community; therefore, the Agropyron smithii - Stipa comata - Bouteloua gracilis Herbaceous Vegetation community from southeastern Alberta includes the Pascopyrum smithii - Stipa comata Central Mixedgrass Herbaceous vegetation from the north-central Great Plains (Comer et al. 1999, NatureServe 2000), and probably the Pascopyrum smithii - Stipa comata Northern Herbaceous Vegetation from Sheridan County (Heidel et al. 2000).

\section{DISTRIBUTION}

SNATREG: Grassland, possibly Rocky Mountain

SSUBREG: Dry Mixedgrass, possibly Montane and Mixedgrass (this report)

SRANGECOM: Reported from the western portion of the Milk River Natural Area and from the Suffield National Wildlife Area; it possibly exists in other locations within the Dry Mixedgrass, Mixedgrass and Cypress Hills Montane Subregions in the southwestern corner of Alberta (this report)

SDISTRIBUTION.COM: Reported from the western portion of the Milk River Natural Area and from the Suffield National Wildlife Area (Grassland Natural Region - Dry Mixedgrass Subregion); it possibly exists in other locations within the Dry Mixedgrass and Mixedgrass Subregions, and within Rocky Mountain Natural Region (Cypress Hills Montane Subregion) in the southwestern corner of Alberta (this report)

\section{ENVIRONMENTAL FACTORS}

SMINELEV: $780 \mathrm{~m}$ (this report)

SMAXELEV: $1365 \mathrm{~m}$ (this report); $1000 \mathrm{~m}$ (Brierley et al.1989)

SLANDFORM: Within the Suffield National Wildlife Area, sites occupied by this community type include: middle and lower terraces, valley walls, hilly outwash deposits, hummocky moraine, and inclined morainal slopes (Adams et al. 1997); it occupies colluvial slopes in the Milk River Natural Area (Brierley et al.1989).

STOP.POSITION: Middle slopes (this report) 
SSLOPE: 10 - 20\% in the Milk River Natural Area (Brierley et al.1989); $<15 \%$ within the Suffield National Wildlife Area (Adams et al. 1997); 0 - 28\% (this report).

SASPECT: West- and some east-facing slopes in the Milk River Natural Area (Brierley et al.1989); variable aspects within the Suffield National Wildlife Area (Adams et al. 1997); variable on additional sites (this report)

SSOIL.TYPE: In the Milk River Natural Area this community occurs on Orthic Brown Chernozems; within the Suffield National Wildlife Area it occurs on Orthic Brown Chernozems, Orthic Regosols, Orthic Gleysols and Rego Brown Chernozems.

SSOIL.MOSTURE: Soils with submesic moisture regimes in the Milk River Natural Area; also soils with subxeric to mesic moisture regimes (this report).

SSOIL.COM: In the Milk River Natural Area this community occurs on well drained, fine to coarse textured soils; within the Suffield National Wildlife Area this community occurs on well drained, sandy Orthic Brown Chernozems; imperfectly drained, sandy loam Orthic Regosols and Orthic Gleysols; well drained, loamy sand Orthic Brown Chernozems, and sandy loam Rego Brown Chernozems; on additional sites it may occur on rapidly to well drained soils (this report).

SENVIRO.COM: This community type occurs at about $1000 \mathrm{~m}$ elevation within the Milk River Natural Area, on west- and some east-facing colluvial slopes (slope $10-20 \%$ ) (Brierley et al.1989). Soils are well drained, fine to coarse textured, Orthic Brown Chernozems with submesic moisture regimes. It also occurs on gentle slopes $(<15 \%)$ with variable aspects within the Suffield National Wildlife Area (Adams et al. 1997). Sites occupied by this community type included: middle terraces with well drained, sandy Orthic Brown Chernozems; lower terraces with imperfectly drained, sandy loam Orthic Regosols and Orthic Gleysols; valley walls with well drained sandy Orthic Brown Chernozems; hilly outwash deposits with well drained, loamy sand Orthic Brown Chernozems; hummocky moraine loam with well drained, sandy Orthic Brown Chernozems; and, inclined morainal slopes with sandy loam Orthic and Rego Brown Chernozems. Finally, this community type may also occur within the Cypress Hills Montane and Mixedgrass Subregions on rapidly to well drained soils, with subxeric to mesic moisture regimes (this report).

\section{BIOLOGICAL AND STRUCTURAL DESCRIPTION}

6a VEGETATION

SSTRATA LIFEFORM: Dwarf shrub; herb

SPCT.COVER: Dwarf shrub 1.3\%; herb 98\% (this report)

SMOST.ABUND.SPP: Agropyron smithii, Stipa comata, Selaginella densa (Bouteloua gracilis, Carex stenophylla - in some areas)

SUNVEGETATED.SURFACE COVER: Low 


\section{SCONSTANT.SPP: Agropyron smithii, Stipa comata}

SVEGETATION.COM: In the Milk River Natural Area this community is dominated by Stipa comata/S. spartea, Agropyron smithii and Selaginella densa (average percent compositional cover of $23 \%, 22 \%$, and $34 \%$, respectively), accompanied by Bouteloua gracilis, Carex spp., Koeleria macrantha, Poa sandbergii, Calamovilfa longifolia, Phlox hoodii and numerous other species (Brierley et al.1989). Within the Suffield National Wildlife Area, Agropyron smithii, Stipa comata and Carex stenophylla dominate, contributing in average $21 \%, 31 \%$ and $19 \%$ to the ground cover, respectively. Additional species include Bouteloua gracilis (3\%), Chenopodium pratericola (4\%), Descurainia pinnata (1\%), Lactuca pulchella, Lygodesmia juncea and Opuntia polyacantha (low covers). Analysis of plots from the ESIS database (this report) indicate that the same community type, found within the Cypress Hills Montane, Dry Mixedgrass and Mixedgrass Subregions of southeastern Alberta, is dominated by Agropyron smithii (16\%), Stipa comata (9.7\%), Bouteloua gracilis (9.7\%) and Selaginella densa (35\%), accompanied by less abundant species such as Koeleria macrantha, Carex filifolia, Agropyron dasystachyum and Stipa viridula.

\section{6c VARIABILITY}

SSPP.COMP.VAR: Bouteloua gracilis seems to have much lower ground cover than Agropyron smithii and Stipa comata within the Milk River Natural Area and the Suffield National Wildlife Area, while it becomes the codominant in the Cypress Hills sites (this report). Carex stenophylla is a codominant species within the Suffield National Wildlife Area. Selaginella densa reaches high ground covers in some areas (Milk River Natural Area and the Cypress Hills plots from this report) while it is not reported from the Suffield National Wildlife Area.

\section{STATUS}

\section{SRANK: S2S3}

SREASONS: Reported from the western portion of the Milk River Natural Area and from the Suffield National Wildlife Area (Grassland Natural Region - Dry Mixedgrass Subregion); it possibly exists in other locations within the Dry Mixedgrass and Mixedgrass Subregions, and within the Rocky Mountain Natural Region (Cypress Hills Montane Subregion) in the southwestern corner of Alberta (this report); it is estimated that there may be about 20 or more occurrences of this community type in Alberta.

SSTATCOM: Reported from the western portion of the Milk River Natural Area and from the Suffield National Wildlife Area (Grassland Natural Region - Dry Mixedgrass Subregion); it possibly exists in other locations within the Dry Mixedgrass and Mixedgrass Subregions, and within the Rocky Mountain Natural Region (Cypress Hills Montane Subregion) in the southwestern corner of Alberta (this report); based on the estimated number of occurrences (about 20 or more) this community should be placed on the provincial tracking list and ranked S2S3.

\section{ANALYSIS PROCEDURES AND DATA MANAGEMENT}


SANALYSIS.COM: Brierly et al. (1989) based their classification on both detailed and reconnaissance site information. On detailed sites, they estimated vegetation cover within five to eight $20 \times 50 \mathrm{~cm}$ microplots arranged at a fixed distance $(100 \mathrm{~m})$ along transects. Vegetation data from detailed plots were grouped by species composition according to tabular methods described in Muller-Dombois and Ellenberg (1974). Plots with similar vegetation structure were grouped into plant communities. Adams et al. (1997) collected the vegetation data (percent cover for each species) from a number of subsamples $(15-20 \mathrm{~cm} \times 50 \mathrm{~cm})$ located within the circular $(200 \mathrm{~m}$ diameter) plots. Their vegetation classification was based on the manual grouping of subsamples using a cluster analysis dendrogram as a general guide. Plant communities were also associated with environmental factors, such as slope and aspect. Since no details on vegetation composition were provided, this community type is probably based on the reconnaissance survey.

Cluster and ordination analysis of the combined ESIS database and the Waterton Lakes database was performed by Geowest personnel. Cluster analysis included species data from 416 plots. Ordination analysis related vegetation data from 120 plots to the following environmental variables: solar radiation (combines slope, aspect, and latitude), drainage class, moisture regimes, elevation, latitude, and longitude (last two variables represent macroclimatic variables - NW position in the province coincides with cooler and wetter climate as oppose to the SE end of the province). In addition to ordination, descriptive statistics (median, minimum, maximum) were calculated for environmental variables. These calculations were done in SPSS for Windows and included both variables used in the ordination and variables with a lot of missing data (soil drainage, site position - macro, site position - meso, nutrient regimes, $\%$ bedrock, $\%$ mineral soil, and $\%$ organic material. The information on Natural Subregion was taken from the GIS based on the geographical position of each plot. The Ecological Site Inventory System (ESIS) electronic database is stored in the Resource Data Division of Alberta Environment, Edmonton.

SANALYSIS.DATA.MANAGE.COM: Ecological Site Inventory System (ESIS) electronic database is stored in the Resource Data Division of Alberta Environment, Edmonton.

\section{REFERENCES}

\section{CITATION:}

Adams, G. D., G. C. Trottier, W. L. Strong, I. D. MacDonald, S. J. Barry, P. G. Gregoire, G. W. Babish and G. Weiss. 1997. Vegetation component report: Canadian Forces Base Suffield national Wildlife area - Wildlife Inventory. Report prepared for the Canadian Wildlife Service, Environment Canada, Edmonton, AB.

Adams, B and D. Moisey. 1999. Analysis of vegetation and soil monitoring records for Milk River Natural Area and Kennedy Creek Ecological Reserve. 1999. Public Lands, Alberta Agriculture, Food and Rural Development, Lethbridge

Brierley, D., D. Bradshaw, and D. Downing. 1989 Milk River Natural Area - biophysical inventory - southern uplands. Report prepared for Alberta Forestry, Lands and Wildlife, land information services division, resource Information Branch, Edmonton, AB. 
Comer, P., L. Allen, Steve Cooper, D. Faber-Langendoen, and G. Jones. 1999. Selected shrubland and grassland communities of the Northern Great Plains. A Report to Nebraska National Forest.

Coupland, R. T. 1950. Ecology of mixed prairie in Canada. Ecological Monographs 20: 271315

Dodd, J. D. and R. T. Coupland. 1966. Vegetation of saline Areas in Saskatchewan. Ecology 47: $958-967$

Fehr, Alan W. 1982. The Candidate Rumsey Ecological Reserve: A Biophysical Inventory. Alberta Energy and Natural Resources.

Heidal, B., S. V. Cooper and C. Jean. 2000. Plant species of special concern and plant associations of Sheridan County, Montana. Report to the U.S. Fish and Wildlife Service. Montana Natural Heritage Program, Helena, Montana.

Mueller-Dombois, D., and H. Ellenberg. 1974. Aims and methods of vegetation ecology. Wiley, New York.

NatureServe: An online encyclopedia of life [web application]. 2000. Version 1.0. Arlington (VA): Association for Biodiversity Information. Available: http://www.natureserve.org

Stacey, E. C. 1927. Ecological studies on the native grasses of the Grande Prairie-Beaverlodge district.

Wallis, C. 1976. Milk River canyon resource evaluation. Report prepared for Planning and Design, Alberta Recreation, Parks, and Wildlife, Edmonton, AB.

Wroe, R. A. 1971. Synecology of a Festuca scabrella Torr. grassland. Ph.D. thesis, Department of Plant Science, University of Alberta, Edmonton, Alberta. 


\section{COMMUNITY CHARACTERIZATION ABSTRACT \\ Carex stenophylla - Agropyron smithii Herbaceous Vegetation}

\section{IDENTIFIERS}

SEL.SUMMARY: This community type occupies depressional sites on well drained sandy Orthic Regosols and Rego Brown Chernozems on Glacio-fluvial terraces, well to rapidly drained loamy sand textured Orthic Brown Chernozems developed on morainal deposits, and on well drained sandy loam to loam Orthic and Calcareous Brown Chernozems on morainal deposits, within the Suffield National Wildlife Area (Dry Mixedgrass Subregion) (Adams et al. 1997). The same community possibly exists northwest of Fairview (Boreal Forest - Dry Mixedwood Subregion), where it occupies steep slopes (25-50\%) with southerly aspects, on very rapidly drained soils with subxeric moisture regimes (community \#47 in this report). In the Suffield National Wildlife Area, Agropyron smithii (43\%) and Carex stenophylla (57\%) dominate, accompanied by only three additional species, Chenopodium pratericola (4\%), Vicia americana $(1 \%)$ and Taraxacum officinale $(<1 \%)$. The same community from the Boreal Forest Region is more sparsely vegetated (ca. $30 \%$ vegetation cover) dominated by $A$. smithii $(7.6 \%)$ and Carex spp. (4.6\%), and accompanied by species such as Amelanchier alnifolia, Symphoricarpos albus, Koeleria macrantha, Stipa curtiseta, and S. comata.

SNAME: Carex stenophylla - Agropyron smithii Herbaceous Vegetation

SCOMNAME: Low sedge - western wheat grass Herbaceous Vegetation

\section{CLASSIFICATION}

SYSTEM: Terrestrial

CLASS: Herbaceous vegetation

SUBCLASS: Perennial graminoid vegetation (grasslands)

GROUP: Temperate or subpolar grasslands

FORMATION: Medium-tall sod temperate or subpolar grasslands

ALLIANCE: Agropyron smithii Herbaceous Alliance

\section{CLASSIFICATION CONFIDENCE LEVEL: 1}

SSIMILAR COMMUNITIES: The Agropyron smithii Herbaceous Vegetation community from Alberta (Coupland 1950, Wallis 1976, Brierley et al. 1989, Adams and Moisey 1999) and the Agropyron smithii (Pascopyrum smithii) Herbaceous Vegetation community type from Saskatchewan and Montana (Dodd and Coupland 1966, Heidel et al. 2000, NatureServe 2000) separate from the Carex stenophylla - Agropyron smithii Herbaceous Vegetation community by being solely dominated by Agropyron smithii and by having much lower cover of Carex stenophylla. The Agropyron smithii - Stipa comata - Bouteloua gracilis Herbaceous Vegetation 
community from Alberta (Brierley et al. 1989, Adams et al. 1997, this report) and the Agropyron smithii - Stipa comata - Bouteloua gracilis Herbaceous Vegetation community from Montana (Heidel et al. 2000) are similar to the stands of the Carex stenophylla-Agropyron smithii Herbaceous Vegetation community from the Boreal Forest Region. However, these Carex stenophylla - Agropyron smithii stands have more sparse vegetation and generally lack Bouteloua gracilis. Relatively low ground cover of Koeleria macrantha $(K$. cristata) in the Carex. stenophylla - Agropyron smithii Herbaceous Vegetation community separates this community type from the Koeleria cristata - Agropyron smithii Herbaceous Vegetation community (Stacey 1927, Wroe 1971, Fehr 1982).

\section{DISTRIBUTION}

SNATREG: Grassland, possibly Boreal Forest

SSUBREG: Dry Mixedgrass, possibly Dry Mixedwood

SRANGECOM: Reported only from the Suffield National Wildlife Area (Adams et al. 1997); possibly exists northwest of Fairview (this report)

SDISTRIBUTION.COM: Reported only from the Suffield National Wildlife Area (Grassland Natural Region - Dry Grassland Subregion) (Adams et al. 1997); possibly exists northwest of Fairview (Boreal Forest - Dry Mixedwood Subregion)(this report)

\section{ENVIRONMENTAL FACTORS}

SLANDFORM: Glacio-fluvial terraces, morainal deposits (Adams et al. 1997)

STOP.POSITION: Depressional sites (Adams et al. 1997); possibly upper slopes in the Boreal Forest (this report)

SSLOPE: Gentle slopes ( $<10 \%)$ or level terrain in the Grassland Natural Region; possibly on steeper slopes (25 - 50\%) in the Boreal Forest Natural Region

SASPECT: Variable aspects in the Grassland Region; southerly aspects in the Boreal Forest Region

SSOIL.TYPE: Orthic Regosols, Rego Brown Chernozems, Orthic Brown Chernozems and Calcareous Brown Chernozems (Adams et al. 1997)

SSOIL.MOSTURE: Subxeric (this report)

SSOIL.COM: Soils include well drained sandy Orthic Regosols and Rego Brown Chernozems, well to rapidly drained loamy sand Orthic Brown Chernozems, and well drained sandy loam to loamy Orthic and Calcareous Brown Chernozems.

SENVIRO.COM: This community type occupies depressional sites on well drained sandy Orthic Regosols and Rego Brown Chernozems on glacio-fluvial terraces, well to rapidly drained loamy 
sand Orthic Brown Chernozems developed on morainal deposits, and on well drained sandy loam to loamy Orthic and Calcareous Brown Chernozems on morainal deposits, within the Suffield National Wildlife Area (Dry Mixedgrass Subregion) (Adams et al. 1997). The same community possibly exists northwest of Fairview (Boreal Forest - Dry Mixedwood Subregion) where it occupies steep slopes $(25-50 \%)$ with southerly aspects, on very rapidly drained soils with subxeric moisture regimes (this report).

\section{BIOLOGICAL AND STRUCTURAL DESCRIPTION}

6a VEGETATION

SMOST.ABUND.SPP: Agropyron smithii, Carex stenophylla

SUNVEGETATED.SURFACE: Mineral soil (this report)

SUNVEGETATED.SURFACE COVER: Low in the Grassland Region (Adams et al. 1997); Mineral soil (20 - 50\%) in the Boreal Forest Region (this report)

SCONSTANT.SPP: Agropyron smithii, Carex stenophylla

SCHARACTERISTIC.SPP: Carex stenophylla

SVEGETATION.COM: In the Suffield National Wildlife Area, Agropyron smithii (43\%) and Carex stenophylla (57\%) dominate, accompanied by only three additional species, Chenopodium pratericola $(4 \%)$, Vicia americana $(1 \%)$ and Taraxacum officinale $(<1 \%)$. The same community from the Boreal Forest Region is more sparsely vegetated (ca. 30\% vegetation cover), dominated by $A$. smithii (7.6\%) and Carex spp. (4.6\%), and accompanied by species such as Amelanchier alnifolia, Symphoricarpos albus, Koeleria macrantha, Stipa curtiseta, and S. comata.

6c VARIABILITY

SSPP.COMP.VAR: Stipa species not reported from the Grassland Region.

SVARIABILITY.COM: Stipa species not reported from the Grassland Region; species of Carex characterizing the community in the Boreal Forest Region (from the ESIS database) is unknown, although it may be $C$. stenophylla, since this species occurs in the general area where this community occurs.

\section{STATUS}

SRANK: S1

SREASONS: Reported only from the Suffield National Wildlife Area (Grassland Natural Region - Dry Grassland Subregion) (Adams et al. 1997); possibly exists northwest of Fairview (Boreal Forest - Dry Mixedwood Subregion)(this report) 
SSTATCOM: Reported only from the Suffield National Wildlife Area (Grassland Natural Region - Dry Grassland Subregion) (Adams et al. 1997); possibly exists northwest of Fairview (Boreal Forest - Dry Mixedwood Subregion)(this report), but this location needs to be confirmed; it should be placed on the provincial community tracking list and ranked S1 until further information is available

\section{ANALYSIS PROCEDURES AND DATA MANAGEMENT}

SANALYSIS.COM: Adams et al. (1997) collected vegetation data (percent cover for each species) from a number of subsamples $(15-20 \mathrm{~cm} \times 50 \mathrm{~cm})$ located within circular $(200 \mathrm{~m}$ diameter) plots. Their vegetation classification was based on the manual grouping of subsamples using a cluster analysis dendrogram as a general guide. Plant communities were also associated with environmental factors, such as slope and aspect. Since no details on vegetation composition were provided, this community type is probably based on a reconnaissance survey. Cluster and ordination analysis of the combined ESIS database (including most of the plots analyzed by M. Willoughby) and the Waterton Lakes database was performed by Geowest personnel. Cluster analysis included species data from 416 plots. Ordination analysis related vegetation data from 120 plots to the following environmental variables: solar radiation (combines slope, aspect, and latitude), drainage class, moisture regimes, elevation, latitude, and longitude (last two variables represent macroclimatic variables - NW position in the province coincides with cooler and wetter climate as oppose to the SE end of the province). In addition to ordination, descriptive statistics (median, minimum, maximum) were calculated for environmental variables. These calculations were done in SPSS for Windows and included both variables used in the ordination and variables with a lot of missing data (soil drainage, site position - macro, site position - meso, nutrient regimes, $\%$ bedrock, $\%$ mineral soil, and $\%$ organic material. The information on Natural Subregion was taken from the GIS based on the geographical position of each plot.

SANALYSIS.DATA.MANAGE.COM: Adams et al. (1997) collected vegetation data (percent cover for each species) from a number of subsamples $(15-20 \mathrm{~cm} \times 50 \mathrm{~cm})$ located within circular ( $200 \mathrm{~m}$ diameter) plots. Their vegetation classification was based on the manual grouping of subsamples using a cluster analysis dendrogram as a general guide. Plant communities were also associated with environmental factors, such as slope and aspect. Since no details on vegetation composition were provided, this community type is probably based on a reconnaissance survey. Cluster and ordination analysis of the combined ESIS database (including most of the plots analyzed by M. Willoughby) and the Waterton Lakes database was performed by Geowest personnel. Cluster analysis included species data from 416 plots. Ordination analysis related vegetation data from 120 plots to the following environmental variables: solar radiation (combines slope, aspect, and latitude), drainage class, moisture regimes, elevation, latitude, and longitude (last two variables represent macroclimatic variables - NW position in the province coincides with cooler and wetter climate as oppose to the SE end of the province). In addition to ordination, descriptive statistics (median, minimum, maximum) were calculated for environmental variables. These calculations were done in SPSS for Windows and included both variables used in the ordination and variables with a lot of missing data (soil drainage, site position - macro, site position - meso, nutrient regimes, $\%$ bedrock, $\%$ mineral soil, and $\%$ organic material. The information on Natural Subregion was taken from the GIS based on the geographical position of each plot. The Ecological Site Inventory System (ESIS) electronic database is stored in the Resource Data Division of Alberta Environment, Edmonton. 


\section{REFERENCES}

\section{CITATION:}

Adams, G. D., G. C. Trottier, W. L. Strong, I. D. MacDonald, S. J. Barry, P. G. Gregoire, G. W. Babish and G. Weiss. 1997. Vegetation component report: Canadian Forces Base Suffield national Wildlife area - Wildlife Inventory. Report prepared for the Canadian Wildlife Service, Environment Canada, Edmonton, AB.

Adams, B and D. Moisey. 1999. Analysis of vegetation and soil monitoring records for Milk River Natural Area and Kennedy Creek Ecological Reserve. 1999. Public Lands, Alberta Agriculture, Food and Rural Development, Lethbridge

Brierley, D., D. Bradshaw, and D. Downing. 1989 Milk River Natural Area - biophysical inventory - southern uplands. Report prepared for Alberta Forestry, Lands and Wildlife, land information services division, resource Information Branch, Edmonton, AB.

Coupland, R. T. 1950. Ecology of mixed prairie in Canada. Ecological Monographs 20: 271315

Dodd, J. D. and R. T. Coupland. 1966. Vegetation of saline Areas in Saskatchewan. Ecology 47: $958-967$

Fehr, Alan W. 1982. The Candidate Rumsey Ecological Reserve: A Biophysical Inventory. Alberta Energy and Natural Resources.

Heidal, B., S. V. Cooper and C. Jean. 2000. Plant species of special concern and plant associations of Sheridan County, Montana. Report to the U.S. Fish and Wildlife Service. Montana Natural Heritage Program, Helena, Montana.

NatureServe: An online encyclopedia of life [web application]. 2000. Version 1.0. Arlington (VA): Association for Biodiversity Information. Available: http://www.natureserve.org

Stacey, E. C. 1927. Ecological studies on the native grasses of the Grande Prairie-Beaverlodge district.

Wallis, C. 1976. Milk River canyon resource evaluation. Report prepared for Planning and Design, Alberta Recreation, Parks, and Wildlife, Edmonton, AB.

Wroe, R. A. 1971. Synecology of a Festuca scabrella Torr. grassland. Ph.D. thesis, Department of Plant Science, University of Alberta, Edmonton, Alberta. 


\section{COMMUNITY CHARACTERIZATION ABSTRACT \\ Distichlis stricta - Agropyron smithii Herbaceous Vegetation}

\section{IDENTIFIERS}

SEL.SUMMARY: This community type occurs in saline wetlands in the Grassland and Parkland regions of eastern Alberta (Wallis 1990). This "saline dry meadow" community is transitional between the driest portion of the halophytic communities and the semi-halophytic communities. Numerous upland species accompanied the two dominant grasses, including Aster ericoides and Grindelia squarrosa. The various locations recorded for this community included Altario, Birch Lake, Capt. Eyre Lake Sand Plain North, Irma-Jarrow Lakes, Kenilworth Lake, Neutral Hills South, Old Channel Lake Springs, and Ribstone South. Wallis (1990) described the Spartina gracilis - Agropyron smithii community type as an open sandy site variant of the Distichlis stricta - Agropyron smithii community.

SNAME: Distichlis stricta - Agropyron smithii Herbaceous Vegetation

SCOMNAME: Salt grass - western wheat grass Herbaceous Vegetation

\section{CLASSIFICATION}

SYSTEM: Terrestrial

CLASS: Herbaceous vegetation

SUBCLASS: Perennial graminoid vegetation (grasslands)

GROUP: Temperate or subpolar grasslands

FORMATION: Medium-tall sod temperate or subpolar grasslands

ALLIANCE: Agropyron smithii Herbaceous Alliance

\section{CLASSIFICATION CONFIDENCE LEVEL: 3}

SSIMILAR COMMUNITIES: Although Distichlis stricta may occur in the Agropyron smithii Herbaceous Vegetation community from Alberta (Coupland 1950, Wallis 1976, Brierley et al. 1989, Adams and Moisey 1999) and possibly in the Agropyron smithii (Pascopyrum smithii) Herbaceous Vegetation from Saskatchewan and Montana (Dodd and Coupland 1966, Heidel et al. 2000, NatureServe 2000), these community types separate from the Distichlis stricta Agropyron smithii Herbaceous Vegetation community by being solely dominated by Agropyron smithii. The Agropyron smithii - Hordeum jubatum Herbaceous Vegetation community (Wallis 1990 ) is another similar community type, but it generally occurs on somewhat drier soils where Hordeum jubatum replaces Distichlis stricta.

\section{RELATED NOMENCLATURE}


SOTHER.NAMES: Distichlis stricta - Agropyron sp. community type (Dodd and Coupland 1966)

SOTHER.NAMES.RELATION.NOTE: The Distichlis stricta - Agropyron sp. community from Saskatchewan's saline areas (Dodd and Coupland 1966) is probably the same community type as Distichlis stricta - Agropyron smithii from the Grassland and Parkland regions of eastern Alberta (Wallis 1990).

SNAMES.COM: The Distichlis stricta - Agropyron sp. community from Saskatchewan's saline areas (Dodd and Coupland 1966) is probably the same community type as Distichlis stricta Agropyron smithii from the Grassland and Parkland Regions of eastern Alberta (Wallis 1990). However, there may be more than one species of Agropyron involved in the Distichlis stricta Agropyron sp. from Saskatchewan's saline areas, but their identification and relative importance were not investigated (Dodd and Coupland 1966).

\section{DISTRIBUTION}

SNATREG: Parkland, Grasslands

SSUBREG: Central Parkland, Northern Fescue, Dry Mixedgrass

SRANGECOM: This community type was described for Altario, Birch Lake, Capt. Eyre Lake Sand Plain North, Irma-Jarrow Lakes, Kenilworth Lake, Neutral Hills South, Old Channel Lake Springs, and Ribstone South

SDISTRIBUTION.COM: This community type occurs within the Parkland (Central Parkland Subregion) and Grassland (Northern Fescue and Dry Mixedgrass Subregions) Natural Regions; it was described for Altario, Birch Lake, Capt. Eyre Lake Sand Plain North, Irma-Jarrow Lakes, Kenilworth Lake, Neutral Hills South, Old Channel Lake Springs, and Ribstone South.

\section{ENVIRONMENTAL FACTORS}

SSOIL.COM: Saline soils

SKEY.ENVIRO.FACTORS: Soil salinity

SENVIRO.COM: Soil salinity is one of the principal factors responsible for the existence of this community type

\section{BIOLOGICAL AND STRUCTURAL DESCRIPTION}

\section{6a VEGETATION}

SMOST.ABUND.SPP: Distichlis stricta, Agropyron smithii

\section{SCONSTANT.SPP: Distichlis stricta, Agropyron smithii}


SCHARACTERISTIC.SPP: many halophytic and salt-tolerant species, such as Aster ericoides and Grindelia squarrosa differentiate this community type from those on non-saline soils.

SVEGETATION.COM: Distichlis stricta and Agropyron smithii dominate the community accompanied by the numerous upland species including Aster ericoides and Grindelia squarrosa.

\section{6b OTHER SPECIES}

SFAUNA.COM: Certain sites associated with this community type are good shorebird feeding habitats; these areas are utilized by Dunlin, Red-necked Phalarope, Sanderling, Baird's Sandpiper, Semipalmated Sandpiper, Lesser Yellowlegs, Marbled Godwits, Willets, Stilt Sandpiper, Piping Plover (endangered species), and many other shorebirds.

SOTHERSPP.COM: Certain sites associated with this community type are good shorebird feeding habitats; these areas are utilized by Dunlin, Red-necked Phalarope, Sanderling, Baird's Sandpiper, Semipalmated Sandpiper, Lesser Yellowlegs, Marbled Godwits, Willets, Stilt Sandpiper, Piping Plover (endangered species), and many other shorebirds.

\section{6c VARIABILITY}

SSPP.COMP.VAR: Wallis (1990) described the Spartina gracilis - Agropyron smithii community type as an open sandy site variant of the Distichlis stricta - Agropyron smithii community in the Grassland and Parkland regions of eastern Alberta.

SVARIABILITY.COM: Wallis (1990) described the Spartina gracilis - Agropyron smithii community type as an open sandy site variant of the Distichlis stricta-Agropyron smithii community.

\section{SPATIAL RELATIONS}

SSPATIAL DISTRIBUTION: This "saline dry meadow" community type is transitional between the driest portion of the halophytic communities and the semi-halophytic communities.

SADJACENT.COMMUNTIES: Distichlis stricta, Puccinellia nuttalliana, Muhlenbergia asperifolia and Hordeum jubatum community types.

SSPATIAL.COM: This "saline dry meadow" community type is transitional between the driest portion of the halophytic communities and the semi-halophytic communities; adjacent communities include the Distichlis stricta, Puccinellia nuttalliana, Muhlenbergia asperifolia and Hordeum jubatum community types.

\section{STATUS}

SRANK: S2

SREASONS: This community type was described for Altario, Birch Lake, Capt. Eyre Lake Sand Plain North, Irma-Jarrow Lakes, Kenilworth Lake, Neutral Hills South, Old Channel Lake 
Springs, and Ribstone South; its occurrence is also possible in numerous other similar sites characterized by Solonetzic soils in the Parkland and Grassland natural regions (Ksenija Vujnovic - personal observations).

SSTATCOM: This community type was described for Altario, Birch Lake, Capt. Eyre Lake Sand Plain North, Irma-Jarrow Lakes, Kenilworth Lake, Neutral Hills South, Old Channel Lake Springs, and Ribstone South. Its occurrence is also possible in numerous other similar sites characterized by Solonetzic soils in the Parkland and Grassland natural regions (Ksenija Vujnovic - personal observations). Until more information is available on the extent of the distribution for this community type, it should be placed on the provincial community tracking list and ranked S2.

\section{ANALYSIS PROCEDURES AND DATA MANAGEMENT}

SANALYSIS.COM: Wallis (1990) based the vegetation description on only a reconnaissance level survey.

SANALYSIS.DATA.MANAGE.COM: Wallis (1990) based the vegetation description on only a reconnaissance level survey.

\section{GENERAL COMMENTS}

SCOMMUNITY.COM: Further study is needed to provide additional information on the Spartina gracilis - Agropyron smithii community type of open sandy sites in the Grassland and Parkland natural regions of eastern Alberta to ascertain whether or not it can be separated from the Distichlis stricta - Agropyron smithii community type. The Spartina gracilis - Agropyron smithii community type is presently considered provincially rare (S2S3)

\section{REFERENCES}

\section{CITATION:}

Adams, B and D. Moisey. 1999. Analysis of vegetation and soil monitoring records for Milk River Natural Area and Kennedy Creek Ecological Reserve. 1999. Public Lands, Alberta Agriculture, Food and Rural Development, Lethbridge

Brierley, D., D. Bradshaw, and D. Downing. 1989 Milk River Natural Area - biophysical inventory - southern uplands. Report prepared for Alberta Forestry, Lands and Wildlife, land information services division, resource Information Branch, Edmonton, AB.

Coupland, R. T. 1950. Ecology of mixed prairie in Canada. Ecological Monographs 20: 271315

Dodd, J. D. and R. T. Coupland. 1966. Vegetation of saline Areas in Saskatchewan. Ecology 47: 958-967 
Heidal, B., S. V. Cooper and C. Jean. 2000. Plant species of special concern and plant associations of Sheridan County, Montana. Report to the U.S. Fish and Wildlife Service. Montana Natural Heritage Program, Helena, Montana.

NatureServe: An online encyclopedia of life [web application]. 2000. Version 1.0. Arlington (VA): Association for Biodiversity Information. Available: http://www.natureserve.org

Vujnovic, Ksenija, Plant Ecologist, 2608-83 Street, Edmonton, AB, T6K 2Y6; tel: (780) 4668837; email: ksenija@home.com

Wallis, C. 1976. Milk River canyon resource evaluation. Report prepared for Planning and Design, Alberta Recreation, Parks, and Wildlife, Edmonton, AB.

Wallis, C. 1990. Reconnaissance survey of saline wetlands and springs in the GrasslandParkland region of Eastern Alberta. World Wildlife Fund, Canada 


\section{COMMUNITY CHARACTERIZATION ABSTRACT}

Koeleria macrantha - Agropyron smithii Herbaceous Vegetation

\section{IDENTIFIERS}

SEL.SUMMARY: This community occurs on drier upland and exposed sites in the Grand Prairie - Beaverlodge area (Peace River Parkland Subregion) (Stacey 1927). It also occurs in the Rumsey Ecological Reserve (Central Parkland Subregion), on level areas and lower slopes with xeric Brown and Black Solonetzic soils (Wroe 1971, Fehr 1982). Koeleria macrantha, Agropyron albicans and A. smithii are the dominant grasses in the Grand Prairie - Beaverlodge area, accompanied by other grass and forb species such as Agrostis hiemalis, Poa interior, Stipa columbiana, $S$. curtiseta, Elymus innovatus, $A$. trachycaulum, and $A$. albicans. A. albicans is more prominent species within the limited range of Niobe. In the Rumsey Ecological Reserve; Koeleria macrantha (59\%), Agropyron smithii (46\%) Selaginella densa (59\%), Carex eleocharis (35\%), Poa secunda (15\%), Grindelia squarrosa (15\%) and Distichlis stricta (8\%) are the most abundant species. Some additional species include Achillea millefolium, Antennaria nitida, Artemisia frigida, Bouteloua gracilis and Hordeum jubatum.

SNAME: Koeleria macrantha-Agropyron smithii Herbaceous Vegetation

SCOMNAME: June grass - western wheat grass Herbaceous Vegetation

\section{CLASSIFICATION}

SYSTEM: Terrestrial

CLASS: Herbaceous vegetation

SUBCLASS: Perennial graminoid vegetation (grasslands)

GROUP: Temperate or subpolar grasslands

FORMATION: Medium-tall sod temperate or subpolar grasslands

ALLIANCE: Agropyron smithii Herbaceous Alliance

CLASSIFICATION CONFIDENCE LEVEL: 2

SSIMIILAR COMMUNITIES: The Agropyron smithii Herbaceous Vegetation community from Alberta (Coupland 1950, Wallis 1976, Brierley et al. 1989, Adams and Moisey 1999) and the Agropyron smithii (Pascopyrum smithii) Herbaceous Vegetation community from Saskatchewan and Montana (Dodd and Coupland 1966, Heidel et al. 2000, NatureServe 2000) separate from the Koeleria macrantha - Agropyron smithii Herbaceous Vegetation community by being solely dominated by Agropyron smithii. The Koeleria macrantha - Agropyron smithii Herbaceous Vegetation community differs from the Agropyron smithii - Bouteloua gracilis Herbaceous Vegetation community from Alberta (Brierley et al 1989, Comer et al. 1999) and the Agropyron smithii (Pascopyrum smithii) - Bouteloua gracilis Herbaceous Vegetation community from 
Saskatchewan and Montana (Coupland 1950, Comer et al. 1999, Heidel et al. 2000) by having a much higher ground cover of Koeleria macrantha. Although Distichlis stricta may occur in the Koeleria macrantha - Agropyron smithii Herbaceous Vegetation community, the lack of a significant Koeleria macrantha component separates the Distichlis stricta - Agropyron smithii Herbaceous Vegetation community from Alberta (Wallis 1990) and the Distichlis stricta Agropyron sp. Herbaceous Vegetation community from Saskatchewan (Dodd and Coupland 1966) from this community type. Low cover of Koeleria macrantha separates the Carex stenophylla - Agropyron smithii Herbaceous Vegetation (Adams et al. 1997, this report) from the Koeleria macrantha - Agropyron smithii Herbaceous Vegetation community. The Agropyron smithii - Artemisia frigida Herbaceous Vegetation community (Adams et al. 1997) and the Agropyron smithii - Hordeum jubatum Herbaceous Vegetation (Wallis 1990) may separate from the Koeleria macrantha - Agropyron smithii Herbaceous Vegetation community by having low cover of Koeleria macrantha. However, a lack of details on the species composition of the Agropyron smithii - Artemisia frigida Herbaceous Vegetation and Agropyron smithii - Hordeum jubatum Herbaceous Vegetation community types does not enable a direct comparison of these community types with the Koeleria macrantha - Agropyron smithii Herbaceous Vegetation community at this time.

\section{RELATED NOMENCLATURE}

SOTHER.NAMES: Koeleria cristata - Agropyron spp. (Stacey 1927); Koeleria - Agropyron Artemisia (Langevin 1973).

SOTHER.NAMES.RELATION.NOTE: The Koeleria cristata - Agropyron spp. community (Stacey 1927) is the same community type as the Koeleria macrantha-Agropyron smithii Herbaceous Vegetation community; the relationship between the Koeleria - Agropyron Artemisia community type from the Kleskun Hills area in the Peace River Parkland Subregion (Langevin 1973) and the Koeleria macrantha - Agropyron smithii Herbaceous Vegetation community is not clear.

SNAMES.COM: The Koeleria cristata - Agropyron spp. community (Stacey 1927) is the same community type as the Koeleria macrantha-Agropyron smithii Herbaceous Vegetation community although in the former type Agropyron albicans seems to be an additional important Agropyron species; the relationship between the Koeleria - Agropyron - Artemisia community type from the Kleskun Hills area in the Peace River Parkland Subregion (Langevin 1973) and the Koeleria macrantha - Agropyron smithii Herbaceous Vegetation community is not clear because Langevin (1973) did not provide details on the species composition.

\section{DISTRIBUTION}

SNATREG: Parkland

SSUBREG: Peace River Parkland, Central Parkland

SRANGE: Grande Prairie - Beaverlodge area 
SDISTRIBUTION.COM: Grande Prairie - Beaverlodge area (Parkland Natural Region -Peace River Parkland) and Rumsey Ecological Reserve (Parkland Natural Region - Central Parkland Subregion)

\section{ENVIRONMENTAL FACTORS}

STOP.POSITION: Level areas and lower slopes in the Rumsey Ecological Reserve

SSOIL.TYPE: Brown and Black Solonetz soils in the Rumsey Ecological Reserve.

SSOIL.MOSTURE: Xeric

SENVIRO.COM: This community occurs on drier upland and exposed sites in the Grand Prairie - Beaverlodge area; it also occurs in the Rumsey Ecological Reserve on level areas and lower slopes with xeric Brown and Black Solonetzic soils

\section{BIOLOGICAL AND STRUCTURAL DESCRIPTION}

\section{6a VEGETATION}

SMOST.ABUND.SPP: Koeleria macrantha, A. smithii, Agropyron albicans, Selaginella densa, Carex eleocharis

\section{SCONSTANT.SPP: Koeleria macrantha, A. smithii}

SVEGETATION.COM: Koeleria macrantha, Agropyron albicans and A. smithii are the dominant grasses in the Grand Prairie - Beaverlodge district area, accompanied by other grass and forb species such as Agrostis hiemalis, Poa interior, Stipa columbiana, S. spartea, Elymus innovatus, Agropyron tenerum, A. inerme, A. caninum, and A. albicans. In the Rumsey Ecological Reserve, Koeleria macrantha (59\%), Agropyron smithii (46\%) Selaginella densa (59\%), Carex eleocharis (35\%), Poa secunda (15\%), Grindelia squarrosa (15\%) and Distichlis stricta (8\%) are the most abundant species. Some additional species include Achillea millefolium, Antennaria nitida, Artemisia frigida, Bouteloua gracilis and Hordeum jubatum.

6c VARIABILITY

SSPP.COMP.VAR: A. albicans is more prominent species within the limited range of Niobe.

SVARIABILITY.COM: A. albicans is more prominent species within the limited range of Niobe.

\section{STATUS}

\section{SRANK: S1S2}

SREASONS: Limited geographical distribution: Grande Prairie - Beaverlodge area (Parkland Natural Region - Peace River Parkland) and Rumsey Ecological Reserve (Parkland Natural 
Region - Central Parkland Subregion); there may be between 5 and 20 occurrences of this community type known so far from Alberta.

SSTATCOM: Limited geographical distribution: Grande Prairie - Beaverlodge area (Parkland Natural Region - Peace River Parkland) and Rumsey Ecological Reserve (Parkland Natural Region - Central Parkland Subregion); based on the estimated number of occurrences (between 5 and 20) it should be placed on the community tracking list and ranked S1S2.

\section{ANALYSIS PROCEDURES AND DATA MANAGEMENT}

SANALYSIS.COM: Stacey (1927) based her classification only on qualitative data with little attention given to forb species; Wroe (1971) defined plant communities based on species dominance and composition. Canopy cover was estimated as percent canopy classes.

SANALYSIS.DATA.MANAGE.COM: Classification based only on qualitative data; little attention given to forb species. Wroe (1971) defined plant communities based on species dominance and composition. Canopy cover was estimated as percent canopy classes.

\section{GENERAL COMMENTS}

SCOMMUNITY.COM: More information is needed on the composition of this community type within the Peace River area to compare it with sites within the Ramsey Ecological Reserve.

\section{REFERENCES}

\section{CITATION:}

Adams, G. D., G. C. Trottier, W. L. Strong, I. D. MacDonald, S. J. Barry, P. G. Gregoire, G. W. Babish and G. Weiss. 1997. Vegetation component report: Canadian Forces Base Suffield national Wildlife area - Wildlife Inventory. Report prepared for the Canadian Wildlife Service, Environment Canada, Edmonton, AB.

Adams, B and D. Moisey. 1999. Analysis of vegetation and soil monitoring records for Milk River Natural Area and Kennedy Creek Ecological Reserve. 1999. Public Lands, Alberta Agriculture, Food and Rural Development, Lethbridge

Brierley, D., D. Bradshaw, and D. Downing. 1989 Milk River Natural Area - biophysical inventory - southern uplands. Report prepared for Alberta Forestry, Lands and Wildlife, land information services division, resource Information Branch, Edmonton, AB.

Comer, P., L. Allen, Steve Cooper, D. Faber-Langendoen, and G. Jones. 1999. Selected shrubland and grassland communities of the Northern Great Plains. A Report to Nebraska National Forest.

Coupland, R. T. 1950. Ecology of mixed prairie in Canada. Ecological Monographs 20:271315 
Dodd, J. D. and R. T. Coupland. 1966. Vegetation of saline Areas in Saskatchewan. Ecology 47: 958-967

Fehr, Alan W. 1982. The Candidate Rumsey Ecological Reserve: A Biophysical Inventory. Alberta Energy and Natural Resources.

Heidal, B., S. V. Cooper and C. Jean. 2000. Plant species of special concern and plant associations of Sheridan County, Montana. Report to the U.S. Fish and Wildlife Service. Montana Natural Heritage Program, Helena, Montana.

Langevin, A. 1973. A preliminary paper on the Kleskun Hills Area. Report prepared by Environmental Research Station, Parks Planning, Alberta.

NatureServe: An online encyclopedia of life [web application]. 2000. Version 1.0. Arlington (VA): Association for Biodiversity Information. Available: http://www.natureserve.org

Stacey, E. C. 1927. Ecological studies on the native grasses of the Grande Prairie-Beaverlodge district.

Wallis, C. 1976. Milk River canyon resource evaluation. Report prepared for Planning and Design, Alberta Recreation, Parks, and Wildlife, Edmonton, AB.

Wallis, C. 1990. Reconnaissance survey of saline wetlands and springs in the GrasslandParkland region of Eastern Alberta. World Wildlife Fund, Canada

Wroe, R. A. 1971. Synecology of a Festuca scabrella Torr. grassland. Ph.D. thesis, Department of Plant Science, University of Alberta, Edmonton, Alberta. 

National Library of Canada

Bibliothèque

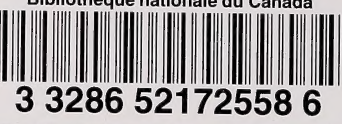

33286521725586 